

$i_{10}^{\infty}$

3द-

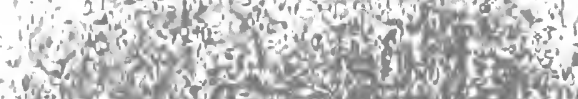

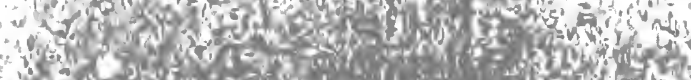

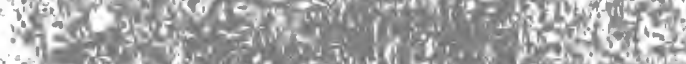

(n)

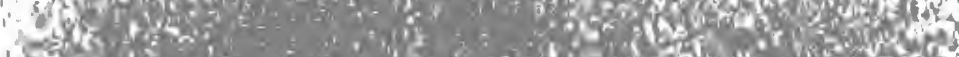

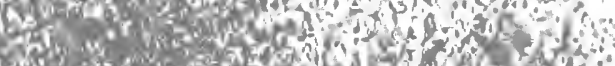

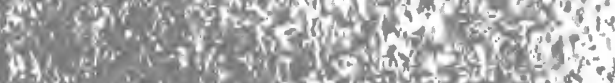

i.

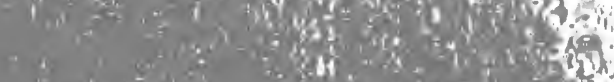

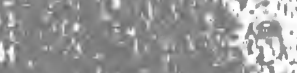

作

$-4 x$

Nofis.

$\operatorname{los}_{1} \times x^{5}$

$=-210$

in

$\therefore$ in

$\{x$ 
IN'TERNATIONAL WA'TERWAYS 


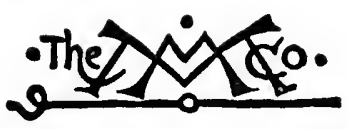

THE MACMILLAN COMPANY

NEW YORK - BOSTON - CHICAGO - DALLAS

ATLANTA - SAN FRANCISCO

MACMILLAN \& CO., Limited

LONDON - BOMBAY - CALCUTTA

MELBOURNE

THE MACMILLAN CO. OF CANADA, LTD.

TORONTO 


\section{INTERNATIONAL WATERWAYS}

I

THE EVOLUTION OF THE PRINCIPLE OF INTERNATIONAL WATERWAYS

II

A REFERENCE-MANUAL TO THE TREATIES, CONVENTIONS, LAWS, AND OTHER FUNDAMENTAL ACTS GOVERNING THE INTERNATIONAL USE OF INLAND WATERWAYS

BY

PAUL MORGAN OGILVIE, M.A.

Les rivières sont des chemins qui marchent.

Blaise de Pascal, Pensees

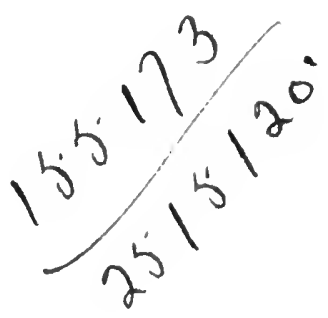

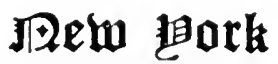

THE MACMILLAN COMPANY

1920

All rights reserved 
Copyright, 1920,

By PAUL MORGAN OGILVIE

Set up and electrotyped. Published, February, 1920 
IN THE MEMORY OF

JAMES OGILVIE

A PIONEER OF

UNFALTERING FAITH 


\section{S}

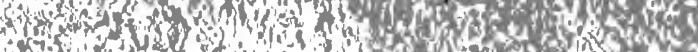
or

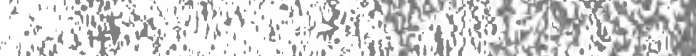

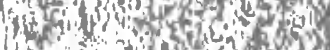

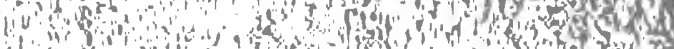
il if
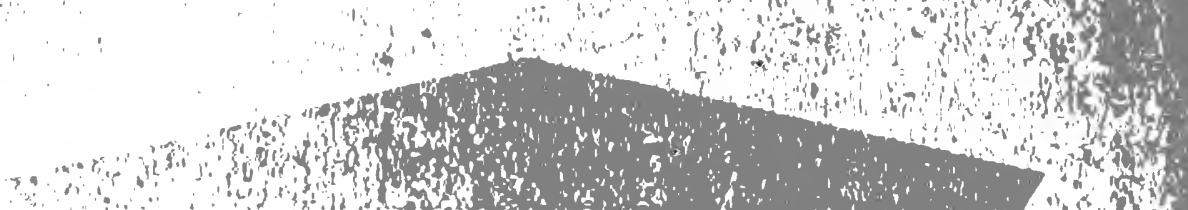

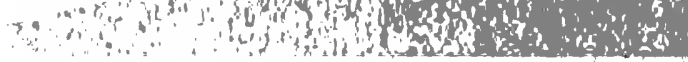

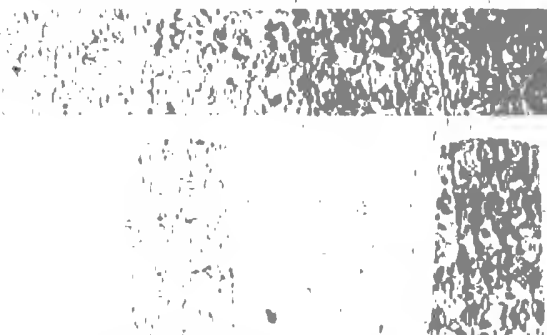

Digitized by the Internef A Archive in 2007 with funding firom Microsoft Corporatión

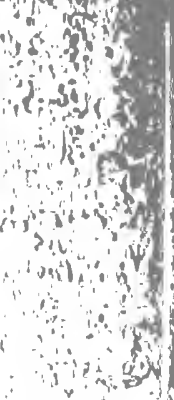

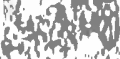

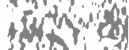

sin

is) 15

dof

m dis
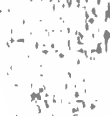

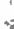

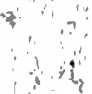

vy a -

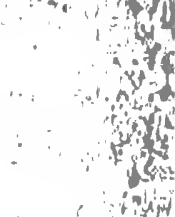




\section{PREFACE}

One hundred and four years ago, when the representatives of the diverse nations of Europe, assembled at the Congress of Vienna, were, in conformity with the stipulations of the Treaty of Paris, instituting the principle of the universal navigation of inland waterways, even those entertaining the most sanguine expectations could not have foreseen the decisive part which this innovation was destined to play in the development of transportation during the ensuing century on the waterways even of distant continents. In 1815 the mechanical propulsion of vessels, which constitutes a most vital element in the utilization of the highways of inland waters, had not been sufficiently perfected to disclose its limitless possibilities in the improvement of international communication and the development of the world-wide commercial and industrial activities of the Nineteenth Century.

In fulfillment of the aspiration "to facilitate the communication between nations, and continually to render them less strangers to each other," as proclaimed by the Peace of Paris in 1814, the nations of the world, through the adoption of the principle of free navigation, have facilitated international commerce and have demonstrated what may be attained through effective international cooperation.

By providing for the international navigation of certain Eu-ropean waterways, in the treaties with Austria, Germany and Poland, the Allied and Associated Powers at the Peace Conference at Paris have lately evinced an enlightened appreciation of the benefit to be derived by all nations from securing; the most ample facilities of intercommunication. These treaty provisions, which are summarized at the conclusion of the Reference-Manual, will become operative upon the establishment 
of peace with the deposit of formal ratifications. Several inland states which would otherwise be isolated are assured of free transit over inland waters to the open sea by virtue of the Treaties of Versailles and Saint Germain-en-Laye.

These fluvial rights may be extended into the space directly above, so that, with the progressive improvement of aerial transportation, such inland water-courses may serve, collaterally, as routes of International Airways. Air-vessels of an inland state might be denied transit over the terrestrial domain of adjacent nations, yet, if the state were situated on an international waterway, as Austria is situated on the Danube, airvessels might follow the course of the river without restraint.

Substantial alterations in the boundaries of a nation may involve a greater dependence upon an international waterway than formerly. Austria, Czecho-Slovakia and Hungary may divert to the Danube commerce which passed through Fiume and Trieste when these Adriatic ports were comprised within the Dual Monarchy. An inland state having no navigable access to the sea may suffer during war economic restrictions which may jeopardize its supply of vital commodities. By reason of the exigencies of the World War, Switzerland, though having no mercantile marine, chartered merchant vessels from meutral and belligerent countries, obtaining some of them from the United States Shipping Board. In accordance with arrangements made with the German Government, these vessels were granted safe conducts on condition that they should bear distinguishing marks indicating the fact that they were chartered by Switzerland and that their cargoes were destined for that country. The United States agreed to permit the Shipping Board's vessels to go without convoy, provided the vessels bore such marks. Under these arrangements, the Swiss flag was flown from the foremast, and the flag of the country where the vessel was registered was displayed from the mainmast. The hull of the ship bore the Swiss cross and the word Schweiz was painted in large letters on the free-board. Flying two flags in this manner, it might be said, that one flag testified 
to the national character of the vessel and the other to the character of the cargo.

Changing political frontiers and the persistent progress of engineering science may terminate at any time the isolation of an inland state by affording access to a navigable waterway communicating with the open sea. In consequence, the principle is perennial in its potentiality, for the boundaries of states are never immutable nor are the limits of navigation on inland waters ordinarily permanent.

Since this survey seeks especially to describe the evolution of the principle, systematic examination of the physical and political conditions warranting universal navigation on inland waters and consideration of the ancillary uses which appertain to the riparian states, exclusively, is reserved for discussion in the subsequent treatise concerning International Rights on Inland Navigable Waterways. However, conventional arrangements and laws regulating the enjoyment of the ancillary uses, - notably participation in the fluvial and lacustrine fisheries and the diversion of waters for power, irrigation, and the maintenance of canals, - together with the agreements governing navigation, are listed alphabetically and chronologically under the diverse continental divisions in the Reference-Manual.

In acknowledgment of the assistance received during the pursuit of this investigation, I tender thanks gratefully to Doctor Ellery Stowell whose stimulating enthusiasm and generous assistance in securing desired information created a source of inspiration throughout the period of inception. Likewise, I am under obligation to the Consular Officers of the United States of America, stationed in Europe, Asia, Africa, and South America, who cheerfully responded to difficult requests for information not readily procurable otherwise. Recognition would be incomplete without commending the exceptionally efficient services rendered by the officers and assistants at the Columbia University Library, the Library of Congress, and the New York Public Library. Virtually all of the sources cited 
will be found available for reference in at least one of these bountiful libraries.

Any expression of gratitude and enduring indebtedness must be inadequate in appreciation of the invigorating and salutary criticism and the encouragement of the constant, kindly counsel and guidance so liberally given by Professor John Bassett. Moore.

Paul Morgan Ogilvie.

Washington, November tenth, 1919. 


\section{CONTENTS}

\section{PART I}

THE EVOLUTION OF THE PRINCIPLE OF INTERNATIONAL WATERWAYS

chapter The Essential Relation of Waterways to International Communication . • . • . . . . . . . . . . 3

II The Advent of Maritime Enterprise . . . . . . 13

III The Institution of Maritime Law . • • • • • 24

IV Discovery Extends Maritime Enterprise Throughout the Seven Seas . . . . . . . . . . . . 42

V The Sovereignty of the Seas . . . . . . . . . 53

VI The Freedom of the Seas . . . . . . . . . . 97

VII Exceptional Limitations on the Freedom of the Seas a 116 VIII The Freedom of Navigation on Inland Waterways . 150

\section{PART II}

A REFERENCE-MANUAL TO THE TREATIES, CONVENTIONS, LAWS, AND OTHER FUNDAMENTAL ACTS GOVERNING THE INTERNATIONAL USE OF INLAND WATERWAYS

I Index of Abbreviations Distinguishing the Principal Documentary Collections . . . . . . . . 175

II The International Inland Waterways of the World by Continental Divisions . . . . . . . . . 180 Europe . . . . . . . . . . . . . . . 180 North America . . . . . . . . . . . . 260 South America . . . . . . . . . . . . 292 Africa . . . . . . . . . . . . . . . 322 Asia, Australia, and Islands of the Sea . . . . . 354 Tentative Provisions Regulating Certain European Waterways . . . . . . . . . . . 376 Bibliography . . . . . . . . . . . . • • 381 $I_{\text {NDEX }}$. . . . . . . . . . . . . . . . . 391 



\section{PART I}

THE EVOLUTION OF THE PRINCIPLE OF INTERNATIONAL WATERWAYS 


\title{
INTERNATIONAL WATERWAYS
}

\author{
CHAPTER I \\ THE ESSENTIAL RELATION OF WATERWAYS TO INTERNATIONAI \\ COMMUNICATION
}

From time immemorial, save in those rare intervals when the transitory sea-power of certain states sought maritime domination, partial or complete, the narrow seas and the vast expanse of ocean have served humanity as a limitless highway for intercommunication.

In its character, the sea is unique, since its illimitable expanse, comprising three-fourths of the earth's surface, remains an effective barrier to the migration and commerce of mankind between the islands and the continents which it surrounds, while the science of navigation continues unknown. Once this science is acquired, forthwith, the sea becomes the broad highway of communication between the nations of the world, connecting the sea-board of maritime states, and the ports situated on the affluent inland waters, with remote regions.

Since civilization is so largely a matter of transportation, the sea must be recognized as a dominant factor in the development of nations, for it provides the most ample, facile and inexpensive means of international communication.

Inventive genius, skill, hardihood, the spirit of daring and adventure enjoy abundant reward when devoted to maritime enterprise. With respect to the fisheries, alone, the sea has given rich harvest, but the intrepid mariners who have dared to venture into unknown waters; who, skirting the uncharted coasts of remote lands, have discovered new and richly endowed regions; these; together with their countrymen, have merited and have been accorded still greater reward. The earliest his- 
torical records chronicle such endeavors, terminating occasionally in disaster and wretched disappointment, but more frequently culminating in brilliant achievement. Such were the famed voyages of the Phœnicians, of the Greeks, who founded colonies, - Magna Grecia, - far to the westward, of the Norsemen under the guidance of Lief the Lucky and Eric the Red; achievements destined to serve through the succeeding centuries as an inspiration to mariners throughout the world to embark upon similar endeavors and to undertake the further extension of maritime enterprise. Eventually, the design of Columbus, accorded a tardy opportunity, brought forth in triumph the new era in national enterprise, compelling a reorganization of policies among the states of Europe.

Man's dominion over the earth began with his earliest ventures on the sea. Whatever force compelled this experiment on the hitherto unknown element, whether the stress of hunger, or the incursion of hostile and stronger tribes, or the failure of coastal fisheries, or simply an active curiosity, seeking to explore the distant seacoast, the result was the immediate development of greater opportunities for man's enterprise. Throughout this early period of development, as in more recent times, maritime states, because of the inherent advantages of their position on the world's great highway, won and maintained a dominant position among nations.

Sea-trade, which eventually became synonymous with worldtrade, developed; and, as an indispensable accompaniment, a constantly expanding code of sea-law evolved. In this body of law a fundamental principle was the essential freedom of the open sea and its connecting waters; a principle universally recognized in modern times although limited by belligerent activities to a degree varying with the scope and intensity of hostilities. In the period of intense colonial and commercial rivalry between European nations, following immediately upon the revolutionary discoveries in the latter part of the fifteenth century, this principle was flagrantly violated. Four centuries elapsed before its complete vindication, when it was recognized 
that discovery beyond the seas, the common enjoyment of the fisheries by all maritime nations, the facile interchange of commodities, is resolved, necessarily, into the one problem of maintaining the freedom of navigation on the high seas and their connecting waters. In the words of Kent (I Commentaries 27): "The open sea is public and common property and any nation or person has ordinarily an equal right to navigate it or to fish therein."

Furthermore, in accordance with the liberal spirit of the new age, an extension of this ancient principle was enunciated almost contemporaneously with the restoration of freedom on the seas (1806), the Congress of Nations at Vienna (1815) proclaiming that henceforth the inland waterways of Europe separating or traversing several states should be open freely to the navigation of vessels from any nation whatsoever. Hitherto, freedom of navigation, which was recognized as a vital element of international commerce, had been concerned solely with the open sea, but the Declaration of the Congress of Vienna accorded an extension to this familiar principle, which was destined to bring increasing benefit as it received a wider application during the succeding decades. Maritime nations, exhausted by the long-continued struggle for domination on the seas, had come to realize the futility of the struggle and were ready to accept the enlightened principle that the sea belongs to all, for common benefit and enjoyment; and, furthermore, that in the interest of international economy the commercial navigation of arterial, inland waterways should be assimilated to that of the high seas.

In his "History of the Greek World" Herodotus declares that the sea is a road, which unites the peoples of the earth to each other. He who dwells inland is as one shut off from the facilities and attractions of human intercourse and unacquainted with the progressive growth of the race. Irrespective of the advent and extension of railroad transportation, the development of steam navigation, contemporaneously with the enunciation and application of the principle of the freedom of navigation 
on inland waterways, terminated this seclusion of inland states. Henceforth, those dwelling on the shores of inland waterways, susceptible of internationalization, were, in respect to commerce, virtually situated on the sea-coast. Reciprocally, by the application of the Vienna Declaration, all the maritime powers of the world enjoy an extended field of enterprise, as these international waterways render easy access to the interiors of vast continents, affording passage to ocean vessels in certain instances three thousand miles inland.

Because of the aggregate number of new trade routes which this principle has developed, omitting all consideration of those which are as yet prospective, it may be ranked with the discovery of the New World and of the sea-route to India in the fifteenth century; the opening of the Suez; and the completion of the Panama Canal, in its profound influence upon the maritime enterprise of the world.

A thorough understanding of this newly acquired right to navigate inland waterways demands an extensive survey of the freedom of navigation on the high seas, a freedom which suffered serious restriction through four centuries, its ultimate affirmation being an essential precursor to the enunciation and acceptance of the still more liberal right. Before proceeding, however, to this examination, certain economic and physical factors inherent in water transportation should be noted, as affording an explanation of the importance attached to maritime affairs in every epoch.

The importance of the sea and of the connecting or tributary waters arises not alone from the fact that were it not for the science of navigation many regions would be isolated, the sea constituting a barrier rather than a great highway, but also from certain physical peculiarities which accord to water transportation advantages not enjoyed by land carriage. The advantages are neither accidental nor temporary but are derived from immutable physical laws. The fundamental difference exists in the fact that the ocean is a highway, as are all navigable waters, over which a given burden may be moved with one- 
sixth the expenditure of force demanded by the most facile of all forms of land carriage, railroad transportation. On waterways, there is only the necessity of supplying the vehicle; whereas on land the highway must first be constructed and thereafter maintained at heavy expense. Whatever form of locomotive power renders maximum efficiency in land carriage may be utilized with equal facility in water transportation. ${ }^{1}$

"As a highway, a railroad competes in vain with a river; the greater speed cannot compensate for the smaller carriage," declares Admiral Mahan. ("Problems of Asia," pg. 38.) "Water traffic for equal distances is much cheaper, being more facile and more copious, and therefore more useful in general."

It is the amount of goods which can be delivered steadily over a long period of time, not speed of delivery alone which is the important consideration in the exchange of commodities. An unfortunate limitation of railways arises from the fact that the carrying capacity reaches an unsurmountable limit as the traffic develops. Moreover, the cost of maintenance of way and of the rolling stock is so high that many goods can not be carried at a profit. A nation, situated similarly to Great Britain with its thirty-nine hundred miles of coast waters, enjoys the most commodious of all highways.

International Water-Borne Commerce.- It is owing to this ease of water transportation that freight seeks sea routes wherever possible; routes which aggregate many times the length of land routes, since from any sea, and from many inland waters, all seas are accessible. International commerce, especially, is predominantly sea borne, that of the United

1 Illustrating the low cost of water transportation, these figures appeared in the "Statistical Abstract of the United States, 1915," page 306, reporting traffic through Sault Sainte Marie:

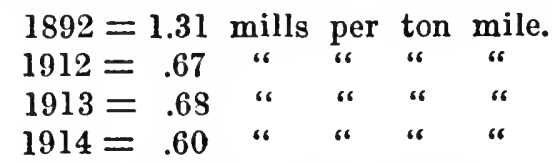

The greatest total of ton-mileage was $65,330,716,791$, carried in 1913 .

The lowest cost per ton-mile in the history of the Great Lakes traffic passing through St. Ste. Marie was six-tenths of a mill, charged in 1914. 
States being nineteen-twentieths, that of Great Britain, as of all insular states, being entirely sea borne. Consequently, an enormous saving accrues to modern society where the right of navigating inland waterways is accorded foreign ships, permitting the continuance of the voyage to distant river or lake ports, thus obviating the needless expense and delay of transshipment at the sea coast, as well as permitting the employment of this least expensive mode of transportation to, or in the vicinity of, the destination. Such an opportunity to effect substantial savings in the movement of goods is of vital importance to modern society, its existence having become largely a question of adequate transportation. Society requires the interchange of an ever-increasing volume of goods, and for this reason the perfection and amplification of means of access to various and remote regions of the world becomes constantly more imperative.

The articles comprising ocean commerce are essential to civilized life; in fact, even savages and semi-civilized races are now dependent on water-borne commerce for many commodities which have become necessities for them. So it is that commerce is necessary for the life of nations and individuals, inasmuch as commodities, whether of essential utility or merely enjoyable, are so widely distributed over the earth. The chronic condition of the Middle Ages, by which a local failure of crops meant death, no longer endures. Modern transportation has rendered such calamities virtually impossible. The commodities of world industry pass over the threshold of each nation and thence over seas into the distant markets of the world, assuring the prosperity and well-being of all who partake of this vital commerce.

Vattel ("Le Droit des Gens," II, sec. 21) accords great importance to the service of international commerce, arguing that "men are, therefore, under an obligation to carry on that commerce with each other, if they wish not to deviate from the views of nature; and this obligation extends also to whole nations or states." 
An incidental benefit of international trade, of an importance only secondary, arises from the dissemination of civilization incident upon this interchange. Montesquieu declares in the "Spirit of Laws" that the history of commerce is that of the communication of peoples. By means of this universal commerce over the waterways of the world, fostered by the facility of transport upon the all-embracing ocean, the former isolation of the various races, because of geographical limitations, becomes obliterated; all mankind being comprehended in this vast interchange. Opportunity is thus afforded for the growth of commercial, intellectual, and political relations, further developing the social instinct. So, the expansion of sea-trade brought knowledge of remote regions, and as commerce extended over this ever-increasing area, developing the resources of new lands, the economies of single nations and of groups of nations became united in one world economy. ${ }^{1}$

\section{Maritime Enterprise Essential to Complete National} Development. - The vital necessity of sea communication in the life of nations is apparent from the evidence of history. Throughout the ages, those nations which gained political prominence had extensive maritime interests, not infrequently acquired at an advanced period in the national existence through pressure of necessity. Though the Egyptians were enabled to continue their policy of national seclusion for a time, yet eventually it became imperative to undertake sea-faring. Being by nature ill-adapted for such an enterprise, the services of a subsidiary state, Phœnicia, were enlisted to secure the success of this endeavor. In a similar manner, Rome secured the support of Masilla (Marseilles). These instances are exceptional. Ordinarily an early predilection was evinced by those states which later were destined to achieve prominence in maritime affairs.

1 Some publicists have contended that through this intimate knowledge of one nation by another, resulting from freedom of commerce, armed conflicts would become impossible; the intricate community of interest among all nations forbidding such resort to force. Such contentions disregard the profound adverse effect of conflicting national ambitions. 
Russia has long recognized the urgent necessity of reaching the open sea, and in the long-continued struggle to gain this objective, has encountered the active hostility of certain European nations which have feared the competition of the vast Empire once it should acquire adequate communication with the world, permitting the development of latent resources and industries. The vital necessity for Russia is the acquisition of waterways affording unrestricted communication between the Empire and every maritime nation, for it is apparent that the development of railways has afforded inadequate relief. For centuries this need has been manifest. Though essentially inland in origin, Russia, through unremitting efforts, has advanced with the conscious purpose of gaining the shore of the open sea. ${ }^{1}$

Although this policy, pursued with unremitting devotion, extended the national domain to the Arctic, the Pacific, the Baltic, the Black and the White seas, yet Russia, for many months each year, is immured behind ice-barriers; international trade in this closed season consisting of that relatively insignificant interchange with neighboring nations, borne upon the inadequate railways. In the endeavor to partake of the freedom of the seas, the territorial acquisitions in Finland and on the Pacific coast, following the Crimean War, are significant. Every difficulty in which China has become involved has afforded opportunity for Russia to extend further southward into Manchuria, seeking a port beyond the winter's ice. Following the opening of the Amur to Russia in 1858, this endeavor was continued insistently, until the interposition of Japan in 1904 compelled the abandonment of further activity in the Far East. (Michie, "The Englishman in China During the Victorian Era," II, pg. 429.) ${ }^{2}$

1 Peter the Great was so impressed with the value of shipping in the development of the Empire that he studied ship-building at Zaandam in Holland (1697), under the incognito of Peter Mikhailov. The hut in which he lodged, once the property of the Czar of Russia, is sheltered beneath the substantial museum which has been recently erected.

2 All ports on the northern coasts of Russia are ice-bound for several months each year with the single exception of Kola, situated at the head 
The ambition of Russia is to gain free access to the Mediterranean, since the development of ports on the northern coasts would fail to meet the economic requirements, overland carriage from the industrial districts to these remote coasts being of prohibitive cost. . It is on the Black Sea that Russia seeks further maritime development, for many important industrial centers are close at hand, while the more distant are in facile communication by means of the admirable system of inland waterways; a result of extensive improvements of the great rivers which flow into this sea.

However, this enormous empire must endure the limitations imposed by adverse geographical and political conditions, unless the termination of the present war shall afford opportunity to crown with success the work begun by Peter the Great and Catherine II. The destiny of Russia in maritime enterprise rests in the determination of the question whether the Bosphorus shall remain under the dominion of a nation heedless of the needs of international communication, or shall become an unrestricted highway. Heretofore, Russia has endured the imperfect and politically dependent access to the sea afforded by these straits, a paradoxical situation, in fact, a free interior sea being connected with the waterways of the world by straits burdened with restrictions, and susceptible of absolute closure at the will of an independent sovereignty.

General Trepoff, the Russian Premier, speaking before the Duma in November, 1916, declared that for more than a thousand years Russia had been reaching southward toward a free

of Catherine Harbor. An off-shoot of the Gulf Stream, rounding Nortl Cape, renders this port ice-free at every season of the year. Here Russia has unobstructed access to the Western Sea, but, as a trade route, Kola suffers serious limitations, being more than eight hundred miles from Petrograd, and nearly two thousand miles from the chief industrial districts. Since the completion of the railway, connecting this newly established port with the interior of Russia (January, 1916), Kola has assumed importance as an entrepot for war munitions. A noteworthy saving has been effected in the transportation of these supplies, as heretofore practically all munitions arriving in Russia from other countries have entered by Vladivostok and the Siberian Railway, in order to avoid the excessive delays experienced at the ports in the White Sea. 
outlet on the open sea, and that this age-long dream, cherished in the hearts of the Russian people, was about to be realized.

For Russia, at least, Napoleon's declaration that Constantinople is the key of the world, has become an inflexible creed.

The Independent States situated within the basin of the Danube await the ultimate and complete establishment of this long-deferred freedom with an anxiety no less acute than that of Russia, since certain of these states are wholly dependent upon the navigation of the Black Sea, of the internationalized Danube, and upon the unrestricted passage of the Bosphorus for continuous participation in the ocean-borne commerce of the world.

The vital necessity of sea-communication in the life of nations is apparent in every phase of the long struggle to gain the unrestricted navigation of the waterways throughout the world; from the earliest period when the sea was available for all who possessed the courage to venture; through the centuries of restrictions following the Middle Age discoveries, successively levied by the dominant maritime nations; to the present epoch of virtual, universal freedom. 


\section{CHAPTER II}

TIIE ADVENT OF MARITIME ENTERPRISE

The importance of freedom of navigation arises principally from the fact that the sea and its connecting waters are the only continuous highways of the world. As Friedrich List declares, the oceans are the world's highway, the nations' parade ground, liberty's cradle, and the playground for the enterprise and energy of all peoples.

"For," as he states in another instance, "the sea gives strength to nations as to individuals, refreshment to their members and life to their minds. It fits them to undertake great projects. . . . From time immemorial salt water has healed national ills. . . The sea strengthens the whole constitution, for it brings riches and enjoyment, comfort and good cheer, within the reach of the mass of the people. . . . The sea has an inexhaustible store of good things for those who have the courage and strength to take them." (Hirst, "Life of Friedrich List," pg. 91.)

Yet the free use of the vast extent of ocean, expressed in the principle of " the freedom of the seas," became an accomplished fact barely a century ago, being still subject to certain limitations both in peace and in war.

Since the vindication of this principle is virtually the genesis of the still more enlightened policy among nations which accords unrestricted commereial navigation on those waters, separating or traversing different sovereignties; since, indeed, the opportunities, the facilities, the benefits of such unrestricted navigation on inland waters differ only from those on the high seas in volume, a brief survey of the development of maritime commerce and maritime law is indispensable as affording a clearer understanding of the inception and development of this 
most liberal principle; a principle which is virtually an extension of that which maintains the freedom of the illimitable sea.

When or where the sea was first impressed into the service of humanity, to assist through the subsequent centuries in the dissemination of civilization, is relatively unimportant in view of larger considerations regarding the characteristics of water transportation which fostered this intercommunication and the resultant enterprise and institutions, continuing in progressive development from the dawn of history. In antiquity, the overseas traffic was negligible. Water-borne commerce followed the courses of the great rivers or close within the sheltering shores of the Euxine and Mediterranean. For a time the value of the sea, save as a fishing ground, was little appreciated, but gradually the advantages of water transportation were realized, and as sea commerce developed, local seclusion was effaced. The facilities offered by the sea-routes, patently superior to those over land, led the early mariners beyond the sight of the familiar coasts, for the advantages of the direct course over that following the sinuosities of the shore were manifest. ${ }^{1}$

Advantages of Maritime Enterprise Appreciated.-On the Mediterranean, where the first extensive maritime trade had its beginning, the advantages of sea communication were readily apparent, for the three continents surrounding this sea comprised the known world, and the Mediterranean rendered the most facile means of communication between them, as the Seven Seas today afford the most advantageous communication between the continents of the globe. From the advent of the Phœnician mariners, throughout the succeeding centuries, the Mediterranean has demonstrated the profound influence which

1 Early man undertook his sea-faring adventures only where protecting sea-ward islands afforded shelter during his novitiate; as in the Egean, along the shores of the North Sea, at the mouths of the Orinoco, in the straits of San Juan de Fuca, and in the quiet waters of the Malay Archipelago and similar island groups in the South Seas. On the coasts of Africa, on the western and southeastern shores of South America, along the unsheltered sea-board of North America, Asia and Europe, there is no evidence of such aboriginal development. In fact, the highest degree of primitive nautical development was attained wherever the shore line was most indented. 
maritime communication exerts upon the progress of humanity. The advantageous maritime situations enjoyed by Persia, Egypt, Greece, and Rome, during their successive periods of pre-eminence, served to accelerate the development and extension of their institutions, both industrial and intellectual. The sea connected these states with all the known world, and the sea-traders, penetrating the most remote regions, together with the thriving colonies, developing in a kindred manner on distant shores, were potent factors in this process of world civilization.

The Phœnicians acquired pre-eminence on the Mediterranean at a very early time, not through slaughter and conquest, but because of their extensive trade, consisting chiefly of necessities. To isolated tribes on the Mediterranean's furthest shores these intrepid mariners carried their products, and, perhaps often unconsciously, the elements of the higher civilization under which they were thriving along the eastern shore. Eventually their commerce extended beyond the confines of the Mediterranean, the necessity of discovering further deposits of the much-prized shell-fish from which the renowned purple dye was extracted being an incentive, no less than the desire for a more expanded trade. Itinerant merchants passed beyond the Pillars of Hercules and were followed by colonists who established settlements in northwestern Africa and on the Iberian Peninsula. Long before the Greeks had undertaken their extensive campaign of colonization, these settlements, originally merely Phœnician trading posts, had developed into thriving colonies at strategic points along the shores of Italy, Africa, Corsica, Gaul, and Spain. Utica and Cadiz (Gades), being advantageously situated, rapidly developed to the estate of prosperous colonies, and Carthage, founded on the site of an abandoned trading station, soon became a mighty city, controlling many subsidiary trading stations throughout the western Mediterranean, and opening additional trade routes along the western shores of Gaul to distant Albion. Still more extended routes to the north and eastward brought the riches of India over 
land and sea in return for the products of these enterprising Phœnician navigators; the first commercial sailors on the high seas in all history. (Pardessus, "Collection de lois maritimes," Vol. I, pg. xviii.) Through their genius, their faith in the permanent advantage of sea transportation, the science of navigation under their influence progressed rapidly, and the sea, hitherto an insurmountable barrier, became a highway over which people voyaged into distant lands. ${ }^{1}$

The enviable position enjoyed by Phœnicia was fully appreciated by contemporaneous nations, and Egypt, Assyria, Babylon, and Persia made successive endeavors to acquire these maritime resources. The efforts of Egypt to secure the assistance of the Phœnician cities displays an unique situation in maritime enterprise, and at the same time affords an early example of governmental recognition of the paramount necessity of sea trade.

As a race, the Egyptians were not interested in navigation and commercial pursuits and made no effort to stimulate communication with foreign states. But at a later epoch, when the resources and industries of Egypt were more fully developed, the necessity of some facile means for the interchange of products with distant foreign nations became imperative. Thereupon, to fulfill this need, important maritime cities in Pho-

1 Raleigh, Works, Vol. VIII, 322-23, comments on the early development of maritime enterprise among the Phœnicians. "The first good ships were among the Tyrians (Strabo, Lib. 16.), and they had good and great ships not long after the war with Troy; and in Solomon's time they were of that account as Solomon invited Hiram, King of Tyre, to join with him in his journey into the East Indies, for the Israelites, till then, never traded by sea, and seldom, if ever, after; and that the Tyrians were the chief in that enterprise it appears in that they were called, ... in the Hebrew, saith Junius (I Kings, C. 9) homines navium; and in our English mariners. .. Hiram sent Solomon ships (II Chronicles, 8) and servants skillful of the sea, whereby it is probable that the Tyrians had used the trade of East India before the days of Solomon, or before the reign of David, when themselves commanded the ports of the Red Sea. The Tyrians were forced to make Solomon the chief of that expedition, and to join with him in the enterprise; for the Tyrians had no pass to the Red Sea, but through the territory of Solomon, and by his sufferance." 
nicia, on the island of Cyprus, and in Asia Minor were enlisted in the Egyptian maritime service. This abrupt departure from an age-long policy brought new prestige to Egypt because of the increased influence secured along the coasts of the Mediterranean, and because of important changes affecting the sea routes to India.

Traffic between the Mediterranean and the remote parts of Asia, since the earliest times, had followed three distinct routes, all of which form important commercial highways in modern times. On the most northerly route, goods were shipped through the AEgean, the Euxine and Caspian seas, and, if destined for India, were carried on by the Indus River. As a commercial highway, this route was subjected to the serious limitation that it required land carriage over the Caucasus Mountains and through Turkestan. (Pardessus, "Collection de lois maritimes," II, xix; III, vi.) Of still greater importance was the central route through the Arabian Sea, the Persian Gulf, and the Euphrates Valley, which afforded opportunity for water transit the entire distance with the exception of the short overland carriage between the upper Euphrates and the shores of the Mediterranean. It was this route which brought continued prosperity to Tyre, Sidon, and to all the Phœnician cities, for the trade with the Orient, facilitated by the opportunity for relatively inexpensive water transportation, was lucrative. The third route, the more southerly, acquired enhanced importance following the active participation of Egypt in maritime affairs, resulting in the foundation of Alexandria and the encouragement of more extensive enterprise in transportation across the low-lying isthmus between the Red Sea and the delta of the Nile. The increasing volume of commerce which passed over this most southerly route, together with the control exercised over the two northern routes through the subsidiary Phœnician cities, accorded the Egyptians a predominant position in world trade. Though the sea-borne traffic followed the Egyptian-Red Sea route in increasing volume, nevertheless, Tyre, Beirut, Sidon, 
and other sea-ports of the Euphrates route maintained an undiminished importance because of the rich trade in Mesopotamia and the incidental trade which still flourished with the Far East.

But the power of Egypt over the seas diminished and the resources of the Phœnicians, passing for a time under Babylonian dominion, eventually became incorporated within the vast Persian Empire. The opportunity for the further expansion of that mighty nation on the shores of the western sea was greatly improved by the acquisition of these extensive maritime interests; but beyond the waters of the Egean the rapid development of a sturdier nation was already challenging the continued extension of Persian power throughout the Mediterranean.

From early times the Greeks had enjoyed a substantial sea trade which extended into the Euxine. The predominance of the Phœnicians in all maritime interests had exerted, heretofore, only negligible curtailment of Grecian industry on the sea. However, now that the vast resources of the Phœnicians were enlisted to fulfill the ambitious designs of the Persians, the further expansion of Grecian trade, as well as the independent existence of the Grecian government, was threatened. With the conflict impending Themistocles appeared as leader of the Greeks and discerned that the issue would be decided, inevitably, by naval operations, for Athens had ceased to exist chiefly as a land power in consequence of the extensive development of maritime interests. (Grote, "History of Greece," (1849), Vol. V, pg. 67.) This insistence upon the urgency of increased naval resources afforded Themistocles sufficient power to meet the vast flotilla of the invading Persians, recruited largely from the Phœnician cities, victoriously at Salamis (October 20, 480 в. c.). Though apparently hopelessly overmatched by the two thousand war-vessels under Xerxes, still, by the skillful manœuvring of the meagre force of three hundred Grecian vessels within the narrow waters, Themistocles achieved a notable victory, compelling the precipitate retreat of the Persian hosts with a loss of more than two hundred ships of 
war. Thenceforth, the powerful influence of Phœnicia in Mediterranean affairs ceased to exist and Greece entered upon an unprecedented development over seas. This noteworthy expansion, both in maritime and colonial interests, was fostered by the shrewd leadership of Pericles, who clearly recognized the value of an extensive maritime influence as a means of strengthening the political prestige and prosperity of the state. To the Athenians he declared that every other interest should yield foremost place to the expansion of overseas commerce. (Pardessus, "Collection de lois maritimes," I, 36.) The example of Rhodes which had developed a noteworthy sea power through a wide-spread carrying trade was an added stimulus.

Athens soon became an universal market and a regular interchange of commodities was carried on with all the known countries of the civilized world, extending throughout Thrace, Asia Minor, Egypt, and to the more remote regions beyond the Bosphorus and in the western Mediterranean. Along these trade routes, temporary posts were established which developed into important colonies under the direction of Pericles, to whom credit is due for establishing the naval and colonial power of Athens on a firm, permanent basis.

Unlike the Greeks, the Romans were not a sea-faring people. Even by the end of the Republic, the Romans were loath to venture upon the open sea. Universally, the ocean was regarded not so much as a means of unlimited communication, an unrestricted highway, connecting the different and most distant countries of the world, but rather as an insurmountable barrier. The Romans expressed their contempt for maritime commerce by prohibiting its pursuit to persons of birth, rank, and fortune; and it was further provided that no senator should acquire a vessel larger than that required to carry his own wine, corn, and other products of his lands. (Phillipson, "International Law and Customs of Ancient Greece and Rome," Vol. II, 369.) (Herron, "Jurisprudence," pg. 29.)

In the growth of naval power, as in the expansion of other maritime interests, Rome exhibited a peculiar conservatism. 
Until the First Punic War, the Roman State had never engaged in hostilities on the seas, and at this crisis, in the absence of adequate knowledge respecting ship-building and navigation, hired vessels were necessarily employed to meet the enemy. Thereupon, the necessity of maritime power was tardily recognized. Fleets, both naval and mercantile, were constructed and under the incentive of the impending peril to the state such rapid progress ensued that Roman sea-power became dominant at the close of the Third Punic War, following the complete destruction of Carthaginian supremacy in the western Mediterranean.

During the Empire, security on the sea became of the utmost importance for the food supplies within Italy soon becarne inadequate. Following the conquest of Egypt, Augustus established a regular fleet to bring the constantly increasing supplies of grain demanded at Rome. As a further safeguard against the disaster which would be wrought by an extended interruption of maritime transportation, Roman conquest was extended progressively along the shores of the Mediterranean. Eventually, through successive acquisitions of territory, the Mediterranean became encircled by the provinces of Rome, rather than embracing them as formerly. In its new character as a vast inland sea, the Mediterranean exerted a powerful and unique service in binding together the mighty world-empire of Rome, through the generous facilities which it afforded for rapid and unrestricted communication between the widely separated provinces. (Kirchoff, "The Sea in the Life of Nations," pg. 399.)

But industry, trade beyond the seas, and all the most prized institutions of civilization are forever threatened by destructive and disintegrating forces. The incursions of barbarous tribes, wanton and harassing attacks by hostile nations, and the insidious inertia and laxity which results from prolonged material welfare, all contributed to the decline and fall of Rome. The once mighty Empire was trampled beneath the invading barbarous hordes and the development of extensive maritime 
enterprise terminated in the impenetrable chaos of the Dark Ages. 1

Sea-faring was destined to continue negligible throughout several centuries, until revived by the pervading enthusiasm of the Holy Crusades, and by the revolutionary discoveries of the fifteenth century, startling all nations into feverish activity with the realization of the limitless possibilities from commerce upon the seas. Thongh interest in navigation survived the collapse of civilization as developed under Roman cultivation, yet it was unmarked by that profound zeal and progressive expansion which had characterized the maritime development of Rome, following the triumphant termination of the Punic wars; and of Phœnicia and Greece at an earlier period.

In Northern Europe, the beneficent sovereignty of Charlemagne afforded a brief opportunity for the revival and development of commerce and navigation, though the enterprise did not assume a world-wide character, the commercial interest being concentrated chiefly on the development of the internal trade. The successive conquests of Charlemagne, culminating in his coronation ( 800 A. D.) by Pope Leo III, as Emperor of the Occident, afforded more extended opportunity for commercial expansion. To facilitate communication between the various provinces of the Occidental Empire and to meet the demands of the increasing volume of inland traffic, extensive operations were undertaken to improve the waterways of the realm. In addition to this notable internal development, Charlemagne sought to extend the commercial interests of his subjects to embrace enterprise of an international character. In pursuance of this policy, the construction of a canal was undertaken, connecting the navigable waters of the Rhine and the Danube rivers, to encourage an increased exchange of

1 Montesquieu, "Esprit de lois," Bk. XXI, c. 17, observes that "after the invasion of the Roman Empire, one effect of the general calamity was the destruction of commerce. . . . Soon was the commerce of Europe almost entirely lost ... there being very little trade in the countries conquered by these barbarians." 
products with Asia Minor and the countries bordering on the Euxine. (Pardessus, "Collection de lois maritimes," I, lxxiv.) But the Norman invasions during the latter years of Charlemagne's reign, compelling a concentration of the national energies for defensive purposes, prevented the consummation of this project, and the continued success which attended the invaders restricted the further expansion of the extensive internal commerce which had already been developed.

In supplanting the Franks, these Northmen showed slight inclination toward the development of maritime enterprise. Invited by the wide freedom of the seas, they sought distant regions, not with the intention of developing commerce and constructive intercommunication, but for the purpose of discovering additional plunder. Their marauding hosts had already invaded the streams of Eastern England; the Elbe; the Rhine, resulting in the plunder of Cologne; and were destined, still later, to extend their activities into the Western Mediterranean, culminating in the conquest of Sicily and the establishment of the kingdom of the Two Sicilies. This expansion into the waters of the Mediterranean brought the Normans into contact with a maritime state which had slowly been extending its commercial interests throughout the East, and which had developed sufficient sea-power to protect this lucrative commerce.

As early as the sixth century (584), when the water-borne trade of Northern Europe was almost wholly local and internal, the Venetians had been invited to form an alliance with the Empire of the East, securing for them the right to trade at Constantinople, free from all vexatious tolls and delays. Gradually Venetian enterprise expanded, developing increased resources in the East and opening a trade route across the Alps into Northern Europe, eventually supplemented by the all-sea route through the Western Mediterranean and the Atlantic.

An unexpected incentive to the lucrative trade which Venice had been developing appeared with the Crusades into the Holy Land. Though the early Crusades of Godfrey of Bouillon 
(1096) and Louis VII (1147) followed land routes, it was soon appreciated that the sea offered an easier, safer highway, and Venice, sharing a minor part of the trade with Genoa and Pisa, enjoyed thereafter great profit from the transportation of these expeditions and from the freights on the subsequent shipments of additional supplies. It is difficult to estimate the influence which this rapidly developing commerce exercised in enlightening the various countries of Europe through the ready means it afforded for the interchange of ideas and for the observation of widely divergent institutions. The Crusades served to accelerate the progress of civilization which was being already consummated by the extension of maritime enterprise, and more quickly developed the conditions which led to the inevitable discoveries beyond the seas during the fifteenth century. 


\section{CHAPTER III}

\section{THE INSTITUTION OF MARITIME LAW}

In reviewing the advent and expansion of maritime enterprise an important development, designed to protect commerce upon all the international waterways of the world, must be considered co-ordinately; the extension of law to maritime affairs. The discovery of the precise source of the various bodies of law which have safeguarded commerce for centuries is relatively unimportant, compared with the recognition of the beneficent influence which these laws have exerted through progressive application to the growing necessities of commerce over the world's waterways. The influence of commerce, uniting humanity by the strongest bonds through the mutual interchange of indispensable commodities, is constantly exerted for securing a more complete development of international law, in which is embodied the maritime law of nations. ${ }^{1}$

Men of different nations engage in the traffic of the sea and serious problems arise in this sea-traffic because of the conflicting interests of the diverse nationalities. Since the use of the sea, subject to occasional exceptions, is regarded as the common right of all mankind, the settlement of the conflicting interests which may arise by a resort to force is inconclusive and unsatisfactory, for the result may be wholly at variance with the justice of the opposing claims. Furthermore, the enjoyment of the resources of the sea may be denied, in a varying degree, both to the disputants and to those disinterested in the controversy. Consequently, in the service of the best interests of all who use

1 Richard Zouche, considering the "Jurisdiction of the Admiralty of England," pg. 8, declares that both common and statute laws of England take notice of the LAW MERCHANT, and leave the causes of merchants to be decided by the rules of that law, which, " as it is part of the law of nature and of nations is universal, and one and the same in all countries of the world." 
the sea, certain principles of justice were necessarily accepted at an early stage in sea-faring, as governing particular circumstances. Gradually, from these fundamental principles, an extensive body of maritime law was developed, occupying an important position in the law of nations. In discussing this early phase of the inception and development of law binding upon different nations, Phillipson declares that the principles of equality, reciprocity, and subservience to the law were not then as explicit and as firmly established as they are now, yet to admit this is not to imply the admission that international law then was a nonentity, but simply to concede that it had not the breadth, the completeness, the firm basis, the scientific coordination of modern law. (Phillipson, "International Law and Custom of Ancient Greece and Rome," Vol. I, 60.)

Because of the widely divergent interests involved, the conduct of commerce must be regulated by law, whether the trade is national or international. The usages of the sea which develop, termed sea-laws by the writers on maritime law in the sixteenth century, may be aceorded the force of customary law; either by the resolutions of a convention of merchants and shippers, as illustrated by the Laws of Wisby, or, like the Laws of Oleron, by the judgments of a maritime court. Such customary law may be supplemented or superseded by the statutory provisions of any sovereignty, though such enactments may exercise no effect upon that part of the customary maritime law which has been embodied in the law of nations, unless it is subsequently received as law by the various maritime states in their mutual relations. Clearly no single nation can change the law of the sea. That law is of universal obligation, and no statute of one nation can create obligations for the whole world. Like all the law of nations it rests upon the consent of civilized communities, accorded force, not because it is prescribed by any superior power, but because generally accepted as a rule of conduct. Whatever its origin, whether in the usages of navigation or in the ordinances of maritime states, or in both, it has become the law of the sea only by the 
concurrent sanction of those nations which constitute the commercial world.

"Many of the usages which prevail, and which have the force of law, doubtless originated in the positive prescriptions of some single state, which were at first of limited effect, but which when generally accepted became of universal obligation. 'The Rhodian law is supposed to have been the earliest system of marine rules. It was a code for Rhodians only, but it soon became of general authority, because accepted and assented to as a wise and desirable system by other maritime nations. The same may be said of the Amalphitan table, the ordinances of the Hanseatic League, and of part of the marine ordinances of Louis XIV. They all became the law of the sea, not on account of their origin, but by reason of their acceptance as such. It is evident that unless general assent is efficacious to give sanction to international law, there never can be that growth and development of maritime rules which the constant changes in the instruments and necessities of navigation require." ("The Scotia," 14 Wallace 170; Moore, "Digest of International Law," I, 3.) ${ }^{1}$

Maritime law must not be considered solely as the law of a particular country but as a part of the general law of nations; including "jurisdiction of all things done upon or relating to the sea, or, in other words, all transactions and proceedings relating to commerce and navigation, and to damages and injuries upon the sea." (Jervey vs. The Carolina, 66 Federal 1013. $)^{2}$

1 Instances might be multiplied wherein an independent sovereign accepted as binding upon his courts certain maritime laws enunciated by another sovereignty. An early example arises in the ordinance of Charles $\mathrm{V}$ of France (1364), admitting Castilians to trade within the ports of Leure and Harfleur, and stipulating that their causes should be adjudicated in accordance with the Laws of Oleron; "selon les coustumes de la mer et les droiz de Layron (Oleron) dehors." Twiss, "Black Book of the Admiralty," II, lxiv.

2 "Maritime law is entirely distinct from the law of the land. It is and always has been a distinct and separate jurisprudence. But though relating to the sea, and radically different in some respects from the con- 
Maritime law had its inception in the necessity for an equitable regulation of the traffic on the common highway of nations. Occupying thus a distinctive domain, special tribunals were established for its administration distinct from those which consider and determine questions according to the ordinary law of the land. Such tribunals were created in the early stages of maritime development, the principles underlying the judgments rendered by these judicial bodies serving to amplify the provisions of the maritime law as it gradually acquired a more comprehensive character. Quite naturally, the necessity for an adequate body of maritime law was first apparent among those nations which enjoyed the highest development of water-borne commerce, whether on the open sea, or on inland waterways, utilized as channels of international communication.

The navigation laws of Babylon recognized that the Euphrates constituted a waterway within the latter category. As a great highway, carrying the trade of the Oriental nations, its importance was comparable to that of the sea. Conflicting interests inevitably clashed, and the effort to render justice in the disputes which arose produced a noteworthy body of law. (Pardessus, "Collection de lois maritimes," I, 20.)

Among the Greeks, in a similar manner, maritime commerce and navigation were at an early epoch in an advanced state of development, and, as a consequence, many regulations in regard to maritime practices developed, contemporaneously. (Phillipson, "The International Law and Custom of Ancient Greece and Rome," II, 368.)

ception of municipal law, it has always been the attribute of some sovereignty, and enforced in the courts of such sovereignty." The Unadilla, 73 Federal, 350 .

"The maritime law is only so far operative as law in any country as it is adopted by the laws and usages of that country. In this respect it is like international law, or the laws of war, which have the effect of law in no country any further than they are accepted and received as such; or like the case of the civil law, which forms the basis of most European laws, but which has the force of law in each state only as it is adopted therein, and with such modifications as are deemed expedient." The Lottawanna, 88 United States 558. 
In the Middle Ages, Venice still further illustrates this inevitable development of law in accordance with the progress of commerce. Within thirty years, the necessities of Venetian sea-trade produced three distinct maritime statutes. Each succeeding statute retained only those provisions of the former code, sometimes with marked revision, which were still applicable to the immediate necessities, while new regulations amplified or supplanted the former provisions to meet the problems resulting from the rapidly expanding maritime interests. (Ashburner, "Rhodian Sea-Law," pg. xlvii.)

The lethargy of Rome, with respect to maritime legislation, stands in direct contrast, and is to be explained by the fact, already mentioned, that the Romans felt indisposed to venture upon overseas enterprise, until a late period of national development. It is significant that the first instance within Roman law where the freedom of the seas is declared common to all nations occurred in the Institutes of Justinian.

"By the law of nature, then, the following things are common to all men; air, running water, the sea, and consequently the shores of the sea. No one, therefore, is debarred from approaching the sea-shore, provided only he does not harm houses, monuments, or buildings, because these are not subject to the law of nations as the sea is." ("Institutes of Justinian," Bk. II, Tit. I, sec. 1.) $)^{1}$

A consideration of the various noteworthy codes of early sea-law, which frequently were accorded the distinction and force of international law, through acceptance by independent nations as a binding declaration of the law governing controversies arising over maritime affairs, discloses many instances of similarity in important provisions. To ascertain the relationship, however, between maritime laws appearing under

1Abdy and Walker, commenting on Schrader's rendering of this passage, "because these are not the common property of the whole world," state that "the use of the open sea is common to all the world; the use of the seashore and that portion of the sea close to the shore is, by universal agreement, public; that is, open to all members of the nation occupying the adjacent country, but not open to the world in general." 
diverse sovereignties and at different epochs; to trace the ultimate source of a specific regulation, frequently becomes an almost insuperable task. To state, conclusively, that one body of law derived much of its inspiration from another, because of the similarity existing between certain provisions, is misleading, since this similarity may well be due, not to imitation, but to the innate, universal justice of the particular regulations.

Early sea-laws sought to prevent the overloading of silips. The Statute of Ancona, and the Consulate of the Sea, provided that a mark should be placed on the exterior of the hull to indicate the maximum load which the vessel was entitled to carry. (Ashburner, "Rhodian Sea-Law," pg. clvii.) Similarly, in 1876, the Merchant Shipping Act of Great Britain prescribed the universal application of the Plimsoll mark to all vessels within British jurisdiction, as a means of indicating the limit to which a ship might be safely loaded. Were it necessary to determine the source of the British regulation, could it be conclusively stated to be within the Statute of Ancona, the Consulate of the Sea, or other early law of the sea?

The importance of considering and comparing these primitive maritime laws arises from the fact that many of the principles therein enunciated have survived the attrition of centuries, thus demonstrating their inherent soundness. Whether conceived independently, or handed down by adoption and adaptation they have ultimately become incorporated in modern maritime law in a form consistent with the present necessities of commerce. The existence of sea-laws during the primitive phases of maritime activity clearly demonstrates that the necessity for the adequate government of commerce by law was early recognized, and that the degree of legal development was commensurate with the expansion of maritime interests. Though certain of these early sea-laws were not framed, specifically, to assure the unrestrained navigation of the sea, yet, in effect, this liberty was attained, since these regulations were designed to prevent anarchy on the common highway of nations. Only the 
presence of law among the conflicting interests of the various nationalities could secure liberty and an approximate equality of opportunity for all.

Development of Sea-Law within the Mediterranean.The sea-laws of Rhodes constitute the earliest, extant system of maritime law, being compiled during the ninth century в. с. (Pardessus, "Collection de lois maritimes," I, 35, 209; Text of the Rhodian Law, I, 231.) （Selden, "Mare Clausum," Lib. I, cap. 10.) (Phillipson, "The International Law and Custom of Ancient Greece and Rome," II, 379.) ${ }^{1}$

Since antiquity, merchants from all quarters of the known world had met on the island of Rhodes, where an extensive and lucrative trade developed. (Pardessus, "Collection de lois maritimes," I, 153; quoting Isidore of Seville, "Originum," Lib. IV, cap. xvii, De legibus rhodiis.) The resources of Rhodes increased with this expanding trade, affording opportunity for a further extension of Rhodian influence throughout the Eastern Mediterranean; while the necessities of this trade demanded an adequate body of law to ensure protection for the various interests. Rhodes ultimately became the chief naval power of the Egean Sea, reaching its maximum strength in the years immediately following the Second Punic War, and this maritime code was extended to regulate all Grecian commercial relationships. (Torr, "Rhodes in Ancient Times," pg. 40.) (Phillipson, "The International Law and Custom of Ancient Greece and Rome," II, 379.) (Pardessus, "Collection de lois maritimes," I, 35.)

But the general acceptance of the comprehensive Rhodian Law was not due solely to the development of naval power, nor to the great influence exerted by Rhodes in maritime enter-

1 While admitting the existence of the Rhodian Sea-Law at a very early date, Ashburner objects to the view that it was framed into statutes as early as the ninth century, declaring that "of the maritime law of the Mediterranean states, no communal statute goes back before the middle of the twelfth century, while the Rhodian Sea-Law was framed (by a private hand) about 600 or $800 \mathrm{~A}$. D., that is, from three to five hundred years previously. However, it is certain that the law existed long before it was put into these statutes." "Rhodian Sea-Law," pg. cxv. 
prise, but must be ascribed largely to the evident justice of the provisions of the Law, which commended them to people of diverse nationalities, securing their ultimate adoption. Long after Rhodian commercial supremacy had ceased to exist, the provisions of the Law endured. At a later time the Rhodian Law furnished many of the principles incorporated in the Roman Maritime Law, while in certain parts of the Mediterranean it represented the living law as late as the fifteenth century. (Phillipson, "The International Law and Custom of Ancient Greece and Rome," II, 380.) ${ }^{\mathbf{1}}$

It is noteworthy that certain principles expressed in the Rhodian Law appear at subsequent periods in the customary law or statutes of various governments; as in the Roman Law, the Byzantine Law, the Rolls of Oleron; but this similarity does not necessarily afford conclusive evidence of common derivation from the Rhodian Law. The likeness may well arise through an independent development of justice, rather than by acceptance or adaptation of the Rhodian Sea-Law to fulfill the necessities of a later age. ${ }^{2}$ (Ashburner, "The Rhodian SeaLaw," pg. cxv.)

1 Selden, "De dominio maris," Bk. I, cap. 10, and Zouche, "The Jurisdiction of the English Admiralty," pg. 3, agree that the Rhodian Sea-Law was afterwards inserted into the body of the Roman Civil Law by the Emperor Justinian.

Ashburner, "Rhodian Sea-Law," pg. xlix, notes that in none of the manuscripts is the substance of the Rhodian Sea-Law changed. In respect to its legal effects, it remained substantially the same from beginning to end.

2 Selden, "Mare Clausum"; Azuni, "Maritime Law"; and Kent, "Commentaries," II, 215, 511, agree in declaring that Rome adopted the maritime law of Rhodes, but this statement is difficult of proof.

Benedict, Yale Law Review, 1909, pg. 232, states that within the Roman code there is only one stipulation which can be said with assurance to be derived from the Rhodian Sea-Law, the authenticity being supported by the statement of the compilers of the Institutes of Justinian. It appears in practically all the important mediæval sea-laws and provides: "'if for the sake of lightening a ship in danger at sea, an ejection shall take place, that which was given up for the general good, shall be replaced according to the proportion of what was saved, by a general contribution." To be operative it was necessary to prove that the ship was in the immediate danger of perishing with the cargo; that the decision of the Captain to eject a portion of the cargo was preceded by a conference with 
If the Rhodian Law was in fact incorporated in that of Rome, it was not transferred in its original form or language; consequently it is impossible to determine what provisions are original and what constitute later additions or modifications. In the present survey, however, the interest in the Rhodian Law and other early codes chiefly centers in the influence which they exerted in securing the unrestricted navigation of the sea.

It was from Rome, in the period when the Imperial jurists enjoyed a three-fold duty as legislators, expounders, and administrators of the law for the whole civilized world, that the first positive declaration of the free and common enjoyment of the sea was enunciated, exhibiting a liberal spirit and a development toward a clearer appreciation of international rights and obligations, in profound contrast to the sea-trading laws of Carthage which had formerly restricted maritime enterprise throughout the western Mediterranean. ${ }^{1}$

The expansion of the Roman Empire until it eventually embraced the Mediterranean, transforming its political character to that of an inland sea, might warrant the interpretation that this statute comtemplated freedom of navigation on the high seas solely for the nationals of Rome. The extension of Roman maritime enterprise, however, to the Euxine, Arabian, the North Sea, and upon the Atlantic, clearly demonstrates that umrestricted use and intercommunication by various nationalities was intended. The beneficent effect of such a body of law

his officers and crew; and that the ship and cargo were saved by this means.

Schomberg, "Laws of Rhodes," pg. 38, states that both William the Conqueror and Henry I accepted this principle of the Rhodian Law relating to ejections, incorporating it within the statutes of the realm.

Twiss, "Black Book of the Admiralty," Vol. I, lxx; text of "Law of Ejection," Vol. I, pg. 127.

1 Montesquieu, "Spirit of Laws," Bk. XXI, chap. xi; "The law of nations which prevailed at Carthage was very extraordinary; all strangers who traded to Sardinia and toward the Pillars of Hercules this haughty republic sentenced to be drowned. . . Being mistress of the coasts of Africa which are washed by the Mediterranean, she extended herself along the ocean." Pardessus, "Collection de lois maritimes," I, 53; text of the "Roman Law," I, 85. 
is increased manifestly when it is adopted and administered by the governments of other independent nations. After the downfall of the Roman Empire, the states of Southern Europe continued to observe the principles proclaimed in the Institutes of Justinian, modified in conformity with the existing maritime conditions. In aequiring the eharacter of international law, through general acceptance, it assured better facilities and freedom for all who engaged in enterprise on the world's waterways. (Twiss, "Black Book of the Admiralty," II, pg. $\mathrm{xl}$.)

No eommunal statute, comprising the maritime law of the Mediterranean states, appears to antedate the Ordinances of Trani (compiled 1063 A. D.), but since the acceptance of this date as authentic is subject to serious doubt, (Ashburner, "Rhodian Sea-Law," pg. cxv.), the most ancient extant source of modern maritime law, beyond question of dispute, is embodied in the Tables of Amalfi, which undoubtedly perpetuated certain institutes of Justinian. ${ }^{1}$

The authority of this code was acknowledged throughout these seas by all maritime states until the lapse of approximately two hundred years had brought about changed conditions, and the development of more powerful states; causes which contributed to render the Amalphitan Law inapplicable. ${ }^{2}$

1 "With regard to the 'Tabula Amalphitana,' recently discovered, critics agree in considering the Latin chapters of it to be of an earlier date than the Italian chapters, and there is nothing in the Latin chapters which precludes referring them to the eleventh century, when there is no doubt that Amalphi was in a state of high commercial prosperity." Twiss, "Black Book of the Admiralty," IV, cxxvii.

2 The following comprise the more important mediæval sea-laws which appeared in the Mediterranean, and may be consulted in Pardessus, "CoIlection de lois maritimes," 6 volumes, as noted:

1. "Ordinances of Trani," 1063 A. D., Vol. V, 237-251.

The date given is disputed, but this is the date appearing in the text. Ashburner, "Rhodian Sea-Law," pg. cxxi.

Pardessus gives both the French and Italian texts.

These Ordinances are a series of decisions made by the Consuls of the Sea; those most versed in maritime affairs; in the city of Trani on the Adriatic, and are considered by Twiss to be the most ancient, extant source of modern Maritime Law. Twiss, "Black Book of Admiralty," II, xliii-iv. 
As the authority of the Law of Amalfi declined, various Mediterranean states discordantly attempted to administer justice, and the resulting chaotic condition continued until the Consolato del Mare gained an authority even greater than that formerly enjoyed by the Tables of Amalfi. The Consulate of the Sea marks the highest development of the mediæval statutes, regulating traffic on the seas, destined to be produced upon Mediterranean shores. This celebrated collection of maritime ordinances and customs was first published at Barcelona (1494), and embodies the rules observed by the commercial judges (Consuls), throughout the Mediterranean, in their dispensation of justice. Within the consular court at Barcelona, these Customs of the Sea were accorded the force of law. (Twiss, "Black Book of the Admiralty," II, lxvi.)

2. Tables of Amalfi, consult Ashburner, "Rhodian Sea-Law," pg. cxx.

The Latin part of these Tables may have existed since the period when Amalfi was an independent duchy; that is prior to 1131 A.D.

3. "Ordinance of Barcelona," 1258 A. D., Latin text, V, 339-46.

4. "Statutes of Cattaro," early fourteenth century, Latin text, V, 17, 96-98.

5. "Statutes of Pera," early fourteenth century, Latin text, VI, 587.

6. "Statutes of Zara," early fourteenth century, Latin text, VI, 605-22.

7. "Statutes of Ancona," 1397 A. D., French and Italian text, V, 116198.

8. "Customs of Bari," Latin text, VI, 625-26.

9. "Consulate of the Sea," end of the fourteenth century.

Belonging to the second stage in the history of maritime law.

Text given in: "Pardessus," II, 1-49; 49-368. Twiss, "Black Book of the Admiralty," Vol. III.

10. "Maritime Law of Venice," Pardessus, Vol. V, chapter xxix, pg. 1-98.

The dates at which these various laws were put in statute form appear in many instances within the manuscript and may be taken in most instances as authentic, except in the doubtful case of the "Ordinances of Trani," 1063 A. D. Ashburner, "Rhodian Sea-Law," pg. cxx.

1 In the endeavor to dispel the confusion which had arisen following the abandonment of the Tables of Amalfi, a general assembly was called, and, with the Tables of Amalfi as a basis, proceeded to digest into one code the maritime laws of the different communities. Regulations from the sea-codes of Aragon, Barcelona, Genoa, Marseilles, Morea, Pisa, and Venice were thus embodied in the Consulate of the Sea. Zouche, "The Jurisdiction of the Admiralty of England," pg. 5.

Ashburner, "Rhodian Sea-Law," pg. exx, expresses a decidedly contrary opinion, describing the Consulate as a very verbose document erected around the obscure nucleus of ancient custom, with every rule accom- 
Many of the customs embodied were derived from very early practices, and the influence exerted was such that for a long period the Consulate was recognized as the law governing prizes in many states, including England. (Robinson, "Consulato del Mare relating to Prize Law.") (Pardessus, "Collection de lois maritimes," II, 1-368.) ${ }^{1}$

But, being designed to govern maritime controversies arising in the Mediterranean, the Consulate was seriously limited in acquiring more extended application, and, for this reason, the mediæval sea-laws instituted upon the Atlantic gained preeminence. The publication of the Rolls of Oleron had an important incidental influence, disassociated from the wide-spread acceptance accorded them, since the existence of these sea-laws demonstrated to the maritime world that an extensive shipping enterprise was being developed beyond the Pillars of Hercules. Maritime interest, concentrated no longer in the Mediterranean, was carried out upon the western sea, where soon it was to enjoy unprecedented opportunity.

Similarly with all the sea-laws developing prior to the discovery of America, the Laws of Oleron sought to protect both private and national interests engaged in maritime undertakings, and to secure enjoyment of the seas. The Laws instituted at Oleron gained the esteem and acceptance of other sov-

panied by elaborate reasons, mostly futile; the greater part of the text comprising ingenious suggestions by learned men, and concludes by declaring that it is doubtful if its stipulations were ever observed by mariners or enforced in any court.

1 Since serious limitation to the right of the unrestricted navigation of the open sea may arise through belligerent activity, a case, arising in the latter part of the twelfth century (1164 A.D.), may be cited as evidence of the early endeavor to protect neutral ships in the exercise of this right, provided such vessels were not engaged in the service of the enemy; the right of detaining a neutral vessel and confiscating any enemy property found on board being recognized by Christian and Mohammedan powers, alike. Consequently, when the Pisans, being at war with Genoa, seized a cargo of alum aboard an Egyptian ship, alleging that it was the property of Genoese merchants, they were constrained to release it upon subsequent proof that it was neutral property. Pardessus, "Collection de lois maritimes," II, cxxii. 
ereignties, because of their reason and equity. (Twiss, "Black Book of the Admiralty," Vol. I, pg. 89, presents the text of the Laws of Oleron.)

Conflicting opinions exist respecting the origin of the Rolls of Oleron, and particularly concerning the interest which Richard I had in their preparation and publication. Schomberg declares that Richard I, while returning from the Holy Land (1194), stopped for a period on the Island of Oleron in the Bay of Biscay, which had served as an important base for the great fleet which he had despatched to the eastern Mediterranean during the second year of his reign. Realizing the need of a maritime code for that region of the world, inasmuch as the Consulato del Miare and the Amalphitan Table applied chiefly to the conditions existing among the states on the Mediterranean, he commanded that one should be prepared. (Schomberg, "Laws of Rhodes," pg. 54.)

Sir John Burroughs, at an earlier date, expressed a similar conviction (Soveraignty of the Seas, pg. 17), declaring that "the famous Lawes of Olleron (which after the Rhodian Lawes were antiquated and absolete) have now well neare 500 yeares been received by all the Christian world for regulating Sea affaires, and deciding maritime controversies, were first declared by King Richard the First (a King of England) at his returne from the Holy Land, and by him caused to be published in the Isle of Olleron."1

But Sir Travers Twiss rejects this view, showing that the Rolls of Oleron are not ordinances, but judgments, and consequently that their character does not sustain the supposition that Richard I caused them to be prepared and published. Admitting that Richard I, upon his return to England, may have sanctioned the observance of these judgments, which

1 A memorandum of 12 Edward III states that the laws and statutes "were corrected, interpreted and declared, and were published in the Island of Oleron by Lord Richard, formerly King of England, in his return from the Holy Land" to maintain peace and justice amongst people of every nation passing through the Sea of England. Twiss, "Black Book of the Admiralty," Vol. I, lvii. 
had already been published, Twiss concludes; "We know not how it happened that Eleanor of Guienne or Richard I of England was able to collect together a body of maritime judgments, which proved to be so faithful and so complete a mirror of the customs observed in the trade between the ports of the Atlantic sea-board of France and those of the rest of Europe, that they have been accepted as law for centuries in the ports of the North Sea, and of the Baltic equally as of the Mediterranean Sea, unless it was that the maritime court of Oleron was in advance of other courts in keeping a careful record of the decisions of its judges, and so possessed a body of judgemade law which would have been songht for in vain in the neighboring courts of Bordeaux and of Rochelle." (Twiss, "Black Book of the Admiralty," IV, pg. exxix.)

Certain similarities, existing between the Rolls of Oleron and the Rhodian Law, have given cause for speculation and debate among publicists in the endeavor to determine whether the stipulations under examination were derived from the earlier code or were the result of an independent development. The eighth article of the Rolls of Oleron exhibits a close similarity to the provision of the Rhodian Law, respecting an ejection of cargo to survive a storm at sea, stipulating: "Also, a shyp be freyght to goo to London or els where and chaunceth the tourment taketh it in the see, and it cannot escape but yf the goodes be cast out, the maister ought to say, "Nates, it behoveth to cast over these goodes to save the shyp." "Continuing, the law provides that the master and three of his companions must take oath that this act was necessary to save the ship, goods cast over being appraised at the value of those saved, and indemnified by a pro rata assessment on the salvaged goods; for, "when it happens that they make jettison from a shyp, it is well written at Rome that all the merchaundise and goodes contained in the ship oughte to contribute pounde for pounde." (Twiss, "Black Book of the Admiralty," Vol. I, pg. $97,127.)^{1}$

1 Other articles in the Rolls of Oleron which are in accord with the 
The consideration of the historical origin of the Rolls of Oleron becomes of secondary importance in comparison with the prestige accorded these judgments through their general adoption by other maritime states. As the wisdom and justice of the provisions within the Rolls of Oleron, regulating the traffic of the seas, became more generally understood and appreciated, various European sovereigns admitted the operation of these laws within the maritime courts of the realm, with the result that the Rolls of Oleron aequired the authority of international law.

As early as the thirteenth century, Alphonso $\mathrm{X}$ of Castile established the Rolls, as a body of positive law for the settlement of disputes arising in all maritime affairs; the judges being specifically directed to observe these regulations in adjudicating causes between merchants and mariners. (Twiss, "Black Book of the Admiralty," Vol. I, lxviii.)

In 1364, Charles V of France, upon admitting the Castilians to the trade of the ports of Leure and Harfleur, provided that all disputes arising should seek redress according to the Laws of Oleron; "selon les coustumes de la mer et les droiz de Layron (Oleron) dehors." (Twiss, "Black Book of the Admiralty," Vol. I, lxiv.)

In England, the maritime (Admiralty) courts of the realm recognized the Laws of Oleron as binding, beginning with the twelfth year of the reign of Edward III. (Twiss, "Black Book of the Admiralty," I, lxi.) ${ }^{1}$

Rhodian Law provide: (Art. 26) "where a ship is engaged entirely by a mercliant, the master cannot take any thing else on board, except necessary provision for the voyage," similar to Art. xxii of the Rhodian Law; and (Art. 25.), " if a merchant is disappointed in getting a ship (i.e. the master does not keep his agreement to carry the goods), then the merchant can secure damages from the master," similar to Art. xx of the Rhodian Law. Pardessus, Vol. I, pgs. 248-249; Twiss, "Black Book of the Admiralty," Vol. I, pgs. 121, 123.

1 Respecting the administration of maritime law by the courts of England, Twiss considers that there is unimpeachable evidence that before the Admiralty jurisdiction was established in England; that is, before causes involving contracts and torts on the high seas were assigned to 
Similarly, the Judgments of Damme, which were observed in Damme, Brugge, and elsewhere in Flanders during the fourteenth century, followed explicitly the twenty-four articles of the Rolls of Oleron, while elsewhere throughout the Baltic, the important trading cities incorporated these provisions within their communal maritime law. (Twiss, "Black Book of the Admiralty," Vol. I, lxiii (note 3), 89 ; Vol. II, xlvii.) (Pardessus, Collection de lois maritimes, Vol. I, 355, (text) 371.) Twiss mentions a curious Flemish text of the Rolls of Oleron, known as the Purple Book of Bruges; preserved in the archives at Bruges; prepared in the fourteenth century, making certain changes in the names of the ports. Indeed, throughout the countries bordering on the Atlantic Ocean and the North Sea, the Judgments of Oleron were observed as the law of the sea, maintaining an authority comparable to that exercised in a former time by the Rhodian Law. (Twiss, "Black Book of the Admiralty," Vol. II, xlix.)

The Laws of Wisbuy, developing within the confines of the Baltic, constitute a partial exception to the general authority of the Rolls of Oleron. A portion of these laws have been accorded an antiquity greater even than those of Oleron. Between these two codes there exists a notable resemblance, particularly in the provisions of the following articles:

the Admiralty Court; that there were courts in England, which administered the customary marine law equally to the foreign and British merchants and mariners. The Domesday of England discloses that in certain of the maritime boroughs there were courts which sat from tide to tide to administer the customary law of the sea to passing mariners. The Domesday of Ipswich is evidence that this practice was observed in the time of Richard I, the earliest extant record of any court which sat for this purpose in England. This court sat daily in the borough of Ipswich, administering the maritime law between strangers, and between natives and strangers. Twiss, "Black Book of the Admiralty," Vol. II, viii, xxxvii.

According to Twiss, the ordinance of Edward III marks the true starting point of the jurisdiction of the Admiralty court in civil suits:

"Item, any contract made between merchant and merchant, or merchant and mariner beyond the seas, or within the fflood marke, shal be tryed before the Admirall and noe where else by the ordinance of the said King Edward and his lords." Twiss, "Black Book of the Admiralty," Vol. I, part C, Art. 21. 


$\begin{array}{ll}\text { Oleron. } & \text { Wisbuy } \\ 1,2 . & 13,14,15 . \\ 7 . & 19 . \\ 8,9,10 . & 12,20,21,28 . \\ 14 . & 26,50,67,70 . \\ 18 . & 31 . \\ 19 . & 32 .\end{array}$

(Pardessus, "Collection de lois maritimes," Vol. I, 425; text, Vol. I, 463.) (Schomberg, "The Laws of Rhodes," pg. 66.)

Twiss considers that the maritime laws of Wisbuy may be classed. with the Judgments of Oleron and with the Customs of the Sea, which were collected and digested into the Consulate of the Sea of Barcelona, thereby forming a continuous chain of maritime law, extending from the easternmost parts of the Baltic, through the North Sea and along the coasts of the Atlantic to the Straits of Gibraltar, and thence to the furthest eastern shores of the Mediterranean. (Twiss, "Black Book of the Admiralty," Vol. IV, xxvi.) ${ }^{1}$

While controversies respecting the origin of the various sealaws lead to interesting discoveries, the real significance arises from the wide-spread acceptance accorded these salutary laws, and the beneficial influence exerted by them over commerce in

1 Welwood, "Abridgement of all Sea-Laws," pg. 100, asserts that the Laws of IVisbuy, amongst the nations beyond the Rhine, are identical with the Laws of Oleron, being translated into Dutch for the use of the sea in those regions.

Zouche, "The Jurisdiction of the Admiralty of England," pg. 6, endorses this conviction.

Twiss, however, considers that the Laws of Wisbuy are composite in origin, declaring: "that it is now placed beyond doubt by the researches of learned scholars of the north of Europe, that the so-called maritime laws of Wisbuy are not all of Gothland origin, but are a compilation of laws derived from three distinct sources, which may be fitly described as a Baltic source, a Flemish (or Gascon) source, and a Dutch source.... Articles 15-19 of the Laws of Wisbuy are of Flemish (or Gascon) origin and are beyond all question a Saxon or Low-German version of the Judgements of Oleron, translated either from the so-called Sea-Laws of Flanders, which are a Flemish translation of the 'Jugements d'Oleron,' or, immediately, from a Gascon text." Twiss, "Black Book of the Admiralty," Vol. IV, pg. xxvii. 
all regions of the sea. Moreover, with the closing years of the fifteenth century, maritime law, as developed throughout the European coasts, was destined to exercise a still more comprehensive influence over the waterways of the world. 


\section{CHAPTER IV}

DISCOVERY EXTENDS MARITIME ENTERPRISE THROUGHOUT THE SEVEN SEAS

The unparalleled voyages of discovery during the fifteenth and sixteenth centuries, epitomized in the high achievements of Vasco da Gama, Magellan, and Columbus, startled Europe into unprecedented activity in maritime affairs. As the possibilities for commercial and industrial development within the newly found continents and the islands of the sea came to be fully comprehended, maritime enterprise was extended throughout the seven seas, and flourished upon the lucrative trade with distant lands.

Wherever commerce ventured, law, the maritime law as received in Europe, followed, until it embraced the world, serving as a protection for the various interests involved and thus tending to preserve the free enjoyment of the seas.

Important incidents in the development of sea-borne trade during the preceding centuries had comprised: The expansion of the Roman Empire until it had absorbed all maritime states bordering on the Mediterranean, thereby bringing a world commerce under the control of a single nation; the destruction of Roman power in the Occident through barbarian invasion, causing the immediate decay of commerce and of the attendant benefits of civilization; and the Crusades, exhibiting a significant union of all Christendom in mutual endeavor, and, incidentally, reviving active interest in maritime affairs. All these incidents of maritime progress, however, were concerned chiefly with the development of Mediterranean commerce. Maritime enterprise and the influence of maritime law did not assume a world-wide character until the discovery of America and of the all-sea route to India disclosed illimitable opportunity. 
Though noteworthy voyages across the North Atlantic, achieved as early as the tenth century, are credited the Norsemen, yet these exploits exercised no apparent influence upon the maritime destinies of the states of Southern Europe, which still constituted the civilized world. ${ }^{1}$

The Crusades afforded opportunity, the first notable opportunity in centuries, for an expansion of maritime trade. This trade consisted not alone in the transport of the Crusaders and of their necessary supplies, but continued to develop, despite the ultimate abandonment of the endeavor to recover the Holy Land, since there had been opportunity for those dwelling in the Occident to become aware of the rich products of the East, and the demand for these products increased rapidly throughout Europe in the years immediately following the Crusades.

The Growth of Moslem Power Compels Maritime Discovery. - The repulse of the Christians had resulted in a corresponding increase of the Moslem power upon the eastern Mediterranean, and this power was exercised to the serious derangement of the European trade routes with the Orient. The demand for the goods of the Far East among the states of Europe was becoming all the while more insistent, and yet the conditions under which this trade was carried on had become so serious as to amount to a virtual prohibition. The seizure of the straits lying between Europe and Asia by the Ottoman Turks compelled the immediate search for an all-sea route to the Indies.

Constantinople, the most resplendent city of all Christendom, had fallen under the onslaught of the Turks (1453), and with it passed the control of the Bosphorus and the Dardanelles; a control which denied to the ships of Christian states access to the rich trade of the Black Sea countries and the region beyond

1 Fiske, "Discovery of America," Vol. I, pg. 101, states that there is no doubt that toward the end of the tenth century people from Iceland founded a colony in Greenland, and that ships from Greenland, a few years later, made voyages along the American coast, chiefly for the purpose of cutting timber, and in all probability voyaging as far south as Massachusetts Bay, since Icelandic chronicles have preserved accounts of these voyages, 
the Caucasus. For more than a century the Turks had been stifling Christian trade within the eastern Mediterranean, especially limiting the extension of this trade into the Far East. The fall of Constantinople, with the immediate exercise of Ottoman dominion and exclusion over the Black Sea route, prohibiting further traffic in this direction and menacing all the existing trade routes with the Orient, threatened the continued prosperity and even the existence of the Mediterranean states.

At this crisis, the possibility of an all-sea route to the Indies, avoiding not only the burdensome restrictions of the Ottoman Turks, but also the great cost, danger, and delay of land carriage necessitated by all the existing routes, employed hitherto, directed an intense and increasing interest toward maritime discovery.

Already Prince Henry the Navigator, son of King John of: Portugal, had conceived the idea of reaching the Indies by circumnavigating Africa, and, in anticipation of the ultimate success of his venture, had besought the Pope, as early as 1441, for the concession of all lands, in perpetuity, which should be discovered while in pursuit of this objective.

Not until the voyage of Bartholomew Diaz, despatched by King John of Portugal, August, 1486, did the possibility of reaching the Indies by this southerly route appear reasonably certain. Diaz succeeded in rounding the Cape of Good Hope, but failed to persuade his sailors to pursue the voyage further; so that the ultimate vindication of Prince Henry's design suffered delay until the triumphant voyage of Vasco da Gama (1497).

Ignorance of Earth's Actual Form Restricts Discoverery. - The universal ignorance with regard to the actual formation of the earth, whether flat or globular, operated as a serious deterrent to the successful completion of voyages of discovery. Expeditions sent out by King John of Portugal returned shortly with alarming reports of impassable waters and noxious airs which threatened the very lives of the explorers.

Two conflicting theories respecting the earth's formation en- 
joyed scientific support. The theory of Pomponious Mela, adopted by Prince Henry the Navigator in his project for reaching the Indies by circumnavigating Africa, sought to demonstrate that the earth consisted of the continents of Asia, Africa and Europe, completely surrounded by the limitless expanse of ocean.

In opposition, the theory of Aristotle continued to receive substantial recognition. Centuries before, Aristotle had declared that the earth was globular in form and that, consequently, the shores of Asia might be attained by voyaging unswervingly westward from the Pillars of Hercules.

Fiske ridicules the popular idea that Columbus originated the theory of the spherical form of the earth, by direct reference to the existing facts; declaring that "a gross historical blunder ... vitiates most of the talk and a good deal of the popular writing about Columbus. It is evidently supposed by many people that the spherical shape of the earth was a new idea in his time; some seem to think that he originated it, or that it was opposed and ridiculed by most of his learned contemporaries, and especially by the clergy. Nothing could be further from the truth. The globular form of the earth was proved by Aristotle and after him accepted by nearly all the ancient philosophers; and, seventeen hundred years before Columbus, the geographer Eratosthenes declared that it would be easy enough to sail from Spain to India on the same parallel, were it not for the vast expanse of the Atlantic Ocean." (Fiske, "Orations," pg. 105.) ${ }^{1}$

1 "The popular notions that the waters of the tropics boiled, that demons and monsters awaited explorers to the westward, and that the earth was a great flat disk, did not pass current among well-informed geographers. Especially since the revision of Ptolemy's works in the fifteenth century, learned men asserted that the earth was spherical in shape, and they even ealeulated its circumference, erring only by two or three thousand miles. It was maintained repeatedly that the Indies formed the western boundary of the Atlantic Ocean, and that consequently they might be reached by sailing due west, as well as by travelling eastward; but at the same time it was believed that shorter routes might be found northeast of Europe, or southward around Africa." Hayes, "History of Modern Europe," I, 50. 
The Voyage of Columbus. - These conflicting theories continued unsettled, for, despite the support accorded them, none dared venture at any distance upon the western ocean to determine the actual situation. It was the imperative necessity of an unrestricted sea route to the Indies which compelled adventure upon the unknown waters of the Atlantic, and Columbus, profoundly convinced of the certainty of success, was, through his stimulating entreaties at the court of Ferdinand and Isabella, enabled to undertake the critical enterprise. ${ }^{1}$

Though failing in his avowed object, Columbus achieved a triumph, termed by Humboldt a conquest of reflection, for he dispelled the long-abiding fear which had deterred men from venturing on the vast expanse of the western ocean, and demon- . strated the limitless possibilities of sea-voyages. To this achievement there attaches greater significance than can be accorded to the discovery of the New World, if such discovery be considered simply as a territorial acquisition; for henceforth commerce and civilization were destined to penetrate the most remote regions of the world, no longer restrained by baseless and exaggerated fears.

Contemporaneous appreciation of the achievement of Columbus is well-expressed in the Bull of Alexander VI, addressed to King Ferdinand and Queen Isabella: "You chose our be-

The globe constructed by Martin Behaim, showing no large area of land between the western coast of Europe and eastern Asia (Cathai), with the exception of the island of Zipangu, serves as a further substan. tiation of the contention that Columbus was aware of the theory which accorded the earth a spherical form. Ravenstein, "Martin Behaim."

1 "In August, 1492, he sailed from Palos with 100 men in three small ships. . . After a tiresome voyage he landed (12 October, 1492) on San Salvador, one of the Bahama Islands. In that bold voyage across the trackless Atlantic lay the greatness of Columbus. He was not attempting to prove a theory that the earth was spherical - that was accepted generally by the well informed. Nor was he in search of a new continent. The realization that he had discovered not Asia, but a new world, would have been his bitterest disappointment. He was seeking merely another route to the spices and treasures of the East; and he bore with him a royal letter of introduction to the great Khan of Cathay." Hayes, "History of Modern Europe," I, 53. 
roved son, Christopher Colon, whom you furnished with ships and men equipped for like designs, so as to make diligent quest for these far-away, unknown countries through the sea, which hitherto no one has sailed; who, in fine, with divine aid nor without the utmost diligence sailing in the Ocean sea, as said, through western waters toward the Indies, discovered certain very far-away islands and even mainlands, that hitherto had not been discovered by others." (Extract from Bull of Alexander VI, "Inter Cætera," Blair, "Philippine Islands," Vol. I, pg. 98.)

The Era of Discovery.- The magnificent adventure of Columbus into the New World exerted an immediate stimulation upon all maritime states. Expeditions were fitted out and despatched upon distant voyages of discovery.

The necessity of securing unrestricted trade routes to the Indies, in order to avoid the impending, complete stagnation of sea-trade among the Mediterranean states, had compelled the undertaking of voyages of discovery over seas; but the unforeseen discovery of the New World, and the alluring possibilities of further development and discovery, aroused a sudden outburst of maritime activity, unparalleled at any former stage of commercial development.

Unfortunately for the Mediterranean states, already suffering the limitations imposed by the Ottoman Turks on the Oriental traffic, the opportunity for vast commercial development and expansion over-seas was confined, almost exclusively, to those nations advantageously situated on the Atlantic seaboard. Due to this mighty display of maritime activity, enterprise, following immediately in the wake of each successive discovery, penetrated every quarter of the globe. Within a single century, expeditions throughout the Americas and virtually throughout every region of the globe brought to Europe an augmented interest in ventures beyond the seas. ${ }^{1}$

1 Illustrating the profound effect, which the discoveries of Columbus, Cabot, Vasco da Gama, and the other mariners of the late fifteenth and 
The expedition of Vasco da Gama, seeking the all-sea route to India, exerted a stimulative influence upon the development of maritime enterprise, scarcely surpassed by the glorious achievement of Columbus. Setting sail from Portugal, July 9, 1497, at the command of the king, da Gama traversed the route first conceived by Prince Henry the Navigator, and explored, in part, by the earlier voyage of Bartholomew Diaz. Rounding the Cape of Good Hope, Vasco da Gama skirted the eastern coasts of Africa, crossed the Indian Ocean, and triumphantly entered the port of Calicut, on the western coast of Hindustan, early the following summer. Although Vasco da Gama had demonstrated the feasibility of an all-sea route to India; returning to Portugal laden with the rich products of the East which repaid the venture sixty-fold; yet the excessive length of this route appeared a serious objection to its general adoption, particularly as the idea persisted that a more expeditious course lay directly westward.

The conviction that the western course to the Indies was clearly feasible, led John Cabot to undertake the notable voyage, resulting in the discovery of northeastern America. In command of the ship Mathew and with a crew of eighteen men, Cabot gained the coast of Labrador, which he believed was actually the northeastern shores of Asia.

On a similar quest, Vasco Nuñez de Balboa first saw the waters of the Pacific from the Isthmus of Panama (1513). Six years later, Magellan set sail upon what was destined to be the first circumnavigation of the globe. Sharing the general objection to the African route because of excessive

early sixteenth centuries, exerted on exploration, the following figures are significant:

In 1400 only 50 million square kilometres of the earth's surface were known. By 1500, 110 million square kilometres were known.

By 1600, 316 million square kilometres were known.

By 1700, 377 million square kilometres were known.

By 1800, 450 million square kilometres were known.

By 1890, 483 million square kilometres were known.

Since it is estimated that the earth's surface comprises $510,000,000$ square kilometres, there remains but $27,000,000$ square kilometres yet to be discovered. Oppel, "Terra Incognita" (publ. 1891). 
length, Magellan was convinced that the Indies might be reached by voyaging to the westward. The island of Cipango, in his belief, lay just beyond the barrier of the New World, which might be rounded at the southern extremity.

Eventually, Magellan succeeded in persuading the king of Spain to send him upon an expedition in quest of the distant Indies. Coasting along the bleak shores of South America, and traversing the tortuous and treacherous straits which now commemorate his steadfast purpose, Magellan sailed out upon the waters of the Pacific. Columbus had fearlessly shown the way across the Sea of Darkness; Magellan had passed beyond that sea, and sailed for the first time across the waters of the New Sea, the Pacific, which none had conceived to exist a decade earlier.

By the peaceful conquests of these fearless navigators throughout the Seven Seas, innumerable trade routes were established; some with the purpose of affording more commodious transport between the regions already known; others for the development of newly discovered regions, and for the interchange of products between these undeveloped countries and civilized Europe. In the profound changes which were rapidly consummated, all former interests were affected, many of them adversely; but the newly created conditions afforded ample compensation for whatever losses were incurred. The entire aspect of maritime affairs throughout the world underwent change with the realization and appreciation of the rewards connected with more ambitious and comprehensive undertakings. The seas were recognized as a source of wealth, not solely because of the rich, yearly harvest of fish and fur, but chiefly because the seas constituted the great highways of $\mathrm{cm}$ merce.

Until the close of the fifteenth century, when voyages of discovery had disclosed to wondering humanity the vast stretches of ocean and the riches of distant lands, hitherto unknown, the Mediterranean and its shores had constituted the civilized world, and had comprised the area wherein com- 
merce and sea-trade had achieved maximum development. But the discoveries of Columbus and throughout the century following his achievement wrough revolution in maritime enterprise and caused the relentless decay of Mediterranean supremacy. European commerce became restive within the narrow confines of the Mediterranean. It broke through the customary bounds and spread throughout the world. But, while Venice and the other maritime cities of Italy, as well as the cities forming the Hanseatic League in the north, were despoiled of their lucrative sea-trade, enterprise elswhere throughout Europe flourished. England and Holland acquired the trade formerly enjoyed by the Hanseatic League, while Portugal and Spain fell heir to that of the Italian cities.

English enterprise was not confined to local trade, but extended into the most remote regions. Trade with Russia was developed by virtue of a treaty negotiated by Chancellor at Moscow (1553); rich argosies brought the products of Asia, Africa, and the Americas into the ports of Europe; while the policy of colonization was instituted to place this exploitation and development on a more secure and permanent basis. ${ }^{1}$

The former power of the Hanseatic League proved inadequate to cope with the expanding sea-power of England, developing under the favorable conditions obtaining with the beginning of the sixteenth century.

The Hanseatic League was not a state, but, as its name implies, simply a league of cities, organized to carry on trade for mutual advantage. Though lacking a requisite structure to accord it recognition as an independent community, yet, being

1 "And now the English began more confidently to survey those countries, carrying their merchandise up the River Dwina in boates made of one whole piece of tree, which they rowed and towed up the streame with halsers as farre as Wologda, and from thence by land 7 days journey to Yeraslaw, and then by the Wolga. . . 30 days, and as many nights, journey downe the River to Astracana. ... And from Astracana, where they built ships, they did by a very great and memorable adventure, many times crosse the Caspian Sea, which is very full of flats and shelves, and pierce through the vast desarts of Hircania, and Bactriana, to Teverin, and Casbin, cities of Persia, in hope at length to discover Cathay." Camden, "History," (1569, A. D.), pg. 105. 
endowed with important political privileges, the League successfully endeavored to preserve the rights of Hanseatic merchants domiciled in foreign countries; to extend Hanseatic trade; and to protect the commerce of the League. It achieved the pinnacle of its importance in the fourteenth century. Following the discovery of America, its trade declined, until the Thirty Years' War and the Treaty of Westphalia completed its downfall.

The expansion of English commercial prestige throughout Northern Europe encountered only the rivalry of the Netherlands, which continued a serious handicap until the termination of the English-Dutch Wars.

To the extent that this unparalleled development in the expansion of sea-trade caused the spread of civilization throughout the world, as the invariable accompaniment of all intercommunication between races, the influence was beneficial. The discoveries, carried on so successfully during the sixteenth century, broadened the field of maritime endeavor manifold, and, in consequence, afforded opportunity for the beneficent extension and administration of maritime law, wherever commerce called the vessels of European nations.

At the outset, the intense rivalry among the nations of Europe operated as an incentive to more brilliant achievement, but this phase of international competition was of short duration. The conflicting interests, aroused by the national ambitions of the principal maritime states, developed a disregard for the freedom of the seas; a principle which had been observed, nominally at least, for centuries.

In the period following close upon the epoch-making discoveries, the idea of sea-power developed, including the idea that maritime pursuits afforded an admirable training for the recruitment of the navy; and, further, that naval power was essential for the extension and protection of the national, commercial interests. When this policy was extended to embrace the exercise of sea-power for the maintenance of exclusive rights on the high seas, the principle of the unrestricted use of the seas was demolished. 
The pronouncement of the eminent scholar and scientist, Lord Francis Bacon, demonstrates the prevailing conviction of this epoch:

"To be Master of the Sea, is an Abridgement (epitome) of a Monarchy. Cicero writing to Atticus, of Pompey his Preparation against Cæsar, saith: 'Consilium Pompeii planè Themistocleum est; Putat enim, qui Mari potitur, eum Rerum potiri.' (Pompey follows the right Themistoclean policy; he considers that he who commands the sea, commands all.) And, without doubt, Pompey had tired out Cæsar, if upon vaine Confidence, he had not left that Way. The Battaile of Actium decided the Empire of the World. The Battaile of Lepanto arrested the Greatnesse of the Turke. There be many Examples, where Sea Fights have beene Finall to the warre; But this is, when Princes or States, have set up their Rest, upon the Battailes. But thus much is certaine; That hee that Commands the Sea, is at great liberty, and may take as much, and as little of the Warre, as he will. Whereas those, that be strongest by land, are many times nevertheless on great Straights. Surely, at this Day, with us of Europe, the Vantage of Strength at Sea (which is one of the Principall Dowries of this Kingdome of Great Brittaine) is Great: Both because, Most of the Kingdomes of Europe, are not meerely Inland, but girt with the Sea, most part of their Compasse; And because, the Wealth of both Indies, seemes in great Part, but an Accessary, to the Command of the Seas." (Francis Bacon, "Of the true Greatnesse of Kingdomes and Estates.")

Sir Walter Raleigh considered the command of the sea indispensable for the adequate expansion of the nation, expressing the dominant idea of the new policy; the sovereignty of the seas; succintly:

"Whosoever commands the sea, commands the trade of the world; whosoever commands the trade commands the riches of the world, and consequently, the world itself." (Raleigh, Works, Vol. VIII, 325.) 


\section{CHAPTER V}

\section{THE SOVEREIGNTY OF THE SEAS}

Prior to the sixteenth century, despite certain transitory attempts at restriction, the navigation and enjoyment of the sea remained common to all nations, this immemorial right being protected and fostered by the various bodies of maritime law which had been accorded acceptance by European states and which afforded security to those who ventured on the seas.

With the dazzling possibilities disclosed in the discovery of the all-sea route to India and of the vast New World, lying beyond the Atlantic, the conflicting interests of ambitious sovereigns exhibited an increasing tendency to disregard rights which, with occasional exceptions, had been enjoyed by all nations since time immemorial. Powerful maritime states, seeking to safeguard enterprises abroad, sought dominion on the seas, and, upon consummation of the endeavor, levied onerous restrictions, through the payment of tribute or otherwise, upon foreign vessels navigating those seas where sovereignty had thus become established. This profound change in the policies of the principal maritime states of Europe was destined to diminish the beneficial operation of the mediæval maritime laws, which necessarily were deprived of their fullest force and vigor until the ultimate abandonment of these pretentions to sovereignty on the open ocean re-established the principle of the freedom of the seas.

Unquestionably, such restrictions could claim the weighty sanction of early, though occasional, precedent, for the endeavor to gain control of navigable waters has endured, with varying intensity, through the ages. Before man had carried this struggle onto the sea, the contest had begun along the courses of important inland waterways, particularly in the valleys of the Tigris and the Euphrates; on the Nile; and throughout the 
course of the Danube from the Alps to the Euxine. Nominally, the high seas have ever been free to the use of ships of all nations, on terms of complete equality, but in the long history of the sea there have occurred certain grave derogations from this beneficent principle; these restrictions, prior to the sixteenth century, arousing the immediate and successful opposition of all maritime states.

In antiquity, whenever one nation enjoyed the resources of the sea to the virtual exclusion of all other maritime states, as in the notable instance of Carthage, the constant employment of force was essential, and when force proved inadequate to maintain the restriction further, the pretension was abandoned. Though this form of exclusive use had its counterpart during the sixteenth and seventeenth centuries among the nations of northern and western Europe, another situation arose within the confined waters of the Mediterranean which was incapable of duplication in the later development of maritime enterprise. This unique condition resulted through no denial of the use of the scas to other nations; through no attempt to exercise naval power to enforce pretensions of exclusive enjoyment; but transpired because the dominant nation had no important competitors in maritime enterprise; either because national resources ensured supremacy in maritime pursuits, as in the instance of Phœnicia; or because the national domain had received such extension as to embrace all important maritime states, as well as the principal navigable waters. The Roman Empire, by securing sovereignty over the lands surrounding the Mediterranean, acquired an exclusive enjoyment without the corresponding necessity of its maintenance through the unremitting employment of sea-power. ${ }^{1}$

The long-established hegemony of the Phœnician cities in the maritime affairs of the Mediterranean, founded upon the first

1 Consideration of the restrictions upon navigation, resulting from the activities of pirates or of other irregular and illegitimate forces, may be dismissed, since significance attaches only to the endeavors of various nations in the fulfillment of national aspirations and ambitions by secking prestige and security through the exercise of dominion on the seas. 
ventures over seas undertaken in these waters, and later expanding under the greater opportunities afforded, successively, by the protection of the empires of Egypt, Babylonia, and Persia, ended disastrously in the expedition undertaken by Xerxes to erush the growing sea-power of Greece. The sea-fight at Salamis ( 480 B. c.) broke the power of the Persians and the subsequent victory at Hydrum (449 в. с.) under the leadership of Cimon compelled the Persians to sign the treaty which marked the termination of Phœnician enterprise, as an integral part of the Persian Empire, in Mediterranean waters.

Plutarch relates that upon the defeat of the Phœnieians at Hydrum by the Athenians, the King of Persia signed a treaty by which he engaged not to approach nearer to the Greek seas than a horseman could ride in one day, and not to allow a single one of his ships of war to appear between the Cyanean and Chelidonian islands. (Plutarch, "Life of Cimon," Chap. xiii.) ${ }^{1}$

Thus, the maritime prestige of the most remarkable seafaring race of antiquity, a race credited by Herodotus with having completed the first eircumnavigation of Africa, at the instance of King Necho of Egypt, six hundred years before the Christian Era, became but a memory in the eastern Mediterranean; but in the west, Carthage, established originally as a trading-post by these enterprising navigators, carried forward the Phœnieian traditions.

The lucrative trade enjoyed in the western Mediterranean afforded Carthage opportunity for more ambitious maritime enterprises, and the consequent extension of Carthaginian power and influence caused apprehension in Greece, Marseilles, and at Rome, where the practical sovereignty of the western Mediterranean, west of Sardinia and Sicily enjoyed by Carthage, was viewed as a serious menace to the continued national development of these states. The arrogant claim then put forth

1 The Cyrean or Black Islands were at the junction of the Bosphorus with the Euxine (Black) Sea. The Chelidonian or Swallow Islands lie off the southern coast of Lycia. 
by Carthage to the exclusive dominion over all the waters of the western Mediterranean, with the stipulation that all strangers who were discovered trading with Sardinia or toward the Pillars of Hercules should be punished by drowning, led to an immediate and energetic denial of these pretensions. (E. C. F. Babelon in the "Encyclopedia Britannica," Vol. V, 428.)

War was declared by Marseilles against Carthage, nominally for the recognition of certain fishing rights which had been hitherto enjoyed by Marseilles within the Mediterranean, but virtually for the vindication of the principle of the unrestricted use of the seas. Though Marseilles failed to establish this righteous claim, the inequality of the terms of the treaty of peace caused such discontent that Marseilles willingly placed the state's resources at the command of Rome in the subsequent wars waged against Carthage.

Elsewhere in the Mediterranean, restrictions upon the freedom of navigation met a vigorous repulse. When the Byzantines, under pressure of necessity, attempted to levy tolls on Greek vessels, sailing in the Pontus, it was regarded as illegitimate conduct, and an appeal was made to the Rhodians, who were then the acknowledged masters of the sea. In the war which followed, Rhodes compelled the Byzantines to abandon all pretensions to the exaction of maritime dues. (Phillipson, "International Law and Custom of Ancient Greece and Rome," Vol. II, 380.)

Similarly, the restrictions imposed by Carthage on the weaker maritime powers became particularly onerous to Rome, due to the rapid development of resources and industries, and the acquisition of outlying provinces. The provisions of the treaties with Carthage, forbidding trade with the Carthaginian territories in Hispania, Africa, and Sardinia ; prohibitions similar to those enforced by Portugal in India at a later time; caused gathering discontent, but the claim to sovereignty on the seas, advanced by Carthage, became an immediate menace to the further expansion of Rome. 
The First Punic War, lasting twenty-seven years (268-241 B. c), was waged by Carthage in defence of the Sicilian territories and for supremacy in the Tyrrhenian Sea. Though Rome acquired Sardinia, Corsica, and Sicily; conquered from Carthage; nothing was accomplished toward establishing the unrestricted use of the sea. The restrictions, however, were destined to be of relatively short duration, for in the two succeeding wars, Roman sea-power was victorious. With the annihilation of the Carthaginian fleet, followed by the destruction of Carthage (146 в. с.), and because of the rapid expansion of the Roman Empire, ultimately encircling the entire Mediterranean, Rome achieved the unique position of the universal dominion of the sea.

Even in this early period of maritime activity, property in the sea was considered legitimate; according to the views of certain jurists; not merely in territorial waters, but in extensive regions throughout the open sea. (Phillipson, "International Law and Custom of Ancient Greece and Rome," II, 376.)

This principle, revived by Venice during the later Middle Ages, was destined to gain such acceptance that many nations were willingly to recognize, tacitly or by treaty, that certain vast areas of the ocean rested under the exclusive sovereignty of a single nation. The significance of this re-assertion, during the period of intense commercial and maritime rivalry which followed the discoveries of the fifteenth century, arises not alone from the fact that these restrictions, laid upon the free navigation of the open sea, affected all the waters of the world, while the earlier pretensions had concerned only the waters of the Mediterranean; nor because these limitations endured for centuries, whereas in the Mediterranean such attempts had met immediate and successful resistance whenever the maritime interests of other states were adversely affected; for these are differences in degree, not in principle; nor should especial significance attach to the fact that this re-assertion followed a period of nearly one thousand years during which the freedom 
of navigation had continued virtually unmolested. Great significance arises, however, from the fact that this endeavor to limit the freedom of the seas gained the mutual acquiescence, and even the support, of certain powerful maritime nations, which sought to establish their pretensions through the employment of force, and the exercise of formal argument, enlisting the services of eminent jurists, in the vain quest of vindication.

With the enormous increase of maritime industry, beginning with the sixteenth century, various claims to dominion over the seas appeared, assuming diverse forms. Monopoly of certain fisheries was demanded; salutes or other maritime honors were exacted; the right to exclude the belligerent operations of other powers from extensive areas of the sea was asserted; leading finally to the claim of absolute sovereignty over certain portions of the high seas, with the corresponding negation of liberty to traverse these waters, unless permission should be accorded by the preliminary payment of tribute. Responsibility for such derogations cannot attach to one nation, exclusively.

While the Republic of Venice claimed sovereignty over the Adriatic, Genoa became dominant in the Ligurian Sea ; Portugal exerted exclusive sovereignty throughout the Indian Ocean, and the Atlantic, south of Morocco, prohibiting all foreigners from navigating or even entering these waters; and Spain appropriated the whole of the Pacific Ocean and the Gulf of Mexico. In the North Atlantic, England exerted sole jurisdiction over the Narrow Seas and upon the Atlantic between North Cape and Cape Finisterre, while Denmark and Sweden enjoyed dominion upon the Arctic and Baltic, jointly. By the end of the sixteenth century, none of the seas surrounding Europe remained free from the claim of some power to proprietary rights, since it had become customary to consider the sea as appropriable. Under the new order, those who still contended for the unrestricted use of the seas were ridiculed by the defenders of Mare Clausum.

Sir John Selden, in his "Epistle Dedicatory" to Charles I, King of Great Britain, declared that there were a few who, 
following chiefly some of the ancient Cæsarian lawyers, endeavored to affirm, or beyond reason too easily to admit that "all Seas are common to the Universality of Mankind."

Welwood contended ("Abridgement of All Sea-Laws.") that no universal liberty existed, accorded as an undisputed right to fish in any sea; taking particular exception to the contention of Grotius who had supported this liberty; and declared that the freedom of navigation should not be confused with the liberty of the fisheries. The English practice under the Commonwealth and Charles II was in accordance with this view, foreigners who intended to fish in the North Sea being required to take out English licenses for the purpose. Denmark adopted a similar policy and required licenses of all fishermen who entered the sea between Norway and Iceland, abandoning this claim because of the insistent opposition of England and the Netherlands during the eighteenth century.

In the restricted use of such appropriated waters, foreigners enjoyed some compensation for the tribute exacted, whether honorary or in specie, because of the reciprocal obligation, generally fulfilled, resting upon the sovereign power to accord full protection against piracy throughout these waters. At this time, when vessels laden with rich cargoes sailed across the unknown ocean and skirted unexplored coasts, the protection thus accorded the shipping of nationals and foreigners, alike, was indispensable, for piracy flourished, the reward being so great, and the likelihood of apprehension, negligible. In fulfilling this obligation of protection to commerce, the antagonism to the exclusive jurisdiction asserted by the particular state became less pronounced, until the right of control over the appropriated waters became recognized and permanently established. This recognition of the established control led inevitably and almost immediately to the claim of absolute property in the open sea, and such claims secured acceptance readily, since at this period control and property were ideas scarcely disassociated; the establishment of one condition induced the recognition of the other, 
In the development from comparative freedom to inflexible restriction, a similar evolution is apparent in the character of waters susceptible of exclusive control. Sovereignty attached originally to the narrow seas, but with the continued development of maritime enterprise the advantages thus accorded proved inadequate to fulfill national ambition. Accordingly, the claims to sovereignty became more comprehensive, embracing vast areas of the open ocean.

The thirteenth century claim of Venice, successfully maintained for several decades, sought exclusive jurisdiction within the Adriatic, a narrow sea. Venice enforced the claim inflexibly, levying heavy imposts upon all ships and all merchandise which traversed the northern Adriatic. Later, with the further expansion of Venetian power, no ship could enter any waters of the Adriatic, except upon sufferance and the payment of tribute. (Daru, "Histoire de la Republique de Venise," Liv. V.)

Westlake suggests ("International Law," I, 165) that the exclusive jurisdiction over the Adriatic, asserted by Venice, may be considered as an enlarged application of the principle of gulfs, "notwithstanding the width of the gulf in question and its not being wholly bordered by Venetian lands."

It would appear, rather, that the assertion and maintenance of sovereignty over the Adriatic arose through the paramount necessity of advancing the interests of the state. Venice, because of an extensive and rapidly developing merchant marine, supported by an adequate navy, was enabled to maintain dominion upon the sea. Indeed, as early as the eighth century, Venice had achieved renown because of the powerful fleet which protected over-seas enterprise. The naval power of Venice was well-recognized by the Italian states at this early time, particularly following the defeat of the Lombards in the sea-fight waged by Venice in behalf of the Exarchate of Ravenna. Charlemagne, jealous of the preference accorded by Venice to the Greek emperors, despatched a fleet to the Adriatic, and 
again Venetian sea-power triumphed.

(Schomberg, " Laws of Rhodes," 50.)

In 1289, when Venice began levying heavy tolls on all vessels navigating the northern Adriatic, Bologna and Ancona, relying upon the principle, long-established and generally observed, that the sea was incapable of sovereignty, sought to resist the Venetian pretensions. Unfortunately, the attempted vindication of this international right failed, because of the superior maritime strength of Venice. Bologna and Ancona were compelled to acknowledge Venetian sovereignty upon the Adriatic, and, thereafter, to pay the tribute demanded for the privilege of entering the appropriated area.

The ambitions of Venice were menaced by the Genoese and the contest for supremacy within the Mediterranean, beginning with the sea-fight off Cyprus (1298), was waged between these two states until the decisive engagement at Chioggia crushed the sea-power of Genoa. Venice now had no important competitor in the Mediterranean sea-trade and entered upon a period of unparalleled maritime enterprise, which achieved the most extended development during the fifteenth century. Each year, in celebration of this maritime supremacy, the Doge cast a ring into the Adriatic to symbolize the traditional marriage, the immemorial union, between Venice and the sea.

The sovereignty exercised by Venice throughout the Adriatic became so inflexible that when the sister of the king of Spain was voyaging to Carniola, being espoused to the king of Hungary, Venice claimed the exclusive right of transporting her from Naples to Trieste. The Spaniards, resenting this restriction on the freedom of the seas, demurred. In answer, Venice threatened to attack any Spanish ship venturing within the waters of the Adriatic, as an enemy of the Republic, and in consequence the Spaniards acknowledged the claim. (Schomberg, "Laws of Rhodes," 48.) (Molloy, "De jure maritimo et navali," Vol. I, 123.) ${ }^{1}$

1 In 1478, Frederick III, Emperor of Germany (1440-1493), was com- 
Genoa, in a similar manner, exercised exclusive jurisdiction upon the Ligurian Sea; considering this portion of the high seas as an integral part of the national domain. Neighboring states enjoyed the use of this sea only by observing the harsh restrictions imposed by Genoa, designating the length of voyages which might be undertaken on the Ligurian and Mediterranean seas. (Heyd, "Histoire du commerce du Levant du Moyen Age," I, 20.) In a vain endeavor to vindicate the right freely to navigate the seas, Pisa, whose interests were most seriously endangered, attacked the Genoese, but suffered decisive defeat (1284) in the naval engagement off Meloria. This victory ruined the maritime power of Pisa, and enabled Genoa to exact an implicit observance of the stipulations and regulations governing the use of these waters by foreign shipping. Strengthened by the additional resources derived from dominion upon the Ligurian Sea, Genoa now entered into active competition with Venice throughout the Levant, seeking the control of the Oriental trade, and succeeded in establishing a lucrative trade route through the Bosphorus and the Euxine.

The continued prosperity of these two states, Genoa and Venice; enjoying, temporarily, exceptional advantages and opportunities upon the sea through the negation of the maritime rights of other Mediterranean states; was destined to collapse under the rigorous, and similar, sovereignty exercised by the Ottoman Turks over the eastern Mediterranean, following the capture of Constantinople (1453).

Though the sea-trade of the Genoese had been seriously crippled by the decisive victory gained by the Venetians at Chioggia, following the seven years of continuous warfare which had begun with the sea-fight off Cyprus (1298), it continued moderately active because of the valuable trade with the Euxine and the distant regions beyond the Caucasus. The irresistible pelled to recognize the sovereignty of Venice throughout the Adriatic; having humbly to obtain permission from the Republic, before transporting grain from Apulia, in southeastern Italy, to the Germanic ports of Carniola. 
expansion of the Ottoman power in the East, culminating in the fall of Constantinople, while threatening destruction to the maritime enterprises of Venice, caused the immediate demoralization and decay of Genoese sea-trade, for passage through the Bosphorus was denied all Christian traders, and the Bosphorus was the artery of Genoese trade with the Orient.

Venice remained the only obstacle to the supremacy of the Ottoman Turks in the eastern Mediterranean, since the power of Genoa, weakened by the years of disastrous conflict with Venice, was inadequate to maintain the unrestricted use of the eastern seas.

In combating the very pretensions to sovereignty on the seas, earlier established and still maintained on the Adriatic, Venice waged unceasing war upon the Turks beginning (1470) with the decisive engagement which destroyed Venetian sea-power in the Grecian seas, and continuing until the Turks succeeded (1503) to the maritime supremacy of Venice throughout the Mediterranean. The ultimate destruction of Turkish maritime sovereignty at Malta (1565) and Lepanto (1571), failed to revive the former enterprise of Genoa and Venice, destroyed by the very weapon which these states had themselves wielded, the denial of the freedom of the seas, for the discovery of the all-sea route to India and of the New World beyond the Western Sea transferred the seat of maritime enterprise to the Atlantic seaboard. States, situated on the enclosed waters of the Mediterranean, suffered the handicap of being far removed from ocean trade routes, reached only by the passage through the Pillars of Hercules, an access controlled by the adjoining states and susceptible of restriction at any time.

Establishment of Exclusive Sovereignty Over the Great Waters.- Spain and Portugal recognized the opportunity and possibilities of world-wide exploration and commeree disclosed by the marvelous voyages of discovery achieved by their respective master mariners, Columbus and Vasco da Gama; and realized, too, their advantageous position for engaging successfully in such enterprise. Not content with the advantages 
inherent in their fortunate situation upon the Atlantic, Spain and Portugal, seeking to safeguard their undertakings still further, advanced preposterous claims to vast areas of land and sea, based superficially upon their discoveries over the world. The unavailing protests of the excluded nations; the apparent sanction given by Papal decree to these pretensions; the eventual acquiescence of other nations prominent in maritime affairs, which later set up similar claims to sovereignty over wide areas of the sea; combined to destroy the freedom of navigation, not only on the Narrow Seas, but even throughout the vast expanse of ocean.

The claims of Portugal and Spain were particularly outrageous, because of their geographical extent and the inflexible denial of innocent passage to the vessels of foreign nations. The Spanish and Portuguese sovereigns, in seeking to exclude all foreign vessels from navigating or even entering the waters thus arrogated to their exclusive use, invariably referred for sanction to the Bull of Alexander VI, as establishing the validity and sanctity of the restrictive regulations.

At the commencement of the great epoch of world-wide discovery, the Popes still claimed to be the masters of the world by divine right and especially of all islands of the sea, deriving their jurisdiction in virtue of the forged donation of Constantine. By the Bull of 1454, Pope Nicholas V granted to King Alphonso $\mathrm{V}$ of Portugal the discoveries already made, OR TO BE MADE, upon the west coast of Africa, in perpetuity. (Westlake, "International Law," I, 96.) The grant of title, in perpetuity, affecting discoveries still to be made, is an interesting commentary on the prevalent custom of this period of enthusiastic exploration. Rights of property were thus assured, even before setting out, whatever might be discovered. In the Bull of 1493 and 1494, issued by Alexander VI, precedent in this regard is scrupulously observed.

Pope Alexander VI, by the Proclamations of May 2 and 4, 1493, recognized the existing rights of Portugal, while at the same time establishing those of Spain. The Bull of May 3, 
1493, "Eximiae devotionis," which was superseded by the Bull of May 4, 1493, grants to Spain the same rights from discovery as had formerly been conferred on Portugal in Africa: "But inasmuch as by this apostolic see have been granted divers privileges, favors, liberties, \&c, \&c, . . . to some kings of Portugal . . . we do by tenor of these presents, as a gift of special favor, empower you and your aforesaid heirs and successors, to the end that in the islands and countries already discovered by you or in your name, and to be discovered hereafter, you may ... use, employ, and enjoy ... all and singular, the graces, privileges, exemptions, liberties, facilities, immunities, letters, and indults that have been granted to the kings of Portugal." (Blair, "The Philippine Islands," Vol. I, 89.)

An additional Bull, granted the same day, "Inter Cætera," gave Spain title to all the lands in the West, recently discovered or yet to be discovered, which had been unknown, hitherto, and not under the dominion of any Christian prince, this Bull being superseded by the Proclamation of May 4, 1493 :

"We . . . by the authority of Almighty God, conferred upon us in blessed Peter and of the vicarship of Jesus Christ, which we hold on earth, do by tenor of these presents give, grant, and assign, forever, to you and your heirs and successors, Kings of Castile and Leon, all and singular, the aforesaid countries and islands thus unknown and hitherto discovered by your envoys, and to be discovered hereafter, providing, however, they at no time have been in the actual temporal possession of any Christian owner." (Blair, "The Philippine Islands," Vol. I, 89.)

In the following year, an imaginary line, drawn from north to south and lying one hundred leagues west of the Azore and Cape Verde islands, apportioned the still unknown regions into two spheres of influence; not with the purpose of dividing and dedicating the remainder of the world to Spain and Portugal, but rather to designate those regions wherein the priority of discovery would invariably and unquestionably accord the right of property. In providing this line there was no intention 
of dividing the New World, since at this date its existence was unknown. The Line simply divided the islands which had already been discovered, while its subsequent importance in the division of property was dependent upon the discoveries which were yet to be made.

The two Bulls which had been issued May 3, 1493, had contained no mention of a specific Line of Demarcation, but Alexander VI, by the decree of May 4, 1493, established the Line in the endeavor to avoid needless disputes arising through uncertainty regarding the actual spheres of the respective sovereignties. East of the Line, Portugal was to retain the rights already acquired, in virtue of earlier explorations and grants of former popes, while future explorations and discoveries which might be undertaken, were to enjoy the advantages, similarly and equally enjoyed by Spain. By the same instrument, Alexander VI assigned to Spain the same exclusive rights of exploration, trade, and colonization over all the lands that should be discovered south and west of the Line, provided that these lands were not already occupied by some Christian sovereign. $^{1}$

The explicit provisions, limiting the activities of Spain exclusively to the westward of the Line, were inserted at the instance of Portugal, admitting under no circumstances any infringement of the monopoly enjoyed along the coasts of Africa.

1 The Bull of May 4, 1493, "Inter caetera," superseding the Bulls of May 3, 1493, "Eximiae devotionis" and "Inter caetera"; established the Demarcation Line, and granted to Spain all lands west and south of this line, if not already in the possesion of any Christian prince.

"We do give, grant, and assign to you and your heirs and successors, Kings of Castile and Leon, . . . all islands and mainlands found or to be found, discovered or to be discovered towards the west and south, by drawing and establishing a line from the Arctic pole, namely the North; to the Antarctic pole, namely the South, no matter whether the said mainlands and islands are found or to be found in the direction of India or towards any other quarter; the said line to the west and south to be distant one hundred leagues from any of the islands commonly known as the Azore and Cabo Verde. . . With this proviso, however, that none of the islands or mainlands ... be in actual possession of any Christian king or prince up to the birthday of our Lord Jesus Christ, just past in the present year, 1493." Blair, "The Philippine Islands," Vol. I, pg. 89. 
The Bull of May 4, 1493, however, did not provide specifically with regard to the East Indian trade. To appease the Spaniards, Alexander VI granted new opportunities to Spain in the Bull of September 25, 1493, which virtually annulled the Bull of Demarcation, as well as all the former concessions which had been accorded to Portugal. Thenceforth, the Spanish monarchs enjoyed full rights in all lands discovered to the south and west " and eastern regions and to India," and might reach the East Indies by constantly voyaging westward from the Line. The Spanish claim to all lands arising from prior discovery would consequently be valid, by virtue of this latest Bull, against the claims of the Portuguese, who had considered, heretofore, that India had been dedicated to them as an exclusive region for discovery, exploration, and development. ${ }^{1}$

This amplification of the Spanish rights, resting upon a corresponding limitation of the Portuguese, led to the immediate remonstrance of King John of Portugal, who appealed to the provisions of the treaty of 1479 between Spain and Portugal, providing that to Portugal should be accorded the field of ocean discovery, while Spain should retain only the Canaries. King John contended, vehemently, that the Line of Demarcation, lying but one hundred leagues westward from the Azore Islands, infringed the immemorial rights of his kingdom, and would not afford his sailors adequate sea-way to undertake expeditions along the African coast and to India.

To compose the difficulties which had thus arisen between the two kingdoms, the treaty of Tordesillas was agreed upon, June 7, 1494, stipulating that the Demarcation Line should be moved two hundred and seventy leagues westward from the point prescribed by the Papal Bull of May 4, 1493; while a sup-

1 The Bull of September 25, 1493, practically annulling the Bull of Demarcation, May 4, 1493, provided: "We do extend and enlarge our aforesaid gift, grant, assignment, and letters, with all and singular, the clauses contained therein, so as to secure to you all islands and mainlands, whatsoever, that are found and to be found, discovered and to be discovered, are or were or seem to be in the route by sea or land to the west or south, but are Now recognized as being in the waters of the west or south and east and India." Blair, "The Philippine Islands," I, pg. 90. 
plementary document of April 15, 1495, provided for appropriate arrangements for the scientific and equitable determination of the new line of demarcation. (Blair, "The Philippine Islands," I, 23. Martens; Supplement, "Rec. de Prin. Traités," Vol. I, pgs. 372, 289.)

Pope Julius II confirmed the treaty of Tordesillas (1506), which, by shifting the Line to a point three hundred and seventy leagues to the west of the Cape Verde and Azore islands, was destined to secure for Portugal the vast area of Brazil; and the interests of Portugal were further safeguarded by the Bull of Leo X, "Præcelsæ," granted to Portugal November 3, 1514, which confirmed all previous papal gifts to Portugal of lands in the East, granting to Portugal all past and future discoveries and conquests, there and elsewhere. (Blair, "The Philippine Islands," I, 90.)

In examining the arrangements established by the Papal Bulls and the compensating treaty of Tordesillas, it is noteworthy that no specific reference was made to the further extension of the Demarcation Line around the world, and that no division of the world was contemplated; though at a later time attempts were made to read such extensions into these early documents. These arrangements sought to avoid futile controversies, and to provide for an unrestricted field for the exploration and conquest of the unknown regions of the world; the exclusive sphere of interest for Portugal lying to the east of the Line; that of Spain lying to the west and southward.

The first instance of the contention that the world had been divided between Portugal and Spain, exclusively, by Papal decree, and of the claim that the Line had extended around the world, appeared at the time of Magellan's notable discoveries, in the endeavor, on the part of Spain, to claim all that might be within the Western Hemisphere. (Blair, "The Philippine Islands," I, 25.)

This unwarranted extension of the Bull of 1493 founded the subsequent claim, advanced by Spain and Portugal alike, that the Pope had granted their respective sovereigns exclusive do- 
minion throughout the seas, comprehended within the limits prescribed by the Line of Demarcation. In contending for the validity of these exclusive privileges, neither Spain nor Portugal regarded the rights of other maritime states upon these seas. Moreover, any relaxation of this restrictive policy, which was always a possibility while the acute controversies continued between Spain and Portugal, was remotely deferred by the incorporation of Portugal (1581) in the kingdom of Philip II. This fusion of Spain and Portugal produced a united kingdom of unlimited maritime dominion. The New World belonged almost wholly to the Spanish sovereigns. ${ }^{1}$

In the acquisition of these vast dominions beyond the seas, maritime enterprise was stimulated through the exceptional opportunities afforded for sea-trade; protected and fostered by the Spanish claim to the exclusive ownership of all waters within the area described in the Bulls of Alexander VI; and the seapower of Spain became formidable within the Mediterranean and upon all the waterways of the world.

Portugal, the earliest and the pre-eminent maritime power of the New Age, the Mistress of the Seas by virtue of her intrepid mariners, the first navigators of the Christian Era to voyage beyond the Equator, contributed her vast naval forces to Spain's already notable sea-power. Prestige and almost unlimited dominion on the sea resulted from this union, culminating in the reign of Charles V, King of Spain, Emperor of Germany, and sovereign, in claim, of the entire Western Hemisphere. Charles $\mathrm{V}$, in his endeavor still further to exalt the power of Spain upon the seas, conceived the project of constructing a canal across the American isthmus to unite the At-

1 Subsequently, more than a hundred years after the dissolution of the union between the two sovereigns (December 3, 1640), Portugal and Spain resolved by the Treaty of Madrid, January 13, 1750, to terminate all past and future disputes by declaring the Bulls of Alexander VI, the Treaty of Tordesillas, and other treaties based thereon null and void; agreeing to desist from all actions and rights which might have existed under previous conventions.

(J. B. Moore, "Brazil and Peru Boundary Question," p. 4; quoting the Y̧ale Review, Vol. I, p. 54.) 
lantic and Pacific, and to facilitate trade between Spain, Peru, and the Philippines, but the lack of sufficient capital, to prosecute the work successfully, prohibited the undertaking. Funds were more urgently needed to maintain the supremacy of the Spanish fleet, for already the maritime states of northern Europe, particularly the Netherlands and England, were making extensive preparations to resist the preposterous claims of Spain to dominion on the seas. The claims of Portugal and Spain, based upon unwarranted extensions of the specific privileges accorded by the Papal Bulls of 1493, being combined by the Act of Union, afforded scanty opportunity for over-seas enterprise among other maritime states. France, Holland, and England had already disregarded the erection of the Demarcation Line, and had ignored the alleged division of dominion, consecrated by Papal decree.

Henry VII of England, in letters patent granted to John Cabot and his sons, May 5, 1496, empowered his grantees to navigate the eastern, western, and northern seas, and "to find, discover, and search out all islands, countries, regions, and provinces of gentiles or infidels, situate in any part of the world, which were unknown to all Christians before these times." (Westlake, "International Law," I, 97.)

By granting this extensive license to his navigators, Henry VII willfully disregarded the claims of Spain and Portugal, based on the Papal Bulls which had been issued three years previously, though the prior rights, acquired by the Spaniards through explorations in the southern seas, were respected in the terms of the regal grant.

Under the protection of these letters patent, John Cabot crossed the line (1497), discovering regions in North America which were immediately claimed by Henry VII.

With similar independence, Francis I claimed an indefinite extent of coast northward from Florida, under the title of New France.

This flagrant disregard by Catholic powers of grants made by the expressed authority of the Pope was surpassed by the 
action of the Protestant states which reasoned that no such Papal grant could restrict their enterprises beyond the seas. The Dutch drove the Portuguese out of the Indian Ocean, and proceeded to establish colonies in these regions as well as in America. Other nations, with like impunity, erected colonies in America and elsewhere throughout the Seven Seas.

Bernardine Mendoza, Spanish Ambassador at the Court of Queen Elizabeth, entered a vigorous protest because of the alleged violation of Spanish rights, committed by Sir Francis Drake in entering the appropriated waters of the Pacific (1580), while on the famous voyage of circumnavigation. In reply, Queen Elizabeth contended that no right of exclusive sovereignty could be recognized in those waters, inasmuch as the alleged disposal of Alexander VI of the vast regions of the sea and of the lands therein, both prior and subsequent to discovery, must be considered void and would not be tolerated by England as a limitation of equal participation and enjoyment in the benefits of navigation and exploration throughout the world. Continuing her reply, Queen Elizabeth denied that any sovereign or nation could claim the exclusive right to navigate the ocean, since its occupation was contrary to the course of nature and public usage; and concluded by declaring that all nations were at liberty to navigate the occan, since the use of the sea is common to all like the air. (Camden, "Annals, 1580.")

In vain did Alberico Gentilis advise the English court that the Spanish pretensions constituted no cause for war. The power of resistance to the Spanish restrictions had been gathering in Northern Europe, particularly in England. The insistence of Spain on the observance of her exclusive rights in all appropriated seas, intensified by other arrogant claims, culminated in the expedition of the Armada. The defeat of this enormous fleet shattered the maritime strength of Spain, and though the union with Portugal continued, until terminated by the revolt of December 3, 1640, Spanish supremacy upon the seas ceased to exist. England, by this decisive victory, settled 
the disputed question: whether maritime nations, other than Spain, were to be permitted to undertake extensive over-seas enterprises, and to extend these activities into the New World. Through the enterprise of the Dutch and English seamen, the center of maritime enterprise was transferred, almost immediately, from Cadiz, Lisbon, and Barcelona, to Amsterdam and London.

The English fully realized the wisdom of Lord Bacon's declaration that the rule of the sea is the epitome of monarchy; advising that England should conquer Spain in order to enjoy the rich heritage of the Spanish carrying trade and the wealth of the numerous Spanish colonies. Nevertheless, the Netherlands surpassed England in the development of maritime resources, and, in consequence, the hostility of England was directed against the menace of the growing Dutch sea-trade. The organization of the Dutch East India Company, which was chartered May 20, 1602, with a capital of $\$ 2,750,000$, indicates the Dutch appreciation of the unlimited possibilities of the newly acquired trade and of the necessity of adequate capital to develop the inherent resources, properly. Although the Dutch Republic was merely a loose federation of seven sovereign provinces, which had united in revolt against the tyranny of Philip II, it acquired increasing wealth and commercial supremacy, due largely to the fortunate situation of Holland at the mouth of the Rhine, the highway of Central Europe.

The Dutch, unlike the Spaniards, the Portuguese, the Danes, and later, the English, sought to establish no restrictions on the free navigation of the sea, consistently maintaining the principle that the open ocean was incapable of appropriation. When Gentilis attempted to vindicate restrictions of the open sea in his "Advocatio Hispanica" (1613), during the struggle between Philip II and the United Provinces, Grotius assailed the claim, as he had earlier contested the pretensions of the Portuguese to property rights in the Eastern Seas; affirming that every nation should exercise the unrestricted enjoyment of the seas.

The beneficent influence of the Dutch was not destined to 
endure. England enjoyed a peculiar strategic position on the Channel and the North Sea, assuring ultimate success to the design of stifling Dutch commerce. The preponderant wealth of England was still upon land, while that of the Dutch was in ships; consequently, during the wars which ensued, the Dutch suffered severely. Every ship and cargo which was captured enriched the English and, correspondingly, weakened the Dutch. The alliance of France with England in the prosecution of the war against Holland accelerated the decline of the United Provinces.

England and France now entered upon a long-continued contest over the distribution of the vast Dutch inheritance, both seeking to extend their commercial and maritime interests. England was soon enabled to achieve enhanced prestige upon the seas through a more rigid enforcement of certain claims to sovereignty over the Four Seas of England, based upon customs, memorials, and treaties, sanctioned by the practice of preceding centuries. France had exhibited no similar interest in acquiring exclusive domain over any portion of the open sea, nor was any belated attempt made to change the French policy in this respect.

Rolle records a document of King Alfred's reign which considers the seas surrounding England as appendant to the kingdom, since the King's sovereignty extends throughout the land into the middle of the Four Seas, which are in consequence, subject to the law of the Crown. (Rolle, "English King's Bench Reports Abridged," I, 528, paragraph \#1.) The Four Seas, as defined by Selden, were those seas which surrounded England, comprising;

The Western, including the Scotch and Irish Seas;

The Northern or North Sea;

The Eastern or German Ocean;

The Southern, including the English Channel and the Bay of Biscay.

(Selden, "Mare Clausum," Lib. II, cap. 1.)

England exercised exclusive sovereignty in the Four Seas, 
with the exception of the sea lying southward. In considering Sir John Constable's case, the court decided that the "interest of the Queen in the sea extends into the Middle of the Sea, betwixt England and Spain. But the Queen hath the whole jurisdiction of the sea between England and France, \&c., \&c., . . . And so it is of Ireland." ("The Queen (Elizabeth) vs. Sir John Constable," (Leonard, "Reports," Vol. III, 72.) ${ }^{1}$

In virtue of dominion over the Four Seas, England demanded homage to the flag from Stadtland (Norway) to Cape Finisterre (Spain), while at intervals there was an evident disposition to extend this claim to Gibraltar. Endeavoring to establish the legality of this sovereignty, Selden argned that the publication of the Laws of the Sea from Oleron at the instance of Richard I, proved that the kings of England had promulgated, for centuries, laws for the government of these seas, and, furthermore, that respect and obedience had been accorded them. And Sir Leoline Jenkins in his "Charge to the Cinque Ports" declared "that the Western World received them (the Laws of Oleron) from England, by way of defence to the sovereignty of our Kings in the British Ocean and to the judgement of our countrymen in sea affairs." As judge of the Court of Admiralty in the reign of Charles II, Sir Leoline Jenkins further asserted the king's sovereignty within the Four Seas, and declared that it was his right and province "to keep the public peace on those seas; ... to preserve his subjects and allies in their possessions and properties upon these seas, and in all freedom and security to pass to and fro on them, upon their lawful occasions "; and he further extended this authority and jurisdiction of the king "to preserve the public peace and to maintain the freedom and security of navigation all the world over; so that not the utmost bound of the Atlantic Ocean, nor any corner of the Mediterranean, nor any part of the South or other seas, but

1 Sir Edward Coke states that "within the Four Seas" means within the jurisdiction of England, and refers to an ancient record of Edward I (1272-1307), preserved in Coke's “Institutes," Vol. IV, pg. 142, in which the king of England is recognized as being in the peaceful possession of the sovereign seignory of the sea of England. Coke, "Institutes of the Law of England," Vol. II, pg. 253. 
that if the peace of God and the King be violated upon any of his subjects, or upon his allies or their subjects, and the offender be afterwards brought up or laid hold of in any of His Majesty's ports, such breach of the peace is to be inquired of and tried in virtue of a commission of oyer and terminer as this is, in such country, liberty, or place as His Majesty shall please to direct:- so long an arm has God by the laws given to his viceregent the King." (Queen vs. Keyn, "Law Reports," II Exchequer Division, 63.) (Scott, "Cases," 154.)

In contending that the English Crown has enjoyed supremacy throughout the Four Seas since earliest times, Selden refers to the Ordinance of King John, issued at Hastings in the second year of his reign (1200), requiring all vessels, of whatever nation, to lower sail on meeting with the King's ships. ${ }^{1}$

As further evidence of the real property rights which were claimed within the Four Seas, the retention by England of the Channel Islands in the Narrow Sea, is significant. When, in the reign of King John (1199-1216), the French secured possession of Normandy, the English claimed that this loss involved the land, solely, and that the adjacent seas remained, as before, within the domain of England. By the English contention the coast line of Normandy constituted the boundary between the two kingdoms. The successful maintenance of this position enabled England to retain full property rights in these islands; Jersey, Guernsey, Alderney, and Sark, lying just off the coast of France; which had hitherto been considered an integral part of the Duchy.

1 "It was ordained at Hastynges for lawe and custome of the sea in the tyme of $K \mathrm{yng} \mathrm{John}$ in the seconde yeare of his raigne, by the advice of his temporall lordes, that if the lieutenant of the Kyng or admirall of the Kyng or his lieutenant in any voyage appointed by Common Counsell of the kyngdom did at sea meet with any shyps or vessells laden or empty which would not stryke and lower their sailes at the command of the Kyng's lieutenant, or the Kyng's admirall, or his lieutenant; but makeing resistaunce against those of the flleet, that yf they can be taken that they be reputed as enemies, and their shyps, vessells, and goodes taken and forfeited, as goodes of enemies. ..."

Twiss. "Monumenta Juridica. Black Book of the Admiralty," Vol. II, Part C, Art. 35, pg. 129. 
There is abundant evidence that these early claims of England to property and jurisdiction in the Four Seas received general acquiescence among the sovereigns of Europe. In a notable congress of the sovereign European states of German or Roman origin (1299), convened upon the initiative of Philip IV of France (1268-1314), it was agreed that the sovereign lordship of the Four Seas belonged to England by prescription; for, if nations acquiesce in a claim to exclusive rights of navigation or fisheries for a long period of time, the right may be claimed by prescription. (Vattel, Book I, Chap. 23.)

In a formal memorial, various maritime states; including Catalonia, Denmark, Fresia, Genoa, Germany, Holland, Norway, and Zealand; conceded that the kings of England from time immemorial, "due temps dont il n'y a de memoire," had been in peaceable possession of the exclusive seignory over the seas of England; undertaking all necessary preparations for the maintenance of peace, and ensuring right and equity between mariners of every nation, voyaging through these waters. ${ }^{1}$

In acknowledging the exclusive dominion throughout the Four Seas, the right of England was vindicated of "making

1 Molloy, “De jure maritimo et navali," Vol. I, pg. 124, relates that "the Maritime Dominion by the laws of England were always accounted the Four Seas; such as are born thereon are not Aliens, and to be within them is to be within the Ligeance of the King and realm of England. . . . The Records in the days of Edward the Third and Henry the Fifth proclaim it, that those kings and their progenitors had ever been Lords of the Seas; and amongst those great instances of proving the sovereignty of the same is that famous Record of Edward the First and Philip the Fair of France (Philip IV), in which were the Procurators of most nations bordering upon the sea, throughout Europe, as the Genoeses, Catalonians, Almaines, Zelanders, Hollanders, Friezelanders, Danes, and Norwygians, besides others under the Dominion of the Roman Empire, where all jointly declare, "That the Kings of England, by right of said Kingdom from time to time, whereof there is no memory to the contrary, have been in peaceable possession of the Sovereign Lordship of the Seas of England, and of the Isles within the same, with power of making and establishing Laws, Statutes, and Prohibitions of Arms, and of ships otherwise furnished than merchant-men use to be, and of taking surety, and affording safeguard in all cases where need shall require, and of ordering all things necessary for the maintaining of Peace, Right, and Equity, among all manner of People, as well of other Dominions as their own, passing through said Seas, and the Sovereign Guard thereof." 
and establishing laws and statutes and restraints of arms," and " all other things which may appertain to the exercise of sovereign dominion."

That England displayed no hesitancy in enforcing the recognition of this dominion is evidenced by reports such as that of Robert Wenyngton of Devonshire, who was commissioned by the King to clear the sea of robbers.

"We met with a fleet of 100 great ships of Pruse, Lubycke, Campe, Rastocke, Holand, Selond, and Flanders, betwixt Guernsey and Portland; and then I came aboard the Admiral and bade them strike in the King's name of England "; which with "great insolence they refused to do"; whereupon a hardfought battle followed and "they yielded all the 100 ships to go with me, in what port that me lust, and my fellows; but they fought with me the day before and shot at us 1000 guns, and quarell out of number, and have slain many of my fellowship and maimed also. Wherefore methinketh that they have forfeited both ships and goods at our Sovereign Lord the King's will . . . and so I have brought them, all the 100 ships, within Wight." ("Paston Letters," Vol. II, 104.)

With the world-wide expansion of maritime enterprise, engendered and developed by the exceptional opportunities disclosed by the unprecedented discoveries of Columbus, Vasco da Gama, Magellan, John Cabot, and other explorers of the sixteenth century, the maintenance of these pretensions to property in the seas became still more advantageous to England and, correspondingly, more onerous to the other maritime states of Europe, particularly those situated on the North and Baltic seas, tributary waters, from which access to the expanse of ocean could only be secured through the sufferance of England in granting passage over the appropriated Four Seas. Appreciating the inherent advantages of the fortuitous geographical position, England sought to enforce still more stringently the proclaimed sovereignty of the seas; foreign vessels being accorded a right of way only upon the payment of tribute. All foreign vessels within the Four Seas, whether men-of-war or 
merchant ships, were compelled to pay honor to the English flag; an act which symbolized the acknowledgment of English maritime sovereignty. In character, this formality was not a mere courtesy, exchanged between equals, but was an expression of submission to the superior might of England. ${ }^{1}$

Foreign sovereigns enjoyed no immunity from the stringent formalities inflexibly exacted by England in securing the universal recognition of this exclusive sovereignty. Philip II of Spain, while voyaging to England (1554) with the intention of marrying Queen Mary, was fired upon by the British Admiral, for presuming to fly the Spanish Royal Ensign within the British Seas.

Following the destruction of the Armada (1588), further restrictions were enforced. The sovereignty upon the Channel was exercised so inflexibly that navigation to and from the dependent North Sea virtually came within the absolute control of England; and dominion was then claimed on the North Sea. In 1606, the King of Denmark, while on a voyage from England to his own country, was compelled to strike the Danish flag in obedience to the English presumption of sovereignty upon this sea.

The wars between England and the United Provinces (1652-1672) were caused, partially, by the staunch refusal of the Dutch to accord the flag-tribute demanded as a symbol of the maritime sovereignty of England. (Gardiner, "Navy Records," Vol. XIII.) In the treaty of peace (1653) between

1 In his “Works," Vol. VIII, pg. 327, Sir Walter Raleigh, referring to the exclusive dominion exercised by England, states: "I . . remember when one ship of her majesty's would have made forty Hollanders strike sail, and to come to anchor. They did not then dispute 'de mari libero,' but readily acknowledged the English to be 'domini maris Britannici.',

When the Spanish fleet was returning with Anne of Austria, daughter of the Emperor Maxmilian and espoused to Philip II of Spain, it omitted the customary salute to the British vessels while passing through the English Channel. Admiral Hawkins, who later performed distinguished service against the Armada, immediately opened fire from the flagship Jesus, in which the whole squadron soon joined, compelling the Spaniards to strike their flags, lower their top-sails, and come to anchor. 
England and the United Provinces, the duty of the flag salute was stipulated (Article XV); this being the first instance of the incorporation of the pretension within a treaty. (Schomberg, "Laws of Rhodes," 48.)

From Cape Finisterre to Stadtland England demanded and was accorded the formal recognition of her sovereignty. The instructions issued to all naval officers for the enforcement of this dominion assumed final form in 1691, during the reign of William III :

"Upon your meeting any ship or ships within his Majesty's seas; which for your better guidance herein you are to take notice that they extend to Cape Finisterre; belonging to any foreign Prince or State, you are to expect them in their passage by you to strike their top-sail and take in their flag, in acknowledgment of his Majesty's sovereignty in these seas; and if any shall refuse, or offer to resist, you are to use your utmost endeavor to compel them thereto, and in no wise suffer any dishonor to be done to his Majesty . . . You are further to take notice in his Majesty's seas his Majesty's ships are in no wise to strike to any; and that in other parts no ship of his Majesty's is to strike her flag or top-sail to any foreigner unless such foreign ship shall have first struck; or at the same time strike, her flag or top-sail to his Majesty's ship."

In the reign of Queen Elizabeth foreign boats were denied enjoyment of the fisheries in all waters immediately adjoining England, a restriction which was eventually extended to comprehend the North Sea. The English sought to establish the right of undivided use of the fisheries, based on prescription, in addition to the claim of sovereignty already asserted over the North Sea. Sweden and Norway had claimed rights in these fisheries at a former time, but, because of the long-continued wars in Scandinavia, had been unable to maintain their exclusive claims. Consequently, the English demanded the recognition of their own exclusive rights on the ground of uninterrupted enjoyment for an extended period, and forbade all but English subjects from engaging in the fisheries in waters ar- 
jacent to the English coasts and in the North Sea, unless foreign fishermen first paid the stipulated license fees.

In 1636 the Dutch attempted to fish without obtaining requisite licenses from England and were immediately driven from the North Sea by the English war-ships. Subsequently, a license fee of $\$ 150,000$ was exacted for permission to continue in the enjoyment of these fisheries.

In the discussion which had arisen between Spain and England in 1580 concerning the alleged violation of the Spanish sovereignty within the Pacific waters, based upon an indefensible interpretation of the Bulls of Alexander VI, Queen Elizabeth had contended that exclusive sovereignty in those distant waters would not be recognized, since the gift by Alexander VI of the New World, as alleged, to Portugal and Spain, exclusively, was void, and could not be recognized as limiting an equal participation by England in maritime enterprise beyond the seas. The position of England was, therefore, somewhat anomalous when confronted by arguments concerning the legality of the restrictions enforced on the Four Seas. Eminent publicists were enlisted to support the doctrine of appropriable seas, and to condone the employment of force, exercised in securing and maintaining the recognition of the exclusive claims to dominion. The English jurists sought justification by an appeal to the precedents of international law, and the officers of the Crown by untiring efforts endeavored to obtain formal recognition of the dominion by treaties with various sovereigns. The halo of legality was designed to envelop and sanction the ceaseless vigilance of hardy sailors and the employment of mighty fleets.

Sir John Selden achieved distinction through the publication of "Mare Clausum" (1635), refuting the liberal principles which had earlier been enunciated by Grotius in the "Mare Liberum " (1609). ${ }^{1}$

1 At the urgent request of James I, Selden had undertaken the refutation of the arguments advanced by Grotius, completing his treatise in 1618. At this time, however, James I was seeking a loan from the king of 
Selden asserted the sovereignty of England over the surrounding seas and declared that by the law of nature the sea was not common to all, but that it was capable of private dominion, like land. (Selden, "Mare Clausum," I, cap. 19.)

"It cannot be amiss for anyone to say," he argued, "that the seas, which might pass into the Dominion of any person, are by the Law of Dominion shut to all others who are not owners or that do not enjoy such a peculiar right. . . The sea is so shut up or separated and secluded for private Dominion no otherwise than the land or a port." (Selden, "Mare Clausum," I, vii.)

In denying the claim of the Dutch and other foreigners to fishing rights within the Seas of England, Selden advances a still more comprehensive claim, contending that only the shores and ports of the sovereigns beyond the sea are to be recognized as the bounds of the sea territory of England, to the southward and eastward. To the north and west, the New World and the North Pole evidently mark the limits of English domain, for Selden stipulates that here the bounds are established at the utmost extent of those seas which are possessed by the English, Scotch, and Irish. (Selden, "Mare Clausum," Book II, cap. 30.)

Enlisting the support of history in vindication of the legality of the English claims, Selden is at times led astray by an apparent confusion of language, since the same term does not invariably express the same idea or scope, and, consequently the distinction between territorial waters and the open sea is insufficiently defined. Nevertheless, Sir John Selden was recognized as the foremost exponent of the doctrine of "Mare Clausum," though numerous, eminent and contemporary jurists sought, in a similar manner, to vindicate the claims of England.

Alberico Gentilis upheld the claim of the English kings to

Denmark and forbade the publication of the work, fearing that certain passages referring to the dominion of the seas might give offense to Denmark and, consequently, jeopardize the success of the negotiations. Twiss. "Black Book of the Admiralty, I, xiii. 
sovereignty throughout the British Seas (1613); Medows, in his "Observations concerning the Dominion and Sovereignty of the Sea," approved a still more restricted doctrine than that advanced by Selden; while Rolle, like many other English authorities, adopted Selden's view and urged the general acceptance of the principle that the sea is the liegance of the King. (Rolle, "English King's Bench Reports," pg. 170, \#18.)

In the case of Ship Money, Rex vs. Hampden, xiii Charles I, 1637, it was established that the king had supreme dominion both by land and by sea, being owner of the sea and of the soil beneath the sea. In the opinion of the Chief Justice, the sole interest and property of the sea by the laws and policy of England rested in the king; the sea and land constituting one kingdom, and, in consequence the subjects of the sovereign must be bound to the defense of both. (Broom, "Constitutional Law," pgs. 303-367.)

Through the constant employment of her maritime resources, assisted in some degree by the consensus of English legal opinion respecting the validity of these claims, England maintained the sovereignty of the Four Seas, while at the same time striving to destroy the pretensions of Spain to the exclusive enjoyment of certain appropriated portions of the ocean. In extent, the Four Seas varied according to the fluctuating maritime strength of England; at times including all waters from Cape Finisterre to an indefinite distance northward and embracing the North Sea on the eastward. Again, with the resumption of hostilities by the adversaries of England, particularly under the attacks of the United Provinces which suffered most severely from the exactions of "Mare Clausum," the exercise of English sovereignty was substantially restrained, being limited in some instances to the Channel.

Although England sought sovereignty solely on contiguous waters, this appropriation of the high seas, in principle, was quite as indefensible as the acts of Spain of which England had complained. In effect, the pretensions of England were perhaps even more exasperating than those of Spain, since the Spanish 
claims affected distant waters, while England had appropriated waters which were essential to the daily welfare and to the future development of maritime enterprise within the United Provinces and the Scandinavian countries. Despite the exactions levied by England upon foreign shipping within the Four Seas, the Dutch continued to enjoy an increasing and lucrative sea-trade.

In an endeavor to protect English shipping from the menace of foreign competition in the carrying trade, Parliament passed the first comprehensive Navigation Act (1651). Heretofore, England had been content to exercise exclusive sovereignty upon the neighboring seas, but the adoption of the Navigation Acts carried this policy into distant waters. Though stated in terms which appeared, superficially, to relate only to the actual entry within the ports of the kingdom and its colonies, yet in effect, due to subsequent interpretation, the Navigation Acts seriously limited the freedom of navigation on the high seas; for it became the law in England and in Europe, in the effort to maintain the respective colonial restrictions, that when foreign commerce to a colony is prohibited, that it thereupon becomes unlawful for foreign vessels to trade in the adjacent seas, in the absence of treaty provisions. This policy had evolved from the mercantilist theories which flourished during the seventeenth and eighteenth centuries, establishing the principle that every country which possessed colonies was entitled to reserve exclusive trade privileges for its own citizens. Colonies were established with the design of extending the commerce of the parent country, there being no intention of founding a new and independent state. So jealously was colonial trade regarded that though commerce might flourish between two European nations, yet no permission to trade with the respective colonies could be implied. War granted no relaxation of this rule, even for the benefit of the parent country. The rule of war of 1756 established the principle that wherever a colonial or coasting trade was prohibited to foreign vessels in time of peace, no neutral vessels could engage in such trade during war, with 
the permission of the belligerent parent country, without immediately assuming an enemy character. No neutral could engage in a trade in which participation was forbidden in peace, without being deprived of the immunities accorded neutral vessels. ("The Immanuel" (1799) 2 C. Rob. Rep., 186.) (Scott, "Cases," pg. 845.) (Hall, "International Law," sec. 234.) (Phillimore, III, 270.) (Twiss, II, sec. 100.) (Rivier, II, 411.) (Bonfils, see. 1534.) ${ }^{1}$

The Navigation Acts (1651), designed to assist in securing maritime supremacy of the high seas by reserving all coasting trade to English ships, manned exelusively by English seamen, virtually secured for British vessels the monopoly of the foreign trade. England defended the passage of this statute as a municipal, rather than as a maritime, law, based on the acknowledged right of every state to regulate navigation within its own waters. Had the effect of the Navigation Acts, as well as of similar laws passed by other European states, been confined to the immediate territorial waters of the kingdom and the subsidiary colonies, no limitation of the free navigation on the sea would have arisen. The subsequent extension or interpretation of these restrictive statutes, however, prohibiting foreign vessels from navigating in the adjacent seas, constituted a serious restriction on the freedom of the seas.

At an earlier period, English statutes, under the respective reigns of Edward III (1327-1377), Richard II (1377-1399),

1 To safeguard, further, the enjoyment of the exclusive colonial trade, Spain organized the "fleet system" (1561); a plan which was not abandoned until "register ships" were substituted (1748), permitting more frequent voyages. The "fleet system" was designed to prevent smuggling with the American colonies of Spain, and to enforce the prohibition of intercolonial trade. No commerce could be carried on between Spain and the colonies, or between the colonies, except by vessels of the "fleet"; sailing usually but once a year in each direction. This system became universal in 1581, when all the European colonies of the world came under Spanish dominion, through the fusion of Spain and Portugal under the crown of Philip II. Later, through the insistent appeals of the American colonies, the onerous restrictions were somewhat relaxed, various ports in Spanish and Portuguese America being opened to intercolonial trade, extending to Brazil. Foreign vessels were excluded from this trade, as they were also excluded from participation in the "fleet." 
and Henry VII (1485-1509), had restricted the importation of various commodities, unless laden in English vessels. In the reign of Richard II, in 1381 and again in 1390, it was provided that no merchandise should be shipped out of the realm, except in English vessels.

These statutes were limited in effect to the ports of the realm, and the restrictions were less comprehensive than those embodied in the Act of 1651, which considered the colonies as an integral part of England.

The Navigation Act of October 9, 1651, provided that " no goods or commodities whatsoever, of the growth of Asia, Africa, or America, or of any islands belonging to them " should be brought into England, Ireland, or other possessions of the English Commonwealth, in any other ships than those owned, commanded, and chiefly manned by English seamen, under penalty of forfeiture of the ship and its cargo; and the Act further stipulated that no European commodities should be brought from any country (to England) in any ship not owned by the people of the Commonwealth, or the people of the country in which the merchandise was produced, under like penalty; the forfeiture of the ship and cargo. ${ }^{1}$

The Long Parliament, by passing the Navigation Act of 1651 , limited the carrying trade of maritime states in every part of Europe, but none suffered so severely as the United Provinces, immediately deprived of the lucrative trade with America. The entire sea-trade of the Dutch was at once jeopardized. Before the passage of the Act, an intense competition had developed between the English and the Dutch for

1 Hill, "History of Diplomacy," III, pg. 9; Seeley, "The Growth of British Policy," II, pg. 25:

"The Navigation Act, which remained substantially in force for nearly two hundred years, is the great legislative monument of the Commonwealth. It . . . laid the foundation of the English commercial empire." By excluding the Dutch from the carrying trade of English commodities, the English secured the monopoly of the transportation over-seas. Hitherto, the Dutch had lived and flourished because of the extensive carrying trade which had developed. Though the maritime enterprise of the Netherlands was to endure another half-century, its decline began with the enforcement of the Navigation Act of 1651. 
the carrying trade of the world. Through the superior enterprise of the Dutch merchants and sailors, the United Provinces had virtually secured the monopoly of this valuable trade. In an endeavor to retrieve lost prestige and to inflict serious limitations on Dutch commercial supremacy, particularly, the Navigation Act was adopted.

Heretofore, the United Provinces had accorded the humble salute demanded by the English of all foreign vessels within the Four Seas, as tribute to the sovereignty of England on these waters; the irritation suffered by the Dutch no doubt being mitigated by a realization of the actual maritime prosperity enjoyed through the rapid development of their sea-trade. To the former limitations within the Narrow Seas to which the Dutch had acquiesced were now added restrictions menacing trade beyond the seas. War ensued the year following the passage of the Navigation Act, waged for the supremacy in maritime commerce, for sea-power.

Following the promulgation of the Navigation Act, seventy Duteh vessels were seized before December, 1651. Seeking the release of these vessels an embassy was despatched from the United Provinces to London, but failed to secure any modification of the statute or of the procedure under which the vessels were condemned.

Early in May, 1652, the commander of a Dutch squadron on meeting the English refused to strike the Dutch ensign, and the English opened fire. Following this incident, the Dutch provided Admiral Tromp with a command of forty war-vessels with explicit orders to support the dignity of the Dutch flag and to protect Dutch merchant vessels from seizure and condemnation. At the same time Robert Blake set forth with the English fleet to enforce the tribute of the flag from all foreign vessels as recognition of England's claim to the sovereignty of the Narrow Seas. Meeting the English fleet, Tromp refused to strike the Dutch flag. The English fired a broadside to compel submission and fighting followed for several hours, resulting in the temporary defeat of Tromp. In later engagements the 
Dutch were more successful, and for a time Tromp sailed victoriously with a broom at the mast-head of his flag-ship, signifying that the Dutch had swept the English from the seas. (Hill, "History of Diplomacy," III, 110.)

The Dutch naval supremacy was short-lived. In the battle of the Texel Tromp met the English under Monk. The gallant Dutch admiral was mortally wounded, and the act of the crew of his flag-ship in withdrawing from the battle precipitated the retreat of the Dutch fleet. The Dutch, having lost seventeen hundred vessels since the commencement of hostilities, and now confronted by a still more serious situation due to the decisive victory of the English at the Texel, proposed a peace which was concluded in $1654 .^{1}$

From the successful issue of this brief war, the English Navy enjoyed increased prestige, while the maritime strength of the Dutch had been seriously weakened due to the excessive loss of merchant ships.

The conflict was renewed (1664), as a result of Dutch hostili ity to the still more exacting stipulations provided by the English Navigation Act of 1663. Without establishing the unquestioned supremacy of either nation, this war was terminated by the treaty of Breda, July 31, 1667. Even while negotiations were in progress between the Netherlands and England, De Ruyter, in command of the Dutch fleet, sailed up the Thames (July 1667), burning dockyards and warehouses at Chatham and blockading London for several weeks. The treaty of Breda established a peace which was welcome to both belligerents and provided that each was to retain all territory captured to May 20, 1667. Though the Dutch thus obtained Surinam, the English enjoyed ample compensation in the New Netherlands, since

1 Important engagements in the English-Dutch War occurred:

February 18/20, 1653, beginning near Portland and ending in the defeat of Van Tromp and de Ruyter off Calais by Blake, Deane, and Monk. June 2, 1653, Blake, Deane (killed), Monk and Penn defeating de Ruyter and Van Tromp off the Essex coast.

July 31, 1653, off the Texel; the decisive action of the war; Lawson, Monk, and Penn defeating Van Tromp.

Spears, "Master Mariners," pg. 174. 
the possibility of serious colonial disputes with the Netherlands was thus eliminated in North America. The acquisition of the New Netherlands, including the territory of New Sweden which the Dutch had obtained in 1655, gave England a continuous colonial possession along the Atlantic seaboard from Acadia to French Florida.

The Navigation Act, however, continued in force, though sufficient modifications were made to permit Dutch vessels to engage in the valuable commerce between England and the Rhine; controlled by the Dutch through the inherent advantages of their geographical situation. (Hill, "History of Diplomacy," III, 73.) Still more important, England insisted that the British sovereignty should be recognized within the Four Seas and, consequently, the Nineteenth Article of the Treaty provided:

"It is likewise agreed, That as well the Ships of War, as the other ships of the United Provinces, meeting with the Ships of War of this State in the British Seas, shall strike their Flag and lower their Top-sail, in the same manner as that has been performed in any former time, under any Government whatsoever." (Art. XIX, Treaty of Peace between Oliver Cromwell, as Protector of England, and the United Provinces of the Low Countries, signed at Breda, July 31, 1667; Justice, "Dominion of the Seas," pg. 542.)

The final conflict between the Dutch and the English arose through the efforts of Louis XIV to secure the Spanish Netherlands and to advance the commercial interests of France. Louis was well aware that France, much like England, was rapidly becoming a commercial and colonial rival of the Netherlands, and it seemed certain that great benefit would result from breaking up the trade monopolies enjoyed by the Dutch. Consequently, Louis endeavored to secure the active support of England. Taking advantage of the controversy between the English king and Parliament, Louis arranged by the secret treaty of Dover (1670) to furnish Charles II with a pension sufficiently ample to free him from further reliance upon Parlia- 
ment, in return for which Charles agreed to withdraw from the Triple Alliance and to assist Louis in the proposed war against the Netherlands.

Louis declared war against the Netherlands, March 28, 1672, and French troops at once invaded Holland and threatened Amsterdam. The English declared war, March 29, 1672, though a heavily laden fleet of Dutch merchantmen had been attacked several days before the formal commencement of hostilities. Against the overwhelming forces of the French and English, the cause of the Dutch was hopeless, and the Treaty of Westminster was signed with England (February, 1674), by which the sovereignty of England, in all parts of the sea from Cape Finisterre to Land Van Staten (Norway), was recognized. In this treaty, the privilege of the flag, constituting the chief cause of the war between England and the Netherlands, formed a separate and important article. The Dutch agreed "to make their ships, whether single or in fleets, strike the flag and lower the top-sail " to those of England, whether single or in fleets, provided they bore the King's flag.

As the immediate result of the Navigation Acts, beginning in 1651, and the successful termination of the war against the Dutch, the maritime strength of England increased enormously; the total tonnage in 1688 being double that of 1666 .

England Achieves Sole Sovereignty of the Seas.- Although England was enabled to enjoy an unprecedented development of maritime enterprise, founded upon the ruin of the great Dutch industry, yet the world-wide supremacy which was achieved by the English merchant marine and the exclusive sovereignty maintained within the Four Seas encountered, at intervals, determined opposition.

Since 1689 France had become a serious competitor for the supremacy in maritime affairs which England was intent upon securing. A critical situation arose (1700), through the proposed union of the French and Spanish kingdoms under the Bourbons. England perceived that such a coalition was destined to result in a vast colonial and commercial monopoly, 
which would threaten the expansion of English enterprise overseas. Consequently, it was recognized as essential for England's welfare that France and Spain be kept apart, since, in thus forestalling the proposed monopoly, opportunities would later arise for obtaining commercial concessions in the French and Spanish colonies alike. With the single purpose of protecting her commercial and maritime interests through the preservation of the Balance of Power in Europe, England undertook the War of the Spanish Succession (1700-1713). England succeeded notably in this endeavor, the Treaty of Utrecht, April 11, 1713, which terminated the war, expressly stating that the kingdoms of France and Spain should never be united. Moreover, England received important territorial and commercial concessions which indisputably accorded the English a dominant position in maritime affairs, securing by the terms of the treaty and the Spanish Asiento: the island of Minorca and the strategic Gibraltar, ensuring control upon the Mediterranean; a preferential tariff for British imports into the great port of Cadiz; the monopoly of the slave trade in Spanish America for thirty years; and the right of sending one ship a year, not exceeding five hundred tons burden, to the Spanish colony of Porto Bello on the Isthmus of Panama, to engage in the general trade. Hitherto, the British had been forbidden to trade with the Spanish possessions in America, and the French had monopolized the traffic in slaves everywhere in the Spanish colonies. (Hayes, "History of Europe," I, 309.)

Although enhanced prestige and extended opportunity for the further expansion of maritime and commercial enterprise was achieved by Great Britain through the favorable conclusion of the war at the Peace of Utrecht, yet France continued as a potential rival to the British commercial development until the decisive Seven Years' War. The maritime supremacy of Great Britain commences with the destruction of French sea-power, and, with the successful conclusion of the Seven Years' War, the British could enjoy the undisputed dominion of the seas, founded upon a paramount sea-power. France had constituted 
the last barrier among the maritime states of Europe to the ultimate dominion on the seas for which England had struggled through three centuries.

In the period immediately following the Seven Years' War (1763-1778), France made desperate and continued efforts, involving great expenditures, to rebuild the navy and to acquire the maritime prestige surrendered to Great Britain as the result of this disastrous war. The endeavor was futile, though French faith in the ultimate rehabilitation continued undiminished until the great English triumph at Trafalgar.

Despite the alliance of Russia, Denmark, Sweden and the Netherlands (1780), familiarly termed the "Armed Neutrality," Great Britain continued to enjoy supreme power on the seas. Though this Alliance claimed to exist solely for the protection of neutral commerce from undue belligerent interference in the war then being waged by England against the French and Spanish colonies and undertook to define what constituted contraband goods and to declare that "free ships" made "free goods," it was in reality designed to limit the maritime activities of Great Britain, who, at this time, had no ally among the European states. As further protecton against British molestation of merchantmen on the high seas, the Alliance agreed to a joint protection of their commerce and provided armed convoys for the protection of all vessels granted registry in any of the Allied states. (Foster, "Century of American Diplomacy," 43.)

The most remarkable undertaking of the Alliance was the attempt to restrict the navigation of foreign powers within the Baltic. The unprecedented pretension, advanced by the Four Powers, that the surrounding states could, by their mutual agreement, convert the Baltic into a closed sea for their own purposes, prohibiting all outside powers from carrying on any belligerent operations upon the appropriated waters, was refused recognition by England, France, and Holland, who were then at war, these powers denying the neutrality of the Baltic, except for the duration of that war. 
A similar restriction was contemplated in the Treaty of Roeskilde (1658) between Sweden and Denmark, in which the contracting powers agreed to exclude foreign ships of war from the Baltic. The convention of August 1, 1780, between Sweden and Russia, to which Denmark and Prussia acceded, was the ultimate development of this policy. By the terms of this treaty, the powers forming the Armed Neutrality agreed "to maintain perpetually that it is a closed sea, and must be regarded as such by its local position, in which all nations may navigate in peace and enjoy the advantages of perfect tranquillity; in consequence, they will undertake all measures to guarantee that sea and its coasts against all hostilities, piracy, and violence." (De Martens, "Recueil," III, 175.) (Westlake, "International Law," I, 201.) (Hall, "International Law," 5th Edit., 148.)

Had this restriction upon the freedom of navigation within the Baltic been realized, it would have effected a union of these states in a mutually benevolent neutrality: "first, if any of them should be at war with an outside power, shielding its coast and commerce in the Baltic from attack or blockade, and allowing it to receive contraband of war by way of that sea, while also permitting it to use the Baltic as a place of arms, and the Sound as a sally port for naval operations in the open sea; secondly, in case of war anywhere, allowing neutral Baltic states to carry on a trade in contraband without interference until the vessels engaged in it reached the open sea."

Although the endeavor of the Armed Neutrality to close the Baltic proved unavailing, a similar restriction was agreed upon by the Treaty of 1794 between Sweden and Denmark, stipulating that the Baltic should always be regarded as a closed sea, against the belligerent action of foreign powers, in order to secure a more perfect tranquillity within these waters. (De Martens, "Recneil," Vol. V, pg. 608) (Wheaton; Lawrence edit.; sec. 331.$)$

This renewed effort to establish restrictions upon the Baltic 
failed, chiefly on account of the maritime predominanee of England. Consequently, when the Czar complained of the bombardment of Copenhagen (1807), referring to the engagement of Russia under the convention of 1780 to guarantee the tranquillity of the Baltic, the British denied that the perpetual neutrality of that sea had ever been recognized. (Westlake, "International Law," I, 201.)

Subsequently, the engagement undertaken by Denmark, pursuant to the two treaties of 1857 - one with the principal maritime states of Europe, and the other with the United States of America, by which Denmark agreed to the amortization of the Sound dues - served to compose further agitation of this question until it was recently revived during the first decade of the twentieth century.

As formerly, the attempt to limit the free navigation of the Baltic, to distinguish between the rights of the military and the mercantile flags within this sea, brought forth an immediate denial. British war-ships were immediately despatehed to the Baltic. Confronted with this exhibition of British sea-power, prepared for the immediate vindication of the freedom of the seas, all further effort to undertake the proposed restrictions were abandoned. The Swedish Minister of Foreign Affairs declared (March, 1907), that while the treaty of 1857 does not relate to ships of war, being restricted by its context to merchant vessels, that nevertheless the Baltic is a "mare liberum," and the Sound a free strait for ships of war, as well as for merchant vessels, according to the general principles of international law. (Westlake, "International Law," I, 204.)

A limitation directed at the maritime supremacy of Great Britain, following the close of the Seven Years' War; a limitation which affected the rights of all maritime states; arose through the re-assertion of the century-old claims of Denmark to the exclusive enjoyment of the fisheries throughout the seas lying between the Danish coasts of Norway and Iceland, and to extend the prohibition so as to embrace the exclusion of foreign fishing 
vessels from the waters within fifteen miles of the Greenland coast. $^{1}$

The olaim of Denmark to the exclusive right to fish within the waters lying between Iceland and Norway was based on the right of property in the adjacent coasts, and, in this respect, was comparable to the claims of England to the waters of the Channel bounded by the lands of the Crown in England and upon the Continent. Henry VII of England admitted the right of Denmark to demand licenses of all foreign vessels fishing in the appropriated seas, and signed a covenant with John II of Denmark (1485), by which it was agreed that English vessels would be permitted to fish and to navigate within the seas between Norway and Iceland only when provided with licenses from the Danish King, these licenses to be valid for a period of seven years. (Westlake, "International Law," I, 166.) (Hall, "International Law," 5th Edit., 141.) (Justice, "Dominion and Laws of the Sea" (1705), pg. 168.) (Selden, "Mare Clausum," Lib. II, cap. 30, 31, 32.) (Daru, "Histoire de Venise," Book V, sec. 21.)

Queen Elizabeth sought to obtain a disavowal of these claims from the king of Denmark, instructing her ambassadors to the Danish court (1602) to undertake negotiations respecting the Sound dues, at the same time that they endeavored to secure the freedom of the northern seas for England. In the effort to

1 By the convention of Calmar (1397), the three Scandinavian states; Denmark, Norway, and Sweden; were united under the sovereignty of Queen Marguerite of Valdemar, daughter of the Danish King, Valdemar Atterdag, and the wife of King Hakon of Norway and Sweden. Sweden, however, broke away from this union, and established an independent kingdom under the leadership of Gustave Vasa, who was proclaimed king (1523). By virtue of this union, Denmark secured control of the coasts of Norway and based the extensive claims to sovereignty over the waters as far as Iceland upon this dominion. Following the downfall of Napoleon, the Treaty of Kiel (1814) provided that Norway should be detached from Denmark and placed under the dominion of Sweden. Denmark evidently suffered this loss as a punishment for endeavoring to remain neutral during the efforts to establish a continental blockade. The destructive bombardment of the capital, Copenhagen, by the English (1807) resulted from irritation and apprehension aroused by Denmark's endeavor to continue neutral. 
secure a renunciation of these exclusive fishery rights from the king of Denmark, Queen Elizabeth declared (1602) that the "law of nations alloweth of fishing in the sea everywhere, even in seas where a nation hath property of command."

In substance, the arguments advanced by England were similar to those employed earlier (1580) in the effort to refute the Spanish claim to dominion in the waters of the Pacific, following the protest of the Spanish ambassador, Mendoza, because of the alleged violation by Sir Francis Drake of the maritime rights of Spain. The attempt of Denmark to reaffirm the ancient, exclusive rights to the fisheries in the northern seas, and the endeavor to establish similar limitations within fifteen miles of the Greenland coast, met immediate opposition. The representations from the governments of England and Holland, whose interests were especially affected, caused the Danish government to withdraw the claim, definitely.

Despite the British demand, toward the close of the eighteenth century, that Denmark should renounce all claim to the exclusive enjoyment of the fisheries in the northern seas, Great Britain, quite inconsistently, continued to exact the humble tribute to British dominion in the Narrow Seas, provided for in the Naval Instructions of William III (1691): "Upon your meeting with any ship or ships within his Majesty's seas; which for your better guidance herein you are to take notice that they extend to Cape Finisterre; belonging to any foreign Prince or State, you are to expect them in their passage to strike their top-sail and take in their flag, in acknowledgment of his Majesty's sovereignty in these seas; and, if any shall refuse, or offer to resist, you are to use your utmost endeavor to compel them thereto, and in nowise to suffer any dishonor to be done to his Majesty. ..."

By the close of the eighteenth century no European nation could disregard with security these inflexible stipulations which had been enforced for more than one hundred years as symbolizing the British command of the seas. With the dawn of the new century, the renaissance of France, engendered by the 
Revolution and matured through the genius of Napoleon, challenged the pretensions of Great Britain to the exclusive dominion of the Four Seas. Napoleon recognized the limitations which France must endure while the sea-power of Great Britain remained predominant. Stimulated by the urgent necessity, the allied French and Spanish fleets within the harbor of Cadiz undertook extensive preparations to shatter the maritime strength of Great Britain. Issuing forth (October 21, 1805), the Allied fleet engaged the British under command of Lord Nelson.

The three-century struggle for maritime supremacy, waged continuously since the epoch-making discoveries at the close of the fifteenth century, terminated at Trafalgar. Thereupon, Great Britain, the ultimate exponent of the restrictive policy of maritime appropriation, a policy which was clearly inconsistent with the former endeavors of England to vindicate the essential freedom of international waterways, enjoyed the undisputed Sovereignty of the Seas. 


\section{CHAPTER VI}

\section{THE FREEDOM OF THE SEAS}

From the second year in the reign of King John (1200) until the year immediately following the victory at Trafalgar, England had asserted exclusive sovereignty upon the Four Seas, and, throughout this period of six hundred years, had enforced the claim to dominion with substantial success, although the appropriated area varied considerably according to the fluctuation of British sea-power.

Other maritime nations - Spain, Portugal, Venice, Denmark - had asserted similar claims to sovereignty or dominion over the open sea, particularly upon appreciating the opportunities disclosed by the over-seas discoveries in the fifteenth and sixteenth centuries. Nevertheless, especial interest attaches to the claims of exclusive sovereignty on the Four Seas, advanced by England, in part, because these claims were maintained for a longer period than similar pretensions asserted by any European power, being accorded formal recognition by treaties with various maritime states, but, chiefly, because England eventually became the sole exponent of the doctrine of "mare clausum," enforced with predominant sea-power, until the policy was ultimately abandoned, voluntarily. The Admiralty Instructions of 1805 retained the stipulation of 1691 that commanders of British war-vessels should exact the tribute of the flag from all foreigners in the Four Seas. Because of the tenacity with which Great Britain adhered to the policy of dominion over the waters within this extended area, the negotiations which had been satisfactorily concluded with the United States (1803) were not ratified by Great Britain because the agreement contemplated the abandonment of the right of search within the Four Seas, during peace, of vessels of the United States. 
Legality of Sovereignty Supported.- Eminent jurists had endeavored to support the legality of the exclusive claims of England. Their arguments, combined with the formal recognition of England's claims as embodied in certain treaties, were advanced to vindicate the justice of dominion exercised within the Four Seas.

Sir John Selden, endeavoring to ascertain the basis of England's claim to the sovereignty of the seas, declared (Mare Clausum) that long before the advent of Julius Cæsar, the ancient Britons, then lords of Great Britain, were sovereign upon the surrounding seas: "The Gauls were utterly ignorant of these shores (Albion in the time of Cæsar) because they were prohibited entrance, and so excluded from the free use of the sea." 1

From this statement Selden argued that because the Britons excluded all foreigners from their territory that they consequently held the sea as part of their domain, thereby disclosing a confusion, which frequently occurs throughout the treatise, between the right of entry into territorial waters or ports, and the freedom of navigation on the high seas. In bringing up the legality of dominion based upon prescription, Selden's argument is less vulnerable, for he demonstrates that the claims of the Norman and Plantagenet kings were accorded formal recognition by various sovereigns. Selden defended the appropriation of the high seas on the ground that the usage of all nations permits the acquisition of seas as a part of the national domain, and Vattel, at a later time, supported the validity of treaties which recognized such exclusive rights; for:

"As everyone is free to renounce his right, a Nation may acquire exclusive rights of navigation and fishing by treaties in which other nations renounce it. . . The latter are bound to observe such treaties; and the nation in whose favor they are made has the right to keep possession of its advantages by

1 Sir John Burroughs, "Soveraignty of the Seas," pg. 7, endeavors to prove by "Cæsar's Commentaries" that even "before the Roman Conquest, the British Nation had the supreame power and command of their owne seas without the competition of any other nations whatsoever." 
force. It was in this way that Austria renounced, in favor of England and Holland, the right to send vessels from the Netherlands to the East Indies." (Vattel, Vol. I, Book I, Chap. xxiii, sec. 284.)

Sir Leoline Jenkins, during Admiralty sessions at Old Bailey, charged that " . . Every Englishman knows that his Majesty hath an undoubted Empire and Soveraignty in the seas that environ these his Kingdoms, which by the ancient Statute Laws; 18 Edward I, de mo. Levandi fines; are called the quatuor Maria, by Foreigners, and by our modern Treaties, the British Seas. . . But besides these Four Seas, which are the peculiar Care, and as it were, Part of the Domaine of the Crown of England, his Majesty hath a Concern and Authority; in Right of his Imperial Crown; to preserve the publick Peace and to maintain the Freedom and Security of Navigation all the World over. . . Y You are, therefore, to enquire, if any Foreign Ship, Man of War, or other, being met with in any Part of the Four British Seas, hath refused to strike her Flag, and lower her Top-sail, to any of his Majesty's Ships or Vessels, carrying his Majesty's Flag, Ensign, or Jack. Or if any Captain or Commander of any Ship or Vessel, carrying the King's Flag, Jack, or Ensign, hath not demanded that Respect due to the King's Colours, when it was delayed, or refused, or not paid at the due Time, and after the accustomed Manner, and hath not pursued such refusers as Pirates." (Charge given by Sir Leoline Jenkins at Admiralty Sessions in Wynne's "Life of Sir L. Jenkins," Vol. I, pg. xc-xcv.) ${ }^{1}$

1 Clavell, "His Majesties Propriety," pg. 1; "The King of Great Britain is Lord of the sea flowing about, as an inseparable and perpetual appendant of the British Empire."

Sir Philip Medows, "Soveraignty of the Seas," pg. 7, affirms England's right of "excluding all foreign Ships of War from passing upon any the seas (sic) of England without special license for that purpose first obtained," and then proceeds to demonstrate that Sea-Dominion and rights of property are identical conceptions, for: "he who affirms a Sea-Dominion, and by it understands anything less than Property, embraces a Cloud for Juno.... Seas... receive their Denominations from the shoars they rowle upon, and Our Seas are the Seas which rowle upon Our Shoars." 
Sir John Burroughs concludes an extended argument in substantiation of England's absolute right of sovereignty on the seas by saying: "And therefore the Soveraignty of our Seas being the most precious Jewell of his Majesties Crowne, and (next under God) the principall meanes of our Wealth and Safetie, all true English hearts and hands are bound by all possible meanes and diligence to preserve and maintaine the same, even with the uttermost hazzard of their lives, their goods and fortunes." (Burroughs, "Soveraignty of the Seas," pg. 56.)

"Mare Liberum," declared Secretary Coke to Sir James Boswell, the English resident at The Hague (1635), " must be answered with a defense of Mare Clausum, not so much by discourse, as by the louder language of a powerful navy; to be better understood, when our strained patience seeth no hope of preserving her right by other means." (Penn, "Memorials," Vol. I, 513; Campbell, "Lives," II, 116.) ${ }^{1}$

Maintenance of Restrictions Exhausting.- Restrictions such as these bore heavily upon nations of lesser sea-power. Ultimate resistance to such pretensions was inevitable. Consequently, an onerous and incessant expenditure was entailed to ensure the continued observance of sovereignty within the appropriated areas. With the exception of Great Britain, all the maritime powers of Europe had relinquished all extensive claims to dominion in the seas by the commencement of the

1 G. F. de Martens, "Summary of the Law of Nations," pg. 161, writing in 1795, considers that the seas which are acknowledged to be free are: the

Spanish Sea

North Sea

Aquitain Sea

White Sea

Mediterranean Sea

Straits of Gibraltar;

while those which are restricted by the dominion of some nation and considered as an integral part of the national domain comprise:

The three straits between Denmark and Sweden, claimed by Denmark;

St. George's Channel, between Scotland and Ireland, claimed by Great Britain;

The Straits of Sicily, between Italy and Sicily, claimed by the king of Sicily;

The Gulf of Bothnia, claimed by Sweden;

The Black Sea, the Agean Sea, and Bosphorus of Thrace, the Propontus, and the Hellespont, claimed by Turkey. 
nineteenth century. The effort entailed to secure the exclusive benefits of the sea, exerted repeatedly since the Age of Discovery, proved too exhausting, nor had any real or lasting benefit resulted from the maintenance of maritime dominion, for the cost was disproportionate. Largely on this account, nations accepted the freedom of the seas, in principle, while the adherence of Great Britain to the obsolescent policy of restriction remained an unique exception to the general European practice. Great Britain had achieved predominance through the defeat of the maritime claims and aspirations of rival European states during three centuries of hostilities and was loath to relinquish the position so difficult to attain. But the changing conditions of maritime enterprise compelled Great Britain to realize the futility of continuing the enforcement of the restrictive policy. British dominion of the seas, because of the changing industrial conditions of the nineteenth century, did not seem destined to achieve adequate commercial advantages to compensate for the exhausting efforts of control on the Narrow Seas; a control which would become increasingly difficult with the inevitable union among the maritime states of Europe for successful resistance. Moreover, upon the termination of the Napoleonic wars, England was enabled to develop far more rapidly in maritime enterprise and industry than any other European nation. The vast aggressions of Napoleon had devastated industry throughout Europe, and the process of rehabilitation was necessarily slow. England, because of her fortunate insular position and the supremacy of her navy, escaped virtually unscathed. The modern and unprecedented development of industry and transportation, founded upon the application of steam power, was commencing and England was enabled to adapt her commerce and industry, immediately, to the changed and more favorable conditions. In consequence, Great Britain recognized that the expansion of national enterprise necessitated peace, the observance of the status quo, and that the unrestricted use of the seas was of paramount necessity for the most favorable development of maritime enterprise. 


\section{The Freedom of the Seas.- Under these circumstances} Great Britain was disposed to admit the illegality of restrictions upon the free navigation of the open sea. The reason and justice inherent in the arguments for Mare Liberum, advanced by eminent publicists, Bynkershoek, Pufendorff, Gentilis, Vattel, and particularly by the celebrated treatise of Grotius (1609), beeame tardily manifest. During the sixteenth and seventeenth centuries when Spain, Portugal, Denmark, and England sought to establish their respective sovereignties throughout the wide expanse of the open sea, scant heed was accorded the jurists who had ardently defended the freedom of the seas, endeavoring by historical example and cogent reasoning to establish the illegality of the attempted appropriations.

Ange de Ubaldis declared that the sea and the shores of the sea were free for the enjoyment of all nations, by virtue of the law of nature and nations, and, furthermore, demonstrated the impossibility of acquiring property in the sea, since the physical circumstances made it impossible to fulfill the obligation of long occupation, necessary to render an object susceptible of possession. (Nys, Acad. Roy. Belgique; "Lettres"; Bulletin, Series 3, 1900, pg. 81.)

Grotius assailed claims of sovereignty upon the seas still more bitterly, and drew forth a rejoinder from Sir John Selden (1625), who undertook the defense of England's exclusive dominion over the Four Seas. Though Grotius was not the first jurist to defend the freedom of the seas, yet his comprehensive treatise was destined to exert a profound influence, subsequently, because of its innate justice. Condemning the pretensions of the Portuguese, specifically, to private property in the Eastern seas, Grotius argued that the sea was free to all who owned ships and wished to use it as a highway for communicating with all the nations of the world, and endeavored to show that the ocean could not be appropriated justifiably by any one nation because of its variable nature; an element which is never the same and so lacking the character necessary in stable property, permitting effective occupation and thereby warranting 
ownership. Any nation, Grotius admitted, was competent to relinquish or renounce this liberty of navigation by a treaty or some other expression of the sovereign will, and he cited notable instances where this renunciation had occurred. (Grotius, "De jure belli et pacis," Lib. II, cap. iii, sec. 15.)

Grotius, and Vattel at a later period, attached particular importance to the inexhaustible character of the sea's benefits, and the consequent imnocent use of the sea which might be enjoyed by all nations.

"If the free and common use of a thing . . . were hurtful or dangerous to a nation," Vattel then considered that, " the care of its own safety would authorize it in subjecting, if it could do so, the object in question to its sovereignty, so as to subject its use to such precautions as prudence might dictate." But this was not the case on the high seas, Vattel declared, for "one may sail and fish without harm or danger to any one. Hence no nation has the right to take possession of the high seas, or to claim the sole right to use them, to the exclusion of others."

"It is clear that the use of the high seas for purposes of navigation and fishing is innocent in character and inexhaustible; that is to say, one who sails the high seas or fishes therein, injures no one, and the sea in both these respects can satisfy the needs of all men. Now, nature does not give men the right to appropriate things the use of which is imnocent and the supply inexhaustible and sufficient for all; for, since each one can obtain from the sea, as common property, what will satisfy his wants, the attempt to make oneself sole master of it and to exclude others would be depriving them unreasonably of the blessings of nature. . . Since, then, the right of navigating and fishing on the high seas is common to all men, the nation which undertakes to exclude another from that advantage does it an injury and gives just cause for war; for nature authorizes a nation to repel an attack; that is, to resist with force any attempt to deprive it of its rights. Let us go farther and say that a nation which seeks to lay claim, without good title, to an exclusive right over the sea, and to maintain it by force, 
does an injury to all nations whose common right it violates; and they may all unite against it to check its claims. It is of the greatest importance to nations that the Law of Nations, which is the basis of their peace, be everywhere respected. If any one openly treads it underfoot all may and should rise against that nation; and by thus uniting their forces to punish their common enemy, they will fulfill their duties toward themselves and toward the human society of which they are members." (Vattel, "Law of Nations," Vol. I, Book I, Chap. xxiii, sec. 281-283.)

Not content with considering the inherent justice of their claims and with reference to precedent, the champions of the freedom of the seas appealed to the principles of the Roman Law for vindication, quoting the passage from the Institutes of Justinian, recognizing the common rights of all men in the enjoyment of the sea:

"By the law of nature, then, the following things are common to all men; air, running water, the sea, and consequently the shores of the sea. No one, therefore, is debarred from approaching the sea-shore, provided only he does not harm houses, monuments, or buildings, because these are not subject to the law of nations as the sea is." ("Institutes Justinian," Book II, Tit. I, sec. 1.)

Beginning with the early nineteenth century, the opinion was becoming universal, chiefly because it was generally recognized that free commercial navigation had become essential to the existence of the modern world, that no state was capable of maintaining effective occupation upon the open sea, and that territorial waters, though remaining under the dominion of the adjacent state, should be held subject to the right of innocent passage by foreign vessels. It was generally admitted that the sea could not be occupied, and that it was indivisible, inexhaustible, and productive, without the labor of man. 
"Down to the beginning of the present century, the course of opinion and practice with respect to the sea had been as follows. Originally it was taken for granted that the sea could be appropriated. It was effectively appropriated in some instances; and in others extravagant pretensions were put forward, supported by wholly insufficient acts. Gradually, as appropriation of the larger areas was found to be generally unreal, to be burdensome to strangers, and to be unattended by compensating advantages, a disinclination to submit to it arose, and partly through insensible abandonment, partly through opposition to the exercise of inadequate or intermittent control, the larger claims disappeared, and those only continued at last to be recognized which affected waters the possession of which was supposed to be necessary for the safety of the state, or which were thought to be within its power to command. Upon this modification of practice it may be doubted whether theories affirming that the sea is insusceptible of occupation had any serious influence. They no doubt accelerated the restrictive movement which took place, but outside the realm of books they never succeeded in establishing predominant authority. The true key to the development of the law is to be sought in the principle that maritime occupation must be effective in order to be valid." (Hall, "International Law," 5th Edit., pg. 151.) (Azuni, "Droit Maritime," Part I, Chap. II, Art. 1.)

The supremacy of the sea attained by Great Britain was necessarily an isolated position. Reference to contemporaneous restrictions, exerted by other maritime powers, in order to vindicate the exercise of British sovereignty of the seas, was no longer possible, since all substantial pretensions of this character had been destroyed by the superior power of the British navy.

The Sovereignty of the Seas Voluntarily Abandoned.Confronted by a radically changed situation in maritime af- 
fairs, the sovereignty of the seas, asserted and maintained with varying success through more than six hundred years, and ultimately secured with the destruction of Napoleon's sea-power, was destined to prove an embarrassment to the advancement of national enterprise, while the universally admitted injustice of the claim threatened the future security of the nation. The British Admiralty Instructions (1805) reciting that "it is expected that the said foreign ships do strike their top-sail and take in their flag in acknowledgement of his Majesty's sovereignty in those seas," was a perpetual insult to the sovereigns of maritime states, which might at any time be challenged by the offended powers. The battles of the Nile, Saint Vincent, Toulon, Ushant, Camperdown, Copenhagen, and the decisive victory off Cape Trafalgar, however, by annihilating the navies of Europe, assured the continued enforcement, - for the immediate future at least, - of England's dominion. Despite these notable victories, Great Britain voluntarily abandoned the sovereignty of the seas, at a time when it might have been exacted more inflexibly than ever before.

In the revision of the "Admiralty Instructions," undertaken the year following Trafalgar (1806), for the first time the Regulation of 1691 was omitted, because of the recommendation of Admiral Gambier under whom the revised "Instructions" were being prepared. This renunciation of a long-cherished dominion was the final recognition among the maritime states of Europe that the open sea, constituting the great highway of commerce and communication between civilized nations and the remotest regions of the earth, should remain unrestricted during the continuance of peace for the complete enjoyment of every nation.

Having tardily recognized the principle of the freedom of the seas, Great Britain's maritime policy became exemplary because of its apparent liberality. National interest assured the acceptance and more extensive application of the principle, for, with the continued development of the British maritime interests, it was indispensable that English vessels should sail 
all seas and affluent waters without suffering burdensome restrictions.

In the subsequent endeavor to secure greater opportunities for maritime enterprise, Great Britain sought the freedom of navigation on arterial rivers - navigable through several states - achieving notable success in the internationalization of the Paraguay, the Danube, the Amazon, the Rio de la Plata, and the other extensive inland waterways throughout the world.

Great Britain demonstrated a genuine and thorough conversion to the principle of maritime freedom by limiting the exercise of national dominion over coastal waters to a maximum extent of three miles, at the same time combating excessive claims to territorial waters advanced by other maritime nations, particularly Russia and the United States.

The Navigation Laws of 1651 , providing that all commerce between England and her colonies must be borne in English ships; as well as all commerce with any other country, except as borne in the vessels of the country of orginal production; had received a subsequent interpretation which served to restrict navigation in the open sea, inasmuch as foreign vessels were forbidden to trade within the seas adjacent to the protected colonies. John Stuart Mill, appreciating the opportunity for an enormous extension of British commercial interests, provided a liberal policy were adhered to, consistently, demonstrated that though the Navigation Laws might be defended upon grounds of political expediency, the restrictions were indisputably disadvantageous, economically, for competition between vessels of different nationalities was impossible, and consequently the British must endure high freight rates. Though the modification of the Navigation Laws (1823) arose through the necessities of domestic welfare; the last and most intense contest between Protection and Free Trade being waged over the proposed repeal of the Laws; the international aspect was also significant.

The Modification Act (1823) empowered the Government to negotiate reciprocity treaties with foreign countries, admitting 
their ships to British ports on the same conditions as British ships, provided British ships enjoyed reciprocal privileges in the favored countries. The Navigation Laws were definitely abolished in 1849, permitting the vessels of every nation to compete with English ships on terms of perfect equality, whether in the ports of the United Kingdom or of the British colonies.

Necessity of Enduring Sea-Power. - The voluntary relinquishment of the sovereignty of the seas did not comprehend any relaxation of British sea-power; an essential element to the national existence of Great Britain, as of all insular states. Sea-power is not equivalent to dominion on the sea. It is employed chiefly in the exercise of certain belligerent rights, limiting the freedom of the seas in conformity with established belligerent rights solely for the duration of the hostilities. Seapower, in peace, does not comprehend the command of the seas; nor the enjoyment of dominion beyond the national territorial limits, seaward; nor the right to visit and search foreign vessels on the high seas; but signifies prestige on the sea, embracing the power of the navy, and all other elements of naval strength; particularly the national mercantile marine. The exercise of sea-power by any maritime state may be legitimate at any time; whereas the exaction of tribute, whether honorary or in the form of monetary payment, based upon the claim to sovereignty in the seas, is indefensible.

In the opinion of Chief Justice Cockburn:

"The claim to such sovereignty (in the seas), at all times unfounded, has long since been abandoned. No one would now dream of asserting that the sovereign of these realms (The United Kingdom) has any greater right over the surrounding seas than the sovereigns of the opposite shores; or that it is the especial duty and privilege of the Queen of Great Britain to keep the peace, in these seas; or that the Court of Admiralty could try a foreigner for an offense committed in a foreign vessel in all parts of the Channel. . . . All these vain and extravagant pretensions have long since given way to the influence of reason and common sense." (Queen vs. Keyn, 1876, "Law 
Reports," 2 Exchequer Div., pg. 63.) (Scott, "Cases," 156.) The employment of sea-power during peace has ensured the safety of the sea, and guaranteed the freedom of navigation by destroying pirates and semi-official marauders, like those sanctioned by the Barbary states. Despairing of the establishment of unrestricted navigation within the Mediterranean, while the maritime weakness of the newly-created United States continued, Thomas Jefferson declared:

"We must consider the Mediterranean as absolutely shut to us until we can open it with money. Whether this will be best expended in buying or in forcing peace is for Congress to determine;" (Jefferson, "Writings," Washington Edit., II, pg. 4), (Mr. Jefferson to Mr. Hawkins, Paris, 1786) and advised that

"Whatever sums we are obliged to pay for the freedom of navigation in the European seas, should be levied on the European commerce with us by a separate impost, that these powers may see that they protect these enormities (the Barbary piracies) for their own loss." (Jefferson, "Writings," Wash. Edit., Vol. I, 509; Mr. Jefferson to General Greene, Paris, 1786.)

During war the exercise of sea-power within the limits prescribed for belligerent action by international law constitutes no illegitimate restriction upon the freedom of the sea, and the employment of sea-power, in accordance with the recognized rules of maritime warfare, may be essential to the very existence of a belligerent state. While continental nations may suffer nothing more serious than burdensome restrictions through the lack of adequate sea-power; dominant sea-power, during war, is indispensable for an insular state, ensuring the protection of the national domain and over-seas commeree, and permitting the destruction of hostile shipping. Premier Asquith, addressing Parliament, February 15, 1916, outlined the inestimable service of the British navy in the performance of four supreme duties: first, the defense of the British shores against the possibility of invasion; second, complete neutralization of 
the aggressive power of a hostile fleet; third, [partial] clearance of the high seas from the menace which early in the war was of a most formidable kind, and the maintenance of a [comparatively] free influx of necessary goods for Great Britain and her allies; fourth, vigilant and continuous stoppage of enemy supplies and enemy trade, one of the most important factors in the final successful prosecution of a war. (New York Times, February $16,1916.)^{1}$

Serious difficulty arises, especially in recent wars, whenever the accepted principles of international law become inadequate to protect the maritime interests of belligerents or neutrals. The abandonment of customary practices, or the institution of unprecedented procedure, may constitute a serious abridgement of the freedom of the seas; the injury to the rights of other nations continuing until such innovations are incorporated within the body of international law through the universal approval of maritime nations. It is incumbent on all belligerents, while engaged in hostilities beyond national territorial waters, to recognize that the sea is the great highway of intercommunication, for the common use and benefit of all nations, in war as in peace, and that, in consequence, belligerent limitations, securing validity only through the consensus of practice among maritime nations, must accord precedence to this paramount right of international navigation. The freedom of the seas signifies

$1 \mathrm{Mr}$. Balfour expressed a similar conviction respecting the essential service of the British navy: "The Grand Fleet, which as a Grand Fleet has never yet had the opportunity of being in action, nevertheless has, from hour to hour and day to day through all the months of this war been the foundation on which everything else has rested. But for the Grand Fleet you could not have driven the enemy's commerce from the seas; you could not now be strangling her economic position; you could not now be transferring your troops freely backward and forward from Great Britain to France, from Canada to Great Britain, from Australia to Egypt; you could not now be carrying on military operations thousands of miles from our shores, absolutely secure from every species of attack by any vessel other than the submarine.... On it depends the whole of the operations carried out by the Allies from Archangel in the north far round to the Persian Gulf, because were the British fleet removed ... the allied nations... would have no means of intercommunication. They would be cut off from the outer world; they would be cut off from each other." New York Times, March 10, 1916. 
that no nation has any jurisdiction upon the high seas, in peace, save over its nationals and vessels rightfully bearing the national flag; while in the abnormal condition of war, a belligerent nation may enjoy, further, the right to prevent the carriage of contraband and to establish effective blockades along the enemy's coasts. Otherwise, beyond the limits of territorial waters, all nations may enjoy equally the navigation, the fisheries, and other advantages of the sea.

Considerations of national security sanction sovereignty upon the narrow strip of coastal waters, modern practice restricting this marginal sea to an extreme width of three miles. The strict observance of the basic principle that the range of cannon; demonstrating the extent of actual, physical control exercisable by the state occupying the adjacent shores and so determining the width of territorial waters within which the jurisdiction of the state is undisputed; would warrant a greatly extended marginal sea. The comprehensive claims of national security and jurisdiction, based on the increased range of modern artillery, have failed to prevail over the conflicting interests of navigation, and, in consequence, the negligible limitation on the freedom of the seas, embodied in the exclusive control accorded over waters for a marine league - three nautical miles - seaward, still enjoys general observance. Since the boundless expanse of the open sea is incapable of continuous control or occupation, no nation may claim exclusive rights of sovereignty, property, or jurisdiction beyond the narrow limits of marginal waters, except as such claims affect national property or persons. Because of the inherent inability to maintain effective control over extensive areas of the sea, states now recognize that the sea is insusceptible of appropriation as property.

Westlake considers that the foundation for the freedom of the seas cannot be discovered in the Roman Law, as frequently asserted, since the Roman jurists who enunciated this principle contemplated only the relation between individuals and the supreme Roman state; no consideration being accorded to 
relations between state and state. Continental writers, on the contrary, support the freedom of the seas largely on the Justinian principle. (Westlake, "International Law," I, 164.) (Rivier (contra) "Principes du droit des gens," Book I, pg. 236.) The argument that the fluidity of water renders the sea incapable of occupation, Westlake considers similarly untenable, since "the fluidity of the atmosphere would equally prove that sovereignty over land cannot extend usque ad coelum."

The sea is incapable of occupation because "the area over which a ship of war can exercise control from her momentary position is insignificant when compared with the vast expanse of ocean, and her control even over that area is not permanent. The possession established by her ceases in fact as soon as she has left her station, and the power of reproducing it at the same station depends on too many contingencies to be that constant power to reproduce at will a possession which has ceased in fact, which is necessary to the continuance of the right." (Westlake, "International Law," I, 164-165.) ${ }^{1}$

Voluntary Limitation on Enjoyment of the Seas.Though the enjoyment of the high seas is a common right of all states, certain limitations or regulations may be enforced to secure the equal rights of all and to ensure order and safety throughout the seas. The laws imposed by maritime states upon their own vessels may prove inadequate to achieve the desired

1 The high seas are the highways of the world and free enjoyment is the common right of all nations. No state has exclusive jurisdiction over the high seas, and national vessels at sea are recognized as of that state; Lord vs. Goodall, N. \& P. S. S. Co. 102 U. S., 541.

Municipal Jurisdiction is co-extensive with the territory of the government exercising it. Admiralty jurisdiction is that which a nation exercises beyond its territorial limits, and upon the high seas. This jurisdiction is exercised because the seas are the peculiar property of no nation, but a common highway for all; and admiralty jurisdiction is properly confined to cases of civil jurisprudence. However, the Congress of the United States has conferred criminal jurisdiction on the admiralty courts; for acts committed on the high seas; at various times since 1789 . Chief Justice Martin in People vs. Tyler (1859), 7 Mich., 161. (Hall, "International Law," 5th Ed., 153.) (Twiss, "International Law," Vol. I, sec. 173.) 
condition, or the situation presented may demand international co-operation for adequate government. The convention signed by various maritime nations following the Titanic disaster recognized the necessity of such united action for securing the safety of life at sea.

Nations occasionally agree to the mutual relinquishment of the fullest enjoyment of their undisputed rights upon the high seas in order to destroy certain adverse influences or to establish, more securely, the freedom of the seas. Other nations may assent to these limitations in furtherance of the common, maritime welfare, but in the absence of such acquiescence their enjoyment of the sea, subject to the existing maritime law, continues unlimited. Notable limitations, of rights on the high seas, agreed to by various nations, include:

The treaties between the United States and Great Britain of April 7, 1862, and February 17, 1863, permitting a mutual search for slavers within two hundred miles of the $\Lambda$ frican coast, south of the thirty-second parallel of North Latitude, and within ninety nautical miles of Cuba, Madagascar, Puerto Rico, and Santo Domingo; this treaty being a temporary departure by the United States from the constantly asserted position that American vessels, during peace, should be subjected to visit and search solely by the war-vessels of the United States;

The General Congress of Brussels, July 2, 1890, providing for a reciprocal search for slaves along the East African coast;

The treaty of 1887 between Belgium, Denmark, France, Germany, Great Britain, and the Netherlands governing the liquor traffic on the North Sea.

Though the ocean is the property of no single nation, the vessels of every nation must observe the general maritime law which all commercial nations have agreed upon by long usage, or otherwise, for governing transit on this common highway. ("Marianna Flora," 11 Wheaton, 405.) Additional rules, supplementing the general maritime law and further safeguarding the navigation of the high seas, may be enacted by any mari- 
time state, but such supplementary legislation can bind national vessels and the vessels of states which accept the additional regulations, solely, unless the rule receives universal sanction through adoption by all maritime powers.

Equal participation in the deep-sea fisheries is a legitimate employment of the high seas which all maritime nations may enjoy: The limitations and regulations imposed correspond with those established to secure the freedom of navigation on the seas, since the yearly production of the fisheries discloses an importance only secondary to that of commercial navigation, the estimated value of the world's fishery products amounting to five hundred million dollars, annually. ("Report of the United States Bureau of Fisheries," 1915.) The protection afforded the fisheries by national regulation within territorial waters is inadequate; consequently, while fishing within territorial waters is reserved exclusively for national vessels, all foreigners being rigorously excluded unless enjoying limited treaty privileges, the undisputed right of fishing on the high seas, enjoyed by all nations, may be restrained or regulated by custom or treaty. $^{1}$

Modern practice exhibits a fundamental departure from the former pretensions of sovereignty maintained by dominant maritime powers. The navigation and fishery regulations which limit the use of the sea to any appreciable degree constitute no derogation from the fundamental principles of international law establishing the freedom of the sea. Although such co-operative restrictions seek the secure and perpetual enjoyment of the sea for all maritime nations, foreign nations

1 Like many other maritime states, Great Britain has agreed to limit her undisputed right to fish in the open sea by the following conventions:

By treaty with the United States, for the protection of the Northeast fisheries; notably the treatics of 1818, 1872, 1892;

By the treaty of 1839, supplemented by the treaty of 1867 , with France, regulating fishing in the adjacent seas;

By the treaty of 1904 with France, relating to the Newfoundland fisheries;

By the treaty of 1882 between Great Britain, Belgium, Denmark, France, Germany, and the Netherlands governing the North Sea fisheries. 
are bound to observe the limitations enacted, only upon voluntary adoption.

Certain indefensible limitations still endure in time of peace, and the magnitude of modern wars exerts serious restrictions upon commerce, frequently intensified by the employment of irregular and unprecedented practices, nevertheless there exists nothing comparable to the former, continued pretensions to the sovereignty of the seas, involving humiliating ceremonies and the payment of tribute. At discretion, a merchant vessel may, or may not, offer the flag salute upon passing war-ships of any sovereign. The ceremony which indicated submission to the maritime dominion of powerful states in previous centuries, has become merely a courtesy to be returned by the fleet-commander.

Aside from the question whether sovereignty comprehended property in the seas, it is beyond dispute that the exercise of sovereignty on the seas resulted in restrictions which are no longer countenanced. While certain exceptional limitations upon the most complete liberty of navigation still endure, the former comprehensive pretensions to dominion over wide areas of the open sea are no longer maintained. Suppressed for three centuries by the intense national rivalries engendered by the unprecedented opportunities for maritime development disclosed by the discovery of the New World, but gaining increasing recognition as the maritime states of Europe realized the futility of endeavoring to maintain a lasting and exclusive dominion over the high seas, the principle of the freedom of the seas ultimately received universal acceptance through the voluntary abandonment by Great Britain of all claims to sovereignty beyond territorial waters. 


\section{CHAPTER VII}

EXCEPTIONAL LIMITATIONS ON THE FREEDOM OF THE SEAS

Before proceeding with the consideration of the freedom of navigation on inland waters, which almost immediately evolved from the establishment of the unrestricted use of the seas, certain exceptional limitations must be briefly noted. The freedom of the seas, like the freedom of navigation on inland, international waterways, enjoys a world-wide observance, albeit certain notable restrictions still exist. In relation to the vast extent of international waterways, both inland and maritime, available for the commerce and enterprise of all nations, the limitations imposed during peace are not particularly burdensome, though significant as demonstrating that the unqualified observance of the principle has not yet been achieved, neither on the high seas nor on inland waterways.

Although pretensions to sovereignty over extensive areas of the high seas are now virtually obsolete, certain claims to restricted maritime areas still persist, based upon the extension of the marginal sea beyond the customary limits, and so enclosing bays, gulfs, and even narrow seas, which justly belong to all nations in common. Long exclusive possession or explicit treaty provisions with other maritime nations may accord a limited or even a complete recognition of such adverse claims. As a rule the presumption is against the validity of all claims exceeding the customary limits of territorial jurisdicton, for, as Vattel demonstrates, "the rights of navigation and fishing and other rights which are exercised on the sea are classed among those rights which may be exercised at will, and which are not subject to prescription, they cannot be lost by a non-user. Hence, although it should happen that a nation had been, from time immemorial, the only one to exercise the right 
of navigating or fishing in certain seas, it could not on that ground claim an exclusive right; for the fact that the other nations did not use their common right of navigating and fishing in the waters in question does not lead to the conclusion that they agreed to renounce their right, and they may still use it as often as they please." But it can happen that "non-user" may take on the character of consent, or implied agreement, and thus become a title in favor of one nation as against another. When a nation is alone in exercising the right of navigating and fishing in certain waters, and claims an exclusive right, and forbids others to exercise their right, IF THEY OBEY the prohibition with sufficient signs of acquiescence, they impliedly renounce their right in favor of the other nation and give it an exclusive right which it may lawfully maintain against them in the future, especially when that right is confirmed by long usage." (Vattel, "Law of Nations," Vol. I, Book I, Chap. xxiii, secs. 285-286.)

International law admits the exercise of national jurisdiction upon inland waters bounded entirely by the territory of a single state and affording access solely to ports within the national domain, as well as over the marginal sea, customarily limited to one marine league seaward. Bays, not exceeding six nautical miles in width, are considered territorial waters, though immemorial usage may permit jurisdiction on waters exceeding these universally recognized limits, particularly if national security is jeopardized otherwise. In the opinion of Vattel, all considerations respecting the marginal seas apply "more especially and with greater reason to roads (anchorages), bays, and straits, inasmuch as they are even more capable of being effectively possessed and are of greater importance to the safety of the state; i.e. . . . bays and straits of small area, and not wide stretches of sea sometimes called by these names, such as Hudson's Bay, and the Straits of Magellan, over which sovereignty, and still less ownership, could be claimed. A bay, entrance into which can be prevented, may be possessed and made subject to the laws of the sovereign; and it is important 
that this be so, since the nation might be much more easily insulted in such waters than along the coast, which is exposed to the winds and force of the waves." (Vattel, "Law of Nations," Vol. I, Book I, Chap. xxiii, sec. 291.) ${ }^{1}$

All other waters constitute the high seas and cannot be restricted by any sovereign, though Phillimore adheres to the view that "the portion of the sea actually occupied by a fleet riding at anchor is within the dominion of the nation to which the fleet belongs, so long as it remains there," a doctrine revived during the progress of the Spanish Claims hearings, December 19, 1901, the Assistant Attorney General declaring that "an United States battleship represents the sovereignty of its country. ... The vessel and the water upon which it floats is United States territory." (Phillimore, "International Law," I, sec. 203; II, sec. 303.) (Spanish Treaty Claims Commission, \# 30, Dec. 19, 1901.) $)^{2}$

Futile efforts during the nineteenth century to establish exclusive claims upon the high seas served further to vindicate the principle universally recognized during the first decade, so that at present the derogations from the complete freedom of the seas involve the extension of marginal waters beyond the customary limits. The exactions of the Barbary pirates; the arrogant claims of Great Britain to the right of visit and search aboard foreign merchant-men during peace; the dues imposed upon navigation within the Danish Sound; and the successive endeavors of Russia and the United States to restrict the sealfishing industry in the Bering Sea, ceased to exist, demon-

1 F. de Martens, "Traité de droit international," Vol. I, sec. 96, pg. 495 ; supported by Oppenheim, "International Law," I, pg. 230; asserts that the extensive Sea of Azov is not open to the navigation of foreign vessels, in the absence of permission from the Russian Government, since communication with the Black and Mediterranean Seas is indirect; it is virtually enclosed by Russian territory; and therefore resembles a gulf more than an open sea.

2 The ocean is "the open sea, the high sea, that which is the common highway of nations, the common domain, within the body of no country and under the particular right or jurisdiction of no sovereign, but open, free and common to all alike, as a common and equal right. U. S. vs. Morel, 26 Fed. Cases, No. 15, 807. 
strating that a recrudescence of the conditions formerly countenanced, and even energetically maintained, had become intolerable to the maritime world.

Impositions of the Barbary States. - The vindication, advanced by the Barbary pirates, for the imposition of tribute money, recalled the exclusive claims of an earlier age, maintained by Venice, Genoa, Spain, Portugal, and England. The Barbary States insisted that their corsairs were not piratical, but were armed forces of the States, despatched officially to collect tribute from all vessels navigating the western Mediterranean, and acting in accordance with the long-established privileges arising from sovereignty on the seas. Though the activities of the Barbary States were confined exclusively to the Mediterranean, a fact which afforded a support to the claim of appropriated waters, the exactions of tribute and the enslavement of the captured voyagers constituted so serious a restriction upon the freedom of navigation that war was declared by the United States against Algiers, the most notorious offender, March 3, 1815. The decisive victories achieved by the American fleet under the command of Bainbridge and Decatur assured the immediate discontinuance by Algiers, Tripoli, and Tunis of the intolerable exactions; the Dey of Algiers agreeing by the treaty of June 30, 1815, that henceforth no tribute should be exacted from vessels of American registry. (Moore, "American Diplomacy," pg. 71.)

Exercise of Visit and Search During Peace.-Inconsistent with Great Britain's apparent abandonment of sovereignty on the sea (1806) was the continuance of a practice particularly abhorrent to the United States : the visit and search of merchant vessels during peace by British war-ships. The customary practice of removing seamen, who were alleged British subjects, and forcibly enlisting them in the service of his Majesty, intensified the resistance to this practice which culminated in the War of 1812. Although the Treaty of Ghent (December 24, 1814), which terminated this war, provided no prohibition of this objectionable practice, this method of abridg- 
ing the freedom of navigation was discontinued. The opinion of Lord Stowell that "no nation can exercise a right of visitation and search upon the common and unappropriated parts of the sea, save only on the belligerent claim" expressed the principle, thenceforth observed. (Le Louis, 2 Dodson, 210, 245.) (Moore, "International Law Digest," II, 886.)

Slave Trade Search.- Subsequent endeavors to establish a qualified right of visit and search, based on international agreement, for the purpose of suppressing the African slave trade proved signally unsatisfactory. Maritime states guarded the principle of the inviolability of merchant ships while on the high seas, during peace, so jealously that the efforts to restrict the slave trade in this manner were unavailing.

The tenth article of the Treaty of Ghent between the United States and Great Britain recited that the traffic in slaves was irreconcilable with the principles of humanity and justice, and that, in consequence, Great Britain and the United States would undertake to promote its abolition. Referring to this article, Secretary of State Adams instructed the ministers of the United States in London (1818), to state to the British Government: "that the admission of a right in the officers of foreign ships of war to enter and search the vessels of the United States, in time of peace, under any circumstances whatever, would meet with universal repugnance in the public opinion of this country." ("American State Papers, Foreign Relations," V, 72.) (Moore, "International Law Digest," II, 918.)

Danish Sound Restrictions.- The immemorial claim of Denmark to the right of levying tolls on all vessels passing through the Sound, the Store Belt, and the Little Belt, still enjoyed recognition during the early part of the nineteenth century. Although this compulsion to pay tribute to the Danish king constituted a limitation on the freedom of navigation, Denmark asserted the legality of this imposition, claiming that the expense of lighting and marking the navigable channels was thus defrayed, and that the right was undeniably recognized by numerous treaties and immemorial usage. The 
continued exaction of the Sound dues terminated in a series of treaties between Denmark and the principal commercial nations, providing for the amortization of the tolls; each nation contributing a specified sum as compensation; the treaty of April 11, 1857, between Denmark and the United States providing for the payment of $\$ 393,911$. (Wheaton; Lawrence edit. ; 1863 ; pg. 335.) (Moore, "International Law Digest," I, 663.)

Bering Sea Claims.- A more comprehensive claim, purporting to restrict navigation on the open sea, was advanced by Russia under the ukase of Emperor Alexander, September 7, 1821. In sanctioning certain regulations of the RussianAmerican Company, which had received various hunting and trading licenses "in the northern seas and along the coasts of America," by virtue of the charter granted by the Imperial edict of Paul I, July 8, 1799; the Emperor Alexander proclaimed that "the pursuits of commerce, whaling, and fishing, and of all other industry, on all islands, ports, and gulfs, including the whole of the northwest coast of America, beginning from Bering's Strait to the $51^{\circ}$ of northern latitude, also from the Aleutian Islands to the eastern coast of Siberia, as well as along the Kurile Islands, from Bering's Strait to the south cape of the island of Urup... were exclusively granted to Russian subjects," and all foreign vessels were forbidden, except in case of distress, "not only to land on the coasts and islands belonging to Russia, as stated above, but also to approach them within less than a hundred Italian miles." (Moore, "International Law Digest," I, 890.)

Following the immediate protest of the American Government, the Russian minister sought to vindicate the proclamation as a measure designed to protect the Russian settlements in America from disturbance and competition, and particularly to prevent all illicit trade in arms and ammunition with the natives. In conclusion, he indicated that the Russian Government might justifiably claim sovereignty over the whole of Bering's Sea and the Pacific Ocean between the Imperial Asi- 
atic and American territories, as a closed sea. (Moore, "Digest," I, 891.) (Westlake, I, 166.) (Hall, 5th Edit., 148.)

Great Britain, until 1806 an ardent defender of sovereignty in the open sea, joined with the United States in challenging the legality of the Russian pretensions. During the progress of the negotiations undertaken at Petrograd the Russian Government admitted that jurisdiction upon the Pacific and Bering Sea should be restricted to the range of artillery from the sea-coast. The attempted prohibition was formally abandoned by treaty with the United States (1824) and Great Britain (1825), stipulating that the citizens of the high contracting parties should be neither disturbed nor restrained either in navigation or fishing on any part of the Pacific Ocean. (De Martens, "Nouv. Recueil," Vol. II, 358; Vol. VI. 684.) (Moore, "Digest," I, 892.)

From that time until the cession of Alaska to the United States, Russia neither asserted nor exercised any exclusive jurisdiction within Bering's Sea or on the Pacific, or sought any exclusive rights in fisheries beyond the ordinary limit of territorial waters, other than the transitory claim to the sole enjoyment of the Sea of Ochotsk fisheries. Referring to the reported exclusion from the Sea of Ochotsk of the British whaling barque Faraway, Mr. Fish instructed the United States minister to Russia (December 1, 1875,) that "there was reason to hope that the practice which formerly prevailed with powerful nations of regarding seas and bays usually of large extent near their coasts as closed to any foreign commerce or fishery not specially licensed by them was without exception a pretension of the past, and that no nation could claim exemption from the general rule of public law, which limits its maritime jurisdiction to a marine league from its coasts. We should particularly regret if Russia should insist on any such pretension." (Moore, "Digest," I, 717.) (Hall, 5th Edit., 148.) (La Ninfa, 75 "Federal Reporter," 517.)

The cession of Alaska to the United States was consummated 
by the Treaty of Washington (March 30, 1867), the Emperor of Russia undertaking, upon the payment of $\$ 7,200,000$, to cede all Imperial territory and dominion on the Continent of America, the western boundary being so drawn as to include numerous islands lying off the Alaskan coast. It is noteworthy, in view of the subsequent claim of the United States, that the treaty contained no stipulations transferring property rights in Bering Sea; the terms expressly conveying the territory and dominion of Russia on the Continent of America and in the adjacent islands. Despite the explicit provisions of the treaty of 1867 , the United States, endeavoring to vindicate the seizure by government revenue cutters of certain Canadian vessels nearly sixty miles from the Alaskan coast (1886, 1887, 1889), advanced claim to jurisdiction within Bering's Sea, as successor to the alleged Russian dominion over these waters.

After quoting the language of the first article of the treaty of cession (March 30, 1867), while charging the jury in the Thornton case (Aug. 30, 1886), Judge Dawson declared that "Russia had claimed and exercised jurisdiction over all that portion of Bering Sea embraced within the boundary lines set forth in the treaty"; that "all claim had been recognized tacitly and acquiesced in by the other maritime powers of the world for a long series of years prior to the treaty "; and that the dominion of Russia having passed to the United States, "all the waters within the boundary set forth in this treaty to the western end of the Aleutian Archipelago and the chain of islands are to be considered as comprised within the waters of Alaska, and all penalties prescribed by law against the killing of fur-bearing animals must therefore attach against any violation of law within the limits described." (Moore, "Digest," I, 896.)

Although the vessels condemned by the United States Court at Sitka were released by Presidential order (1886), additional seizures and condemnations occurred in 1887, pending the conclusion of the negotiations undertaken by the United States with the governments of France, Great Britain, Japan, and 
Russia to prohibit the indiscriminate killing of fur-seals through co-operative regulation. Certain objections, lodged by Canada, terminated the conference; and the United States Congress forthwith enacted the law of March 2, 1889, reciting that section 1956 of the Revised Statutes, forbidding the killing of fur-bearing animals in Alaskan waters should thenceforth apply "to all the dominion of the United States in the waters of Bering Sea." Following the establishment of this law, the seizure of vessels in the North Pacific beyond the territorial waters of the United States was renewed, energetically (1889). In the endeavor to vindicate the exercise of jurisdiction in an area of the open sea fifteen hundred by six hundred miles in extent, the United States claimed that Bering Sea was not comprehended in the term "Pacific Ocean," employed in the Russian treaties of 1824 and 1825, and contended that both before the acquisition of Alaska from Russia, and subsequently when Alaska was in the possession of the United States, the waters of Bering's Sea were, and had been, treated as territorial waters, and that therefore seals and all other animals and fish found in the prescribed area were the property of the United States. (Alverstone, "Recollections of Bench and Bar," pg. 223.) ${ }^{1}$

Great Britain refused to accept the American interpretation, asserting that the waters of Bering Sea, other than the usual territorial waters, must be considered as high seas and that, therefore, anyone had a right to capture animals or fish therein; and proposed an arbitration of the divergent opinions concerning the jurisdictional rights of the United States. The Court of Arbitration, established by the Treaty of Washington between the United States and Great Britain; February 29, 1892 ; determined that Russia had neither exercised nor conveyed an exclusive jurisdiction over Bering Sea, outside the

1 According to Hall, the United States held the position that a state has the right to make enactments under which it can assume jurisdiction on the high seas, exercisable at an indefinite distance outside territorial waters, for the purpose of safe-guarding property, and of protecting itself against a threatening invasion of its interests. Hall, 5th Edit., pg. 257. 
usual territorial waters, and that, in consequence, the United States had no further rights within these waters than those enjoyed by Russia until the cession of Alaska. This decision reaffirmed the established principle that the laws of a state cannot operate beyond the marginal sea against the vessels or subjects of another state, except with the state's express or tacit assent; such operation constituting a restriction upon the freedom of the seas.

Following the award of the Bering Sea Tribunal, the United States Courts refused to entertain jurisdiction over foreign vessels seized beyond the three-mile limit, although continuing to enforce the statutes, passed by Congress for the protection of fur-bearing animals within sixty geographical miles of the Alaskan coast, against citizens of the United States. ("James G. Swan," 77 Federal, 473. $)^{1}$

Acting in accordance with the provisions of the Treaty of Arbitration, the Tribunal prescribed regulations to prevent the extermination of the fur-seals, having competence, by virtue of the treaty to limit the freedom of the seas to this extent, though solely with reference to the acts of the two contracting parties. This prohibition forbade pelagic seal-fishing within sixty miles of the Pribyloff Islands during a specified closed season; May-August. These regulations, which the appropriate, subsequent legislation of Great Britain and the United States made binding upon their respective nationals, proved inade-

1 The award of the arbitrators under the Convention signed by Great Britain and the United States; February 29, 1892; with regard to furbearing seals in Bering Sea, by which the contracting parties agreed that the decision of the tribunal of arbitration should be a final settlement of all questions submitted, became the supreme law of the land and as binding on the courts as an act of Congress. By the award it was settled that the United States had no exclusive jurisdiction in the waters of the Bering Sea, outside the ordinary three-mile limit, and no right of property in or protection over the fur-bearing seals frequenting the islands of the United States when found outside of such three-mile limit. Therefore, the act of March 2, 1889, declaring that the Revised Statutes, section 1956, which forbids the killing of fur-bearing animals in Alaska and waters thereof, shall apply to "all the domain of the United States in the waters of Bering's Sea," must be construed to mean the waters within three miles of the shore of Alaska. "La Ninfa"; 1896; 75 Federal, 513. 
quate, as fishing vessels from other maritime states continued an unrestrained destruction. Following extended negotiations, the protection and preservation of the fur-seals in the North Pacific was assured through international co-operation, agreed upon by the treaty concluded at Washington, July 7, 1911; between Great Britain, Japan, Russia, and the United States. This convention, effective from December 15, 1911, will remain in force for fifteen years, and thereafter until twelve months have elapsed following notice of withdrawal from one, or all, of the parties.

Prior to the decision of the Bering Sea Tribunal, the Russian Government had seized American fishing vessels beyond the Imperial Asiatic territorial waters, defending this extensive exercise of jurisdiction by reference to the position assumed by the United States in the dispute then pending with Great Britain. The claims for indemnity arising from these seizures remained in abeyance until the convention of St. Petersburg (Petrograd), August 26-September 8, 1900, between Russia and the United States was agreed upon, providing for an arbitration of the rights involved. The arbitrator, after observing that there existed between the United States and Russia at the time of the seizure no convention regulating the taking of fur-seals in such manner as to affect the ordinary rules of jurisdiction under the law of nations, declared that, whether the seizure took place twenty, or only eleven, miles from land, it was made outside Russian territorial waters; that the contention that a ship of war might pursue outside territorial waters a vessel whose crew had committed an unlawful act in the territorial waters or on the territory of the state, was not in conformity with the law of nations, since the jurisdiction of the state could not be extended beyond the territorial sea, unless by express convention; and that it was therefore unnecessary to consider the alleged grounds for inferring that the vessel had been guilty of the illegal hunting of seals in the territorial waters or on the territory of Russia. An award was made in favor of the claimants, consequently, for $\$ 28,588$, 
with interest at six per cent. (Moore, "Digest," I, 929.)

The illegality of the former exercise of sovereignty on the high seas, disclosing insuperable tenacity for three centuries, despite the futile endeavors of less powerful maritime states, was formally established by the Bering Sea Tribunal. While the denial of the United States' claim removed the last pretension to jurisdiction on the open sea and discouraged the subsequent establishment of similar restrictions, the exercise of sovereignty by certain nations over enclosed seas, and extensive bays and marginal waters continued, constituting notable limitations upon the freedom of fishing and navigation.

Excessive Claims to Marginal Waters. - The exercise of sovereignty over marginal waters acquires validity from the patent ability of the adjacent state to command the coastal waters by means of shore batteries and the coast guard, and from the undeniable necessity of establishing such control for the security of the fiscal and commercial interests of the state and for the safety of the inhabitants. The boundary of marginal territorial waters has been fixed by general maritime practice at one marine league from shore. ${ }^{1}$

In establishing this limitation to more extended claims over the marginal sea, the particular interests of the great maritime powers are discernable, seeking the most complete freedom for the expansion of over-seas transportation. Some states regard the generally recognized three-mile limit as inadequate for their peculiar situation and attempt the exercise of jurisdiction further seaward. Such claims to the adjacent seas, exceeding the usual marine league, regardless of the apparent justice of the particular claim, must be regarded as a restriction upon the freedom of the sea, as long as the consensus of international opinion adheres to the narrower limitation. As Hall observes:

"It is felt, and growingly felt, not only that the width of three miles is insufficient for the safety of the territory, but

1 A statute mile $=5,280$ feet., 1609 metres ; a nautical mile $=6,080 \mathrm{ft}$., 1852 metres; a league $=18,240 \mathrm{ft}$., 5556 metres, or three nautical miles. 
that it is desirable for a state to have control of a larger space of water for the purpose of regulating and preserving the fisheries in it, the productiveness of sea-fisheries being seriously threatened by the destructive methods of fishing which are commonly employed, and in many places by the greatly increased number of fishing vessels frequenting the grounds. After being carefully studied and reported upon by a Committee of the Institut de Droit International, the subject was exhaustively discussed by the Institut at its meeting in Paris, in 1894, the exceptionally large number of thirty-nine members being present. With regard to the necessity of ascribing a greater breadth than three miles of territorial waters to the littoral state there was no difference of opinion. As to the extent to which the marginal belt should be enlarged, and the principle upon which such enlargement should be based, the same unanimity was not manifested; but ultimately it was resolved by a large majority that a zone of six marine miles from low water mark ought to be considered territorial for all purposes, and that in time of war a neutral state would have the right to extend this zone, by declaration of neutrality or by notification, for all purposes of neutrality, to a distance from shore corresponding to the extreme range of cannon." (Hall, "International Law," 5th Edit., 154.)

Whatever burden results from the increased territorial jurisdiction derived from the seaward extension of the marginal sea, falls chiefly upon the fishing industries of foreign states, inasmuch as the right of innocent passage secures the uninterrupted enjoyment of navigation to all maritime states, regardless of the width of territorial waters established. Indeed, the extensions to the usual three-mile limit, at present existing, contemplate, almost exclusively, the protection of coastal fisheries, subject to the paramount right of foreign navigation.

Great Britain regulates the pearl fisheries of Ceylon for a distance of twenty miles seaward, basing the claim of jurisdiction upon an appropriation of the bed of the sea. Norway ex- 
ercises an exclusive claim to fisheries within four nautical miles of the coast, this limitation being so construed as to include many large bays and fiords. On December 11, 1911, Russia voluntarily abandoned further claim to extend the limit of territorial waters from three to twelve miles from the coast. ${ }^{1}$

Bays and Gulfs. - Clearer instances of existing encroachments upon the open sea appear in the appropriation of bays and gulfs, as maritime territory, when the distance from shore to shore greatly exceeds the permissible six miles. Basically these claims arise from an inordinate extension of the marginal sea across the entrance waters. France claims bays and inlets which do not exceed the maximum width of ten miles; Holland considers the Zuyder Zee territorial water; Great Britain exercises jurisdiction over large bays on the English, Scotch, and Canadian coasts; while the United States has virtually appropriated the waters of Delaware and Chesapeake bays. (Hall, "International Law," 5th Edit., 150, 155-158.) Furthermore, in the British-French Convention of 1839 and 1843, and the North Sea Convention of 1882, the width of ten miles at the mouth is adopted as the definition, with certain exceptions, for determining which are to be treated as territorial waters, in fulfilling the provisions of the conventions. The practical circumstances which govern necessitate this definition in fishery conventions. The waters on either side of the bay, within three miles of the shore are admittedly territorial, and it is consequently assumed that any attempt to fish in the narrow strip of water remaining in the middle of bays which are less than ten miles in width will be unprofitable,

1 Denmark continued to claim a twenty-mile marginal sea surrounding the coasts of Iceland, founded upon immemorial use, but by the fishing regulations of 1872 , the ordinary three-mile limit was voluntarily established. Hall, 5th Ed., pg. 148.

The revenue acts of some nations provide for the exercise of governmental authority beyond the usual extent of the marginal sea. Justification for the consequent interference with the movements of foreign vessels while traversing the high seas is sought in the plea of national selfdefense, but no general consent of nations exists to accord this practice the semblance of legality. Moore, "Digest," I, pg. 726. 
and would be attended with a constant risk of violating the rights of the territorial sovereign. (Moore, "Digest," I, 717.)

Great Britain, in claiming dominion over Conception Bay on the Newfoundland coast, and the United States, by assuming exclusive jurisdiction over Delaware and Chesapeake bays, were compelled to seek vindication of these extensive claims on grounds other than an appeal to the right of the marginal sea would warrant. The fact that the British Government had exercised dominion over Conception Bay for an extended period with the acquiescence of other maritime nations, together with the enactments of Parliament, declaring that this bay constituted an integral part of the national domain, sufficed to establish the British claim of sovereignty, although the entrance of the bay is approximately forty miles wide. (Direct U. S. Cable Co. vs. Anglo-American Telegraph Co., (1877), L. R., 2 App. Cas., 394.) (Moore, "Digest," I, 740.)

In establishing the exclusive jurisdiction of the United States over the waters of the Delaware and Chesapeake bays, the Second Court of Commissioners of the Alabama Claims decided that "its headlands (Chesapeake Bay) are well marked, and but twelve miles apart; that it and its tributaries are wholly within our own territory; that the boundary lines of adjacent States encompass it; that from the earliest history of the country it has been claimed to be territorial waters, and that the claim has never been questioned; that it cannot become the pathway from one nation to another; and remembering the doctrines of the recognized authorities upon international law, as well as the holdings of the English Courts as to the Bristol Channel and Conception Bay, and bearing in mind the matter of the brig Grange and the position of the Government as to Delaware Bay, we are forced to the conclusion that Chesapeake Bay must be held to be wholly within the territorial jurisdiction and authority of the Government of the United States." (Stetson vs. United States, "Court of Commissioners of Alabama Claims," 1885.) (32 "Albany Law 
Journal," 484.) (Scott, "Cases," 143.) (Moore, "International Arbitrations," IV, 4332-4341; Vol. V, 4675.) (Moore, "Digest," I, 742.)

Entire Seas. - While it is apparent that moderate restrictions still endure on certain maritime waters close in-shore, the former pretensions to sovereignty on the open seas no longer exist, since even the exclusive sovereignty established throughout the Inland Sea of Japan, the unique instance considered by certain publicists as a derogation from the universally recognized principle, merely involves the customary practice of appropriating bays and other enclosed maritime waters, the inaccurate and misleading nomenclature, by employing improperly the term "sea," causes the confusion occasionally arising with reference to this appropriation.

However, the dominion exercised by the Japanese Government over this enclosed sea differs materially from that which is elsewhere recognized over marginal, territorial waters, admitting the right of innocent passage. The exclusive rights maintained on the Inland Sea of Japan correspond to those enjoyed by the United States within the Chesapeake and Delaware bays, for it is considered maritime territory, thus justifying the exclusion of foreign shipping whenever essential for the security of the national interests.

The valuable fisheries, in which all maritime nations should be at liberty to participate, were these waters in reality a portion of the high seas, are reserved exclusively for Japan. ${ }^{1}$

Restrictions on the Black Sea.- At a former time, Turkey similarly asserted an exclusive ownership throughout the Black

1 In deciding the case of the "Emperor of Japan vs. the P. \& O. S. S. Co.," the British Supreme Court at Shanghai declared that the Inland Sea of Japan constituted a part of the high seas, but on appeal the English Privy Council reversed this decision, without attempting to determine the actual character of the Inland Sea under international law.

Regarding the re-opening of the Inland Sea, consult the Agreement of Yokohama of July 25, 1863, signed by the representatives of France, Great Britain, the Netherlands, and the United States for the purpose of ensuring united effort by the Occidental Powers; Hertslet, "Commercial Treaties," Vol. XII, pg. 589. 
Sea, chiefly because it was enclosed by Turkish territory. (Wheaton, Lawrence' Edit., 329.) During the nineteenth century, through European intervention, the Black Sea was declared free, though Turkey was permitted to retain certain restrictive rights over the Bosphorus and Dardanelles. In consequence, a paradoxical situation was established; the Black Sea, nominally an interior sea and available for the unrestricted navigation of all maritime powers under the law of nations, became politically and geographically a closed sea, since the straits affording access to and from the waterways of the world might at any time be closed at the will of the Turkish Empire. ("Revue des Deux Mondes," XXIX, pg. 807.)

In 1905, a recrudescence of the former restrictive policy appeared in the agitation for neutralizing the Baltic. Following the Declaration of Independence by Norway and the visit of the German Emperor to Copenhagen, there was short-lived agitation, sedulously fostered by the German press, to secure the closure of the Baltic, as an inland sea, so that the nations enjoying dominion upon the surrounding coasts might undertake co-operative measures for excluding foreign war-ships. Almost immediately a portion of the English fleet was despatched on a cruise through the Baltic to demonstrate that the freedom of navigation by merchant or war-vessels within these waters could not be denied to foreign powers with impunity. It is noteworthy that no Baltic power acted upon the suggestion of establishing the contemplated restrictions upon the Baltic, a recognition of the principle that any attempt to close the open sea against belligerent action is as indefensible as excluding peaceful commerce and fishing.

Though the proposed restrictions on the Baltic failed, the limitations upon the Black Sea, on the Inland Sea of Japan, and over certain extensive bays and gulfs still endure. The indefensible restrictions continually imposed upon the Black Sea and the Inland Sea of Japan, together with the limitations 
arising through the extravagant claims to gulfs, bays, and the marginal sea which still exist elsewhere throughout the world, are for the most part remnants of an earlier régime in international relations which countenanced the appropriation of the high seas. Though the principle of the freedom of the seas, manifestly fully applicable only during peace, has achieved universal acceptance, these derogations continue to endure in fact, being imposed in some instances by the very maritime states which on former occasions most urgently sought the abolition of all restrictions on the sea. In relation to the heavy burdens imposed upon the enterprise of all maritime states, sanctioned by the law of nations, during the progress of naval warfare, these isolated instances of appropriation of the open waters of the sea are comparatively unimportant.

Limitations During War. - War denies the unrestricted use of the sea, varying in extent with the magnitude of the conflict, but neutral commerce can demand no redress for the belligerent exactions, provided that the eustomary laws of war are observed. With the outbreak of war belligerents may visit and search all vessels on the high seas to establish their nationality, whether neutral or enemy, and the character of their service, whether innocent or noxious. If the circumstances warrant, the vessels thus detained and examined may be seized and subsequently condemned in prize court proceedings. By the exercise of rights accorded by the law of war, belligerents may seize enemy ships wherever found, except when within the territorial waters of neutral states. The ships of neutrals are similarly subjected to seizure and condemnation while in the enemy service, or while endeavoring to violate an effective blockade, or under certain circumstances, while engaged in carrying contraband. In addition belligerents may restrict the use of the high seas by maintaining an effective blockade of the enemy's coasts, extending for an indefinite distance sea-ward, and by excluding neutral vessels from the radius of action while engaged in battles on the high seas, but the establishment of "strategic areas" through the 
employment of contact mines or other means has not received the sanction of international law. The restrictions imposed by war upon neutral shipping cannot be considered an unwarranted exercise of sovereignty on the seas, since the practice of all maritime nations recognizes the necessity and legality of this belligerent procedure. It is recognized that the complete observance of the rights of neutrals would deprive sea-power of its chief value, while the accordance of the fullest license to belligerent sea-power would restrict neutral enterprise unbearably and unwarrantably. The laws of maritime warfare represent a virtual compromise between the irreconcilable interests of neutrals and belligerents, engendered by the abnormal conditions existing during war. A belligerent or neutral action, violating the established principles of international law governing maritime warfare, constitutes either a limitation on the freedom of the seas, or an invasion of the recognized rights of belligerency, warranting ultimate redress.

Changing conditions of naval warfare may require unprecedented procedure, necessitating indemnification if the illegality of the act is subsequently established. Belligerents are more frequently the transgressors, employing innovations in the pursuit of victory which may seriously infringe the rights of neutrals. Many innovations are constructive, necessary changes in the laws of war necessitated by modern mechanical industries and inventions, and the eventual rejection or adoption of the objectionable practice by nations in their mutual, subsequent relations will determine legality. An adequate consideration of restrictions recently imposed on neutral maritime commerce would demand disproportionate space, and brief reference to the more serious impositions must suffice to illustrate the constant dangers and costly delays encountered by neutral vessels during maritime war. A most scrupulous observance of neutrality will not always vouchsafe security for the over-seas commerce of a nation, in the event that the bel- 
ligerents are intent on achieving victory regardless of the corresponding rights of neutrals.

In the Napoleonic Wars, the United States became, eventually, the only neutral nation of importance and was forced to endure extravagant denials of neutral rights, principally in the form of paper blockades established by the British Orders in Council, and the Napoleonic Decrees. Napoleon, in his endeavor to subdue England, sought to destroy all neutral commerce destined for British ports. By the Milan Decree, December 17, 1807, Napoleon proclaimed that any ships which submitted to visit and search by British vessels; consented to voyage to Great Britain; paid any tax to the English Government; or sailed to or from a British port or one of the British possessions, or any port of a country occupied by British forces, would be condemned by the French Prize Courts upon capture. The British Orders in Council were quite as indefensible and particularly incensed the United States because their imposition was aggravated by the continued and unjustifiable exercise of the claim of impressment. By the Order in Council of November 11, 1807, Great Britain forbade all neutral vessels to trade with ports in the control of France or Napoleon's allies, or even with any port in Europe which excluded the vessels of Great Britain, unless permission should be obtained at a British port.

The United States opposed the exaggerated denials of neutral rights embodied in the British Orders and the French Decrees by protests, measures of non-intercourse, the establishment of embargoes, and, against Great Britain, by armed resistance to these indefensible pretensions. An embargo was established upon the suggestion of Thomas Jefferson by the Congressional Act of December 22, 1807, which prohibited the sailing of all merchant ships, save vessels in the coasting trade, from any American port, this Act being supplemented by the still more stringent legislation of January 9, 1808. Incensed by this effort at retaliatory legislation, Napoleon issued 
the Bayonne Decree, April 17, 1808, stipulating that all American vessels which should enter the ports of France, Italy, or the Hanse Towns should be seized "because no vessels of the United States can now navigate the seas without violating the law of those States." (Richardson, "Messages," Vol. X, pg. 261.)

Since the Napoleonic period there have occurred no great maritime wars, and, in the interim, modern invention has provided many mechanical developments, including the steamship, railroad transportation, and wireless communication, revolutionizing former concepts and rendering former regulations inadequate and obsolete. The Franco-Prussian War, 1870; the Russo-Turkish War, 1877; the war between Chili and Peru, 1879; the Spanish-American War, 1898; and the South African War, 1900, proceeded along the established, orthodox principles, since the maritime conflict was of short duration and engendered few complicated situations respecting neutral rights. But with the Russo-Japanese War, 19031904, practices were instituted which have enjoyed an exotic development in the present conflict, frequently disregarding neutral property rights, and even endangering the safety of neutrals and non-combatants.

During the Russo-Japanese War, belligerents were permitted to sink neutral prizes, to warn neutral vessels from entering certain strategic areas, thus denying the right of using the common highway of the open sea, and to scatter mines on the open sea, rendering navigation in those regions constantly dangerous long after the termination of the war. The innovation, during the Russo-Japanese War, of the strategic area, a belligerent appropriation of the high seas reserved for hostile enterprises, has been extended in the World War (1914-1919) to include entire seas. An exercise of belligerent power so contradictory to the principle of the freedom of the seas is indefensible; while the practice of indiscriminate mine-sowing within the appropriated area partakes of a criminal character, inasmuch as vessels, cargoes, and human lives are seriously 
endangered for an indeterminate period following the conclusion of peace.

The indiscriminate sinking of merchantmen by submarines, frequently without warning, affords further evidence of the present denial of neutral rights wherever belligerent necessity appears paramount; but the manner in which the submarine is employed by the Central Powers in the course of the present conflict is so savage and indefensible that consideration of the legality is as superfluous as it is futile. The sinking of merchant vessels, whether of neutral or belligerent registry, without warning, without even the slightest pretense of establishing their hostile character by visit and search or otherwise, without the slightest endeavor being made to provide for the safety of the passengers and crew aboard, must search throughout the history of the sea, in vain, for precedent, for a comparable display of such wanton cruelty.

The unprecedented extension of contraband; the employment of a doctrine of continuous voyage which contemplates ultimate consumption rather than ultimate destination; and the establishment of pseudo-blockades, which debar commerce from neutral and belligerent ports alike, has effected a limitation of legitimate, maritime commerce which neutral states may enjoy with each other and with their colonies, and with belligerent ports under.certain limitations, which can only be condoned by reference to the reciprocal ruthlessness of the World War.

In defense of these unwarranted restrictions it may be urged that fundamental developments in commerce, industry, and governmental institutions have rendered former regulations of warfare inapplicable. A government engaged in war may mobilize the national economic resources so exhaustively that it becomes impossible to determine contraband in accordance with the established practice. It becomes increasingly difficult to designate goods which are clearly useful for military purposes and those wholly innocent, and, in consequence, the contraband list becomes progressively more comprehensive.

The alternative or supplementary procedure is the mainte- 
nance of a blockade, a method of curtailing enemy commerce which has become highly dangerous for the blockading squadron due to the perfection of submarines and air craft, as well as being unsatisfactory because of the development of facilities for rapid inland transportation by railways and waterways, permitting the importation of goods through the ports of adjacent neutral countries. The Declaration of Paris provided that blockades, in order to be binding must be effective; that is to say, maintained by force sufficient really to prevent access to the coasts of the enemy. By signing the Treaty of Paris, March 30, 1856, Austria, France, Great Britain, Prussia, Russia, Sardinia and Turkey agreed to the Declaration which was included in the text of the Treaty, and this principle has since been recognized and subscribed to by all civilized nations. The effectiveness of a blockade is manifestly a question of fact and if it is apparent that the blockade does not apply impartially to the vessels of all nations, it cannot be considered legally binding.

Lord Robert Cecil, Parliamentary Under Secretary for Foreign Affairs, has frankly recognized the inadequacy of the British pseudo-blockade, which is incapable of restricting trade between German Baltic ports and those of Denmark, Norway and Sweden, declaring in the House of Commons that Great Britain was endeavoring to do with success something that no nation had ever tried before, the blockade of an enemy state through neutral countries. Heretofore, it has been a cardinal principle of international law that the blockade of neutral ports, during the progress of war, is absolutely forbidden.

A complex and difficult situation, quite as serious as that arising through the impossibility of maintaining the "close" blockade, and affecting the interests of belligerents and neutrals alike, has developed from the possibility of corporate ownership of vessels, inasmuch as the laws determining the right of national registry are at wide variance among maritime states. If a belligerent, on the seizure of a vessel owned by a neutral corporation, should refuse to accept the registry as conclusive 
evidence of enemy character and should proceed to investigate the corporate nationality in search of enemy shareholders to warrant the condemnation of the vessel, while providing compensation for the neutral shareholders, the resultant chaotic situation would become a virtual denial of neutral navigation on the high seas. The innovation might be carried farther, in practice, and applied to merchandise owned by neutral corporations. The consequent endeavor to establish enemy shareholders would plunge all commerce into an interminable litigation. On the other hand, if no attempt were made to discover enemy ownership under the protection of neutral corporations in maritime states having lax regulations governing registry, it might be possible for a belligerent, maritime state, which was incapable of defending vessels of its own registry on the high seas, to secure a dominant share of stock in neutral ship-owning corporations, and direct the movements of the vessels, accordingly. Many of the advantages which would be enjoyed were the vessels sailing under the belligerent flag might be acquired, especially in instances where the belligerent shareholders could control the policies of the corporation.

Condemnation follows the seizure of an enemy merchant ship, while a vessel of neutral registry is inviolable, whether owned by an individual, a neutral partnership, or a corporation, except for infractions of the law of contraband and blockade. There is no legal difference, as to a plea of alien enemy, between a corporation and an individual. ("Society of the Propagation of the Gospel vs. Wheeler," 2 Gall. 105.) ("Martine vs. Life Insurance Society," 53 N. Y. 339.) (Moore, " Digest," VII, 434.)

Wherever aliens may become shareholders in shipping corporations complications may arise. ${ }^{1}$

1 At the Venice meeting of the Institute of International Law (1896), a resolution was adopted governing the use of the national flag for merchant ships which provided:

"Section I: Acquisition of the Right to the Flag of a State.

"Article 1. The ship should be inscribed on the register kept for this purpose by authorized officials, in conformity with the laws of the State. 
The navigation laws of the leading maritime countries disclose a wide variance and latitude respecting the grant of national registry where shares in the corporation are held by aliens.

United States Law of Registry.- Under the navigation laws of the United States "the registration of a vessel is not compulsory upon her owner. It is a privilege or advantage of which he may or may not avail himself, as he chooses. 'The statute merely provides that vessels not registered pursuant to law, except such as shall be duly qualified according to law, for carrying on the coasting or fishing trade, shall not be regarded as vessels of the United States and shall not be entitled to the benefits and privileges pertaining to such vessels."

"Registration under the American flag is restricted to vessels owned wholly by American citizens. A citizen may, however, be an entity like a corporation organized and chartered under the laws of the United States and the States thereof; and citizens of FOREIGN COUNTRIEs may own stock in such corporations." ("U. S. Rev. Stat." 4131, enacted June 17, 1864.) ("Spec. Agents' Series \# 114," 1916, pg. 8.)

"Various documents are necessary to the proper registration of a vessel under the laws of the United States. A carpenter's certificate testifying that the vessel was built under his direction and containing descriptive details must be produced. ("U. S. Rev. Stat." 4147.) The owner of the vessel or, if possible, the master, applying for registration must make oath as to his nationality and to the nationality of all the owners

"Article 2. To be inscribed on this register, more than half the ship must be the property:

1. Of nationals; or

2. Of a company under a collective name or a commandite, of which more than half the members personally responsible are nationals; or

3. Of a national stock company (joint-stock or commandite), twothirds at least of the directors of which are nationals; the same rule applies to associations and other legal persons owning ships.

"Article 3. The concern (whether an individual shipowner, a company or a corporation) must have its headquarters in the State whose flag the ship must fly and in which it must be registered."

(Institut de Droit International; Annuaire; Vol. 15, pg. 201; Carnegie trans., pgs. 135-137.) 
of the ship, if there be more than one. ("U. S. Rev. Stat." 4142.) In the case of corporations, it is provided that the president or secretary or any other duly authorized officer or agent of the company, must swear to the ownership of the vessel without designativg the NaMes of the persons composing the company. The oath of an officer or agent is sufficient without requiring the oath of any other person interested and concerned with such vessel." ("U. S. Rev. Stat." 4139, as amended by the act of June 24, 1902.) ("Spec. Agents" Series," \#114, 1916, pg. 10.)

"Vessels owned by American citizens have always been entitled to fly the flag of the United States without being doeumented and could be operated under the American flag in foreign waters. Such vessels could not, however, engage in any form of trade with Ameriean ports except under prohibitory penalties. The first registry act of September 1, 1789, confined American registry to ships built in the United States. The right of American eitizens, however, to own ships built abroad has never been questioned, and was very elearly affirmed in the letter of Thomas Jefferson, Secretary of State, May 3, 1793. The policy of eneouraging domestic ship-building adopted in the first years of the Republic had for its purpose the development of means of national defense rather than of protection of domestie industry in the sense in which these words are used in tariff discussions. To give effect to this policy, Congress at the outset passed legislation providing that only documented ships could engage in the trade of the United States, and divided these documents into three classes: First, the register for general purposes of trade and obligatory in foreign trade; second, the enrollment for vessels in the coasting trade; and third, the annual license authorizing the vessel for a year to engage in the coasting trade or in the fisheries, respectively." ("Annual Report, Commissioner of Navigation," 1914, pg. 28-29.)

The British Law of Registration.- The British Navigation Law governing the registry of vessels and the display of 
the national flag is lenient. The British law does not require that vessels flying the British flag shall have been constructed in Great Britain or its possessions or that such vessels shall be officered by British subjects or manned by British crews made up in whole or in part of British subjects. However, " a ship is not deemed to be a British ship unless it is owned wholly by: (1) Natural born British subjects, (2) persons legally naturalized, (3) persons made denizens by letters of denization, and (4) bodies corporate established under and subject to the laws of some part of Great Britain and having their principal place of business in those dominions. Every registrar of British ships is required to keep a book called the register book, in which are entered the name and description of her owner or owners. A corporation must be registered as owner by its corporate name. In addition to the information relating to the ownership of the vessel, there must also be entered in the registry book the name of the ship and the port to which she belongs, the tonnage details comprised in the surveyor's certificate, and the particulars respecting her origin as stated in the declaration of ownership." ("Great Britain, Merchant Shipping Act of 1894," Part I, sec. 1, 5.) ("Special Agents" Series," \#114, 1916, pg. 11.)

"In this connection it is interesting to note that under the accepted interpretation of the term "British ship," unless it is employed by a government under marque, the nationality of the owner is generally the criterion of the nationality of a vessel, at any rate, in so far as regards the duties and liabilities of its owners and persons belonging thereto. Hence a Britishowned ship is a British ship for such purposes, even if it is not registered in Great Britain, or if it is registered in and carries the flag of a foreign country." (Temperley and Moore, "The Merchant Shipping Acts," 2nd Edit. (1907), pg. 2.) (Chartered Mercantile Bank of India vs. Netherlands India S. N. Co. (1883), 10 Queen's Bench Div., 534-36.) (Spec. Agents' Series, \# 114, 1916, pg. 11.)

The French Law of Registry.- In France, by the Law of 
September 21, 1793, as modified by the Law of June 11, 1845, "French registry is accorded only to vessels at least fifty per cent. of which is owned by French citizens. It is also specified that the captain, the officers, and at least three-fourths of the crew must be French subjects. An exception as to nationality of the crew is made in the case of vessels operating in the Far East. . . Since in the case of vessels belonging to corporations, it is difficult to make certain that the required conditions of ownership are being fulfilled, the customs administration, acting under a decision of the Conseil d'Etat, dated April 15, 1887, grants corporations the benefits of French registration only provisionally and upon the condition that the director must prove his qualifications as a director and as a French citizen, and likewise prove that the vessel is actually owned by the society (company) of which he is a director. The law of April 7, 1902, stipulates that joint stock companies (sociétés anonymes) or other legal entities, owning vessels that receive one of the subsidies provided for by this law, must have a majority of French citizens in their executive board, or board of directors, and that the president of the board of directors, the managing director, and the manager of such corporations must be French citizens." (French Law of April 7, 1902, regulating the Merchant Marine, Chap. I, Art. 1.) (Spec. Agents' Ser., \# 114, 1916, pg. 15.)

"Since the special requirements as to the nationality of the officers and directors of corporations receiving subsidies under the law of April 7, 1902, offered an easy solution of problems regarding the nationality of vessels owned by corporations and registered under the general registration laws, it was decided to incorporate these special requirements in the general registration laws. This was accomplished by a circular of instruction issued January 26, 1910, by the Customs Service. The universal rule now is, therefore, that all corporations applying for French registers must show that the president, managing director, and manager, as well as a majority of the board of directors, are citizens of France." (Ripert, "Droit mari- 
time," (1913), Vol. I, pg. 249.) (Spec. Agents' Ser., \# 114, 1916, pg. 15. $)^{1}$

"The French law specifies three circumstances under which a vessel forfeits its register: (1) By refitting and repairing in a foreign country at a cost of more than fifteen francs per ton, unless in case of necessity that is approved in a report signed by the captain and officers and also; according to the facilities which may exist in the port in which such refitting took place; by the consul or any other French official, or by two merchants of the place; (2) by the alteration in build, or tonnage, or in any other respect, without obtaining a new certificate of French registration; and (3) by the sale to a FOREIGNER of the whole or more than ONE-HALIF interest in the ship." (Loi du 27 Vendémiaire, An II, Art. 16, as modified by the law of April 7, 1902, Art. 15.) (Spec. Agents' Ser., \# 114, pg. 16.)

Navigation Laws of Japan.-By the navigation laws of Japan, " only registered vessels are allowed to operate under the Japanese flag, except in the cases of sailing vessels of less than twenty tons gross, or of less than two hundred koku capacity; boats or vessels of any kind propelled wholly or principally by sculls or oars; hulks and laid-up vessels; and sailing vessels employed solely in navigating smooth-water routes. Foreignbuilt ships may, if owned by Japanese citizens, be granted Japanese registration, but only vessels built in Japan and owned by Japanese citizens can engage in the ocean trade receiving subsidies under the Ocean Lines Subsidy Act of March $25,1909 . \ldots$ The detailed laws relating to registration are to be found in the Law of Ships, enacted March 7, 1899, and in special administrative regulations pertaining thereto. Article 1 of this law provides as follows:

A ship is a Japanese ship:

1. If it belongs to a Japanese public authority;

1 The port to which a French vessel belongs and where it registers is deemed to be its legal domicile. Ordonnance du Octobre 31, 1784, Tit. vii, art. 7; and Réglement général de 1866, Art. 170. (Spec. Agents' Ser., No. 114, pg. 15.) 
2. If it belongs to a Japanese subject;

3. If it belongs to a commercial company having its principal office in Japan; provided all the partners in the case of an ordinary partnership, all the partners with unlimited liability in the case of a limited partnership or a joint-stock limited partnership, and all the directors in the case of a joint-stock company are Japanese subjects;

4. If it belongs to a juridical person having its principal office in Japan, provided all its representatives are Japanese subjects;

5. A ship belonging to a limited partnership formed before the Commercial Code took effect is a Japanese ship, if all the managing partners are Japanese subjects."

"A ship loses its Japanese nationality if an alien becomes one of the co-owners, or partner in an ordinary partnership, or one of the partners with unlimited liability in a limited partnership or in a joint-stock limited partnership owning the ship. If the ship belongs to a corporation (société anonyme), all the directors must be Japanese citizens, otherwise the ship will become a foreign ship. However, the transfer to an alien of shares in a joint-stock company does not affect the nationality of the ship, unless the alien is appointed a director." (Yang Yin Hang, "The Commercial Code of Japan," (translation), Univ. of Penn. Law School Ser. No. 1, 1911.) (Spec. Agents' Ser. No. 114, pg. 17.)

Norwegian Ship-Registry.- Norwegian registry is restricted to vessels owned exclusively by Norwegian citizens. If the vessel belongs to a stock company, the head office and the place of management must be in Norway, and the managers must be Norwegian citizens and shareholders (Norwegian Maritime Law of July 20, 1893, Chap. 1, Sec. 1), and in the event of a change occurring in the nationality of the owners "with the result that the ship ceases to be a Norwegian ship, her name shall be struck off only when after four months no notification shall have been given to the effect that the owner- 
ship has been so arranged as to prevent the ship from losing her right to carry the Norwegian flag." (Norwegian Maritime Law of May 4, 1901, governing the Registration of Vessels, Sec. 16.) (Spec. Agents' Ser., No. 114, pg. 13, 16.)

Laws of Germany Governing Registration.-The German law governing the employment of the Imperial mercantile flag is particularly severe. "Vessels flying the German flag must be the exclusive property of German citizens. Regular partnerships and limited partnerships are considered as German citizens, if the personally responsible partners are all citizens of Germany; likewise, other commercial corporations, registered companies, and other legal entities if they have headquarters in Germany, and limited partnerships with shares, if all their personally responsible stockholders are citizens of Germany. In this connection it is interesting to note that if an owner of an interest in a registered German vessel loses his citizenship; or if an interest in a vessel owned by a German citizen is transferred to a foreigner, otherwise than by sale (for example, by inheritance, the introduction of joint property in marriage, possession by limitation, and appropriation); the ship retains its right to fly the German flag for the period of one year. ... The registration laws of Germany do not require that vessels flying the German flag shall have been constructed in Germany or that such vessels shall be officered by German citizens and be manned in whole or in part by Germans." 1

From the foregoing comparison of the navigation laws of the principal maritime nations, it is evident that there is a wide divergence in the regulations governing ownership and registry,

1 The present law of Germany relating to registry of vessels is contained in the Ship Registry Act of June 22, 1899, which took effect on January 1, 1900. Spec. Agents' Series, No. 114, pg. 12.

The German Law of October 21, 1915, forbids the transference, in whole or in part, of the ownership in merchant vessels that are already built or in the course of construction, to persons who are not German subjects. Provision is made for severe punishments for the contravention or an attempted contravention of this statute, even if committed by Germans domiciled abroad. Consular Reports, No. 271 (1915), pg. 694. 
in some degree comparable to the disparity of the various state statutes regulating the establishment and regulation of corporations throughout the United States. In a similar manner, advantage may be taken of the more liberal registration laws should a belligerent state, whose merchant vessels could not set forth on the high seas because of predominant hostile seapower, contemplate the circumvention of this inhibition through the acquisition of partial or dominant corporate ownership in vessels under neutral registry. If a belligerent state were at liberty to continue maritime enterprise by seeking neutral corporate registry, while vessels of its own registry were subject to seizure by a superior enemy force holding command of the seas, the consequent limitation on sea-power would arouse the chief maritime states to vigorous opposition. If, on the other hand, the exercise of sea-power is accorded paramount consideration, permitting inquiry into the nationality of the shareholders comprising the neutral corporation, and allowing condemnation of the vessel, with compensation to the neutral shareholders, whenever enemy subjects are discovered to be owning stock in the neutral corporation, then the limitation upon neutral shipping would become unendurable, since all neutral vessels of corporate ownership, particularly those accorded registry in maritime states having notoriously liberal regulations, would be subjected to suspicion, detention and examination, with consequent condemnation wherever the existence of enemy shareholders could be established.

The most facile means of composing interests so diametrically at variance would appear to be the general adoption by all maritime states of more exacting laws governing the grant of national registry, similar in general purpose to the laws of Germany and Norway.

During the session of the American Institute of International Law at Havana, Cuba, January 22, 1917, certain radical measures were proposed, as an integral part of a suggested Code of Maritime Neutrality, in the endeavor to determine some method of securing neutral rights and the freedom of commerce in 
time of war. Chapter III of the Code, entitled "Freedom of Commerce in Time of War" provided: Art. 7: "The commercial blockade, both of the belligerent ports and the maritime zones along belligerent coasts, is formally forbidden, no matter what the means by which the blockade is to be effected."

Art. 8: "Private property in the open sea is inviolable. Belligerent and neutral merchant vessels may in no case be confiscated, nor sunk, under any pretext whatever. If carrying contraband, this may be confiscated or destroyed by the captor."

Art. 9: "The right of search is abolished. The local authorities of each country shall vise the papers of merchant vessels leaving port for a belligerent port."

"Belligerent vessels may not stop neutral merchant vessels or merchant vessels belonging to other belligerents except to demand examination of the vessel's papers. Despite the regularity of the said papers, they (belligerent vessels) may proceed to the search of merchant vessels. If shown that the vessel does not carry contraband, the searching vessel shall be condemned to pay to the vessel searched a fine to be determined by the conference of neutrals; and in case the vessel searched carries contraband, the country whose authority viséed the false passport shall be condemned to pay an indemnity to be determined by the said conference of neutrals."

"Vessels not carrying duly viséed papers may be searched conformable to present international practice without the right to an indemnity."

Art. 11: "The official or private postal correspondence of neutrals or belligerents found in the open sea on board a neutral or enemy vessel is inviolable. It may not be seized, even under the pretext of the police right of warships over merchant ships of their own nationality."

Considering the indefensible limitations which still exist in . isolated instances upon the freedom of the sea during peace, and the restrictions imposed by the recognized laws of war, together with recent belligerent practices, innovations which 
may or may not be incorporated ultimately within the law of nations, necessitated by the changed conditions of maritime warfare, it is evident that the absolutely unrestricted use of the seas, at all times, remains to be established. The partial restrictions which still endure in time of peace, exerting a negligible limitation on the freedom of the seas, are but a slight handicap to the pursuit and extension of maritime enterprise. The onerous restrictions occur during war.

The usage of the sea is, in principle, free to all maritime nations throughout the world, subject only to such derogations as arise from the necessary respect to the equal rights of others, or those which are recognized by reason of long-established usage, or the obligations of treaties or international law. 'The limitations upon the freedom of navigation, endured by neutrals during war, are defensible only by general usage or by virtue of specific treaty stipulations. Though a belligerent may secure command of the sea there is no assumption, as formerly, of the complete ownership; the sovereignty of the seas. Such pretensions to dominion, maintained through an extended period of futile contest, terminated in the universal recognition of the freedom of the seas at the beginning of the nineteenth century. The appreciation by all nations of the incalculable benefit to be secured by the destruction of the anachronistic pretensions which had endured for three centuries, engendered an energetic co-operation among the principal European maritime nations to extend still further the opportunity for commereial intercourse with all the world through the establishment of a similar freedom of navigation, for commercial purposes, upon all the navigable, inland waterways, traversing or separating several states; a liberty of commereial navigation, in peace, which approximates the freedom of the seas, and which may escape the restrictions imposed by belligerent seapower, because of the concurrent rights or obligations of neutrality appertaining to the riverain states. 


\section{CHAPTER VIII}

\section{THE FREEDOM OF NAVIGATION ON INLAND WATERWAYS}

Since the freedom of commercial navigation on international, inland waterways has been evolved from the fundamental principle which assures the common benefit of the high seas to all maritime nations without the necessity of preliminary treaty, it might appear that the declaration of a Congress of Nations, defining explicitly the conditions warranting the international use of inland waterways, would suffice for the immediate establishment of the right on all inland waters susceptible of internationalization. Certain fundamental differences in the character of the respective rights forbid such procedure.

The freedom of navigation on the high seas arises from the recognized inability of any nation to acquire property beyond the waters of the marginal sea, with the result that claims to sovereignty are untenable. The freedom of navigation on inland waters exists by virtue of the voluntary modification by the riverain states of the fullest enjoyment of their jurisdictional rights, undeniably appertaining to the exercise of sovereignty throughout the national domain. From the moment a foreign vessel enters the territorial waters serious problems arise, problems concerned with the public safety, health, and finance of the nation. The peculiar conditions surrounding the commercial navigation by foreign vessels of a particular inland waterway necessitate appropriate recognition and adequate protection. As a necessary preliminary, therefore, the interests and security of the riverain states must be vouchsafed by the execution of treaties or other appropriate instruments, sanctioned by all foreign states which scek to engage in such inland transportation, save in the exceptional instances when the 
participation by foreign vessels is provided for by the municipal legislation of the riverain states. All rights of property over such inland waters are retained by the riverain states, as are compatible with the stipulated enjoyment of peaceful commercial navigation by foreign vessels.

Obligations imposed upon the riverain states in obedience to the principles of international law must be scrupulously observed and this obedience may accord commercial opportunities to foreign vessels upon inland waterways, impossible to secure on the high seas. In the present war between the Entente and the Central Powers, the dominant sea-power of Great Britain has driven enemy shipping from the high seas, yet on the international waterways of China, Teutonic commercial navigation, protected by the neutrality of the Chinese, has enjoyed extensive development since the outbreak of the war. Wherever the riverain states remain neutral, the enjoyment of inland, commercial navigation by vessels of a foreign power engaged in war cannot be interrupted, despite the superior sea-power of the enemy.

Objections are sometimes raised to the application of the principle of freedom of navigation on inland waterways because of certain difficulties encountered in properly safeguarding the interests of the territorial sovereign. Opposition, based on similar grounds, would exclude foreign merchant vessels from sailing through the marginal sea; yet this right of innocent passage is clearly recognized.

Restrictions in Former Periods. - Until the establishment of the right of navigation on European arterial waterways through the unequivocal declaration of the Congress of Nations at Vienna, the use of inland waters, even when restricted to riverains exclusively, suffered burdensome limitations, varying in intensity with the power of the local sovereignty to compel observance. The situation during feudal times became so unendurable that extended commercial navigation virtually ceased. In this period, the rivers passed out of the public domain and came into the exclusive jurisdiction of the king's 
vassals, whose single purpose was to exact the maximum profit through the exploitation of commerce, whether borne upon the highways or on the navigable rivers, particularly throughout Central Europe. Rivers assumed a private character upon the imposition of this prohibition of general enjoyment, and navigation was burdened with excessive tolls, rights of passage, forced anchorages, seriously restricting the transit both of travellers and of merchandise. Confronted with the abuses which hindered the free navigation of waterways within the domain, the imperial or royal power appeared helpless to afford adequate relief.

Throughout the Middle Ages the Rhine constituted the principal commercial route between the Orient and the Occident, two main routes diverging at the head of navigation, one continuing southward over the Alps to the port of Venice, the other turning eastward to the navigable Danube leading to Constantinople. Along the highway of the Rhine important commercial centers, notably Strassbourg, Frankfort, Mainz, and Cologne, enjoyed exceptional prosperity, which in some instances was derived from the heavy tolls exacted from all shipping under the claim of forced anchorages or trans-shipments. With the discovery of the New World and of the all-sea route to India; fundamental changes in the commercial routes which destroyed the pre-eminence of Venice and Genoa and established the center of maritime enterprise at London, Antwerp, and Amsterdam, thenceforth; the Rhine retained its valuable commerce. In the latter part of the sixteenth century, however, exactions levied on the Rhine became so serious as to threaten communication with the sea. Having suffered heavy losses during the progress of the war with Spain, the Dutch sought to recoup by imposing costly license charges on navigation with the Rhine ports, which had been formerly unrestricted during Spanish dominion. The terms of the Peace of Westphalia (1648), consummated the ruin of commercial navigation along the Rhine by permitting the Dutch, who were seeking commercial monopoly, to levy onerous tolls on all cargoes, and by 
sanctioning the Dutch claim to prohibit the passage of certain important staples, as salt and sugar, if loaded on other than Dutch vessels. (Clapp, "The Navigable Rhine," pg. 4.)

The navigation of the Scheldt was similarly restricted. Article XIV of the Treaty of Westphalia, agreed upon by France, Sweden, and the Emperor of Germany, while recognizing the independence of the United Provinees, further provided for the closure of the Scheldt to the advantage of the Dutch. Forthwith communication with the Spanish Netherlands, by way of the Scheldt, was forbidden to all vessels except those under Dutch registry. The eession of the Spanish Netherlands to Austria by the Treaty of Utrecht (1713) did not secure a relaxation of this burdensome restriction. The United Provinees contended that the channels through Duteh territory which vessels necessarily followed in navigating the Seheldt to and from the sea were maintained only by constant industry and heavy cost, and that consequently the Scheldt channel, in this portion of its course, should be considered an artificial communication, rather than a natural waterway.

The petty prinees of the Holy Roman Empire, who had dominion on the principal commercial waterways, seized the opportunity afforded by the weakened control of their Emperor, resulting from the Peace of Westphalia, to secure enhanced revenues by the imposition of local traffic tolls. The tolls levied on the Rhine navigation proved particularly remunerative since this river was the chief commercial highway between the North Sea, Central Europe, and the Adriatic. Formerly the cargoes of rich merchandise had been carried from the great entrepot of Venice, but with the development of the ports on the North Sea the direction of the commerce was reversed.

In the eighteenth century, the charges levied by the various toll stations for passage between Bingen and Coblenz amounted to one-third of the eargo's valuation. Opposition appeared as futile as it was insistent. Predominant among the jurists who early recognized the unreasonable character of the arbitrary 
dues and regulations, exacted by the riparians, was Grotius. In endeavoring to demonstrate the injustice of the pretensions and to secure the relaxation of the burdensome limitations, he declared that by a qualified restriction of property rights advantages might well accrue to others without injury being necessarily suffered in consequence of this liberality. The principle advocated by Grotius that "whatever land, rivers, or parts of the sea have become the property of any people ought to lie open to passage by those who have need of it for just cause, as . . . a desire to trade with a nation not contiguous to them," did not receive the assent of European nations, in its application to inland waterways, until the nineteenth century, when it was tardily recognized that arbitrary exactions, limiting the freedom of arterial inland waters, were detrimental to the fundamental interests of all commercial nations. (Grotius, "De jure belli et pacis," L, II, C. 2, sec. 12, 14.) (Westlake, "International Law," Vol. I, pg. 146.)

Liberté, Égalité, Fraternité, so frequently proclaimed during the French Revolutionary period, found frequent opportunity for expression in the many treaties involving territorial changes, particularly with reference to the freedom of navigation on inland waters, necessitated by the succession of sovereignties due to extensive military conquests. The treaty stipulations conceded the liberty of navigation to the riverain states, solely, all foreign states being denied participation, inasmuch as no reciprocal, corresponding advantages could be extended.

The decree of the French Convention, November 16, 1792, relating to the freedom of navigation on the Scheldt, marks this stage in the development of the principle which was destined to receive still more liberal expression, twenty-three years later, at the Congress of Nations. The French Convention, declaring that a nation cannot without injustice pretend to the right of occupying the channel of a river exclusively and hindering neighboring peoples who dwell on its upper waters from enjoying the same advantages, decreed that the Scheldt 
should henceforth be freely navigable by all nations holding territory along its navigable course.

Linguet (1736-1794) had already declared that since the freedom of the seas was accepted as a cardinal principle in the law of nations that arterial rivers should enjoy a similar freedom, not exclusively for the benefit of the co-riparians, but for the equal participation of all maritime nations. Not until the Peace of Paris and the Congress of Vienna was the universal navigation of inland waterways recognized as an international concern, however. The Congress of Nations at Vienna, by assuring the freedom of navigation on arterial waterways through formal recognition of the principle and explicit provision for adequate regulations to assure the continued enjoyment of these exceptional advantages, in conformity with the fundamental stipulations of the Treaty of Paris, exhibited a full appreciation of the more enlightened policies which were destined to govern commercial and maritime relations during the nineteenth century. The last pretension to sovereignty on the seas had been voluntarily abandoned a decade previously. The principle recognized by the Congress of Vienna assured enhanced opportunity and benefit to all commercial nations by the assurance of extended facilities for transportation over the waterways of the world. Forthwith, all inland waterways separating or traversing several states were susceptible of internationalization throughout their entire navigable course, subject only to the police power of the riverain states. Foreign vessels, engaged in commercial navigation on inland waters, thenceforth, were assured rights equal to those enjoyed by the vessels of riverain states. ${ }^{1}$

1 Koch and Schoell, "Histoire Abrégée des Traités de Paix," Vol. X, pp. 485, 490, 528, 531, present an extended discussion of the Peace of Paris of May 30, 1814; Martens, "Recueil," Vol. XIII, p. 1, contains the complete text.

Concerning the deliberations of the Powers with reference to the establishment of universal freedom of navigation on arterial, inland waterways in conformity with the Fiftl Article and the second section of the Third Secret Article of the Treaty of Paris, consult Koch and Schoell, "Histoire Abrégée," Vol. XI, pp. 14, 247, 340, 394. 
No specific limitation was placed on the navigable extent of any river, since the actual ability to navigate determines the head of navigation in each instance. Consequently, improvements affecting the navigable, natural channel; dredging, blasting, or other form of rectification; materially affect the interests of foreign vessels. Improvements in the natural channel of a river, already available for international navigation, may permit the employment of larger vessels or the extension of navigation further upstream, while improvements which extend the navigable course of a river, wholly within the jurisdiction of one state, into the domain of an adjacent state, will warrant the establishment of international rights, notwithstanding the indisputable national character of the river before the improvements were completed. The claim of international rights on an inland waterway may arise or lapse at any time. Rectifieations of the frontiers and other extensions or limitations to the territorial domain of states adjacent to a navigable river, as well as substantial improvements of the navigable channel itself, vitally affect the international character of all waterways, as the sovereignty over inland waters is appurtenant to the terrestrial sovereignty, and, consequently, the determination of the national or international character of an inland waterway remains, perennially, a potential problem.

The Influence of Modern Invention.- Foreign nations would secure negligible benefit from the exereise of this right in the absence of mechanical power for the propulsion of vessels, while the riverain states would necessarily be limited to that eommerce which could be floated downstream or laboriously brought inland by the tedious process of towing. Following the discovery of the New World an extensive maritime trade developed confined almost wholly to the sea-coasts. Inland navigation continued relatively unimportant until the achievement of Fulton, benefiting inland and maritime navigation alike. The invention of the steamship permitted the consignment of cargoes directly into the interior of vast continents from foreign sea-ports. The navigation of inland 
waterways no longer necessitated burdensome charges and indefinite delays. Before the advent of steam navigation on the Mississippi, boatmen who had floated heavily laden barges downstream to the markets at Baton Rouge and New Orleans seldom ventured on the arduous return voyage, preferring to accept a nominal price for the barges when discharged or to abandon them altogether and to journey homeward overland. Steam vessels converted the Mississippi and its numerous tributaries into broad highways through the unsettled wilderness, regardless of the direction of the current, carrying cargoes along the main river between the Falls of Saint Anthony and the Gulf and on all the navigable tributaries, eastward as far as the Alleghanies, westward up the great Missouri River to the foot of the Rocky Mountains.

Mechanical Appliances Facilitating Navigation.- The modern invention of various mechanical appliances to facilitate navigation; dredging machinery, hydro-electric locks, the screw-propellor, travelling cranes and hoists for the expeditious trans-shipment of cargoes; has disclosed further and unforeseen opportunities for inland navigation. With appropriate dredging machinery waterways may be improved at relatively small cost, permitting the employment of larger vessels for inland transit and the enjoyment of inexpensive water transportation to remote industrial districts. Vessels equipped with the screw propellor may be employed advantageously either on the high seas or for inland navigation. Cargoes may be embarked at the sea-ports or inland ports of one country and transported by inland waterways and the high seas to interior points on distant continents without the necessity of transshipment. A ship may take cargo at New York, Chicago, Montreal, or Duluth and may voyage continuously until arrival at the proposed destination, whether three thousand miles up the Amazon at the port of Iquitos, Peru; or Matadi on the Congo; or Asuncion, Paraguay, more than a thousand miles inland on the Rio de la Plata; or Hankow on the Yang-tsekiang, six hundred miles from the sea; or in Europe at one 
of the many river ports of the Danube; and, in time of peace, no nation may in any degree prohibit this right of unrestricted navigation on inland waterways.

The advantages accorded by the right to navigate inland, international waterways, permitting the pursuance of a continuous voyage from the port of embarkation to that of destination, are apparent even in comparatively shallow waters, ill-adapted for "ocean-inland" navigation. The Rhine can accommodate vessels under six feet draught for a distance of three hundred and fifty miles from the North Sea. In consequence of this physical limitation most commodities are more cheaply carried in barges. Nevertheless, a serviceable type of steamer has developed, capable of plying between the various river ports and the sea-ports of the Azores, Portugal, Spain, and of the countries bordering on the North Sea and the Mediterranean. Varying in tonnage from 342-1770 tons, these skillfully designed vessels carry an extensive commerce from inland ports without necessitating the transference of cargo. (Clapp, "The Navigable Rhine," pg. 46.) This service was instituted in 1888 with the formation of the "Rhine and Sea Navigation Company" at Cologne, and the success attending this innovation rapidly increased the number of vessels engaged. Since 1903 , the "Rhine-Sea" traffic has declined as a result of the shallow channel between Cologne and Rotterdam, compelling the lighterage of a large share of cargo before the vessel may proceed upstream, and thus forfeiting the chief advantage of this service, through transportation. The "Rhine-Sea" traffic in 1902 constituted one twenty-eighth of the total river shipping passing the Dutch-German border, but by 1907 this traffic had diminished until it was but one sixty-sixth of the total. (Clapp, "The Navigable Rhine," pg. 64, 76.) ${ }^{1}$

1 According to the returns from Lobith at the Dutch frontier, the "Rhine-Sea" traffic in 1907 comprised 347,000 tons. Cologne received the largest share; 74,000 tons; while the German harbors on the North Sea and the Baltic participated in 73 per cent. or 250,000 tons, Hamburg alone enjoying 33 per cent. The traffic upstream, consisting of sugar, oils and fats, flour, flax, barley, coffee, cement, lumber, etc., amounted to 
Even under the most favorable circumstances these vessels would operate both at sea and on the Rhine at some disadvantage in comparison with the vessels designed especially for maritime or inland service, a fact due principally to the shallowness of the Rhine. Elsewhere, on larger rivers such as the Amazon, the Columbia, and the Rio de la Plata, sea-going vessels suffer no serious limitation when employed in inland navigation.

Modern machinery, designed for the expeditious trans-shipment of freight, enables commerce to utilize the recognized advantages of water-transportation where continuous voyages are impracticable or wholly impossible. Since waterways afford the least expensive and most commodious of all means of transport, it is important to avoid all unnecessary carriage overland. With modern loading machinery the opportunity for utilizing waterways is greatly improved, since cargoes may be trans-shipped expeditiously from ocean vessels to river boats, reaching final destination, when necessary, by subsequent transference from inland navigation to railroad or other means of over-land transit. In Germany, where particular importance is attached to the proper co-relation of railway and waterway transport, inasmuch as every consumer is deemed to be vitally interested in reducing the final cost of commodities through the most efficient method of transportation, it has been determined that water transit is cheaper than rail wherever the destination is at least twenty-five miles distant, both terminals being situated on a first class waterway. If one terminal is at some distance from navigable waters, compelling the transshipment of the freight enroute, water carriage may still be used at a saving, if the total distance is not less than forty-five miles. Where both terminals are off the main, navigable waterway, necessitating two transfers, from rail to boat and from boat to rail, water transportation will not be advantageous unless the

168,321 tons; while downstream 174,090 tons were carried, comprising brick, clay, manufactured iron, metals, soda, wine, etc. Clapp, "The Navigable Rhine," pg. 77. 
distance is at least one hundred miles. (Clapp, "The Navigable Rhine," pg. 28; quoting Peters, "Schiffartsabgaben," Leipzig, 1908.) This comparison which contemplates the use of the most efficient machinery for trans-shipment demonstrates the great importance of international rights of navigation on inland waterways, even in the event that such waters are insufficient to accommodate ocean-going vessels. Where shallow water precludes the employment of vessels designed for the deep sea, a supplementary service of river boats may be established and the cargoes transferred without prohibitive delay or expense. The comparison is also important in disclosing the inherent advantages of water transportation in relation to the most facile means employed on land: railroad carriage. The indispensable services of inland waterways are recognized even in such countries as Belgium where railroad development has been most extensive. The Belgian Government, though owning both waterways and railways, was compelled to lower the railroad freight charges because of the severe competition of water transportation. In a similar manner, the Rhine competes seriously with the railways and compels the maintenance of low rates. Every facility is afforded for the trans-shipment of freight from water to rail to secure the most inexpensive transportation. In France, as in America, this co-operative spirit does not exist in any comparable degree. The privatelyowned, French railways compete severely with the extensive system of waterways and usually offer no adequate facilities for the transference of cargoes. (Clapp, "The Navigable Rhine," pg. 68.)

In the United States there is apparent a more pronounced hostility between the railroads and the inland shipping interests, reflected in the establishment by the railways of particularly low rates wherever water competition is encountered; the railroads thus securing the bulk of the traffic and recouping whatever losses are incurred by a relative increase in the rates on freight which is unaffected by water competition. This policy received judicial sanction in 1888 , one year after 
the passage of the Interstate Commerce Act, by the declaration that the "long and short haul" clause of the Act was inoperative when water competition was present. Despite the facilities for water transportation in the United States, the discriminatory railroad rates and the difficulties attending the collection and distribution of freight for inland water transit have unfortunately retarded the development of this national, commercial asset, although on the Great Lakes peculiar conditions of navigation have developed a noteworthy and extensive commerce. The assertion that elsewhere the inadequacy of the navigable channels restricts the development of transportation over American waterways is scarcely candid. The Mississippi has a depth of nine feet from the Gulf to Cairo, Illinois, a distance of eight hundred miles; of eight feet from Cairo to Saint Louis which is two hundred miles further upstream; and the entire Mississippi system offers two thousand five hundred miles of six-foot navigation; the identical depth which on the Rhine is available for only three hundred and fifty miles from the sea, yet carries an enormous commerce. (Clapp, "The Navigable Rhine," pg. 122.)

The conditions prevailing in France, the United States, and in certain other countries where vast railroad interests have developed, demanding protection until some method of co-ordinating the conflicting interests of water and rail shall be devised are mentioned as exceptional. The artificial limitations which accord railroad transportation an apparent superiority are abnormal. The inherent advantages of waterways over railways for freight carriage are readily apparent wherever there is opportunity for an equitable comparison of the service rendered. The development of railroad transportation during the latter part of the nineteenth century, astounding as it has been, when compared with the volume of traffic borne by inland waterways compels the recognition of the superiority of water transit whenever it is available.

In considering the practical effect of the adoption by the Congress of Vienna of the enlightened principle which accords 
all nations the right to navigate as international waterways interior seas, lakes, rivers, and supplementary canals which are navigable through several states it is essential to recognize that the trade of the world would have secured insignificant benefit, in comparison with the actual development, had not the introduction of steam navigation been almost coeval with the Congress. Without the opportunity for an extensive exercise of the right afforded by mechanical invention, the participation of foreign powers in the navigation of international, inland waterways would have remained necessarily negligible. The progressive extension and development of this wholly new right in connection with the increasing employment of improved mechanical appliances has conferred an inestimable benefit on the civilized world. Co-riverains and foreign maritime states have profited alike. In sparsely settled countries, where the construction of railroads has awaited more favorable conditions, an international river may afford the only means of access between the interior and the commercial world. A state, situated on the lower course of an arterial river, might endeavor to forbid passage through its riverain, territorial waters to foreign, commercial vessels seeking trade with isolated states in the interior. By virtue of the embodiment of the principle of international navigation on inland waterways in the public law of Europe by the Act of the Congress of Nations and the consistent employment of the right throughout the world during the nineteenth century such a restrictive exercise of property rights could not long endure. The world-wide practice of nations contributes strength and prestige to the principle. In both South America and Africa, countries almost wholly dependent upon lakes and rivers for inland communication, particular importance has attached to the establishment of international waterways. In South America the free navigation of inland waters becomes a virtual necessity since lofty mountain ranges and extensive virgin forests have retarded railroad building because of the enormous expense entailed and the dubious prospect for an adequate return on the investment. 
The mighty river systems of South America compensate, affording access thousands of miles inland. Since the principal rivers have become internationalized, the vessels of all maritime nations may freely engage in commerce with distant interior points. The Amazon is the highway leading to Bolivia, Peru, Ecuador, Colombia, Venezuela, and to the valuable rubber producing districts of Brazil. The Orinoco also affords access to Central Colombia and Venezuela. The Rio de la Plata, the great southern highway, formed by the confluence of the Paraguay and Paraná rivers, communicates with Argentina, Bolivia, Brazil, Paraguay, and Uruguay and is navigable for ocean vessels to Corumbá, Brazil, during the season of high water. ${ }^{1}$

In Europe, the Danube, opened freely to the navigation of all nations by the Treaty of Paris (1856), constitutes the chief commercial highway, as was also true during the Middle Ages, between Central Europe and the Near East. The vessels of many nations: Austria, Great Britain, Greece, Hungary, Roumania, Russia, Servia, engaged in traffic on this river and its principal tributaries before the commencement of the European War of $1914 .{ }^{2}$

1 In 1913, 1,372 vessels; 634 being Argentine; with an aggregate tonnage of 294,887 tons entered the port of Asuncion, Paraguay. 1,289 vessels departed from the port of Asuncion, aggregating 233,657 tons. Vessels engaged in the river traffic between Asuncion and river ports further upstream entered the port of Asuncion to the number of 1,078 with a tonnage of 59,830; while 2,061 vessels cleared from Asuncion with a total tonnage of 80,191 ; these vessels for the most part being engaged in regular routes. Stateman's Yearbook, 1915, pg. 1206.

2 Vessels entering and leaving the Danubian ports of Roumania:

British vessels; 1912; 247 with an aggregate tonnage of 548,217 ; 1913; 278 vessels aggregating 669,589 tons; while in 1914 the number was reduced to 187 with a tonnage of 461,810 , owing to the closure of the Bosphorus and of the upstream ports. In this same period there were 299 Greek vessels aggregating 558,666 tons in 1912; 112 with 24,729 tons, a decrease caused by the war in the Balkans, in 1913; and 157 with 333,030 tons in 1914. Austro-Hungarian vessels numbered 143 in $1912 ; 158$ in 1913; and 82 in 1914; having respectively $310,974,313,219$, and 161,677 tons. The vessels of all other nations numbered 1,008 in $1912 ; 902$ in 1913; and 718 in 1914; aggregating for the respective years 1,788,156; $1,737,300$; and $1,356,090$ tons. Stateman's Yearbook, 1915, pgs. 1262, 1331. 
Political Advantages Secured by Inland States.-But the benefit accruing from endowing an arterial waterway with freedom of navigation is not confined to the commercial advantages secured by foreign and riverain states alike. Certain important political advantages are immediately acquired by an inland state which hitherto has been denied access to the open sea. Prior to the internationalization of the river, not only would such a state be denied direct communication with the world as the result of its disadvantageous, geographic position, but it could not claim to have a mercantile flag entitled to international respect on the high seas. A state cannot accept the real authority and responsibility, which the grant of registry implies, according with it the right to fly the national flag, unless the ship belongs to a port of the state, accessible from the sea, where, on the return of the vessel, the officers, crew, or passengers may be punished for any offences committed at sea. (Westlake, "International Law," I, 169.)

An inland state, however, can demand respect for its flag on vessels navigating interior lakes or seas lying between two or more states. On the international lakes, Geneva and Constance, lying between Switzerland and the neighboring states, the vessels engaged in navigation display the flags of their respective nationalities: Austrian, French, German, Italian, or Swiss. The flag of Switzerland is accorded implicit respect on these waters, despite the fact that on the high seas it would not be entitled to recognition. The difficulties encountered by the Swiss in undertaking maritime enterprise are aggravated by the inability of the national flag to afford Swiss-owned vessels protection, necessitating the adoption, as a foster-flag, the emblem of some maritime state whose laws permit the use of the national registry and the national flag by foreign-owned vessels. An interesting commentary on the position of vessels thus sheltering under the protection of a benign state occurred during the Franco-German War. When the French conseil d'état considered the case of the Swiss-owned vessel, Palme, it ordered restitution, although it was captured while flying the 
North-German flag. The fact that Switzerland forbids citizens to employ the Swiss flag for maritime enterprise was fundamental in securing the release of the vessel. (Westlake, "International Law," II, 170.)

This limitation on Swiss enterprise over seas will terminate with the completion of the extensive improvements undertaken on the upper eourse of the Rhine. The deepening of the navigable channel and the construction of locks to surmount the Falls of Schafthausen will afford vessels access from the sea to Lake Constance. The river Rhine, established as an international waterway by the express terms of the Congress of $\mathrm{Vi}$ enna, will become the principal highway for Swiss commerce. The right of Switzerland to demand respect for the national flag at sea will accrue whenever it becomes physically possible, through the adequate improvement of the Rhine channel, for a Swiss vessel to undertake a voyage upon the high seas from a river port within Switzerland and to return once more to the port of departure.

Elsewhere the acquisition of rights to a maritime flag has followed the internationalization of a river. Before Bulgaria secured access to the Egean Sea, respect was rendered its merchant flag, since the Bulgarian river-ports on the international Danube fulfilled the stipulated requirements for recognition. Servia, still further upstream, likewise enjoys the right of a mereantile flag entitled to international respect, and sea-going vessels of various nations trade with Servian ports. In South America, the internationalization of the Paraná and Paraguay rivers renders similar advantages to Bolivia and Paraguay; countries lying far inland and dependent upon the freedom of navigation over these mighty waterways for the continued enjoyment of maritime commerce and industry.

Bulgaria, Bolivia, Paraguay, and Servia have secured the commercial advantages of maritime states, while located at great distance from the sea-coast. The internationalization of a river, navigable from the sea, has the practical effect of endowing all inland states situated on its navigable course with 
many of the rights, privileges, and obligations appertaining to nations located on the open sea. River-ports of the inland states virtually become sea-ports, and the inland states, accordingly, enjoy recognition of the national flag at sea.

Similar rights may accrue to an interior state, like Switzerland, situated on a river, capable of sufficient rectification and improvement to afford access to the sea, but such rights continue dormant until through navigation has been accomplished in fact. An inland state situated on a river which is incapable of adequate improvement to secure commercial navigation to and from the sea; and Afghanistan is the only existing instance of this unfortunate position; cannot contemplate the acquisition of rights peculiar to maritime states while the present territorial boundaries continue.

Throughout the world the progressive exercise of the principle has dedicated many thousand miles of inland waterways to the unrestricted commercial use of nations, maritime and inland alike. The freedom of navigation on inland waterways is not confined to the great continents, but has extended to the islands of the sea. Great Britain and the Netherlands by the treaty of May 16, 1895, agreed to the unrestricted commercial navigation of the Fly River in New Guinea; having already provided for a similar liberty on several rivers in Borneo by the convention of June 20, 1891.

The civilization which developed at an early period in the Mediterranean countries was confined necessarily to the seacoasts because of the inadequate facilities for continued intercommunication with distant interior regions. The civilization which the modern European nations have carried to the remotest parts of the world has depended upon the facility of communication and transportation. The science of navigation, assisted by the more recent mechanical inventions, has carried on this dissemination in every region of the Seven Seas and throughout the inland waterways of vast continents. No interior point, however far removed from the sea-board, may be considered isolated, if situated upon a navigable 
affluent of the ocean, since the enlightened principle contributed by the Congress of Vienna to the law of nations assures direct and unrestricted communication with the wide regions of the earth. The right of navigating arterial, inland waterways is intimately affiliated with the freedom of the seas.

The emancipation of the seas indicated a disposition among maritime nations to banish the destructive policies obtaining since the Dark Ages which imposed needless burdens on the sea-trade of the world and evidenced a desire developing among nations to participate more equitably in the benefits of maritime enterprise. With Great Britain's abandonment of sovereignty over the Four Seas (1806), the maritime freedom became established; extending to all nations the right to navigate or fish or otherwise employ the sea without restraint. Appreciating the advantages derived from an equality of participation in the benefits of the sea, and believing that under certain circumstances the unrestricted commercial navigation of inland waters, navigable from the sea, would prove similarly beneficial to the maritime enterprise of all countries, the Congress of Nations incorporated the principle in the Public Law of Europe. Thenceforth, no nation could with impunity impose restrictions on commercial navigation neither on the high seas nor on the great, arterial waterways traversing or separating the domains of several states.

The sea has ever been the highway of international commerce and intercommunication, for the ocean carrying trade is chiefly between nations, not between different portions of the same nation, save only in the instance of insular states. "More than anything else," says Kirkoff, " sea-trade, together with every sort of activity demanding transmarine effort, whether it be vast industrial enterprises, technical achievements on the sea, or colonization, establishes an intimate connection between a nation and the great world. . . . It welds together in indissoluble union the interior of the state with its coast provinces, the only paths along which lively exchange is effected with foreign regions." (Kirchoff, "The Sea in the Life of 
Nations," in the Annual Report of the Smithsonian Institution, 1900-1901, pg. 399.) Every state, realizing the inestimable benefit of the sea, seeks to extend its domain to the littoral. Where adverse circumstances thwart the national ambition of acquiring maritime territory, an alternative remains in the undeveloped possibilities of an inland, international waterway.

Switzerland, in endeavoring to maintain the national industries and foreign trade in competition with rival nations and to secure continued prosperity for its inhabitants, has been seriously restricted by the heavy charges for railway transportation between the Alps and the sea and by the onerous customs dues of the surrounding states. Realizing that an unrestricted highway of communication with the sea is essential to its future existence in the relentless industrial conflict, Switzerland has undertaken the extensive improvement of the Rhine; the completion of which will afford direct communication with all the maritime nations of the world.

In theory, and almost without exception in practice, the freedom of the seas has become an uncontested principle; and, similarly, the right appertaining to arterial inland waters, evolved from the freedom of the seas, has been accepted by all nations and applied to all waterways which conform to the stipulations. The freedom of the high seas has not yet been fully achieved, in time of peace, because of abnormal extensions of the marginal sea or appropriations, of maritime territory which rightfully belongs to the world in common; while during war, the unrestrained exactions of belligerents, in the event of a prolonged and bitterly waged conflict, amount to the virtual denial of the sea to all neutral nations. Ultimately, through the slow process of international consensus, all maritime nations will participate in the commercial navigation of the sea without suffering the restrictions imposed by belligerents nor the exactions of nations indefensibly limiting the peaceful use of the world's waterways.

The progress of liberation, continuing throughout the nine- 
teenth century, warrants this conviction; whole seas have gradually been delivered from age-long restrictions; the extent of the marginal sea has been restricted; the states situated on the same navigable waterway have recognized the benefit to be derived from mutual participation; and based on this enlightened conception international law has sanctioned the principle that wherever three or more states are accessible from the sea, the communicating waterway shall be dedicated to the commercial navigation of all the world. The application and practice of this principle during the nineteenth century has dispelled doubts, originally entertained, so that nations now evince a desire to permit the participation of foreign vessels in the coasting trade of international waterways; and in the navigation of waters - like the Karun in Asia, the San Francisco and Tocantins in South America, and the waterways of China and Honduras - exclusively within the national domain.

The freedom of the seas; expressed in principle by Grotius in the seventeenth century, and vindicated in practice at the commencement of the nineteenth; engendered the principle which received initial acceptance among nations barely a century ago and which, during the nineteenth century, received repeated confirmation by the Treaty of Paris (1856); the Brazilian Decree of 1867 ; the Congress of Berlin (1878); and the Treaty of London (1883) ; until, with the advent of the twentieth century, all waterways susceptible of internationalization are freely dedicated to commercial navigation by every nation. The implicit observance of international law assures each maritime state equality of opportunity for participation in the lucrative enterprises of the sea and for engaging in commercial navigation upon the affluent inland waterways of the world. This beneficent principle; first proclaimed at the termination of the destructive Napoleonic Wars, at a time when nations were disposed to espouse genuinely constructive measures; may be interpretated as an appreciation of the necessity of international co-operation, particularly in all commercial 
and maritime interests, and as an expression of a profound belief in the enduring value, to all maritime states, of the absolute freedom of all waterways, whether maritime or inland. It represents an enlightened interpretation of political, economic, and social relations by affording enhanced facilities for commercial and intellectual intercourse among all nations; a significant contrast to the universal conception of the world and of the mutual obligations incumbent on every state, entertained until the disastrous Napoleonic conflict compelled the renovation of international relations.

The necessities, and in some instances the continued prosperity and development, of states under the existing conditions of modern civilization demand the implicit observance of the principles of international law governing the freedom of the seas and of inland waterways which constitute, for some inland states, the only independent highway of communication with the open sea, assuring the uninterrupted intercourse of the nations of the world.

Speaking before the United States' Senate, President Wilson demonstrated the necessity of co-operation and the strictest observance of the law among nations:

"So far as practicable, moreover, every great people now struggling toward a full development of its resources and of its powers should be assured a direct outlet to the great highways of the sea. Where this cannot be done by the cession of territory, it can no doubt be done by the neutralization of direct rights of way under the general guarantee which will assure the peace itself. With a right comity of arrangement no nation need be shut away from free access to the open paths of the world's commerce. And the paths of the sea must alike in law and in fact be free. The freedom of the seas is the sine qua non of peace, equality and co-operation. No doubt a somewhat radical reconsideration of many of the rules of international practice hitherto thought to be established may be necessary in order to make the seas indeed free and common in practically all commerce for the use of mankind, 
but the motive of such changes is convincing and compelling. There can be no trust or intimacy between the peoples of the world without them. The free, constant, unthreatened intercourse of nations is an essential part of the process of peace and development. It need not be difficult either to define or to secure the freedom of the seas if the governments of the world sincerely desire to come to an agreement concerning it. It is a problem closely connected with the limitation of naval armaments and the co-operation of the navies of the world in keeping the seas at once free and safe. . . . The question of armaments, whether on land or sea, is the most determined and intensely practicable question connected with the future fortunes of nations and of mankind." (President Wilson, Address to the United States Senate, January 22, 1917 New York Sun, Jan. 22, 1917.) 

PART II

A REFERENCE-MANUAL TO THE TREATIES, CONVENTIONS, LAWS, AND OTHER FUNDAMENTAL ACTS GOVERNING THE INTERNATIONAL USE OF INLAND WATERWAYS 



\section{SECTION I}

\section{INDEX OF ABBREVIATIONS DISTINGUISHING THE PRINCIPAL DOCUMENTARY COLLECTIONS}

Charles; UST:

Clercq; RTF :

Cussy/Hauterive; RTC: CUSSY; Ferdinand de:

HAUTERIVE; Alexandre M. B. de L.d': Recueil des Traités de Commerce et de Navigation de la France, avee les Puissances étrangères, depuis la Paix de Westphalie, en 1648, suivi de Recueil des Principaux Traités de même Nature conclus par les Puissances étrangères entre elles, depuis la même époque. 10 vols. Paris: Rey et Gravier, 18341844.

Cussy/Martens:

Rec. Man., Ser. I:

\section{CUSSY; Ferdinand de:}

MARTENS; Karl von: Recueil Manuel et Pratique de Traités, Conventions et autres Actes diplomatiques, sur lesquels sont établis les relations et les rapports existant aujourd'hui entre les divers états souverains du globe, depuis l'année 1760 jusqu'à l'époque actuelle. (First Series) 7 vols. Leipzig, Brockhaus, 1846-1857. 
Cussy/Martens:

Rec. Man., Ser. II:

Deschamps/Renault;

RIT: RENAULT; Louis: Recueil international des Traités du XIX Siècle; contenant l'ensemble du droit conventionnel entre les états et les sentences arbitrales. (Contains the original texts with the French version.) Paris, 1914.

RIT: DESCHAMPS/RENAUIT: Recueil international des Traités du XX Siècle .... continuation. Paris.

Dodd; Modem Consti- DODD; W. F.: Modern Constitutions. tutions: 2 vols.

Dumont; Corps Univ. DUMONT; Jean:

Dipl: BARBEYRAC; J.:

ROUSSET; J.: Corps Universel Diplomatique du Droit des Gens. (Charlemagne-1726) 8 vols. Amsterdam, 17261731.

Dumont; Corps Univ. DUMONT/BARBEYRAC/ROUSSET: Dipl. Suppl.: Corps Universel Diplomatique du Droit des Gens .... (continuation). Supplement. 5 vols. Amsterdam, 1739.

$\mathrm{GB}: \mathrm{BFSP}:$

GB:TR.SER. :

Hertslet; Africa :

Hertslet; China:
GREAT BRITAIN: British and Foreign State Papers. Vol. I-Vol. CVII; 1806/1807-1913/1914. London, Foreign Office.

GREAT BRITAIN: Treaty Series. London, 1892 (Vol. I.)-date.

HERTSLET; Edward: Map of Africa by Treaty. 3 vols. 3rd Edit. London, 1909.

HERTSLET; Edward :

HERTSLET; Godfrey E. P.: China Treaties. 2 vols. London, 1908. 
Hertslet; COM. TR. :

Hertslet; Europe:

Koch/Schoell; Hist. Abr.Tr: SCHOELL; Maximilian S. F.:

Lagemans; Netherlands: LAGEMANS; E. G.: Recueil des

Malloy; UST:

Martens; Rec. Russ:

Martens; Loix \& Ord.:

Martens; RPT : Histoire Abregée des Traités de Paix entre les Puissances de l'Europe depuis la Paix de Westphalie. 15 vols. Paris, 1817-18. Traités et Conventions conclus par le Royaume des Pays-Bas avec les Puissances étrangères; depuis 1813 jusqu'à nos jours. 14 vols. The Hague, 18591901.

HERTSLET ; Edward: Commercial Treaties; A Complete Collection of the Treaties and Conventions subsisting between Great Britain and Foreign Powers; and of the Laws, Decrees, Orders in Council, \&c, concerning the same . . . London, 1827 (Vol. I.)-1895 (Vol. XIX.) HERTSLET; Edward: Map of Europe by Treaty . . . since the General Peace of 1814. 4 vols. London, 1875 (First Edit.), 1891 (Second Edit.).

KOCH; Christophe G.:

MALLOY; William: Treaties, Conventions, International Acts, Protocols, and Agreements between the United States of America and other Powers; 17761909. 2 vols. Washington, 1910. Supplementary volume compiled by Garfield Charles; Washington, 1913. (See: Charles; UST.)

MARTENS; Fedor F.: Recueil des Traités et Conventions conclus par la Russie avec les Puissances étrangères. 15 vols. St. Petersburg, Ministry of Communications, 1874-1909. MARTENS; G. F. von: Loix et Ordonnances des diverses Puissances européenes concernant le commerce, la navigation, etc . . depuis le milieu du Septième Siècle. Gottingen, 1802.

MARTENS; G. F. von: Recueil des 
Martens; RT:

Martens; NRT:

Martens; RT.SUPPL.:

Martens; RT.NS :

Martens; NRG.SER.I.:

Martens; NRG.SER.II.

Martens;

NGR.SER.III. :

Moore; Int.Arb. :

Moore; ILD :

Neumann; RTA:

Norway; Treaties:
Principaux Traités d'Alliance, de Paix, de Trêve; . . . 1761-1801. 7 vols. Gottingen, 1791-1801.

MARTENS; G. F. von: Recueil des Traités d'Alliance, de Paix, de Trêve, ... depuis 1761. 8 vols. Gottingen, 1817-1835.

MARTENS; G. F. von: Nouveau Recueil des Traités d'Alliance, de Paix, de Trêve; . . . 1808-1842. 16 vols. Gottingen, 1817-1842.

MARTENS; G. F. von: Supplément au Recueil des Principaux Traités d'Alliance, etc. 10 vols. Gottingen, 18021828.

MARTENS; G. F. von: Nouveaux Supplemens au Recueil des Traités; 17611842. 3 vols. Gottingen. 1839-1842.

MARTENS; G. F. von: Nouveau Recueil Général des Traités. Series I. 22 vols. Gottingen, 1843-1875.

MARTENS; G. F. von: Nouveau Recueil Général des Traités. Series II. 35 vols. Gottingen, 1876-1908.

MARTENS; G. F. von: Noureau Recueil Général des Traités; 19091913. Series III. 7 vols. Leipzig, 1909-1913.

MOORE; John Bassett: History and Digest of the International Arbitrations to which the United States has been a party ...6 vols. Washington, 1898. MOORE; John Bassett: A Digest of International Law. 8 vols. Washington, 1906.

NEUMANN; Leopold: Recueil des Traités et Conventions conclus par l'Austriche avec les Puissances étrangères depuis 1763 jusqu'à nos jours. 24 vols. Leipzig/Vienna, 1855-1909.

NORWAY: Recueil des Traités de la Norvège. Kristiana, 1907. 
Olivart; Colecc. Tratados: los Tratados, Convenios y Documentos Internacionales. 9 vols. Madrid, 189099.

RT.PAIX:

Stowell; Int. Cases:

Sturdza ; Rec. Doc. :

US : For. Rel. :
Recueil des Traitéz de Paix ... depuis la Naissance de Jesus-Christ jusqu'à present. 4 vols. Amsterdam, 1700. MUNRO; Henry F.: STOWELL; Ellery C.:

International Cases. 2 vols. New York, 1916.

STURDZA; Dimitrie A.: Recueil des Documents relatifs à la Liberté de Navigation du Danube. Berlin, 1904. UNITED STATES : Foreign Relations. Washington, 1870-date. 


\section{SECTION II}

\section{THE INTERNATIONAL INLAND WATERWAYS OF THE WORLD BY CONTINENTAL DIVISIONS}

\section{EUROPE}

ADIGE.

1797; Oct. 17: Campo Formio. Treaty. Austria/France. Art. XI. Reciprocal freedom of navigation. Martens, RT, VI, 424. 1801; Febr. 9 : Lunéville. Treaty. Austria/France. Art. 14. Freedom of navigation; prohibition of tolls; maintenance of warvessels forbidden. Neumann, RTA, II, 5; Univ. of Penn., Transl. \& Reprints, II, 12, No. 2.

1815; June 9: Vienna: Treaty. Austria, France, Great Britain, Portugal, Prussia, Russia, Spain, Sweden. Art. 93: Boundary. Cussy/Hauterive, RTC, I, pt. 1, 78; Deschamps/Renault, RIT, I, 319; Hertslet, Europe, 263; Lagemans, Netherlands, I, No. 30; Martens, NRT, II, 436.

1866 ; Aug. 23; Treaty of Prague extinguished international rights by ceding Venetia to Italy.

\section{ANGOUSTRINE CANAL.}

1866; May 26: Bayonne. Treaty. France/Spain. Art. 27: Boundary. Olivart, Colece. Tratados, IV, 246-62.

1868; July 11: Bayonne. Convention. France \& Spain. Arts. VII, VIII: Regulations. Hertslet, Europe, 1844; Olivart, Colecc. Tratados, IV, 322-30.

\section{ANNECY LAKE}

1815; Nov. 3: Paris. Protocol. Austria, Great Britain, Prussia, Russia. Art. 4; Boundary. Hertslet, Europe, 328.

1815; Nov. 20: Paris. Treaty. Austria, France, Great Britain, Prussia, Russia. Art. 3: Hertslet, Europe, 346, 370.

1860; Aug. 23: Paris. Convention. France/Sardinia. Art. 6: Hertslet, Europe, 1453.

\section{ARAVO}

1866; May 26: Bayonne. Treaty. France \& Spain. Art. 20: Hertslet, Europe, 1647; Olivart, Colecc. Tratados, IV, 246-62. 


\section{ARVE}

1815; Mar. 29: Vienna. Treaty. Art. I. (Included in Annex XII of Final Act): Boundary. Hertslet, Europe, 70.

1815; May 20: Vienna: Treaty. Austria, France, Great Britain, Prussia, Russia, Sardinia. Art I of Annex B. B. (Formed Annex 13 of Final Act): Boundary. Hertslet, Europe, 164.

1815; June 9: Vienna. Treaty. Austria, France, Great Britain, Portugal, Prussia, Russia, Spain, Sweden. Art. 80; 118, sec. 12; Annex 12: Hertslet, Europe, 80, 273, 275.

1816; Mar. 16: Turin. Treaty. Geneva, Sardinia, Swiss Confederation. Art. I: Thalweg Boundary. Hertslet, Europe, 424.

1819; July 20: Frankfort. Treaty. Austria, Great Britain, Prussia, Russia. Art. 41: Thalweg Boundary. Hertslet, Europe, 611.

1904; March 9: Paris. Convention. France/Switzerland. Regulation of fisheries. Martens, NRG, SER. II, XXXIII, 501.

\section{AVETO}

1766; Mar. 10: Turin. Treaty. Parma/Sardinia. Preamble: Boundary. Hertslet, Europe, 693.

1822; Nov. 26: Turin. Treaty. Parma/Sardinia. Boundary. Hertslet, Europe, 693.

\section{BIDASSOA}

1683; Oct. 19: Madrid. Treaty. France/Spain. Reciprocal freedom of navigation \& fishing. Dumont, Corps Univ. Dipl., VII, 71; RT. PAIX, IV, 482.

1685 ; Oct. 19 : Madrid. Treaty. France/Spain. Freedom of navigation \& fishing for the subjects of both nations. Cussy/Hauterive, RTC, I, pt. 1, 361 .

1856; Dec. 2: Bayonne. Treaty. France/Spain. Arts. 1; 9; 20-25; 28: Freedom of navigation \& fishing. Hertslet, Europe, 1291; 1294-95.

1859 ; Mar. 31: Bayonne. Additional Act. France/Spain. Regulating fisheries. GB.BFSP, Vol. 50, 1006; Hertslet, Europe, 3214.

1868; July 11: Bayonne. Additional Act. France/Spain. Navigation Regulations. Hertslet, Europe, 1846.

1879; Mar. 30: Bayonne. Declaration. France/Spain. Arts. VIXII: Delimination of boundaries. Art. XII: Reaffirming Fishing Regulations of Dec. 2, 1856 \& Mar. 31, 1859. Clercq, RTF, XII, 394.

1886; Feb, 18: Bayonne. Convention. France/Spain. Fishing 


\section{Bidassoa}

Regulations. Clercq, RTF, XVII, 77; GB.BFSP, Vol. 77, 1073;

Martens, NRG, Ser. II, XII, 687.

1888; Jan. 19 : Madrid. Protocol. France/Spain. Concerning fishing rights. Martens, NRG, SER. III, III, 253, 256.

1890; May 10: Bayonne. Agreement. France/Spain. Navigation Regulations; suppression of contraband trade. GB.BFSP, Vol. 82, 1015; Martens, NRG, SER. II, XVIII, 72.

1894; Oct. 4: Bayonne. Declaration. France/Spain. Fishing Regulations. Martens, NRG, SER. III, VII, 421.

1906; June 9: Bayonne. Declaration. France/Spain. Regulating Fisheries. Martens, NRG, SER. III, VII, 422.

1908; Apr. 6: Bayonne. Declaration. France/Spain. Concerning riverain fisheries. Martens, NRG, SER, III, III, 256. :

\section{BLIESSE}

1825; July 5: Paris. Convention. Bavaria/France. Art. I. Thalweg Boundary. Hertslet, Europe, 727.

1827; June 11: Paris. Declaration. France/Prussia. Art. V. Boundary. Hertslet, Europe, 768.

1829; Oct. 23: Sarrebruck. Convention. France/Prussia. Art. XII. Mutual Fishing Rights. Hertslet, Europe, 837.

\section{BOUNDARY WATERWAYS}

AUSTRIA/ITALY

1867; Dec. 22 : Venice. Convention. Arts. 3; 6. Hertslet, Europe, 1833.

AUSTRIA/POLAND.

1776; Feb. 9: Warsaw. Convention. Art. 5. Neumann, RTA, I, 196.

AUSTRIA/SARDINIA

1834; Dec. 4: Turin. Treaty. Arts. 1-24: Suppression of Contraband aboard Vessels navigating Frontier Waters. Martens, NRT, XIII, 198-205.

\section{AUSTRIA/SERVIA}

1882 ; Feb. 10/22 : Belgrade. Convention. Arts. I-XXVII. Riverain Navigation Regulations. GB.BFSP, Vol. 73, 519; Neumann, RTA, XI, 1441-43.

\section{BADEN/SWITZERLAND}

1908; Nov. 17: Convention. Regulation of Fisheries. Martens, NRG, SER. III, IV, 875 . 
BELGIUM/FRANCE/GERMANY.

1887; Oct. 8: Agreement. Paris. Regulating Closure of International Canals. Martens, NRG, SER. II, XV, 747.

\section{BELGIUM/FRANCE/GERMANY/NETHERLANDS}

1908; June 1: Convention; supplementing Treaty of Feb. 4, 1898; governing navigation. Martens, NRG, SER. III, IV, 270.

\section{BELGIUM/NETHERLANDS}

1831; Nov. 15. London. Treaty. (1) Belgium/Netherlands. (2) Austria, Belgium, France, Great Britain, Prussia, Russia. Art. IX. Reciprocal Freedom of Navigation on all waterways forming or traversing the international boundary. Cussy/Hauterive, RTC, I, pt. 2, 283; Hertslet, COM. TR, IV, 31; Hertslet, Europe, 864.

1839; April 10/19: London. Treaty. (1) Belgium/Netherlands. (2) Austria-Hungary, Belgium, France, Great Britain, Netherlands, Prussia, Russia. Arts. 8; 9; 10 \& Annex: Reciprocal Freedom of Navigation on Waterways traversing or forming international boundary. Clereq. RTF. IV, 470-477; Cussy/Martens, Rec. Man. Ser. I, IV, 575; Hertslet, COM. TR., V, 354, 359; Hertslet, Europe, 987-998; Lagemans, Netherlands, Vol. II, no. 165; Neumann, RTA, IV, 416, 421; Sturdza, Rec. Doc. 854-55.

1842; Nor. 5: The Hague. Treaty. Belgium/Netherlands. Arts. 38-49; Navigation Regulations. Hertslet, Europe, 1029; Martens, NRG. SER. I, III, 622; Sturdza, Rec. Doc., 862.

1843; May 20; Antwerp. Additional Agreement. Belgium/Netherlands. Regulating Fishing and Navigation. Cussy/Martens, Rec. Man., Ser. I, V, 306, citing Moniteur Belge, 1842 ; Martens, NRG. SER. I, 294, 307, 334, 339, 381.

1843; Aug. 8: Maastricht. Convention. Belgium/Netherlands. Arts. 35-36. Hertslet, Europe, 1031.

1851; Oct. 3: The Hague. Agreement. Belgium/Netherlands. Navigation Regulations. Lagemans, Netherlands, III, no. 269.

\section{FRANCE/GERMANY}

1871; May 10: Frankfort. Treaty. France/Germany. Art. V. Navigation. Martens, NRG. SER. I. XIX, 688. 


\section{Boundary Waterways}

Regulating the establishment of ferries on all boundary waterways. Clercq, RTF, IV, 308: Martens, NRT, XIII, 406-407.

\section{FRANCE/SPAIN}

1866; May 26: Bayonne. Treaty. France/Spain. Delimitation of International Boundaries. Olivart, Colecc. Tratados, IV, 246-262.

1866; May 26: Bayonne. Additional Agreement. France/Spain. Arts. 8-21: Regulation \& Enjoyment of Frontier Waters. Olivart, Colecc. Tratados, IV, 331, 335-340.

FRANCE/SWITZERLAND; notably the Doubs, the Rhone, and Geneva (Leman) Lake.

1880; Dec. 28: Paris. Convention. France/Switzerland. Governing fisheries in frontier waterways. Clercq, RTF, XII, 619; Hertslet, Europe, 3252 ; Martens, NRG, SER. II. IX, 111.

1884, Dec. 9: Paris. Convention. France/Switzerland. Fisheries Regulations. Clereq, RTF, XIV, 428.

1888; April 14: Berne. Agreement. France/Switzerland. Fisheries Regulations; abrogating arrangement of Dec. 9, 1884; modifying Convention of Dec. 28, 1880. France, Journal Officiel, Sept. 1, 1888; Hertslet, Europe, 3280; Martens, NRG, SER. II, XIV, 410.

1891; Mar. 12: Berne. Convention. France/Switzerland. Fisheries Regulations; modifying Arts. 2, $3 \& 8$ of Convention of Dec. 28, 1880. Clereq, XIX, 62; Martens, NRG. SER. II, XVIII, 238.

1891; July 30 : Berne. Agreement. France/Switzerland. Regulating fisheries in frontier waters. Clercq, RTF, XIX, 250; Martens, NRG, SER. II., XVIII, 848; XXI, 24.

1904; March 9: Paris. Convention. France/Switzerland. Regulating Fisheries. Martens, NRG. SER. II., XXXIII, 501.

1909: Jan. 20: Lausanne. Agreement. France/Switzerland. Fisheries Regulations; supplementing Convention of March 9, 1904. Martens, NRG. SER. III., V, 318.

\section{HANOVER/LUBECK}

1844; Feb. 14: Dresden. Treaty. Hanover/Lubeck. Art II. Mutual freedom of navigation. Martens, NRG. SER. I., VI, 131.

\section{ITALY/SWITZERLAND.}

1882 ; Nov. 8: Berne. Convention. Italy/Switzerland. Regulating fisheries in frontier waters. Martens, NRG. SER. II, IX, 564. 
1906; June 15: Lugano. Convention. Italy/Switzerland. Fisheries regulation. Martens, NRG. SER. II, XXXV, 471.

\section{NETHERLANDS/PRUSSIA.}

1816; June 26: Aix-la-Chapelle (Aachen). Treaty. Netherlands/ Prussia. Art. 27: Reciprocal enjoyment of navigation and fishing. Hertslet, Europe, 451.

\section{PORTUGAL/SPAIN}

1866; Apr. 27: Lisbon. Convention. Portugal/Spain. Art. VI: Police and Navigation Regulations. Olivart, Colecc. Tratados, IV, 240, 244.

1872; Dec. 20: Lisbon. Treaty. Portugal/Spain. Art. 16: Participation in Coasting Trade, whether Fluvial or Maritime, expressly Forbidden; Stipulation of Treaty of Lisbon, Apr. 27, 1866, concerning Freedom of Fluvial Navigation explicitly confirmed. Olivart, Colecc. Tratados, VII, 315, 322.

\section{RUSSIA/SWEDEN}

1810; Nov. 8/20: Tornea. Treaty. Russia/Sweden. Arts II, IV: Mutual liberty of navigation. Cussy/Hauterive, RTC, V, pt. 2,515 .

\section{BOURNA SOLA LAKE}

1856; May 30: Paris. Treaty. Austria, France, Great Britain, Prussia, Russia, Sardinia, Turkey. Art. 20: Boundary. Hertslet, Europe, 1250, 1259.

\section{BOURGET LAKE}

1815; Nov. 3: Paris. Protocol. Austria, Great Britain, Prussia, Russia. Art. IV. Boundary. Hertslet, Europe, 328.

1815; Nov. 20: Paris. Treaty. Austria, France, Great Britain, Prussia, Russia. Art. 3: Boundary. Hertslet, Europe, 347.

\section{BOYANA}

1877; Mar. 31: London. Protocol. Austria-Hungary, France, Germany, Great Britain, Italy, Russia. Concerning desirability of free navigation. Hertslet, Europe, 2563.

(*NOTE :

(1878; Mar. 3: San Stephano. Treaty. Russia/Turkey. Art. I. Navigation to be regulated by the European Commission entrusted with the establishment of boundary of Montenegro. 


\section{Boyana}

Hertslet, Europe, 2675. *Being inoperative, this treaty was supplanted by Treaty of Berlin, July 13, 1878. Hertslet, Europe, 2783.)

1878; July 13: Berlin. Treaty. Austria-Hungary, France, Germany, Great Britain, Italy, Russia, Turkey. Art. 29 : Montenegro granted complete freedom of navigation. Hertslet, Europe, 2764, 2783.

1879; Mar. 18: London. Notification. British Board of Trade. British Consul at Scutari reports Boyana open to merchant ships. GB. BFSP, Vol. 70, 241.

\section{BROMBERG CANAL}

1807; July 7: Tilsit. Treaty. France/Prussia. Art. 17: Navigation exempt from all dues. Cussy/Hauterive, RTC, III, pt. 1,43 .

\section{BUG}

1776; Feb. 9: Warsaw. Convention. Austria/Poland. Art. 5. Mutual liberty of navigation. Neumann, R'TA, I, 196.

1815; June 9: Vienna. Treaty. Austria, France, Great Britain, Portugal, Prussia, Russia, Spain, Sweden. Art. 5: Thalweg Boundary. Hertslet, Europe, 218.

1829; July 10: Radziwilow. Treaty. Austria/Russia. Preamble \& Art. 3: Thalweg Boundary. Hertslet, Europe, 810-11.

\section{CERCHIO}

1844; Nov. 28: Florence. Treaty. Austria, Lucca, Modena, Sardinia, Tuscany. Art. 9: Thalweg Boundary. Hertslet, Europe, 1055 .

\section{CISA}

1844; Nov. 28: Florence. Treaty. Austria, Lucca, Modena, Sardinia, Tuscany. Art. 5: Constitutes International Boundary. Hertslet, Europe, 1052.

CONSTANCE LAKE

1844; Jan. 30: Munich. Treaty. Austria/Bavaria. Arts. 1; 8-12: Boundary \& Navigation. Hertslet, Europe, 1034.

1850; Dec. 16: Munich. Treaty. Austria/Bavaria. Arts. 4; 5; 6: Boundary. Hertslet, Europe, 1146.

1853; May 2: Berne. Convention. Bavaria/Switzerland. Navigation Regulations. Martens, NRG. SER. I, XX, 112. 
Constance Lake

1854; - - Convention. Austria/Bavaria/Wurtemburg. Suppression of contraband trade. Cussy/Martens, Rec. Man., Ser. I, VII, 359. (Cited; no text.)

1854; Oct. 20/31: Stuttgart/Zurich. Convention. Baden/Switzerland. Art. 1: Boundary. Hertslet, Europe, 1219-20.

1857; Aug. 31: Constance. Convention. Austria, Baden, Bavaria, Switzerland, Wurtemburg. Regulating level of waters. Martens, NRG. SER. I, XX, 115.

1867; Sep. 22: Bregenz. Convention. Austria, Baden, Bavaria, Switzerland, Wurtemburg. Navigation Regulations. Martens, NRG. SER. I, XX, 117; Neumann, RTA, V n. s., 255.

1867; Sep. 28 : St. Gall. Convention. Baden/Switzerland. Navigation Regulations. Cussy/Martens, Rec. Man, Ser. II, I, 441. Martens, NRG. SER. I, XX, 139.

1875; March 25; including Declarations of Nov. 30 \& Dec. 5, 1875 : Basle. Convention. Baden/Switzerland. Regulating fisheries in the Lake \& in the Rhine \& its affluents. Martens, NRG. SER. II, II, 60.

1884; Sep. 21: Colmar. Convention. Alsace-Lorraine, Baden, Switzerland. Fisheries Regulations. Martens, NRG. SER. II, X, 523.

1887 ; May 18 : Lucerne. Convention. Alsace-Lorraine, Baden, Switzerland. Protection of mutual fishing privileges. Martens, NRG. SER. II, XIV, 350.

1892 ; May 6 : Bregenz. Agreement. Austria, Baden, Bavaria, Switzerland, Wurtemburg. Revised Navigation Regulations; modifying stipulations of Treaty of Bregenz, Sept. 22, 1867. Martens, NRG, SER. II, XVIII, 903; XX, 354. Neumann, RTA, XX n. S., 417.

1895; Jan. 14: Vienna. Regulation. Austrian Government. Governing Transportation of Explosives. Neumann, RTA, XVII n. s., 207.

1896; Mar. 20: Vienna. Convention. Austria/Switzerland. Governing Navigation in conformity with special Sanitary Regulations. GB. BFSP, Vol. 88, 365; Martens, NRG, SER. II, XXIII, 262 ; XXIV, 660.

1899 ; Apr. 8: Constance. Treaty. Austria, Baden, Bavaria, Switzerland, Wurtemburg. Revised Navigation Regulations; modifying stipulations of Treaty of Sept. 22, 1867. Martens, NRG, SER. II, XXX, 206.

1908; Nov. 17: Convention. Regulation of Fisheries. Baden/Switzerland, Martens, NRG, SER. III, IV, 875 . 


\section{Constance Lake}

1910; Jan. 1: Treaty. Austria, Baden, Bavaria, Switzerland, Wurtemburg. Governing Navigation. Martens, NRG, SER. III, VII, 435. (Commentary: OPPENHEIM, Int. Law, I, 230; RIVIER, Principes du Droit des Gens, I, 230.)

\section{DANUBE}

1680 ; December: (Month of Ramadan, 1091): Capitulations. Nethetherlands/Ottoman Porte. Art. 58: Fluvial Transportation secured for Dutch vessels. Cussy/Hauterive, RTC, IV, pt. 2, 480. 1699; January 26: Carlowitz. Treaty. Austria, Poland, Russia, Venice, Turkey. Dumont; Corps Univ. Dipl., VII, part 2, 448, $451,453$.

1718; July 21/27: Passarowitz. Treaty. Austria/Ottoman Porte. Arts. $2 ; 4 ; 5$ : Freedom of Fluvial Transit for Austrian subjects to Black Sea, Ibraila, Kilia, etc. Cussy/Hauterive, RTC, I, pt. 2, 113; Neumann, RTA, I, 1.

1739; Sept. 18: Belgrade. Treaty. Austria/Ottoman Porte. Art. 7: Regulation of Danubian Fisheries. Cussy/Hauterive, RTC, I, pt. 2, 114.

1774; July 10: Koutschouc-Kaynardgi. Treaty. Ottoman Porte/ Russia. Art. 10: Privilege of Commercial Navigation \& Fluvial Transportation granted to Russian vessels. Cussy/Hauterive, RTC, V, pt. 2, 141.

1779; May 13: Teschen. Convention. Austria/Bavaria (The Elector Palatine). Art. 5: Reciprocal Freedom of Navigation. Hertslet, Europe, III, 2012; Martens, RT, II, 671; Neumann, RTA, I, 244. (Commentary: ENGELHARDT, Histoire du Droit Fluvial Conventionnel, 46; MOORE, Int. Arb., pg. 4853; MOORE, ILD, I, 629.)

1783; June 10/21: Constantinople. Russia/Turkey. Regulating commerce and navigation. GB: BFSP; XIII, 902.

1784; Feb. 24: Passarowitz. Treaty. Austria/Turkey. Art. IV, Art. VI: Freedom of Navigation. Martens, RT, III, 723. (Commentary: GEFFCKEN, La Question du Danube, p. 6; SCHUYLER, American Diplomacy, 353.)

1784; Aug. 31: Munich. Treaty. Austria/Bavaria. Art. IV: Reciprocal Freedom of Navigation in conformity with Art. V of 
Treaty of Teschen. Art. X: Exclusive right of fisheries on respective sides of thalweg. Cussy/Hauterive, R'TC, I, pt. 2, 48; Martens, RT, III, 755.

1791; Aug. 4: Sistova. Treaty. Russia/Turkey. Martens, RPT, V, 244.

1791; Dec. 9/1792; Jan. 9: Jassy. Treaty. Russia/Turkey. GB : BFSP; XIII, 902; Martens, NRG, Ser. I, V, 53.

1812; May 6/28: Bucharest. Treaty. Russia/Turkey. Art. IV: Navigation \& Fishing throughout lower course to be enjoyed in common. Cussy/Hauterive, RTC, V, pt. 2, 190. Koch/Schoell, Hist. Abr. Tr., XIV, 539. (Commentary: DESPAGNET, Droit Int. Publ., 64:3; WOOLSEY, Intro. Int. Law, sec. 62.)

1815; May 30 : Constantinople. Firman. Turkish Government. Assuring Austrian Vessels Free Transit. Neumann, RTA, VI, 476. 1816; Apr. 14: Munich. Treaty. Austria/Bavaria. Art. IX: Reaffirmation of stipulations governing freedom of navigation formerly existing; adoption of principles sanctioned by the Final Act of Vienna. Cussy/Hauterive, RTC, I, pt. 2, 51; Martens, NRT, III, 15.

1826; Sept. 25/Oct. 7: Akkerman. Convention. Russia/Turkey. Supplementing Treaty of Bucharest of May 28, 1812. GB: BFSP, XIII, 899; Hertslet, Europe, I, 747.

1829; Sept. 14: Adrianople. Treaty. Russia/Turkey. Art. 3: Thalweg Boundary; Freedom of Commercial Navigation; Navigation by Russian War-vessels to terminate at Confluence of Pruth. Hertslet, Europe, 815-16. (Commentary: DESPAGNET, Droit Int. Pub., 643; GEFFCKEN, La Question du Danube, 6; L. LEVI, Int. Law, 53; WOOLSEY, Intro. Int. Law, sec. 62.)

1834; - : Constantinople. Hatti-Sheriff (Decree). Turkish Government. Art. III: Thalweg Boundary; Art. 7: Liberty of Navigation for Inhabitants of Moldavia \& Wallachia. Hertslet, Europe, 951.

1835; Mar. 4: Athens. Treaty. Austria/Greece. Art. 17: Commercial Navigation. Cussy/Hauterive, RTC, IV, pt. 2, 393.

1840 ; July 13/25: St. Petersburg. Convention. Austria \& Russia. Arts. 1, 2, 5: Freedom of Transit throughout course for all vessels enjoying commercial navigation of Black Sea. Cussy/ Martens, Rec. Man. Ser. I, V, 52; GB: BFSP, Vol. 28, 1060 ; Hertslet, Europe, 1018; Martens, Rec. Russ., IV, pt. 1, 487; Martens, NRG, SER. I, I, 209; Neumann, RTA, IV, 460; Sturdza, Rec. Doc., 7. (Commentary: GEFFCKEN, La Question du 


\section{Danube}

Danube, 7; HOLLAND, European Concert in the Eastern Question, pg. 229; SCHUYLER, American Diplomacy, 353.) (NOTE: Correspondence between Great Britain and Russia concerning obstructions to navigation in the Sulina Channel; 1849-53; GB. BFSP, Vol. 44, 417.)

1850; Nov. 1/13: Vienna. Protocol of Conference. Austria/Russia. Prolonging Convention of July 13/25, 1840, governing navigation. Cussy/Martens, Rec. Man. SER. I, VI, 433; GB. BFSP, Vol. 39, 104; Hertslet, Europe, 1142; Neumann, RTA, V, 265.

1851; Dec. 2: Vienna. Treaty. Austria/Bavaria. Arts. 1-17: Freedom of Navigation, including Danubian tributaries. Cussy/ Martens, Rec. Man. SER. I, VI, 655; Martens, Vol. 16, NRG, SER. I, part 2, pg. 63; Neumann, RTA, V', 448-54; Sturdza, Rec. Doc., 609. (Commentary: HOLLAND: European Concert, 229.)

1853 ; June 18/30: Munich. Declaration. Bavaria/Russia. Arts. I, II: Stipulating that Bavarian vessels shall enjoy same freedom of navigation as Austrian in Russian dominions; that Russian vessels in Bavarian fluvial territory shall have identical privileges as Austrian. Cussy/Martens, Rec. Man., SER. I, VII, 245; Neumann, RTA, VI n. s., 516.

1853 ; Nov.: Bucharest. Declaration. Russian Government of Wallachia. Regulating neutral navigation during Turko-Russian War. Hertslet, COM. TR., Vol. IX, 684.

1854; Aug. 8: Vienna. Agreement. Austria/Great Britain. Sect. 2, Navigation. Hertslet, Europe, 1216, 1218.

1854; Dec. 28 : Memorandum. Austria, France, Great Britain. Sect.

2. Presented to the Russian Government respecting navigation.

Hertslet, Europe, 1225.

1855; Mar. 21/23: Vienna. Protocol of 'Conference. Austria, France, Great Britain, Russia, Turkey. Freedom of Navigation. GB. BFSP : Vol. 45, 68, 73; Hertslet, Europe, 1233.

1855; June 5: Vienna. Protocol. Austria, Bavaria, Wurtemburg. Accession of Wurtemburg to the Treaty of Dec. 2, 1851, between Austria \& Bavaria governing navigation. Martens, NRG, Ser. I, XVI, pt. 2, 71; Sturdza, Rec. Doc., 618. (Commentary: HOLLAND; European Concert, 229.)

1856; Feb. 25, 28; Mar. 6, 12, 18, 29 : Paris. Conference Protocols. Austria, France, Great Britain, Prussia, Russia, Sardinia, 'Turkey. Navigation. Hertslet, Europe, 1274; GB. BFSP, Vol. 46, pg. 63 (Feb. 25), 67 (Feb. 28), 75 (Mar. 6), 84 (Mar. 12), 90 (Mar. 18), 114 (Mar. 29). 
1856; Mar. 30: Paris. Treaty. Austria-Hungary, France, Great Britain, Prussia, Russia, Sardinia, Turkey. Arts. XV-XXI: Freedom of Navigation. Clercq, RTF, VII, 59; Cussy/Martens, Rec. Man. SER. I, VII, 497; GB. BFSP, Vol. 46, 8; Hertslet, COM. TR., X, 533, 536; Hertslet, Europe, 1250, 1257; Martens, Rec. Rus., XV, 316; Martens, NRG, Ser. I, XV, 770; Sturdza, Rec. Doc., 32. (Commentary: ENGELHARDT, Hist. du Droit Fluv. Convent., 88-91; ENGELHARDT, Du Rég. Convent. des Fleuves Int., 169; GEFFCKEN, La Question du Danube, 11, 19 ; HALLECK, Int. Law, I, 187; HAZEN, Europe since 1815, pg. 615; HOLLAND, European Concert, 230 ; LEON LEVI, Int. Law, 51; MOORE, Int. Arb., 4853; MOORE, ILD, I, 630 ; OPPENHEIM, Int. Law, I, 228; PHILLIMORE, I, 232 ; SCHUYLER, Am. Diplomacy, 352, 353, 356; TWISS, Law of Nations, (Peace), 242; WESTLAKE, I, 152.)

1857; Jan. 6: Paris. Protocol of Conference. Austria-Hungary, France, Great Britain, Prussia, Russia, Sardinia, Turkey. Regulating Navigation at Delta and Composing the Conflicting Sovereignties therein. GB. BFSP, Vol. 47, 92; Hertslet, COM. TR, X, 553; Hertslet, Europe, 1298. (Commentary: Correspondence between France \& Great Britain concerning the Protocol of Paris, Jan. 6, 1857, governing navigation within the Delta; Jan. 7, 1857. GB. BFSP., Vol. 56, 691.

1857; June 19: Paris. Treaty. Austria-Hungary, France, Great Britain, Prussia, Russia, Sardinia, Turkey. Arts. II, IVi: Establishment of Boundaries in the Danubian Delta; erection of works to facilitate navigation. GB. BFSP, Vol. 47, 60; Hertslet, COM. TR., X, 960; Hertslet, Europe, 1321-22.

1857 ; Nov. 7 : Vienna. Convention. Austria, Bavaria, Turkey, Wurtemburg. Arts. I-XLVII: Navigation Regulations. Annuaire des Deux Mondes, 1858; Cussy/Martens, Rec. Man., Ser. II, I, 71; GB. BFSP, Vol. 57, 786; Martens, NRG, Ser. I, XVI, pt. 2, 75; Strudza, Rec. Doc. 51. (NOTE: This Navigation Act became invalid by reason of the refusal of the Powers in Conference at Paris; Mar. 22-Apr. 19, 1858; to accord it sanction.) (Commentary: ENGELHARDT, Hist. du Droit Fluv. Convent., 92; GB. Parl. Papers, 1878, Turkey, no. 29; HOLLAND, European Concert, 230; TWISS, Law of Nations (Peace), 243; WESTLAKE, Int Law, I, 152.)

1858; May 22/Aug. 19: Paris. Protocol of Conferences. AustriaHungary, France, Great Britain, Prussia, Russia, Sardinia, Turkey. Prolonged powers of the European Commission until 


\section{Danube}

completion of the works under progress. Hertslet, Europe, 1327; Martens, NRG, Ser. I, XVI, pt. 2, 50. (Commentary: HOLLAND, European Concert, 230; SCHUYLER, Am. Diplomacy, 354; WESTLAKE, Int. Law, I, 152-53.)

1858; Aug. 19: Paris. Treaty. Austria-Hungary, France, Great Britain, Prussia, Russia, Sardinia, Turkey. Organization of the United Principalities of Moldavia \& Wallachia. Art. II: Renewal of Stipulations embodied in Treaty of Paris,- March 30, 1856,- concerning boundaries, etc. GB. BFSP, Vol. 48, 70; Hertslet, Europe, 1329-49.

1859 ; Mar. 1: Agreement. Vienna. Austria, Bavaria, Turkey, Wurtemburg. Additional Articles affixed to the Navigation Act of Nov. 7, 1857. GB. BFSP, Vol. 57, 801; Sturdza, Rec. Doc., 78. (NOTE: The Paris Conference refused sanction of this Navigation Act.)

1859 ; Sep. 6 : Paris. Protocol. Austria, France, Great Britain, Prussia, Russia, Sardinia, Turkey. Concerning Navigation. Hertslet, Europe, 1377, 1379.

1860; June 27: Galatz. Act of European Commission. Austria, France, Great Britain, Prussia, Russia, Sardinia, Turkey. Police Regulations governing Navigation of Lower Danube. Martens, NRG, Ser. I, XVI, pt. 2, 622.

1860; July 25: Galatz. Act of European Commission. Austria, France, Great Britain, Prussia, Russia, Sardinia, Turkey. Tariff of Navigation Dues applicable to the Sulina Mouth. Martens, NRG, Ser. I, XVI, pt. 2, 632.

1862; Jan. 6: London. Order in Council. British Government. Enforcing the Regulations, Orders, etc., enacted by the European Commission governing the Navigation of the Danube. GB. BFSP, Vol. 52, 473.

1864; Nov. 21: Galatz. Act of European Commission. Austria, France, Great Britain, Prussia, Russia, Sardinia, Turkey. Provisional Navigation \& Police Regulations. GB. BFSP., Vol. 54, 558; Martens, NRG, Ser. I, XVIII, 118.

1864; Nov. 30 : London. Order in Council. British Government. Concerning Navigation of Danube. GB. BFSP, Vol. 54, 890.

1865; Oct. 26 : Galatz. Protocol of Conference. Austria, France, Great Britain, Prussia, Russia, Sardinia, Turkey. Police \& Navigation Regulations applicable to the lower course; establishment of Navigation Dues to be levied on vessels leaving the River. Clercq, RTF, IX, 373; GB. BFSP, Vol. 55, 87.

1865; Nov. 2: Galatz. Public Act. Commissioners of Austria, 
France, Great Britain, Prussia, Russia, Sardinia (Italy), Turkey. Navigation Regulations. Clercq, RTF, IX, 374; 377; Cussy/ Martens, Rec. Man., Ser. II, I, 344; GB. BFSP, Vol. 55, 93; Hertslet, COM. TR., XII, 884; 924; Hertslet, Europe, 3218; Martens, NRG, Ser. I, XVIII, 143, 145; Neumann, RTA, IV n. s., 304; Sturdza, Rec. Doc., 80. (Commentary: ENGELHARDT, Du Rég. Convent., 176; GEFFCKEN, La Question du Danube, 20; TWISS, Law of Nations, I, 247.)

1866; March 10-June 4: Paris. Protocols of Conferences. Austria, France, Great Britain, Italy (Sardinia), Prussia, Russia, Turkey. Ratification of Navigation Regulations instituted by the European Commission at Galatz; Nov. 2, 1865. GB. BFSP, Vol. 57, 533; GB. Parl. Papers, 1878, Turkey, no. 29, pg. 22; GB. Parl. Paps., 1867, United Principalities, 20 ; Martens, NRG, Ser. I, XVIII, 166.

1866; Mar. 28: Paris. Protocol. Austria-Hungary, France, Great Britain, Italy, Prussia, Russia, Turkey. Specific Sanction of Public Act; Nov. 2, 1865 ; governing Navigation. Clercq, R'TF, IX, 493; GB. BFSP, Vol. 56, 624; Hertslet, COM. TR., Vol. 12, 919. (NOTE: Amended by Additional Act of May 28, 1881.)

1866; Apr. 9: Windsor. Order in Council. British Government. Navigation of the channels of the Danubian Delta. GB. BFSP, Vol. 56, 625; Hertslet, COM. TR., Vol. 12, 920.

1867; Apr. 26: Galatz. Tariff. European Commission. Tonnage Dues applicable to Steam Vessels. GB. BFSP, Vol. 58, 527.

1868; Apr. 16: Galatz: Act. European Commission. Pilotage Regulations. Martens, NRG, Ser. I, XX, 29.

1868; Apr. 30: Galatz. Convention. Austria, France, Great Britain, Italy, North German Confederation, Turkey. Guaranteeing the Danubian Loan for Rectifying the Navigable Channels. Clercq, RTF, X, 69; Cussy/Martens, Rec. Man., Ser. II, I, 489; GB. BFSP, Vol. 58, 7 ; GB. Parl. Papers, 1868; Hertslet, COM. TR., XII, 1206; Hertslet, Europe, 1838; Martens, NRG, Ser. I, XVIII, 156. (NOTE: British Parliament sanctioned the execution of this Convention by H. M. Government; Stat. 31 \& 32 Victoria, c. 126.)

1868; July 31: London. Act. British Parliament. Providing for the Execution of the Convention of Galatz; Apr. 30, 1868. GB. BFSP, Vol. 58, 71; GB. Statutes, 31 \& 32 Victoria cap. 126; Hertslet, COM. TR., Vol. 12, 1215.

1868; Oct. 29: Galatz. Protocol. European Commission. Concern- 


\section{Danube}

ing adequate guarantees for a loan; works of rectification. Clercq. RTF, X, 213.

1869; Jan./Feb.: International Act, signed by each Power individually: France, Jan. 19; Great Britain, Feb. 6; Italy, Jan. 12; Prussia, Jan. 25; Turkey, Dec. 30, 1868. Guaranteeing loan for the improvement of the navigable channels \& the Sulina mouth. Clercq, RTF, X, 255.

1869; Apr. 21: Buda-Pest. Act. Hungarian Government. Regulations governing Navigation of Inland Waterways issued by the Hungarian Minister of Commerce. Sturdza, Rec. Doc., 621.

1869 ; Oct. 30 : Galatz. Act. European Commission. Pilotage Regulations on the Lower Danube. GB. BFSP, Vol. 60, 445.

1869 ; Nov. 2 : Galatz. Agreement. European Commission \& Turkey. Repayment of Funds advanced by the Turkish Government to the European Commission. Clereq, RTF, X, 316.

1870; Nov. 8/9: Galatz. Act. European Commission. Modifications of Act of Nov. 2, 1865; Navigation and Police Regulations; Schedule of Dues payable by outbound vessels at Sulina Mouth. GB. BFSP, Vol. 62, 540; Hertslet, COM. TR., XIII, 847, 876, 889; Martens, NRG, Ser. I, XX, 40.

1871; Jan. 17/Mar. 14: London. Protocols of Conferences; nos. 1-6. Austria, France, Germany, Great Britain, Italy, Russia, Turkey. Navigation of the Channels of the Danubian Delta. GB. BFSP, Vol. 61, 1193; Hertslet, Europe, 1926.

1871; Mar. 13: London. Treaty. Austria-Hungary, France, Germany, Great Britain, Italy, Russia, Turkey. Arts. IV-VII: General Revision of the Stipulations of the Treaty of Paris; March 30, 1856; relating to Navigation; the European Commission; the Riverain Commission; \& Neutrality. Clereq, RTF, X, 461; GB. BFSP, Vol. 61, 7; Hertslet, COM. TR., Vol. 13, 746 ; Hertslet, Europe, 1919, 1922 ; Martens, NRG, Ser. I, XVIII, 303 ; Sturdza, Rec. Doc., 108. (Commentary: ENGELHARD'T, Hist. du Droit Fluv. Convent., pg. 93; GEFFCKEN, La Question du Danube, 19; HALLECK, Int. Law, I, 187; HOLLAND, European Conceert, 231; MOORE, ILD, I, 630; SCHUYLER, Am. Diplomacy, 356; TWISS, Law of Nations (Peace), 243.)

1871; Nov. 1/4: Galatz. Act. European Commission. Navigation \& Police Regulations on Lower Course. GB. BFSP, Vol. 62, 1213.

1874; Aug. 31 : Vienna. Law. Austrian Government. Regulations governing Danubian Navigation issued by the Austrian Ministry of Commerce. Sturdza, Rec. Doc., 661 . 
1875; Nov. 10 : Galatz. Act. European Commission; representing Austria-Hungary, France, Germany, Great Britain, Italy, Russia, Turkey. Police \& Navigation Regulations; collection of dues on fluvial traffic through Sulina Mouth. GB. BFSP, Vol. 67, 639; Martens, NRG, Ser. II, III, 572, 604.

1877; May 6/31: Correspondence. Austria-Hungary, Russia, Turkey; Vienna, May 6; St. Petersburg, Apr. 30/May 12; Vienna, May 22; Constantinople, May 31. Concerning protection of neutral rights of fluvial navigation pending Crimean War. Martens, NRG, Ser. II, III, 201.

1877; Aug. 17: Galatz. Notification. European Commission. Adoption of Tonnage Measurement as instituted by Great Britain on Suez Canal for employment on Danube; effective Jan. 1, 1878. Hertslet, COM. TR., XIV, 1169.

1878; Feb. 19/Mar. 3: San Stephano. Treaty. Russia \& Turkey. Art. XIII: Removal of Obstructions in the Sulina Mouth. Hertslet, Europe, 2672, 2675. (NOTE: All but twelve of the twenty-nine articles of this treaty were abrogated by the Treaty of Berlin, 1878. Article XIII continued in force. HOLLAND, European Concert, 222.)

1878; June 26/July 8: Berlin. Provisional Agreement. Austria \& Servia. Providing for the Improvement of the Navigable Channel through the Iron Gates. Martens, NRG, Ser. II, VIII, 319; XIV, 277; Sturdza, Rec. Doc., 125.

1878; July 13: Berlin. Treaty. Austria-Hungary, France, Germany, Great Britain, Italy, Russia, Turkey. Arts. 52-57: Regulating Danubian Navigation from the Iron Gates to Galatz. Clercq, RTF, XII, 316 ; GB. BFSP, Vol. 69, 749 ; GB. For. Office, Danube, 1882, no. 2; GB. For. Office, Turkey, 1878, no. 29 ; GB. Parl. Sess. Papers, 1878, vol. 82 ; Hertslet, COM. TR., XIV, 1175-76; Hertslet, Europe, 2759 ; Martens, NRG, Ser. II, III, 449 ; Sturdza, Rec. Doc., 123. (Commentary : ENGELHARDT, Hist. du Droit Fluv. Convent., 93-94; GEFFCKEN, La Question du Danube, 24; HOLLAND, European Concert, 221; MOORE, Int. Arb., 4853; MOORE ILD, I, 631; SCHUYLER, Am. Diplomacy, 357-63; TWISS, Law of Nations (Peace), 244-45.)

1879; Jan. 27/Feb. 8: Constantinople. Agreement. Russia \& Turkey. Russia relieved of all obligation for interruption of navigation on Danube during the recent war. Hertslet, Europe, $2845,2850$.

(NOTE: 1879; Nov. 10: Galatz. Convention. Austria-Hungary, 


\section{Danube}

France, Germany, Great Britain, Italy, Russia, Turkey. Internal Regulations governing the Sessions of the European Commission. Martens, NRG, Ser. II, IX, 712.)

1880; Nov. 29 : Galatz. Regulation. European Commission. (Austria-Hungary, France, Germany, Great Britain, Roumania, Russia, Turkey.) Stipulating the Duties \& Privileges of the Bureau of Verification at the Port of Sulina. Martens, NRG, Ser. II, IX, 717 .

(Commentary :

(1880; Sept./Dec.: Correspondence. Bulgaria \& Great Britain. Relating to alleged violations of Art. XI \& Art. LII of the Treaty of Berlin; July 13, 1878. GB. BFSP, Vol. 72, 1226.

1881; May 19: Galatz. Act. European Commission. Navigation \& Police Regulations applicable from Galatz to the Black Sea. GB. BFSP, Vol. 78, 325; Hertslet, COM. TR., XV, 878; Martens, NRG, Ser. II, IX, 254; Sturdza, Rec. Doc., 136. (NOTE: These regulations were modified by decisions of the European Commission of May 23, 1882 ; May 19, 1883; Nov. 10, 1883; Nov. 16,1883 ; and were supplanted by the Regulations of Nor. 18, 1887. Hertslet, COM. TR., XVII, 878.)

1881; May 28: Galatz. Additional Act. European Commission. Supplementing the Navigation Regulations of Nov. 2, 1865, for the Government of Navigation within the Danubian Delta. Cussy/Martens, Rec. Man., Ser. II, III, 276; GB. BFSP, Vol. 72, 7; GB. For. Office, 1882, no. 1; Hertslet, COM. TR., XV, 424, 427; Hertslet, Europe, 3053-60; Martens, NRG, Ser. II, VIII, 207; IX, 253; Sturdza, Rec. Doc., 189. (Commentary: TWISS, Law of Nations (Peace), 247.)

1882; Feb. 10/22 : Belgrade. Convention. Austria \& Servia. Arts. 1-27: Reciprocal Freedom of Navigation on Danube and navigable Tributary Waters, whether natural or artificial. GB. BFSP, Vol. 73, pg. 519; Neumann, RTA, XI, 1441; Sturdza, Rec. Doc., 843.

1882; June 2: Galatz. Act. European Commission. Navigation Regulations establishing Police Surveillance from the Iron Gates to Ibraila. Martens, NRG, Ser. II, IX, 344.

1882; Nov. 16: Galatz. Act. European Commission. (AustriaHungary, France, Germany, Great Britain, Italy, Roumania, Russia, Turkey.) Regulating the imposition of Sanitary Taxes on Navigation through the Sulina Mouth. Martens, NRG, Ser. II, X, 614 . 
1883; Feb. 8/Mar. 10: London. Protocols of Conferences. Powers signatory to the Treaty of Berlin, July 13, 1878: Austria-Hungary, France, Germany, Great Britain, Italy, Russia, Turkey. Respecting adequate supervision of navigation. Clercq, RTF, XIV, 141; GB. BFSP, Vol. 74, 1231; Martens, NRG, Ser. II, IX, 346.

1883; Mar. 10: London. Convention. Austria-Hungary, France, Germany, Great Britain, Italy, Russia, Turkey. Amplifying the Navigation \& Police Regulations between the Iron Gates \& Ibraila; prolonging the powers of the European Commission. Clercq, RTF, XIV, 178; Cussy/Martens, Rec. Man., Ser. II, III, 464; GB. BFSP, Vol. 74, 20 ; GB. For. Office, Danube, 1883, no. 5; Hertslet, COM. TR., XV, 1070; Hertslet, Europe, 3104; Martens, NRG, Ser. II, IX, 392; Sturdza, Rec. Doc., 478. (Commentary: ENCY. BRITANNICA, VII, 822 ; ENGELHARDT, Hist. du Droit Fluv. Convent., 95-96; FRANCE, Affaires Etrangères, Ministère des Documents Diplomatiques, 1883, Navig. du Danube; Confer. et Traité de Londres; GB. For. Office, Danube, 1883 ; no. 1, Correspondence concerning navigation; no. 2, Protocols of Conferences held at London; no. 3, Despatches to H. M. Representatives Abroad relating to Danubian Navigation; no. 4, Despatch from H. M. Commissioner transmitting Protocol No. 24, June 2, 1882 ; GB. PARL. PAPS., Danube, No. 2, 1883, Docs. Nos.: c3525 ; c3526 ; c3527 ; c3591; c3804; MOORE, Int. Arb., 4854; MOORE, ILD, I, 631; TVISS, Law of Nations (Peace), 247-49.)

1883; Apr. 23 : London. Declaration of the Powers. Austria-Hungary, France, Germany, Great Britain, Italy, Russia, Turkey. Respecting the Provisional Continuance of the Powers of the European Commission. Hertslet, COM. TR., XVII, 1179; Martens, NRG, Ser. II, X, 616.

1884; Jan. 15: London. Notification. British Representative of the European Commission. Announcing the Extinction of the Danubian Rectification Loan of 1868. Hertslet, COM. TR., XVII, 1039, 1040.

1887; Nov. 18: Galatz. Act. European Commission. Navigation, Police \& Tariff Regulations, including reference to the regulations of Dec. 31, 1880; May 19, 1881; Nov. 21, 1882; \& Dec. 2, 1884. Hertslet, COM. TR., XVII, 878, 909.

1889; Nov. 19: Galatz. Act. European Commission. Tariff of Navigation Dues applicable to Traffic through the Sulina Mouth. GB. BFSP, Vol. 81, 1295 ; Hertslet, COM. TR., XVIII, 1055. 


\section{Danube}

1891; May 21: Galatz. Act. European Commission. Navigation Regulations for Lower Danube. Sturdza, Rec. Doc., 687.

1891; May 28: Galatz. Act. European Commission. Regulations governing the Port of Sulina \& the Police and Navigation of the Danube. Sturdza, Rec. Doc., 714.

1893 ; Apr. 15 : Dresden. International Sanitary Convention. Austria-Hungary, Belgium, France, Germany, Italy, Luxemburg, Montenegro, Netherlands, Russia, Switzerland. (NOTE: Acceded to by Great Britain, July 13/15, 1893. Hertslet, COM. TR., XIX, 250.) Arts. 1, 2; Annex 2: Establishing Sanitary Regulations for the Port of Sulina \& Regulating Movements of Vessels throughout the Navigable Course of the River during Cholera Epidemics. Hertslet, COM. TR., XIX, 249; Sturdza, Rec. Doc., 809.

1897; May 18: Venice. Sanitary Convention. Austria-Hungary, Belgium, France, Germany, Great Britain, Greece, Italy, Luxemburg, Montenegro, Netherlands, Persia, Portugal, Roumania, Russia, Turkey, Servia, Spain, Switzerland. Title VII: Governing the Navigation of Inland Waterways,-Rivers, Lakes \& Canals; Title IX: Specific Regulations for the Navigation of the Danube. Sturdza, Rec. Doc., 812.

1899; July 14: Buda-Pest. Law. Hungarian Government. Regulations issued by the Royal Hungarian Ministry of Commerce governing navigation \& the imposition of taxes upon traffic between Moldova \& Turnu-Severin. Sturdza, Rec. Doc., 508. (Commentary: BONFILS, Droit Int., Note 1, pg. 335.)

1901; Feb. 9/22: Bucharest. Convention. Roumania \& Russia. Regulating Riverain Fisheries. Deschamps/Renault, RIT, (XX Siècle); Neumann, RTA, XX n. s., 493; Sturdza, Rec. Doc., 825.

1901; Nov. 29 : Sofia. Convention. Bulgaria \& Roumania. Regulatory Measures for the Conservation of Riverain Fisheries. Martens, NRG, Ser. II, XXXIII, 277; Sturdza, Rec. Doc., 831. 1902 ; Jan. 15 : Bucharest. Convention. Roumania \& Servia. Regulating Riverain Fisheries. Sturdza, Rec. Doc., 834.

1903; Jan. 18/31: Convention. Hungary/Roumania. Riverain Fisheries Regulations. Sturdza, Rec. Doc., 838.

1906; Dec. 23/1907; Jan. 5: Bucharest. Convention. Roumania/ Servia. Navigation Regulations. GB. BFSP, Vol. 101, 573.

1907; Oct. 8: Buda-Pest. Treaty. Austria \& Hungary. Regulating Riverain Navigation. Martens, NRG, Ser. III, II, 48, 82, 86. 1907; Oct, 16/29: Bucharest, Convention, Roumania \& Russia, 
Riverain Fisheries Regulations. GB. BFSP, Vol. 101, pg. 569; Martens, NRG, Ser. III, I, 907.

1908; Feb. 27/March 11: Bucharest. Convention. Roumania \& Servia. Regulating fisheries in that portion of the Danube forming the International Boundary. GB. BFSP, Vol. 102, 791; Martens, NRG, Ser. III, IV, 219.

1918; May 6: Bucharest. Treaty. Austria-Hungary, Bulgaria, Germany, Roumania, Turkey. Arts. 24, 25, 26: Regulating Navigation; stipulations governing transit of war-vessels. Am. Assoc. Internat. Concil., Pamph. no. 128, 28-34; New York Times, May 9, 1918.

(NOTE:

(1918; Nov. 11: Senlis. Armistice. Germany \& the Allied Powers. Art. XV: Imposed the Abandonment of the terms provided by the Treaty of Bucharest; May 6, 1918.) (N. Y. Times; Nov. 12, 1918, pg. 3.)

\section{DNIEPER}

1686; May 6: Moscow. Treaty. Poland/Russia. Art. III: Cession of territory on eastern bank to Russia (Little Russia); Thalweg constituting international boundary. Koch/Schoell, Hist. Abr. Tr., XIII, 102.

1818; Aug 5/17: St. Petersburg. Convention. Austria \& Russia. Arts. I, II, III : Reciprocal Freedom of Navigation. Cussy/ Hauterive, RTC, V, pt. 2, 444; Martens, NRT, IV, 540.

\section{DNIESTER}

1810; March 7/19: Leopoldstadt. Treaty. Austria \& Russia. Arts.

2, 3, 4: Establishing \& Regulating Mutual Liberty of Navigation. Cussy/Hauterive, RTC, I, pt. 2, 175; Cussy/Martens, Rec. Man., Ser. I, Vol. II; Martens, NRT, 1, 254; Martens, RT. SUPPL., V, 252; Neumann, RTA, II, 331; (Commentary: PHILLIMORE, Int. Law, Vol. 1, 232.)

1812; May 28: Treaty. Russia \& Turkey. Art. IV: Navigation. Martens, NRT, III, 299.

1815; Apr. 21/May 3: Vienna. Treaty. Austria/Russia. Art. 24 : Reciprocal Freedom of Navigation upon the Dniester and on all waterways, whether natural or artificial, within boundaries of 


\section{Dniester}

former Kingdom of Poland. Cussy/Hauterive, RTC, I, pt. 2, 183.

1818; Aug. 5/17: St. Petersburg. Convention. Austria and Russia. Arts. I, II, III: Stipulations ensuring freedom of navigation. Cussy/Hauterive, RTC, V, pt. 2, 444; Martens, NRT, IV, 540. 1829; July 10: Radziwilow. Treaty. Austria/Russia. Preamble; Art. III: Thalweg Boundary. Hertslet, Europe, 810-11.

\section{DOUBS}

1824; Nov. 24: Neufchatel. Agreement. France, Neufchatel, Switzerland. Preamble; Arts. 1; 2-6: Navigation Regulations. Hertslet, Europe, 720-21.

1880; Dec. 28 : Paris. Convention. France/Switzerland. Title III (Arts. 12-27): Protecting and Regulating Fisheries throughout riverain boundary. Clercq, RTF, XIII, 619; Hertslet, Europe, 3252 ; Martens, NRG, Ser. II, IX, 111.

1884; Dec. 9: Paris. Convention. France/Switzerland. Modifying stipulations concerning fisheries in that portion of Doubs forming International Boundary. Clercq, XIV, 428.

1888; Apr. 14. Berne. Agreement. France/Switzerland. Amending Convention of Dec. 28, 1880, and Abrogating Arrangement concluded at Paris; Dec. 9, 1884. France, Journal Officiel, Sept. 1, 1888; Hertslet, Europe, 3280; Martens, NRG, Ser. II, XIV, 410.

1891; Mar. 12 : Berne. Arrangement. France/Switzerland. Arts. I, II: Fishing in Frontier Waters; modifying certain articles of the Convention of Paris, Dec. 28, 1880. Clercq, RTF, XIX, 62; Martens, NRG, Ser. II, XVIII, 238.

1891; July 30: Berne. Convention. France/Switzerland. Regulating Fisheries in Boundary Waters. Clercq, RTF, XIX, 250; Martens, NRG, Ser. II, XVIII, 848; XX்I, 24.

1904; Mar. 9: Paris. Treaty. France/Switzerland. Fisheries Regulations. Martens, NRG, Ser. II, Vol. XXXIII, 501.

1909; Jan. 20: Lausanne. Agreement. France/Switzerland. Fisheries Regulations, supplementing Convention of Paris, Mar. 9, 1904. Martens, NRG, Ser. III, Vol. V, 318-19.

\section{DOURO}

1835; Aug. 31 : Lisbon. Treaty. Portugal/Spain. Reciprocal Freedom of Navigation. (Arts. 1-13). Cussy/Martens, Rec. Man. Ser. I, IV, 423 ; GB. BFSP, XXIII, 1046 ; Martens, NRT. XIV, 97; Olivart, Colecc. Tratados, I, 70-74. (Commentary: MOORE, Int. Arb., 4853; MOORE, ILD, I, 629 ; PHILLIMORE. 
Int. Law, I, 232). NOTE: The earlier Treaty of August 31, 1829, which provided for a similar freedom of navigation was refused ratification by the Government of Queen Donna Maria II (Portugal).

1840; May 18/23: Lisbon. Convention. Portugal and Spain. Navigation Regulations. GB. BFSP, XXX, 242, 254; Martens, NRG, Ser. I, I, 98; Olivart, Colecc. Tratados, I, 74-96.

1840 ; May 23 : Lisbon. Law. Portuguese Government. Decree governing imposition \& collection of tariff duties. GB. BFSP, $\mathrm{XXX}, 252$.

1841; Feb. 23. Madrid. Law. Spanish Government. Decree regulating imposition of Customs Duties. GB. BFSP, XXX, 254.

1866; Apr. 27: Lisbon. Convention. Portugal/Spain. Art. V: Reciprocal Freedom of Navigation throughout Navigable Course. Art. VI: Police \& Navigation Regulations. Olivart, Colece. Tratados, IV, 240, 242-44.

1872; Dec. 20 : Lisbon. Treaty. Portugal/Spain. Art. 16 : Participation in Coasting Trade, whether Fluvial or Maritime, expressly Forbidden; Stipulations of Treaty of Lisbon, Apr. 27, 1866, concerning Freedom of Fluvial Navigation explicitly confirmed. Olivart, Colecc. Tratados, VII, 315, 322.

1877; Jan. 16: Lisbon. Agreement. Portugal/Spain. Sect. II, Arts. 13-29 \& Addit. Art.: Regulations governing Fluvial Navigation \& Commerce in conformity with Convention of Lisbon; Apr. 27, 1866. Olivart, Colece. Tratados, VII, 187, 201-211.

1885 ; Oct. 2 : Madrid. Convention. Portugal/Spain. Sect. V, Arts. 39-54, 56; Commercial Navigation throughout Course available for Portuguese \& Spanish subjects, alike; Discriminatory Treatment explicitly Forbidden. Olivart, Colecc. Tratados, VIII, $529,543-551$.

1887; Jan. 16: Agreement. Portugal \& Spain. Navigation Regulations. GB. BFSP, Vol. 68, 145.

\section{DREWENZ}

1817; Nov. 11/Oct. 30: Berlin. Treaty. Prussia \& Russia. Art. XII: Thalweg Boundary; Navigation. Hertslet, Europe, 539.

\section{DRINA}

1882; Feb. 10/22: Belgrade. Treaty. Austria/Servia. Arts. 1-27: Reciprocal Freedom of Navigation. GB. BFSP, Vol. 73, 519; Neumann, RTA, XI, 1441.

DÜNA

1818; Aug. 5/17: St Petersburg. Convention. Austria \& Russia. 


\section{Düna}

Arts. I, II, III: Freedom of Navigation. Cussy/Hauterive, RTC, V, pt. 2, 444. Martens, NRT, IV, 540.

\section{ELBE}

1660; Feb. 13: Whitehall. Treaty. Denmark/Great Britain. Art. XVII: English vessels to enjoy exemption from tolls between Port of Gluckstadt \& the sea. Hertslet, COM. TR., I, 183.

1670; July 11: Copenhagen. Treaty. Denmark/Great Britain. Art. XXI: Exemption from tolls provided for English vessels and their cargoes. Hertslet, COM. TR., I, 195. (NOTE: The Provisions of Art. XVII of the Treaty of Feb. 13, 1660, and of Art. XXI of the Treaty of July 11, 1670, were renewed by the Thirteenth Article of the Treaty of Kiel, 1814.)

1815; May 18: Vienna. Treaty. Austria, Prussia, Russia, Saxony. Art. XVII: Applying the principles enunciated in Annex XVI of the Final Act of the Congress to the navigation of the Elbe. Hertslet, Europe, 141; Martens, NRT, IV, 280-81; (Commentary: MOORE, Int. Arb., 4852 ; MOORE, ILD, I, 629 ; SCHUYLER, Am. Diplomacy, 350; TWISS, Law of Nations (Peace), 253-54.)

1815; June 9: Vienna. Final Act of Congress. Austria, France, Great Britain, Portugal, Prussia, Russia, Spain, Sweden. Annex IV : Navigation Regulations. Cussy/Hauterive, RTC, I, pt. 1, 78 ; Deschamps/Renault, RIT, I, 319 ; GB. BFSP, II, 162 ; Hertslet. Europe, 263; Lagemans, Netherlands, I, no. 30; Martens, NRT, II, 436.

1819; Aug. 28: Dresden. Convention. Prussia and Saxony. Art. 34: Navigation. Hertslet, Europe, 618.

1821; June 23: Dresden. Treaty. Anhalt-Dessau, Austria, Denmark, Hanover, Hanseatic Cities (for Hamburg), MecklenburgSchwerin, Prussia, Saxony. Arts. 1-33: Stipulating Freedom of Navigation in conformity with the General Principles of the Congress of Vienna. Cussy/Hauterive, RTC, I, pt. 2, 27; Cussy/Martens, Rec. Man., Ser. I, III, 518; GB. BFSP, VIII, 953, 964; Hertslet, COM. TR., X, 489; Hertslet, Europe, 671, 688 ; Doc. no. 110 ; Doc. no. 111; Martens, NRT, V, 714; Neumann, RTA, III, 613; Sturdza, Rec. Doc., 596. (Commentary: MOORE, Int. Arb., 4852 ; MOORE, ILD, I, 629 ; PHILLIMORE, Int. Law, I, 232 ; TWISS, Law of Nations, (Peace), 255; WESTLAKE, Int. Law, I, 151.)

1824; Sep. 18: Hamburg. Protocol. Anhalt-Dessau, Austria, Denmark, Hanover, Hamburg, Mecklenburg-Schwerin, Prussia, Sax- 
ony. Revision of Navigation Regulations by Riverain Commission in conformity with Art. XXX of the Treaty of Dresden; June 23, 1821. Cussy/Hauterive, RTC, V, 296; Martens, NRT, VI, 588.

1828; Feb. 8: Declaration. Riverain States of the Elbe. Proclaiming the Prolongation of the Convention of June 23, 1821, and the revised regulations governing cargoes. Cussy/Martens, Rec. Man., Ser. I, IV, 143; GB. BFSP, XVI, 1265; Martens, NRT, VII, 547.

1828; July 28: Treaty. Anhalt-Dessau (Coethen) \& Prussia. Freedom from imposition of transit dues by subjects of the Contracting States. Cussy/Martens, Rec. Man., Ser. I, IV, 174; Martens, RT. SUPPL., XI, 653.

1831; May 17: Treaty. Accession of Anhalt-Bernburg to Treaty of July 28, 1828, between Anhalt-Coethen, Anhalt-Dessau, and Prussia. Cussy/Martens, Rec. Man., Ser. I, IV, 321; Martens, NRT., IX, 365 .

1835 ; Aug. 29 : Convention. Prussia and Saxony. Regulating Imposition of transit duties. Cussy/Martens, Rec. Man., Ser. I, IV, 423; Martens, NRT, XIII, 411.

1842; Jan. 15: Convention. Belgium and Hanover. Concerning Collection of the Stade Toll. GB. BFSP, XXXI, 861.

1843; May 13: Dresden. Convention. Denmark/Hanover. Regulating riverain navigation. GB. BFSP, XXXI, 989; Martens, NRG, Ser. I, V, 292.

1843 ; Aug. 30 : Dresden. Convention. Denmark, Hanover, Mecklenburg-Schwerin, Prussia, Saxony. Governing Imposition of Stade Toll and Regulating Navigation. Cussy/Martens, Rec. Man. Ser. I, V, 343; Martens, NRG, Ser, I, V, 530. (Commentary: TWISS, Law of Nations (Peace), 255.)

1844; Apr. 9: Dresden. Treaty. Hamburg/Hanover. Navigation Regulations. Martens, NRG, Ser. I, VI, 370.

1844; Apr. 13: Dresden. Treaty. Anhalt-Bernberg, AnhaltCoethen, Anhalt-Dessau, Austria, Hamburg (Free City), Hanover, Lubeck (Free City), Mecklenburg-Schwerin, Prussia, Saxony. Arts. 1-V; VII: Additional Regulatory Stipulations modifying Treaty of Dresden; June 23, 1821; governing Navigation and the Imposition of the Stade Toll. Art. VI: Annulled Art. XV of Treaty; June 23, 1821. Cussy/Martens, Rec. Man., Ser. I, V, 387 ; GB. BFSP, XXXIT, 20, 22, 24; Hertslet, Europe, 1036; Martens, NRG, Ser. I, VI, 463, 473. (Commentary: PHILLIMORE, Int. Law, I, 232.) 


\section{Elbe}

1844; Apr. 13: Dresden. Treaty. (Separate Convention). Denmark \& Hanover. Imposition of Stade Toll. GB. BFSP, XXXV, 1009.

1844; Apr. 14: Dresden. Additional Act. Confirmed by Riverain States signatory to Treaty of April 13, 1844. Cussy/Martens, Rec. Man. Ser. I, V, 383; Martens, NRG, Ser. I, VI, 386.

1844; July 22 : London. Treaty. Great Britain/Hanover. Art. VI: British Vessels placed upon Identical Footing with regard to Imposition of Stade (Brunhausen) Toll as Vessels of the Riverain States signatory to the Treaty of Dresden; Apr. 13, 1844. GB. BFSP, XXXII, 8; Hertslet, COM. TR., VII, 729, 732 ; Hertslet, Europe, 1041. (NOTE: Abrogated by Treaty of Hanover; June 22, 1861. Clereq, RTF, VIII, 288.)

1844; Sept. 8: Hanover. Law. Hanoverian Government Ordinance providing for the Reduction of the Stade Toll on Vessels \& Cargoes of Great Britain, Germany, Belgium, Mexico, Prussia, Sweden and Norway, and the United States of America. GB. BFSP, XXXII, 868.

1844; Sept. 26: Hanover. Law. Hanoverian Government. Ordinance providing for the Reduction of the Stade Toll on Vessels and Cargoes of Belgium, Denmark and Hamburg. GB. BFSP, XXXII, 869.

1851; Dec. 2 : Protocol. Riverain States: Anhalt-Bernburg, AnhaltCoethen, Anhalt-Dessau, Austria, Hamburg, Hanover, Lubeck, Mecklenburg-Schwerin, Prussia, Saxony. Embodying the Third Revision of the Treaty of Dresden; June 23, 1821; regulating Navigation. Cussy/Martens, Rec. Man. Ser. I, VI, 695.

1853; Dec. 20: Magdeburg. Treaty. Denmark, MecklenburgSchwerin, Prussia, Saxony. Riverain Navigation Regulations. Cussy/Martens, Rec. Man., Ser. I, VII, 285.

1854; Feb. 8: Convention. Anhalt-Bernburg, Anhalt-Coethen, Anhalt-Dessau, Austria, Hamburg, Hanover, Lubeck, MecklenburgScliwerin, Prussia, Saxony. Governing Navigation. GB. BFSP, Vol. 55, 915; Neumann, R'TA, VI, 130.

1861; Feb. 18: Convention. Hanover. Belgium and Hanover. Imposition of the Stade Toll. GB. BFSP, Vol. 51, 844; Martens, NRG, Ser. I, XVII, part 1, 306.

1861; June 22: Hanover. Treaty. Austria-Hungary, Belgium, Brazil, Bremen, Denmark, France, Great Britain, Hamburg, Hanover, Lubeck, Mecklenburg-Schwerin, Netherlands, Portugal, Prussia, Russia, Spain, Sweden and Norway. Abolishing the Stade (Brunhausen) Toll. Clereq, RTF, VIII, 288; Cussy/Mar- 
tens, Rec. Man., Ser. II, I, 189; GB. BFSP. Vol. 51, 27, 32 ; Hertslet, COM. TR., XI, 355; Hertslet, Europe, 1471, 1474; Lagemans, Netherlands, Vol. 5, Doc. no. 406; Martens, NRG, Ser. I, Part 1, XVII, 406, 419, 424 ; Neumann, RTA, III, n. s., 24. (Commentary: HEFFTER, Droit Int. Public, sec. 77, note 10; TWISS, Law of Nations (Peace), 255; WESTLAKE, Int. Law, I, 161.)

1861; Nov. 6: Berlin. Treaty. Hanover and the United States. Arts. I-VI : Abolishing the Stade Toll. GB. BFSP. Vol. 51, 490; Malloy, UST, 899. (Commentary: SCHUYLER, Am. Diplomaey, 351; WESTLAKE, Int. Law, I, 161.)

1863; Apr. 4: Convention. Riverain States. Providing for the Administration \& Collection of the Joint Elbe Tolls at Wittenberg. GB. BFSP, Vol. 55, 938, 958.

1870; June 22: Vienna. Treaty. Austria/Germany. Abolishing Navigation Dues. Cussy/Martens, Rec. Man, Ser. II, II, 45; GB. BFSP, Vol. 63, 594; Hertslet, Europe, 1875 ; Martens, NRG, Ser. I, XX, 345; Neumann, RTA, VII n. s., 76.

1871; Apr. 16: Berlin. Constitution. German Empire. Art. 54: Navigation of Inland Waterways. Dodd, Modern Constitutions, I, 343.

1881; Dee. 12: Notification. Hamburg. Concerning Navigation \& the Authority of the German Customs Union. GB. BFSP, Vol. 72, 1191.

1908; Nov. 14: Berlin. Treaty. Hamburg and Prussia. Providing for the Improvement of the Navigable Channels. Martens, NRG, Ser. III, IV, 844.

\section{ELSTER}

1815; June 9: Vienna. Treaty. (Final Act of the Congress). Austria, France, Great Britain, Portugal, Prussia, Russia, Spain, Sweden. Art. XV: Navigation; Thalweg Boundary. Cussy/ Hauterive, RTC, I, pt. 1, 78; Deschamps/Renault, RIT, I, 319 ; GB. BFSP, II, 162 ; Hertslet, Europe, 222 ; Lagemans, Netherlands, I, Doc. no. 30 ; Martens, NRT, II, 436.

\section{EMS}

1815; May 29 : Vienna. Treaty. Hanover and Prussia. Arts. I; V :

Establishment of Boundary; Freedom of Navigation, subject to certain tolls levied upon Hanoverian and Prussian Vessels alike. Cussy/Hauterive, IV, pt. 2, 401; Hertslet, Eurone, 174-75. 1815; June 9 : Vienna. Final Act of the Congress. Austria, France, 
Great Britain, Portugal, Prussia, Russia, Spain, Sweden. Arts. 27 , sec. 3 ; 30 ; 118, sec. 6 ; \& Annex 6 : Boundary and Navigation Regulations. Cussy/Martens, Rec. Man., Ser. I, III, 61; 74-75; 103; Hertslet, Europe, 232-33; 272-75; Martens, NRT, II, 398.

1824; July 2: Meppen. Treaty. Hanover/Netherlands. Art. 41: Boundary. Hertslet, Europe, 716.

1834; July 11/30: Agreement. Hanover/Netheriands. Establishment of buoys along navigable channel. Lagemans, Netherlands, II, Doc. no. 139.

1843; Mar. 13: Berlin. Treaty. Hanover/Prussia. Navigation Regulations. Martens, NRG, Ser. I, V, 125. (Commentary: WESTLAKE, Int. Law, I, 151.)

1871; Apr. 16: Berlin. Constitution. German Empire. Art. 54: Navigation of Inland Waterways. Dodd, Modern Constitutions, I, 343.

1896; Oct. 16: Berlin. Treaty. Germany/Netherlands. Providing for Works ensuring Safety of Navigation: Beacons, Buoys, Lighthouses. GB. BFSP, Vol. 88, pg. 468; Lagemans, Netherlands, XIII, Doc. no. 847; Martens, NRG, Ser. II, XXV, 56.

\section{ENZA}

1844; Nov. 28: Florence. Treaty. Austria, Lucca, Modena, Sardinia, Tuscany. Art. IV : Thalweg Boundary. Hertslet, Europe, $1048 ; 1057$.

\section{ESPIERRE CANAL}

1884; May 14: Paris. Convention. Belgium/France. Facilitating the Maintenance of the Canal. Martens, NRG, Ser. II, XII, 621.

\section{FLOSS-GRABEN}

1815; May 18: Vienna. Treaty. Austria, Prussia, Russia, Saxony. Art. 17: Freedom of Navigation; applying the Principles enunciated in Annex XVI of the Final Act. Hertslet, Europe, 141.

1815 ; June 9 : Vienna. Final Act of the Congress. Austria, France, Great Britain, Portugal, Prussia, Russia, Spain, Sweden. Art. 15: Boundary. Hertslet, Europe, 222.

\section{FORON}

1816; Mar. 16: Turin. Treaty. Geneva, Sardinia, Switzerland. Art. I, III: Boundary. Hertslet, Europe, 424. 
1819 ; July 20 : Frankfort. Treaty. Austria, Great Britain, Prussia, Russia. Art. 41: Boundary. Hertslet, Europe, 612.

\section{GARDA IAKE}

1859; Nov. 10: Zurich. Treaty. Austria, France, Sardinia. Art. I, III: Boundary established in middle of the Lake. Art. XVIII: Freedom of Navigation instituted. Hertslet, Europe, 1393, 1401, 1403, 1409.

1860; June 16: Peschiera. Final Act of Demarcation. Endorsed by the Military Commission appointed in conformity with the Treaty of Zurich; Nov. 10, 1859. Hertslet, Europe, 1439.

1860; June 16: Peschiera. Treaty. Austria, France, Sardinia. Formal Adoption of Boundary endorsed by the Military Commission. Martens, NRG, Ser. I, XVII, part 2, pg. 5.

1866; Oct. 3: Vienna. Treaty. Austria \& Italy. Art IV: Rectification of Boundaries by reason of the addition of LombardoVenetia to Italy. Hertslet, Europe, 1749.

1867; Dec. 22 : Venice. Convention. Austria/Italy. Arts. I, III, VI: Boundary agreement; Rectification of Navigation. Hertslet, Europe, 1833, 1835.

1883; Aug. 9: Riva. Convention. Austria and Italy. Regulation \& Protection of Fisheries. Martens, NRG, Ser. II, XI, 598; Neumann, RTA, XII n. s., 1.

\section{GENEVA LAKE}

1815; Mar. 29: Vienna. Treaty. Formed Annex XII of the Final Act of the Congress; June 9, 1815. Art. I: Boundary. Hertslet, Europe, 70.

1815; June 9: Vienna. Final Act of the Congress. Austria, France, Great Britain, Portugal, Prussia, Russia, Spain, Sweden. Arts. 80 ; 118, sec. 12 ; \& Annex XII: Boundary. Hertslet, Europe, $257,273,275$.

1815; Nov. 20: Paris. Treaty. Austria, France, Great Britain, Prussia, Russia. Art. I, sec. 3: Boundary. Hertslet, Europe, 345.

1819; July 20: Frankfort. Treaty. Austria, Great Britain, Prussia, Russia. Art. 41: Boundary. Hertslet, Europe, 611.

1880; Dec. 28: Paris. Convention. France/Switzerland. Chap. I, Arts. 1-10; Fisheries Regulations. Clercq, RTF, XII, 619; Hertslet, Europe, 3252; Martens, NRG, Ser. II, IX, 111.

1884; Dec. 9 : Paris. Convention. France/Switzerland. Governing Fisheries; partially revising stipulations of Treaty of Paris; Dec. 28, 1880. Clereq, RTF, XIV, 428. 


\section{Geneva Lake}

1887; July 9 : Paris. Convention. France/Switzerland. Navigation Regulations. Martens, NRG, Ser. II, XIV, 357.

1888; Apr. 14: Berne. Agreement. Trance/Switzerland. Abrogating Convention of Paris; Dec. 9, 1884; modifying further the Convention of Paris of Dec. 28, 1880 ; providing additional fisheries regulations. France, Journal Officiel, Sept. 1, 1888; Hertslet, Europe, 3280 ; Martens, NRG, Ser. II, XIV, 410.

1891; Mar. 12: Berne. Convention. France/Switzerland. Arts. I, II : Fisheries Regulations; modifying Arts. 2, 3, and 8 of Convention of Paris; Dec. 28, 1880. Clercq, RTF, XIX, 62; Martens, NRG, Ser. II, XVIII, 238.

1891; July 30: Berne. Agreement. France/Switzerland. Additional Stipulations to the Convention of Dec. 28, 1880, governing fisheries. Clercq, RTF, XIX, 250; Martens, NRG, Ser. II, XVIII, 848; XXI, 24.

1902; Sept. 10: Paris. Convention. France/Switzerland. Police \& Navigation Regulations. Text issued by the Swiss Govt., Berne, 1902. (NOTE: In force since Nov. 1, 1902.)

1904; Mar. 9: Paris. Convention. France/Switzerland. Regulating Fisheries. Martens, NRG, Ser. II, XXXIII, 501.

1909; Jan. 20: Lausanne. Agreement. France/Switzerland. Fisheries Regulations; supplementing Convention of March 9, 1904. Martens, NRG, Ser. III, V, 318.

(NOTE :

(1911; July 24: Intercantonal Agreement regulating Police \& Navigation on Lake Geneva; approved by the Federal Council, Jan. 30, 1912. Text published at Lausanne, 1912.)

(NOTE :

(1912; May 4, 7, 10, 17 and June 17: Intercantonal Convention governing Police \& Navigation adopted by the Cantons: Berne, Geneva, Valais, Vaud. Text issued by the State Chancellor, Geneva, 1912.)

GERA

1815; Sept. 22: Paris. Convention. Prussia \& Saxe-Weimar. Art. VIII : Reciprocal Freedom of Navigation. Hertslet, Europe, 309.

1871; Apr. 16: Berlin. Constitution. German Empire. Art. 54: Navigation of Inland Waterways. Dodd, Modern Constitutions, I, 343. 
1815; June 9: Vienna. Final Act of the Congress. Art. XV: Boundary. Austria, France, Great Britain, Portugal, Prussia, Russia, Spain, Sweden. Hertslet, Europe, 229.

1819; July 20 : Frankfort. Treaty. Austria, Great Britain, Prussia, Russia. Art. XIII: Boundary. Hertslet, Europe, 598.

\section{GORO}

1815; June 9: Vienna. Final Act of Congress. Austria, France, Great Britain, Portugal, Prussia, Russia, Spain, Sweden. Art. 95, sec. 4: Adopted as Boundary between Austria and the Papal States. Hertslet, Europe, 264.

\section{GUADIANA}

1878; Aug. 6: Convention. Portugal \& Spaill. "Diaro do Governo," Aug. 13, 1878.

1893; Sept. 27 : Agreement. Portugal/Spain. Establishing Fluvial Boundary. GB. BFSP, Vol. 86, 1301.

1907; June 5: Agreement. Portugal \& Spain. Emplacement of Lights and Buoys in the Navigable Channel. Martens, NRG, Ser. III, V, 901.

\section{HERMANCE}

1815; Mar. 29 : Vienna. Treaty. Formed Annex XII of Final Act of the Congress; June 9, 1815. Art. I: Boundary. Hertslet, Europe, 70.

1815; May 20: Vienna. Treaty. (Formed Annex XIII of Final Act of the Congress.) Austria, France, Great Britain, Prussia, Russia, Sardinia. Art. I; Annex BB: Boundary. Hertslet, Europe, 164.

1815; June 9: Vienna. Final Act of the Congress. Austria, France, Great Britain, Portugal, Prussia, Russia, Spain, Sweden. Arts. 80 ; 118, sec. 12; and Annex XII : Boundary. Hertslet, Europe, $257,273,275$.

1816; Mar. 16: Turin. Treaty. Geneva, Sardinia, Switzerland. Arts. I, II: Boundary. Clercq, RTF, III, 1-2. Hertslet, Europe, 424-25.

1819 ; July 20 : Frankfort. Treaty. Austria, Great Britain, Prussia, Russia. Art. 41: Boundary. Hertslet, Europe, 611.

HONDT

1795; May 16: The Hague. Treaty. France and The Netherlands. Art. 18: Reciprocal Freedom of Navigation, including Affluents. Cussy/Hauterive, RTC, II, pt. 1, 373; Koch/Schoell, Hist. Abr. 


\section{Hondt}

Tr., IV, 293. (Commentary: ENGELHARDT, Hist. du Droit

Fluv. Convent., 51; SCHUYLER, Am. Diplomacy, 346-47.)

1839; Apr. 19: London. Treaty. Austria-Hungary, Belgium, France, Great Britain, Netherlands, Prussia, Russia. Annex, Art. IX: Freedom of Fluvial Navigation. Hertslet, COM. TR., $\mathrm{V}, 354,359$.

\section{INN}

1779; May 13: Teschen. Convention. Austria \& Bavaria (The Elector Palatine). Art. V: Reciprocal Freedom of Navigation. Hertslet, Europe, III, 2012 ; Neumann, RTA, I, 243-44. (Commentary: MOORE, Int. Arb., 4853.)

1784; Aug. 31; Munich. Treaty. Austria \& Bavaria. Art. IV: Reciprocal Liberty of Navigation, in conformity with Art. V of the Treaty of Teschen. Art. X: Exclusive enjoyment of fisheries on the respective sides of the International Boundary. Cussy/Hauterive, RTC, I, pt. 2, 48.

1816; Apr. 14: Munich. Treaty. Austria and Bavaria. Art. IX:

Renewal of former stipulations governing Navigation \& Fisheries; adoption, in addition, of the principles proclaimed by the Congress of Vienna. Cussy/Hauterive, RTC, I, pt. 2, 51.

1844; Jan. 30: Munich. Treaty. Austria \& Bavaria. Arts. 1-7: Boundary. Hertslet, Europe, 1034.

1850; Dec. 16: Munich. Treaty. Austria \& Bavaria. Arts. 1-2: Boundary. Hertslet, Europe, 1146.

1851; Dec. 2: Vienna. Treaty. Austria \& Bavaria. Arts. 1-17: Mutual Liberty of Navigation. Neumann, RTA, V, 448-54. 1866 ; Nov. 10 : Vienna. Declaration. Rectification of the Navigable

Channel. Neumann, RTA, IV n. s., 601.

1877; Jan. 7: Vienna. Law. Austrian Government. Regulating Navigation of the Inn \& its Affluents. Neumann, RTA, X, n. s., 24 .

JACOBS-ELF, or WORIEMA

1826 ; May 14: St. Petersburg. Convention. Russia and Sweeden \& Norway. Arts. 2, 9: Freedom of Navigation \& Fishing. Hertslet, Europe, 745-46. 


\section{JURA}

1779; May 13: Teschen. Convention. Austria \& Bavaria. Art. V : Reciprocal Freedom of Navigation. Hertslet, Europe, 2012; Neumann, RTA, I, 243-44.

\section{KARA-KOURT}

1857; Jan. 6: Paris. Protocol. Austria, France, Great Britain, Prussia, Russia, Sardinia, Turkey. Bessarabian Frontier Boundary. Hertslet, Europe, 1299.

\section{KONGAMA}

1810; Nov. 8/20: Tornea. Treaty. Russia \& Sweden. Art. I: Thalweg Boundary. Arts II, IV: Renewal of existing Freedom of Navigation. Cussy/Hauterive, RTC, V, pt. 2, 515. Hertslet, Europe, 2028.

\section{KONGE-AA}

1864; Oct. 30: Vienna. Treaty. Austria, Denmark, Prussia. Art. V: Thalweg Boundary. Hertslet, Europe, 1632.

\section{KOUBAN}

1829; Sept. 14: Adrianople. Treaty. Russia \& Turkey. Art. IV'; Fluvial Boundary. Hertslet, Europe, 817.

\section{LAHN}

1844; Oct. 16: Coblenz. Treaty. Hesse, Nassau, Prussia. Providing for Works of Rectification to facilitate Navigation. Martens, NRG, Ser. I, VII, 420.

1871; Apr. 16: Berlin. Constitution. German Empire. Art. 54; Navigation of Inland Waterways. Dodd, Modern Constitutions, I, 343.

\section{IAIBLACH}

1844; Jan. 30: Munich. Treaty. Austria \& Bavaria. Art. 14: Fluvial Boundary. Arts. 28-29: Fisheries exclusively reserved to Bavaria. Hertslet, Europe, 1034.

\section{IA LAIRE}

1814; May 30: Paris. Treaty. Austria, France, Great Britain, Prussia, Russia. Art. III, sec. 7 : Boundary. Clercq, RTF, II, 418; Cussy/Hauterive, RTC, I, pt. 1, pg. 58; Hertslet, COM. TR., I, 249; Hertslet, Europe, 6-8; Neumann, RTA, II, 466.

1816; Mar. 16: Turin. Treaty. Geneva, Sardinia, Switzerland. Art. I: Boundary. Hertslet, Europe, 423.

1819; July 20: Frankfort. Treaty. Austria, Great Britain, Prussia, Russia. Art. 41: Boundary. Hertslet, Europe, 610. 


\section{Lauter}

\section{LAUTER}

1815; Nov. 20: Paris. Treaty. Austria, France, Great Britain, Prussia, Russia. Art. I: Boundary. Hertslet, Europe, 344-45. (NOTE: Spain acceded to this Convention, June 8, 1817.)

1819; July 20: Frankfort. Treaty. Austria, Great Britain, Prussia, Russia. Art. V: Boundary. Hertslet, Europe, 593.

1825; July 5: Paris. Convention. Bavaria \& France. Art. II, sec 4: Thalweg Boundary. Hertslet, Europe, 729.

\section{LAX-ELF}

1826; May 14: St. Petersburg. Convention. Russia and Sweden \& Norway. Art. II: Boundary. Hertslet, Europe, 745.

\section{LECK}

1831; Mar. 31 : Mainz. Convention. Baden, Bavaria, France, Hesse, Nassau, Netherlands, Prussia. Preamble: Navigation. Clercq, RTF, IV, 24; Hertslet, Europe, 849.

1844; Jan. 30: Munich. Treaty. Austria \& Bavaria. Arts. I: 5-12: Boundary. Hertslet, Europe, 1034.

1850; Dec. 16: Munich. Treaty. Austria \& Bavaria. Art. 2; 4-6: Boundary. Hertslet, Europe, 1146.

1868; Oct. 17: Mannheim. Convention. Baden, Bavaria, France, Hesse-Darmstadt, Netherlands, Prussia. Art. I: Navigation assimilated to the Rhine System. Hertslet, Europe, 1849.

\section{LISCOARTA}

1835; Mar. 4: Berlin. Treaty. Prussia and Russia. Art. 51: Boundary. Hertslet, Europe, 955.

\section{LLIVIA CANAL}

1868; July 11: Bayonne. Convention. France and Spain. Arts. VII, VIII, sect. 2: Regulating the Use and Diversion of Waters, Establishing an International Supervisory Commission. Hertslet, Europe, 1844; Olivart, Colece. Tratados, IV, 322-30.

\section{IUGANO ILAKE}

1882; Nov. 8: Berne. Convention. Italy/Switzerland. Regulating \& Protecting the Fisheries in Frontier Waters. Martens, NRG, Ser. II, IX, 564.

1901; Jan. 8: Rome. Agreement. Italy/Switzerland.

1901; Jan. 18: Berne. Governing the Operations of the Customs Houses on the Lake. Deschamps/Renault, RIT (XXe Siècle), 456. 
Lugano Lake

1906; June 13: Lugano. Convention. Italy/Switzerland. Protection of Fisheries. GB. BFSP, Vol. 101, 411; Martens, NRG, Ser. II, XXXV, 471.

1911; Feb. 8: Rome. Convention. Italy/Switzerland. Additional Stipulations to the Convention of June 13, 1906. GB. BFSP, Vol. 105, 680.

\section{LYS}

1713; Apr. 11: Utrecht. Treaty. France \& the United Provinces. Established Freedom of Navigation on the Lys from its confluence with the Deule to head of navigation; stipulating that no toll or imposition should be levied. Clereq, RTF, I, 1, 10. (Commentary: NYS, Droit Int., I, 476.)

1714; Sept. 7: Baden. Treaty. Austria \& France. Art. 22: Freedom of Navigation; specific exemption from imposition of all tolls. Dumont, Corps Univ. Dipl., VIII, part 1, 436, 439. (Commentary: ENGELHARDT, Hist. du Droit Fluv. Convent., 47 ; NYS, Droit Int., I, 476.)

1820; Mar 28: Courtrai. Treaty. France \& the Netherlands. Art.

I: Boundary. Arts. V, VI: Navigation Regulations. Clereq, RTF, III, 223; Cussy/Hauterive, RTC, I, pt. 1, 241; Hertslet, Europe, 624-25.

\section{MAGGIORE LAKE}

1814; May 30 : Paris. Treaty. Austria, France, Great Britain, Prussia, Russia. Separate, Secret Art. II: Boundary. Hertslet, Europe, 18.

1834; Dec. 4: Turin. Treaty. Austria/Sardinia. Arts. 1-24: Suppression of Contraband Trade aboard Vessels navigating the Lake. Martens, NRT, XIII, 198-205.

1851; Nov. 22 : Turin. Convention. Austria/Sardinia. Regulations for Repression of Contraband aboard Vessels navigating the Lake. Cussy/Martens, Rec. Man., Ser. I, VI, 649. (Commentary: FIORE, Droit Int. Publ., II, 80, sec. 796.)

1852; Jan. 19: Milan. Agreement. Austria/Sardinia. Relating to mooring by Sardinian Steam Vessels. Martens, NRG, Ser. I, XVI, pt. 1, 198.

1860; Apr. 25: Locarno. Convention. Sardinia \& Switzerland Navigation Regulations. Martens, NRG, Ser. I, XX, 161.

1882 ; Nov. 8: Berne. Convention. Italy/Switzerland. Regulating \& Protecting the Fisheries. Martens, NRG, Ser. II, IX, 564.

1901; Jan. 8: Rome. Agreement. Italy/Switzerland. 1901; Jan. 18: Berne. Governing the Operations of the Customs 


\section{Maggiore Lake}

Houses on the Lake. Deschamps/Renault, RIT (XXe Siècle), 456.

1906; June 13: Lugano. Convention. Italy/Switzerland. Protection of Fisheries. GB. BFSP, Vol. 101, 411; Martens, NRG, Ser. II, XXXV, 471.

1911; Feb. 8: Rome. Convention. Italy/Switzerland. Additional Stipulations to the Convention of June 13, 1906. GB. BFSP, Vol. 105, 680 .

\section{MAGRA}

1844; Nov. 28: Florence. Treaty. Austria, Lucca, Modena, Sardinia, Tuscany. Arts. 5, 9: Demarcation of Boundary. Hertslet, Europe, $1052,1057$.

\section{MAIN}

1804; Aug. 15: Paris. Convention. France \& Germany. Art. 24 : Navigation. Clercq, RTF, II, 91; Cussy/Hauterive, RTC, I, pt. 1, 125; Cussy/Martens, Rec. Man., Ser. I, II, 314; Martens, RT, VIII, 268. (Commentary: ENGELHARDT, Hist. du Droit Fluv. Convent., 62.)

1810; Sept. 8: Paris. Treaty. Baden \& Hesse-Darmstadt. Art. V. Cussy/Hauterive, RTC, I, pt. 2, 227 ; Martens, RT. SUPPL., V, 280.

1815; March 20 : Vienna. Treaty. Formed Annex XVI of the Final Act. Freedom of Navigation. GB. BFSP, II, 178; Hertslet, Europe, 91; Martens, NRT, II, 447.

1815; June 9 : Vienna. Final Act of the Congress. Arts. 117, 118, sec. 11, \& Annex XVI: Freedom of Navigation; Forced Anchorage \& Trans-shipment of Cargoes Abolished. Cussy-Hauterive, RTC, I, pt. 1, 94; Hertslet, COM. TR., I, 3, 41; Hertslet, Europe, 272-73, 276; Neumann, RTA, II, 673; Sturdza, Rec. Doc., 2-4. (Commentary: MOORE, ILD, I, 628.)

1816; June 29: Frankfort. Convention. Hesse-Cassel \& HesseDarmstadt. Art. 13: Obstruction to Navigation; Construction of Bridges. Hertslet, Europe, 456.

1828; Jan. 18: Munich. Treaty. Bavaria \& Wurtemburg. Art. XXIX. Cussy/Hauterive, RTC, I, pt. 2, 259; Martens, NRT, VII, 539 .

1835 ; July 30/Aug. 15 : Carlsruhe. Treaty. Baden, Hesse, Wurtemburg. Cussy/Martens, Rec. Man., Ser. I, IV, 422; Martens, NRT, XIIT, 412.

1842; July 1: Carlsruhe. Agreement. Riverain States: Baden, Hesse, Wurtemburg. Regulating Navigation. Cussy/Martens, 
Rec. Man., Ser. I, V, 189; Martens, NRG, Ser. I, IV, 630. 1866; Aug. 22 : Berlin. Treaty. Bavaria \& Prussia. Art. 10: Abolition of Navigation Dues. Hertslet, Europe, 1714.

1866; Sept. 3: Berlin. Treaty. Hesse-Darmstadt \& Prussia. Art. 12: Transit Dues Abolished. Hertslet, Europe, 1732.

1871; Apr. 16: Berlin. Constitution. German Empire. Art. 54: Navigation of Inland Waterways. Dodd, Modern Constitutions, I, 343.

1906; Apr. 21 : Berlin. Convention. Baden, Bavaria, Hesse, Prussia. Providing for the Canalization of the Channel. Martens, NRG, Ser. III, I, 349.

\section{MARNE-RHINE CANAL}

1871; May 10: Frankfort. Treaty. France \& Germany. Art. V: Navigation. Hertslet, Europe, 1955, 1957.

1871; Dec. 11: Frankfort. Convention. France \& Germany. Art. 14: Supplementing the Stipulations of the Treaty of Frankfort; May 10, 1871. Hertslet, Europe, 1968, 1971.

1873 ; Apr. 23 : Strassburg. Agreement. France/Germany. Governing Maintenance of the Canal. Martens, NRG, Ser. II, X, 449.

\section{MEUSE}

1675; Oct. 25: Chateau Freyr-sur-Meuse. Treaty. France \& the Spanish Netherlands. (Holland acceded on Dec. 17, 1675.) Art. I: Freedom of Fluvial Transportation,- except for Contraband Articles as Cannons, Muskets and other Firearms, \& similar Munitions of War,- for the Subjects of France, Holland, \& the Spanish Netherlands. Cussy/Hauterive, RTC, I, pt. 1, 226.

1779; Nov. 18: Brussels. Treaty. France \& Hungary. Art. XXX: Facilitating Navigation of Semoy \& Meuse. Hertslet, Europe, 2012.

1785; Nov. 8: Fontainebleau. Treaty. Austria/Netherlands. Art. VI: Regulation \& Protection of Navigation. Hertslet, Europe, 2016.

1792; Nov. 16: Law. Decree of the National Provisional Executive Council of France. Abolishing the Restrictions instituted by the Barrier Conventions; Treaty of Münster, January 30, 1648. Koch/Schoell, Hist. Abr. Tr., IV, 218. (Commentary : ENGELHARDT, Hist. du Droit Fluv. Convent., 50.)

1795; May 16: The Hague. Treaty. France \& the Netherlands. Art. 18: Reciprocal Freedom of Navigation from Source to the Sea for the Contracting Powers and Nations enjoying favored Treatment. Cussy/Hauterive, RTC, II, pt. 1, 373; Koch/Schoell, 


\section{'Meuse}

Hist. Abr. Tr., IV, 293; Martens, RPT, V, 532. (Commentary : ENGELHARDT, Hist. du Droit Fluv. Convent., 51.)

1797; Oct. 17 : Campo Formio. Treaty. Austria/France. Secret Article II: Liberty of Navigation accorded French Vessels, free from all tolls, throughout Austrian territory. Koch/Schoell, Hist. Abr. Tr., V, 55 ; Martens, RPT, VII, 209 ; Martens, RT, VI, 426, 428; Univ. of Penn., Transl. \& Reprints, II, no. 2, pg. 5.

1801; Feb. 9: Luneville. Treaty. France/Germany. Free Navigation of Rhine \& its Affluents for Co-Riparians. Martens, RPT, VII, 538-544; Martens, RT, VII, 296-302. (Commentary: SCHUYLER, Am. Diplomacy, 346-47.)

1815; Mar. 20 : Vienna. Treaty. Formed Annex XVI of the Final Act. Arts. 1, 4, 5, 6: Freedom of Navigation. Hertslet, Europe, 91-92; Martens, NRT, II, 447. (Commentary: KLÜBER, Actes du Cong. de Vienne, III, 239.)

1815 ; June 9 : Vienna. Final Act of the Congress. Austria, France, Great Britain, Portugal, Prussia, Russia, Spain, Sweden. Arts. 117; 118, sec. 16; \& Annex XVI: Freedom of Navigation; Forced Anchorage \& Trans-shipment of Cargoes Abolished. Cussy/Hauterive, RTC, I, pt. 1, 94; GB. BFSP, II, 178; Hertslet, COM. TR., I, 3, 41; Hertslet, Europe, 272-73, 276; Neumann, RTA, II, 673; Sturdza, Rec. Doc., pg. 2. (Commentary: MOORE, IID, I, 628.)

1831; Nov. 15: London. Treaty. Austria, Belgium, France, Great Britain, Prussia, Russia. Arts. IX \& X: Reciprocal Freedom of all Waterways forming or crossing the International Boundary; subject only to equitable maintenance tolls. Cussy/Hauterive, RTC, I, pt. 2, 283; Hertslet, COM. TR., IV, 13, 26, 31; Hertslet, Europe, 864.

1833 ; May 21: London. Convention. France, Great Britain, Netherlands. Art. IV: Providing for Liberty of Commercial Navigation to be governed, in so far as appropriate, by the Convention of Mainz, May 31, 1831, regulating Rhine navigation. GB. BFSP, XX, 282; Hertslet, COM. TR., IV, 353; Hertslet, Europe, 922 .

1833; June 1: Notification. Given by France, Great Britain to Belgium. Concerning the Accession of Belgium to the Convention of London; May 21, 1833. Hertslet, COM. TR., V, 21.

1833; June 10: London. Treaty. Adhesion of Belgium to C'onvention of London; May 21, 1833. Hertslet, COM. TR., V, 21, 23.

1833; Nov. 18: Zonhoven. Convention. Belgium/Netherlands. Navigation Regulations. Martens, NRT, XIII, 134-147. 
(NOTE:

(1833; November: Correspondence between Belgium \& the Netherlands relating to the Navigation of the Meuse. GB. BFSP, XX, 743 ; Martens, NRT, XIII, 138.)

1839; Apr. 19 : London. Treaty. Austria-Hungary, Belgium, France, Greeat Britain, Netherlands, Prussia, Russia. Art. IX \& Annex: Mutual Liberty of Navigation. Clercq, RTF, IV, 470-73; 47577; Cussy/Martens, Rec. Man., Ser. I, IV, 575; Hertslet, COM. TR., V, 354, 359, 361; Hertslet, Europe, 986-998; Lagemans, Netherlands, Vol. II, Doc. no. 165; Neumann, RTA, IV, 416, 421; Sturdza, Rec. Doc., 854-55.

1839 ; Oct. 12 : Maastricht. Convention. Belgium \& the Netherlands. Establishment of Sovereignty in common over Meuse where forming International Boundary. Lagemans, Netherlands, Vol. II, Doc. no. 172.

1842; May 12: The Hague. Convention. Belgium/Netherlands. Facilitating Navigation. GB. BFSP, Vol. 31, 845.

1842; Nov. 5: The Hague. Treaty. Belgium/Netherlands. Arts. 50-55: Navigation Regulations. GB. BFSP, XXXI, 815; Hertslet, Europe, 1029-30; Martens, NRG, Ser. I, III, 622, 626; Sturdza, Rec. Doc., 862, 868.

1843; May 20: Antwerp. Convention. Belgium \& the Netherlands. Regulating Fisheries \& Navigation; Concerning settlement of fluvial disputes. Cussy/Martens, Rec. Man., Ser. I, V, 306; Martens, NRG, Ser. I, V, 294, 306-307, 334, 389, 381.

1843; Aug. 8: Maastricht. Convention. Belgium \& the Netherlands. Art. 12: Fisheries; Art. 13; Arts. 35, 36: Navigation Regulations. GB. BFSP, XXXV, 1202, 1220-21. Hertslet, Europe, 1031.

1845; July 12: The Hague. Convention. Belgium \& the Netherlands. Improvement of Meuse Navigation; construction of Canal between Liége \& Maastricht. Martens, NRG, Ser. I, VIII, 383. 1846; July 29: The Hague. Treaty. Belgium \& the Netherlands. Navigation Regulations. GB. BFSP, Vol. 35, 1222; Martens, NRG, Ser. I, IX, 274.

1850; Aug. 8: The Hague. Law (Royal Decree). Netherlands. Permitting the Suppression of Navigation Tolls as Established by Law of May 20, 1843. Lagemans, Netherlands, Docs. no. 197; no. 243 ; no. 244 .

1850 ; Sept. 5: The Hague. Convention. Belgium \& the Netherlands. Concerning Canalization of the Meuse between Liége 


\section{Meuse}

\& Maastricht. Lagemans, Netherlands, III, Doc. no. 247. 1851; May 8: Brussels. Convention. Belgium \& the Netherlands. Suppression of Transit Tolls. Lagemans, Netherlands, Vol. III, Docs. no. $258 ; 265$.

1851; Sept. 2: The Hague. Law (Royal Decree). Netherlands. Abolishing Navigation Dues in conformity with Law of Aug. 8, 1850. Lagemans, Netherlands, Doc. no. 265.

1851; Oct. 3: The Hague. Agreement. Belgium \& the Netherlands. Relating to Obstruction of Waterways affording access between the Contracting Parties. Lagemans, Netherlands, III, Doc. no. 269.

1852; Apr. 23: The Hague. Convention. Belgium/Netherlands. Maintenance \& Protection of Banks. Lagemans, Netherlands, Vol. IV, Doc. no. 282.

1860; Dec. 11: The Hague. Convention. Belgium/Netherlands. Regulating Navigation by Steam Vessels. Lagemans, Netherlands, Vol. V, Doc. no. 401.

1861; Sept. 21: Brussels. Convention. Belgium/Netherlands. Arts. 1-12: Establishing Regulations governing Utilization of Waters. Lagemans, Netherlands, V, Doc. no. 408, 116-119.

1863; May 12: The Hague. Treaty. Belgium/Netherlands. Governing Diversion \& Utilization of Waters from the Meuse. Lagemans, Netherlands, Vol. V, Doc. no. 432; Martens, NRG, Ser. II, I, 117.

1873; Jan. 11: Brussels. Convention. Belgium/Netherlands. Modifying Art. VI of the Treaty of The Hague, May 12, 1863, regulating Diversion of Waters. Martens, NRG, Ser. II, I, 123.

1881; Aug. 9 : Paris. Agreement. Belgium/Netherlands. Establishing an International Telegraph Line to facilitate Navigation on the Canalized Meuse. Martens, NRG, Ser. II, VIII, 444.

1885; Oct. 31: The Hague. Convention. Belgium/Netherlands. Police \& Navigation Regulations; modifying the stipulations of the Treaty of Antwerp, May 20, 1843. GB. BFSP, Vol. 76, 41617; Hertslet, Europe, 3277 ; Lagemans, Netherlands, IX, Doc. no. 701; Martens, NRG, Ser. II, XI, 663.

\section{MINCIO}

1859; July 11: Villa Franca. Treaty. Austria/France. Thalweg Boundary. Hertslet, Europe, 1374.

1859; Nov. 10: Zurich. Treaty. Austria, France, Sardinia. Arts. 1, 3, 4, 19, 20: Thalweg Boundary; Obstructions in Channel. Hertslet, Europe, 1383-1410. 
1859; Nov. 10 : Zurich. Treaty. France/Sardinia. Art. I: Thalweg Boundary. Hertslet, Europe, 1392.

1859; Nov. 21: Zurich. Agreement. Austria, France, Sardinia. Thalweg Boundary. Hertslet, Europe, 1414.

1860; June 16: Peschiera. Final Act of Demarcation. Endorsed by the Military Commission appointed in conformity with the Treaty of Zurich; Nov. 10, 1859. Hertslet, Europe, 1439, 1443.

1860; June 16: Peschiera. Treaty. Austria, France, Sardinia. Formal Adoption of Thalweg Boundary endorsed by the Military Commission. Martens, NRG, Ser. I, XVII, part 2, pg. 5.

1866 ; Oct. 3: Vienna. Treaty. Austria \& Italy. Art. IV : Rectification of Boundaries by reason of the addition of LombardoVenetia to Italy. Hertslet, Europe, 1749.

\section{MINHO}

1901; Sept. 14-20; 24: Agreement. Portugal \& Spain. Regulating the Mutual Enjoyment of the Riverain Fisheries. Deschamps/ Renault, RIT (XXe Siècle), 105.

\section{MOSELLE}

1797; Oct. 17: Campo Formio. Treaty. Austria/France. Secret Article II: Freedom of Navigation through German territory at Mouth of the River guaranteed to French Vessels. Koch! Schoell, Hist. Abr. Tr., V, 55 ; Martens, RPT, VII, 209 ; Martens, RT, VI, 426, 428; Univ. of Penn., Trans. \& Reprints, II, no. 2, 5.

(NOTE :

(1773; Oct. 29 : Convention. Elector of Treves \& France. Liberty of Navigation. Nys, Droit Int., I, 476.)

1815; Mar. 20: Vienna. Treaty. Formed Annex XVI of the Final Act. Freedom of Navigation. Hertslet, Europe, 91; Martens, NRT, II, 447. (Commentary: KLÜBER, Actes du Cong. de Vienne, III, 239.)

1815; June 9 : Vienna. Final Act of the Congress. Austria, France, Great Britain, Portugal, Prussia, Russia, Spain, Sweden. Arts. 117; 118, sec. 16; \& Annex XVI: Freedom of Navigation; Forced Anchorage \& Trans-shipment of Cargoes Abolished. Cussy/Hauterive, RTC, I, pt. 1, 94; GB. BFSP, II, 178; Hertslet, COM. TR., I, 3, 41; Hertslet, Europe, 272-73, 276 ; Neumann, RTA, II, 673; Sturdza, Rec. Doc. pg. 2. (Commentary: MOORE, ILD, I, 628.)

1816; June 26: Aix-la-Chapelle. Treaty. Netherlands \& Prussia. Art. I: Boundary. Hertslet, Europe, 452. 


\section{Moselle}

1819; July 20 : Frankfort. Treaty. Austria, Great Britain, Prussia,

Russia. Art. XIII: Boundary. Hertslet, Europe, 597-98.

1820; Mar. 28: Courtrai. Treaty. France/Netherlands. Art. I: Boundary. Hertslet, Europe, 625.

1871; May 10: Frankfort. Treaty. France/Germany. Arts. 5, 14: Navigation; Canalization of Channel. Hertslet, Europe, 1955, 1957, 1961; Martens, NRG, Ser. I, XIX, 688.

1871; Dec. 11 : Frankfort. Convention. France/Germany. Art. 14 : Rectification of Navigable Channel; supplementing Stipulations of Treaty of Frankfort; May 10, 1871. Hertslet, Europe, 1968, 1970-71.

\section{MUONIS; or MUONIO}

1810; Nov. 8/20: Tornea. Treaty. Russia \& Sweden. Arts. II, IV : Reciprocal Freedom of Navigation. Cussy/Hauterive, RTC, V, pt. 2, 515; Hertslet, Europe, 2028.

\section{NAHE}

1815; June 9 : Vienna. Final Act of the Congress. Austria, France, Great Britain, Portugal, Prussia, Russia, Spain, Sweden. Art. XXV : Boundary. Hertslet, Europe, 229; Lagemans, Netherlands, Doc. no. 30.

1819 ; July 20 : Frankfort. Treaty. Austria, Great Britain, Prussia, Russia. Art. 13: Boundary. Hertslet, Europe, 598.

\section{NECKAR}

1815; Mar. 20: Vienna. Treaty. Formed Annex XVI of the Final Act. Freedom of Navigation. Hertslet, Europe, 91; Martens, NRT, II, 447. (Commentary: KLÜBER, Actes du Cong. de Vienne, III, 239.)

1815; June 9 : Vienna. Final Act of the Congress. Austria, France, Great Britain, Portugal, Prussia, Russia, Spain, Sweden. Arts. 117; 118, sec 16; \& Annex XVI: Freedom of Navigation; Forced Anchorage \& Trans-shipment of Cargoes Abolished. Cussy/Hauterive, RTC, I, pt. 1, 94; GB. BFSP, II, 178; Hertslet, COM. TR., I, 3, 41; Hertslet, Europe, 272-73, 276; Lagemans, Netherlands, I, Doc. no. 30; Neumann, RTA, II, 673; Sturdza, Rec. Doc., pg. 2.

1828; Jan. 18: Munich. Treaty. Bavaria \& Wurtemburg Art. 29. Cussy/Hauterive, RTC, I, pt. 2, 259 ; Martens, NRT, VII, 539.

1835; May 12: Berlin. Treaty. Baden, Bavaria, Hesse, Prussia, Saxony, Thuringian League, Wurtemburg. Arts. 15, 16, 17: 
Reciprocal Abolition of Navigation Dues. Martens, NRT, XIII, $228,240-41$.

1835; July 24: Convention. Baden, Hesse, Wurtemburg. Regulation of Navigation Tolls. Martens, NRG, Ser. I, IV, 280.

1835; July 30/Aug. 15: Carlsruhe. Convention. Baden, Hesse-

Darmstadt, Wurtemburg. Navigation Regulations. Cussy/Martens, Rec. Man., Ser. I, IV, 422; Martens, NRT, XIII, 412.

1842; July 1: Carlsruhe. Convention. Baden, Hesse-Darmstadt, Wurtemburg. Art. I: Ensuring Freedom of Navigation; Clearance of Obstructions in Channel. Cussy/Martens, Rec. Man., Ser. I, V, 189; Hertslet, Europe, 1027; Martens, NRG, Ser. I, IV, 630 .

1871; Apr. 16: Berlin. Constitution. German Empire. Art. 54: Navigation of Inland Waterways. Dodd, Modern Constitutions, I, 343.

\section{NEISSE}

1815; June 9 : Vienna. Final Act of the Congress. Art. 15: Thalweg Boundary. Hertslet, Europe, 221.

1871; Apr. 16: Berlin. Constitution. German Empire. Art. 54: Navigation of Inland Waterways. Dodd, Modern Constitutions, I, 343.

\section{NETZE}

1807; July 7: Tilsit. Treaty. France \& Prussia. Art. 17: Abolition of all Tolls upon Vessels in transit to \& from the Vistula. Cussy/Hauterive, RTC, III, pt. 1, 43.

\section{NIEMEN}

1825; Feb. 27/Mar. 11: Berlin. Convention. Prussia \& Russia. Arts. 5, 6: Prohibiting Imposition of Tolls on Navigation of Niemen \& its Affluents. Cussy/Hauterive, RTC, V, pt. 2, 390; GB. BFSP, XII, 927; Martens, NRT, VI, 688.

\section{NIERS CANAL}

1895; May 16: The Hague. Treaty. Germany/Netherlands. Improvement \& Maintenance of the Canal. Lagemans, Netherlands, XII, Doc. no. 825 ; Martens, Ser. II, XXIII, 44.

\section{NIERS}

1895; May 16: The Hague. Treaty. Germany/Netherlands. Improvement \& Maintenance of the Navigable Channel. Lagemans, Netherlands, XII, Doc. no. 825 ; Martens, Ser. II, XXIII, 44. ODER 1648; Oct. 24: Osnabruck. Treaty. (Peace of Westphalia). France, 


\section{Oder}

Germany, Sweden. Art. X, sec. 1: Boundary. Dumont, Corps Univ. Dipl., VI, 469, 481.

1818; Dec. 7/19 : St. Petersburg. Treaty. Prussia/Russia. Art. II:

Relating to the Polish Provinces; Perfect, Reciprocal Freedom of Navigation. GB. BFSP, V, 945-46; Martens, NRT, IV, 582-84.

1825; Feb. 27/March 11: Berlin. Convention. Prussia/Russia. Art. IV : Freedom of Navigation on basis of Absolute Equality. Cussy-Hauterive, RTC, V, pt. 2, 390; GB. BFSP, XII, 927; Martens, NRT, VI, 688.

\section{OURE}

1815; June 9 : Vienna. Final Act of the Congress. Austria, France,

Great Britain, Portugal, Prussia, Russia, Spain, Sweden. Arts. 25, 68: Boundary. Hertslet, Europe, 229, 252.

1816; June 26: Aix-la-Chapelle. Treaty. Netherlands \& Prussia. Art. 27: Reciprocal Freedom of Navigation. Hertslet, Europe, 452.

\section{PASWIG LAKES}

1826; May 14: St. Petersburg. Convention. Russia and Sweden \& Norway. Art. II: Boundary. Hertslet, Europe, 745.

\section{PASWIG}

1826 ; May 14: St. Petersburg. Convention. Russia and Sweden \& Norway. Art. II: Boundary. Art. IX: Freedom of Navigation; Flottage of Timber; Regulation of Fisheries. Hertslet, Europe, 745-46.

\section{PO}

1177; June 8: Ferrara. Convention. Bologna, Ferrara, Mantua, Milan, Modena, Ravenna, Venice. Establishing Freedom of Fluvial Navigation. NYS, Rev. Gene. du Droit Int., Vol. XI, 192, 197; citing Pasolini, "Documenti Riguardanti antiche Relazioni fra Venezia e Ravenna," Doc. no. 3, pg. 13.

1757; Nov. 30/Dec. 7: Milan \& Rome. Treaty. Austria \& Rome. Arts. II, IV: Navigation. Cussy/Hauterive, RTC, I, pt. 2, 143-44.

1814; May 30 : Paris. Treaty. Austria, France, Great Britain, Prussia, Russia. Separate, Secret Art. II: Boundary. Hertslet, Europe, 18.

1815 ; June 9 : Vienna. Final Act of the Congress. Austria, France, Great Britain, Portugal, Prussia, Russia, Spain, Sweden. Art. 96: Application of the General Principles governing Freedom 
of Navigation as embodied in Annex XVI. Art. 95, sec. 2: Thalweg Boundary. Cussy/Hauterive, I, pt. 1, 70; Hertslet, COM. TR., I, 3 ; Hertslet, Europe, 264 ; Lagemans, Netherlands, I, Doc. no. 30; Neumann, RTA, II, 673. (Commentary: MOORE, Int. Arb., 4852 ; MOORE, ILD, I, 629 ; PHILLIMORE, Int. Law (1879), I, 232.)

1821; Oct. 16: Convention. Austria \& Parma. Governing Imposition of Navigation Dues. Neumann, RTA, III, 650.

1825 ; Sep. 3: Milan. Convention. Austria/Parma. Providing for the Joint Imposition of Navigation Dues. Neumann, RTA, IV, 116.

1834; Dec. 4: Turin. Treaty. Austria/Sardinia. Arts. 1-24: Suppression of Contraband Trade aboard Vessels navigating the River. Martens, NRT, XIII, 198-205.

1849; July 3: Milan. Treaty. Austria, Modena, Parma. Arts. IXXIV \& Additional Arts. 1 \& 2: Freedom of Navigation. Cussy/Martens, Rec. Man., Ser. I, VI, 293; GB. BFSP, Vol. 38, 130 ; Hertslet, COM. TR., IX, 930 ; Hertslet, Eúrope, 1095 ; Martens, NRG, Ser. I, XIV, 525 ; Neumann, RTA, V, 118. (Commentary: MOORE, Int. Arb., 4852; SCHUYLER, Am. Diplomacy, 351; WESTLAKE, Int. Law, I, 151.)

1849; July 3: Milan. Convention. Austria/Parma. Demarcation of Sovereign Rights over Fluvial Territory. Cussy/Martens, Rec. Man., Ser. I, VI, 299; Hertslet, Europe, 1104, Doc. no. 213. 1849; Aug. 6: Milan. Convention. Austria/Sardinia. Art. V: Boundary. Cussy/Martens, Rec. Man., Ser. I, VI, 300.

1849; Aug. 8: Milan. Treaty. Austria/Modena. Art. V: Thalweg Boundary. Hertslet, Europe, 1112; Neumann, RTA, V, 146. 1850 ; Feb. 12: Portici. Accession of the Pope to the Treaty of Milan, July 3, 1849, establishing Freedom of Navigation, including all tributaries below confluence of the Ticino. GB. BFSP, Vol. 38, 136; Hertslet, COM. TR., IX, 935 ; Hertslet, Europe, 1123 ; Martens, NRG, Ser. I, XIV, 532. (Commentary: MOORE, IID, I, 629.)

1851; Oct. 18: Vienna. Treaty. Austria/Sardinia. Art. 12: Reciprocal Freedom of Navigation. Cussy/Martens, Rec. Man., Ser. I, VI, 626; 630; GB. BFSP, Vol. 42, 1285, 1287, 1297.

1851; Nov. 22: Turin. Convention. Austria/Sardinia. Art. I: Suppression of Contraband Trade aboard Vessels navigating the River. Cussy/Martens, Rec. Man., Ser. I, VI, 649. (Commentary: WESTLAKE, Int. Law, I, 151.)

1859; Nov. 10 : Zurich. Treaty. Austria, France, Sardinia. Arts. I, 
III: Thalweg Boundary. Art. XVIIJ - Recognition of the Liberty of Navigation, including Affluents, in conformity with existing treaties. Annuaire des Deux Mondes, 1858-59, pg. 1000; Hertslet, Europe, 1392-93, 1409. (Commentary : FIORE, Droit Int. Publ., Vol. II, pg. 80, sec. 796; NYS, Droit Int., I, 476-77.) 1859; Nov. 21: Zurich. Protocol of Conference. Austria, France, Sardinia. Demarcation of International Boundary in Thalweg. GB. BFSP, Vol. 50, 1019 ; Hertslet, Europe, 1414.

1860 ; June 16 : Peschiera. Final Act of Demarcation. Endorsed by the Military Commission appointed in conformity with the Treaty of Zurich; Nov. 10, 1859. Hertslet, Europe, 1439, 1443. 1860; June 16: Peschiera. Treaty. Austria, France, Sardinia. Formal Adoption of Thalweg Boundary endorsed by the Military Commission. Martens, NRG, Ser. I, XVII, part 2, pg. 5.

(NOTE:

(FIORE, Droit Int. Publ., Vol. II, pg. 80, considers all international rights on the Po extinguished by Treaty of Vienna, Oct. 3, 1866; NYS, Droit Int., I, 477, states that these rights still endure.)

PODHORCE; SBRUCZ; or ZBRUCZ

1829; July 10/June 28: Radziwilow. Treaty. Austria \& Russia. Preamble; Art. III: Thalweg Boundary. Hertslet, Europe, 810-11.

\section{POLISH WATERWAYS}

I. RIVERS: AA, (Tributaries), Muscha, Njemenek; BUG, or BOUG, (Trib.), Kodyma; DNIEPER, (Tribs.), Beresina, Pripet, Teterew; DNIESTER, (Tribs.), Sbrucz, Sereth; DUNA, or DWINA; NIEMEN, or MEMEL, (Tribs.), Dubissa, Newjasha, Schara, Scheschupa, Wilija; PRUTH; VISTULA, (Tribs.), Bug, Narew, Piliza, Wjeprsh; WARTHE, or WARTA, (Tribs.), Netze, Prosna; WINDAU.

II. CANALS: AUGUSTOWO, connecting Narew \& Niemen rivers;

\begin{tabular}{|c|c|c|c|}
\hline $\mathrm{ACHOH}$ & “ & "6 & Netze \& Vistula \\
\hline 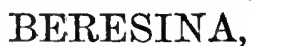 & " & “ & Beresina \& Ulla \\
\hline $3 \mathrm{E}$ & « & " & Oder \& Vistula \\
\hline $2 J$ & " & “ & Bug \& Pripet \\
\hline דרה & 6 & " & Pripet \& Schara \\
\hline 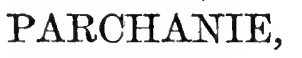 & " & “ & Netze \& Vistula \\
\hline NDAL & “ & " & Dubissa \& Windau \\
\hline
\end{tabular}


Polish Waterways

1815; Apr. 21/May 3 : Vienna. Treaty. Austria/Russia. Arts. 2429: "The Navigation of all the Rivers and Canals throughout the whole extent of the ancient kingdom of Poland (as it existed before the year 1772) to their mouths, as well in ascending as in descending, shall be free, so as not to be interdicted to any inhabitant of the Polish provinces, subject to either the Russian or Austrian Government." Cussy/Hauterive, RTC, I, pt. 2, 183; Cussy/Martens, Rec. Man., Ser. I, III, 103-111; Hertslet, Europe, 100. (Commentary: MOORE, Int. Arb., 4852; MOORE, ILD, Vol. I, 629.)

1815; Apr. 21/May 3 : Vienna. Treaty. Prussia/Russia. Arts. 2225: Formed Annex II of the Final Act. Freedom of Navigation on all Rivers and Canals of the former Kingdom of Poland; subject to regulations similar to those adopted by Austria \& Russia in Treaty of even date. Cussy/Martens, Rec. Man., Ser. I, III, 111-116; Hertslet, Europe, 111-12.

1815; June 9 : Vienna. Final Act of the Congress. Austria, France, Great Britain, Portugal, Prussia, Russia, Spain, Sweden. Arts. 14 ; 108-116; 118, sec. 1 , sec. 2 , sec. 16 ; Annex 1; Annex 2; Annex 16: Freedom of Navigation on all Rivers \& Canals of the ancient Kingdom of Poland. Hertslet, Europe, 221, 269, 272-73, 276.

1818; Aug. 5/17: St. Petersburg. Convention. Austria \& Russia. Art. II: Renewal of Stipulations concerning Freedom of Navigation embodied in Art. 24 of Treaty of Vienna; Apr. 21/May 3, 1815. Art. III: Application of these Stipulations to all Canals, existing or constructed in future. Cussy/Hauterive, RTC, V, pt. 2, 445; Martens, NRT, IV, 540.

\section{PORTA}

1844; Nov. 28: Florence. Treaty. Austria, Lucca, Modena, Sardinia, Tuscany. Arts. 2, 9: Boundary. Hertslet, Europe, 1049, 1055 .

\section{PROSNA}

1815; June 9 : Vienna. Final Act of the Congress. Art. II: Thalweg Boundary. Hertslet, Europe, 217.

1836; Dec. 1/13: Tarnowitz. Convention. Prussia \& Russia. Demarcation of Boundary. Hertslet, Europe, 964.

\section{PRUTH}

1812; May 28: Bucharest. Treaty. Russia \& Turkey. Art. IV: Thalweg Boundary from Moldavian Frontier to confluence with 


\section{Pruth}

Danube. Hertslet, Europe, 2030 ; Koch/Schoell, Hist. Abr. Tr., XIV, 539; Martens, NRT, III, 399.

1818; Aug. 5/17: St. Petersburg. Convention. Austria \& Russia. Arts. I, II, III : Liberty of Navigation reserved for exclusive enjoyment of the Riverain Powers. Cussy/Hauterive, RTC, V, pt. 2, 444; Martens, NRT, IV, 540.

1829; July 10: Radziwilow: Treaty. Austria \& Russia. Preamble:

Boundary. Hertslet, Europe, 810.

1829; Sept. 14: Adrianople. Treaty. Russia/Turkey. Art. III: Boundary. Hertslet, Europe, 815.

1856; Mar. 30: Paris. Treaty. Austria-Hungary, France, Great Britain, Prussia, Russia, Sardinia, Turkey. Art. XX: Boundary. GB. BFSP, Vol. 46, 8 ; Hertslet, COM. TR., X, 533, 536; Hertslet, Europe, 1250, 1259; Sturdza, Rec. Doc., 32.

1857; Jan. 6: Paris. Protocol of Conference. Austria-Hungary, France, Great Britain, Prussia, Russia, Sardinia, Turkey. Boundary in Thalweg. GB. BFSP, Vol. 47, 92; Hertslet, COM. TR., X, 553; Hertslet, Europe, 1298-99.

1857; Apr. 11/Mar. 30: Kichineff. Agreement. Austria-Hungary, France, Great Britain, Russia, Turkey. Art. I: Thalweg Boundary. Hertslet, Europe, 1314.

1866; Dec. 3/15: Bucharest. Convention. Austria, Russia, and the United Principalities of Moldavia \& Wallachia. Arts. 1-32: Navigation Regulations. GB. BFSP, Vol. 58, 631; Hertslet, Europe, 1789-1796; Martens, NRG, Ser. I, XX, 296; Martens, Rec. Russ., IV, part 2, 858; Neumann, RTA, IV n. s., 606; Sturdza, Rec. Doc., 760. (Commentary: MOORE, Int. Arb., 4852; MOORE, ILD, I, 629.)

1871; Jan. 27-28/Feb. 8-9: Bucharest. Regulatory Convention. Instituted by the Permanent Mixed Commission of the Pruth. (Representatives of Austria, Russia, \& Roumania.) Governing Police \& Navigation; followed by Provisional Tariff Table. GB. BFSP, Vol. 63, 989; Hertslet, Europe, 1909; Martens, NRG, Ser. II, I, 485; Neumann, RTA, VII, n. s., 186.

1895; Feb. 18/March 2: Bucharest. Convention. Austria-Hungary, Roumania, Russia. (Permanent Mixed Commission.) Navigation Regulations. GB. BFSP, Vol. 87, 508; Neumann, RTA, XVII, 295.

1896; Apr. 1/13: Galatz. Law. Permanent Mixed Commission. Navigation \& Police Regulations. Sturdza, Rec. Doc., 768.

1896 ; Apr. 22 : Galatz. Law. Permanent Mixed Commission representing Austria-Hungary, Roumania, \& Russia. Provisional 
Tariff to be levied on Navigation. Sturdza, Rec. Doc., 799. 1896; May 7: Galatz. Law. Permanent Mixed Commission. Sanitary Regulations applicable to the Navigation of the Pruth. Sturdza, Rec. Doc., 795.

1901; Feb. 9/21: Bucharest. Convention. Roumania \& Russia. Regulating Fisheries in Danube \& Pruth. Deschamps/Renault, RIT (XXe Siècle); Neumann, RTA, XX n. s., 493; Sturdza, Rec. Doc., 825.

1907; Oct. 16/29 : Bucharest. Convention. Roumania \& Russia. Governing Riverain Fisheries. GB. BFSP, Vol. 101, 569; Martens, NRG, Ser. III, I, 907.

\section{PUYCERDA CANAL}

1866; May 26: Bayonne. Treaty. France/Spain. Art. IV: Demarcation of Frontiers. Olivart, Colecc. Tratados, IV, 246-262. 1868; July 11: Bayonne. Convention. France/Spain. Utilization \& Enjoyment of the waters of the Canal. Arts. IV, V. Hertslet, Europe, 1844; Olivart, Colecc. Tratados, IV, 311-320.

\section{QUEICH; or DE LA QUEICH}

1814 ; May 30 : Paris. Treaty. Austria, France, Great Britain, Prussia, Russia. Art. III, sec. 5: Boundary. Hertslet, Europe, 5.

\section{RAOUR}

1868; July 11: Bayonne. Convention. France \& Spain. Art. I, part 2: Boundary; amplifying Treaty of Bayonne; May 26, 1866. Hertslet, Europe, 1844; Olivart, Colecc. Tratados, IV, 306-308.

\section{RHINE}

Principal Tributaries: Lahn; Lippe; Main; Moselle; Neckar; Ruhr. 1648; Oct. 24: Münster. Treaty. Germany \& France. (Peace of Westphalia.) Art. 85: Assuring Liberty of Navigation for Riverain Inhabitants. Cussy/Hauterive, RTC, I, pt. 1, 32; Koch/Schoell, Hist. Abr. Tr., I, 236.

1667; Feb. 17 (o. s.): Arbitral Award. Representatives of France \& Sweden. Composing Dispute between the Elector of Mainz $\&$ the Elector Palatine concerning Rhine Tolls. RT. PAIX, Vol. IV, 187, 189.

1697; Oct. 30: Ryswick. Treaty. France \& Germany. Art. 18: Stipulated that navigation \& auxiliary uses of the river should remain free to the subjects of the Contracting Parties, as well as to all others who wished to navigate, pass, or transport merchandise. Cussy/Hauterive, RTC, I, pt. 1, 33; Dumont, Corps 


\section{Rhine}

Univ. Dipl., VII, pt. 2, 421; Koch/Schoell, Hist. Abr. Tr., I, 441. (Commentary: NYS, Droit Int., I, 476.)

1714; Mar. 6: Rastadt. Treaty. France \& Germany. Art. VI: Reciprocal Freedom of Navigation. Cussy/Hauterive, RTC, I, pt. 1, 35.

1714; Sept. 7 : Baden. Treaty. France \& Germany. Art. VI: Renewal of Stipulations embodied in Art. 18 of Treaty of Ryswick, -Oct. 30, 1697,-guaranteeing mutual enjoyment of Navigation \& Auxiliary Uses. Cussy/Hauterive, RTC, I, pt. 1, 37; Dumont, Corps Univ. Dipl., VII, pt. 1, 436; Koch/Schoell, Hist. Abr. Tr., II, 141.

1751; Apr. 28: Munich. Treaty. The Elector of the Palatinate \& France. Arts. 1-10: Navigation Regulations. Cussy/Hauterive, RTC, I, pt. 1, 119.

1751; May 29: Munich. Treaty. Accession of the Elector of Mainz to the Treaty of Munich, Apr. 28, 1751, governing navigation. Arts. 1-7. Cussy/Hauterive, RTC, I, pt. 1, 121.

1795; May 16: The Hague. Treaty. France/Netherlands. Art. 18: Reciprocal Freedom of Navigation, including affluents. Cussy/Hauterive, RTC, II, pt. 1, 373; Koch/Schoell, Hist. Abr. Tr., IV, 293; Martens, RPT, V, 532. (Commentary: ENGELHARDT, Hist. du Droit Fluv. Conv., 51.)

1796; Aug. 22: Paris. Treaty. Baden/France. Arts. 8, 9, 11, 12, 13, \& Separate Secret Art. III: Reciprocal Freedom of Navigation; Transit Dues abolished where Rhine separates the respective parties. Clercq, RTF, I, 292; Cussy/Hauterive, RTC, I, pt. 1, 123.

1797; Oct. 17: Campo Formio. Treaty. Austria \& France. Secret Art. II : Navigation to be free to the subjects of the Contracting States from Hüningen to the Frontier of the Batavian Republic. Koch/Schoell, Hist. Abr. Tr., V, 55; Martens, RPT, VII, 209; Martens, RT, VI, 426; Univ. of Penn., Transl. \& Reprints, II, no. 2, pg. 4.

1801; Feb. 9: Luneville. Treaty. France \& Germany. Freedom of Navigation, including affluents, ensured to co-riparians. Martens, RT, VII, 296-302; Martens, RPT, VII, 538-544. (Commentary: SCHUYLER, Am. Dipl., 346-47.)

1802; May 23: Paris. Treaty. France \& Prussia. Art. 3: Suppression of Rhine Tolls. Clercq, RTF, I, 584.

1804; Aug. 15, (27 Thermidor, an XII.): Paris. Convention. France \& Germany. Arts. 2, 10, 12, 19, 20, 23, 30, 31, 39, 40, 41, 90, 91, 93: Reciprocal Freedom of Navigation; Regulation 
of the Customs Duties on Rhine Commerce; Establishment of Governing Board with Central Bureau at Mainz. Clercq, RTF, II, 91; Cussy/Hauterive, RTC, I, pt. 1, 125; Cussy/Martens, Rec. Man., II, 314; Martens, RT, VIII, 261. (Commentary: CLAPP, The Navigable Rhine, 11; ENGELHARDT, Du Rég. Conv. des Fleuves Int., 174; ENGELHARDT, Hist. du Droit Fluv. Conv., 62.)

1810; Feb. 16: Paris. Treaty. France \& the Grand Duchy of Frankfort. Art. VI: Regulating Imposition of Customs. Clercq, RTF, II, 311.

1813; Apr. 29: Paris. Treaty. Baden, Bavaria, France, Hesse, Nassau. Arts. 1-5: Administration of the Works for Improving the Navigable Channel. Clercq, RTF, II, 379.

1814; May 30: Paris. Treaty. Austria, France, Great Britain, Portugal, Prussia, Russia, Spain, Sweden. Art. V: Freedom of Navigation from Headwaters to the Sea. Art. 3: Boundary Thalweg. Clercq, RTF, II, 418; Cussy/Hauterive, RTC, I, pt. 1, 58; Hertslet, COM. TR., I, 249 ; Hertslet, Europe, 8; Neumann, RTA, II, 466; Sturdza, Rec. Doc., pg. 1. (Commentary: ENGELHARDT, Hist. du Droit Fluv. Conv., 63-64; KOCH/ SCHOELL, Hist. Abr. Tr., X, 490 ; MOORE, ILD, I, 628.)

1815 ; Mar. 20 : Vienna. Treaty. Formed Annex XVI of the Final Act. Arts. 1-32. Clercq, II, 463; Hertslet, Europe, 78.

1815; Mar. 24: Vienna. Agreement. Embodied in Annex XVI of the Final Act. Governing Navigation. Clercq, RTF, II, 463. 1815; June 8: Vienna. Federative Constitution of Germany. Formed Annex IX of Final Act. Art. XV: Navigation. Hertslet, Europe, 204.

1815; June 9: Vienna. Final Act of the Congress. Arts. 111; 117; 118, sec. 16; \& Annex. XVI: Freedom of Navigation; Forced Anchorage \& Transhipment of Cargoes Abolished; Neutrality during Hostilities. Cussy/Hauterive, RTC, I, pt. 1, 78; Deschamps/Renault, RIT, XIXe Siècle; GB. BFSP, II, 162 ; Hertslet, COM. TR., 1, 3, 19 ; Hertslet, Europe, 272-73; 276; Lagemans, Netherlands, Vol. I, Doc. no. 30; Neumann, RTA, II, 673 ; Martens, NRT, II, 436; Sturdza, Rec. Doc., pg. 2. (Commentary: BONFILS, Droit Int., sec. 525, pg. 330; CLAPP, The Navigable Rhine, 13; KOCH/SCHOELL, Hist. Abr. Tr., XI, 394; MOORE, Int. Arb., 4851; WHEATON (Lawrence Edit.), Elem. of Int. Law, Chap. IV, sec. 17.)

1815; Nov. 20: Paris. Treaty. Austria, France, Great Britain, Prussia, Russia. Art. I, sec. 2: Thalweg Boundary. Hertslet, Europe, 345 . 


\section{Rhine}

1819; July 20: Frankfort. Treaty. Austria, Great Britain, Prussia, Russia. Art. V: Established Boundary between Bavaria \& France. Hertslet, Europe, 593.

1820; Aug. 25: Mainz. Convention. Baden \& France. Art. II : Regulating the Establishment of Customs Bureaux between Basle \& Strassbourg. Art. I: Stipulating Freedom of Navigation. Clercq, RTF, III, 240; Cussy/Hauterive, RTC, I, pt. 1, 141; Cussy/Martens, Rec. Man. III, 483.

1825; July 5: Paris. Convention. Bavaria \& France. Art. II: Boundary. Hertslet, Europe, 728.

1826; Sept. 10: Château of Loo. Law. Netherlands Government. Decree of the King concerning Freedom of Navigation; excusing Navigators from the Complete Observance of the Netherlands Law of Aug. 22, 1822; recognizing the River Lek as continuation of the Rhine. Cussy/Martens, Rec. Man, IV, 31; GB. BFSP, XIII, 1109; Hertslet, COM. TR., III, 314, 317.

1827; March 1: Brussels. Law. Government of the Netherlands. Royal Decree governing Navigation of River. GB. BFSP, XV, 1227; Hertslet, COM. TR., IV, 338-350.

1828; Jan. 18: Munich. Treaty. Bavaria/Wurtemburg. Art. XXIX. Cussy/Hauterive, RTC, I, pt. 2, 259; Martens, NRT, VII, 539 .

1831; Mar. 31: Mainz. Convention. Baden, Bavaria, France, Hesse-Darmstadt, Nassau, Netherlands, Prussia. Chap. I-X; Arts. 1-109; including appended Protocol: Freedom \& Regulation of Navigation. Clercq, RTF, IV, 24; Cussy/Hauterive, RTC, I, pt. 1, 155, 305; Cussy/Martens, Rec. Man., IV, 271; GB. BFSP, Vol. 18, 1076; Vol. 19, 88; Hertslet, COM. TR., X, 471; Hertslet, Europe, 848; Lagemans, Netherlands, Vol. II, Doc. no. 127; Martens, NRT, IX, 252.: (NOTE: This Convention incorporated certain stipulations embodied in the Convention of Paris, Aug. 15, 1804; the Treaty of Paris, May 30, 1814; the Congress of Vienna, June 9,1815 ; \& the Convention of Mainz, Aug. 25, 1820. Cussy/Hauterive, RTC, I, pt. 1, 125, 58, 78, 141.) (Commentary: CLAPP, The Navigable Rhine, 13-14, 20; ENGELHARDT, Hist. du Droit Fluv. Conv., 79, 96; KENT, Commentaries, 125; SCHUYLER, Am. Diplomacy, 348; TWISS, Law of Nations (Peace), 245-46; WESTLAKE, Int. Law, I, 151.)

1831; June 28: Law. Government of the Netherlands. Royal Decree. According Sanction to the Convention of Mainz, March 
31, 1831, within Dominions of the Netherlands. Lagemans, Netherlands, II, Doc. no. 128.

1831; Sept. 20: Mainz. Convention. Baden/France. Supervision of Navigation in conformity with Art. 101 of the Convention of Mainz; March 31, 1831. Clereq, RTF, IV, 129.

1831; Nov. 15: London. Treaty. Austria-Hungary, Belgium, France, Great Britain, Prussia, Russia. Freedom of Navigation; specific application of stipulations embodied in Arts. 108117, sanctioned by the Congress of Vienna, June 9, 1815. Cussy/Hauterive, RTC, I, pt. 2, 283.

1832; Mar. 27: Convention. Baden \& Bavaria. Rectification of the Navigable Channel. Cussy/Martens, IV, 355; Martens, NRT, $\mathrm{XI}, 454$.

1834; Dec. 1: Mainz. Convention. Central Commission of Rhine Navigation (Baden, Bavaria, France, Hesse-Darmstadt, Nassau, Netherlands, Prussia.) Adoption of Four Supplementary Articles in modification of the first Four Articles of the Convention of Mainz; March 31, 1831. Clereq, RTF, IV, 280; GB. BFSP, Vol. 23, 641; Lagemans, Netherlands, II, Doc. no. 140, no. 142; Martens, NRT, XII, 734; Martens, NRG, Ser. I, II, 537.

1835; May 12: Berlin. Treaty. Baden, Bavaria, Hesse, Prussia, Saxony, Thuringian League, Wurtemburg. Arts. 15, 16, 17 : Reciprocal Abolition of Navigation Dues. Martens, NRT, XIII, 228, 240. (NOTE: Accession of Baden to Treaty of Berlin proclaimed; Carlsruhe, Nov. 26, 1835. Martens, NRT, XIII, 435-37.)

1835 ; Aug. 1: Mainz. Convention. Baden, Bavaria, France, HesseDarmstadt, Nassau, Netherlands, Prussia. Additional Articles, no. 5, no. 6; supplementing Convention of Mainz, Mar. 31, 1831. Clereq, RTF, IV, 308.

1835; Dec. 3 : Paris. Law. French Government. Ordinance governing Navigation. GB. BFSP, Vol. 23, 641.

1836 ; March 2: Law. Government of the Netherlands. Royal Decree ratifying Supplementary Articles, I-IV, adopted by Convention of Mainz, Dec. 1, 1834; Modifying Convention of March 31, 1831. GB. BFSP, Vol. 38, 617; Lagemans, Netherlands, II, Doc. no. 142.

1837; Aug. 1: Mainz. Convention. Baden, Bavaria, France, HesseDarmstadt, Nassau, Netherlands, Prussia. Central Rhine Navigation Commission. Additional Articles, nos. V-IX; revising 


\section{Rhine}

Convention of Mainz, March 31, 1831. Clereq, RTF, IV, 380; Lagemans, Netherlands, Doc. no. 153a, no. 168.

1837; Oct. 13: Frankfort. Convention. Baden/Frankfort. Reciprocal Freedom from Navigation Tolls upon Rhine \& Affluent Waters within Jurisdiction of the Contracting States. Martens, NRT, XIV, 307-308.

1837; Oct. 31: Carlsruhe. Convention. Baden/France. Supervising the Collection of Navigation Tolls at the Bureaux of Strassburg \& Vieux-Brisach. Clercq, RTF, IV, 387.

1838; July 23, 24 \& 25: Friburg. Protocols of Conferences. Baden \& France. Concerning Bridges of Hunningue \& Vieux-Brisach. Clereq, RTF, IV, 419.

1839; May 29: Carlsruhe. Agreement. Baden/France. Approving Protocol of Friburg, July 23/25, 1838, concerning Construction of Bridges. Clercq, RTF, IV, 488.

1839; June 25: Law. Government of the Netherlands. The Hague. Royal Decree providing for Navigation Regulations, in conformity with Addit. Articles embodied in Convention of Aug. 1, 1837. GB. BFSP, Vol. 38, 620; Lagemans, Netherlands, Doc. no. 168.

1839; July 27: Mainz. Convention. Baden, Bavaria, France, Hesse-Darmstadt, Nassau, Netherlands, Prussia. (Central Rhine Navigation Commission.) Supplementary Articles, nos. 10, 11, 12, 13; amplifying Convention of Mainz; March 31, 1831. Clercq, RTF, IV, 495; Lagemans, Netherlands, Vol. II, Doc. no. $169 \mathrm{~b}$; Doc. no. 189.

1840; July 9 : Convention. Baden, Bavaria, Hesse-Darmstadt, Nassau. Supervising Navigation. Martens, NRG, Ser. I, I, 153.

1840; Sept. 21: Mainz. Convention. Baden, Bavaria, France, Hesse-Darmstadt, Nassau, Netherlands, Prussia. (Central Rhine Navigation Commission.) Articles XIV \& XV: Navigation Regulations; supplementing Convention of Mainz, March 31, 1831. Clercq, RTF, IV, 588; Cussy/Martens, Rec. Man., V, 70; Lagemans, Netherlands, Vol. II, Doc. no. 185a; Vol. III, Doc. no. 192; Martens, NRG, Ser. I, I, 386.

1841; Aug. 21: Law. Government of the Netherlands. The Hague. Royal Decree governing Navigation; embodying provisions of Additional Arts. X-XIII; July 27, 1839. GB. BFSP, Vol. 38, 621; Lagemans, Netherlands, Doc. no. 189.

1842; Feb. 17: Law (Royal Decree). Government of the Netherlands. The Hague. Navigation Regulations; confirming Additional Arts. 14-15 of Convention of Mainz; Sept. 21, 1840. 
GB. BFSP, Vol. 38, 625; Lagemans, Netherlands, Doc. no. 192. 1843; Aug. 28: Carlsruhe. Protocol. Baden/France. Regulating Maintenance of Ferry between Au \& Lauterburg. Clercq, RTF, $\mathrm{V}, 109$.

1844; Jan. 5: The Hague. Law (Royal Order). Government of the Netherlands. Navigation Regulations observing Add. Article XV. GB. BFSP, Vol. 38, 626; Lagemans, Netherl., Doc. no. 204.

1844; Apr. 20/26: Convention. Baden \& France. Regulating Imposition of Navigation Tolls. Clereq, RTF, V, 170; Cussy/Martens, Rec. Man., V, 388.

1844; Aug. 27/30: Mainz. Convention. Baden, Bavaria, France, Hesse-Darmstadt, Nassau, Netherlands, Prussia. (Central Rhine Navigation Commission.) Additional Articles, nos. 16 \& 17; supplementary to the Convention of Mainz, March 31, 1831. Clercq, RTF, V, 196 ; GB. BFSP, Vol. 34, 1294; Lagemans, Netherlands, Vol. III, Docs. no. 204a, no. 215. Martens, NRG, Ser. I, VIII, 576.

1844; Sept. 17: Mainz. Convention. Baden, Bavaria, France, Hesse-Darmstadt, Nassau, Netherlands, Prussia. (Central Rhine Navigation Commission.) Ratification of Supplementary Article, no. 18, modifying the Convention of Mainz, Mar. 31, 1831. Clercq, RTF, V, 224; Lagemans, Netherlands, III, Doc. no 204 b, no. 219.

1845; March 18, 19, \& 29: Law. Government of the Netherlands. The Hague. Modifying the Existing Regulations governing Navigation, in conformity with Stipulations of Convention of Mainz; March 31, 1831. Lagemans, Netherlands, Vol. III, Docs. no. 207,208 , \& no. 209.

1845; Nov. 1: The Hague. Law (Royal Order). Government of the Netherlands. Navigation Regulations; embodying Additional Articles Nos. 16 \& 17 of Aug. 27/30, 1844. GB. BFSP, Vol. 38, 631; Lagemans, Netherlands, Doc. no. 215.

1845; Nov. 26: Law (Royal Order). Government of the Netherlands. Governing Navigation; modifying Law of Nov. 1, 1845, respecting Addit. Art. 16. GB. BFSP, Vol. 38, 637; Lagemans, Netherlands, Doc. no. 216.

1846; May 30: Mainz. Convention. Baden, Bavaria, France, Hesse-Darmstadt, Nassau, Netherlands, Prussia. (Central Rhine Navigation Commission.) Promulgation of Eighteenth Additional Article; supplementing the Convention of Mainz; 


\section{Rhine}

March 31, 1831. Cussy/Martens, Rec. Man. V, 645; Martens, NRG, Ser. I, IX, 172.

1846; June 28: The Hague. Law (Royal Decree). Government of the Netherlands. Navigation Ordinance; observing stipulations of 18th Additional Article. GB. BFSP, Vol. 38, 637; Lagemans, Netherlands, Doc. no. 219.

1847; Aug. 17: Mainz. Protocol of Conference. Baden, Bavaria, France, Hesse-Darmstadt, Nassau, Netherlands, Prussia. (Session of the Central Rhine Commission.) Cussy/Martens, Rec. Man., VI, 161.

1847; Aug. 19/Sept. 3: Mainz. Convention. Baden, Bavaria, France, Hesse-Darmstadt, Nassau, Netherlands, Prussia. Additional Article, No. 19, revising the Convention of Mainz; March 31, 1831. Clercq, RTF, V, 556; Cussy/Martens, Rec. Man. VI, 318; Lagemans, Netherlands, III, Docs. No. 228b, No. 240.

1849; Oct. 11: The Hague. Law (Royal Decree). Government of the Netherlands. Additional Navigation Regulations; in conformity with 19th Additional Article of Aug. 19/Sept. 3, 1847. GB. BFSP, Vol. 38, 639; Lagemans, Netherlands, Doc. no. 240. 1850; Aug. 8: The Hague. (Royal Decree). Government of the Netherlands. Repealing the Transit \& Navigation Dues as Imposed by the Convention of Mainz, March 31, 1831; and Sanctioned by the Netherlands Royal Decree of June 28, 1831. GB. BFSP, Vol. 42, 1274; Hertslet, COM. TR, IX, 559 ; Lagemans, Netherlands, Vol. III, Doc. no. 244.

1852; Sept. 8: Mainz. Convention. Baden, Bavaria, France, Hesse-Darmstadt, Nassau, Netherlands, Prussia. (Central Rhine Commission.) Additional Article, No. 20, modifying the Convention of Mainz, March 31, 1831. Clercq, RTF, VI, 114; Lagemans, Netherlands, Vol. III, Dòc. no. 265a, no. 300.

1852; Nov. 11: The Hague. Law (Royal Decree). Netherlands. Promulgation of 20 th Additional Article; amplifying Art. 59 of Convention of Mainz, March 31, 1831. Lagemans, Netherlands, Doc. no. 300 .

1853; May 2: Berne. Convention. Bavaria/Switzerland. Navigation Regulations. Martens, NRG, Ser. I, XX, 112.

1853; July 29: Convention. Baden \& Switzerland. Providing for a Partial Suppression of Customs Duties \& for the Diminution of Navigation Tolls on the Upper Rhine. Cussy/Martens, Rec. Man., VII, 303.

1854; Oct. 20/31: Stuttgart/Zurich. Convention. Baden \& Switzer- 
land. Art. I, II : Protection \& Supervision of the Riverain Fisheries. Hertslet, Europe, 1219.

1856; Nov. 26: Mainz. Protocol of the Conference. Central Commission of Rhine Navigation. Clereq, RTF, VII, 189; GB. BFSP, Vol. 49, 1288.

1856; Nov. 29: Mainz. Convention. Baden, Bavaria, France, Hesse-Darmstadt, Nassau, Netherlands, Prussia. (Central Commission of Rhine Navigation.) Rectification of Navigable Channel between Bingen \& Mainz. Clercq, RTF, VII, 192; GB. BFSP, Vol. 49, 1297; Lagemans, Netherlands, Vol. IV, Doc. no. 359.

1857; Feb. 25: Carlsruhe. Convention. Baden/France. Supervision \& Rectification of Obstacles and Embankments. Clercq, RTF, VII, 214.

1857; July 2: Carlsruhe. Convention. Baden/France. Governing the Construction of Bridges over the Navigable Channel. Clercq, RTF, VII, 291.

1857; Nov. 16: Carlsruhe. Convention. Baden/France. Restrictions imposed on Construction of Bridge at Strassburg; specifications regarding precise elevation above river's highest level. Clercq, RTF, VII, 342.

1858; May 7: Mainz. Convention. Baden, Bavaria, France, Hesse-Darmstadt, Nassau, Netherlands, Prussia. Specifications imposed for Construction of Fixed Bridge at Cologne. Clercq, RTF, VII, 395.

1860; Apr. 3: Mainz. Convention. Baden, Bavaria, France, HesseDarmstadt, Nassau, Netherlands, Prussia. Regulating Construction of Permanent Bridge at Mainz. Clercq, RTF, VIII, 38.

1860; Apr. 3: Mainz. Convention. Baden, Bavaria, France, HesseDarmstadt, Nassau, Netherlands, Prussia. Additional Article, no. 21, amplifying the Convention of Mainz; Mar. 31, 1831. Rectification of the Navigable Channel between Bingen \& Mainz. Clercq, R'TF, VIII, 37; GB. BFSP, Vol. 50, 1084.

1860; Sept. 30: Carlsruhe. Convention. Baden/France. Restricting the Establishment of Ferries to 16 Specified Positions; 7 being exclusively controlled by the French, 9 under sole control of Baden. Clercq, RTF, VIII, 126; Martens, NRG, Ser. I, XVII, part 1, 275.

1864; May 23: The Hague. Law (Royal Decree). Netherlands. Regulating Police Supervision of Fluvial Navigation. Lagemans, Netherlands, Doc. no. 458. 


\section{Rhine}

1864; July 10: The Hague. Law. Government of the Netherlands. Police Regulations governing Fluvial Navigation. Lagemans, Netherlands, V, Doc. no. 459.

1866; Aug. 17: Berlin. Treaty. Baden \& Prussia. Art. IX: Navigation Dues Abolished to the extent that co-riverain states undertake similar action, simultaneously. Hertslet, Europe, $1707,1709$.

1866; Aug. 22 : Berlin. Treaty. Bavaria \& Prussia. Art. X: Transit Dues Abolished provided Co-riverain States undertake similar action. Hertslet, Europe, 1714.

1866; Sept. 3: Berlin. Treaty. Hesse-Darmstadt \& Prussia. Art. 12: Navigation Tolls Abolished from the date that other Germanic Riverain States Adopt Similar Measures. Hertslet, Europe, 1732.

1867; Sept. 22: Bregenz. Convention. Austria, Baden, Bavaria, Switzerland, Wurtemburg. Governing navigation of Lake Constance \& the upper course of the Rhine. Martens, NRG, Ser. I, XX, 117; Neumann, RTA, V, n. s., 255.

1867; Sept. 28: St. Gall. Convention. Baden \& Switzerland. Governing Navigation of the Rhine between Constance \& Schaffhausen. Cussy/Martens, Rec. Man., Ser. II, I, 441; Martens, NRG, Ser. I, XX, 139.

1868; Oct. 17: Mannheim. Convention. Baden, Bavaria, France, Hesse-Darmstadt, Netherlands, Prussia (including Hesse-Nassau.) Navigation Regulations; revising the Convention of Mainz, March 31, 1831, and the Twenty Additional Articles subsequently adopted. Clercq, RTF, X, 177; GB. BFSP, Vol. 59, 870 ; Hertslet, Europe, 1847, 1849; Lagemans, Netherlands, Vol. VI, Docs. nos. 510, 511, 512, 513; Martens, NRG, Ser. I, XX, 355 ; Martens, NRG, Ser. II, IV, 599, 613, 617; Sturdza, Rec. Doc., 575. (Commentary: BLUNTSCHLI, Droit Int., sec. 314, pg. 197; BONFILS, Droit Int., sec. 526, pg. 331; CLAPP, The Navigable Rhine, 16; ENGELHARDT, Hist. du Droit Fluv. Conv., 97; WESTLAKE, Int. Law, I, 153.)

1869; Nov. 27: Mannheim. Convention. Baden, Bavaria, France, Hesse-Darmstadt, Netherlands, Prussia (including Nassau.) Establishing Uniform Regulations for the Protection of Fisheries in the Rhine \& Tributary Waters. Lagemans, Netherlands, VI, Doc. no. 526.

1869 ; Dec. 9 : Berne. Convention. Baden \& Switzerland. Regulating Fisheries between Basle \& Constance. Martens, NRG, Ser. I, XX, 166. 
1871; Apr. 16: Berlin. Constitution. German Empire. Art. 54: Navigation of Inland Waterways. Dodd, Modern Constitutions, I, 343.

1871; Sept. 19: Vienna. Convention. Austria \& Switzerland. Rectification of the Navigable Channel. Martens, NRG, Ser. $\mathrm{I}, \mathrm{XX}, 171$.

1875; Mar. 25 : Basle. Convention. Baden \& Switzerland. Protection \& Regulation of Fisheries in the Rhine, its Tributary Waters, \& Lake Constance; followed by the Declarations of Nov. 30, 1875 \& Dec. 5, 1875. Martens, NRG, Ser. II, II, 60. 1877; July 14: Mulhausen. Convention. Alsace-Lorraine, Baden, Switzerland. Accession of Alsace-Lorraine to the Convention of Basle; March 25, 1875. Martens, NRG, Ser. II, II, 64.

1877; Sept. 4: Mannheim. Convention. Germany \& the Netherlands. Police Regulations; supplementary to the Convention of Mannheim, Oct. 17, 1868. Martens, NRG, Ser. II, IV, 618, 622.

1879; May 10: Basle. Convention. Baden \& Switzerland. Navigation Regulations effective between Basle \& Newhausen. Martens, NRG, Ser. II, IX, 593.

1885; June 30: Berlin. Convention. Riverain States: Baden, Bavaria, Hesse-Darmstadt, Netherlands, Oldenburg, Prussia, Switzerland, Wurtemburg. Regulating \& Protecting the Riverain Fisheries. Lagemans, Netherlands, Vol. IX, Doc. no. 698.

1887; May 18: Lucerne. Convention. Alsace-Lorraine, Baden, Switzerland. Guaranteeing Mutual Enjoyment of Riverain Fisheries. Martens, NRG, Ser. II, XIV, 350.

1887; Sept. 3: Mainz. Convention. Central Commission of Rhine Navigation. Providing Additional Police Supervision of Riverain Navigation. Lagemans, Netherlands, X, Doc. no. 718.

1892; Dec. 30: Treaty. Austria \& Switzerland. Rectification of Navigable Channel. GB. BFSP, Vol. 84, 690.

1894; May 31: Mannheim. Convention. Riverain States: Baden, Bavaria, Hesse-Darmstadt, Netherlands, Oldenburg, Prussia, Switzerland, Wurtemburg. Police \& Navigation Regulations. Lagemans, Netherlands, Supplement, XIII, Doc. no. 812.

1895; Sept. 18: Mannheim. Convention. Alsace-Lorraine, Baden, Bavaria, Hesse-Darmstadt, Netherlands, Prussia. Additional Article defining intention of Articles $32-40$ embodied in Convention of Mannheim; Oct. 17, 1868. GB. BFSP, Vol. 87, 788; Lagemans, Netherlands, Vol. XIII, Doc. no. 834; Martens, NRG, Ser. III, II, 796. 


\section{Rhine}

1897; May 29: Mainz. Convention. Central Commission of Rhine Navigation. Navigation Regulations. Lagemans, Netherlands, Vol. XIII, Doc. no. 860.

1898; June 4: Mannheim. Convention. Riverain States: Baden, Bavaria, Hesse-Darmstadt, Netherlands, Oldenburg, Prussia, Switzerland, Wurtemburg. Navigation Regulations. Lagemans, Netherlands, Vol. XIV, Doc. no. 882.

1902 ; Sept. 4: Mannheim. Convention. Riverain States: Restrictions imposed upon Transportation of Inflammable Materials. Lagemans, Netherlands, XV, Doc. no. 930.

1905; May 24: Mannheim. Convention. Riverain States: Restrictions governing Transportation of Explosives. Lagemans, Netherlands, XVI, Doc. no. 960.

1906; Sept. 14: Mannheim. Convention. Riverain States: Police Supervision \& Equipment of Vessels. Lagemans, Netherlands, XVI, Docs. nos. 981, 982, 983.

1908; Nov. 17: Convention. Baden \& Switzerland. Protection of Fisheries; revising Stipulations of Treaty of July 3, 1897. Martens, NRG, Ser. III, IV, 875.

\section{RHINE-RHONE CANAL}

1871; May 10: Frankfort. Treaty. France \& Germany. Arts. I, $V$; Regulating Navigation \& Providing for Maintenance. Hertslet, Europe, 1955-57; Martens, NRG, Ser. I, XIX, 688.

1871; Dec. 11: Frankfort. Convention. France/Germany. Supplementing Provisions embodied in Treaty of Frankfort; May 10, 1871. Art. XIV : Appointment of Commissioners entrusted with Regulating Navigation. Hertslet, Europe, 1968, 1970.

\section{RHINE-SCHELDT CONNECTING WATERWAYS}

1831; Nov. 15: London. Treaty. Austria-Hungary, Belgium, France, Great Britain, Prussia, Russia. Art. IX: Reciprocal Freedom of Navigation of Waterways forming or traversing the International Frontier. Art. X: Exclusive Use of Canals. Cussy/Hauterive, RTC, I, pt. 2, 283; Hertslet, COM. TR., IV, 31; Hertslet, Europe, 864.

1839 ; April 10 : London. Convention. Belgium/Netherlands.

Apr. 19 : London. Treaty. Austria-Hungary, Belgium, France, Great Britain, Netherlands, Prussia, Russia. Art. IX: Reciprocal 
Rhine-Scheldt Waterways

Freedom of Navigation. Clercq, RTF, IV, 470-477; Cussy/Martens, Rec. Man., IV, 575; Hertslet, COM. TR., V, 354, 359; Hertslet, Europe, 987-998; Neumann, RTA, IV, 416, 421; Sturdza, Rec. Doc. 854, 855.

1842 ; Nov. 5: The Hague. Treaty. Belgium/Netherlands. Arts. 38-49: Navigation Regulations. Hertslet, Europe, 1029; Martens, NRG, Ser. I, III, 622 ; Sturdza, Rec. Doc. 862.

1843; May 20: Antwerp. Convention. Belgium/Netherlands. Composing Fluvial Disputes; Protection of Fisheries in Communal Waters; Navigation Regulations. Cussy/Martens, Rec. Man. V, 306; Martens, NRG, Ser. I, V, 294, 307, 339, 381; Moniteur Belge, 1842/1843.

1843; Aug. 8: Maastricht. Convention. Belgium \& the Netherlands. Arts. 12-13: Protection \& Mutual Enjoyment of the Fisheries. Arts. 35-36: Navigation Regulations. GB. BFSP., Vol. 35, 1202, 1220-21; Hertslet, Europe, 1031.

1851; Oct. 3: The Hague. Agreement. Belgium \& the Netherlands. Regulations governing the Periodic Closure of Rivers \& Canals rendering access between the Contracting Powers. Lagemans, Netherlands, Vol. III, Doc. no. 269.

RHINE-WESER CANAL

1871; Apr. 16: Berlin. Constitution. German Empire. Art. 54: Navigation of Inland Waterways. Dodd, Modern Constitutions, I, 343.

1906; Mar. 29: Berlin. Treaty. Bremen \& Prussia. Maintenance

\& Navigation Regulations. Martens, NRG, Ser. III, I, 336.

1906; Oct. 19/30: Berlin. Treaty. Prussia \& Schaumburg-Lippe.

Administration of the Canal. Martens, NRG, Ser. III, I, 339.

1911; Mar. 1/13: Berlin. Agreement. Prussia \& SchaumburgLippe. Supplementing the Stipulations of the Treaty of Berlin; Oct. 19/30, 1906. Martens, NRG, Ser. III, VII, 889.

RHONE

1760; Mar. 24: Turin. Treaty. France/Sardinia. Arts. 12, 13, 14:

Reciprocal Freedom of Navigation. Cussy/Hauterive, RTC,

III, 281. (Commentary: NYS, Droit Int., I, 476.)

1815; Mar. 29: Vienna. Treaty. Included in Annex XII of the

Final Act. Art. I: Thalweg Boundary. Hertslet, Europe, 70.

1815; May 20: Vienna. Treaty. Austria, France, Great Britain, Prussia, Russia, Sardinia. Annex B. B.; Art. I: Thalweg

Boundary. Hertslet, Europe, 164.

1815; June 9: Vienna. Treaty. Austria, France, Great Britain, 


\section{Rhone}

Portugal, Prussia, Russia, Spain, Sweden. Art. 80; Art. 118, sec. 12; Annex 12: Boundary. Hertslet, Europe, 80, 257, 273, 275.

1815; Nov. 3: Paris. Agreement. Austria, Great Britain, Prussia, Russia. Art. IV: Boundary. Hertslet, Europe, 328.

1815; Nov. 20: Paris. Treaty. Austria, France, Great Britain, Prussia, Russia. Art. III : Boundary. Hertslet, Europe, 347. 1816; Mar. 16: Turin. Treaty. Geneva, Sardinia, Switzerland. Art. I: Boundary. Hertslet, Europe, 423-24.

1819; July 20: Frankfort. Treaty. Austria, Great Britain, Prussia, Russia. Art. 41: Thalweg Boundary. Hertslet, Europe, 610-11.

1880; Dec. 28: Paris. Convention. France/Switzerland. Chapter II; Art. XI: Supervision of Fisheries in Affluents of Lake Geneva (Leman); notably the Rhone. Clercq, RTF, XII, 619; Hertslet, Europe, 3252; Martens, NRG, Ser. II, IX, 111. 1884; Dec. 9: Paris. Convention. France/Switzerland. Protection of Fisheries in the Affluents of Lake Leman (Geneva); revising Convention of Paris, Dec. 28, 1880. Clereq, RTF, XIV, 428.

1888; Apr. 14: Berne. Agreement. France/Switzerland. Supervision of Fisheries in Frontier Waters; abrogating Arrangement of Dec. 9, 1884; modifying Convention of Paris, Dec. 28, 1880. France, Journal Officiel, Sept. 1, 1888; Hertslet, Europe, 3280; Martens, NRG, Ser. II, XIV, 410.

1891; Mar. 12: Berne. Convention. France/Switzerland. Regulation of Fisheries in Boundary Waters; revising certain stipulations of Convention of Paris, Dec. 28, 1880. Clercq, RTF, XIX, 62; Martens, NRG, Ser. II, XVIII, 238.

1891; July 30 : Berne. Agreement. France/Switzerland. Governing Fisheries in Frontier Waters. Clereq, RTF, XIX, 250; Martens; NRG, Ser. II, XVIII, 848; XXI, 24.

1904; March 9: Paris. Convention. France/Switzerland. Regulating Fisheries. Martens, NRG, Ser. II, Vol. 33, 501.

1909; Jan. 20: Lausanne. Agreement. France/Switzerland. Fisheries Regulations; revising Convention of Paris, March 9, 1904. Martens, NRG, Ser. III, V, 318, 319. 
Portugal, Prussia, Russia, Spain, Sweden. Art. XV: Boundary. Hertslet, Europe, 223.

1816; Apr. 14: Munich. Treaty. Austria \& Bavaria. Art. IX: Renewal of Former Stipulations governing Mutual Utilization; Adoption of the Principles embodied in the Final Act of the Congress of Vienna concerning Freedom of Navigation. Cussy/Hauterive, RTC, I, pt. 2, 51; Hertslet, Europe, 439; Martens, NRT, III, 15 ; Martens, RT. SUPPL., VII. (Commentary: MOORE, Int. Arb., 4853.)

1831; May 17: Treaty. Anhalt-Bernburg \& Prussia. Concerning Imposition of Navigation Tolls. Cussy/Martens, Rec. Man. IV, 321; Martens, NRT, IX, 361.

\section{SALZA; or SAIZACH}

1779; May 13: Teschen. Convention. Austria \& Bavaria (The Elector Palatine). Art. V: Reciprocal Freedom of Navigation. Hertslet, Europe, Vol. III, 2012; Martens, RPT, II, 671; Neumann, RTA, I, 243-44. (Commentary: ENGELHARDT, Du Rég. Conv., 257.)

1784; Aug. 31: Munich. Treaty. Austria \& Bavaria. Art. IV: Reciprocal Freedom of Navigation in conformity with Art. V. of the Convention of Teschen; May 13, 1779. Art. X: Exclusive Enjoyment of Fisheries on Respective Sides of Thalweg. Cussy/Hauterive, RTC, I, pt. 2, 48.

1816; Apr. 14: Munich. Treaty. Austria \& Bavaria. Art. IX: Renewal of Former Stipulations ensuring Mutual Enjoyment; Adoption of the Principles concerning Freedom of Navigation embodied in the Final Act of the Congress of Vienna. Cussy/Hauterive, RTC, pt. 2, 51; Hertslet, Europe, 439; Martens, NRT, III, 15; Martens, RT. SUPPL., VII.

1851; Dec. 2: Vienna. Treaty. Austria \& Bavaria. Art. 1-17: Reciprocal Freedom of Navigation. Neumann, RTA, 448-54. 1873; Feb. 9: Convention. Austria \& Bavaria. Demarcation of Fluvial Boundary. GB. BFSP, Vol. 65, 1293.

\section{SAMBRE}

1675; Oct. 25: Château Freyr-sur-Meuse. Treaty. France \& the Spanish Netherlands. (Holland acceded on Dec. 17, 1675.) Art. I: Reciprocal Freedom of Fluvial Transportation for the Subjects of France, Holland, \& the Spanish Netherlands; except for Prohibited Articles of Contraband, as Firearms \& similar Munitions of War. Cussy/Hauterive, RTC, I, pt. 1, 226. 


\section{Sambre}

1820; Mar. 28: Courtrai. Treaty. France/Netherlands. Art. I: Fluvial Boundary. Hertslet, Europe, 625.

SAN

1864; Aug. 20: Cracow. Treaty. Austria-Hungary \& Russia. Rectification of the Navigable Channel where forming International Boundary. GB. BFSP, Vol. 65, 333, 339; Hertslet, Europe, 3216; Martens, NRG, Ser. I, XX, 288; Neumann, RTA, III, n. s., 485.

1871; May 27: Agreement. Austria-Hungary \& Russia. Regulation of Navigable Course. GB. BFSP, Vol. 65, 339.

\section{SARATSIKA}

1857; Jan. 6: Paris. Protocol. Austria-Hungary, France, Great Britain, Prussia, Russia, Sardinia, Turkey. Bessarabian Boundary; Thalweg. Hertslet, Europe, 1299.

\section{SARRE}

1773; Oct. 29: Convention. France \& Elector of Trèves. Mutual Liberty of Navigation. (Commentary: NYS, Droit Int., I, 476.) 1815; June 9: Vienna. Treaty. Austria, France, Great Britain, Portugal, Prussia, Russia, Spain, Sweden. Art. 25: Fluvial Boundary. Hertslet, Europe, 229.

1815; Nov. 20: Paris. T'reaty. Austria, France, Great Britain, Prussia, Russia. (Spain adhered to this Convention; June 8, 1817.) Art. I: Fluvial Boundary. Hertslet, Europe, 344.

1819; July 20: Frankfort. Treaty. Austria, Great Britain, Prussia,

Russia. Art. 13: Boundary. Hertslet, Europe, 597.

1827; June 11: Paris. Agreement. France \& Prussia. Art. V: Fluvial Boundary. Hertslet, Europe, 768.

1829 ; Oct. 23; Sarrebruck. Convention. France \& Prussia. Art. 12: Mutual Enjoyment of Fisheries. Hertslet, Europe, 837.

\section{SARRE CANAI}

1861; Apr. 4: Paris. Convention. France \& Prussia. Arts. I-V: Providing for the Construction, Maintenance, \& Reciprocal Enjoyment of Navigation of the Canal. Cussy/Martens, Rec. Man., Ser. II, I, 160.

1871; May 10: Frankfort. Treaty. France \& Germany. Art. V': Regulating Navigation \& Providing for Maintenance. Hertslet, Europe, 1955, 1957; Martens, NRG, Ser. I, XIX, 688.

1871; Dec. 11: Frankfort. Convention. France/Germany. Supplementing Stipulations embodied in Treaty of Frankfort; May 10, 1871. Art. 14: Appointment of Commissioners entrusted 
with Regulating \& Maintaining Navigation. Hertslet, Europe, 1968, 1970.

\section{SAVE}

1739; Sept. 18: Belgrade. Treaty. Austria \& Turkey. Art. 7 : Supervision of Fluvial Fisheries. Cussy/Hauterive, RTC, I, pt. $2,114$.

1882; Feb. 10/22: Belgrade. Convention. Austria/Servia. Arts. I-XXVII: Regulating Reciprocal Enjoyment of Navigation. GB. BFSP, Vol. 73, 519; Neumann, RTA, XI, 144.

\section{SCHELDT; or ESCAUT}

1212; Feb. 24: Breda. Treaty. Brabant \& Breda. Imposition of Tolls upon Vessels en route to Scaldam at Stryne in Zealand. RT. PAIX, Vol. I, 51.

1648; Jan. 30: Münster. Treaty. (Peace of Westphalia.) Spain \& the United Provinces. Recognized the Independent Dominion of the United Provinces on both Banks of the lower Scheldt. Art. 14: Confirmed the Right of the Provinces to prohibit the Navigation by Foreign Vessels on the Scheldt \& all Affluents, including the Sas \& Zwin Canals. Cussy/Hauterive, RTC, Vol. III, 3; Dumont, Corps Univ. Dipl., VI, pt. 1, pg. 429; Koch/ Schoell, Hist. Abr. Tr., Vol. I, 168; Vol. IV, 60; Martens, RPT, VI, 146. (Commentary: HALLECK, Int. Law, I, 187; OPPENHEIM, Int. Law, I, 227; RIVIER, Prin. du Droit des Gens, I, 222; TWISS, Law of Nations (Peace), 233; WHEATON, Elem. Int. Law, (Lawr. Edit.), Chap. IV, sec. 15.) 1785; Sept. 20: Paris. Treaty. Austria/Netherlands. Art. 6, Art. 15: Renewed Stipulations of Art. 14 of the Treaty of Münster, Jan. 30, 1648, recognizing the Exclusive Sovereignty of the United Provinces over the Scheldt from Saftigen to the Sea. Martens, RPT, II, 598-601. (Commentary: ENGELHARDT, Hist. du Droit Fluv. Convent., 47; WESTLAKE, Int. Law, I, 148.)

1785; Nov. 8: Fontainebleau. Treaty. Austria/Netherlands. Art. II: Renewal of Stipulations embodied in Treaty of Münster; Jan. 30, 1648. Art. 7: Recognition by Joseph II of Validity of Dutch Claim to Exclusive Enjoyment. Koch/Schoell, Hist. Abr. Tr., IV, 80; Martens, RPT, II, 602-608.

1792 ; Nov. 20: Antwerp. Law. Decree of the Provisional Executive Council. Abrogating the Restrictions imposed by the Barrier Convention; Treaty of Münster, Jan. 30, 1648. Proclaiming Freedom of Fluvial Navigation. Koch/Schoell, Hist. Abr. 


\section{Scheldt}

Tr., IV, 218. (Commentary: ENGELHARDT, Hist. du Droit Fluv. Conv., 50.)

1795; May 16: The Hague. Treaty. France/Netherlands. Art. 18:

Established Freedom of Navigation for the Vessels of the Contracting States \& those Nations friendly to them upon the Hondt, Meuse, Rhine, \& Scheldt. Cussy/Hauterive, RTC, II, Pt. 1, 373; Koch/Schoell, Hist. Abr. Tr., IV, 293; Martens, RPT, $\mathrm{V}, 532$.

1814; May 30 : Paris. Treaty. Austria, France, Great Britain, Portugal, Prussia, Russia, Spain, Sweden. Separate, Secret Art. III: Providing for the Establishment of Freedom of Navigation. Hertslet, Europe, 19; Neumann, RTA, II, 474; Sturdza, Rec. Doc., pg. 1. (Commentary: ENGELHARDT, Hist. du Droit Fluv. Conv., 64, 77.)

1815 ; Mar. 20: Vienna. Treaty. Formed Annex XVI of the Final Act. Clercq, RTF, II, 463; Hertslet, Europe, 78, 91; Martens, NRT, II, 447.

1815 ; June 9 : Vienna. Final Act of the Congress. Liberty of Navigation. Cussy/Hauterive, RTC, I, pt. 1, 72-96; GB. BFSP, II, 178; Hertslet, COM. TR., I, 3, 41; Hertslet, Europe, 272276; Neumann, RT $\Lambda, \Pi, 673$; Sturdza, Rec. Doc., 2-4. (Commentary: MOORE, ILD, I, 628.)

1820; Mar. 28: Courtrai. Treaty. France/Netherlands. Art. I: Boundary. Hertslet, Europe, 625.

1831; Nov. 15: London. Treaty. Austria-Hungary, Belgium, France, Great Britain, Prussia, Russia. Providing for the Separation of Belgium from the Kingdom of the Netherlands. Art. 9: Reciprocal Freedom of Navigation, subject only to Equitable Tolls, in conformity with Arts. 108-117 of the Final Act of the Congress of Vienna. Cussy/Hauterive, RTC, I, pt. 2, 282-83; Hertslet, COM. TR., IV, 13, 26, 31; Hertslet, Europe, 863-64.

1833 ; May 21: London. Convention. France, Great Britain, Netherlands. Art. III; Explanatory Art.: Pending Definitive Treaty between the Netherlands \& Belgium Complete Freedom of Navigation Continues. GB. BFSP, XX, 282; Hertslet, COM. TR., IV, 353, 355-56; Hertslet, Europe, 921-23.

1833; June 1: Notification. Tendered by the British \& French Governments. Concerning Adherence of Belgium to Convention of London; May 21, 1833. Hertslet, COM. TR., V, 21.

1833; June 10: Brussels. Note. Belgian Government. Accession of Belgium to the Convention of May 21, 1833. Hertslet, COM. TR., 23 ; Hertslet, Europe, 924. 
1839 ; Apr. 10: London. Treaty. Belgium/Netherlands.

Apr. 19: London. Convention. Austria-Hungary, Belgium, France, Great Britain, Netherlands, Prussia, Russia. Art. IX:

Mutual Liberty of Navigation. Clercq, RTF, 470-77; Cussy/ Martens, Rec. Man., Ser. I, IV, 573-77; Hertslet, COM. TR., V, 354, 359 ; Hertslet, Europe, 986-98; Neumann, RTA, IV, 416, 421; Sturdza, Rec. Doc., 854-55.

1839 ; June 5 : Brussels. Law. Belgian Government. Reimbursement of Navigation Tolls imposed by the Dutch Government. GB. BFSP, Vol. 37, 1352; Hertslet, COM. TR., V, 31.

1839; Oct. 23: Antwerp. Provisional Agreement. Belgium \& the Netherlands. Police \& Navigation Regulations. Lagemans, Netherlands, II, Docs. no. 174 , no. 175.

1842; Nov. 5: The Hague. Treaty. Belgium/Netherlands. Arts. 16-19 : Freedom of Navigation. GB. BFSP, Vol. 31, 815; Hertslet, Europe, 1029; Martens, NRG, Ser. I, III, 613, 617, 622; Sturdza, Rec. Doc., 856, 862.

1843; May 20: Antwerp. Convention. Belgium \& the Netherlands. Police \& Navigation Regulations, supplementing Provisional Agreement of Oct. 23, 1839. Cussy/Martens, Rec. Man., V, 306 ; GB. BFSP, Vol. 37, 1848-49 ; Martens, NRG, Ser. I, V, 29495, 307, 332, 334, 339, 381. Sturdza, Rec. Doc., 867.

1843; Aug. 8: Maastricht. Convention. Belgium \& the Netherlands. Arts. 12-13: Protection of Fisheries. Arts. 35-36: Navigation Regulations. GB. BFSP, Vol. 35, 1202, 1220-21; Hertslet, Europe, 1031.

1845; Nov. 10: Brussels. Treaty. Belgium \& the United States. Art. IV: Restitution by the Belgian Government of Tolls imposed by the Netherlands upon Vessels of the United States. Malloy, UST, 65. (NOTE: Terminated by Notice from Belgian Government; August 20, 1858.)

1846; July 29: The Hague. Treaty. Belgium/Netherlands. Arts. 1-29 \& Annex: Navigation Regulations. Martens, NRG, Ser. I, Vol. IX, 273-292.

1851; Oct. 3: The Hague. Agreement. Belgium \& the Netherlands. Regulating Annual Chômage of Waterways communicating between the Contracting Parties. Lagemans, Netherlands, III, Doc. no. 269.

1851; Oct. 27: London. Treaty. Belgium/Great Britain. Art. 7: Providing for Restitution by the Belgian Government of Transit Dues levied by the Netherlands upon British Merchant-Vessels. 


\section{Scheldt}

Hertslet, COM. TR., IX, 143. (NOTE: Terminated by Notice

from Belgian Government; Sept. 9, 1862.)

1862; July 23: London. Treaty. Belgium/Great Britain. Arts. 20-21: Abolition of Belgian Tonnage Dues; Reduction of Pilotage Charges; Identical Treatment respecting Remission of Tolls imposed by the Netherlands. Hertslet, COM. TR., XI, 71.

1863; May 12 : The Hague.' Treaty. Belgium/Netherlands. Redemption of the Scheldt Toll; stipulating amount agreed upon for Capitalization. Cussy/Martens, Rec. Man., Ser. II, I, 277; GB. BFSP, Vol. 53, 15; Hertslet, Europe, 1533; Lagemans, Netherlands, V, Doc. no. 434. (Commentary: SCHUYLER, Am. Dipl., 349-50).

1863; May 20: Brussels. Convention. Belgium \& the United States. Arts. 1-6: Redemption of Scheldt Tolls. Malloy, UST, 73.

1863; June 8: Agreement. Belgium \& Hanover. Abolition of Scheldt Dues. GB. BFSP, Vol. 53, 255.

1863; June 13: Brussels. Law. Belgian Government. Concerning

Negotiation of Treaty with Maritime Powers for the Extinction of the Scheldt Dues. GB. BFSP, Vol. 60, 43.

1863; July 15: Brussels. Agreement. Belgium \& the Netherlands. Governing Reduction of Pilotage Charges. GB. BFSP, Vol. 53, 230 ; Martens, NRG, Ser. II, I, 127.

1863; July 15: Brussels. Notification. Netherlands. Explanatory Statement issued by the Minister of the Netherlands. GB. BFSP, Vol. 53, 16; Hertslet, Europe, 1557.

1863; July 16 : Brussels. Treaty. Austria-Hungary, Belgium, Brazil, Bremen, Chile, Denmark, France, Great Britain, Hamburg, Hanover, Italy, Lubeck, Mecklenburg-Schwerin, Netherlands, Oldenburg, Peru, Portugal, Prussia, Russia, Spain, Sweden \& Norway, Turkey. Redemption of Scheldt Tolls. Annex I: Stipulations provided by the Treaty of The Hague, May 12, 1863, between Belgium \& the Netherlands. Clercq, RTF, VIII, 600; Cussy/Martens, Rec. Man., Ser. II, I, 275; GB. BFSP, Vol. 53, 8; Hertslet, COM. TR., XI, 1097; Hertslet, Europe, 1550, 1557; Lagemans, Netherlands, V, Docs. no. 437 , no. $437^{\mathrm{b}}$; Martens, NRG., XVII, pt. 2, 223, 235.

1863; July 20: Brussels. Treaty. Belgium \& the United States. Arts. 1-6: Extinguishment of the Scheldt Dues. GB. BFSP, Vol. 54, 1131; Malloy, UST, 75-76.

1863; Aug. 3: Brussels. Convention. Belgium \& Great Britain. Regulating Mode of Payment for Redemption of Navigation Tolls. GB. BFSP, Vol. 53, 17; Hertslet, COM. TR., XI, 1103; Hertslet, Europe, 1561; Martens, NRG, Ser. II, I, 111. 
1863; Aug. 11: Brussels. Agreement. Belgium \& the Netherlands. Tariff of Pilotage Charges. GB. BFSP, Vol. 53, 233.

1863; Aug. 11: Brussels. Notification. Belgian Government. Respecting the Participation of the Netherlands in the Advantages stipulated by Art. III of the Treaty of Brussels; June 16, 1863. Martens, NRG, Ser. II, I, 128.

1863; Sept. 19: The Hague. Convention. Belgium \& the Netherlands. Agreement upon Pilotage \& Navigation Regulations in conformity with Art. $\nabla$ of Treaty of The Hague; May 12, 1863. Lagemans, Netherlands, Vol. V, Doc. no. 440; Martens, NRG, Ser. II, I, 126.

1863; Sept. 29: Convention. Belgium \& the Netherlands. Reduction of Pilotage Charges. GB. BFSP, Vol. 53, 229; Hertslet, Europe, 1556.

1864; Sept. 8/20: Athens. Convention. Belgium/Greece. Arrangement for the Extinction of Scheldt Toll. Martens, NRG, Ser. II, I, 113.

1864; Sept. 28: Brussels. Treaty. Belgium/Greece. Mode of Payment for the Redemption of the Toll. GB. BFSP, Vol. 54, 949; Hertslet, Europe, 1556, note.

1864; Oct. 23/Nov. 4: Athens. Additional Agreement. Belgium \& Greece. Supplementing Convention of Athens; Sept. 8/20, 1864. Martens, NRG, Ser. II, I, 114.

1865; Dec. 26: Antwerp. Agreement. Belgium/Netherlands. Respecting Lighting \& Marking of Navigable Channel. Martens, NRG, Ser. II, I, 131.

1866; Mar. 21: The Hague. Convention. Belgium \& the Netherlands. Establishment of Additional Lighthouses in Estuary \& throughout Navigable Course. Martens, NRG, Ser. II, I, 130. 1868; Oct. 2: Accession of the Argentine Confederation to Treaty of Brussels; July 16, 1863. GB. BFSP, Vol. 62, 649.

1870; Mar. 18: Berlin. Treaty. Belgium \& Mecklenburg-Schwerin. Arrangement for Redemption of Scheldt Toll. Martens, NRG, Ser. II, I, 115.

1870; June 14: Quito. Convention. Belgium/Ecuador. Capitalization of the Scheldt Toll. Martens, NRG, Ser. II, I, 116.

1870; Dec. 23: Berlin. Additional Agreement. Belgium \& Mecklenburg-Schwerin. Amplifying Treaty of Berlin, March 18, 1870, governing Redemption of Toll. Martens, NRG, Ser. II, I, 116. 1873; Apr. 10: Flushing. Convention. Belgium \& the Netherlands. Modification of Pilotage Regulations; relieving certain types of vessels from the necessity of employing pilots. GB. BFSP, Vol. 65, 507; Martens, NRG, Ser. II, I, 130. 


\section{Scheldt}

1873; May 8: Antwerp. Additional Article. Belgium \& the Netherlands. Modifying Convention of The Hague, March 31, 1866, respecting adequate lighting of navigable channel. Martens, NRG, Ser. II, I, 135.

1873; Aug. 2: The Hague. Convention. Belgium \& the Netherlands. Revising Pilotage Regulations; establishing additional lighthouses in Estuary \& along Navigable Course. Martens, NRG, Ser. II, 129, 134.

1875; June 29 : Antwerp. Convention. Belgium \& the Netherlands. Pilotage Regulations; relieving vessels which secure pilots in the English Channel or Straits of Dover for Riverain Ports from all Additional Charges. GB, BFSP, Vol. 66, 242; Martens, NRG, Ser. II, I, 224.

1875; Sept. 29: The Hague. Treaty. Belgium \& the Netherlands. Pilotage Regulations. Martens, NRG, Ser. II, I, 223.

1876; Apr. 7: Convention. Belgium \& Netherlands. Amplification of Pilotage Regulations. GB. BFSP, Vol. 67, 81.

1880; June 11: Brussels. Agreement. Belgium \& the Netherlands. Rectification of Navigable Channel; Emplacement of Additional Beacons. Martens, NRG, Ser. II, VIII, 157, 161.

1881; Feb. 9 : The Hague. Convention. Belgium \& the Netherlands. Perfection \& Completion of the Buoying of the Navigable Course. Martens, NRG, Ser. II, VIII, 156, 160.

1884; Apr. 3: The Hague. Agreement. Belgium \& the Netherlands. Navigation Regulations; revising stipulations of Convention of Antwerp; May 20, 1843. GB. BFSP, Vol. 75, 321; Hertslet, Europe, 3258.

1891; Mar. 25/Nov. 30 : Flushing. Agreement. Belgium \& the Netherlands. Police \& Navigation Regulations. Lagemans, Netherlands, Vol. XI, Doc. no. 758.

1901; Mar. 23: The Hague. Convention. Belgium \& the Netherlands. Protection of Navigation. Deschamps/Renault, RIT, (XXe Siècle), pg. 30, 31.

1904; Oct. 27: Flushing. Convention. Belgium \& the Netherlands. 1905 ; Apr. 5 : Establishment of Additional Beacons \& Buoys throughout Navigable Course. Lagemans, Netherlands, XVI, Doc. no. 958; Martens, NRG, Ser. II, Vol. 34, 579.

1907; Apr. 30/Oct. 8: The Hague. Agreement \& Confirmatory Convention. Belgium/Netherlands. Improvement of Lighting \& Buoying Facilities along Navigable Channel. GB. BFSP, Vol. 100, 861; Martens, NRG, Ser. III, I, 893.

1908; Sept. 18: Brussels. Law (Royal Decree). Belgian Govern- 
ment. Sanitary Regulations applicable to Vessels arriving at Antwerp. GB. BFSP, Vol. 101, 697.

\section{SCHWALB}

1825 ; July 5 : Paris. Convention. Bavaria/France. Art. I: Fluvial Boundary. Hertslet, Europe, 727.

1825 ; Dec. 9 : Weissenburg. Convention. Bavaria \& France. Art. I:- Boundary between France \& Rhenish Bavaria. Hertslet, Europe, 736.

\section{SCHWARZE-ELSTER; or SCHWARZ-WASSER-ELSTER}

1815; May 18: Vienna. Treaty. Austria, Prussia, Russia, Saxony. Art. 17: Freedom of Navigation; adopting Principles embodied in Annex XVI of Final Act of the Congress. Hertslet, Europe, 141.

1815; June 9: Vienna. Final Act of the Congress. Art. XV: Boundary. Hertslet, Europe, 222.

\section{SCUTARI LAKE}

1878; July 13: Berlin. Treaty. Austria-Hungary, France, Germany, Great Britain, Italy, Russia, Turkey. Art. 29: Enjoyment of Navigation reserved exclusively for the two adjacent Nations. Hertslet, Europe, 2783.

\section{SEMOY}

1779; Nov. 18: Brussels. Treaty. France/Hungary. Art. 30: Facilitating Navigation of Semoy \& Meuse. Hertslet, Europe, 2012. 1785; Nov. 8: Fontainebleau. Treaty. Austria \& the Netherlands. Protection \& Regulation of Navigation. Hertslet, Europe, 2016; Koch/Schoell, Hist. Abr. Tr., IV, 80; Martens, RPT, II, 602608.

1820; Mar. 28: Courtrai. Treaty. France/Netherlands. Art. 41: Freedom of Navigation; Administration of Works for Rectification of Navigable Channel; Thalweg Boundary. Cussy/Hauterive, RTC, I, pt. 1, 242 ; Hertslet, Europe, 626.

\section{SPREE}

1815; June 9: Vienna. Final Act of the Congress. Art. XV: Boundary. Hertslet, Europe, 222.

\section{SQUINCIO LAKE}

1844; Nov. 28: Florence. Treaty. Austria, Lucea, Modena, Sardinia, Tuscany. Arts. 4, 9: Constitutes Portion of International Boundary. Hertslet, Europe, 1052, 1055. 


\section{Stecknitz Canal}

1815; June 9: Vienna. Final Act of the Congress. Art. 30: Freedom of Navigation accorded by Prussia to Hanoverian Subjects. Hertslet, Europe, 234; Martens, NRT, II, 399.

1847; June 23: Copenhagen. Treaty. Denmark/Lubeck. Art. 12 : Respecting Obstruction to Navigation; Construction of Bridges over the Canal. Martens, NRG, Ser. I, Vol. X, 600, 608.

\section{STYR}

1829; July 10: Radziwilow. Treaty. Austria \& Russia. Art. 3: Fluvial Boundary. Hertslet, Europe, 810.

\section{SURE}

1815; June 9: Vienna. Final Act of the Congress. Art. 68: Boundary. Hertslet, Europe, 252.

1831: Nov. 15: London. Treaty. Austria, Belgium, France, Great Britain, Prussia, Russia. Art. II: Thalweg Boundary. Hertslet, Europe, 860.

1839; Apr. 19: London. Convention. Austria-Hungary, Belgium, France, Great Britain, Netherlands, Prussia, Russia. Art. II \& Annex: Thalweg Boundary; supplanting stipulations of Treaty of London; Nov. 15, 1831. Hertslet, Europe, 983-998.

\section{TAGLIATA}

1849; Aug. 8: Milan. Treaty. Austria \& Modena. Art. II: Fluvial Boundary. Hertslet, Europe, 1114.

\section{TAGUS}

1829; Aug. 31: Madrid. Treaty. Portugal \& Spain. Reciprocal Freedom of Navigation. GB. BFSP, Vol. 49, 1345.

1866; Apr. 27: Lisbon. Treaty. Portugal/Spain. Art. 6: Police \& Navigation Regulations Facilitating Fluvial Transit. Olivart, Colecc. Tratados, IV, 240-44.

1872; Dec. 20 : Lisbon. Treaty. Portugal/Spain. Art. 16: Coasting Trade Forbidden; Freedom of Navigation Confirmed. Olivart, Col. Trat., VII, 315.

1885; Oct. 2: Madrid. Treaty. Portugal/Spain. Art. 55: Reciprocal Freedom of Navigation. Olivart, Colecc. Tratados, VIII, $529,551$.

\section{TARTARES}

1868; July 11: Bayonne. Convention. France/Spain. Art. III, sec. 2: Regulating Use of Waters. Hertslet, Europe, 1844; Olivart, Colecc. Tratados, IV, 310-11. 
TERNEUZEN; or GHENT CANAL

1831; Nov. 15: London. Treaty. Austria, Belgium, France, Great Britain, Prussia, Russia. Art. 10: Mutual Freedom of Canal Navigation. Cussy/Hauterive, RTC, I, pt. 2, 283; Hertslet, COM. TR., IV, 13, 26, 31; Hertslet, Europe, 864.

1839 ; Apr. 10 : London. Treaty. Belgium/Netherlands.

Apr. 19: London. Convention. Austria-Hungary. Belgium, France, Great Britain, Netherlands, Prussia, Russia. Art. IX \& Annex: Reciprocal Freedom of Canal Navigation. Clercq, RTF, 470-77; Cussy/Martens, Rec. Man., Ser. I, IV, 573-77; Hertslet, COM. TR., V, 354, 359; Hertslet, Europe, 986-98; Neumann, RTA, IV, 416, 421; Sturdza, Rec. Doc., 854-55.

1842; Nov. 5: The Hague. Treaty. Belgium/Netherlands. Arts. 4, 5, 6, 20-49: Navigation Regulations. GB. BFSP, Vol. 31, 815; Hertslet, Europe, 1029; Martens, NRG, Ser. I, III, 613, 617, 619, 622 ; Sturdza, Rec. Doc., 856-57; 862.

1843; May 20: Antwerp. Convention. Belgium \& the Netherlands. Police \& Navigation Regulations. Cussy/Martens, Rec. Man, V, 306; Martens, NRG, Ser. I, V, 294-95, 307, 332, 334, 339, 367, 381 ; Sturdza, Rec. Doc., 867.

1843 ; Aug. 8: Maastricht. Convention. Belgium \& the Netherlands. Navigation Regulations. GB. BFSP, Vol. 35, 1202, 1220-21; Hertslet, Europe, 1031.

1851; Apr. 24: The Hague. Convention. Belgium \& the Netherlands. Modifying Provisions of the Treaty of Antwerp, May 20, 1843, governing Navigation. Lagemans, Netherlands, III, Doc. no. 257.

1851; Oct. 3: The Hague. Agreement. Belgium \& the Netherlands. Regulating Annual Closure of Waterways communicating between the Contracting Parties. Lagemans, Netherlands, III, Doc. no. 269.

1853; Feb. 10: The Hague. Convention. Belgium \& the Netherlands. Providing Additional Navigation Regulations. Lagemans, Netherlands, IV, Doc. no. 303.

1862; Sept. 24: The Hague. Convention. Belgium \& the Netherlands. Navigation Regulations. Lagemans, Netherlands, V, Doc. no. 419.

1879; Oct. 31: Brussels. Convention. Belgium \& the Netherlands. Rectification \& Maintenance of the Canal. Hertslet, Europe, 3251; Martens, NRG, Ser. II, VIII, 152.

1888; Jan. 5: Brussels. Agreement. Belgium \& the Netherlands. Boundary. Hertslet, Europe, 3279. 


\section{Terneuzen Canal}

1895; June 29: Brussels. Convention. Belgium \& the Netherlands. Police \& Navigation Regulations. GB. BFSP, Vol. 87, 403; Lagemans, Netherlands, XIII, Doc. no. 832.

1902; March 8: The Hague. Convention. Belgium \& the Netherlands. Navigation Regulations; revising certain provisions of Treaty of Brussels; June 29, 1895. GB. BFSP, Vol. 96, 809; Lagemans, Netherlands, XV, Doc. no. 923.

\section{TICINO}

1814; May 30 : Paris. Treaty. Austria, France, Great Britain, Portugal, Prussia, Russia, Spain, Sweden. Separate, Secret Art. II: Boundary. Hertslet, Europe, 18.

1834; Dec. 4: Turin. Treaty. Austria/Sardinia. Suppression of Contraband aboard Vessels navigating the River. Martens, NRT, XIII, 198.

1849; Aug. 6: Milan. Treaty. Austria/Sardinia. Art. 3: Boundary. Hertslet, Europe, 1110.

1851; Oct. 18: Vienna. Treaty. Austria/Sardinia. Art. 12: Reciprocal Freedom of Navigation, including Tributaries. Cussy/ Martens, Rec. Man., Ser. I, VI, 626, 630; GB. BFSP, Vol. 42, 1285, 1287, 1297.

1851; Nov. 22: Turin. Convention. Austria/Sardinia. Art. I: Suppression of Contraband Trade. Cussy/Martens, Rec. Man., Ser. I, VI, 649.

1859; Nov. 10: Zurich. Treaty. Austria, France, Sardinia. Arts. 19, 21. Hertslet, Europe, 1410.

\section{TORNEA}

1809; Sept. 5/17: Friedrichshaven. Russia/Sweden. Arts. IV, V: Established as Frontier. Koch/Schoell, Hist. Abr. Tr., XIV, 209.

1810; Nov. 8/20: Tornea. Treaty. Russia/Sweden. Art. I: Thalweg Boundary. Arts. II, IV: Reciprocal Freedom of Navigation. Art. V: Guaranteeing Mutual Enjoyment of the Salmon Fisheries for One Hundred Years. Cussy/Hauterive, RTC, V, pt. 2, 515. Hertslet, Europe, 2028.

1872; Mar. 25/Apr. 6: St. Petersburg. Agreement. Russia \& Sweden. Protecting \& Regulating the Fisheries in the River Tornea $\&$ Affluents. Martens, NRG, Ser. II, I, 596.

\section{TORT}

1868; July 11: Bayonne. Convention. France/Spain. Art. III, Sec. 2: Governing Utilization of Waters. Hertslet, Europe, 1844; Olivart, Colece. Tratados, IV, 310-11. 
1847; June 23: Copenhagen. Treaty. Denmark/Lubeck. Art. 13 : Respecting Obstruction to Navigation; Construction of Bridges over the River. Martens, NRG, Ser. I, Vol. X, 604, 609.

1853; June 15: Convention. Denmark \& Lubeck. Supervision \& Protection of Fluvial Fisheries. Cussy/Martens, Rec. Man., Ser. I, VII, 302.

\section{TRESA}

1861; Oct. 5 : Lugano. Convention. Italy \& Switzerland. Art. V: Established as Fluvial Boundary; Jurisdiction \& the Fisheries being reserved for the Exclusive Enjoyment of Switzerland. Hertslet, Europe, 1492.

\section{UNSTRUT}

1815; Sept. 22 : Paris. Convention. Prussia \& Saxe-Weimar. Art. 8: Mutual Liberty of Navigation. Hertslet, Europe, 309.

1871; Apr. 16: Berlin. Constitution. German Empire. Art. 54: Navigation of Inland Waterways. Dodd, Modern Constitutions, I, 343.

\section{URBELCHA}

1856; Dec. 2 : Bayonne. Treaty. France \& Spain. Arts. IV, V: Thalweg Boundary. Hertslet, Europe, 1291, 1293.

\section{VALCARLOS}

1856; Dec. 2: Bayonne. Treaty. France \& Spain. Art. 7: Thalweg Boundary. Hertslet, Europe, 1291, 1294.

\section{VANERA}

1866; May 26: Bayonne. Treaty. France/Spain. Art. 9: Demarcation of Boundary. Olivart, Colecc. Tratados, IV, 246-262. 1868; July 11 : Bayonne. Convention. France/Spain. Art. VI, sec. 2: Governing Utilization \& Enjoyment of the Waters. Hertslet, Europe, 1844; Olivart, Colecc. Tratados, IV, 320-22.

\section{VISTULA}

1648; Oct. 24: Osnabruck. Treaty. France, Germany, Sweden. Art. IX: Recognized the Validity of the Established Navigation Tolls. Dumont, Corps Univ. Dipl., VI, 469, 480.

1775; Mar. 16: Warsaw. Treaty. Austria \& Poland. Arts. VI, VII: Reciprocal Freedom of Navigation. Cussy/Hauterive, RTC, I, pt. 2, 154. 


\section{Vistula}

1776; Feb. 9: Warsaw. Convention. Austria/Poland. Art. V: Mutual Liberty of Navigation. Neumann, RTA, I, 196.

1807; June 25/July 7: Tilsitt. Treaty. France \& Prussia. Art. 20: Abolition of Navigation Dues. Cussy/Hauterive, RTC, III, pt. 1, 43, 267; Martens, RT, VIII, 639, 665.

1807; June 25/July 7: Tilsitt. Treaty. France \& Russia. Art. 8: Abolition of Fluvial Navigation tolls; embodying stipulations similar to those included in Art. 20 of Treaty between France \& Prussia. Cussy/Hauterive, RTC, III, pt. 1, 43, 267; Martens, RT, VIII, 639, 665 .

1815; Apr. 21/May 3: Vienna. Treaty. Austria/Russia. Art. 24: Freedom of Navigation; including all waterways, whether natural or artificial, within former Kingdom of Poland. Cussy/ Hauterive, RTC, I, pt. 2, 183; Cussy/Martens, Rec. Man., Ser. I, III, 103-111; Martens, NRT, II, 231.

1815; Apr. 21/May 3: Vienna. Treaty. Prussia/Russia. Arts. 4, 5, 9, \& 22: Freedom of Navigation. Cussy/Hauterive, RTC, I, pt. 2, 373, 375 ; Cussy/Martens, Rec. Man., Ser. I, III, 111116; Martens, NRT, II, 242.

1815; May 4: Vienna. Convention. Austria, Prussia, Russia. Accession of Austria to the Stipulations imposed by the Treaty of Vienna between Prussia \& Russia of May 3, 1815. Martens, NRT, III, 127.

1815; May 18: Vienna. Treaty. Austria, Prussia, Russia, Saxony. Art. 22: Fluvial Boundary. Formed Annex IV of the Final Act of the Congress. Hertslet, Europe, I, 143.

1815; June 9 : Vienna. Final Act of the Congress. Arts. 2, 4, 14: Thalweg Boundary; Navigation. Hertslet, Europe, 217; Martens, NRT, II, 387. (Commentary: PHILLIMORE, Int. Law, I, 232.)

1818; Aug. 5/17: St. Petersburg. Convention. Austria \& Russia. Arts. 1, 2, 3, 4-9: Liberty of Navigation reserved for Exclusive Enjoyment of Riverain States. Cussy/Hauterive, RTC, V, pt. 2, 444; Martens, NRT, IV, 540.

1818; Dec. 7/19: St. Petersburg. Treaty. Prussia \& Russia. Art. II: Abolition of all Navigation Dues, except the Toll Levied in Prussia, termed Schiffsgefässgelder. GB. BFSP, V, 945, 947; Martens, NRT, IV, 582-84.

1825; Feb. 27/Mar. 11: Berlin. Convention. Prussia \& Russia. Art. V, VI: Mutual Enjoyment of Fluvial Navigation; Freedom from Tolls. Cussy/Hauterive, RTC, V, pt. 2, 390; GB. BFSP, XII, 927 ; Martens, NRT, VI, 688. 
1826; Dec. 14/26: Brody. Treaty. Austria \& Russia. Arts. 5, 6: Fluvial Boundary. Hertslet, Europe, 762.

(NOTE: 1844; March 4: London. Law. Great Britain. British Order in Council granting specified Trade Privileges to Austrian Vessels through Assimilation of Ports in Estuary of Vistula to Ports within Austrian Dominion by reason of Freedom of Navigation enjoyed by the Dual Monarchy throughout Navigable Course. GB. BFSP, Vol. 39, 1151; Hertslet, COM. TR., VI, 48-50.)

1864; Aug. 20: Cracow. Treaty. Austria \& Russia. Rectification of Navigable Channel where constituting International Boundary. GB. BFSP, Vol. 65, 333, 339; Hertslet, Europe, 3216; Martens, NRG, Ser. I, XX, 288; Neumann, RTA, III, n. s., 485. 1871; May 27 : Agreement. Austria \& Russia. Regulation of Navigable Course. GB. BFSP, Vol. 65, 339.

WAAL

1868; Oct. 17: Mannheim. Convention. Baden, Bavaria, France, Hesse-Darmstadt, Netherlands, Prussia. Art. I: Specifically included as Integral Part of the Rhine System \& subjected to Identical Regulations ensuring Freedom of Navigation. Hertslet, Europe, 1849.

\section{WARTHE; or WARTHA}

1705 ; Nov. 18: Warsaw. Treaty. Poland \& Sweden. Art. VI: Established Reciprocal Freedom of Navigation; providing, further, for the Destruction of Obstacles in the Navigable Channel. Dumont, Corps Univ. Dipl., VIII, part II, pg. 1; Koch/Schoell, Hist. Abr. Tr., XIII, 192.

1815 ; June 9 : Vienna. Final Act of the Congress. Art. II: Boundary. Hertslet, Europe, 217.

1818; Dec. 7/19: St. Petersburg. Treaty. Prussia \& Russia. Art. II: Abolition of all Navigation Dues, except the Toll imposed by Prussia, known as Schiffsgefässgelder. GB. BFSP, V, 945, 947; Martens, NRT, IV, 584.

1825; Feb. 27/Mar. 11: Berlin. Convention. Prussia \& Russia. Arts. 5, 6: Mutual Enjoyment of Fluvial Navigation; Freedom from Tolls. Cussy/Hauterive, RTC, V, pt. 2, 390; GB. BFSP, XII, 927; Martens, NRT, VI, 688. 


\section{Weisse-Elster}

Art. 17: Freedom of Navigation adopting Principles embodied in Annex XVI of Final Act of the Congress. Hertslet, Europe, 141.

1815 ; June 9 : Vienna. Final Act of the Congress. Art. 15: Boundary. Annex IV: Navigation. Hertslet, Europe, 222.

\section{WESER}

1648; Oct. 24: Osnabruck. Treaty. (Peace of Westphalia.) Germany \& Sweden. Art. IX: Reciprocal Freedom of Navigation. Cussy/Hauterive, RTC, I, pt. 2, 195 ; Dumont, Corps Univ. Dipl., VI, 469,480 .

1803; Apr. 6: Rastadt (Ratisbon). Convention. France \& Oldenburg. Arts. IV-VIII: Concerning Regulation \& Ultimate Extinction of the Elsfleth Toll. Clercq, RTF, II, 57.

1818; Nov. 14: Aix-la-Chapelle. Protocol of Congress. Austria, France, Great Britain, Prussia, Russia. Respecting the Elsfleth Toll. Clereq, RTF, III, 174; GB. BFSP, V, 1085 ; Hertslet, Europe, 569; Martens, NRT, IV, 554.

1819; Aug. 25: Convention. Bremen (Hanseatic Cities) \& Oldenburg. Providing for the Suppression of the Elsfleth Toll under the Guarantee of the Germanic Confederation. Cussy/Martens, Rec. Man., Ser. I, III, 449; Martens, NRT, IV, 645.

1823; Sept. 9 : Minden. Convention. Bremen/Hanover. Arts. IIV: Freedom of Navigation. Cussy/Martens, Rec. Man., Ser. I, III, 570; Hertslet, Europe, 706; Martens, NRT, VI, 336.

1823 ; Sept. 10: Minden. Convention. Bremen/Prussia. Concerning Art. $X \nabla$ of the General Act of Navigation signed by the Riverain States; Sept. 10, 1823. Cussy/Martens, Rec. Man., Ser. I, III, 570; Martens, NRT, VI, 338.

1823 ; Sept. 10 : Minden. Treaty. Brunswick/Hanover. Regulating Tolls imposed on Fluvial Navigation. Cussy/Hauterive, RTC, I, pt. 2, 337; Martens, RT. SUPPL., X.

1823; Sept. 10: Minden. Convention. Brunswick \& Hesse-Cassel. Governing Imposition of Navigation Dues. Martens, RT. SUPPL., $\mathrm{X}$.

1823; Sept. 10: Minden. Treaty. Brunswick/Oldenburg. Tariff of Navigation Tolls. Martens, RT. SUPPL., X.

1823; Sept. 10: Minden. Convention. Riverain States: Bremen, Brunswick, Hanover, Hesse-Cassel, Lippe, Oldenburg, Prussia. General Act regulating Freedom of Navigation. Cussy/Martens, Rec. Man., Ser. I, III, 570; Hertslet, Europe, 710 ; Martens, NRT, VI, 301, 840. 
1825; Dec. 21 : Bremen. Convention. Brunswick/Hanover. Tariff of Navigation Tolls. Cussy/Hauterive, I, pt. 2, 337; Martens, RT. SUPPL., $X$.

1825; Dec. 21: Bremen. Treaty. Brunswick/Hesse-Cassel. Regulating Imposition of Navigation Dues. Martens, RT. SUPPL., $\mathrm{X}$.

1825; Dec. 21: Bremen. Agreement. Brunswick \& Oldenburg. Tolls applicable to Fluvial Navigation. Martens, RT. SUPPI., $\mathrm{X}$.

1825 ; Dec. 21 : Bremen. Convention. Bremen, Brunswick, Hanover, Hesse-Cassel, Lippe, Oldenburg, Prussia. General Act of the Riparian States governing Freedom of Navigation; amplifying Convention of Minden; Sept. 10, 1823. Hertslet, Europe, 738; Martens, NRG, Ser. I, II, 572.

1839; Aug. 16: Nenndorf. Convention. Bremen, Brunswick, Hanover, Hesse-Cassel, Lippe, Oldenburg, Prussia. Supplementary Regulations adopted by the Riverain States revising the Navigation Convention of Minden; Sept. 10, 1823. Cussy/Martens, Rec. Man., Ser. I, IV, 616; Martens, NRT, XVI, 572; Martens, NRG, Ser. I, II, 572.

1856; Jan. 26: Bremen. Treaty. Bremen, Hanover, Hesse-Cassel, Prussia. Arts. I-III: Suspending Imposition of Navigation Tolls. Cussy/Martens, Rec. Man., Ser. I, VII, 468; Martens, NRG, Ser. I, XVI, part 1, 440.

1871; Apr. 16: Berlin. Constitution. German Empire. Art. 54: Navigation of Inland Waterways. Dodd, Modern Constitutions, I, 343.

1876; Mar. 6: Berlin. Convention. Bremen, Oldenburg, Prussia. Concerning the Maintenance of Buoys in Lower Course. Martens, NRG, Ser. II, II, 290.

1906; Mar. 29: Berlin. Treaty. Bremen \& Prussia. Dredging of Navigable Channel throughout Lower Course. Martens, NRG, Ser. III, I, 331.

WORIEMA. See JACOBS-ELF.

\section{WORMS}

1815; June 9: Vienna. Final Act of the Congress. Art. 25: Art. 66: Boundary. Hertslet, Europe, 230, 249. 


\section{Worms}

1868; Dec. 11: Aix-la-Chapelle. Treaty. Netherlands \& Prussia. Art. I: Boundary. Hertslet, Europe, 1862.

\section{YALPOUK}

1856; Mar. 30: Paris. Treaty. Austria, France, Great Britain, Prussia, Russia, Sardinia, Turkey. Art. 20: Bessarabian

Frontier; Thalweg Boundary. Hertslet, Europe, 1250, 1259.

1857; Jan. 6: Paris. Protocol of Conference. Austria, France, Great Britain, Prussia, Russia, Sardinia, Turkey. Bessarabian Frontier; Thalweg Boundary. Hertslet, Europe, 1298-99.

1857; June 19: Paris. Treaty. Austria-Hungary, France, Great Britain, Prussia, Russia, Sardinia, Turkey. Arts. II, IV: Establishment of Boundaries in the Danubian Delta. GB. BFSP, Vol. 47, 60 ; Hertslet, COM. TR., X, 960 ; Hertslet, Europe, 132122.

\section{YSSEL}

1835; May 14: The Hague. Law (Royal Decree). Government of the Netherlands. Imposition of Navigation Tolls. GB. BFSP, Vol. 42, 1274, note.

1850; Aug. 8: The Hague. Law (Royal Decree). Government of the Netherlands. Abolition of Transit \& Navigation Dues; imposed in conformity with the Royal Decree of May 14, 1835. GB. BFSP, Vol. 42, 1274; Hertslet, COM. TR., IX, 559; Lagemans, Netherlands, Doc. no. 243, no. 244.

1894; Mar. 10: The Hague. Treaty. Netherlands/Prussia. Concerning Demarcation of International Fluvial Boundary. GB. BFSP, Vol. 87, 797; Martens, NRG, Ser. II, Vol. 22, 549.

\section{ZBOROWSKI}

1835; Mar. 4: Berlin. Treaty. Prussia \& Russia. Art. 51: Establishment of Fluvial Boundary. Hertslet, Europe, 955.

\section{ZBRUCZ. See PODHORCE.} $1=1+1$

ZUID-WILLEMS-WAART (CANAL)

1831; Nov. 15: London. Treaty. Austria, Belgium, France, Great Britain, Prussia, Russia. Art. 10: Mutual Freedom of Canal Navigation. Cussy/Hauterive, RTC, I, pt. 2, 283; Hertslet, COM. TR., IV, 13, 26, 31; Hertslet, Europe, 864. 1839 ; Apr. 10 : London. Treaty. Belgium/Netherlands.

Apr. 19: London. Convention. Austria-Hungary, Belgium, France, Great Britain, Netherlands, Prussia, Russia. Art. IX \& Annex: Reciprocal Freedom of Canal Navigation. Clercq, RTF, 
Zuid-Willems-Waart

470-77; Cussy/Martens, Rec. Man., Ser. I, IV, 573-77; Hertslet, COM. TR., V, 354, 359; Hertslet, Europe, 986-98; Neumann, RTA, IV, 416, 421; Sturdza, Rec. Doc. 854-55.

1839; Nov. 6: Maastricht. Agreement. Belgium/Netherlands. Regulating Canal Navigation. Lagemans, Netherlands, II, Doc. no. 178.

1842; Nov. 5: The Hague. Treaty. Belgium/Netherlands. Art. 55: Supervision of Canal Navigation. GB. BFSP, Vol. 31, 815 ; Hertslet, Europe, 1029 ; Martens, NRG, Ser. I, III, 613, 619, 622 ; Sturdza, Rec. Doc. 868.

1843; May 20: Antwerp. Convention. Belgium/Netherlands. Police \& Navigation Regulations. Cussy/Martens, Rec. Man., Ser. I, V, 306; Martens, NRG, Ser. I, V, 294-95, 307, 332, 334, 339, 367, 381; Sturdza, Rec. Doc., 867.

1843; Aug. 8: Maastricht. Convention. Belgium/Netherlands. Navigation Regulations. GB. BFSP, Vol. 35, 1202, 1220-21; Hertslet, Europe, 1031.

1846; July 29: The Hague. Treaty. Belgium/Netherlands. Navigation; Diversion of Waters for Maintenance. GB. BFSP, Vol. 35, 1222-24; Martens, NRG, Ser. I, IX, 274.

1851; Oct. 3: The Hague. Agreement. Belgium/Netherlands. Regulating Annual Chômage of Arterial Waterways. Lagemans, Netherlands, III, Doc. no. 269.

1856; Dec. 11: Brussels. Agreement. Belgium/Netherlands. Modifying certain Provisions of the Convention of Maastricht, Nov. 6,1839 , governing Navigation of the Canal. Lagemans, Netherlands, IV, Doc. no. 360.

1861; Sept. 21: Brussels. Convention. Belgium/Netherlands. Arts. I, II, VI: Diversion of Waters from Meuse for Maintenance of Navigation. Lagemans, Netherlands, V, Doc. no. 408.

\section{ZWIN CANAL}

1648; Jan. 30: Münster. Treaty. (Peace of Westphalia.) Holland \& Spain. Art. 14: Navigation expressly Reserved to Dutch Vessels. Cussy/Hauterive, RTC, III, 3; Dumont, Corps Univ. Dipl., VI, pt. 1, 429; Koch/Schoell, Hist. Abr. Tr., Vol. I, 168; Vol. IV, 60; Martens, RPT, VI, 146.

1785; Sept. 20 : Paris. Treaty. Austria/Netherlands. Arts. 6, 15 : Stipulations of Treaty of Münster, Jan. 30, 1648, recognizing exclusive Dutch Sovereignty \& Enjoyment of the Canal, Renewed. Martens, RPT, II, 598-601.

1785; Nov. 8: Fontainebleau. Treaty. Austria/Netherlands. Art. 


\section{Zwin Canal}

7: Validity of Dutch Claims Recognized by Austria. Koch/ Schoell, Hist. Abr. Tr., IV, 80; Martens, RPT, II, 602-608. 1843; Aug. 8: Maastricht. Convention. Belgium \& the Netherlands. Art. 31: Freedom of Navigation. Hertslet, Europe, 1031. 1869; Mar. 15 : Sluis (L'Ecluse). Convention. Belgium \& the Netherlands. Demarcation of Fluvial Boundary. Lagemans, Netherlands, VI, Doc. no. 523; Martens, NRG, Ser. I, XX, 546.

1872; May 24: Bruges. Convention. Belgium/Netherlands. Maintenance of Channels \& Embankments along Navigable Course. Martens, NRG, Ser. II, I, 136.

\section{NORTH AMERICA}

\section{AGUAN; or ROMAN}

(NOTE:

(1859; Feb. 22 : Contract. North American Agricultural \& Navigation Company and Republic of Honduras. Granting Privilege of Navigation. GB. BFSP, Vol. 51, 907.

(1860; Feb. 20: Law (Presidential Decree). Government of Honduras. Extending \& Prolonging the Navigation Privileges accorded by the Agreement of Feb. 22, 1859. GB. BFSP, Vol. 51, 907.)

1880; Nov. 1: Tegucigalpa. Constitution. Republic of Honduras. Chap. IV; Sec. 26: Freedom of Navigation of Inland Waterways granted to All Flags. Hertslet, COM. TR., Vol. 17, 777.

1904; Sept. 2: Tegucigalpa. Constitution. Republic of Honduras. Chap. XVIII, Art. 141: Navigation of Rivers opened freely to the Flags of All Nations. GB. BFSP, Vol. 7, 1255, 1272.

APALACHICOLA; or CATAHOUCHE; or CHATTAHOOCHEE 1782; Nov. 30 : Paris. Treaty. Great Britain/United States.

1783; Sept. 3: Art. II: Thalweg Boundary. Malloy, UST, 580-81; $586-88$.

1795; Oct. 27: San Lorenzo el Real. Treaty. Spain \& the United States. Art. II: Establishment of International Boundary in Mid-Channel. Malloy, UST, 1640. (NOTE: Abrogated by Art. XII of Treaty of Washington; Feb. 22, 1819.) 
ARKANSAS

1819; Feb. 22: Washington. Treaty. Spain \& the United States. Art. 3: Reciprocal Freedom of Navigation; Common Enjoyment of Ancillary Uses where forming International Frontier. Malloy, UST, 1651, 1653. (NOTE: Annulled by Annexation of Texas by the United States. New Boundaries established by Treaty of Guadaloupe Hidalgo, Feb. 2, 1848, between Mexico \& the United States. Malloy, UST, 1107.)

BELIZE; or JABON; or SIBUN; or WALLIS

1783; Sept. 3: Versailles. Treaty. Great Britain \& Spain. Art. 6: Demarcation of Fluvial Boundary; Recognition of Reciprocal \& Exclusive Freedom of Navigation. Hertslet, COM. TR., II, 235, 239.

1786; July 14: London. Treaty. Great Britain/Spain. Art. 2: Established Boundary in Thalweg Art. 3: Granted Freedom of Navigation to British Vessels to \& from the Sea. Hertslet, COM. TR., II, 247. (NOTE: Confirmed by First Additional Article of Treaty of July 5, 1814.)

BLACK RIVER CANAL. See CANALS.

BOUNDARY WATERWAYS between CANADA \& the UNITED STATES

Including :

Canals;

Champlain Lake;

Niagara River;

Ontario Lake;

Detroit River;

Erie Lake;

Huron Lake, comprising North Channel, but excluding Georgian Bay;

Lake of the Woods;

Memphremagog Lake;

Rainy Lake \& River;

Saint Clair Lake \& River;

Saint Croix River;

Saint John River;

Saint Lawrence River;

Saint Mary's Lake \& River;

Superior Lake;

Superior-Lake of the Woods System (See NOTE).

See also CANALS; GREAT LAKES \& CONNECTING WATERS.

(NOTE:

(SUPERIOR-LAKE OF THE WOODS SYSTEM; notably: Cypress Lake; Fowl Lakes; Lac Bois Blanc; La Croix Lake; Little Vermillion Lake; Namecan Lake; Pigeon River; Saisaginaga River. 


\section{Boundary Waterways}

The Second Article of the Treaty of Washington, August 9, 1842, provided for the demarcation of the International Boundary through these Waters; stipulating further that

"All the water communications and all the usual portages along the line from Lake Superior to the Lake of the Woods, and also Grand Portage, from the shore of Lake Superior to the Pigeon River, as now actually used, shall be free and open to the use of the citizens and subjects of both countries." Malloy, UST, 650, 652-53.)

1782 ; Nov. 30 : Paris. Treaty. Great Britain/United States.

1783; Sept. 3: ART. II: Designating Water-Boundary; St. Croix River to Lake of the Woods. Malloy, UST, 580-81; 586-88.

1794; Nov. 19 : London. Treaty. Great Britain/United States. Art.

3: Stipulated that British Subjects, Citizens of the United States, \& Indians dwelling on either side of the International Boundary should at all times be privileged freely to pass \& repass by Inland Navigation into the Domains of the Contracting Parties,- Hudson's Bay Country being excepted,- upon all the Lakes, Rivers, \& Waters, thereof. Malloy, UST, 590. (Commentary: MOORE, ILD, I, 674.)

1796; May 4: Philadelphia. Additional Agreement. Great Britain/

United States. Supplementing Art. II. of Treaty of London, Nov. 19, 1794, by explicitly providing that no subsequent Treaty Stipulation by either of the High Contracting Parties with any Third Power should diminish in any degree the complete Freedom of Navigation on all Boundary Waterways. Malloy, UST, 607609.

1814; Dec. 24: Ghent. Treaty. Great Britain/United States. Arts.

V, VI, VII: Demarcation of Water-Boundary from St. Croix River to the Lake of the Woods. Hertslet, COM. TR., II, 383; Malloy, UST, 612-19.

1817; Apr. 28/29: Washington. Agreement. Great Britain/United

States. Limiting Naval Forces on Boundary Waters. Hertslet, COM. TR., IX, 763; Malloy, UST, 628-29. (Commentary: MOORE, ILD, I, 692.)

1818; Apr. 28: Washington. Law (Presidential Proclamation). United States. Giving effect to Agreement of Apr. 28/29, 1817. Am. State Paps., For. Relats., IV, 202 ; GB. BFSP, V, 1200-1201; Malloy, UST, 630 ; Richardson, Messages \& Papers, II, 36; U. S. STAT., XI, 766.

1842; Aug. 9: Washington. Treaty. Great Britain/United States. Arts. 1, 2, 3, 6, 7: Demarcation of Boundary ; Freedom of Navigation. Hertslet, COM. TR., VI, 856; Malloy, UST, 650, 653, 
Boundary Waterways

1854; June 5: Washington. Treaty. Great Britain/United States. Art. 4: Privilege of Navigation. Cussy/Martens, Rec. Man., Ser. I, 338-342 ; Hertslet, COM. TR., IX, 1001; Malloy, UST, $668,671$.

1871; May 8: Washington. Treaty. Great Britain/United States. Arts. 26-28: Freedom of Navigation. Hertslet, COM. TR., Vol. 13, 970, 982 ; GB. BFSP, Vol. 61, 52 ; Malloy, UST, 711. (Commentary: Message of President U. S. Grant transmitting Treaty between Great Britain \& the United States; Washington, May 8, 1871. US. FOR. RELS., 1873, Vol. III, 261-424. CALEB CUSHING; The Treaty of Washington (1871); its negotiation, execution, \& the discussions relating thereto. New York, 1873, viii, 280.)

1908; Apr. 11: Washington. Treaty. Great Britain/United States. Treaty No. I: Boundary \& Navigation Stipulations. Treaty No. II: Fisheries Regulations. GB. BFSP, Vol. 101, 224; Malloy, UST, Treaty No. I, pg. 815; Treaty No: II, pg. 827.

1909; Jan. 11: Washington. Treaty. Great Britain/United States. Navigation Regulations; Prevention of Pollution; \& Supervision of Diversion of Waters for Power \& Irrigation. Art. I: Provided that the Navigation of All Boundary Waterways should perpetually continue Free to Both Nations. Charles, UST, 39, 47; GB. BFSP, Vol. 102, 137; Martens, NRG, Ser. III, IV, 208; US. FOR. RELS, 1910, pg. 533.

1911; May 19 : Ottawa. Law. Canadian Government. Act relating to the Establishment of the International Joint Commission in execution of Treaty of Washington; Jan. 11, 1909. GB. BFSP, Vol. 104, 390.

1914; Apr. 3: Ottawa. Law. Canadian Government. Act complying with the Stipulations of the Waterways Treaty; Washington, Jan. 11, 1909. GB. BESP, Vol. 107, 413.

CANALS

See also: BOUNDARY WATERWAYS; GREAT LAKES \& CONNECTING WATERS.

CANADIAN CANALS; Freedom of Navigation enjoyed by Vessels of the United States.

Chambly;

St. Andrews;

Cornwall (St. Lawrence System); St. Lawrence System, comprising Lachine (St. Lawrence System); the Cornwall, Lachine, SouMurray;

Ottawa; langes, \& Williamsburg Canals;

Rideau;

St. Ours;

St. Peters; 
Canals; Canadian.

Sault Sainte Marie;

Soulanges (St. Lawrence System);

Trent;
Welland;

Williamsburg, comprising the Farran's Point, Galops, \& Rapide Plat Canals; (St. Lawrence System).

CANALS OF THE UNITED STATES; Freedom of Navigation enjoyed by Canadian Vessels.

Black River;

Champlain, or Whitehall;

Erie;
Oswego;

St. Clair Flats;

Sault Sainte Marie.

1854; June 5: Washington. Treaty. Great Britain/United States. Art. 4: Privilege of Navigation on Canals of St. Lawrence System accorded to Citizens \& Inhabitants of the United States. Cussy/ Martens, Rec. Man., Ser. I, 338-342; Hertslet, COM. TR., IX, 1001; Malloy, UST, 668, 671. (NOTE: Upon notice from the United States this convention was terminated; Mar. 17, 1866.)

1871; May 8: Washington. Treaty. Great Britain/United States. Art. 27: Reciprocal Freedom of Navigation established upon certain Frontier Canals. Hertslet, COM. TR., Vol. 13, 970, 982; GB. BFSP, Vol. 61, 52; Malloy, UST, 700, 711; US. FOR. RELATS., 1871, 531. (Commentary: CUSHING, Treaty of Washington, 242; MOORE, Int. Arbs., 195; MOORE, ILD, I, 679-80; WESTLAKE, Int. Law, I, 158.)

(NOTE :

(1888; Aug. 23: Washington. Special Message to Congress despatched by President Grover Cleveland. Concerning Violation by the Canadian Government of Art. 27 of the Treaty of Washington,-May 8, 1871,--granting Freedom of Navigation for American Vessels upon Canadian Canals. Moore, ILD, I, 681; Richardson, Messages \& Papers, VIII, 626; US. FOR. REL., 1888, I, 813, 816, 824-25; US. House Ex. Doc., 50th CONG., 1st Sess., No. 7 .

(1890; Apr. 11: Ottawa. Law (Orders in Council).

(1892; Apr. 4: Canadian Government. Imposing Discriminatory Canal Tolls upon American \& Canadian Vessels contrary to the Provisions of Art. 27 of the Treaty of Washington; May 8, 1871. US. FOR. REL., 1892, 251-254, 272-74, 277-287, 301-304, 355-339. 
(1892; Aug. 18: Washington. Proclamation by President Harrison. Announcing Adoption of Retaliatory Measures by the United States; sanctioned by Act of Congress of July 26, 1892. Richardson, Messages \& Papers, IX, 290; US. FOR. Rel., 1892, 339.

(1892; Dec. 6: Washington. Fourth Annual Message of President Harrison. Reference to the Suspension of the Free Use of St. Mary's Canal by Canadian Vessels as Retaliation for Exactions levied upon American Vessels navigating Canadian Canals contrary to Art. 27 of Treaty of Washington; May 8, 1871. Richardson, Messages \& Papers, IX, 314.

(1893; Feb. 13: Ottawa. Law (Order in Council). Canadian Government. Establishing Equality of Enjoyment; abolishing all provisions granting toll rebates to Canadian vessels. Richardson, Messages \& Papers, IX, 378.

(1893; Feb. 23: Washington. Proclamation of President Harrison. Establishing Equality of Enjoyment; withdrawing Proclamation of Aug. 18, 1892, imposing measures of retaliation upon Canadian vessels navigating American Canals. Richardson, Messages \& Papers, IX, 379 ; US. FOR. REL., 1893, 329, 331, 337, 340. (1893; Dec. 4: Washington. First Annual Message of President Cleveland. Referring to Canal Tolls Controversy \& its ultimate amicable Settlement. Moore, ILD, I, 683; Richardson, Messages \& Papers, IX, 437.)

1896; Apr. 17: Ottawa. Law (Order in Council). Canadian Government. Abolishing All Fees formerly imposed upon Vessels Navigating Canadian Inland Waterways above Montreal. US. FOR. REL., 1896, 364.

1909; Jan. 11: Washington. Treaty. Great Britain/United States. Art. I: Provided that the Navigation of All Boundary Waterways should continue free perpetually to Both Nations; this Right being extended to all canals connecting boundary waterways, now existing, or which may hereafter be constructed, on either side of the International Boundary. Charles, UST, 39, 47; GB. BFSP, Vol. 102, 137; Martens, NRG, Ser. III, IV, 208; US. FOR. REL., 1910, 533.

1914; Apr. 3: Ottawa. Law. Canadian Government. Act complying with the Stipulations of the Waterways Treaty; Washington, Jan. 11, 1909. GB. BFSP, Vol. 107, 413.

\section{CHAMALECON}

1880; Nov. 1: Tegucigalpa. Constitution. Republic of Honduras. Chap. IV, Sec. 26: Freedom of Navigation extended to Vessels of all Nations. Hertslet, COM. TR., Vol. 17, 777. 


\section{Chamalecon}

1904; Sept. 2: Tegucigalpa. Constitution. Republic of Honduras. Chap. XVIII, Art. 141: Navigation opened freely to Merchant Vessels of All Nations. GB. BFSP, Vol. 97, 1255, 1272.

\section{CHAMBLY CANAL. See CANALS.}

CHAMPLAIN; or WHITEHALL CANAL. See CANALS.

CHAMPLAIN LAKE. See also BOUNDARY WATERWAYS.

1817; Apr. 28/29. Washington. Agreement. Great Britain/United

States. Restricting Naval Forces on the Lake to One Vessel, respectively. Am. State Paps., For. Rels., IV, 202; GB. BFSP, V, 1200; Hertslet, COM. TR., IX, 763; Malloy, UST, 628-29. (Commentary: FOSTER, Am. Dipl., 252.)

(NOTE:

(1848; Apr. 7: Washington. Letter from Mr. Buchanan, Federal Secretary of State, to the Governors of New York \& Vermont, respecting the Freedom of Navigation enjoyed by Citizens \& Subjects of Great Britain \& the United States upon the Lake. MOORE, ILD, I, 677; citing 36 MS. DOM. LET., 405.)

1908; Apr. 11: Washington. Treaty. Great Britain/United States. Treaty No. II: Protection of Fisheries. GB. BFSP, Vol. 101, 224 ; Malloy, UST, 827.

1909; Jan. 11: Washington. Treaty. Great Britain/United States. Art. I: Freedom of Navigation. Charles, UST, 39, 47; GB. BFSP, Vol. 102, 137; Martens, NRG, Ser. 3, IV, 208; US, FOR. REL., 1910, pg. 533.

CHATTAHOOCHEE; or CATAHOUCHE. See APALACHICOLA.

CHOLUTECA

1880; Nov. 1: Tegucigalpa. Constitution. Republic of Honduras. Chap. IV, Sec. 26: Freedom of Navigation granted to Vessels of all Nations. Hertslet, COM. TR., Vol. 17, 777.

1904; Sept. 2: Tegucipalpa. Constitution. Republic of Honduras. Chap. XVIII, Art. 141: Navigation extended freely to Vessels of all Nations. GB. BFSP., Vol. 97, 1255, 1272.

COCO; or SEGOVIA; or WANKS ; or YORO

Freedom of Navigation established by Identical Provisions applicable to CHOLUTECA River.

\section{COLORADO}

1848; Feb. 2: Guadalupe Hidalgo. Treaty. Mexico \& the United States. Art. V: Demarcation of International Boundary. Art. 
VI: Established Freedom of Navigation in Lower Course \& through Gulf of California. Malloy, UST, 1107-1111. (Commentary: ENGELHARDT, Hist. du Droit Fluv. Conv., 83; MOORE, ILD, I, 639.)

1853; Dec. 30: Washington. Treaty. Mexico/United States. Art. IV : Recognition of Right of Navigation through Mexican Territory. Malloy, UST, 1123.

1884; Nov. 12: Washington. Treaty. Mexico/United States. Demarcation of Boundary Line. Malloy, UST, 1159; Martens, NRG, Ser. II, XIII, 675.

1889; March 1: Washington. Treaty. Mexico/United States. Art.

I: Fluvial Boundary Disputes to be referred to an International Boundary Commission. Arts. II \& III: Institution of the International Boundary Commission. Art. $\nabla$ : Regulating Works or Obstructions which infringe the stipulations of Treaty of Nov. 12, 1884 \& Feb. 2, 1848, prohibited. Malloy, UST, 1167-69. 1895; Oct. 1: Washington. Convention. Mexico/United States. Agreement prolonging the terms of the Treaty of March 1, 1889. Malloy, UST, 1175-76.

\section{COLUMBIA}

Including Passage of Cascade \& Celilo Canals.

1846; June 15: Washington. Treaty. Great Britain/United States. Art. II : Granted Freedom of Navigation to British Vessels between Canadian Territory and the Sea. Hertslet, COM. TR., VIII, 931; Malloy, UST, 656-57. (Commentary: HALL, Int. Law, 5th Edit., 109-110; MOORE, ILD, I, 638; TWISS, Law of Nations (Peace), I, secs. 125, 126; WEBSTER, Writings, Vol. IX, 76.)

1909; Jan. 11: Washington. Treaty. Great Britain/United States. Art. I: Mutual Liberty of Navigation. Charles, UST, 39; GB. BFSP, Vol. 102, 137; Martens, NRG, Ser. 3, IV, 208; US. FOR. RELS., 1910, pg. 533.

CORNWALI CANAL. See CANALS.

CYPRESS LAKE. See BOUNDARY WATERWAYS; SuperiorLake of the Woods System.

DETROIT.

See also: BOUNDARY WATERWAYS; GREAT LAKES \& CONNECTING WATERS.

1842; Aug. 9: Washington. Treaty. Great Britain/United States. Art. 7: All Channels freely available for the Vessels of both 


\section{Detroit}

Nations, regardless of precise location of International Boundary. Hertslet, COM. TR., VI, 856; Malloy, UST, 650, 654-55.

\section{ERIE BARGE CANAL. See CANALS.}

ERIE LAKE

See also: BOUNDARY WATERWAYS; GREAT LAKES \& CONNECTING WATERS.

1782 ; Nov. 30 : Treaty.

1783 ; Sept. 3 : Paris. (See Boundary Waterways.)

1814; Dec. 24: Ghent. Treaty. Great Britain/United States. Arts.

VI, VII: Demarcation of International Boundary. Hertslet, COM. TR., II, 383; Malloy, UST, 612-19.

1822 ; June 18: Utica. Agreement. Commissioners of Great Britain

\& the United States. Concerning the Establishment of the Water-Boundary in conformity with Art. VI of Treaty of Ghent; Dec. 24, 1814. Hertslet, COM. TR., IV, 493. Malloy, UST, 620-23.

1908; Apr. 11: Washington. Treaty. Great Britain/United States.

Treaty No. II: Protection of Fisheries. GB. BFSP., Vol. 101, 224 ; Malloy, UST, 826.

1909; Jan. 11: Washington. Treaty. Great Britain/United States. Art. I: Reciprocal Freedom of Navigation. Charles, UST, 39, 47; GB. BFSP, Vol. 102, 137; Martens, NRG, Ser. 3, IV, 208; US. FOR. RELS., 1910, pg. 533.

\section{FARRAN'S POINT CANAL. See CANALS.}

FOWL LAKES. See BOUNDARY WATERWAYS; Superior-Lake of the Woods System.

GALOPS CANAL. See CANALS.

GILA

1848; Feb. 2: Guadalupe Hidalgo. Treaty. Mexico/United States. Art. V: Thalweg Boundary. Art. VII: Navigation Free \& Common to the Vessels \& Citizens of both Countries. Malloy, UST, 1107-1111. (Commentary: MOORE, ILD, I, 639.)

1853; Dec. 30 : Washington. Treaty. Mexico/United States. Art. IV : Stating that by reason of the territorial cession stipulated under Art. I the provisions under Arts. $6 \& 7$ of the Treaty of Guadalupe Hildago, Feb. 2, 1848, assuring Freedom of Navigation, become inoperative. Malloy, UST, 1123.

1880; Nov. 1: Tegucigalpa. Constitution. Republic of Honduras. 
Chap. IV, Sec. 26 : Freedom of Navigation granted to All Flags. Hertslet, COM. TR, Vol. 17, 777.

1904; Sept. 2: Tegucigalpa. Constitution. Republic of Honduras. Chap. XVIII, Art. 141: Navigation opened to the Vessels of All Nations. GB. BFSP, Vol. 97, 1255, 1272.

GREAT LAKES \& CONNECTING WATERS.

See also: BOUNDARY WATERWAYS;

CANALS.

GREAT LAKES: Erie; Huron; Ontario; Superior.

CONNECTING WATERS: Natural; Detroit River; Niagara River; St. Clair Lake \& River; St. Mary's Lake \& River. Artificial (Canals); Saint Clair Flats; Sault Sainte Marie; and Welland Canals.

1814; Dec. 24 : Ghent. Treaty. Great Britain/United States. Arts 6, 7: Demarcation of International Boundary. Hertslet, COM. TR., II, 383; Malloy, UST, 612-19.

1817; Apr. 28/29: Washington. Agreement. Great Britain \& the United States. Limiting Naval Forces on the Great Lakes. Hertslet, COM. TR., IX, 763; Malloy, UST, 628-29. (Commentary: AM. ACAD. POL. \& SOC. SC, Vol. 45, 57; AM. JOUR. INT. LAW., Jan. 1915, pg. 270; CHAMBERLAIN, Treaties ... pg. 102; FOSTER, Am. Dipl., 252; G. HUNT, Writings . . . Jas. Madison, VIII, 345; LAWRENCE, Int. Law, 598; MOORE, ILD, I, . . 677, 692 ...; Vol. V, 214, 323, RICHARDSON, Messages \& Papers, IX, 333; STOCKTON, Int. Law, 122, 124; US. H. EX. DOC., No. 471, 56th Cong., 1st Sess, pg. 28-34.)

1818; Apr. 28: Washington. Law (Presidential Proclamation). United States. Giving effect to the Naval Agreement of Washington; Apr. 28/29, 1817. Am. Stat. Paps., For. Rels., IV, 202; GB. BFSP, V, 1200; Hertslet, COM. TR., IX, 762; Malloy, UST, 630 ; Richardson, Messages \& Papers, II, 36.

1822; June 18: Utica. Agreement. Commissioners of Great Britain \& the United States. Concerning the Demarcation of the International Water-Boundary in conformity with Art. VI of Treaty of Ghent; Dec. 24, 1814. Hertslet, COM. TR., IV, 493; Malloy, UST, $620-23$.

1842; Aug. 9: Washington. Treaty. Great Britain/United States. Arts. 1, 2, 3, 6, 7: Establishment of Boundary; Freedom of Navigation. Hertslet, COM. TR., VI, 856; Malloy, UST, 650, 653. (Commentary: CRANDALL, Treaties ... 526; MOORE, 


\section{Great Lakes \& Connecting Waters}

Int. Arbs., 194; MOORE, ILD, I, 678; SNOW, Am. Dipl., 80-

82; WEBSTER, Works, VI, 351-52.)

1854; June 5: Washington. Treaty. Great Britain/United States. Art. IV : Recognized Mutual Liberty of Navigation. Cussy/Martens, Rec. Man., Ser. I, VII, 338-342; Hertslet, COM. TR., IX, 1001; Malloy, UST, 668, 671.

1871; May 8: Washington. Treaty. Great Britain/United States. Art. 27: Welland \& St. Clair Flats Canal open freely to navigation by Vessels of both Nations. GB. BFSP, Vol. 61, pg. 52; Hertslet, COM. TR., XIII, 970, 982; Malloy, UST, 711. (Commentary: MOORE, Int. Arbs., 170.)

1908; Apr. 11: Washington. Treaty. Great Britain/United States. Treaty No. I: Boundary \& Navigation Stipulations. Treaty No. II: Fisheries Regulations. GB. BFSP, Vol. 101, 224; Malloy, UST, Treaty No. I, pg. 815; Treaty No. II, pg. 826.

1909; Jan. 11: Washington. Treaty. Great Britain/United States. Navigation Regulations; Prevention of Pollution; Supervision of Diversion of Waters for Power \& Irrigation. Art. I: Navigation of Great Lakes \& Connecting Waters perpetually Free to Vessels of both Nations. Charles, UST, 39, 47; GB. BFSP, Vol. 102, 137; Martens, NRG, Ser. 3, IV, 208; US. FOR. RELS., 1910, pg. 533 .

1911; May 19: Ottawa. Law. Canadian Government. Act relating to the Establishment of the International Joint Commission in conformity with Stipulations of Treaty of Washington; Jan. 11, 1909. GB. BFSP, Vol. 104, 390.

1914; Apr. 3: Ottawa. Law. Canadian Government. Act complying with Provisions of the Waterways Treaty; Washington, Jan. 11, 1909. GB. BFSP, Vol. 107, 413.

\section{HONDO; or RIO HONDO}

1783; Sept. 3: Versailles. Treaty. Great Britain/Spain. Art. VI: Demarcation of Fluvial Boundary; Recognition of Reciprocal \& Exclusive Freedom of Navigation. Hertslet, COM. TR, II, $235,239$.

\section{HONDURAS}

By virtue of the Fundamental Law, Merchant Vessels of all Nations may freely navigate the Inland Waterways of Honduras;

Notably the Rivers: 
AGUAN; or ROMAN;

CHAMALECON;

CHOLUTECA;

COCO; or SEGOVIA; or

WANKS; or YORO;

GOASCORAN;
LEAN ;

NEGRO; or TINTO;

PATUCA, with Tributary GUA-

YAPE;

ULUA, with Tributaries SANTIAGO, SULACO, \& YOJOA.

1880 ; Nov 1: Tegucigalpa. Constitution. Republic of Honduras. Chap. IV, Sec. 26: Freedom of Navigation granted to ALI Flags. Hertslet, COM. TR., Vol. 17, 777.

1904; Sept. 2: Tegucigalpa. Constitution. Republic of Honduras. Chap. XVIII, Art. 141: Navigation accorded freely to Merchant Vessels of All Nations. GB. BFSP, Vol. 97, 1255, 1272.

HURON LAKE

See also: BOUNDARY WATERWAYS; GREAT LAKES AND CONNECTING WATERS.

1782; Nov. 30: Treaty.

1783; Sept. 3: Paris. (See Boundary Waterways.)

1814; Dec. 14: Ghent. Treaty. Great Britain/United States. Arts. VI, VII: Demarcation of International Boundary. Hertslet, COM. TR., II, 383; Malloy, UST, 612-19.

1822 ; June 18: Utica. Agreement. Commissioners of Great Britain \& the United States. Concerning the Establishment of the Water-Boundary in conformity with Art. VI of Treaty of Ghent; Dec. 24, 1814. Hertslet, COM. TR., IV, 493; Malloy, UST, 620-23.

1908; Apr. 11: Washington. Treaty. Great Britain/United States. Treaty No. II: Regulations for Protection of Fisheries in the Lake \& North Channel; Georgian Bay being explicity excluded. GB. BFSP, Vol. 101, 224; Malloy, UST, 827.

1909; Jan. 11: Washington. Treaty. Great Britain/United States. Art. I: Reciprocal Freedom of Navigation. Charles, UST, 39, 47; GB. BFSP, Vol. 102, 137; Martens, NRG, Ser. 3, IV, 208; US. FOR. RELS, 1910, pg. 533.

JABON. See BELIZE.

LAC BOIS BLANC. See BOUNDARY WATERWAYS; SuperiorLake of the Woods System.

LACHINE CANAL. See CANALS.

LA CROIX LAKE. See BOUNDARY WATERWAYS; SuperiorLake of the Woods System. 


\section{Lake of the Woods}

LAKE OF THE WOODS. See also BOUNDARY WATERWAYS. 1782 ; Nov. 30/Sept. 3, 1783: Treaty. Paris. (See Boundary Waterways.)

1814; Dec. 24: Ghent. Treaty. Great Britain/United States. Art. 7: Demarcation of Water-Boundary. Hertslet, COM. TR., II, 384; Malloy, UST, 612-19.

1818; Oct 20: London. Convention. Great Britain/United States. Art. II: Establishment \& Location of Boundary. Hertslet, COM. TR., II, 392; Malloy, UST, 631-33.

1842; Aug. 9: Washington. Treaty. Great Britain/United States. Art. II : Demarcation of Boundary; Freedom of Navigating on the Lake \& on communicating Boundary Waterways. Hertslet, COM. TR., VI, 856; Malloy, UST, 650, 652. (Commentary: MOORE, ILD, I, 677-78; SNOW, Am. Dipl., 82; WEBSTER, Works, VI, 351-52.)

1908; Apr. 11: Washington. Treaty. Great Britain/United States. Treaty No. I : Boundary \& Navigation Stipulations. Treaty No. II: Fisheries Regulations. GB. BFSP, Vol. 101, 224; Malloy, UST, $815 ; 827$.

1909; Jan. 11: Washington. Treaty. Great Britain/United States. Art. I: Reciprocal Freedom of Navigation. Charles, UST, 39, 47; GB. BFSP, Vol. 102, 137; Martens, NRG, Ser. 3, IV, 208; US. FOR. RELS., 1910, pg. 533.

(NOTE:

(1914; Jan. 14: Decision. International Joint Waterway Commission. Concerning the Application of the Greater Winnipeg Water District for Approval of the Diversion of Waters from Lake of the Woods \& Shoal Lake for Sanitary \& Domestic Purposes. Washington, Govt. Print. Office, 1914.)

(NOTE:

(1917; June 13: Final Report. International Joint Waterway Commission. Respecting Demarcation of Lake of the Woods Boundary. US. OFFICIAL BULLETIN, June 13, 1917, Washington, G. P. O.)

(Commentary:

(International Joint Commission: Report concerning Maintenance of Levels \& Utilization of Waters of Lake of the Woods. Washington, G. P. O., 1916/1917, 4 vols.)

LEAN

1880; Nov. 1: Tegucigalpa. Constitution. Republic of Honduras. Chap. IV, Sec. 26: Freedom of Navigation granted to All Flags. 
Hertslet, COM. TR., Vol. 17, 777.

1904; Sept. 2: Tegucigalpa. Constitution. Republic of Honduras. Chap. XVIII, Art. 141: Navigation of River opened freely to the Merchant Vessels of All Nations. GB. BFSP, Vol. 97, 1255, 1272 .

LITTLE VERMILLION LAKE. See BOUNDARY WATERWAYS; Superior-Lake of the Woods System.

\section{MEMPHREMAGOG LAKE}

See also: BOUNDARY WATERWAYS. 1908; Apr. 11: Washington. Treaty. Great Britain/United States. Treaty No. II: Protection of Fisheries. GB. BFSP, Vol. 101, 224; Malloy, UST, 827.

1909; Jan. 11: Washington. Treaty. Great Britain/United States. Art. I: Reciprocal Freedom of Navigation. Charles, UST, 39, 47; GB. BFSP, Vol. 102, 137; Martens, NRG, Ser. 3, IV, 208; US. FOR. REL., 1910, pg. 533.

\section{MICHIGAN LAKE}

For Freedom of Navigation on Waterways communicating with the Atlantic Ocean,

See BOUNDARY WATERWAYS; CANALS; ST. LAWRENCE RIVER SYSTEM.

1854; June 5: Washington. Treaty. Great Britain/United States. Art. IV : British Subjects granted Liberty of freely navigating the Lake, as long as American Citizens continued to enjoy unrestricted navigation of the St. Lawrence. Cussy/Martens, Rec. Man., Ser. I, 338-342; Hertslet, COM. TR., IX, 1001; Malloy, UST, 668,671 .

(NOTE:

(This Convention was terminated, following due notice from the United States; March 17, 1866.)

1871; May 8: Washington. Treaty. Great Britain/United States. Art. 28: Granted Privilege of Navigation to British Merchant Vessels. Hertslet, COM. TR., XIII, 970, 982; GB. BFSP, Vol. 61, pg. 52; Malloy, UST, 711. (Commentary; CUSHING, Treaty of Washington, 242.)

1909; Jan. 11: Washington. Treaty. Great Britain/United States. Art. I: Expressly providing for Freedom of Navigation by Brit- 


\section{Michigan Lake}

ish Vessels. Charles, UST, 39; GB. BFSP, Vol. 102, 137; Martens, NRG, Ser. 3, IV, 208; US. FOR. RELS., 1910, pg. 533.

MILK-ST. MARY River System

1909; Jan. 11: Washington. Treaty. Great Britain/United States. Art. VI: Constituting Joint Supervision to ensure equal apportionment of the Waters for Power \& Irrigation. Charles, UST, 39, 47; GB. BFSP, Vol. 102, 137; Martens, NRG, Ser. 3, IV; 208; US. FOR. RELS., 1910, pg. 533.

\section{MISSISSIPPI}

1762; Nov. 3: Fontainebleau. Convention. France/Spain. Cession of Louisiana, including Island of New Orleans, by France to Spain; Thalweg Boundary. Martens, RPT, I, 17. (Commentary: SNOW, Am. Dipl., pg. 3.)

1763; Feb. 10: Paris. Treaty. France/Great Britain/Spain. Cession to Great Britain of Territory of Louisiana lying East of Mid-Channel of the River, except Island of New Orleans. Art. 7: Mutual Liberty of Navigation from Source to the Sea; Freedom from Detention, Visitation, or Payment of Tolls expressly Stipulated. Cussy/Hauterive, RTC, I, pt. 1, 386-88; Cussy/Martens, Rec. Man., Ser. I, I, 29. (Commentary: ENGELHARDT, Hist. du Droit Fluv. Conv., 45; SCHUYLER, Am. Dipl., 269; SNOW, Am. Dipl., 4; WHEATON, Elem. Int. Law (Lawr. Edit.), Chap. IV; sec. 18, 257; WINSOR, Mississippi Basin, 424.)

1782 ; Nov. 30 : Paris. Provisional Treaty of Peace. Great Britain/ United States. Art. II : Thalweg Boundary. Art. VIII : Fluvial Navigation from Source to Sea to remain forever Free \& Open to the Subjects of Great Britain \& to the Citizens of the United States. Malloy, UST, 580, 583. (Commentary: MOORE, ILD, $\mathrm{V}, 372$.

1783; Sept. 3: Paris. Definitive Treaty of Peace. Great Britain/ United States. Art. II: Thalweg Boundary. Art. VIII: Renewed Provisions of Art. 8 of the Treaty of Paris, Nov. 30, 1782, ensuring complete Freedom of Navigation for both Nations. Malloy, UST, 586, 589. (Commentary: MOORE, ILD, I, 624; SNOW, Am. Dipl. 67, 106.)

1783; Sept. 3: Paris (Versailles). Treaty. Great Britain/Spain. Retrocession of Territory of Louisiana, East of the River (The Floridas), to Spain. Cussy/Hauterive, RTC, II, pt. 2, 491-95. 
(NOTE:

(SPAIN PROHIBITS NAVIGATION ON THE LOWER MISSISSIPPI following Conclusion of Peace between Great Britain \& the United States by Treaty of Paris, Sept. 3, 1783. ENGELHARDT, Hist. Droit Fluv. Conv., 46; HALL, Int. Law, 5th Edit., 132; SNOW, Am. Dipl., 109; TRESCOTT, Dipl. Hist. . .

Admins. of Washington \& Adams, 260.)

(NOTE :

(Resolution adopted by the Congress of the Confederation, September 1788, declaring: "The free navigation of the river Mississippi is a clear and essential right of the United States, . . . to be considered and supported as such." SCHUYLER, Am. Dipl., 271.)

(NOTE:

(1790; Aug. 2: Instructions to Mr. Carmichael despatched by Mr. Jefferson, Federal Secretary of State; urging the necessity of establishing freedom of navigation by the Spanish Government. Am. State Paps., For. Rels., I, 247; Barbé Marbois, Hist. of Louisiana, 158; Moore, ILD, I, 624.)

(NOTE:

(SPAIN CLAIMS EXCLUSIVE ENJOYMENT OF NAVIGATION even North of the Thirty-first Degree of Latitude. Am. State Paps., For. Rels., I, 308.)

1794; Nov. 19: London. Treaty. Great Britain/United States. Art. III: Reciprocal Freedom of Navigation Recognized. Malloy, UST, 590. (Commentary: Spain protests against the Third Article of Treaty of London, Nov. 19, 1794. SCHUYLER, Am. Dipl., 278; SNOW, Am. Dipl., 68-69, 73.)

1795; Oct. 27 : San Lorenzo-el-Real. Treaty. Spain/United States. Art. IV : Freedom of Navigation from Source to Gulf of Mexico reserved exclusively for Spanish subjects \& Citizens of the United States; Liberty of extending this privilege to other Nations reserved by Spain. Art. 22: Right of Depositing Merchandise at New Orleans conceded by Spain. Cussy/Hauterive, RTC, II, part 2, 343; Cussy/Martens, Rec. Man., Ser. I, 105; Malloy, UST, 1640, 1642. (Commentary: H. ADAMS, Hist. of U. S., I, 348-49; ENGELHARDT, Hist. Droit. Fluv. Conv., 46; FOSTER, Cent. Am. Dipl., 188; T. J. LAWRENCE, Int. Law, 209; MOORE, Int. Arbs., II, 998; MOORE, ILD, I, 624; PHLIIMORE, Int. Law, I, 241; SCHUYLER, Am. Dipl., 276- 


\section{Mississippi}

77; SNOW, Am. Dipl., 106; TWISS, Law of Nations (Peace), sec. 145.)

1796; May 4: Philadelphia. Agreement. Great Britain/United States. Additional, Explanatory Article supplementing Article III of Treaty of London, Nov. 19, 1794; explicitly providing that no subsequent treaty should derogate in any degree from complete liberty of navigation on all boundary waterways. Malloy, UST, 607-609. (Commentary: SCHUYLER, Am. Dipl., 278.)

(NOTE :

(1797; May 6 : Protest Presented by the Spanish Minister to the Federal Secretary of State; denying the right of the United States to grant British subjects the privilege of navigating the Mississippi. Am. State Papers, For. Rels., II, 15.)

(NOTE :

(1797; May 17: Reply of Mr. Timothy Pickering to the Spanish Minister admitting the justice of the Remonstrance; provided the right of the United States to participate freely in the navigation of the Mississippi originated in the Treaty of San Lorenzoel-Real; Oct. 27, 1795. Am. State Papers, For. Relats, II, 16.)

1800; Oct. 1: San Ildefonso. Treaty. France/Spain. Art. III: Retrocession of Louisiana to France; Mid-Channel constituting Boundary. Clercq, RTF, I, 411-12. (Commentary: MOORE, Am. Dipl. 226; SNOW, Am. Dipl., 46.)

1803; Apr. 30 : Paris. Treaty. France/United States. Art. I: Cession of Louisiana by France. Art. III: Demarcation of Boundaries. Malloy, UST, 508-11.

1814; Dec. 24: Ghent. Treaty. Great Britain/United States. Formal Recognition of the Lapse of Navigation Privileges formerly accorded British Subjects; the United States refusing to renew the Stipulations governing Freedom of Navigation embodied in Treaty of London, Nov. 19, 1794, unless proof submitted that a navigable portion of the system lay within Canadian Dominion. Hertslet, COM. TR., II, 382-84. (Commentary: H. ADAMS, Hist. of the U. S., IX, 44; LAWRENCE, Int. Law, 230, 569; SCHUYLER, Am. Dipl., 281; SNOW, Am. Dipl., 74.)

1819; Feb. 22: Washington. Treaty. Spain/United States. Art. II: Cession of The Floridas to the United States; Mississippi thus becoming a National Waterway. Art. 12: Annulling Articles $2,3,4,21$, \& the second section of Art. 22 of the Treaty of San Lorenzo-el-Real; Oct. 27, 1795. Cussy/Hauterive, RTC, 
II, part 2, 361; Malloy, UST, 1651-57. (Commentary : MOORE,

Int. Arbs., 4796, 4800-01; MOORE, ILD, I, 624-25.)

\section{MOBILE}

(NOTE :

(1805; Dec. 3: Washington. Fifth Annual Message. Thomas Jefferson, President of the United States, declared: "On the Mobile, our commerce passing through that river continues to be obstructed by arbitrary duties and vexatious searches." This controversy with Spain ceased upon the conclusion of the Treaty of Washington, Feb. 22, 1819, (Art. II.), by acquisition of entire navigable course.)

MURRAY CANAL. See CANALS.

NAMECAN LAKE. See BOUNDARY WATERWAYS; SuperiorLake of the Woods System.

\section{NEGRO; or TINTO}

1880; Nov. 1: Tegucigalpa. Constitution. Republic of Honduras. Chap. IV, Sec. 26: Freedom of Navigation granted to All Flags. Hertslet, COM. TR., Vol. 17, 777.

1904; Sept. 2: Tegucigalpa. Constitution. Republic of Honduras. Chap. XVIII, Art. 141: Navigation of River opened freely to the Merchant Vessels of All Nations. GB. BFSP, Vol. 97, 1255, 1272. GREAT LAKES \& CONNECTING WATERS.

1814; Dec. 24: Ghent. Treaty. Great Britain/United States. Demarcation of International Boundary. Hertslet, COM. TR., II, 383; Malloy, UST, 612-19.

1822 ; June 18 : Utica. Agreement. Commissioners of Great Britain $\&$ the United States. Concerning the Demarcation of the WaterBoundary in conformity with Art. VI of Treaty of Ghent; Dec. 24, 1814. Hertslet, COM. TR., IV, 493; Malloy, UST, $620-$ 23.

1906; June 29: Washington. Law. United States. Act of Congress; controlling and regulating the utilization of the waters of Niagara River, for the purpose of preserving Niagara Falls, \&c. GB. BFSP, Vol. 101, 635.

1908; Apr. 11: Washington. Treaty. Great Britain/United States. 


\section{Niagara}

Treaty No. II: Regulations for Protection of the Fisheries. GB. BFSP, Vol. 101, 224; Malloy, UST, 827.

1909; Jan. 11: Washington. Treaty. Great Britain/United States. Art. I: Reciprocal Freedom of Navigation. Charles, UST, 39; GB. BFSP, Vol. 102, 137; Martens, NRG, Ser. 3, IV, 208; US. FOR. RELS., 1910, pg. 533.

\section{NICARAGUA LAKE}

1858; Apr. 15: Treaty. Costa Rica \& Nicaragua. Art. 2: Demarcation of Water-Boundary. Art. 9: Neutralization of the Lake in event of War. MOORE, Int. Arbs., 4706-08.

1886 ; Dec. 24: Guatemala. Treaty. Costa Rica \& Nicaragua. Submitting the Controversy concerning the Validity of the Treaty of Apr. 15, 1858, to the Arbitration of the United States. MOORE, Int. Arbs., 4704.

1888; March 22: Washington. Award by President Cleveland. Composing the Boundary Dispute between Costa Rica \& Nicaragua. MOORE, Int. Arbs., 1945, 1964; MOORE, ILD, III, 259. (Commentary: Correspondence relating to the Boundary Dispute between Costa Rica \& Nicaragua: U. S. FOR. RELATS., 1893, 202, 216, 266, 270, 281, 286-87, 289, 294; 1894, 180, 192-93.)

1896; Mar. 27: Treaty. Costa Rica \& Nicaragua. Embodying the Award of President Cleveland concerning the Boundary Dispute; involving the Validity of the Treaty of April 15, 1858. U. S., FOR. RELATS., 1896, 100-102.

(NOTE :

(For the Award of General Alexander, appointed Engineer-Umpire by President Cleveland, in conformity with terms of the Treaty of March 27, 1896, see: US. FOR. RELATS., 1897, 113-16; 111, $330,419-421$.) GREAT LAKES \& CONNECTING WATERS.

1782; Nov. 30;

1783; Sept. 4: Paris. Treaty. (See Boundary Waterways.)

1814; Dec. 24: Ghent. Treaty. Great Britain/United States. Art. VI: Demarcation of International Boundary. Hertslet, COM. TR., II, 383; Malloy, UST, 612-19.

1817; Apr. 28/29: Washington. Agreement. Great Britain \& the United States. Limiting Naval Forces on the Lake. Hertslet, COM. TR., IX, 763; Malloy, UST, 628-29. 


\section{Ontario Lake}

1818; Apr. 28: Washington. Law (Presidential Proclamation). United States. Giving effect to the Naval Agreement of Washington; Apr. 28/29, 1817. Am. State Paps., For. Rels., IV, 202; GB. BFSP, V, 1200; Hertslet, COM. TR., IX, 762; Malloy, UST, 630 ; Richardson, Messages \& Papers, II, 36.

1822; June 18: Utica. Agreement. Commissioners of Great Britain $\&$ the United States. Concerning the Demarcation of the WaterBoundary in conformity with Art. VI of Treaty of Ghent; Dec. 24, 1814. Hertslet, COM. TR., IV, 493; Malloy, 620-23.

1908; Apr. 11: Washington. Treaty. Great Britain/United States. Treaty No. II: Protection of Fisheries. GB. BFSP, Vol. 101, 224; Malloy, UST, 827.

1909; Jan. 11: Washington. Treaty. Great Britain/United States. Art. I: Reciprocal Freedom of Navigation. Charles, UST, 39 ; GB. BFSP, Vol. 102, 137; Martens, NRG, Ser. 3, IV, 208; US. FOR. RELS., 1910, pg. 533.

OSWEGO CANAL. See CANALS.

OTTAWA CANAL. See CANALS.

\section{PATUCA}

1880; Nov. 1: Tegucigalpa. Constitution. Republic of Honduras. Chap. IV, Sec. 26: Freedom of Navigation granted to All Flags. Hertslet, COM. TR., Vol. 17, 777.

1904; Sept. 2: Tegucigalpa. Constitution. Republic of Honduras. Chap. XVIII, Art. 141: Navigation of the River opened freely to the Merchant Vessels of All Nations. GB. BFSP, Vol. 97, $1255,1272$.

PIGEON. See BOUNDARY WATERWAYS; Superior-Lake of the Woods System.

\section{PORCUPINE}

1871; May 8: Washington. Treaty. Great Britain/United States. Art. 26: "The Navigation . . . ascending and descending, from, to, and into the sea, shall forever remain free and open for the purposes of commerce to the subjects of Her Britannic Majesty and to the citizens of the United States." GB. BFSP, Vol. 61, 51; Hertslet, COM. TR., XIII, 970, 981; Malloy, UST, 700, 711. (Commentary: MOORE, Am. Dipl., 83; MOORE, ILD, I, 635 ; US. FOR RELS., 1892, 335, 337; WESTLAKE, Int. Law, I, 158.) 


\section{Porcupine}

1898; Feb. 2: Washington. Law. United States. Navigation Regu-

lations. U. S., Treasury Dept. Circular, No. 24.

1898; June 6: Washington. Law. United States. Navigation Regulations. U. S., Treasury Dept. Circular, No. 98.

RAINY LAKE. See also BOUNDARY WATERWAYS.

\section{RAINY RIVER}

1782; Nov 30/Sept. 3, 1783 : Paris. Treaty. (See Boundary Waterways.)

1814; Dec. 24: Ghent. Treaty. Great Britain/United States. Demarcation of Water-Boundary. Hertslet, COM. TR., II, 383; Malloy, UST, 612-19.

1842; Aug. 9: Washington. Treaty. Great Britain/United States. Art. II : Demarcation of Boundary; Freedom of Navigation on the Lake, River, and Communicating Frontier Waterways. Hertslet, COM. TR., VI, 856; Malloy, UST, 650, 652. (Commentary: MOORE, Int. Arbs., 193; MOORE, ILD, I, 677-78.) 1908; Apr. 11: Washington. Treaty. Great Britain/United States. Treaty No. I: Boundary \& Navigation Stipulations. Treaty No. II: Fisheries Regulations. GB. BFSP, Vol. 101, 224; Malloy, UST, $815 ; 827$.

1909; Jan. 11: Washington. Treaty. Great Britain/United States. Art. I: Reciprocal Freedom of Navigation. Charles, UST, 39; GB. BFSP, Vol. 102, 137; Martens, NRG, Ser. 3, IV, 208; US. FOR. RELS., 1910, pg. 533. (Commentary: U. S. GRANT, The International Boundary between Lake Superior \& the Lake of the Woods; in Minnesota Hist. Soc. Collects., VIII, pg. 1.)

\section{RAPIDE PLAT CANAL. See CANALS.}

\section{RED RIVER OF THE NORTH}

1879; July 30/Aug. 12: Washington. Agreement. Great Britain/ United States. (1) Mr. Evarts, Secretary of State, to Sir E. Thornton, concerning certain restrictions imposed on American Vessels navigating the River within the Dominion of Canada; Washington, July 30, 1879. (2) Reply of Sir E. Thornton, Aug. 12, 1879, assuring Freedom of Navigation for Vessels of the United States. GB. BFSP, Vol. 70, 1197-98.

\section{RED RIVER; or RIO ROXO DE NACOGDOCHES}

1819; Feb. 22: Washington. Treaty. Spain/United States. Art. 3 : Reciprocal Freedom of Navigation; Common Enjoyment of 
Ancillary Uses where forming International Frontier. Malloy, UST, 1651, 1653.

(NOTE:

Annulled by Annexation of Texas by the United States. New Boundaries established by Treaty between Mexico \& the United States; Guadalupe Hidalgo, Feb. 2, 1848. Malloy, UST, 1107.)

\section{RIDEAU CANAL. See CANALS.}

RIO GRANDE; or RIO GRANDE DEL NORTE; or RIO BRAVO 1848; Feb. 2: Guadalupe Hidalgo. Treaty. Mexico/United States. Art. V: Delimination of International Boundary. Art. VII: Mutual Liberty of Navigation. Malloy, UST, 1107-1111. (Commentary: ENGELHARDT, Hist. Droit Fluv. Conv., 83; MOORE, ILD, I, 639 ; SNOW, Am. Dipl.)

1853; Dec. 30: Washington. Treaty. Mexico/United States. Art. IV : Restricted Scope of Art. 7 of Treaty of Guadalupe Hidalgo, Feb. 2, 1848, by limiting Reciprocal Freedom of Navigation to the Course lying south of Latitude 31 deg., 47 min., 30 sec. Malloy, UST, 1123.

1884; Nov 12: Washington. Treaty. Mexico/United States. Demarcation of Boundary Line. Malloy, UST, 1159; Martens, NRG, Ser. 2, XIII, 673-75.

1889; March 1: Washington. Treaty. Mexico/United States. Art. I: Fluvial Boundary Disputes to be referred to an International Boundary Commission. Arts. II \& III: Institution of the International Boundary Commission. Art. V: Prohibition of Works or Obstructions deemed in contravention of the stipulations of the Treaties of Feb. 2, 1848 \& Nov. 12, 1884. Malloy, UST; $1167-69$.

1895; Oct. 1: Washington. Convention. Mexico/United States. Agreement prolonging the stipulations of the Treaty of March 1, 1889. Malloy, UST, 1175-76.

1896; Nov. 6: Washington. Convention. Mexico/United States. Prolonging Operation of Treaty of Washington, March 1, 1889, concerning Water-Boundary. Malloy, UST, 1179.

1897; Oct. 29: Washington. Convention. Mexico/United States. Extending the Duration of the Treaty of Washington, March 1, 1889, for a period of one year. Malloy, UST, 1181.

1898; Dec. 2: Washington. Convention. Mexico/United States. Continuing the Stipulations of the Treaty of Washington, March 1, 1889, in force an additional year. Malloy, UST, 1182. 


\section{Rio Grande}

1899; Dec. 22: Washington. Convention. Mexico/United States.

Renewing Operation of Treaty of Washington, March 1, 1889,

for the Ensuing Year. Malloy, UST, 1191.

1900; Nov. 21: Washington. Convention. Mexico/United States. Water-Boundary. Malloy, UST, 1192-93.

1905; Mar. 20: Washington. Convention. Mexico/United States.

Arts. I-IV: Elimination of Obstructions in the Navigable Channel. GB. BFSP, Vol. 98, 753; Malloy, UST, 1199; Martens, NRG, Ser. 3, I, 299.

1906; May 21: Washington. Convention. Mexico/United States. Arts. 1-6: Diversion \& Equitable Distribution of the Waters of the Rio Grande. GB. BFSP, Vol. 101, 469; Malloy, UST, 1202-1203; Martens, NRG, Ser. 2, Vol. 35, 461.

1910; Jan 24: Washington. Treaty. Mexico/United States. Providing for the Arbitration of the Boundary Dispute arising from Divergent Interpretation of the Treaties of Feb. 2, 1848 \& Dec. 30,1853 , concerning Subsequent Changes in the Navigable Channel. Charles, UST, 91.

1911; June 15: Arbitral Sentence rendered by the Commission established in conformity with the Arbitration Treaty; Washington, Jan. 24, 1910. Martens, NRG, Ser. 3, VI, 66.

\section{ROMAN. See AGUAN}

\section{SABINE}

1819; Feb. 22: Washington. Treaty. Spain/United States. Art. 3: Reciprocal Freedom of Navigation; Common Enjoyment of Ancillary Uses from the Sea throughout Course forming International Frontier. Malloy, UST, 1651, 1653. (NOTE: Annulled by Annexation of Texas by the United States. New Boundaries established by Treaty between Mexico \& the United States; Guadalupe Hidalgo, Feb. 2, 1848. Malloy, UST, 1107.)

\section{ST. ANDREW'S CANAL. See CANALS.}

ST. CLAIR FLATS CANAL. See CANALS; GREAT LAKES \& CONNECTING WATERS.

ST. CLAIR LAKE See also: BOUNDARY WATERWAYS; GREAT LAKES \& CONNECTING WATERS.

ST. CLAIR RIVER

1782; Nov. 30 : Paris. Provisional Treaty.

1783: Sept. 3: Paris. Definitive Treaty of Peace. Great Britain/ 
United States. Art. III: Demarcation of International Boundary. Malloy, UST, 580-81; 586-88.

1814; Dec. 24: Ghent. Treaty. Great Britain/United States. Art. VI: Demarcation of Boundary. Hertslet, UOM. TR., 383 ; Malloy, UST, 612, 616.

1822; June 18: Utica. Agreement. Commissioners of Great Britain \& the United States. Establishing precise location of the International Boundary in the Lake \& River, in conformity with Art. VI of the Treaty of Ghent, Dec. 24, 1824. Hertslet, COM. TR., IV, 493, 497; Malloy, UST, 620-23.

1842; Aug. 9: Washington. Treaty. Great Britain/United States. Arts. 1, 2, 3, 6, 7: Demarcation of Boundary; Freedom of Navigation. GB. BFSP, Vol. 51, 934-37; Hertslet, COM. TR., VI, 856 ; Malloy, UST, $650,653$.

1854; June 5: Washington. Treaty. Great Britain/United States. Art. IV: Recognized Reciprocal Freedom of Navigation. Cussy/Martens, Rec. Man., Ser. 1, Vol. VII, 338-342; Hertslet, COM. TR., IX, 1001; Malloy, UST, 668, 671.

1871; May 8: Washington. Treaty. Great Britain/United States. Art. 27: Open freely to the Navigation of the Vessels of Both Nations. GB. BFSP, Vol. 61, pg. 52 ; Hertslet, COM. TR., Vol. 13, 970, 982; Malloy, UST, 711.

1908; Apr. 11: Washington. Treaty. Great Britain/United States. Treaty No. I: Boundary \& Navigation Stipulations. Treaty No. II: Fisheries Regulations; Art. IV, sec. 9 specifically including St. Clair Lake \& River. GB. BFSP, Vol. 101, 224; Malloy, UST, $815,827$.

1909; Jan. 11: Washington. Treaty. Great Britain/United States. Art. I: Perpetual Freedom of Navigation assured to Vessels of Both Nations. Charles, UST, 39; GB. BFSP, Vol. 102, 137; Martens, NRG, Ser. 3, IV, 208; US. FOR. RELS., 1910, 533.

ST. CROIX. See also BOUNDARY WATERWAYS. 1782; Nov. 30 : Paris. Provisional Treaty.

1783; Sept. 3: Paris. Definitive Treaty of Peace. Great Britain/ United States. Art. II: Demarcation of International Boundary. Malloy, UST, 580-81; 586-88.

1794; Nov. 19: London. Treaty. Great Britain/United States. Arts. II, V: Boundary. Malloy, UST, 590.

1798; Oct. 25: Agreement. Commissioners of Great Britain \& the United States. Declaring, in conformity with Art. $V$ of Treaty of London, Nov. 19, 1794, what River was intended as the "St. 


\section{St. Croix}

Croix" by the Definitive Treaty of Paris, Sept. 3, 1783. Hertslet, COM. TR., IX, 761.

1814; Dec. 24: Ghent. Treaty. Great Britain/United States. Art. V: Demarcation of International Boundary. Hertslet, COM. TR., II, 378, 382-83; Malloy, UST, 612-19. (Commentary: SNOW, Am. Dipl., 68, 69, 73.)

1842; Aug. 9: Washington. Treaty. Great Britain/United States. Arts. 1, 6: Demarcation of Boundary. GB. BFSP, Vol. 51, 934-37; Hertslet, COM. TR., VI, 854, 856, 858; Malloy, UST, $650,653$.

1847; June 28: Washington. Decision. Commissioners of Great Britain \& the United States appointed by terms of Treaty of Washington, Aug. 9, 1842. Establishing International Boundary in the St. Croix. Hertslet, COM. TR., Vol. 14, 669.

1908; Apr. 11: Washington. Treaty. Great Britain/United States. Treaty No. I, Art. II: Demarcation of Boundary. Treaty No. II: Protection of Fluvial Fisheries. GB. BFSP, Vol. 101, 224; Malloy, UST, 815, 827.

1909; Jan. 11: Washington. Treaty. Great Britain/United States. Art. I: Reciprocal Freedom of Navigation. Charles, UST, 39; GB. BFSP, Vol. 102, 137; Martens, NRG, Ser. 3, IV, 208; US. FOR. RELS., 1910, 533.

ST. FRANCIS. See also BOUNDARY WATERWAYS; St. John River System.

1842; Aug. 9: Washington. Treaty. Great Britain/United States. Art. I: Thalweg Boundary. Art. VI: Demarcation of International Boundary. GB. BFSP, Vol. 51, 934-37; Hertslet, COM. TR., VI, 854; Malloy, UST, 650, 653.

1847; June 28: Washington. Decision. Commissioners of Great Britain \& the United States appointed in conformity with Treaty of Washington, Aug. 9, 1842. Designating International Fluvial Boundary. Hertslet, COM. TR., Vol. 14, 669.

1909; Jan. 11: Washington. Treaty. Great Britain/United States. Art. I: Perpetual Freedom of Navigation assured to Vessels of Both Nations. Charles, UST, 39; GB. BFSP, Vol. 102, 137; Martens, NRG, Ser. 3, IV, 208; US. FOR. RELS., 1910, 533.

ST. JOHN. See also BOUNDARY WATERWAYS.

1782; Nov. 30 : Paris. Provisional Treaty.

1783; Sept. 3: Paris. Definitive Treaty of Peace. Great Britain/ United States. Demarcation of International Boundary. Malloy, UST, 580-81; 586-88. 
1814; Dec. 24: Ghent. Treaty. Great Britain/United States. Art. V: Demarcation of Boundary from the Atlantic to the River St. Lawrence. Hertslet, COM. TR., II, 378, 382-83; Malloy, UST, 612-19.

1831; Jan. 10: The Hague. Arbitral Award. King of the Netherlands. Composing the Dispute between Great Britain \& the United States concerning the location of the Boundary stipulated by Art. $\mathrm{V}$ of Treaty of Ghent, Dec. 24, 1814. Hertslet, COM. TR., IV, 521.

1842; Aug. 9: Washington. Treaty.. Great Britain/United States. Art. I: Thalweg Boundary. Art. III: Reciprocal Freedom of Navigation. Art. VI: Demarcation of International Boundary. GB. BFSP, Vol. 51, 934-37; Hertslet, COM. TR., VI, 854-56; Malloy, UST, 650-51, 653. (Commentary: MOORE, Int. Arbs., 151; MOORE, ILD, I, 636; WEBSTER, "Writings," XII, 23 ; U. S., 24th Cong., 1st Sess., Sen. Doc. No. 414, pg. 62.)

1843; Aug. 22 : London. Law. Act of Parliament of Great Britain. Establishing Freedom of Fluvial Transit for American Vessels \& Commerce in conformity with Treaty of Washington, Aug. 9, 1842. Hertslet, COM. TR., VI, $865 ; 6$ \& 7 Vict., cap. 84.

1847; June 28: Washington. Decision. Commissioners of Great Britain \& the United States appointed by terms of Treaty of Washington, Aug. 9, 1842. Designating International Fluvial Boundary. Hertslet, COM. TR., Vol. 14, 669.

1853; Aug. 20 : London. Law. Act of Parliament of Great Britain. Fulfilling Stipulations of Treaty of Washington, Aug. 9, 1842. Hertslet, COM. TR., IX, 444.

1854; June 5: Washington. Treaty. Great Britain/United States. Art. IV, par. 4: Established Privilege of Flottage of Produce upon St. John \& Affluents subject to no Duties or Tolls. Cussy/ Martens, Rec. Man., Ser. I, VII, 338-342; Hertslet, COM. TR., IX, 1001; Malloy, UST, 668, 671.

1871; May 8: Washington. Treaty. Great Britain/United States. Arts. 27, 28: Freedom of Navigation. Art. 31: Exemption from Canadian Export Duties for Produce transported by the River St. John. GB. BFSP, Vol. 61, 52; Hertslet, COM. TR., XIII, 970, 981; Malloy, UST, 700-11, 713. (Commentary: CUSHING, Treaty of Washington, 1871, pg. 243; MOORE, Int. Arb., 4751; MOORE, ILD, I, 637.)

1908; Apr. 11: Washington. Treaty. Great Britain/United States. Treaty No. II; Protection of Fluvial Fisheries. GB. BFSP, Vol. 101, 224; Malloy, UST, 815, 827. 


\section{St. John}

1909; Jan. 11: Washington. Treaty. Great Britain/United States. Art. I: Perpetual Freedom of Navigation assured to Vessels of Both Nations. Charles, UST, 39; GB. BFSP, Vol. 102, 137; Martens, NRG, SER. 3, IV, 208; US. FOR. RELS, 1910, pg. 533.

\section{ST. LAWRENCE}

See also: BOUNDARY WATERWAYS; CANALS.

1782 ; Nov. 30 : Paris. Provisional Treaty.

1783; Sept. 3: Paris. Definitive Treaty of Peace. Great Britain/ United States. Art. II: Demarcation of International Boundary. Malloy, UST, 580-81; 586-88.

1814; Dec. 24: Ghent. Great Britain/United States. Arts. V, VI: International Fluvial Boundary. Hertslet, COM. TR., II, 378, 382-83; Malloy, UST, 612-19.

1822; June 18: Utica. Agreement. Commissioners of Great Britain \& the United States. Establishing Precise Location of International Fluvial Boundary in conformity with Art. VI of Treaty of Ghent, Dec. 24, 1814. Hertslet, COM. TR., IV, 493, 497; Malloy, UST, 620-23.

1831; Jan. 10: The Hague. Arbitral Award. King of the Netherlands. Deciding the Dispute between Great Britain \& the United States concerning Location of Water-Boundary stipulated by Art. $\mathrm{V}$ of Treaty of Ghent, Dec. 24, 1814. Hertslet, COM. TR., IV, 521.

1842; Aug. 9: Washington. Treaty. Great Britain/United States. Arts. I, VI: Demarcation of International Boundary. Art. VII : All Channels available for Navigation of Both Nations, irrespective of Precise Location of Boundary. GB. BFSP, Vol. 51, 934-37; Hertslet, COM. TR., 854-56; Malloy, 650-51, 653, 654-55. (Commentary: WHEATON, Elem. Int. Law (Lawr. Edit.), Chap. IV, sec. 19, pg. 261.)

1854; June 5: Washington. Treaty. Great Britain/United States. Art. IV: Reciprocal Freedom of Navigation, subject to subsequent termination of the privilege upon due notification. Cussy/ Martens, Rec. Man., Ser. I, VII, 338-342; Hertslet, COM. TR., IX, 1001; Malloy, UST, 668, 671. (Commentary: ENGELHARDT, Hist. Droit Fluv. Conv., 82 ; LAWRENCE, Int. Law, 209; MOORE, Int. Arb., 4747; MOORE, ILD, I, 633-34; 678; PHILLIMORE, Int. Law, 3rd Edit., I, 643-645; WESTLAKE, Int. Law, I, 155; WHEATON, Elem. Int. Law (Dana Edit.), 283-287, Note 287-288.) 
(NOTE:

(PRELIMINARIES UNDERTAKEN BY THE UNITED STATES FOR INSTITUTING FREEDOM OF NAVIGATION ON THE RIVER ST. LAWRENCE; 1823-1854:

AM. STATE PAPS., For. Rels., VI, 757-58, 769, 772;

BUCHANAN, "Writings," collected by J. B. MOORE, Washington, Apr. 12, 1848, VIII, 49; Washington, May 1, 1848, VIII, 56 ;

GALLATIN, "Writings," collected by H. ADAMS, II, 315 ;

GB. BFSP, Vol. 19, 1067; Correspondence between Great Britain \& the United States, 1824-1827, concerning institution of Freedom of Navigation;

HALI, Int. Law, 5th Edit., 133-138;

MADISON, "Writings," collected by G. HUNT, Montpelier, Nov. 13, 1823, Vol. 9, 164;

SCHUYLER, Am. Dipl., 283-84, 287-88;

US. CONGRESSIONAL GLOBE, 1849-50, 31 Cong., 1st Sess., May 2, 1850, pg. 893-94; 31 Cong., 2nd Sess., pg. 751;

US. 31 Cong., 1st Sess., House Jol., 450; House Misc. Doc., No. 22, 29 ; House Report, No. 295;

US. 31 Cong., 2nd Sess., House Report, No. 4, 72.)

1866; Mar. 17: Treaty of Washington, June 5, 1854, was terminated upon this date following appropriate notice given by the United States; Privilege of Navigation for American Vessels consequently extinguished. Moore, ILD, I, 634; Schuyler, Am. Dipl., 290. (Commentary: President Grant's Annual Message of 1870, Richardson, VII, 104.)

1871; May 8: Washington. Treaty. Great Britain/United States. Arts. 26, 27: Perpetual Freedom of Navigation for American Vessels throughout Lower Course. GB. BFSP, Vol. 61, 52 ; Hertslet, COM. TR., XIII, 970, 981; Malloy, UST, 700-11. (Commentary: CUSHING, The Treaty of Washington of 1871, pgs. 203-221, 241-247; MOORE, Int. Arbs., 170, 195, 816, 4057, 4751; MOORE, ILD, I, 635; V, 723; SNOW, Am. Dipl., 95-99; WESTLAKE, Int. Law, I, 158.)

1902; June 18: Washington. Law. Act of Congress of the United States. Permitting Construction of Dam by the Canadian Government at Les Galops Island for Improvement of Navigation. GB. BFSP, Vol. 96, 180.

1908; Apr. 11: Washington. Treaty. Great Britain/United States. Treaty No. I: Boundary \& Navigation Regulations. Treaty 
St. Lawrence

No. II: Protection of Fluvial Fisheries. GB. BFSP, Vol. 101, 224 ; Malloy, UST, 815, 827.

1909; Jan. 11: Washington. Treaty. Great Britain/United States.

Art. I: Perpetual Freedom of Navigation for Vessels of Both

Nations. Charles, UST, 39 ; GB. BFSP, Vol. 102, 137 ; Martens, NRG, Ser. 3, IV, 208; US. FOR. RELS., 1910, pg. 533.

ST. MARY'S; or Sault Sainte Marie CANAL. See CANALS.

ST. MARY'S LAKE See also: BOUNDARY WATERWAYS; GREAT LAKES \& CONNECTING WATERS.

ST. MARY'S RIVER

1782; Nov. 30 : Paris. Provisional Treaty.

1783; Sept. 3: Paris. Definitive Treaty of Peace. Great Britain/

United States. Art. II: Delimination of International Boundary. Malloy, UST, 580-81; 586-88.

1814; Dec. 24: Ghent. Treaty. Great Britain/United States. Art.

VII: International Fluvial Boundary. Hertslet, COM. TR., II, 378, 383; Malloy, UST, 612-19.

1842; Aug. 9: Washington. Treaty. Great Britain/United States. Art. II: Thalweg Boundary. GB. BFSP, Vol. 51, 934; Hertslet, COM. TR., VI, 854-56; Malloy, UST, 650, 653.

1908; Apr. 11: Washington. Treaty. Great Britain/United States.

Treaty No. I: Boundary \& Navigation Regulations. Treaty No.

II: Protection of Fisheries. GB. BFSP, Vol. 101, 224; Malloy, UST, 815, 827.

1909; Jan. 11: Washington. Treaty. Great Britain/United States.

Art. I: Perpetual Freedom of Navigation for Vessels of Both Nations. Charles, UST, 39; GB. BFSP, Vol. 102, 137 ; Martens, NRG, Ser. 3, IV, 208; US. FOR. RELS., 1910, pg. 533.

\section{ST. MARY'S}

1782; Nov. 30 : Paris. Provisional Treaty.

1783; Sept. 3: Paris. Definitive Treaty of Peace. Great Britain/ United States. Art. II: Thalweg Boundary. Malloy, UST, $580-81 ; 586-88$.

1795; Oct. 27 : San Lorenzo-el-Real. Treaty. Spain/United States. Art. II: Thalweg Boundary. Cussy/Hauterive, RTC, II, part 
2, 343; Cussy/Martens, Rec. Man., Ser. I, 105; Malloy, UST, 1640, 1642. (Commentary: THE APOLLON, 1824, IX WHEATON, 362; MOORE, ILD, I, 627.)

1819; Feb. 22: Washington. Treaty. Spain/United States. Art. 2: Cession of The Floridas to the United States; The St. Mary's River thus becoming a National Waterway. Art. 12: Annulling Articles 2, 3, 4, 21, \& 22, sec. 2 of Treaty of San Lorenzo-el-Real; Oct. 27, 1795. Cussy/Hauterive, RTC, II, part 2, 361; Malloy, UST, $1651-57$.

ST. MARY'S.

See: BOUNDARY WATERWAYS; MILK/ST. MARY'S RIVER SYSTEM.

ST. OURS CANAL. See CANALS.

ST. PETER'S CANAL. See CANALS.

SAISAGINAGA. See BOUNDARY WATERWAYS; SuperiorLake of the Woods System.

\section{SAN JUAN}

1858; Apr. 15: Treaty. Costa Rica \& Nicaragua. Art. II: Demarcation of Water-Boundary. Art. IV : Costa Rica to be jointly responsible for Custody \& Defense of the River. Art. VI: Exclusive Jurisdiction over the River Granted to Nicaragua, subject to Free Navigation by Costa Rican Vessels. MOORE, Int. Arbs., $4706-4707$.

(NOTE :

(1852; Apr. 30: Treaty. Washington. Great Britain \& United States. (Webster-Crampton Agreement.) Art. III: Concerning the Costa Rican/Nicaraguan Boundary; Navigation of the San Juan River.)

(NOTE :

(Costa Rican Claims to the Enjoyment of the River. GB. BFSP, 1860, pg. 52.)

1886; Mar. 16: Law. Decree of the Costa Rican Government, concerning Fluvial Navigation. GB. BFSP, Vol. 78, 803. (NOTE: Operation of this law was suspended on Dec. 24, 1886.)

1886; Dec. 24: Guatemala. Treaty. Costa Rica/Nicaragua. Submitting the Controversy concerning the Validity of the Treaty of Apr. 15, 1858, to the Arbitration of the United States. Moore, Int. Arbs., 4704.

1888; March 22: Washington. Award of President Cleveland. Com- 
San Juan

posing the Boundary Dispute between Costa Rica \& Nicaragua. Moore, Int. Arbs., 1945, 1964; Moore, ILD, III, 259. (Commentary: Correspondence relating to the Boundary Dispute between Costa Rica \& Nicaragua: US. FOR. RELS., 1898, 202, 216, 266, 270, 281, 286-87, 289, 294; 1894, 180, 192-93.)

1896; March 27: Treaty. Costa Rica \& Nicaragua. Embodying the Award of President Cleveland composing the Boundary Dispute between the Two Nations. US. FOR. RELS., 1896, 100-102.

(NOTE: For the Award of General Alexander, appointed Engineer-Umpire by President Cleveland, in conformity with Terms of the Treaty of March 27, 1896, see US. FOR. RELS., 1897, $111,113-116,330,419-21$.)

SAULT SAIN'TE MARIE; or ST. MARY'S CANAL.

See: CANALS; GREAT LAKES \& CONNECTING WATERS.

SEGOVIA. See COCO.

SIBUN. See BELIZE.

SOULANGES CANAL. See CANALS.

STIKINE

1871; May 8: Washington. Treaty. Great Britain/United States. Art. 26: "Navigation . . ascending and descending, from, to, and into the sea, shall forever remain free and open for the purposes of commerce . . . subject to any laws and regulations of either country within its own territory, not inconsistent with such privilege of free navigation." GB. BFSP, Vol. 61, 51-52; Hertslet, COM. TR., XIII, 970, 981-82; Malloy, UST, 700, 711. (Commentary: MOORE, Am. Dipl., 83; MOORE, ILD, I, 63536 ; US. FOR. RELS., 1892, 335, 337; WESTLAKE, Int. Law, $\mathrm{I}, 158$.

1898; May 9 : Washington. Law. United States. Navigation Regulations. US. Treasury Dept. Circ., No. 76.

1903; Jan. 24: Washington. Treaty. Great Britain/United States. Arts. 1-6: Providing for Submission of the Existing Boundary Dispute to an Arbitral Tribunal. Malloy, UST, 787.

1903; Oct. 20: Washington. Decision. Final Award by the Arbitral Tribunal constituted by Treaty of Washington, Jan. 24, 1903; establishing the Disputed International Boundary upon the Mainland. Malloy, UST, 792; US. FOR. RELS., 1903, pg. 543. 
(Commentary: ALVERSTONE, Recollections of Bench \& Bar (London, 1914); MOORE, Am. Dipl., 213-14, 219; MOORE, ILD, 466-475.)

SUPERIOR LAKE See also: BOUNDARY WATERWAYS; GREAT LAKES \& CONNECTING WATERS.

1782; Nov. 30: Paris. Provisional Treaty.

1783; Sept. 3: Paris. Definitive Treaty of Peace. Great Britain/ United States. Art. II: Demareation of International Boundary. Malloy, UST, 580-81; 586-88.

1814; Dec. 24: Ghent. Treaty. Great Britain/United States. Arts.

6, 7: International Boundary. Hertslet, COM. TR., II, 378, 383 ; Malloy, UST, 612-619.

1908; Apr. 11: Washington. Treaty. Great Britain/United States. Treaty No. I: Boundary \& Navigation Regulations. Treaty No.

II: Protection of Fisheries. GB. BFSP, Vol. 101, 224; Malloy, $815,827$.

1909; Jan. 11: Washington. Treaty. Great Britain/United States. Art. I: Perpetual Freedom of Navigation for Vessels of Both Nations. Charles, UST, 39; GB. BFSP, Vol. 102, 137; Martens, NRG, Ser. 3, IV, 208; US. FOR. RELS., 1910, pg. 533.

TINTO. See NEGRO.

TRENT CANAL. See CANALS.

\section{ULUA}

1880; Nov. 1: Tegucigalpa. Constitution. Republic of Honduras. Chap. IV, Sec. 26: Freedom of Navigation granted to All Flags. Hertslet, COM. TR., Vol. 17, 777.

1904; Sept. 2: Tegucigalpa. Constitution. Republic of Honduras. Chap. XVIII, Art. 141: Navigation of the River opened freely to the Merchant Vessels of All Nations. GB. BFSP, Vol. 97, $1255,1257$.

WALLIS. See BELIZE.

WANKS. See COCO.

WELLAND CANAL

See also: CANALS;

GREAT LAKES \& CONNECTING WATERS.

1871; May 8: Washington. Treaty. Great Britain/United States. Art. 27: Freedom of Navigation granted American Vessels on Absolute Equality with Canadian. GB. BFSP, Vol. 61, 51-52; Hertslet, COM. TR., XIII, 970, 981-82 ; Malloy, UST, 700, 711. 
Williamsburg Canal

WILLIAMSBURG CANAL. See CANALS.

YORO. See COCO.

\section{YUKON}

1871; May 8: Washington. Treaty. Great Britain/United States. Art. 26: "Navigation . . . ascending and descending, from, to, and into the sea, shall forever remain free and open for the purposes of commerce... subject to any laws and regulations of either country within its own territory, not inconsistent with such privilege of free navigation." GB. BFSP, Vol. 61, 51-52; Hertslet, COM. TR., XIII, 970, 981-82; Malloy, UST, 700, 711. (Commentary: MOORE, Am. Dipl., 83; MOORE, ILD, 626-36; US. FOR. RELS., 1892, 335, 337; WESTLAKE, Int. Law, I, 158.)

1898; Feb. 2: Washington. Law. United States. Navigation Regulations. US. Treas. Dept. Circ., No. 24.

1898; Feb. 5: Ottawa. Law. Canadian Government. Regulations governing Navigation within British Territory. US. Treas. Dept. Circular, No. 26.

1898; June 6: Washington. Law. United States. Navigation Regulations. US. Treas. Dept. Circ., No. 98.

\section{SOUTH AMERICA}

AGUARICO; or SAN MIGUEL.

See: AMAZON; COLOMBIAN WATERWAYS; PERUVIAN WATERWAYS.

\section{AMAKURU}

1897; Feb. 2: Treaty. Great Britain \& the United States of Venezuela. Art. II: Providing for Submission of Boundary Dispute to an Arbitral Tribunal. Hertslet, COM. TR., Vol. 21, 1123.

1899 ; Oct. 3 : Paris. Decision. Award of the Tribunal of Arbitration constituted under Art. II of Treaty of Feb. 2, 1897. Composing Boundary Dispute between Great Britain \& Venezuela and Providing that, in time of Peace, Merchant Vessels of All Nations should enjoy Freedom of Navigation. Hertslet, COM. TR., Vol. 21, 1123. (Commentary: ALVERSTONE, Recollections of Bench \& Bar, London, 1914, pg. 239; HALL, 5th Edit., Int. Law, 112-113; OPPENHEIM, Int. Law, I, 228; US., 50th Cong., 2nd Sess., House Exec. Doc., Vol. I, 698.) 
AMAZON

* Conventions concerning Liberty of Navigation preceding the Brazilian Imperial Decree of December 7, 1866, establishing Universal Freedom.

1851; July 26: Lima. Treaty. Peru/United States. Art. III: Most Favored Nation Treatment. Art. X: Participation in Fluvial Navigation. Malloy, UST, 1388; Moore, ILD, I, 641. (NOTE: This Convention was terminated, Dec. 9, 1863, upon Preliminary Notice tendered by Peru in 1862.)

1851; Oct. 23: Lima. Treaty. Brazil/Peru. Establishing Reciprocal Freedom of Navigation, including Affluents. Annuaire des Deux Mondes, (1852-1853), pg. 934; Cussy/Martens, Rec. Man., Ser. I, VI, 640; GB. BFSP, Vol. 42, 1308; US., 33rd Cong., 1st Sess., House Misc. Doc., No. 22, pg. 13. (Commentary : This Treaty expired October 23, 1858, being followed by a temporary Fluvial Convention. MOORE, ILD, I, 645; SCHUYLER, Am. Dipl., 330; WOOLSEY, Int. Law, sec. 62.)

1852; Aug. 30: Rio de Janeiro. Law (Imperial Decree). Brazilian Government. Regulating Navigation by Steam Vessels. GB. BFSP, Vol. 42, 1304.

1853; Jan. 27: La Paz. Law. Decree of the Bolivian Government. Declaring all navigable Bolivian Waterways, affluent to the Amazon, free to the commerce \& navigation of all nations. GB. BFSP, Vol. 55, 505; Hertslet, COM. TR., Vol. 13, 152-53; US. 33rd Cong., 1st Sess., House Misc. Doc., No. 22, pg. 16.

1853 ; Apr. 15 : Lima. Law. Decree of Peruvian Government establishing Loreto \& Nauto as Ports of Entry for Vessels from Brazil \& Most Favored Nations. Moore, ILD, I, 641.

(Commentary: REFUSAL OF BRAZIL TO ABIDE BY TERMS OF TREATY OF LIMA; OCTOBER 23, 1851.

(1853; July 13: Lima. Invitation extended by the Peruvian Government to Brazil, Ecuador, New Granada, \& Venezuela to attend a Conference at Lima for the purpose of placing Amazonian Navigation on Equitable Basis. US. 33rd Cong., 1st Sess., House Misc. Doc., No. 22, pg. 22.

(1853; Oct. 17: Quito. President of Ecuador (Urbina) to Brazilian E. E. \& M. P. in Ecuador (Lisboa), assuring cooperation of Ecuador in promoting navigation on the Amazon. US., 33rd Cong., 1st Sess., House Misc. Doc., No. 22, pg. 11.

(1853; Dec. 5: Washington. First Annual Message of President 
Amazon

Pierce, assailing the Restrictive Policy maintained by Brazil. Richardson, Messages \& Papers, V, 211.

(1854; Jan. 13: New York. Formal Notice issued by the ConsulateGeneral of the Brazilian Empire that Observance of Treaty of Lima, Oct. 23, 1851, by Brazil was terminated. US. 33rd Cong., 1st Sess., House Misc. Doc., No. 22, pg. 13.)

1854; Jan. 4: Lima. Law. Decree of Peruvian Government modifying Decree of April 15, 1853, by restricting Navigation to Brazilian Vessels. Moore, ILD, I, 645.

1854; Oct. 2 : Rio de Janeiro. Law. Decree of the Brazilian Government revising contract with the Company for the Navigation \& Commerce of the Amazon. GB. BFSP, Vol. 58, 678 .

(NOTE :

(1854; Dec. 4: Washington. Second Annual Message of President Pierce, referring to unsuccessful endeavors to secure Freedom of Navigation. Richardson, Messages \& Papers, V, 280.

1858; May 13: La Paz. Treaty. Bolivia/United States. Arts. 26, 27: Freedom of Navigation; confirming rights previously granted by Decree of January 27, 1853. Malloy, UST, 113; US. FOR. RELS., 1871, pg. 41.

1858; Nov. - : Treaty. Brazil \& Peru. Provisionally securing for Peru the Privilege of Navigation, subject to charges for lighting, pilotage, \& police supervision. Moore, ILD, I, 645.

* Institution of Universal Freedom of Navigation.

1866; Dec. 7: Rio de Janeiro. Law (Imperial Decree). Brazilian Government. Opening Navigation to the Merchant Vessels of All Nations. GB. BFSP, Vol. 58, 551; Hertslet, COM. TR., XIII, 157. (Commentary: HALL, Int. Law, 5th Edit., 138139 ; MOORE, ILD, I, 640-641, 645 ; RICHARDSON, Messages \& Papers, VI, 578: Third Annual Message of President Andrew Johnson; "Brazil, with enlightened sagacity \& comprehensive statesmanship, has opened the great channels of the Amazon $\&$ its tributaries to universal commerce."; SCHUYLER, Am. Dipl., 344; US. 33rd Cong., 1st Sess., House Exec. Doc., No. 53, parts $1 \& 2$; House Misc. Doc., No. 22; US., 32nd Cong., 2nd Sess., Sen. Exec. Doc., No. 32.)

1867; July 31: Rio de Janciro. Law. (Imperial Decree). Brazilian Government. Navigation Regulations; enumerating tributaries open to commerce. GB. BFSP, Vol. 58, 551-567; Hertslet, COM. TR., XIII, 158. 
Amazon

1868; Dec. 17: Lima. Law. Decree of Peruvian Government declaring Navigation of All Rivers open to Merchant Vessels irrespective of Nationality. GB. BFSP, Vol. 65, 1240; Hertslet, COM. TR., XIV, 432. (Commentary： WHEATON, Elem. Int. Law (Lawrence' Edit.), 363-365.)

1873; Jan. 25: Rio de Janeiro. Law (Imperial Decree). Brazilian Government. Extending further facilities for Navigation upon the tributary Madeira. GB. BFSP, Vol. 65, 607; Hertslet, COM. TR., XIV, 202; US. FOR. RELS., 1899, pg. 123.

1891; Oct. 10: Treaty. Brazil \& Peru. Providing Additional Navigation Regulations. US. FOR. RELS., 1903, pgs. 36-43. (Commentary: MOORE, ILD, I, 647.)

1902; Aug. 8: Rio de Janeiro. Circular Notice issued by Brazilian Government. Suspending Freedom of Amazonian Navigation for Bolivian Exports \& Imports. GB. BESP, Vol. 95, 774. (Commentary: Vigorous Protests submitted by France, Germany, Great Britain, Switzerland, \& the United States. MOORE, "Brazil \& Peru Boundary Question," pg. 13.)

1903; Feb. 20: Rio de Janeiro. Law (Circular Notice.) Brazilian Government. Partial Restoration of Freedom of Commercial Navigation; Transportation of Munitions of War destined for Bolivia being prohibited. GB. BFSP, Vol. 96, pg. 388; US. FOR. RELS., 1903, pg. 42.

1903; Nov. 17 : Petropolis. Treaty. Bolivia \& Brazil. Establishing in perpetuity the most ample Freedom of Transit \& Fluvial Navigation for Both Nations, recognizing the Right of Each to Maintain Customs Agents in Certain Ports of the Other Country. US. FOR. RELS., 1903, pg. 36-43. (Commentary: MOORE, "Brazil \& Peru Boundary Question," pgs. 15-16.)

1904; July 12: Rio de Janeiro. Agreement. Brazil/Peru. Provisional Stipulations for Settlement of Navigation Controversy. Moore, ILD, I, 648; US. FOR. RELS., 1903, 36-43.

1907; Apr. 24: Bogota. Treaty. Brazil/Colombia. Recognized Freedom of Navigation between Colombian Territory \& the Sea on all Affluents of the Amazon navigable within Colombian Dominion. Am. Jour. Int. Law, Vol. III, Suppl., pg. 97; GB. BFSP, Vol. 100, 809-810.

1908; Aug. 21: Rio de Janeiro. Treaty. Brazil \& Colombia. Art. I: Absolute Freedom of Navigation for Brazilian \& Colombian Vessels. Art. 17: This Freedom established in Perpetuity. Am. Jour. Int. Law, Vol. 5, Suppl., pg. 79, 1909; Sept. 8: Rio de Janeiro. Treaty. Brazil/Peru. Complete 
Amazon

Freedom of Navigation on All Amazonian Affluents navigable within Peru. GB. BFSP, Vol. 102, 199; Martens, NRG, Ser. 3, VI, 849, 851.

1910; Aug. 12: Rio de Janeiro. Treaty. Bolivia/Brazil. Art. VIII: Merchant Vessels of All Nations granted Freedom of Navigation between Bolivia \& the Sea. Martens, NRG, Ser. 3, VII, 632.

(NOTE:

(Special Concessions were extended to Brazilian passenger \& cargo vessels under Presidential Decree of November, 1914, for reorganization of the Brazilian merchant marine \& coasting trade. GB. Dipl. \& Consular Reports, No. 5451, pg. 38.)

APURE

See also: COLOMBIAN WATERWAYS; ORINOCO.

1847; May 14: Caracas. Law. Decree of Venezuelan Government granting Exclusive Privileges of Navigation to certain American Citizens. GB. BFSP, Vol. 39, 1348.

1849; May 2: Caracas. Law. Decree of Venezuelan Government granting Exclusive Navigation Privileges to certain American Citizens. GB. BFSP, Vol. 39, 1079.

ARAGUARY; or ARAWARI

1802; March 27: Amiens. Convention. Batavian Republic, France, Great Britain, Spain. Art. 7: Provided that Navigation should be enjoyed in common throughout the Course by the two Adjacent Nations; France \& Portugal. Clercq, RTF, I, 484-486. (Commentary: ENGELHARDT, Hist. Droit Fluv. Conv., 81.)

\section{ARGENTINE WATERWAYS}

Notably the Rivers:

Chico;

Chubut;

Colorado;

Deseado;

Gallegos;

Negro; or Sauces;

Paraguay;

Parana;
Pilcomayo;

Rio de la Plata;

Salado;

Santa Cruz;

Uruguay;

Vermejo; or Bermejo; or Rio Grande. 


\section{Argentine Waterways}

1860; Sept. 25: Buenos Aires. Law. Constitution of the Argentine Confederation. Art. 26: "Navigation on the rivers in the interior of the nation is free to ALL flags, and subject to no other regulations than those proclaimed by the national authority." Dodd, Modern Constitutions (1909), I, pg. 8; Hertslet, COM. TR., XII, 117.

\section{ATRATO. See COLOMBIAN WATERWAYS.}

\section{BARIMA}

1897; Feb. 2: Treaty. Great Britain \& Venezuela. Stipulating Freedom of Navigation for Merchant Vessels of All Nations. Art. II: Providing for Submission of Boundary Dispute to an Arbitral Tribunal. Hertslet, COM. TR., Vol. 21, 1123.

1899; Oct. 3: Paris. Decision. Award of the Tribunal of Arbitration constituted under Art II of Treaty of Feb. 2, 1897. Composing Boundary Dispute between Great Britain \& Venezuela; Providing, further, that Merchant Vessels of All Nations, in time of peace, should enjoy Freedom of Navigation. Hertslet, COM. TR., Vol. 21, 1123. (Commentary: ALVERSTONE, Recollections of Bench \& Bar, (London, 1914), pg. 239; HALL, Int. Law, 5th Edit., 112-113; OPPENHEIM, Int. Law, I, 228; US., 50th Cong., 2nd Sess., House Exec. Doc., Vol. I, 698.)

BENI. See also: BOLIVIAN WATERWAYS.

1853; Jan. 27: La Paz. Law. Decree of the Bolivian Government. Freedom of Fluvial Navigation. Hertslet, COM. TR., XIII, 152-153.

BERMEJO. See VERMEJO; Argentine Waterways.

\section{BOLIVIAN WATERWAYS}

Notably the Rivers of the Amazonian System; the Abuna, or Negro; Beni; Madeira; \& Mamoré; and of the Rio de la Plata System; the Paraguay \& Pilcomayo.

1853; Jan. 27: La Paz. Law (Presidential Decree). Bolivian Government. Declaring that All Navigable Waterways within the National Domain \& Affluent to the Amazon \& Rio de la Plata to be free to the Commerce \& Navigation of All Nations. GB. BFSP, Vol. 55, 505; Hertslet, COM. TR., XIII, 152-53.

1908; July 22: La Paz. Treaty. Bolivia/Germany. Art. IV: Bolivia accords the right of Free Navigation on All Bolivian 


\section{Bolivian Waterways}

Waterways to the Merchant Marine of Imperial Germany. Martens, NRG, Ser. 3, IV, 284.

1910; Aug. 12: Rio de Janeiro. Treaty. Bolivia/Brazil. Art. VIII: Freedom of Navigation for the Merchant Vessels of All Nations between Bolivia \& the Sea. Martens, NRG, Ser. 3, VII, 632 .

\section{BOUNDARY WATERWAYS}

\section{BOLIVIA/BRAZIL}

1910; Aug. 12: Rio de Janeiro. Treaty. Reciprocal Freedom of Navigation on all Boundary Waterways. Martens, NRG, Ser. 3, VII, 632 .

\section{BRAZIL/COLOMBIA}

1908; Aug. 21: Rio de Janeiro. Treaty. Mutual Liberty of Navigation on All Boundary \& Bi-National Waterways. Martens, NRG, Ser. 3, IV, 312.

BRAZIL/URUGUAY

1909; Oct. 30: Rio de Janeiro. Treaty. Reciprocal Freedom of Navigation. GB. BFSP, Vol. 102, 204; Martens, NRG, Ser. 3, VI, 858.

CAQUETA; or JAPURA. See YAPURA.

CASIQUIARE CANAL. See AMAZON; ORINOCO.

CAUCA; Affluent of Madeira River. See COLOMBIAN WATERWAYS.

CHAMBIRA; or CHAMBIRA-YACU. See .AMAZON; ECUADOREAN WATERWAYS; PERUVIAN WATERWAYS.

CHAPARE. See also BOLIVIAN WATERWAYS.

1853; Jan. 27: La Paz. Law (Presidential Decree). Bolivian Government. Opened freely to the Commercial Navigation of All Nations. GB. BFSP, Vol. 55, 505; Hertslet, COM. TR., XIII, 152-53.

CHICAMOCHA. See SOGAMOSO.

CHICO. See ARGENTINE WATERWAYS.

CHIMORE. See also BOLIVIAN WATERWAYS. 1853; Jan. 27 : La Paz. Law (Presidential Decree). Bolivian Gov- 
ernment. Freedom of Commercial Navigation available for Vessels of All Nations. GB. BFSP., Vol. 55, 505; Hertslet, COM. TR., XIII, 152-53.

CHUBUT. See ARGENTINE WATERWAYS.

COCA; Affluent of Napo River. See AMAZON; COLOMBIAN, ECUADOREAN, \& PERUVIAN WATERWAYS.

\section{COLOMBIAN WATERWAYS}

(NEW GRANADIAN) Notably the Rivers:

* Aguarico, or San Miguel; ** Meta;

** Apure;

Atrato;

Cauca ;

* Coca;

** Guaviare, or Guabiare;

** Inirida;

* Napo;

* Putumayo, or Iça;

Sogamoso, or Chicamocha;

* Waupes, or Uapes;

* Yapurá, or Japurá, or Caquetá.

Magdalena;

* Amazonian System.

** Affluent of Orinoco.

1852; Apr. 7: Bogota. Law. Government of New Granada. Freedom of Navigation accorded Native (Domestic) \& Foreign Steam

' Vessels. GB. BFSP, Vol. 63, 1079; Hertslet, COM. TR., XIV, 421.

1856; May 24: Bogota. Law. New Granada. Fluvial Navigation open to Vessels of All Nations. GB. BFSP, Vol. 63, 1080 ; Hertslet, COM. TR., XIV, 421.

1861; July 30: Bogota. Law. Decree of Government of New Granada. Freedom of Navigation for Steam Vessels. GB. BFSP, Vol. 63, 1081; Hertslet, COM. TR., XIV, 424.

1864; May 19/25: Bogota. Law. United States of Colombia. Navigation Regulations; qualifying former freedom. GB. BFS.P, Vol, 61, 140; Hertslet, COM. TR., XIII, 363; XIV, 251.

1907; Apr. 24: Bogota. Treaty. Brazil/Colombia. Recognized Freedom of Navigation between Colombian Territory \& the Sea on all Affluents of the Amazon navigable within Colombian Dominion. Am. Jour. Int. Law, III, Suppl., 97; GB. BFSP, Vol. 100, 809-810.

1908; Aug. 21: Rio de Janeiro. Treaty. Brazil/Colombia. Art. I: Absolute Freedom of Navigation for Brazilian \& Colombian 


\section{Colombian Waterways}

Vessels. Art. 17: This Freedom established in Perpetuity. Am. J. Int. Law, V, 79.

COLORADO. See ARGENTINE WATERWAYS.

CONI. See also BOLIVIAN WATERWAYS.

1853; Jan. 27: La Paz. Law. Bolivian Government. Freedom of Commercial Navigation available for Vessels of All Nations. GB. BFSP, Vol. 55, 505; Hertslet, COM. TR., XIII, 152-153.

CORIOCO; or CORISCO. See also BOLIVIAN WATERWAYS. 1853; Jan. 27: La Paz. Law. Bolivian Government. Freedom of Commercial Navigation available for Vessels of All Nations. GB. BFSP, Vol. 55, 505; Hertslet, COM. TR., XIII, 152-53.

CURARAY; Affluent of Napo River. See AMAZON; ECUADOREAN WATERWAYS; PERUVIAN WATERWAYS.

\section{DESEADO. See ARGENTINE WATERWAYS.}

\section{ECUADOREAN WATERWAYS}

Notably the Rivers tributary to the Amazon:

Chambira, or Chambira-Yacu;

Coca;

Curaray;

Napo;

Pastaça, or Pastasa, or Pastaza;

Paute;

Tigre, or Nigre, or Pequena.

1853; Nov. 26: Quito. Law. Decree of the Ecuadorean Government. Establishing Freedom of Navigation on All Affluents of the Amazon within the National Dominion; expressly stipulating the entire exemption from all charges or duties on vessels \& cargoes. US., 33rd Cong., 1st Sess, House Misc. Doc., No. 22, 12. (Commentary: MOORE, ILD, I, 627; PHILLIMORE, Int. Law, I, 246; WHEATON, Elem. Int. Law (Lawrence), Chap. IV, 270, citing ANNUAIRE DES DEUX MONDES, 1853/1854, pg. 824.)

1870; Jan. 31; Quito. Law. Decree of the Ecuadorean Government. Restricting operation of the Law of Nov. 26, 1853, by limiting navigation of Inland Waterways to Vessels of Ecuadorean Ownership. Moore, ILD, I, 627.

GALIEGOS. See ARGENTINE WATERWAYS. 
HUALLAGA. See AMAZON; PERUVIAN WATERWAYS.

HYABARY; or YACARANA; or YAQUIRANO. See YAVARI.

ICA. See PUTUMAYO.

INIRIDA. See COLOMBIAN WATERWAYS; ORINOCO.

IRENG

1904; June 6: Rome. Decision. Arbitral Award rendered by the King of Italy. Establishing Boundary between Brazil \& British Guiana in Thalweg \& stipulating, further, that Both Nations should enjoy Freedom of Navigation. GB. BFSP, Vol. 99, 930.

ITENES; or ITENEZ. See also BOLIVIAN WATERWAYS. 1853; Jan. 27: La Paz. Law. Bolivian Government. Freedom of Commercial Navigation available for Vessels of All Nations. GB. BFSP, Vol. 55, 505 ; Hertslet, COM. TR., XIII, 152-153.

JAGUARY ; or YAGUARON

1909; Oct. 30: Rio de Janeiro. Treaty. Brazil/Uruguay. Reciprocal \& Exclusive Freedom of Navigation for Merchant Vessels of Both Nations; including free passage through the Brazilian waters of Lagoa de los Patos, Rio Grande San Pedro, \& Rio San Gonzalo. GB. BFSP, Vol. 102, 204; Martens, NRG, Ser. 3, VI, 858.

JAPURA; or CAQUETA.

See YAPURA

LAGOA DE LOS PATOS

1909; Oct. 30: Rio de Janerio. Treaty. Brazil/Uruguay. Reciprocal Freedom of Navigation. (Arts. 2, 6.) GB. BFSP, Vol. 102, 204; Martens, NRG, Ser. 3, VI, 858.

MADEIRA

See also: AMAZON; BOLIVIAN WATERWAYS.

1853; Jan. 27: La Paz. Law. Bolivian Government. Freedom of Commercial Navigation available for Vessels of All Nations. GB. BFSP, Vol. 55, 505; Hertslet, COM. TR., XIII, 152-153.

1866; Dec. 7: Rio de Janeiro. Law (Imperial Decree). Brazilian Government. Opening Navigation to the Merchant Vessels of All Nations. GB. BFSP., Vol. 58, 551; Hertslet, COM. TR., XIII, 157.

1867; July 31: Rio de Janeiro. Law (Imperial Decree). Brazilian 


\section{Madeira}

Government. Navigation Regulations; enumerating tributaries open to commerce. GB. BFSP, Vol. 58, 551-567; Hertslet, COM. TR., XIII, 158.

1873; Jan. 25 : Rio de Janeiro. Law (Imperial Decree). Extending further facilities for Navigation. GB. BFSP, Vol. 65, 607; Hertslet, COM. TR., XIV, 202; US. FOR. RELS., (1899), 123. 1903; Nov. 17: Petropolis. Treaty. Bolivia \& Brazil. Establishing in perpetuity the most ample Freedom of Transit \& Fluvial Navigation for Both Nations. US. FOR. RELS, (1903), 36-43. 1910; Aug. 12: Rio de Janeiro. Treaty. Bolivia/Brazil. Art. VIII: Merchant Vessels of All Nations granted Freedom of Navigation between Bolivia \& the Sea. Martens, NRG, Ser. 3 , VII, 632 .

\section{MAGDALENA. See COLOMBIAN WATERWAYS.}

MAMORE. See also BOLIVIAN WATERWAYS.

1853; Jan. 27 : La Paz. Law. Decree of the Bolivian Government. Freedom of Commercial Navigation accorded Vessels of All Nations. GB. BFSP, Vol. 55, 505; Hertslet, COM. TR., XIII, 152-53.

MAPIRE. See also BOLIVIAN WATERWAYS.

1853; Jan. 27 : La Paz. Law. Decree of the Bolivian Government. Freedom of Commercial Navigation accorded Vessels of All Nations. GB. BFSP, Vol. 55, 505; Hertslet, COM. TR., XIII, 152-53.

MARACAIBO; or MARACAYBO; LAKE, including TRIBUTARY WATERS. See also VENEZUELAN WATERWAYS. 1869; May 14: Caracas. Law. Congress of the United States of Venezuela. Art. I: Opening the Lake \& All Tributary Waters "in all the extension of Venezuela to merchant steam vessels under foreign flags." Moore, 'Int. Arbs., II, 1696.

1869; July 1: Caracas. Law. Presidential Decree in conformity with Law of May 14, 1869. Arts. I-VI: Navigation Regulations applicable to the Lake \& Tributary Waters. Moore, Int. Arbs., II, 1697-98.

MARANON. See AMAZON; PERUVIAN WATERWAYS.

MORONA. See AMAZON; ECUADOREAN WATERWAYS; PERUVIAN WATERWAYS. 


\section{MERIM LAKE}

1909; Oct. 30: Rio de Janeiro. Treaty. Brazil/Uruguay. Reciprocal \& Exclusive Freedom of Navigation for Merchant Vessels of Both Countries. GB. BFSP, Vol. 102, 204; Martens, NRG, Ser. III, VI, 1858.

META. See COLOMBIAN WATERWAYS; ORINOCO.

NAPO; including the Tributaries: See AMAZON,

Aguarico;

Coca ; \&

Curaray.
COLUMBIAN

ECUADOREAN \&

PERUVIAN WATERWAYS.

NEGRO. See also AMAZON.

1866; Dec. 7: Rio de Janeiro. Law (Imperial Decree). Brazilian Government. Opening Navigation to the Merchant Vessels of All Nations. GB. BFSP, Vol. 58, 551; Hertslet, COM. TR., XIII, 157.

1867; July 31: Rio de Janeiro. Law (Imperial Decree). Brazilian Government. Navigation Regulations. GB. BFSP, Vol. 58, 551-567; Hertslet, COM. TR., XIII, 158.

NEGRO; or SAUCES. See ARGENTINE WATERWAYS.

NIGRE; or PEQUENA. See TIGRE.

ORINOCO

See also: COLOMBIAN WATERWAYS; VENEZUELAN WATERWAYS.

1847; May 14: Caracas. Law. Decree of Venezuelan Government granting Exclusive Privileges of Navigation to certain American Citizens. GB. BFSP, Vol. 39, 1348.

1849; May 2: Caracas. Law. Decree of Venezuelan Government granting Exclusive Navigation Privileges to certain American Citizens. GB. BFSP, Vol. 39, 1079.

1864; Dec. 12: Caracas. Law. Decree of Venezuelan Government raising Blockade of the River. GB. BFSP, Vol. 55, 293.

1865; Jan. 20: London. Notification. British Government. Respecting raising of the Blockade on Orinoco. GB. BFSP, Vol. $55,293$.

1869 ; May 14: Caracas. Law. Congress of the United States of Venezuela. Art. I: Opening the River \& its Affluents freely to the Navigation of Foreign Vessels. Moore, Int. Arbs., II, 1696.

1869; July 1: Caracas. Law. Presidential Decree in conformity 


\section{Orinoco}

with Law of May 14, 1869. Arts. 1-6: Regulating Navigation by Foreign Merchant Vessels upon the Orinoco \& Tributaries. Moore, Int. Arbs., II, 1697-98.

1873; Aug. (no date): Caracas. Law. Concession by Venezuelan Government to General Perez of Exclusive Right of Navigation on Orinoco \& Affluents. US., 50th Cong., 1st Sess., Sen. Ex. Doc., No. 139, pg. 32.

1880; Feb. 10: Caracas. Law. Decree of Venezuelan Government. Abolishing Custom House at Ciudad Bolivar; Prohibiting Trade with Ports along Orinoco. GB. BFSP, Vol. 71, 226.

1893; July 1: Caracas. Law. Decree of Venezuelan Government. Closing Navigation of the Macareo \& Pedernales Channels to Vessels in Foreign Trade. US. FOR. RELS., (1893), 729, 735, 737,740 .

1894; June 6: Caracas. Law. Decree of Venezuelan Government. Instituting Severe Penalties for Infraction of Law of July 1, 1893, closing the Macareo \& Pedernales Channels. US. FOR. RELS, (1894), 794-95, 798-99. (Commentary: HALL, Int. Law, 5th Edit., 112-13; MOORE, ILD, I, 650.)

(NOTE:

(REPORT OF COLOMBIAN MINISTER OF FOREIGN AFFAIRS,

(1894: "This right of Colombia has been confirmed still more now that the frontier limits have been decided, and it is admitted that the territory of our country extends as far as the left bank of the Orinoco. The river there having become international, its navigation is free to both countries." US. FOR. RELS, (1894), 200.)

(NOTE:

(1902; Nov. 14: London. Notification. British Government. Blockade of Venezuelan River Ports. GB. BFSP, Vol 95, 471.)

\section{OYAPOCK}

1815; June 9: Vienna. Final Act of the Congress of Nations. Art. 107: Demarcation of Boundary between Brazilian \& French Territory. Hertslet, Europe, 269.

1817; Aug. 28: Paris. Convention. France \& Portugal. Art. I: Demarcation of International Boundary. Hertslet, Europe, 530. 
See also: ARGENTINE WATERWAYS; BOLIVIAN WATERWAYS; PARAGUAYAN WATERWAYS.

1828; Aug. 27: Rio de Janeiro. Treaty. Brazil/Rio de la Plata (or Buenos Aires, or Argentina). Addit. Article: Reciprocal Freedom of Navigation. GB. BFSP, Vol. 15, 935, Martens, NRT, VII, 686.

1852; July 15: Asuncion. Treaty. Argentina/Paraguay. Arts. 78: Mutual Liberty of Navigation, including Affluents. GB. BFSP, Vol. 42, 1256-57.

1852; Aug. 28: Buenos Aires. Law. Decree of the Argentine Confederation. Concerning Navigation on Waterways within the National Dominion. GB. BFSP, Vol. 49, 1261; Hertslet, COM. TR., X, 44.

1853; Jan. 27: La Paz. Law. Decree of Bolivian Government. Freedom of Commercial Navigation accorded Vessels of All Nations. GB. BFSP, Vol. 55, 505; Hertslet, COM. TR., XIII, 152-53.

1853; March 4: Asuncion. Treaty. France/Paraguay. Art. II: Freedom of Navigation \& Landing granted French Vessels to Ports of Asuncion \& Incarnation (Encarnacion). Cussy/Martens, Rec. Man, Ser. 1, VII, 179; GB. BFSP, Vol. 44, 1091.

1853; March 4: Asuncion. Treaty. Great Britain/Paraguay. Art. II : Freedom of Navigation \& Landing accorded British Vessels. Cussy/Martens, Rec. Man., Ser. 1, VII, 184; GB. BFSP, Vol. 42, pg. 19; Hertslet, COM. TR., IX, 602-603.

1853; March 4: Asuncion. Treaty. Paraguay/Sardinia. Freedom of Navigation \& Landing for Sardinian Vessels. (Citations above.)

1853; March 4: Asuncion. Treaty. Paraguay/United States. Freedom of Navigation \& Landing, including Ports of Asuncion \& Encarnacion, granted American Vessels. (Citations above.)

(NOTE :

(1853; June 3: London. British Parliament. Debate in the House of Lords respecting Navigation of the River Paraguay. GB. (Hansard), Parl. Debates, Vol. 127, No. 6, 1073-74)

1853; July 10: San Jose de Flores. Treaty. Argentina/France. Freedom of Navigation. GB. BFSP, Vol. 44, 1071. (Commentary: BONFILS, Droit Int., 335; LAWRENCE, Int. Law, 210.)

1853; July 10: San Jose de Flores. Treaty. Argentina/Great 


\section{Paraguay}

Britain. Freedom of Navigation. GB. BFSP, Vol. 42, pg. 3. 1853; July 10: San Jose de Flores. Treaty. Argentina/United States. Freedom of Navigation. (Commentary: President Franklin Pierce refers to the enlightened policy of Argentina \& Paraguay in opening their arterial waterways to the merchant vessels of all nations in the First Annual Message; Washington, Dec. 5, 1853. Richardson, Messages \& Papers, V, 212. In his Second Annual Message, President Franklin Pierce discusses the recently concluded treaties with Argentina, Paraguay, \& Uruguay establishing freedom of navigation for American vessels on the Rio de la Plata \& certain tributaries. Richardson, Messages \& Papers, V, 280.)

1854; Oct. 3: Asuncion. Law. Decree of the Paraguayan Government. Art. I: Excluding Foreign Vessels of War from Fluvial Navigation. GB. BFSP, Vol. 45, 1312-13. (Commentary: J. BUCHANAN, First Annual Message, Dec. 8, 1857. Richardson, Messages \& Papers, V, 449.) (SCHUYLER, Am. Dipl., 327.)

1855; Apr. 27 : Asuncion. Treaty. Brazil/Paraguay. Arts. 2, 20 : Establishing Reciprocal Freedom of Navigation in perpetuity. GB. BFSP, Vol. 49, 1195.

1856; Mar. 7: Parana. Treaty. Argentina/Brazil. Arts. 14, 16, 19: Reciprocal Freedom of Navigation on the Rivers Paraguay, Parana, \& Uruguay. Cussy/Martens, Rec. Man., Ser. 1, VII, 476 ; GB. BFSP, Vol. 46, 1310-14.

1856; April 6: Rio de Janeiro. Treaty. Brazil/Paraguay. Arts. 2, 4: Reciprocal Freedom of Navigation on Rivers Paraguay \& Parana; specifically excluding Affluents. Art. 5: Exemption from Dues expressly stipulated. Cussy/Martens, Rec. Man., Ser. 1, VII, 516-17; GB. BFSP, Vol. 46, 1299-1300.

1856; July 29: Asuncion. Treaty. Argentine/Paraguay. Art. 17: Navigation of Rivers Paraguay, Parana \& Vermejo (Bermejo) recognized as entirely Free \& Common to Argentine \& Paraguayan Men-of-War \& Merchantmen, in conformity with existing Regulations in Both Republics. GB. BFSP, Vol. 46, 1305. (Commentary: MOORE, Int. Arbs., 4783.)

1857; Nov. 20: Treaty. Argentina/Brazil. Universal Freedom of Navigation from Estuary of the River La Plata to all Inland Ports. GB. BFSP, Vol. 49, 1306. (Commentary: BONFILS, Droit Int., 335; MOORE, Am. Dipl., 83, 85.)

1858; Feb. 12: Asuncion. Agreement. Brazil/Paraguay. Protocols 
of Conferences concerning Mutual Liberty of Fluvial Navigation. GB. BFSP, Vol. 49, 1282, 1284.

1859; Feb. 4: Asuncion. Treaty. Paraguay/United States. Art. II: Provided that Merchant Vessels of the United States should enjoy Freedom of Navigation on Paraguay \& Parana as far as Brazilian Boundary. Malloy, UST, 1364. (Commentary: MOORE, Int. Arbs., 1487, 1493; MOORE, ILD, I, 640 ; RICHARDSON, Messages \& Papers, V, 560,-Third Annual Message of President Buchanan, Dec. 19, 1859.)

1860 ; Sept. 25 : Buenos Aires. Law. Constitution of the Argentine Confederation. Art. 26: "Navigation on the rivers in the interior of the nation is free to All Flags, and subject to no other regulations than those proclaimed by the national authority." Dodd, Modern Constitutions (1909), I, 8; Hertslet, COM. TR., XII, 117.

1876; Feb. 3: Buenos Aires. Treaty. Argentine/Paraguay. Art. 15: Reciprocal Freedom of Navigation. Cussy/Martens, Rec. Man., Ser. 2, II, 527. (Commentary: MOORE, Int. Arbs., 4783.)

1884; Oct. 16: Asuncion. Treaty. Great Britain/Paraguay. Arts. 2, 4: Recognized Free Navigation of British Vessels on Rivers Paraguay \& Parana. GB. BFSP, Vol. 75, 941; GB. Sess. Papers, (1907), Commercial No. 3.

1884; Oct. 16: Asuncion. Protocol. Great Britain/Paraguay. Stipulating that Arts. $2 \& 3$ of Treaty of even date shall be construed as according British Vessels participation in the Coasting Trade. GB. BFSP, Vol. 75, 942; Hertslet, COM. TR., Vol. 17, 857.

1908; July 22: La Paz. Treaty. Bolivia/Germany. Art. IV: Bolivia accords the Right of Free Navigation to German Merchant Vessels. Martens, NRG, Ser. 3, IV, 284.

1910; Aug. 12: Rio de Janeiro. Treaty. Bolivia/Brazil. Freedom of Navigation for Merchant Vessels of All Nations. Martens, NRG, Ser. 3, VII, 632. 


\section{Paraguayan Waterways}

\section{PARAGUAYAN WATERWAYS.}

See also: ARGENTINE WATERWAYS;

Notably the Rivers:

PARAGUAY.

Paraguay; including Affluents Apa, Aquidaban, \& Fogones;

Parana;

Pilcomayo;

Vermejo, or Bermejo.

1845; May 20: Asuncion. Law. Paraguayan Government. Freedom of Navigation on National Waterways. GB. BFSP, Vol. $45,1312$.

1852; July 15: Asuncion. Treaty. Argentina/Paraguay. Arts. 112: Mutual Liberty of Navigation, including Affluents. GB. BFSP, Vol. 42, 1256-57.

1853; March 4: Asuncion. Treaty. France/Paraguay.

${ }^{*}$ Great Britain/Paraguay.

*Paraguay/Sardinia.

*Paraguay/United States.

Freedom of Navigation \& Landing accorded Merchant Vessels of the Contracting Parties. Cussy/Martens, Rec. Man., Ser. 1, VII, 179, 184; GB. BFSP., Vol. 42, 19 ; Vol. 44, 1091; Hertslet, COM. TR., IX, 602-603.

* Separate Conventions signed by Great Britain, Sardinia, \& the United States with Paraguay.

(NOTE:

(1853; June 3: London. British Parliament. Debate in House of Lords concerning Navigation of River Paraguay. GB. Parliamentary Debates, Vol. 127, No. 6, 1073-74.)

1854; Oct. 3: Asuncion. Law. Decree of the Paraguayan Government. Art. I: Excluding Foreign Vessels of War from Fluvial Navigation. GB. BFSP, Vol. 45, 1312-13. (Commentary: J. Buchanan, First Annual Presidential Message delivered Dec. 8, 1857, R.TCHARDSON, Messages \& Papers, V, 449.) 
of Rio de la Plata (or Buenos Aires, or Argentina.) Addit. Article: Reciprocal Freedom of Navigation. GB. BFSP, Vol. 15, 935 ; Martens, NRT, VII, 686.

1841 ; Nov. 23 : Law. Decree of Congress of Province of Corrientes. Admitting Merchant Vessels of All Nations to Fluvial Navigation. Martens, NRG, Ser. 1, II, 321.

(NOTE:

(This law was designed to interest foreign shipping in inland navigation during the controversy between the Province of Corrientes \& President Rosas, but the blockade established by Buenos Aires rendered it inoperative.)

1845; May 20: Asuncion. Law. Paraguayan Government. Freedom of Navigation on National Waterways. GB. BFSP, Vol. $45,1312$.

(NOTE:

(1849; Nov. 24: Buenos Aires. Treaty. Argentina/Great Britain. Art. IV: Recognition by Great Britain that Navigation of Parana is exclusively National. Hertslet, COM. TR., VIII, 106; Martens, NRG, Ser. 1, II, 48.)

(NOTE:

(1850; Aug. 31: Buenos Aires. Treaty. Argentina/France. Art. VI: Navigation of River Parana recognized as exclusively $\mathrm{Na}$ tional by France. Martens, NRG, Ser. 1, II, 53. (Commentary: SCHUYLER, Am. Dipl., 319-320.)

*This Convention was rejected by the French National Assembly.

(NOTE:

(1851; Nov. 21: Monte Video. Convention. Brazil, Corrientes, Entre Rios, Uruguay. Concerning the future Establishment of Freedom of Fluvial Navigation. GB. BFSP, Vol. 60, 383.)

1852; July 15: Asuncion. Treaty. Argentina/Paraguay. Art. I: Boundary. Arts. III, VII: Conceding Reciprocal Freedom of Navigation, including Affluents. GB. BFSP, Vol. 42, 1256-57. 1852; Aug. 28: Buenos Aires. Law. Decree of the Argentine Confederation. Granting Free Navigation of Inland Waterways to Foreign Merchant Vessels. GB. BFSP, Vol. 49, 1261; Hertslet, COM. TR., X, 44.

1852 ; Oct. 3: Buenos Aires. Law. Decree of the Provisional Director of Argentine Confederation. Declaring Navigation of River open to Merchant Vessels of All Nations. GB. BESP, Vol. 


\section{Parana}

42, 1313. (Commentary: MOORE, ILD, I, 640; SCHUYLER, Am. Dipl., 319.)

1852; Oct. 18: Buenos Aires. Law. Argentine Confederation. Navigation Regulations. GB. BFSP, Vol. 42, 1314.

1853; March 4: Asuncion. Treaty. France/Paraguay.

*Great Britain/Paraguay.

*Paraguay/Sardinia.

*Paraguay/United States.

Freedom of Navigation \& Landing granted Merchant Vessels of the Contracting Parties as far Inland as the Port of Encarnacion. Cussy/Martens, Rec. Man., Ser. 1, VII, 179, 184; GB. BFSP, Vol. 42, 19 ; Vol. 44, 1091; Hertslet, COM. TR., IX, 602 .

* Separate Conventions signed by Great Britain, Sardinia, \& the United States with Paraguay.

(NOTE:

(1853; June 3: London. British Parliament. Debate in House of Lords concerning Navigation of River Parana. GB. PARL. DEBATES, Vol. 127, No. 6, 1073-74.)

1853; July 10: San Jose de Flores. Treaty. Argentina/France. Arts. 1, 2, \& 8: Freedom of Navigation accorded to Merchant Vessels of All Nations. Annuaire des Deux Mondes, (1853! 1854), pg. 947; Clercq, RTF, VI, 377; Cussy/Martens, Rec. Man., Ser. 1, VII, 259; GB. BFSP, Vol. 44, 1071; Martens, NRG, Ser. 2, X, 294.

1853; July 10: San Jose de Flores. Treaty. Argentina/Great

Britain. Art. I: Confirming the Decree of the Provisional Director of the Argentine Confederation, Oct. 3, 1852, proclaiming the Navigation of the River Parana freely open to the Merchant Vessels of All Nations. Cussy/Martens, Rec. Man., Ser. 1, VII, 261; GB. BFSP, Vol. 42, 3; Hertslet, COM. TR., IX, 191.

1853; July 10: San Jose de Flores. Treaty. Argentina/United States. Arts. 1-8: Freedom of Navigation. GB. BFSP, Vol. 42, 718; Malloy, UST, 18-20. (Commentary: BONFILS, Droit Int., pg. 335 ; LAWRENCE, Int. Law, 210 ; MOORE, Am. Dipl., 83-86; PHILLIMORE, Int. Law, (1879 Edit.), I, 246; RICHARDSON, Messages \& Papers, V, 212: First Annual Message delivered by President Pierce, Dec. 3, 1853; V, 280: President Pierce mentions the establishment of freedom of navigation in 
his Second Annual Message, Dec. 4, 1854; SCHUYLER, Am. Dipl., 322-325.)

1854; Oct. 3: Asuncion. Law. Decree of Paraguayan Government. Art. I: Excluding Foreign Vessels of War from Fluvial Navigation. GB. BFSP, Vol. 45, 1312-13. (Commentary: RICHARDSON, Messages \& Papers, V, 449: First Annual Message delivered by President Buchanan, Dec. 8, 1857; SCHUYLER, Am. Dipl., 327.)

1854; Nov. 30 : Paris. Law. Promulgation by the French Government of the Treaty of San Jose de Flores, July 10, 1853, establishing Freedom of Fluvial Navigation. GB. BFSP, Vol. 44, 1071.

1855; Apr. 27 : Asuncion. Treaty. Brazil/Paraguay. Arts. 2, 20 : Establishing Reciprocal Freedom of Navigation in Perpetuity. GB. BFSP, Vol. 49, 1195.

1856; March 7: Parana. Treaty. Argentina/Brazil. Arts. 14, 16 : Reciprocal Freedom of Navigation. Art. 19: Regulations applicable during War. Cussy/Martens, Rec. Man., Ser. 1, VII, 476; GB. BFSP, Vol. 46, 1310-1314.

1856; April 6: Rio de Janeiro. Treaty. Brazil/Paraguay. Arts. 2, 4: Mutual Liberty of Navigation; specifically excluding Affluents. Art. 5: Exemption from Transit Dues expressly stipulated. Cussy/Martens, Rec. Man., Ser. 1, VII, 516-17; GB. BFSP, Vol. 46, 1299-1300.

1856; July 29: Asuncion. Treaty. Argentina/Paraguay. Art. 17: Navigation recognized as entirely Free \& Common to Men-ofWar \& Merchant Vessels of Both Nations, subject to appropriate regulations. GB. BFSP, Vol, 46, 1305. (Commentary: MOORE, Int. Arbs., 4783.)

1857; Nov. 20: Treaty. Argentina/Brazil. Freedom of Navigation. GB. BFSP, Vol. 49, 1306. (Commentary: BONFILS, Droit Int., 335; MOORE, Am. Dipl., 83, 85.)

1858; Feb. 12: Asuncion. Agreement. Brazil/Paraguay. Protocols of Conferences concerning Mutual Enjoyment of Fluvial Navigation. GB. BFSP, Vol. 49, 1282, 1894.

1858; May 13: La Paz. Treaty. Bolivia/United States. Arts. 26 \& 27: Recognizing Freedom of Navigation on the rivers Amazon and La Plata, including the affluents; all river ports, accessible from the sea, being open freely. Malloy, UST, 113, 122, 124.

1859; Feb. 4: Asuncion. Treaty. Paraguay/United States. Art. II: Stipulated that Merchant Vessels of the United States should enjoy perfect Freedom of Navigation throughout Paraguayan 


\section{Parana}

Dominion. Malloy, UST, 1364. (Commentary: MOORE, Int. Arbs., 1487, 1493; MOORE, ILD, I, 640 ; RICHARDSON, Messages \& Papers, V, 560,-Third Annual Message of President Buchanan delivered Dec. 19, 1859.)

1860; Sept. 25: Buenos Aires. Law. Constitution of the Argentine Confederation. Art. 26: "Navigation on the rivers in the interior of the nation is free to All Flags, and subject to no other regulations than those proclaimed by the national authority." Dodd, Modern Constitutions, (1909), I, 8; Hertslet, COM, TR., XII, 117.

1876; Feb. 3: Buenos Aires. Treaty. Argentina/Paraguay. Art. 15: Reciprocal Freedom of Navigation. Cussy/Martens, Rec. Man, Ser. 2, II, 527. (Commentary: MOORE, Int. Arbs., 4783.)

1884; Oct. 16: Asuncion. Treaty. Great Britain/Paraguay. Arts.

2, 4: Recognized Free Navigation by British Vessels on Rivers Paraguay \& Parana. GB. BFSP, Vol. 75, 941; GB. SESS. PAPS., Commercial, (1907), No. 3.

1884; Oct 16: Asuncion. Protocol. Great Britain/Paraguay. Stipulating that Arts. $2 \& 3$ of Treaty of Even Date must be construed as recognizing the Participation of British Vessels in the Coasting Trade on the Rivers designated. GB. BFSP, Vol. 75, 942; Hertslet, COM. TR., Vol. 17, 857.

PASTACA; or PASTASA; or PASTAZA. See AMAZON; ECUDOREAN WATERWAYS; PERUVIAN WATERWAYS.

PAUTE. See AMAZON; ECUADOREAN WATERWAYS; PERUVIAN WATERWAYS.

PEQUENA; or NIGRE. See TIGRE.

PERUVIAN WATERWAYS. See also AMAZON.

Notably the Amazonian Tributaries:

Caquetá; or Japurá; or Yapurá;

Chambira; or Chambira-Yacu;

Hullaga ;

Madre de Dios;

Maranon;

Morona;

Napo;

Pastaça, or Pastasa, or Pastaza;
Paute;

Putumayo, or Iça;

Santiago;

Tigre, or Nigre, or Pequena;

Ucayali;

Yavari, or Yacarana, or Yaquitano, also written Hyabary. 
Peruvian Waterways

1851; July 26: Lima. Treaty. Peru/United States.

*See AMAZON.

1851; Oct. 23: Lima. Treaty. Brazil/Peru.

*See AMAZON.

1852 ; Aug. 30: Rio de Janeiro. Law (Imperial Decree). Brazilian Government. Navigation Regulations.

*See AMAZON.

1853; Jan. 27: La Paz. Decree of the Bolivian Government. Declaring All Amazonian Affluents, navigable within Bolivian Territory, Free to the Commerce \& Navigation of All Nations. GB. BFSP, Vol. 55, 505; Hertslet, COM. TR., XIII, 152; US., 33rd Cong., 1st Sess., House Misc. Doc., No. 22, pg. 16.

1853; Apr 15: Lima. Law. Decree of Peruvian Government establishing Loreto \& Nauto as Ports of Entry. Moore, ILD, I, 641.

1854; Jan. 4: Lima. Law. Decree of Peruvian Government modifying Law of April 15, 1853, by restricting Navigation to Brazilian Vessels. Moore, ILD, 645.

1866; Dec. 7: Rio de Janeiro. Law (Imperial Decree). Brazilian Government. Opening Navigation of the Amazon to the Merchant Vessels of All Nations. GB. BFSP, Vol. 58, 551; Hertslet, COM. TR., XIII, 157.

1867; July 31: Rio de Janeiro. Law (Imperial Decree). Brazilian Government. Navigation Regulations. GB. BFSP, Vol. 58, 551-567; Hertslet, COM. TR., XIII, 158.

1868; Dec. 17: Lima. Law. Decree of Peruvian Government declaring Navigation of All Rivers open to Merchant Vessels of All Maritime Nations. GB. BFSP, Vol. 65, 1240; Hertslet, COM. TR., XIV, 432. (Commentary: MOORE, ILD, I, 645; WHEATON, Elem. Int. Law (Lawrence' Edit.), 363-365.)

1909; Sept. 8: Rio de Janeiro. Treaty. Brazil/Peru. Complete Freedom of Navigation on All Amazonian Affluents navigable within Peru. GB. BFSP, Vol. 102, 199; Martens, NRG, Ser. 3, VI, 849, 851.

PILCOMAYO.

See also: ARGENTINE WATERWAYS; BOLIVIAN WATERWAYS; PARAGUAYAN WATERWAYS.

1845; May 20: Asuncion. Law. Paraguayan Government. Freedom of Navigation on National Waterways. GB. BFSP, Vol. $45,1312$.

1852; July 15: Asuncion. Treaty. Argentina/Paraguay. Arts. 1- 


\section{Pilcomayo}

12: Mutual Liberty of Navigation, including Affluents. GB. BFSP, Vol. 42, 1256-57.

1853; Jan. 27: La Paz. Law (Presidential Decree). Bolivian Government. Declaring All Affuents of the Rio de la Plata, navigable within Bolivian Territory, Free to the Commerce \& Navigation of All Nations. GB. BFSP, Vol. 55, 505; Hertslet, COM. TR., XIII, 152; US., 33rd Cong., 1st Sess., House Misc. Doc., No. 22, pg. 16.

1853; March 4: Asuncion. Treaty. France/Paraguay.

* Great Britain/Paraguay.

*Paraguay/Sardinia.

*Paraguay/United States.

Freedom of Navigation \& Landing accorded Merchant Vessels of the Contracting Parties. Cussy/Martens, Rec. Man., Ser. 1, VII, 179, 184; GB. BFSP, Vol. 42, 19; Vol. 44, 1091; Hertslet, COM. TR., IX, 602-603.

*Separate Conventions signed by Great Britain, Sardinia, \& the United States with Paraguay.

1854; Oct. 3 : Asuncion. Law. Decree of Paraguayan Government. Excluding Foreign Vessels of War from Fluvial Navigation. GB. BFSP, Vol. 45, 1312-13.

1905; Sept. 11: Buenos Aires. Convention. Argentina/Paraguay. Appointing Joint Commission for Determining Fluvial Boundary. GB. BFSP, Vol. 98, 770.

1908; July 22: La Paz. Treaty. Bolivia/Germany. Art. IV: Bolivia grants Right of Free Navigation to German Merchant Vessels. Martens, NRG, Ser. 3, IV, 284.

1910; Aug. 12: Rio de Janeiro. Treaty. Bolivia/Brazil. Art. VIII: Freedom of Navigation for Merchant Vessels of All Nations. Martens, NRG, Ser. 3, VII, 632.

PIRAY. See also BOLIVIAN WATERWAYS.

1853; Jan. 27: La Paz. Law (Presidential Decree). Bolivian Government. Opened freely to the Commercial Navigation of All Nations. GB. BFSP., Vol. 55, 505; Hertslet, COM. TR., XIII, 152-53.

PLATA; or RIO DE LA PLATA.

See also: ARGENTINE WATERWAYS;

PARAGUAY;

PARANA;

URUGUAY. 
1828; Aug 27: Rio de Janeiro. Treaty. Brazil/Rio de la Plata (Buenos Aires, or Argentina). Addit. Article: Reciprocal Freedom of Navigation, including Tributary Rivers. Cussy/Hauterive , RTC, I, part 2, 321; GB. BFSP, Vol. 15, 935; Martens, NRT, VII, 686.

(NOTE:

(1849; Nov. 24: Buenos Aires. Treaty. Argentina/Great Britain. Art. IV: Recognition by Great Britain that Navigation of Rio de la Plata is exclusively National. Hertslet, COM. TR., VIII, 106 ; Martens, NRG, Ser. 1, II, 48.)

(NOTE:

(1850; Aug. 31: Buenos Aires. Treaty. Argentina/France. Art. VI: Navigation of Rio de la Plata recognized by France as exclusively National. Martens, NRG, Ser. 1, II, 53. (Commentary: SCHUYLER, Am. Dipl. 319-320.)

*The French National Assembly rejected this Convention.

1851; May 24: Montevideo. Declaration. Uruguayan Government. Concerning Navigation of Rio de la Plata \& Affuents. GB. BFSP, Vol. 42, 1315.

(NOTE :

(1851; Oct. 12: Rio de Janeiro. Treaty. Brazil/Uruguay. Arts. 15-17: Stipulating the Employment of Appropriate Measures to secure Co-operation of Adjacent Riverain States for Establishing Freedom of Navigation. GB. BFSP, Vol. 40, 1141-49.)

(NOTE:

(1851; Oct. 12/13: Rio de Janeiro. Treaty. Argentina/Brazil. Art. 14: Agreement to invite Riverain States to Cooperate in establishing Free Navigation. Schuyler, Am. Dipl., 320.)

(NOTE:

(1851; Nov. 21: Monte Video. Convention. Brazil, Corrientes,

Entre Rios, Uruguay. Art. 14: Concerning the future Establishment of unrestricted Navigation of the Rio de la Plata \& Tributary Rivers. GB. BFSP, Vol. 60, 383.)

1852; Aug. 28: Buenos Aires. Law. Decree of the Argentine Confederation. Granting Free Navigation to Foreign Merchant Vessels. GB. BFSP, Vol. 49, 1261; Hertslet, COM. TR., X, 44.

1852 ; Oct. 3 : Buenos Aires. Law. Proclamation of the Provisional Director in conformity with the Decree of the Argentine Confederation, Aug. 28, 1852, declaring Navigation of River open 


\section{Plata}

to Merchant Vessels of All Nations. GB. BFSP, Vol. 42, 1313. (Commentary: MOORE, ILD, I, 640; SCHUYLER, Am. Dipl., 319.)

1853; March 4: Asuncion. Treaty. (For Full Citation, See PARANA.)

*France/Paraguay.

*Great Britain/Paraguay.

*Paraguay/Sardinia.

*Paraguay/United States.

(*France, Great Britain, Sardinia, \& the United States signed Separate Conventions with Paraguay.)

1853; July 10: San Jose de Flores. Treaty. Argentina/France. Arts. 1, 2 \& 8: Freedom of Navigation granted to Merchant Vessels of All Nations. Annuaire des Deux Mondes, (1853/ 1854), pg. 947; Clercq, RTF, VI, 377; Cussy/Martens, Rec. Man., Ser. 1, VII, 259; GB. BFSP, Vol. 44, 1071; Martens, NRG, Ser. 2, X, 294.

1853; July 10: San Jose de Flores. Treaty. Argentina/Great Britain. Art. I: Confirming the Decree of the Provisional Director of the Argentine Confederation, Oct. 3, 1852, proclaiming the Navigation of the Rio de la Plata freely open to the Merchant Vessels of All Nations. Cussy/Martens, Rec. Man., Ser. 1, VII, 261; GB. BFSP, Vol. 42, 3; Hertslet, COM. 'TR.; IX, 191.

1853; July 10: San Jose de Flores. Treaty. Argentina/United

States. Arts. 1-8: Freedom of Navigation. GB. BFSP, Vol. 42, 718; Malloy, UST, 18-20. (Commentary: See PARANA.) 1856; March 7: Parana. Treaty. Argentina/Brazil. Arts, 14, 16: Reciprocal Freedom of Navigation. Art. 19: Special Regulations applicable during War. Cussy/Martens, Rec. Man., Ser. 1, VII, 476; GB. BFSP, Vol. 46, 1310-1314.

1856; July 29: Asuncion. Treaty. Argentina/Paraguay. Art. 17: Navigation recognized as entirely Free \& Common to Men-ofWar \& Merchant Vessels of Both Nations subject only to Appropriate Regulations. GB. BFSP, Vol. 46, 1305.

1857; Nov. 20: Treaty. Argentina/Brazil. Freedom of Navigation. GB. BFSP, Vol. 49, 1306.

1858; May 13: La Paz. Treaty. Bolivia/United States. Art. 26: "In accordance with fixed principles of International Law, Bolivia regards the rivers Amazon and $\mathrm{La}$ Plata as highways or channels opened by nature for the commerce of all nations." Malloy, UST, 113, 122. 
1860 ; Sept. 25 : Buenos Aires. Law. Constitution of the Argentine Confederation. Art. 26: "Navigation on the rivers in the interior of the nation is free to All Flags, and subject to no other regulations than those proclaimed by national authority." Dodd, Modern Constitutions, (1909), I, 8; Hertslet, COM. TR., XII, 117.

1876; Feb. 3: Buenos Aires. Treaty. Argentina/Paraguay. Art. 15: Reciprocal Freedom of Navigation. Cussy/Martens, Rec. Man., Ser. 2, II, 527. (Commentary: MOORE, Int. Arbs., 4783.)

1885; July 17: Vienna. Treaty. Argentine Republic/Norway \& Sweden. Art. II: Navigation of River \& Inland Waterways. NORWAY, Treaties, pg. 87.

1888; Aug. 14: Montevideo. Convention. Argentina/Uruguay. Regulating Pilotage in Waters of Rio de la Plata. Martens, NRG, Ser. 3, II, 795.

1909; Jan. 5: Montevideo. Agreement. Joint Declaration by the Governments of Argentina \& Uruguay. Concerning Free Navigation of Rio de la Plata. GB. BFSP, Vol. 103, 357.

1910; Jan. 5: Montevideo. Protocol. Argentina/Uruguay. Sect. 3: "The navigation \& use of the Waters of the Rio de la Plata will continue without alteration as up to the present...." Martens, NRG, Ser. 3, VI, 876.

PUTUMAYO; or IÇA.

See also: AMAZON; COLOMBIAN WATERWAYS; PERUVIAN WATERWAYS.

1906; July 6; Lima. Agreement. Colombia/Peru. Art. III: Reciprocal Freedom of Commercial Navigation on Putumayo \& Affluents. Martens, NRG, Ser. 3, VI, 635.

1907; Apr. 24: Bogota. Agreement. Brazil/Colombia. Reciprocal Freedom of Navigation, including Privilege of proceeding with War-Vessels in Waters of Other Power. GB. BFSP, Vol. 100, 809; Martens, NRG, Ser. 3, I, 789.

RIO GRANDE; or BERMEJO. See VERMEJO.

SALADO. See ARGENTINE WATERWAYS.

SAMA

1883; Oct. 20 : Lima. Treaty. Chile/Peru. Art. II: Demarcation of Fluvial Boundary. GB. BFSP, Vol. 74, 349-350, 352. 


\section{San Francisco}

\section{SAN FRANCISCO}

1866; Dec. 7: Rio de Janeiro. Law (Imperial Decree). Brazilian Government. Opening Navigation to the Merchant Vessels of All Nations. GB. BFSP, Vol. 58, 551; Hertslet, COM. TR., XIII, 157.

1867; July 31: Rio de Janeiro. Law (Imperial Decree). Brazilian Government. Navigation Regulations; enumerating tributaries open to commerce \& merchant-vessels. GB. BFSP, Vol. 58, 551567 ; Hertslet, COM. TR., XIII, 158.

\section{SAN GONZALO}

1909; Oct. 30 : Rio de Janeiro. Treaty. Brazil/Uruguay. Art. II, VI: Freedom of Navigation granted to Uruguayan Vessels. GB. BFSP, Vol. 102, 204; Martens, NRG, Ser. 3, VI, 858.

SAN MIGUEL; or AGUARICO. See AMAZON; COLOMBIAN WATERWAYS; PERUVIAN WATERWAYS.

SAN PEDRO; or RIO GRANDE DE SAN PEDRO

1909; Oct. 30: Rio de Janeiro. Treaty. Brazil/Uruguay. Arts. II, VI: Reciprocal Freedom of Navigation. GB. BFSP, Vol. 102, 204; Martens, NRG, Ser. 3, VI, 858.

SANTA CRUZ. See ARGENTINA WATERWAYS.

SANTIAGO. See AMAZON; ECUADOREAN WATERWAYS; PERUVIAN WATERWAYS.

SAUCES; or NEGRO. See ARGENTINE WATERWAYS.

SOGAMOSO; or CHICAMOCHA. See COLOMBIAN WATERWAYS.

\section{TAKUTU}

1904; June 6: Rome. Decision. Arbitral Award rendered by King of Italy. Establishing Boundary between Brazil \& British Guiana in Thalweg \& stipulating further, that Both Nations should enjoy Freedom of Navigation. GB. BFSP, Vol. 99, 930.

TAPAJOZ

1866; Dec. 7: Rio de Janeiro. Law (Imperial Decree). Brazilian Government. Opening Navigation to the Merchant Vessels of all Nations. GB. BFSP, Vol. 58, 551; Hertslet, COM. TR., XIII, 157. 
1867; July 31: Rio de Janeiro. Law (Imperial Decree). Brazilian Government. Navigation Regulations. GB. BFSP, Vol. 58, 551-567; Hertslet, COM. TR., XIII, 158.

TIGRE; or NIGRE; or PEQUENA. See AMAZON ; ECUADOREAN WATERWAYS; PERUVIAN WATERWAYS.

\section{TOCANTINS}

1866; Dec. 7: Rio de Janeiro. Law (Imperial Decree). Brazilian Government. Opening Navigation to the Merchant Vessels of All Nations. GB. BFSP, Vol. 58, 551; Hertslet, COM. TR., XIII, 157.

1867; July 31: Rio de Janeiro. Law (Imperial Decree). Brazilian Government. Navigation Regulations. GB. BFSP, Vol. 58, 551-567; Hertslet, COM. TR., XIII, 158.

UCAYALI. See AMAZON; PERUVIAN WATERWAYS.

URUGUAY

See also: ARGENTINE WATERWAYS; PLATA (RIO DE LA PLATA).

1828; Aug. 27: Rio de Janeiro. Treaty. Brazil/United Provinces of Rio de la Plata (Buenos Aires, or Argentina). Addit. Article: Reciprocal Freedom of Navigation. Cussy/Hauterive, RTC, I, Part 2, 321; GB. BFSP, Vol. 15, 935 ; Martens, NRT, VII, 686.

1851; May 24: Montevideo. Declaration. Uruguayan Government. Concerning Navigation of Rio de la Plata \& Tributary Rivers. GB. BFSP, Vol. 42, 1315.

1851; Oct. 12: Rio de Janeiro. Treaty. Brazil/Uruguay. Art. 14: Reciprocal Freedom of Navigation. GB. BFSP, Vol. 40, 1141-49. (Commentary: SCHUYLER, Am. Dipl., 320.)

(NOTE :

(1851; Oct. 12/13: Rio de Janeiro. Treaty. Argentina/Brazil. Agreement to invite Riverain States to Cooperate in establishing Unrestricted Navigation. Schuyler, Am. Dipl., 320.) (NOTE:

(1851; Nov. 21: Montevideo. Convention. Brazil, Corrientes, Entre Rios, Uruguay. Concerning Future Establishment of Free Navigation on Rio de la Plata \& Tributary Waters. GB. BFSP, Vol. 60, 383.)

1852; July 15: Asuncion. Treaty. Argentina/Paraguay. Art. III: 


\section{Uruguay}

Free Navigation accorded to Paraguayan Postal Boats \& Escorting Vessels as far as San Borja on the River Uruguay. GB. BFSP, Vol. 42, 1256-57.

1852; Aug. 28: Buenos Aires. Law. Decree of the Argentine Confederation. Granting Free Navigation to Foreign Merchant Vessels. GB. BFSP, Vol. 49, 1261; Hertslet, COM. TR., X, 44.

1852 ; Oct. 3 : Buenos Aires. Law. Proclamation of the Provisional Director in conformity with the Decree of Aug. 28, 1852, declaring Navigation of the River open to Merchant Vessels of All Nations. GB. BFSP, Vol. 42, 1313. (Commentary: MOORE, ILD, I, 640.)

1852; Oct. 18: Buenos Aires. Law. Argentine Confederation. Navigation Regulations. GB. BFSP, Vol. 42, 1314.

1853; July 10: San Jose de Flores. Treaty. Argentina/France. Arts. 1, 2, \& 8: Freedom of Navigation granted to Merchant Vessels of All Nations throughout Argentine Dominion. Annuaire des Deux Mondes, (1853/1854), pg. 947; Clercq, RTF, VI, 377; Cussy/Martens, Rec. Man., Ser. 1, VII, 259; GB. BFSP, Vol. 44, 1071; Martens, NRG, Ser. 2, X, 294.

1853; July 10: San Jose de Flores. Treaty. Argentina/Great Britain. Art. I: Confirming Decree of the Provisional Director of the Argentine Confederation, Oct. 3, 1852, proclaiming the Navigation of the Uruguay freely open to the Merchant Vessels of All Nations. Cussy/Martens, Rec. Man., Ser. 1, VII, 261; GB. BFSP, Vol. 42, 3; Hertslet, COM. TR., IX, 191.

1853; July 10: San Jose de Flores. Treaty. Argentina/United States. Arts. 1-8: Freedom of Navigation. GB. BFSP, Vol. 42, 718; Malloy, UST, 18-20. (Commentary: See PARANA.)

1853; Oct. 10: Montevideo. Law. Decree of Uruguayan Government. Opening All Inland Waterways freely to the Commercial Navigation of Foreign Vessels. GB. BFSP, Vol. 70, 364; Hertslet, COM. TR., XV, 1097.

1854; June 2: Montevideo. Law. Decree of Uruguayan Government. Regulations governing Participation by Foreign Merchant Vessels in Inland Navigation. Hertslet, COM. TR., Vol. 14,690 .

1856; March 7: Parana. Treaty. Argentina/Brazil. Arts. 14, 16: Reciprocal Freedom of Navigation. Art. 19: Special Regulations applicable during War. Cussy/Martens, Rec. Man., Ser. 1, VII, 476; GB. BFSP, Vol. 46, 1310-1314.

1857; Nov. 20: Treaty. Argentina/Brazil. Mutual Enjoyment of 
Fluvial Navigation. GB. BFSP, Vol. 49, 1306. (Commentary: BONFILS, Droit Int., 335.)

1860; Sept. 25: Buenos Aires. Law. Constitution of the Argentine Confederation. Art. 26: "Navigation on the rivers in the interior of the nation is free to All Flags, and subject to no other regulations than those proclaimed by national authority." Dodd, Modern Constitutions, (1909), I, 8; Hertslet, COM. TR., XII, 117.

1885; July 17: Vienna. Treaty. Argentina/Norway \& Sweden. Art. II: Freedom of Inland Navigation. NORWAY, Treaties, pg. 87.

VALENCIA LAKE

1869; May 14: Caracas. Law. Venezuelan Government.

See VENEZUELAN WATERWAYS.

1869 ; July 1: Caracas. Law. Presidential Proclamation.

\section{VENEZUELAN WATERWAYS}

Notably: MARACAIBO LAKE \& TRIBUTARY WATERS; ORINOCO RIVER \& AFFLUENTS; VALENCIA LAKE.

1869; May 14: Caracas. Law. Congress of the United States of Venezuela. Art. I: "From the publication of this decree the navigation of the river Orinoco and its affluents, the Lake of Valencia, the Lake of Maracaibo and its tributaries in all the extension of Venezuela, is thrown open to merchant steam vessels under foreign flags that undertake the inland navigation, in conformity with the regulations on the matter; the respective States being subject to the restrictions established by Base Four of the Thirteenth Article of the Constitution, Section I." MOORE, Int. Arbs., II, 1696-97.

1896 ; July 1: Caracas. Law. Presidential Proclamation in conformity with the Decree of May 14, 1869. Arts. 1-6: Regulating Navigation by Foreign Merchant Vessels upon the National Inland Waterways as designated. MOORE, Int. Arbs., II, 1697-98.

VERMEJO; or BERMEJO; or RIO GRANDE. See also ARGENTINE WATERWAYS.

1852; July 15: Asuncion. Treaty. Argentina/Paraguay. Art. V: "The navigation of the Bermejo is perfectly common to the two states." GB. BFSP, Vol. 42, 1256-57.

1853; Jan. 27: La Paz. Law (Presidential Decree). Bolivian Government. Declaring the Navigation Free to the Merchant Vessels of All Nations. GB. BFSP, Vol. 55, 505; Hertslet, COM. TR., XIII, 152-153. 


\section{Vermejo}

1856; July 29: Asuncion. Treaty. Argentina/Paraguay. Art. 17: Specifically Recognized Reciprocal Freedom of Navigation on the Vermejo. GB. BFSP, Vol. 46, 1305. (Commentary: MOORE, Int. Arbs., 4783.)

WAUPES; or UAPES. See COLOMBIAN WATERWAYS.

YAPURA; or CAQUETA; or JAPURA.

See also: AMAZON; COLOMBIAN WATERWAYS; PERUVIAN WATERWAYS.

1908; Apr. 15: Lima. Convention. Brazil/Peru. Arts. 1-3: Mutual Enjoyment of Fluvial Navigation. Art. III: "In navigating both up as well as down the stream of the Yapura, Brazilian and Peruvian vessels shall be under the obligation of calling at the fiscal or military posts which either country possesses or may establish on that river." GB. BFSP, Vol. 102, 912.

YAVARI; or HYABARY; or YACARANA; or YAQUTTANO. See AMAZON; PERUVIAN WATERWAYS.

\section{AFRICA}

\section{ABY LAGOON}

1889; Aug. 10: Paris. Agreement. France/Great Britain. Art. III, sect. 2: Establishing Freedom of Navigation for Vessels of Both Nations. Hertslet, Africa, No. 226, 731; Hertslet, COM. TR., Vol. 18, 420-421.

\section{ADDO}

1889; Aug. 10 : Paris. Agreement. France/Great Britain. Art. IV, sect. 1: Establishing Freedom of Navigation for Vessels of Both Nations. Hertslet, Africa, No. 226, 731; Hertslet, COM. TR., Vol. 18, 420-421.

\section{AJARRA; or ADJARRA}

1889; Aug. 10: Paris. Agreement. France/Great Britain. Art. IV, sect. 1: Establishing Freedom of Navigation for Vessels of Both Nations. Hertslet, Africa, No. 226, 732 ; Hertslet, COM. TR., Vol. 18, 421. 
AKA

1890; July 1: Berlin. Agreement. Germany/Great Britain. Art. IV, sect. 1: Thalweg Boundary. Hertslet, Africa, No. 270, 900, 903; Hertslet, COM. TR., Vol. 18, 459.

\section{AKOBO}

1902; May 15: Adis Ababa. Treaty. Ethiopia/Great Britain. Art. I: Demarcation of International Boundary in Thalweg. Hertslet, Africa, No. 100, 431.

AKWAYAFE; or AKPAKORUM; or AKWAJAFE

1913; Mar. 11: London. Agreement. Germany/Great Britain. Art. 18, sect. 1: Thalweg Boundary. Art. 23: Reciprocal Freedom of Navigation subject to no Differential Treatment whatsoever. Art. 29: Equal Enjoyment of Navigation \& Fishing. Great Britain, Treaty Series, (1913), No. 13.

\section{ALBERT NYANZA}

1885; Feb. 26: Berlin. Final Act of the Congress. Art. II: Recognizing Freedom of Navigation for All Flags. Chap. IV; Arts. 13-25: Act of Navigation for the Congo System. Art. VIII: Right of Surveillance vested in the International Navigation Commission of the Congo, as Instituted by Art. 17 of the General Act. Hertslet, Africa, No. 128, 472, 474-481.

1906; May 9: London. Agreement. Great Britain/Independent State of the Congo. Art. III: Forbidding the Erection of Works on Tributary Waters diminishing Volume of Water entering the Lake. Hertslet, Africa, No. 165, 585.

\section{ANEBIR; or ANJIBIR}

1913; Mar. 11: London. Agreement. Germany/Great Britain. Sect. I, Art. 12: Thalweg Boundary. Art. 29: Equal Enjoyment of Navigation \& Fishing. Great Britain, Treaty Series, (1913), No. 13.

\section{ANYALO; or ANUBE}

1913; Mar. 11: London. Agreement. Germany/Great Britain. Sect. I, Art. 10: Thalweg Boundary. Art. 29: Equal Enjoyment of Navigation \& Fishing GB. Treaty Series, (1913), No. 13. 


\section{Aruwimi}

ARUWIMI. See also CONGO.

1885; Feb. 26: Berlin. Final Act of the Congress. Art. II: Establishing Freedom of Navigation for All Flags. Art. VIII: Right of Survelllance vested in the International Navigation Commission. Chap. IV; Arts. 13-25: Navigation Act for Congo System. Hertslet, Africa, No. 128, 472, 474-481.

\section{ATBARA}

I891; Apr. 15: Rome. Protocol. Great Britain/Italy. Art. I: Demarcation of Fluvial Boundary. Art. III: Regulating Diversion of Waters; Irrigation Works must not diminish Customary Flow of the Nile. Hertslet, Africa, No. 289, 949; Hertslet, COM, TR., Vol. 19, 688.

\section{AWA; or AUA}

1913; Mar. 11: London. Agreement. Germany/Great Britain. Sect. I, Art. 16: Boundary in Thalweg. Art. 29: Equal Enjoyment of Navigation \& Fishing. GB. Treaty Series, (1913), No. 13.

\section{BARO; or GAMBELLA}

1902; May 15: Adis Ababa. Treaty. Ethiopia/Great Britain. Art.

I: Thalweg Boundary. Hertslet, Africa, No. 100, 431.

BENUE; or CHADDA. See also NIGER.

1885; Feb. 26: Berlin. Final Act of the Congress. Chap. V; Arts. 26-33: Act of Navigation for Niger System. Hertslet, Africa, No. $128,481-484$.

(NOTE :

(1885; June 5: London. Notification. British Government. Proclaiming the Institution of a British Protectorate comprising Both Banks of the River Benue from its confluence with the Niger up to \& including Ibi. Hertslet, Africa, No. 8, 123.

1886; July 27/Aug. 2: Supplementary Agreement. Germany/Great Britain. Recognizing the Benue as International Boundary. Hertslet, Africa, No. 263, 880-881.

1890; July 1: Berlin. Agreement. Germany/Great Britain. Arts. 5, 8: Granting Freedom of Fluvial Transit. Hertslet, Africa, No. 270, 902-903; Hertslet, COM. TR., Vol. 18, 459.

1893; Nov. 15 : Berlin. Agreement. Germany/Great Britain. Arts. I \& II: Demarcation of Boundary. Art. VI: Mutual Freedom of Navigation Recognized. Hertslet, Africa, pg. 915; Hertslet, COM. TR., Vol. 19, 253, 254. 
1894; Mar. 15: Berlin. Convention. France/Germany. Art. III: Mutual Agreement to observe the Dispositions under Articles 26-33 of the Treaty of Berlin, Feb. 26, 1885, concerning Universal Freedom of Navigation \& Commerce. Am. Jour. Int. Law, VI, Suppl., pg. 97; MARTENS, NRG, Ser. 3, I, 603.

1908; Apr. 18: Berlin. Convention. France/Germany. Art. II: Obligates Germany to respect the Provisions of the Treaty of Berlin, Feb. 26, 1885, governing Freedom of Navigation \& Commerce. Am. Jour. Int. Law, VI, Suppl., 105; Hertslet, Africa, No. 379, 1215-1222; Martens, NRG, Ser. 3, I, 612.

1911; Nov. 4: Berlin. Convention. France/Germany. Arts. 12-13: Mutual Enjoyment of Navigation. Martens, NRG, Ser. 3, V, 643,658 .

BEWA; or BIWA

1903; June 25: Mano-Sulija. Agreement. Great Britain \& Liberia. Established International Boundary along Left Bank to the Sea-Coast. Hertslet, Africa, No. 352, 1136.

BIJA; or IMBA. See IMBA.

\section{BLACK VOLTA}

1898; June 14: Paris. Agreement. France/Great Britain. Art. I: Thalweg Boundary. Art. IX: Specifically provides for Reciprocal Freedom of Riverain Navigation \& Commerce during a Thirty Year Period from date of ratifying the Agreement. Hertslet, Africa, No. 241, 785-786.

\section{BLUE NILE}

1891; Mar. 24: Rome. Agreement. Great Britain/Italy. Art. 1: Demarcation of Fluvial Boundary. Hertslet, COM. TR., Vol. 19, 686 .

\section{BOUNDARY WATERWAYS}

\section{FRANCE/GERMANY}

1911; Nov. 4: Berlin. Convention. France/Germany. Art. 10: Reciprocal Freedom of Navigation on All Boundary Waterways. Martens, NRG, Ser. 3, V, 643, 657-58.

\section{FRANCE/LIBERIA}

1907; Sept. 18: Paris. Convention. France/Liberia. Art. III: Equal Enjoyment of Navigation on All Boundary Waterways. Hertslet, Africa, No. 353, 1141; Martens, NRG, Ser. 3, III, 1004. 


\section{Boundary Waterways}

GERMANY/GREAT BRITAIN. In the Yola-Lake Chad District. 1906; March 19: London. Treaty. Germany/Great Britain. Wherever Boundary is formed by Rivers, the Inhabitants on Both Banks shall enjoy Equal Rights of Navigation \& Fishing. Martens, NRG, Ser. 3, II, 691.

\section{BUSI}

1891; June 11: Lisbon. Treaty. Great Britain/Portugal. Fluvial Transit of Persons \& Goods accorded Vessels of All Nations. (Arts. 12-13.) Hertslet, Africa, No. 310, 1022; Hertslet, COM. TR., Vol. 19, 781.

\section{CAMBOMPO}

1893; May 31/June 5: London. Agreement. Great Britain/Portugal. Art. V: Provisional International Boundary established in Thalweg. Hertslet, Africa, No. 311, 1028. (NOTE: This territory came wholly under British dominion in 1905.)

\section{CAJET}

1886; May 12: Paris. Convention. France/Portugal Art. I: Thalweg Boundary. Hertslet, Africa, No. 208, 674.

\section{CAMPO}

1885; Dec. 24: Agreement. France/Germany. Art. I: Recognizing Freedom of Navigation for Vessels of Both Nations. Hertslet, Africa, No. 195, 653.

1911; Nov. 4: Berlin. Convention. France/Germany. Art. 10: Mutual Enjoyment of Navigation. Martens, NRG, Ser. 3, V, $643,657-58$.

CASSAI; or KASSAI. See KASSAI.

\section{CAVALLY}

1892; Dec. 8: Agreement. France/Liberia. Art. II: Mutual Enjoyment of Navigation. Hertslet, Africa, No. 351, 1134.

1907; Sept. 18: Paris. Convention. France/Liberia. Art. III: Reciprocal Freedom of Navigation. Hertslet, Africa, No. 353, 1140-41; Martens, NRG, Ser. 3, III, 1004.

\section{CHAD LAKE}

1890; July 1: Berlin. Agreement. Germany/Great Britain. Arts. 5, 8: Equal Opportunity accorded Vessels of Both Nations to participate in Navigation. Hertslet, Africa, No. 270, 902-903; Hertslet, COM. TR., Vol. 18, 459. 
1893; Nov. 15 : Berlin. Agreement. Germany/Great Britain. Art. II: Deliminating International Boundary. Art. VI: Mutual Freedom of Navigation Recognized. Hertslet, COM. TR., Vol. $19,254$.

1898; June 14: Paris. Agreement. France/Great Britain. Arts. I-IV: International Boundary Established. Art. IX: Reciprocal Freedom of Navigation \& Commerce during a Thirty Year Period from date of Ratification. Hertslet, Africa, No. 241, 785-88.

1904; April 8: London. Treaty. France/Great Britain. Art. VIII:

Designates Line of International Boundary in the Lake. Hertslet, Africa, No. 251, 818-19.

1906; May 29: London. Treaty. France/Great Britain. Art. II: Guaranteeing Free Navigation on the Lake to British \& French Nationals \& Protégées. Hertslet, Africa, No. 256, 845.

1908; Apr. 18: Berlin. Convention. France/Germany. Art. IV : Mutual Enjoyment of Navigation \& the Fisheries in the Lake. Am. Jour. Int. Law, VI, Suppl., 105; Hertslet, Africa, No. 379, 1215-1222; Martens, NRG, Ser. 3, I, 612.

1911; Nov. 4 : Berlin. Convention. France/Germany. Arts. 12-13: Reciprocal Enjoyment of Navigation. Martens, NRG, Ser. 3, $\nabla, 643,657-58$.

CHADDA; or BENUE. See BENUE.

CHARI; or SHARI. See SHARI.

\section{CHILOANGO}

1885; Feb. 5 : Paris. Convention. France/International Association of the Congo. Art. III: Established Boundary in Thalweg from Ocean to Northernmost Source. Hertslet, Africa, No. 152, 564.

1885 ; Aug. 1: Brussels. Notification. Circular Note issued by the Administrator-General of the Department of Foreign Affairs of the Independent State of the Congo. Declaring Neutrality \& Indicating Territorial Limits; Thalweg of Chiloango forming portion of International Boundary. Hertslet, Africa, No. 145, 552.

1886; May 12: Paris. Convention. France/Portugal. Arts. I-III : Territorial Rights of Portugal on Both Banks of Lower Course of the River Recognized. Art. III: Thalweg established as Boundary between Congo Free State \& Portugal. Hertslet, Africa, No. 208, 673-675. 


\section{Chilwa Lake}

\section{CHILWA; or SHIRWA LAKE}

1893; May 31/June 5: London. Agreement. Great Britain/Portugal. Art. I: Demarcation of International Boundary. Hertslet, Africa, No. 311, 1027-1029.

\section{CHIUTA LAKE}

1893; May 31/June 5 : London. Agreement. Great Britain/Portugal. Art. I: Establishing International Boundary. Hertslet, Africa, No. 311, 1027-1029.

\section{CHOBE; or KWANDO}

1890; July 1: Berlin. Agreement. Germany/Great Britain. Art. III, Sect. 2: International Boundary follows Thalweg to confluence with Zambesi. Hertslet, Africa, No. 270, 902; Hertslet, COM. TR., Vol. 18, 459.

CONGO. Including All Tributary Waterways of the System, Notably:

The Rivers:

Aruwimi ;

Kalombo, or Kilambo;

Kandcko;

Kassai;

Kwa;

Lobai;

Lomami ;

Luapula ;

Lukualli;

Lukuga;

Lulanga ;
Mfini;

Pama;

Rusizi;

Sanga;

Ubangi.

The Lakes:

Kivu;

Leopold II;

Mweru;

Tanganyika;

Tumba, or Matumba.

1885; Feb. 26: Berlin. General Act of the Congress of Nations: Austria-Hungary, Belgium, Denmark, France, Germany, Great Britain, Italy, Netherlands, Norway, Portugal, Russia, Spain, Sweden, Turkey, United States of America. Art. I: Designating Boundaries of the Congo Basin. Art. II: Establishing Freedom of Navigation throughout the Congo System for All Nations. Chap. IV, Arts. 13-25: Act of Navigation applicable to the Congo \& Tributary Waterways. Art. VIII: Right of Surveillance vested in the International Navigation Commission of the Congo, as designated in Article 17 of the General Act. Clercq, RTE, XIV, 447-454; GB. BFSP, Vol. 76, 4; Hertslet, Africa, No. 128, 472, 474-481; Hertslet, COM. TR., Vol. 17, 68; 
Martens, NRG, Ser. 2, X, 414. (Commentary: DESPAGNET, Droit Int., 639; ENGELHARDT, Hist. Droit Fluv. Conv., 101; HALL, Int. Law, 5th Edit., 89-92; LAWRENCE, Int. Law, 210; MOORE, ILD, I, 652; OPPENHEIM, Int. Law, I, 228; SCHUYLER, Am. Dipl., 364-366; US. FOR. RELS., (1888), I, 27; US. SEN. EX. DOC., No. 196, pgs. 298, 300, 303,-49th Cong., 1st Sess.; WESTLAKE, Int. Law, I, 158; WOOLSEY, Intro. to Study of Int. Law, sec. 62. (NOTE: Correspondence between Great Britain \& Portugal during the years 1882, 1883, \& 1884 concerning navigation of the river Congo. GB. BFSP, Vol. 75, 1272.)

1887; Apr. 26: Brussels. Law. Decree of the Independent State of the Congo, concerning Navigation. GB. BFSP, Vol. 78, 86.

1891; Jan. 24: Brussels. Treaty. Independent State of the Congo \& the United States of America. Art. VI: Freedom of Navigation upon All Inland Waterways. Am. Jour. Int. Law, III, Suppl., pg. 65 ; Malloy, UST, 331.

1908; Apr. 18: Berlin. Convention. France/Germany. Art. II: Mutual Participation in Navigation \& Commerce, pursuant to the Joint Navigation Regulations designated in an earlier section of Article II. Am. Jour. Int. Law, VI, Suppl., 105-106; Hertslet, Africa, No. 379, 1215-1222; Martens, NRG, Ser. 3, I, 612.

1911; Nov. 4 : Berlin. Convention. France/Germany. Arts. 12-13: Reciprocal Enjoyment of Navigation. Martens, NRG, Ser. 3, $\nabla, 643,657-58$.

CROCODILE; Affluent of the KOMATI. See SABI.

\section{CROSS; or OLD CALABAR}

1885; Apr. 25/June 16: Agreement. Germany/Great Britain. Demarcation of International Fluvial Boundary. Hertslet, Africa, No. 260, 868-69.

1886; July 27/Aug. 2: Supplementary Agreement. Germany/Great Britain. Concerning Boundary on Cross River. Hertslet, Africa, No. 263, 880-881.

1890 ; July 1: Berlin. Agreement. Germany/Great Britain. Art. IV: Demarcation of Boundary. Hertslet, Africa, No. 270; Hertslet, COM. TR., Vol. 18, 459.

1893; Nov. 15: Berlin. Agreement. Germany/Great Britain. Art. I: Designating International Boundary. Hertslet, Africa, No. 275, 913-914; Hertslet, COM. TR., Vol. 19, 253-54. 


\section{Cross}

1913; March 11: London. Convention. Germany/Great Britain. Sect. II, Art. I, Par. 1: "The navigation on all the course of the Cross River within Southern Nigeria shall remain open to German merchant-vessels . . . subject to the same rules as regards navigation on the river as are applicable to British vessels, and to no special rules, duties, or restrictions."

Par. 2: "No import, export, or transit dues shall be levied on transit traffic." Sect. I, Art. 26: Recognition of Fishing Rights. GB. BFSP, Vol. 106, 782; GB. Treaty Series, (1913), No. 13, pg. 240.

CUANGO; or KUANGO; or KWANGO See LUKUALLI.

CUNENE; or KUNENE

1886; Dec. 30: Lisbon. Agreement. Germany/Portugal. Art. I: Thalweg Boundary. Hertslet, Africa, No. 216, 703.

DAKKA; DAKA; KULUPENE; or LAKKA 1890; July 1: Berlin. Agreement. Germany/Great Britain. Art.

IV: Demarcation of Boundary. Hertslet, Africa, No. 270, 900, 903 ; Hertslet, COM. TR., Vol. 18, 459.

1901; Sept. 26: Berlin. $\}$ Convention. Germany/Great Britain. Art.

I: Thalweg Boundary. Hertslet, Africa, No. 280, 927.

1904; June 25 : Berlin. Agreement. Germany/Great Britain. Confirming International Boundary established along Thalweg. Hertslet, Africa, No. 283, 935.

DCHAWE; or SHAVOE. See SHAVOE.

EDWARD \& GEORGE LAKE

1885; Feb. 26: Berlin. General Act of Congress of Nations. Art. II: Establishing Freedom of Navigation for All Flags. Art. VIII: Right of Surveillance vested in the International Navigation Commission. Chap. IV ; Arts. 13-25: Navigation Regulations. Hertslet, Africa, No. 128, 472, 474-481.

\section{FARO}

1906; March 19: London. Treaty. Germany/Great Britain. Art. 
I: Demarcation of Fluvial Boundary. Freedom of Navigation \& Fishing to be enjoyed equally by Both Nations. Hertslet, Africa, No. 284, 937-38; Martens, NRG, Ser. 3, II, 691.

\section{GAERESI.}

1912; July 22/Aug. 9: Lisbon. Agreement. Great Britain \& Portugal. Annex I: Thalweg Boundary. GB. Treaty Series, (1912), No. 21.

\section{GAMBELLA. See BARO.}

\section{GAMBIA.}

1857; March 7 : London. Agreement. France/Great Britain. Art. III: French Vessels granted Free Access to the Gambia, subject to the same tolls, duties \& regulations as British Vessels. Hertslet, Africa, No. 221, 717.

1889; Aug. 10: Paris. Agreement. France/Great Britain. Art. I, sects. 1 \& 2: Establishing British Control over Both Banks of the Gambia from Sea-Coast to the French Frontier at Yarbatenda. Hertslet, Africa, No. 226, 729.

1904; April 8: London. Convention. France/Great Britain. Art. V : Establishing Freedom of Navigation based on the provisions of the Congress of Berlin; Feb. 26, 1885. Hertslet, Africa, No. 251, 817. (Commentary: OPPENHEIM, Int. Law, I, 590.)

GANALE; or DJUBA. See JUBA.

GONGOLA. See NIGER.

\section{GREAT SCARCIES.}

1882; June 28: Paris. Treaty. France/Great Britain. Art. I: Great Britain secures complete control over the River; France secures like Dominion over the Mellicourie. Hertslet, Africa, No. 224.

1889 ; Aug. 10 : Paris. Agreement. France/Great Britain. Demarcation of International Boundary. Hertslet, Africa. No. $226,729-730$.

1895; Jan. 22/Feb. 4: Paris. Agreement. France/Great Britain. Art. I: Specified this River as integral part of Boundary between French Guinea \& Sierra Leone; expressly stipulating that Inhabitants of Both Nations should enjoy Freedom of Navigation. GB. BFSP, Vol. 87, 14; Hertslet, Africa, No. 237, 757, 763. 


\section{Honde}

HONDE.

1912; July 22/Aug. 9: Lisbon. Agreement. Great Britain \&

Portugal. Annex I: Thalweg Boundary. GB. Treaty Series, (1912), No. 21.

\section{IMBA; or BIJA.}

1913; March 11: London. Agreement. Germany/Great Britain. Sect. I, Art. 9: Thalweg Boundary. Art. 29 : Equal Enjoyment of Navigation \& Fishing. GB. Treaty Series, (1913), No. 13.

ISANGO. See SEMLIKI.

JALIBA. See also: NIGER.

1885; Feb. 26: Berlin. General Act of Congress of Nations. Chap.

V; Arts. 26-33: Navigation Regulations. Hertslet, Africa, No. $128,481-484$.

1893; Nov. 15: Berlin. Agreement. Germany/Great Britain. Art. VI: Mutual Freedom of Navigation Recognized. Hertslet, Africa, pg. 915; Hertslet, COM. TR., Vol. 19, 253, 254.

\section{JIPE LAKE.}

1890 ; July 1: Berlin. Agreement. Germany/Great Britain. Art. I, sec. 1: Demarcation of Boundary. Hertslet, Africa, No. 270, 902 ; Hertslet, COM. TR., Vol. 18, 459.

1892 ; Oct. 27 : Taveta. Agreement. Germany/Great Britain. Relating to International Boundary. Hertslet, Africa, No. 272, 909. 1892 ; Dec. 24: Zanzibar. Protocol. Germany/Great Britain. Establishing Point where Boundary shall meet the Lake. Hertslet, Africa, No. 272, 909.

1893; July 25: Berlin. Agreement. Germany/Great Britain. Definitive Convention designating International Boundary. Hertslet, Africa, No. 274, 911.

JORA.

1912 ; July 22/Aug. 9 : Lisbon. Agreement. Great Britain/Portugal. Annex I: Thalweg Boundary. GB. Treaty Series, (1912), no. 21.

JUBA; or DJUBA; or GANALE.

1889; Aug. 3: London. Agreement. Great Britain/Italy. Art. V: Joint \& Equal Rights of Navigation for Both Nations recognized. Hertslet, Africa, No. 331, 1090.

1890 ; July 1: Berlin. Agreement. Germany/Great Britain. Art. I: Demarcation of Fluvial Boundary. Hertslet, Africa, No. 270, 901; Hertslet, COM. TR., Vol. 18, 459. 
1891; March 24: Rome. Agreement. Great Britain/Italy. Art. I: Thalweg Boundary. Hertslet, Africa, No. 288, 948; Hertslet, COM. TR., Vol. 19, 686.

KADUNA. See NIGER.

KALOMBO; or KILAMBO. See also CONGO.

1885; Feb. 26: Berlin. General Act of the Congress. Universal

Freedom of Navigation. Hertslet, Africa, No. 128, 472, 474-481. 1890 ; July 1: Berlin. Agreement. Germany/Great Britain. Art. I, sect. 2: Thalweg Boundary from Lake Tanganyika. Hertslet,

Africa, No. 270, 902; Hertslet, COM. TR., Vol. 18, 459.

1901; Feb. 23: Berlin. Agreement. Germany/Great Britain. Section I: Thalweg Boundary. Hertslet, Africa, No. 279, 925-26.

KAMBOMPO. See CAMBOMPO.

KANDCKO. See also CONGO.

1885; Feb. 26: Berlin. General Act of the Congress. Universal Freedom of Navigation established. Hertslet, Africa, No. 128, $472,474-481$.

1908; Apr. 18: Berlin. Convention. France/Germany. Mutual Freedom of Navigation \& Commerce. Am. Jour. Int. Law, VI, Suppl., 105; Hertslet, Africa, No. 379, 1215-1222 ; Martens, NRG, Ser. 3, I, 612.

1911; Nov. 4: Berlin. Convention. France/Germany. Reciprocal Enjoyment of Navigation. Martens, NRG, ser. 3, V, 643, $657-58$.

KASSAI. See also CONGO.

1885; Feb. 26: Berlin. General Act of the Congress. Universal Freedom of Navigation recognized. Hertslet, Africa, No. 128, 472, 474-481.

1891; May 25: Lisbon. Treaty. Independent State of the Congo \& Portugal. Art. I: Thalweg Boundary. Hertslet, Africa, No. 170, 592-93.

\section{KIBISH. See SACCHI.}

KILAMBO. See KALOMBO.

KILUNGA; or KILANGE.

1906; March 19: London. Agreement. Germany/Great Britain. 


\section{Kilunga}

Art. III: Thalweg Boundary; Equal Enjoyment of Navigation $\&$ the Fisheries expressly stipulated. Hertslet, Africa, No. 284, 937-38; Martens, NRG, Ser. 3, II, 691.

KIVU LAKE.

See also: CONGO.

1885; Feb. 26: Berlin. General Act of the Congress. Art. II: Universal Freedom of Navigation. Chap. IV : Arts. 13-25; Act regulating Navigation. Art. VIII : Right of Surveillance vested in the International Navigation Commission. Hertslet, Africa, No. 128, 472, 474-481.

KOMADUGU; or KOMADUGU WAUBE; or KOMADUGU YOBE. 1904; April 8: London. Convention. France/Great Britain. Art. VII: Subjects of Both Nations assured of Equal Enjoyment of Riverain Fisheries. Hertslet, Africa, No. 251, 818-819. (Commentary: OPPENHEIM, Int. Law, I, 593.)

1910: Feb. 19: London. Agreement. France/Great Britain. Art. I: Thalweg Boundary. GB. Treaty Series, (1912), No. 1.

KOMATI. See SABI.

KUBANGO; or OKAVANGO; or TONKE.

1886; Dec. 30 : Lisbon. Agreement. Germany/Portugal. Art. I: Thalweg Boundary. Hertslet, Africa, No. 216, 703.

KUILU

See also: CONGO. 1885; Feb. 26: Berlin. General Act of the Congress. Art. II: Universal Freedom of Navigation. Chap. IV; Arts. 13-25: Act regulating Navigation. Art. VIII : Right of Surveillance vested in the International Navigation Commission. Hertslet, Africa, No. 128, 472, 474-481.

1891; May 25: Brussels \& Lisbon. Treaty. Independent State of the Congo \& Portugal. Art. I, sec. 1: Establishing Fluvial Boundary. Hertslet, Africa, No. 170, 593.

KULUPENE; or DAKA. See DAKKA.

\section{KULUSULO.}

1904; June 25 : Berlin. Agreement. Germany/Great Britain. Thalweg Boundary. Hertslet, Africa, No. 283, 935.

KUNENE. See CUNENE.

KWA.

See also: CONGO. 1885; Feb. 26 : Berlin. General Act of the Congress. Art. II: Uni- 
versal Freedom of Navigation. Chap. IV. Arts. 13-25: Act regulating Navigation. Art. VIII: Surveillance vested in the International Commission. Hertslet, Africa, No. 128, 472, 474481.

KWANDO; or KUANDO. See CHOBE.

KWANGO; Tributary of Lukualli. See LUKUALLI.

LAKKA; or DAKA; or KULUPENE. See DAKKA.

LAVUA; or LUALABA. See LUAPULA.

LEOPOLD II LAKE.

See also: CONGO.

1885; Feb. 26 : Berlin. General Act of the Congress. Art. II: Universal Freedom of Navigation. Chap. IV, Arts. 13-25: Act regulating Navigation. Art. VIII: Right of Surveillance vested in the International Commission of Navigation instituted by Article 17 of the Final Act. Hertslet, Africa, No. 128, 472, $474-481$.

LIMPOPO.

1890; Aug. 20 : London. Treaty. Great Britain/Portugal. Freedom of Navigation. Martens, NRG, Ser. II, XVI, 929.

1891; June 11: Lisbon. Treaty. Great Britain/Portugal. Art. XII: Recognized Universal Freedom of Navigation. Hertslet, Africa, No. 310, 1022; Hertslet, COM. TR., Vol. 19, 781.

LOANGE; Tributary of Kassai. See CONGO.

LOANGWA; or AROANGWA.

1893; May 31/June 5: London. Agreement. Great Britain/Portugal. Art. I: Establishing International Boundary. Hertslet, Africa, No. 311, 1027-1029.

1911; Oct. 21/Nov. 20 : London. Agreement. Great Britain/Portugal. Annex I: Thalweg Boundary. GB Treaty Series, (1912), No. 16.

\section{LOBAI}

See also: CONGO. 1885; Feb. 26 : Berlin. General Act of the Congress. Art. II: Uni versal Freedom of Navigation. Chap. IV, Arts. 13-25: Act regulating Navigation. Art. VIII: Right of Surveillance vested 
Lobai

in the International Navigation Commission. Hertslet, Africa, No. 128, 472, 474-481.

1908; Apr. 18. Berlin. Convention. France/Germany. Mutual Enjoyment of Fluvial Navigation \& Commerce. Am. Jour. Int. Law, VI, Suppl., 105; Hertslet, Africa, No. 379, 1215-1222; Martens, NRG, Ser. 3, I, 612.

1911; Nov. 4: Berlin. Convention. France/Germany. Reciprocal Freedom of Navigation. Martens, NRG, Ser. 3, V, 657-658.

LOGONE; or LOGOGNE.

1894; March 15 : Berlin. Convention. France/Germany. Art. III: Mutual Agreement to observe the Dispositions governing Freedom of Navigation embodied in Arts. 26-33 of Treaty of Berlin; Feb. 26, 1885. Am. Jour. Int. Law, VI, Suppl., 97; Martens, NRG, Ser. 3, I, 603.

1908; Apr. 18: Berlin. Convention. France/Germany. Art. II: Renewing Art. III of Treaty of March 15, 1894, providing for Mutual Enjoyment of Fluvial Navigation \& Commerce. Am. Jour. Int. Law, VI, Suppl., 105 ; Hertslet, Africa, No. 379, 12151222 ; Martens, NRG, Ser. 3, I, 612.

1911; Nov. 4: Berlin. Convention. France/Germany. Art. 10: Freedom of Navigation. Martens, NRG, Ser. 3, V, 657-58.

LOMAMI. See also CONGO.

1885; Feb. 26: Berlin. General Act of the Congress. Art. II: Universal Freedom of Navigation. Chap. IV, Arts. 13-25; Act regulating Navigation. Art. VIII: Right of Surveillance vested in the International Navigation Commission. Hertslet, Africa, No. 128, 472, 474-481.

LUAPULA; or LAVUA; or LUALABA - See also: CONGO. 1885 ; Feb. 26: Berlin. General Act of the Congress. Art. II: Universal Freedom of Navigation. Chap. IV, Arts. 13-25; Act regulating Navigation. Art. VIII : Right of Surveillance vested in the International Navigation Commission. Hertslet, Africa, No. 128, 472, 474-481.

1894; May 12: Brussels. Agreement. Great Britain \& the Independent State of the Congo (H. M. King Leopold II). Art. I, sec. 6: Demarcation of International Boundaries. Hertslet, Africa, No. 163, 578-583.

1906; May 9: Brussels. Agreement. Great Britain/Independent State of the Congo. Revising stipulations of Agreement of May 12, 1894. Hertslet, Africa, No. 164, pg. 584. 
LUCALLA; or LUCULLA.

1885; Feb. 14: Berlin. Convention. Independent Association of the Congo \& Portugal. Art. III: Thalweg Boundary. Hertslet, Africa, No. 169, 591.

1885; Aug. 1: Brussels. Notification. Circular Note issued by the Administrator-General of the Department of Foreign Affairs for the Independent State of the Congo. Declaring Neutrality; Indicating Territorial Limits. Hertslet, Africa, No. 145, 552.

1891; May 25: Brussels. Convention. Independent State of the Congo \& Portugal. Art. II: Demarcation of Fluvial Boundary. Hertslet, Africa, No. 170, 594-595.

LUKUALLI; or KWANGO

See also: CONGO.

1885; Feb. 26: Berlin. General Act of Congress. Art. II: Universal Freedom of Navigation. Chap. IV, Arts. 13-25: Act regulating Navigation. Art. VIII: Right of Surveillance vested in the International Navigation Commission. Hertslet, Africa, No. 128, 472, 474-481.

1891; May 25: Lisbon. Treaty. Independent State of the Congo \& Portugal. Art. I: Thalweg Boundary. Hertslet, Africa, No. 170, 593.

LUKUGA; A River connecting Lake Tanganyika with the Upper Congo.

See also: CONGO. 1885 ; Feb. 26 : Berlin. General Act of the Congress. Art. II: Universal Freedom of Navigation. Chap. IV, Arts. 13-25: Act regulating Navigation. Art. VIII: Right of Surveillance vested in the International Navigation Commission. Hertslet, Africa, No. 128, 472, 474-481.

LULANGA

See also: CONGO. 1885 ; Feb. 26 : Berlin. General Act of the Congress. Art. II: Universal Freedom of Navigation. Chap. IV, Arts. 13-25: Act regulating Navigation. Art. VIII : Right of Surveillance vested in the International Navigation Commission. Hertslet, Africa, No. 128, 472, 474-481.

LUNDE; or LUNTE; or LANDE.

1890; Aug. 20 : London. Treaty. Great Britain/Portugal. Mutual Enjoyment of Navigation. Martens, NRG, Ser. 2, XVI, 929. 1891; June 11: Lisbon. Treaty. Great Britain/Portugal. Universal Freedom of Navigation. Hertslet, Africa, No. 310, 1022; Hertslet, COM. TR., Vol. 19, 781. 
Maia

MAIA

1911; Jan. 21: Monrovia. Convention. Great Britain \& Liberia. Art. I: Thalweg adopted as International Boundary. Art. II: Stipulated that Thalweg should constitute Boundary along All Rivers \& Streams \& Provided for Reciprocal Freedom of Navigation along these Waterways. GB. Treaty Series, (1911), No. 16.

\section{MAIETEB}

1902; May 15: Adis Ababa. Treaty. Ethiopia, Great Britain, Italy. Annex, Art. I: Demarcation of International Boundary in Thalweg. Hertslet, Africa, No. 100, 433.

MAKONA; or MOA.

1907; Sept. 18: Paris. Convention. France/Liberia. Art. I: Demarcation of Boundary. Art. III: Reciprocal Freedom of Navigation. Hertslet, Africa, No. 353, 1140-41; Martens, NRG, Ser. 3, III, 1004.

1913 ; Sept. 4: London. Agreement. France/Great Britain. Art. IV: Thalweg Boundary. Art. VI: Reciprocal Freedom of Navigation \& Fishing. Art. VIII : Equal Enjoyment of Fluvial Fisheries for Inhabitants of Both Countries. GB. Treaty Series, (1913), No. 19.

MAKUA; Affluent of the River Ubangi. See CONGO.

\section{MAKWOI.}

1911; Jan. 21: Monrovia. Convention. Great Britain \& Liberia. Art. I: Thalweg adopted as International Boundary. Art. II: Stipulated that Thalweg should constitute Boundary along All Frontier Streams \& Recognized Reciprocal Freedom of Navigation along these Waterways. GB. Treaty Series, (1911), No. 16.

MALAGARAZI; or UKUMBI. See UGALA.

MAMOUDIE CANAL.

1841; Oct. 12: Alexandria. Law. Notification by Viceroy of the Egyptian Government. Regulating Navigation of the Canal. GB. BFSP, Vol. 29, 1195. Hertslet, COM. TR., X, 602.

MANOH; or MANO.

1911; July 25: Monrovia. Convention. Great Britain \& Liberia. Freedom of Navigation. GB. BFSP, Vol. 107, 539.

1913; Apr. 10: Monrovia. Convention. Great Britain \& Liberia. Arts. 1-9: Regulating Freedom of Navigation; Providing 
Adequate \& Appropriate Facilities for Entry \& Clearance of Goods shipped by River Boats. GB. BFSP, Vol. 106, 798; GB. Treaty Series, (1913), No. 6, pg. 88.

MAO BULO; or MAIO M'BULO.

1913; March 11: London. Agreement. Germany/Great Britain. Sect. I, Art. 1: Thalweg Boundary. Art. 29: Equal Enjoyment of Navigation \& Fishing. GB. Treaty Series, (1913), No. 13.

MAO KALO; or MAIO KALO.

1913; March 11: London. Agreement. Germany/Great Britain. Sect. I, Art. 8: Thalweg Boundary. Art. 29: Equal Enjoyment of Navigation \& Fishing. GB. Treaty Series, (1913), No. 13.

MAO KAM; or MAIO KAM.

1913; Mar. 11: London. Agreement. Germany/Great Britain. Sect.

I, Art. 5: Thalweg Boundary. Art. 29: Equal Enjoyment of Navigation \& Fishing. GB. Treaty Series, (1913), No. 13.

MAO TATI; or MAIO TATI.

1913; March 11: London. Agreement. Germany/Great Britain. Sect. I, Art. 9: Thalweg Boundary. Art. 29 : Mutual Enjoyment of Navigation \& Fishing. GB. Treaty Series, (1913), No. 13.

\section{MAREB.}

1902; May 15: Adis Ababa. Treaty. Ethiopia, Great Britain, Italy. Annex, Art. I: Demarcation of Fluvial Boundary. Hertslet, Africa, No. 100, 433.

\section{MARQUARI; or MEKWER.}

1913; March 11: London. Agreement. Germany/Great Britain. Sect. I, Art. 9: Thalweg Boundary. Art. 29 : Mutual Enjoyment of Navigation \& Fishing. GB. Treaty Series, (1913), No. 13.

MATUMBA LAKE. See TUMBA LAKE. ·

\section{MAUWA.}

1911; Jan. 21: Monrovia. Convention. Great Britain \& Liberia. Art. I: Thalweg Boundary. Art. II: Stipulated that Thalweg should constitute Boundary along all Frontier Rivers \& Streams \& Recognized Reciprocal Freedom of Navigation along these Waterways. GB. Treaty Series, (1911), No. 16. 


\section{MAYO-KEBBI.}

1894; March 15 : Berlin. Convention. France/Germany. Art. III: Mutual Agreement to observe the Dispositions governing Freedom of Navigation embodied in Arts. 26-33 of the Congress of Berlin; Feb. 26, 1885. Am. Jour. Int. Law, VI, Suppl. 97; Martens, NRG, Ser. 3, I, 603.

1908; Apr. 18: Berlin. Convention. France/Germany. Art. II:

Renewing Art. III of Treaty of March 15, 1894, providing for Mutual Enjoyment of Fluvial Navigation \& Commerce. Am. Jour. Int. Law, VI, Suppl., 105; Hertslet, Africa, No. 379, 1215-1222; Martens, NRG, Ser. 3, I, 612.

1911; Nov. 4: Berlin. Convention. France/Germany. Art. 10: Reciprocal Freedom of Navigation. Martens, NRG, Ser. 3, V, 657-658.

\section{MAZOE.}

1891; June 11: Lisbon. Treaty. Great Britain/Portugal. Universal Freedom of Navigation. Hertslet, Africa, No. 310, 1018, 102122; Hertslet, COM. TR., Vol. 19, 781.

\section{MELI.}

1913; Sept. 4: London. Agreement. France/Great Britain. Art. III : Thalweg Boundary. GB. Treaty Series, (1913), No. 19.

MFINI. See also CONGO.

1885; Feb. 26 : Berlin. General Act of the Congress. Art. II: Universal Freedom of Navigation. Chap. IV, Arts. 13-25; Act regulating Navigation. Art. VIII: Right of Surveillance vested in the International Navigation Commission. Hertslet, Africa, No. 128, 472, 474-481.

\section{MOMBEZI. See PUNGWE.}

MONO.

1908; Apr. 18: Berlin. Convention. France/Germany. Agreement to observe the Stipulations governing Freedom of Navigation embodied in Arts. 26-33 of the Congress of Berlin; Feb. 26, 1885. Am. Jour. Int. Law, VI, Suppl., 105; Hertslet, Africa, No. 379, 1215-1222; Martens, NRG, Ser. 3, I, 612.

1911; Nov. 4: Berlin. Convention. France/Germany. Art. 10: Reciprocal Freedom of Navigation. Martens, NRG, Ser. 3, V, $657-658$.

1912; Sept. 28: Paris. Convention. France/Germany. Mutual 
Recognition of Equal Enjoyment of Navigation on the River Mono. Martens, NRG, Ser. 3, VII, 381, 395.

\section{MORNO.}

1913; March 11: London. Agreement. Germany/Great Britain. Sect. I, Art. 9: Thalweg Boundary. Art. 29: Equal Enjoyment of Navigation \& Fishing. GB. Treaty Series, (1913), No. 13.

\section{MORRO.}

1911; Jan. 21: Monrovia. Convention. Great Britain \& Liberia. Art. I: Thalweg Boundary. Art. II: Reciprocal Freedom of Navigation. GB. Treaty Series, (1911), No. 16.

\section{MUNI.}

1900; June 27: Paris. Treaty. France \& Spain. Art. V: Accorded to French \& Spanish Vessels Reciprocal Freedom of Access in the Territorial Waters of the Other Power; Recognized Equal Enjoyment of the Fluvial Fisheries. Hertslet, Africa, No. 359, 1166.

MWERU; or MOERO; LAKE

See also: CONGO. 1885; Feb. 26 : Berlin. General Act of the Congress. Art. II: Universal Freedom of Navigation. Chap. IV, Arts. 13-25: Act regulating Navigation. Art. VIII: Right of Surveillance vested in the International Navigation Commission. Hertslet, Africa, No. 128, 472, 474-481.

1894; May 12: Brussels. Agreement. Great Britain \& the Independent State of the Congo. (H. M. King Leopold II). Art. I, sec. 6: Demarcation of International Boundary. Hertslet, Africa, No. 163, 578-583.

\section{NIGER.}

Including All Tributary Waterways of the System, Notably the Rivers

Benue, or Chadda;

Fatiko;

Gongola;

Jaliba;

\section{Kaduna; \\ Sokoto; \\ Tembé-Counda, or Tembi- Koundo.}

1885; Feb. 26: Berlin. General Act of the Congress of Nations: Austria-Hungary, Belgium, Denmark, France, Germany, Great Britain, Italy, Netherlands, Norway, Portugal, Russia, Spain, Sweden, Turkey, United States of America. Chap. V, Arts. 2633: Act governing the Universal Freedom of Fluvial Navigation. 


\section{Niger}

Clercq, RTF, XIV, 447, 454; GB. BFSP, Vol. 76, 4; Hertslet, Africa, No. 128, 481-484; Hertslet, COM. TR., Vol. 17, 73 ; Martens, NRG, Ser. 2, X, 414. (Commentary: See also CONGO. AM. PHILOSOPHICAL SOC., Proceedings, XXVI, 462; BONFILS, Droit Int., 337.)

1886; July 10: London. Law. Royal Charter granted to the National African Company. British Government. Sect. 15: "The Company shall be subject to \& shall perform, observe, \& undertake all the observations \& stipulations relating to the River Niger, its affluents, branches, \& outlets, or the territories neighboring thereto, or situate in Africa, contained in \& undertaken by ourselves under the General Act of the Conference of the Great Powers at Berlin, February 26, 1885, or in any other Treaty, Agreement, or Arrangement between ourselves \& any other State or Power, whether already made or hereafter to be made." Hertslet, Africa, No. 10, 126.

1891; June 26: Paris. Treaty. France/Great Britain. Demarcation of International Boundary. Hertslet, Africa, No. 232, 743744.

1893; Nov. 15: Berlin. Agreement. Germany/Great Britain. Art. VI: Mutual Freedom of Navigation Recognized. Hertslet, Africa, pg. 915; Hertslet, COM. TR., Vol. 19, 255.

1896; Jan. 15: Treaty. Germany/Great Britain. Art. V: Utilization of the Niger. GB. Parl. Papers, Treaty Series, (1896), No. 5.

1898; June 14: Paris. Agreement. France/Great Britain. Arts. I-VI: Demarcation International Boundary. Art. IX: Recognizing Mutual Enjoyment of Navigation \& Commerce during a Thirty Year Period from Date of Ratification. Hertslet, Africa, No. 241, 785-788.

1903; Aug. 10: London. Law (Order in Council). British Government. Act regulating Navigation on Niger \& Affluents. GB. BFSP, Vol. 96, 230.

\section{NILE.}

1841; Oct. 12: Alexandria. Law. Notification by Viceroy of the Egyptian Government. Granting Foreigners the Privilege of Building Vessels and of Navigating the River, subject to Pub- 
lished Regulations. GB. BFSP, Vol. 29, 1195; Hertslet, COM. TR., X, 602.

1891; Apr. 15: Rome. Agreement. Great Britain/Italy. Art. I: Demarcation of Boundary. Art. III: Regulating Diversion of Waters; Irrigation Works on the Tributary Atbara must not diminish Usual Volume. Hertslet, Africa, No. 289, 949; Hertslet, COM. TR., Vol. 19, 688.

1902 ; May 15 : Adis Ababa. Treaty. Ethiopia/Great Britain. Forbidding Construction of Works diminishing or obstructing the Customary Flow of the Nile. Hertslet, Africa, No. 100, 431432.

1906; May 9: London. Agreement. Great Britain/Independent State of the Congo. Art. III: Regulating Diversion of Waters. Art. VI, VII: Establishing Freedom of Navigation on the Upper Nile for Vessels under the Belgian, British, Congolese, or Egyptian Flags. Hertslet, Africa, No. 165, 584-586.

\section{NUON.}

1907; Sept. 18: Paris. Convention. France/Liberia. Art. III: Reciprocal Freedom of Navigation. Art I: Demarcation of Fluvial Boundary. Hertslet, Africa, No. 353, 1141; Martens, NRG, Ser. 3, III, 1004.

\section{NYASSA LAKE.}

1890; July 1: Berlin. Agreement. Germany/Great Britain. Art.

I, sect. 2: Establishing International Boundary. Art. VIII:

Freedom of Navigation \& Passage. Hertslet, Africa, No. 270, 900, 903; Hertslet, COM. TR., Vol. 18, 459.

1891; June 11: Lisbon. Treaty. Great Britain/Portugal. Art. V:

Establishing Boundary. Art. XII: Recognizing Universal Freedom of Navigation. Hertslet, Africa, No. 310, 1022; Hertslet, COM. TR., Vol. 19, 777, 779.

1893; May 31/June 5: London. Agreement. Great Britain \&

Portugal. Art. I: Provisional International Boundary. Hertslet, Africa, No. 311, 1027-28.

OCPARA; or OKPA.

1898; June 14: Paris. Convention. France/Great Britain. Art. II: Adopted as International Boundary. Hertslet, Africa, No. 241, 786.

1900; Dec. 22: Paris. Agreement. France/Great Britain. Report of the Commissioners establishing Boundary in Thalweg. Hertslet, Africa, No. 245, 799. 


\section{Ocpara}

1906; Oct. 19 : Paris. Agreement. France/Great Britain. Annex I, Arts. 16-17: Thalweg Boundary. Hertslet, Africa, No. 258, 853.

OKAVANGO. See KUBANGO.

OLD CALABAR. See CROSS.

OLIPHANTS; Affluent of River Limpopo. See LIMPOPO.

\section{ORANGE.}

1890; July 1: Berlin. Agreement. Germany/Great Britain. Art. III, sect. 1: Demarcation of Boundary along Northern Bank. Hertslet, Africa, No. 270, 899-900; Hertslet, COM. TR., Vol. 18, 458-59.

PAMA; Tributary to the River Ubangi.

See also: CONGO. 1885; Feb. 26: Berlin. General Act of the Congress. Art. II: Universal Freedom of Navigation. Chap. IV, Arts. 13-25: Act regulating Navigation. Art. VIII: Right of Surveillance vested in the International Navigation Commission. Hertslet, Africa, No. 128, 472, 474-481.

1908; Apr. 18: Berlin. Convention. France/Germany. Mutual Freedom of Navigation \& Commerce. Am. Jour. Int. Law, VI, Suppl., 105; Hertslet, Africa, No. 379, 1215-1222 ; Martens, NRG, Ser. 3, I, 612.

1911; Nov. 4: Berlin. Convention. France/Germany. Reciprocal Enjoyment of Navigation. Martens, NRG, Ser. 3, V, 643, 657658.

PIBOR; Afluent of the River Sobat.

1902; May 15: Adis Ababa. Treaty. Ethiopia/Great Britain. Art.

I: Demarcation of Boundary. Hertslet, Africa, No. 100, 431.

PUNGWE, Including Affluents MOMBEZI \& RUERA.

1890; Nov. 14: London. Agreement. Great Britain \& Portugal.

Arts. I, II: Freedom of Navigation, including the Unrestricted Use of Landways along Innavigable Sections. Hertslet, Africa, No. 309, 1014; Hertslet, COM. TR., Vol. 18, 1051; Martens, NRG, Ser. 2, XVI, 942; XVIII, 160.

1891; June 11: Lisbon. Treaty. Great Britain/Portugal. Art. XII : Recognizing Universal Freedom of Navigation. Hertslet, Africa, No. 310, 1022 ; Hertslet, COM. TR., Vol. 19, 777, 781. 
1912; July 22/Aug. 9: Lisbon. Agreement. Great Britain \& Portugal. Establishing International Boundary in Thalweg of the Rivers Mombezi, Pungwe, \& Ruera, respectively. GB. Treaty Series, (1912), No. 21.

\section{RAFIN DONGA.}

1913; March 11: London. Agreement. Germany/Great Britain. Sect. I, Art. 9 : Thalweg Boundary. Art. 29 : Equal Enjoyment of Navigation \& Fishing. GB. Treaty Series, (1913), No. 13.

\section{RAHAD.}

1891; April 15: Rome. Agreement. Great Britain/Italy. Art. II: Demarcation of Fluvial Boundary. Hertslet, Africa, No. 289, 949; Hertslet, COM. TR., Vol. 19, 688.

\section{ROVUMA.}

1886; Dec. 3/4: Zanzibar. Agreement. Germany, Great Britain, Zanzibar. Art. I: Defining Territorial Limits; Establishing Boundary along Right (Southern) Bank of the Rovuma. Hertslet, Africa, No. 41, 304.

1886; Dec. 30 : Lisbon. Agreement. Germany/Portugal. Art. II: Thalweg Boundary. Hertslet, Africa, No. 216, 704.

1890 ; July 1: Berlin. Agreement. Germany/Great Britain. Art. I, sect. 2: Demarcation Boundary. Hertslet, Africa, No. 20, 899900 ; Hertslet, COM. TR., Vol. 18, 458-59.

1891; June 11: Lisbon. Treaty. Great Britain/Portugal. Art. I, sec. 1: Establishing Boundary of British \& Portuguese Spheres of Influence. Hertslet, Africa, No. 310, 1022; Hertslet, COM. TR., Vol. 19, 777-780.

1894; Aug. 30/Sept. 1: Lisbon. Agreement. Germany \& Portugal. Thalweg Boundary. Hertslet, Africa, No. 217, 706.

\section{RUDOLPH, or RUDOLF, LAKE.}

1907; Dec. 6: Adis Ababa. Agreement. Ethiopia \& Great Britain. Demarcation of Boundary-Line in North-westerly Direction across the Lake. Hertslet, Africa, No. 103, 445.

\section{RUERA. See PUNGWE.}

RUO; Tributary to River Shire.

1891; June 11: Lisbon. Treaty. Great Britain/Portugal. Art. I, sect. 1: Establishing Respective Spheres. Hertslet, Africa, No. 310, 1022; Hertslet, COM. TR., Vol. 19, 777-780. 


\section{Ruo}

1893; May 31/June 5: London. Agreement. Great Britain \& Portugal. Art. I: Boundary. Hertslet, Africa, No. 311, 102729.

RUSIZI; or RUSSISI

See also: CONGO.

1885; Feb. 26: Berlin. General Act of the Congress. Art. II: Universal Freedom of Navigation. Chap. IV, Arts. 13-25: Act regulating Navigation. Art. VIII : Right of Surveillance vested in the International Navigation Commission. Hertslet, Africa, No. 128, 472, 474-481.

SABI; or SAVE: Including Affluents Crocodile \& Komati.

1890; Aug. 20: London. Treaty. Great Britain/Portugal. Establishing Freedom of Navigation. Martens, NRG, Ser. 2, XVI, 929.

1891; June 11 : Lisbon. Treaty. Great Britain/Portugal. Art. XII: Universal Freedom of Navigation for Transport of Persons \& Merchandise. Hertslet, Africa, No. 310, 1022; Hertslet, COM. TR., Vol. 19, 777-780.

SACCHI; or KIBISH.

1907; Dec. 6: Adis Ababa. Agreement. Ethiopia \& Great Britain. Thalweg Boundary. Hertslet, Africa, No. 103, 445.

SANGA

See also: CONGO.

1885; Feb. 26 : Berlin. General Act of the Congress. Art. II: Universal Freedom of Navigation. Chap. IV, Arts. 13-25: Act regulating Navigation. Art. VIII: Right of Surveillance vested in the International Navigation Commission. Hertslet, Africa, No. 128, 472, 474-481.

1908; Apr. 18: Berlin. Convention. France/Germany. Art. II: Mutual Freedom of Navigation \& Commerce in conformity with Stipulations of Arts. 26-33 of the General Act of Berlin. Am. Jour. Int. Law., VI, Suppl., 105; Hertslet, Africa, No. 379, 1215-1222; Martens, NRG, Ser. 3, I, 612.

1911; Nov. 4: Berlin. Convention. France/Germany. Art. 10: Reciprocal Enjoyment of Navigation. Martens, NRG, Ser. 3, V, 657. (Commentary: GB. Dipl. \& Consular Reports, French Congo, (1914), pg. 3.)

1912; Sept. 28: Paris. Convention. France/Germany. Navigation Regulations. Martens, NRG, Ser. 3, VII, 135.

SEMLIKI; or ISANGO.

1906; May 9: London. Agreement. Great Britain/Independent 
State of the Congo. Art. III: Forbidding Construction of any Works diminishing the Customary Flow of the River. Hertslet, Africa, No. 165, 584-585.

SETIT.

1902; May 15: Adis Ababa. Treaty. Ethiopia, Great Britain, Italy. Annex, Art. I: Thalweg constitutes Boundary to confluence with the River Maieteb. Hertslet, Africa, No. 100, 433.

\section{SHARI; or CHARI.}

1893; Nov. 15: Berlin. Agreement. Germany/Great Britain. Art. IV : Demarcation of Fluvial Boundary. Art. VI: Freedom of Navigation Recognized. Hertslet, Africa, pg. 915; Hertslet, COM. TR., Vol. 19, 254-55.

1894; March 15: Berlin. Convention. France/Germany. Art. III: Mutual Agreement to observe the Stipulations governing Freedom of Navigation embodied in Arts. 26-33 of the Congress of Berlin; Feb. 26, 1885. Am. Jour. Int. Law, VI, Suppl., 97; Martens, NRG, Ser. 3, I, 603.

1908; Apr 18: Berlin. Convention. France/Germany. Art. II: Renewing Art. III of Treaty of March 15, 1894, providing for Mutual Enjoyment of Fluvial Navigation \& Commerce. Am. Jour. Int. Law, VI, Suppl., 105 ; Hertslet, Africa, No. 379, 12151222 ; Martens, NRG, Ser. 3, I, 612.

1911; Nov. 4: Berlin. Convention. France/Germany. Art. 10: Reciprocal Freedom of Navigation. Martens, NRG, Ser. 3, V, 657-58.

SHAVOE; or DCHAWE; Affluent of the River Volta.

1890; July 1: Berlin. Agreement. Germany/Great Britain. Art. IV, sec. 1: Adopted as Boundary between the Gold Coast \& German Togoland. Hertslet, Africa, No. 270, 899-900, 903; Hertslet, COM. TR., Vol. 18, 458-459.

\section{SHIRE}

1890; Aug. 20: London. Convention. Great Britain \& Portugal. Free Navigation for Merchant Vessels of All Nations. Martens, NRG, Ser. 2, XVI, 929. (Commentary: Correspondence between Great Britain \& Portugal during the years 1876 \& 1877 concerning navigation of the River Shiré.) GB. BFSP, Vol. 68,1345 .)

1890 ; Nov. 14 : London. Agreement. Great Britain/Portugal. Arts. 


\section{Shire}

I-II: Freedom of Navigation, including the Unrestricted Use of Landways along Innavigable Sections of the River. Hertslet, Africa, No. 309, 1014; Hertslet, COM. TR., Vol. 18, 1051; Martens, NRG, Ser. II, XVI, 942; XVIII, 160.

1890; Nov. 18: Lisbon. Law (Royal Decree). Government of Portugal. Art. I: "The Navigation of the Rivers Zambesi and Shiré, in so far as they are under the sovereignty, protectorate, or influence of Portugal, is free to the vessels of All Nations, in accordance with the principles which the Governments of France and Great Britain agreed to establish on the Niger, in virtue of the General Act of Berlin in 1885." GB. BFSP, Vol. 82, 338; Hertslet, Africa, No. 309, 1015-16; Hertslet, COM. TR., Vol. 18, 1052.

1891; June 11: Lisbon. Treaty. Great Britain/Portugal. Art. XII: Establishing Freedom of Navigation for Vessels of All Nations throughout the Navigable Course, including Affluents \& Outlets. Hertslet, Africa, No. 310, 1022; Hertslet, COM. TR., Vol. 19, 777, 781.

1892 ; May 18: Lisbon. Law (Royal Decree). Government of Portugal. Regulating Navigation of the Shiré. GB. BFSP, Vol. 87, 1108; Hertslet, COM. TR., Vol. 21, 1129.

1893 ; May 31/June 5 : London. Agreement. Great Britain \& Portugal. Art. I: Fluvial Boundary Line. Hertslet, Africa, No. 311, 1027-29.

\section{SHIRWA LAKE. See CHILWA LAKE.}

\section{SOBAT}

1902; May 15: Adis Ababa. Treaty. Ethiopia, Great Britain, Italy. Art. III: Forbidding the Construction of Works impeding or diminishing the Customary Flow of the River into the Nile. Hertslet, Africa, No. 100, 432-433.

SOKOTO

See also: NIGER. 1885; Feb. 26 : Berlin. General Act of the Congress. Chap. V, Arts. 26-33: Act regulating the Navigation of the Niger System. Hertslet, Africa, No. 128, 481-484.

1893; Nov. 15: Berlin. Agreement. Germany/Great Britain. Art.

VI: Mutual Freedom of Navigation Recognized. Hertslet, $\Lambda$ frica, pg. 915 ; Hertslet, COM. TR., Vol. 19, 253-54. 
sect. 2: Thalweg Boundary. Hertslet, Africa, No. 270, 899-900; Hertslet, COM. TR., Vol. 18, 459.

1901; Feb. 23: Berlin. Agreement. Germany/Great Britain. Sect. I: Thalweg Boundary. Hertslet, Africa, No. 279, 925-26.

\section{STEFANIE LAKE}

1907; Dec. 6: Adis Ababa. Agreement. Ethiopia, Great Britain, Italy. Demarcation of International Boundary. Hertslet, Africa, No. 103, 445.

\section{TANA}

1886; Oct. 29/Nov. 1: London. Agreement. Germany/Great Britain. Art. III: Thalweg to constitute Boundary from Sea to the Equator. Hertslet, Africa (1896 edit.), pg. 616.

1886; Dec. 3/4: Zanzibar. Agreement. Germany, Great Britain, Zanzibar. Art. I: Defining Respective Spheres of Influence. Art. II: Thalweg of the River Tana \& its Affluents to mark International Boundary from Equator to the Sea. Hertslet, Africa, No. 41, 304-305.

1885 ; Feb. 26 : Berlin. General Act of the Congress. Art. II: Universal Freedom of Navigation. Art. VIII : Right of Surveillance vested in the International Navigation Commission. Art. 1325 of Chap. IV : Act regulating Navigation. Hertslet, Africa, No. 128, 472, 474-481.

1889 ; Aug. 10: Berlin. Agreement. Germany/Great Britain. Art. VIII: Recognizing Free Transit of Vessels. Hertslet, COM. TR., Vol. 18, 459.

1890; July 1: Berlin. Agreement. Germany/Great Britain. Art. VIII: Universal Freedom of Navigation; Expressly recognized concerning Vessels of the Contracting Powers, forbidding Transit Dues. Hertslet, Africa, No. 270, 900-902; Hertslet, COM. TR., Vol. 18, 459.

1894; May 12: Brussels. Agreement. Great Britain \& H. M. King Leopold II, Sovereign of the Independent State of the Congo. Art. I, sec. 6 : Designating Boundary. Hertslet, Africa, No. 163, 578-583.

1906; May 9: London. Agreement. Great Britain/Independent State of the Congo. Modifying Agreement of Brussels, May 12, 1894, concerning Boundaries in Africa. Hertslet, Africa, No. 165, 584-86. (Commentary: Consult, also, the Conventions 


\section{Tanganyika Lake}

of April 14, 1893; November 15, 1893 ; March 19, 1906 ; \& July 18, 1906. Hertslet, Africa, pgs. 910, 913, 937, 942.)

TENDO; or TANOE; LAGOON.

1889; Aug. 10: Paris. Agreement. France/Great Britain. Art. III, sect. 2: Establishing Freedom of Navigation for Vessels of Both Nations. Hertslet, Africa, No. 226, 731; Hertslet, COM. TR., Vol. 18, 420-421.

TENDO; or TANOE; RIVER.

1889; Aug. 10: Paris. Agreement. France/Great Britain. Art. III, sect. 2: Establishing Freedom of Navigation for Vessels of Both Nations. Hertslet, Africa, No. 226, 731; Hertslet, COM. TR., Vol. 18, 420.

1893; July 12: Paris. Agreement. France/Great Britain. Arts. 2, 3, 4: Demarcation of Fluvial Boundary. Art. 5: Mutual Enjoyment of Riverain Fisheries. Hertslet, Africa, No. 236, 756; Hertslet, COM. TR., Vol. 19, 228.

1907; June 16/25: London. Agreement. France/Great Britain. Regulating the Dredging of Gold in the Neutral Waters of the River Tendo. GB. BFSP, Vol. 100, 498; Hertslet, Africa, No. 259, 861; Martens, NRG, Ser. III, VI, 790.

\section{TIEL}

1906; March 19: London. Treaty. Germany/Great Britain. Art. II: Demarcation of Fluvial Boundary. Freedom of Navigation \& Fishing to be enjoyed equally by Both Nations. Hertslet, Africa, No. 284, 937-38; Martens, NRG, Ser. III, II, 691.

\section{TONKE; or OKAVANGO. See KUBANGO.}

\section{TSANA LAKE}

1902; May 15: Adis Ababa. Treaty. Ethiopia, Great Britain, Italy. Art. III: Forbidding the Construction of Works impeding or diminishing the Customary Flow of Water from the Lake into the Nile. Hertslet, Africa, No. 100, 432-33.

TUMBA; or MATUMBA LAKE

See also: CONGO. 1885; Feb. 26 : Berlin. General Act of the Congress. Art. II: Universal Freedom of Navigation. Chap. IV, Arts. 13-25: Act regulating Navigation. Art. VIII : Right of Surveillance vested in the International Navigation Commission. Hertslet, Africa, No. 128, 472, 474-481. 
1885; Feb. 26 : Berlin. General Act of the Congress. Art. II: Universal Freedom of Navigation. Chap. IV, Arts. 13-25: Act regulating Navigation. Art. VIII : Right of Surveillance vested in the International Navigation Commission. Hertslet, Africa, No. 128, 472, 474-481.

1908; Apr. 18: Berlin. Convention. France/Germany. Art. II: Mutual Freedom of Navigation \& Commerce in conformity with the Dispositions of Arts. 26-33 of the General Act of Berlin. Am. Jour. Int. Law, VI, Suppl., 105; Hertslet, Africa, No. 379, 1215-1222; Martens, NRG, Ser. III, I, 612.

1911; Nov. 4: Berlin. Convention. France/Germany. Art. 10: Reciprocal Enjoyment of Navigation. Martens, NRG, ser. 3, V, 657. (Commentary: GB. Dipl. \& Consular Reports, French Congo, (1914), pg. 3.)

1912 ; Sept. 28: Paris. Convention. France/Germany. Navigation Regulations. Martens, NRG, Ser. III, VII, 135.

UGALA; or MALAGARAZI; or UKUMBI See also: CONGO. 1885; Feb. 26 ; Berlin. General Act of the Congress. Art. II: Universal Freedom of Navigation. Chap. IV, Arts. 13-25: Act regulating Navigation. Art. VIII: Right of Surveillance vested in the International Navigation Commission. Hertslet, Africa, No. 128, 472, 474-481.

ULAFU; or ULDAFU.

1913; Sept. 4: London. Agreement. France/Great Britain. Art. II: Thalweg Boundary. GB. Treaty Series, (1913), No. 19.

\section{UTAMBONI; or OUTEMBONI}

1900; June 27: Paris. Treaty. France \& Spain. Art. V : Accorded to French \& Spanish Vessels Reciprocal Freedom of Access into the Territorial Waters of the Other Power; Recognized Equal Enjoyment of the Fluvial Fisheries. Hertslet, Africa, No. 359, 1166.

\section{VICTORIA NYANZA}

1886; Dec. 3/4: Zanzibar. Agreement. Germany, Great Britain, Zanzibar. Art. III: Designating the Precise Point at which the International Boundary shall strike the Lake-Shore. Hertslet, Africa, No. 41, 304-305.

1890; July 5: Berlin. Agreement. Germany/Great Britain. Art. 


\section{Victoria Nyanza}

I, sect. 1: Demarcation of Boundary on the Lake. Hertslet,

Africa, No. 270, 902; Hertslet, COM, TR., Vol. 18, 459.

1904 ; July 15 : London. Law (Order of the Foreign Office Secretary).

British Government. Designating certain Islands within the

Lake to be under British Dominion, in accordance with the

East African Order in Council of 1902. Hertslet, Africa, No.

$82,386$.

\section{VOLTA}

1887; Dec. (no. date): Agreement. Joint Recommendations of the British \& German Commissioners adopted by the British Government, March 12th, \& by the German Government, March 14th, 1888. Establishing Fluvial Boundary between the Respective Territories. Hertslet, Africa, No. 268, 890-91.

1890; July 1: Berlin. Agreement. Germany/Great Britain. Art. IV : Demarcation of International Boundary. Hertslet, Africa, No. 270, 900-903; Hertslet, COM. TR., Vol. 18, 458-459.

\section{WOM}

1913; March 11: London. Agreement. Germany/Great Britain. Sect. I, Art. 9 : Thalweg Boundary. Art. 29 : Recognizing Equal Rights of Navigation \& Fishing. GB. Treaty Series, (1913), No. 13.

YEDERAM; or YADSERAM

1906; March 19: London. Treaty. Germany/Great Britain. Art. IV : Demarcation of Boundary; Recognizing Equal Enjoyment of Navigation \& Fishing by Inhabitants of Both Countries. Hertslet, Africa, No. 284, 937-38; Martens, NRG, Ser. III, II, 691.

\section{ZAMBESI}

1884; Dec. 18: Berlin. Announcement delivered before the West African Conference by the Portuguese Delegate that the Government of Portugal had introduced, voluntarily, the System of Free Navigation upon the Zambesi System. Hertslet, COM. TR., Vol. 17, 1357.

1885; Feb. 26: Berlin. General Act of the Congress of Nations: Austria-Hungary, Belgium, Denmark, France, Germany, Great Britain, Italy, Netherlands, Norway, Portugal, Russia, Spain, Sweden, United States of America. Clercq, RTF, XIV, 447, 454; GB. BFSP, Vol. 76, 4; Hertslet, Africa, No. 128, 472, 474- 
481; Hertslet, COM. TR., Vol. 17, 65, 68; Martens, NRG, Ser. 2, X, 414. Chap. I, Art. I, sect. 3; Art. II: Freedom of Navigation accorded the Vessels of the Contracting Powers, exclusively. (Commentary: Correspondence between Great Britain \& Portugal concerning the navigation of the River Zambesi: 1. During the years $1876 \& 1877$, - GB. BFSP, Vol. 68, 1345; 2. During the years 1882, 1883, \& 1884,-GB. BFSP, Vol. 75, 1272; 3. During the years $1887 \& 1888$, discussing especially the refusal of the Portuguese Authorities at Mozambique to permit foreign vessels to participate in the navigation of the River Zambesi, the presumption of the Portuguese Government being contested, and not admitted, by the British,- - GB. BFSP, Vol. 79, 1062.)

1890; July 1: Berlin. Agreement. Germany/Great Britain. Art. III, sect. 2 : Demarcation of Fluvial Boundary. Hertslet, Africa, No. 270, 900-903; Hertslet, COM. TR., Vol. 18, 459.

1890; Aug. 20: London. Convention. Great Britain \& Portugal. Art. XII: Free Navigation accorded to Merchant Vessels of All Nations. Martens, NRG, Ser. 2, XVI, 929.

1890; Nov. 14: London. Agreement. Great Britain/Portugal. Arts. I-II : Freedom of Navigation, including the Unrestricted Use of Landways along Innavigable Sections of the Course. Hertslet, Africa, No. 309, 1014; Hertslet, COM. TR., Vol. 18, 1051; Martens, NRG, Ser. II, XVI, 942; XVIII, 160.

1890; Nov. 18: Lisbon. Law (Royal Decree). Portuguese Government. Art. I: "The Navigation of the Rivers Zambesi and Shiré, in so far as they are under the sovereignty, protectorate, or influence of Portugal, is free to the vessels of All $\mathrm{Na}$ tions. . .." GB. BFSP, Vol. 82, 338; Hertslet, Africa, No. 309, 1015-16; Hertslet, COM. TR., Vol. 18, 1052.

1891; June 11: Lisbon. Treaty. Great Britain/Portugal. Arts. 1113: Establishing Freedom of Navigation for Vessels of All Nations throughout the Navigable Course, including Affluents and Outlets. Hertslet, Africa, No. 310, 1022; Hertslet, COM. TR., Vol. 19, 777-781.

1892; May 18: Lisbon. Law (Royal Decree). Government of Portugal. Regulating Navigation upon the Zambesi. GB. BFSP, Vol. 87, 1108; Hertslet, COM. TR., Vol. 21, 1129.

1893; May 31/June 5: London. Agreement. Great Britain \& Portugal. Art. I: Fluvial Boundary; Demarcation of Respective Spheres of Influence. Hertslet, Africa, No. 311, 1027-29. 
AMUR

\section{ASIA, \\ AUSTRAIIA, \& \\ ISLANDS OF THE SEA}

1858; May 16/28: Aigun. Treaty. China/Russia. Art. I: Recipro. cal Freedom of Navigation; Participation by Foreign Vessels explicitly Prohibited. Hertslet, China, No. 80, 454. (Commentary: H. B. MORSE, The International Relations of the Chinese Empire, pg. 477.)

1860 ; Nov. 2/14: Peking. Treaty. China/Russia. Governing Freedom of Navigation \& Commerce. Hertslet, China, No. 82, 462. 1881; Feb. 12/24: St. Petersburg. Treaty. China/Russia. Art. 18: Confirming the Reciprocal Rights of Navigation as embodied in Art. I of 'Treaty of Aigun, May 16/26, 1858. Hertslet, China, No. 85, 490.

1905; Dec. 22: Aigun (Aihun). Additional Agreement. China/ Japan. Establishing Aigun as a Treaty Port; Access granted Vessels by River Amur. Hertslet, China, No. 67, 393.

1911; Dec. 7/20: Tsitsikar. Treaty. China/Russia. Demarcation Fluvial Boundary. GB. BFSP, Vol. 104, 883.

ARGUN

See also: AMUR.

1911; Dec. 7/20: Tsitsikar. Treaty. China/Russia. Demarcation of Fluvial Boundary. GB. BFSP, Vol. 104, 883.

1912; Oct. 21/Nov. 3: Urga. Convention. Mongolia (China) \& Russia. Art. XII: Navigation available for Russian Subjects \& Russian Vessels. Martens, NRG, Ser. III, VII, 17.

\section{BORNEO}

Waterways of the Island of Borneo, including the River Seboekoe (Seboukou, or Sibuku) and some 15 minor streams.

1891; June 20: London. Convention. Great Britain \& the Netherlands. Art. VI: "The navigation of all rivers flowing into the sea between Batoe-Tinagat and the River Siboekoe shall be free, except for the transportation of war material, and no transport duties shall be levied on other goods passing up those rivers." GB. BFSP, Vol. 83, 41; Hertslet, COM. TR., Vol. $19,755-56$.

(NOTE :

(A controversy concerning this area continued for many years be- 
tween the British North Borneo Company and the Netherlands; the British claiming the River Soboekoe for the southern boundary, while the Netherlands considered Cape Batoe-Tinagat the appropriate boundary. The British Company of North Borneo raised its flag on this river, September 7, 1883, in reply to the erection of a boundary obelisk by the Dutch Government upon Cape Batoe-Tinagat, and an English vessel made an extensive survey up the River Soboekoe, which accommodates vessels drawing 21 feet. V. de Saint-Martin, Geographie Universelle, (Paris, 1892).)

1915 ; Sept. 28: London. Treaty. Great Britain/Netherlands. Demarcation of Fluvial International Boundaries; Compromising the Rival Claims. GB. Treaty Series, (1915), No. 12.

CAMBODIA LAKE. See GRAND LAKE OF CAMBODIA.

CANTON; or CHU-KIANG; or PEARL See also: WEST RIVER. 1842; Aug. 29: Nanking. Treaty. China/Great Britain. Art. II: Preliminary Provisions governing Foreign Access to Port of Canton; Privilege of Residence accorded British Subjects for Purposes of Trade. Hertslet, China, No. 1, pg. 3.

1847; April 6: Convention. China/Great Britain. Granting Entry to British Vessels at Termination of Two-year Period. Hertslet, China, No. 5, 18.

1858; June 18: Tientsin. Treaty. China/United States. Art. XIV : Navigation of the River granted American Vessels between the Port of Canton \& the Sea. Hertslet, China, No. 94, (Commentary: C. J. H. HAYES, History of Modern Europe, II, 562563.)

1858; June 26: Tientsin. Treaty. China/Great Britain. Art. I: Renewing \& Confirming Dispositions of Art. II of Treaty of Nanking, Aug. 29, 1842. Art. 54: Confirming Provisions of Treaty of April 6, 1847. Hertslet, China, No. 6, 18-19.

1861; Sept. 2: Tientsin. Treaty. China/Germany. Art. VI: Free Navigation between Canton \& the Sea. Hertslet, China, No. 56. 1863; July 13: Tientsin. Treaty. China/Denmark. Art. XI: Permitting Navigation by Danish Vessels. Hertslet, China, No. 38. 1863; Oct. 6: Tientsin. Treaty. China/Netherlands. Art. II: Stipulating that Dutch Merchant Vessels may navigate freely between Canton \& the Sea. Hertslet, China, No. 70.

1865 ; Nov. 2 : Peking. Treaty. Belgium/China. Art. XI: Securing for Belgian Vessels enjoyment of Fluvial Navigation. Hertslet, China, No. 34, 226. 


\section{Canton}

1869; Sept. 2: Peking. Treaty. Austria/China. Art. VIII: Freedom of Navigation between Canton \& the Sea granted Austrian Vessels. Hertslet, China, No. 33.

1880; March 31: Additional Agreement. China/Germany. Regulating Participation by German Vessels in Commercial Navigation. Hertslet, China, No. 57.

1898; July 28: Peking. Law. Universal Freedom of Navigation. See CHINESE INLAND WATERWAYS.

CAO-BANG

See also: WEST.

1887; June 26 : Peking. Treaty. China/France. Art. VI: Governing Navigation by French Vessels within Chinese Dominions. Hertslet, China, No. 48.

1898; July 28: Peking. Law. Universal Freedom of Navigation. See CHINESE INLAND WATERWAYS.

\section{CASPIAN SEA}

1813; Oct. 12: Gulistan. Treaty of Perpetual Peace. Persia \& Russia. Art. V: Freedom of Navigation, including Enjoyment of Coasting Trade, by the Merchant Vessels of Both Nations recognized; Russia obtaining the Sole Right of Maintaining War-Vessels upon the Sea. Cussy/Hauterive, RTC, V, part 2, 109. (Commentary; BONFILS, Droit Int., sec. 495, pg. 308; HEFFTER, Droit Int. Publ., Sec. 77, Note 2; RIVIER, Droit des Gens. I, 144, 230.)

1828; Feb. 22: Turkmanchai. Treaty. Persia/Russia. Art. VIII:

Reciprocal Freedom of Navigation, including the Privilege of Coasting Trade \& the Landing of Merchandise, for Merchant Vessels of Both Nations. Sole Right of Russia to maintain War-Vessels on the Caspian re-affirmed. Cussy/Hauterive, RTC, V, part 2, 112. (Commentary: MOORE, ILD, I, 669; OPPENHEIM, Int. Law, I, 231. PHILLIMORE, Int. Law, I, sec. 205.)

1869; Nov. 24: St. Petersburg. Law. (Decision of the Imperial Council.) Government of Russia. Prohibiting the Establishment of Companies for the Navigation of the Caspian Sea, and to Foreigners even the Acquisition or Possession of Stock Shares in Navigation Undertakings operating upon the Sea. GB. BFSP, Vol. 63, 925; Hertslet, COM. TR., XIII, 744.

CHIEN-TANG. See TSIEN-TANG.

CHINESE INLAND WATERWAYS

Pursuant to the Imperial Regulations issued at Peking by the 
Chinese Inland Waterways

Tsung-li Yamên on July 28th, 1898, the steam vessels of all nations enjoy equal freedom with native vessels upon the Inland Waterways of China -

\section{The Rivers}

\section{Notably}

Canton, or Chu-kiang, or Pearl;

Cao-Bang, A tributary of Tso-kiang;

Han-kiang;

Hoang-ho, or Hwang-ho;

Hun-ho, A tributary of the Liao-ho;

Hun-ho, A tributary of the Pai-ho;

Hwai-ho;

Liao-ho;

Lwan-ho;

Min-kiang;

Pai-ho, or Pei-ho;

Pei-kiang;

Song-ki-kong, A tributary of the Tso-kiang;

Tsien-Tang, or Chien-Tang;

Tso-kiang, An affluent of the West River;

Tumen;

Tung-kiang;

West, or Si-kiang;

Whangpoo, or Huangpoo, or Woosung;

Wu-kiang;

Yalu;

Yang-tsze-kiang;

Yung-kiang.

The Lakes

Po-Yang-Lu;

Tung-Ting-lu and

The Grand, or Imperial Canal.

1898; July 28: Peking. Law. Government of China. Arts. I-IX.

Regulations issued by the Tsung-li Yamên to the Chinese Superintendents of Trade opening the navigable, inland waterways of the Empire to merehant vessels, if duly registered, whether native, or under flags of foreign nations. Hertslet, China, No. 138, 721-722.

1898 ; September (no date): Peking. Law. Government of China. Supplementary Regulations amplifying the Law of July 28, 1898, governing the Navigation of the Inland Waterways of the Empire. Hertslet, China, No. 140, 726-727. 
Chinese Inland Waterways

1902 ; Sept. 5: Shanghai. Treaty. China/Great Britain. Confirming the Regulations governing Inland Navigation as embodied in the Law of July 28, 1898, \& September, 1898. GB. BFSP, Vol. 95, 54; Hertslet, China, No. 28, 171.

1903; Oct. 8: Shanghai. Treaty. China/United States. Art. IV : Abolishing the Li-kin Barriers on All Roadways, Railways, \& Waterways throughout the Empire. Art. XII: Confirming the Stipulations of the Law of July 28th, 1898, \& September, 1898, establishing and governing Universal Freedom of Navigation on Inland Waterways within the Imperial Dominions. Hertslet, China, No. 100; Malloy, UST, 261-267.

\section{CHU-KIANG; or PEARL. See CANTON.}

EUPHRATES See also: SHAT-EL-ARAB. 1834; Dec. 29: Constantinople. Law (Firman). Turkish Government. Announcing that Permission is granted British Vessels to participate in Fluvial Navigation \& Proclaiming Appropriate Protective Measures. Hertslet, COM. TR, XIII, 838-39.

(NOTE:

(Order despatched by the Grand Vizir, Raouf, September 13, 1842, to the Pasha of Aleppo permitting the crews of British vessels navigating the River Euphrates to land and to remain ashore, temporarily. Hertslet, COM. TR., XIII, 839.)

(NOTE:

(Despatch from the Grand Vizir, Raouf, to the Pasha of Bagdad, April 2, 1846, concerning the liberty of navigation accorded British ressels upon the Rivers Tigris and Euphrates. Hertslet, COM. TR., XIII, 840.)

1861; Jan. 15: Constantinople. Law (Viziral Order). Turkish Government. Despatch to the Governor-General of Bagdad concerning the Navigation of British Vessels upon the Tigris \& Euphrates; Identical Duties to those levied on Ottoman Vessels to be imposed. Hertslet, COM. TR., XIII, 845 .

\section{FLY RIVER (ISLAND OF NEW GUINEA)}

1895; May 16: The Hague. Treaty. Great Britain \& The Netherlands. Designating the Boundaries between the Possessions of Great Britain \& The Netherlands in the Island of New Guinea. Art. V: "The navigation of the Fly River is free to the subjects of both Contracting Powers,- excepting as regards the carriage of war-like stores, - and no duty shall be imposed on other goods conveyed by that river." Hertslet, COM. TR., Vol. 20, 813. 
GRAND; or IMPERIAL CANAL.

See also: CHINESE INLAND WATERWAYS.

1895; Apr. 17 : Shimonoseki. Treaty. China/Japan. Art. VI, sect.

2: Freedom of Navigation upon the Canal granted Japanese Merchant Vessels. Hertslet, China, No. 62.

1898; July 28: Peking. Law. Government of China. Universal Freedom of Navigation. Hertslet, China, No. 138.

\section{GRAND LAKE OF CAMBODIA (or SIAM)}

1870; July 14: Saigon. Treaty. France/Siam. Art. I: Relinquishment by the Kings of Siam \& Cambodia of Exclusive Jurisdiction over the Lake; French Fishing Vessels to be exempt from All Imposts. GB. BFSP, Vol. 70, 291; Martens, NRG, Ser. II, XII, 630 .

HAN-KIANG. See also: CHINESE INLAND WATERWAYS. 1858; June 18: Tientsin. Treaty. China/United States. Art. 14: Navigation of the River granted American Vessels between the Port of Chao-Chau \& the Sea. Hertslet, China, No. 94. 1898; July 28: Peking. Law. Chinese Government. Universal Freedom of Navigation. Hertslet, China, No. 138.

HOANG-HO; or HWANG-HO.

See also: CHINESE INLAND WATERWAYS. 1898; July 28: Peking. Law. Chinese Government. Universal Freedom of Navigation. Hertslet, China, No. 138.

1904; (no precise date): Peking. Law. Chinese Imperial Decree creating Tsi-nan (Chinan) a Treaty Port. Hertslet, China, No. $211,1211$.

HUANGPOO; or WOOSUNG. See WHANGPOO.

HUN-HO (Liao-ho System).

See also: CHINESE INLAND WATERWAYS.

1898; July 28: Peking. Law. Chinese Government. Universal Freedom of Navigation. Hertslet, China, No. 138.

1903; Oct. 8: Shanghai. Treaty. China/Japan. Art. 10: Mukden established as Treaty Port; Access granted to Japanese Vessels in conformity with Law of July 28, 1898. Hertslet, China, No. 66,387 .

1903; Oct. 8: Shanghai. Treaty. China/United States. Art. 12: China opens the Port of Mukden to Commerce \& Navigation in 


\section{Hun-ho}

fulfillment of the Imperial Law of July 28, 1898. Hertslet, China, No. 100, 574; Malloy, UST, 261, 267.

HUN-HO (Pai-ho System).

See also: CHINESE INLAND WATERWAYS. 1896; July 21: Peking. Treaty. China/Japan. Art. V: Permitting Japanese Merchant Vessels to ascend the River to Ta-Tung. Hertslet, China, No. 64

1898; July 28: Peking. Law. Chinese Government. Universal Freedom of Navigation. Hertslet, China, No. 138.

HWAI-HO. See also: CHINESE INLAND WATERWAYS. 1898; July 28: Peking. Law. Chinese Government. Universal Freedom of Navigation. Hertslet, China, No. 138.

\section{IMPERIAL CANAL. See GRAND CANAL.}

\section{INDUS}

1843; March 13: Law. Notification issued by the Governor-General of the British Government in India. Freedom of Navigation for the Vessels of All Nations Instituted. Martens, NRG, Ser. I, V, 125 .

\section{IRRAWADDY}

1894; March 1: London. Convention. China/Great Britain. Establishing Reciprocal Freedom of Fluvial Navigation. (Art. XII.) Hertslet, China, No. 20, 107; Hertslet, COM. TR., Vol. 19, 163, 169.

1896; Jan. 15: Agreement. France/Great Britain. Art. IV: Concerning Enjoyment of Navigation. Hertslet, China, No. 101.

1897; Feb. 4: Peking. Agreement. China/Great Britain. Art. XII: Regulating Fluvial Navigation. Hertslet, China, No. 22, 117.

\section{IRTISH}

1864; Sept. 25/Oct. 7: Tchuguchak. Agreement. China \& Russia. Art. I: Establishing Boundary in Thalweg. Hertslet, China, No. 83.

1912; Oct. 21/Nov. 3: Urga. Convention. Mongolia (China) \& Russia. Art. XII : Navigation freely available for Russian Vessels. Martens, NRG, Ser. III, VII, 17.

\section{KARUN}

1888; Oct. 30: Teheran. Law. Notification by the Persian Government to the Representatives of the Foreign Powers establishing 
Freedom of Navigation: "The Persian Government, with a view to the extension of commerce \& wealth in her provinces \& the progress of agriculture in Khuzistan \& Ahwaz, has ordered that commercial steamers of all nations, without exception, besides sailing vessels which formerly navigated the Karun River, undertake the transport of merchandise . . . from Muhammereh (Mohammera) to the dyke at Ahwaz." GB. BFSP, Vol. 79, 781; Hertslet, COM. TR., Vol. 18, 945. (Commentary: MOORE, ILD, I, 652; STATESMAN'S YEAR BOOK, (1915), 1218.)

ITAH-HO.

See also: CHINESE INLAND WATERWAYS. 1858; June 26: Tientsin. Treaty. China/Great Britain. Art. II: Opening the Port of Newchwang to trade \& navigation with British Vessels. Hertslet, China, No. 6, 23.

1861; Sept. 2: Tientsin. Treaty. China/Germany. Art. VI: Free Navigation between the Inland Treaty Ports \& the Sea. Hertslet, China, No. 56.

1863; July 13: Tientsin. Treaty. China/Denmark. Art. XI: Danish Vessels granted Freedom of Navigation to trade with Port of Newchwang. Hertslet, China, No. 38.

1863; Oct. 6: Tientsin. Treaty. China/Netherlands. Art. II: Granting Dutch Vessels access to the Open River Port. Hertslet, China, No. 70.

1864; Oct. 10: Tientsin. Treaty. China/Spain. Art. V: Permitting Spanish Vessels to frequent the Port of Newchwang. Hertslet, China, No. 91.

1865; Nov. 2: Peking. Treaty. Belgium/China. Art. XI: Freedom of Fluvial Navigation. Hertslet, China, No. 34, 226.

1880; March 31: Additional Agreement. China/Germany. Regulating Navigation on the River. Hertslet, China, No. 57.

1898; July 28: Peking. Law. Chinese Government. Universal Freedom of Navigation. Hertslet, China, No. 138.

1903; Oct. 8: Shanghai. Treaty. China/Japan. Art. 10: Mukden opened as Treaty Port; Access granted to Japanese Vessels in conformity with Law of July 28, 1898. Hertslet, China, No. 66, 387.

1903; Oct. 8: Shanghai. Treaty. China/United States. Art. 12 : Establishing Mukden as Treaty Port and Granting Access to American Vessels. Hertslet, China, No. 100, 574; Malloy, UST, $261,267$.

1905; Dec. 22: Aigun (Aihun). Additional Ağreement. China/ Japan. Art. I: Permitting Trade with certain River-Ports. Hertslet, China, No. 67, 393. 


\section{Lwan-ho}

LWAN-HO. See also: CHINESE INLAND WATERWAYS. 1898; July 28: Peking. Law. Chinese Government. Universal Freedom of Navigation. Hertslet, China, No. 138.

\section{MEKONG}

1884; May. 11: Tientsin. Preliminary Convention. China \& France. Art. III: France secures Enjoyment of Free Traffic along the Mekong Valley. Hertslet, China, No. 44, 294.

1886; April 25: Tientsin. Treaty. China/France. Arts. X, XII : Recognizing Reciprocal Freedom of Navigation; Establishing Regulations governing Customs Examination. Hertslet, China, No. $47,306$.

1895; June 20: Peking. Convention. China/France. Arts. IV, IX: Revising Stipulations of Treaty of Tientsin, April 25, 1886, regulating Imposition of Customs Duties on Goods in Transit. Hertslet, China, No. 53, 325.

MIN-KIANG. See also: CHINESE INLAND WATERWAYS. 1842; Aug. 29 : Nanking. Treaty. China/Great Britain. Art. II:

Preliminary Provisions governing Foreign Access to Port of

Foochow; Privilege of Residence granted British Subjects.

Hertslet, China, No. 1, 3.

1844; Oct. 24: Whampoa. Treaty. China/France. Art. II: French Merchant-Vessels permittted to enter \& participate in Commerce. Hertslet, China, No. 39, 258; Martens, NRG, Ser. 1, VII, 431. 1847; March 20: Canton. Treaty. China/Norway \& Sweden. Art.

III: Access freely granted to Swedish \& Norwegian MerchantVessels. Hertslet, China, No. 93, 527.

1858; June 1/13: Tientsin. Treaty. China/Russia. Art. III: Liberty of Navigation. Hertslet, China, No. 81, 456.

1858; June 18: Tientsin. Treaty. China/United States. Art. 14: Equal Freedom of Access \& Navigation. Hertslet, China, No. $94,540,545$.

1858; June 26: Tientsin. Treaty. China/Great Britain. Arts. 1, 10: Renewing \& Confirming Art. II of Treaty of Nanking, Aug. 29, 1842, permittting Trade \& Navigation. Hertslet, China, No. $6,18$.

1861; Sept. 2: Tientsin. Treaty. China/Germany. Art. VI. Hertslet, China, No. 56, 331, 333.

1863; July 13: Tientsin. Treaty. China/Denmark. Art. XI: Governing the Entry \& Navigation of Danish Merchant Vessels. Hertslet, China, No. 38, 249-251. 
Min-kiang

1863; Oct. 6: Tientsin. Treaty. China/Netherlands. Art. II: Navigation of Dutch Vessels. Hertslet, China, No. 70, 407.

1864; Oct 10: Tientsin. Treaty. China/Spain. Art. V. Hertslet, China, No. 91, 512-13.

1865; Nov. 2 : Peking. Treaty. Belgium/China. Art. XI. Hertslet, China, No. 34, 225.

1866; Oct. 26 : Peking. Treaty. China/Italy. Art. XI. Hertslet, China, No. 60, 354-55.

1869; Sept. 2: Peking. Treaty. Austria-Hungary/China. Art. VIII: Freedom of Access \& Navigation. Hertslet, China, No. $33,215-16$.

1880; March 31: Peking. Additional Agreement. China/Germany. Art. I. Hertslet, China, No. 57, 342.

1898; July 28: Peking. Law. Chinese Government. Universal Freedom of Navigation. Hertslet, China, No. 138.

\section{MONGOLIAN WATERWAYS}

\section{Notably}

The Rivers

Amur;

Argun;

Irtish;

Orkhon;

Selenga ;

Yenisei.

Onon;

1912; Oct. 21/Nov. 3: Urga. Convention. China/Russia. Art. XII: Freedom of Navigation granted to Russian Vessels on All Mongolian Waterways entering Russian Dominions. Martens, NRG, Ser. III, VII, 17.

\section{MURRAY (Australia)}

(NOTE:

(The Murray River System is strictly an Intercolonial Waterway. Until the Act of Confederation, January 1, 1901, the Riparian States, exercising an independent sovereignty, regulated the mutual use of the River by convention. Hazen, Europe since 1815, 532-33.)

1873; April 25: Sydney. Law. Act sanctioned by the Government of New South Wales, providing for the Suspension of the Imposition of Customs Duties on the River Murray. Hertslet, COM. TR., Vol. 17, 679.

1873; May 20/23: Sydney. Melbourne. Convention. New South Wales \& Victoria. Concerning the Imposition of Duties levied 


\section{Murray (Australia)}

on Traffic borne by the River Murray. Hertslet, COM. TR., Vol. 17, 681.

1873; May 27/June 6: Sydney. Adelaide. Convention. New South Wales \& South Australia. Respecting the Levy of Duties upon Commerce transported by the River Murray. Hertslet, COM. TR., Vol. 17, 684.

1873; June 25/July .7: Adelaide. Sydney. Convention. New South Wales \& South Australia. Regulating Importation by the River Murray. Hertslet, COM. TR., Vol. 17, 685.

\section{MUTAN-KIANG}

1905; Dec. 22 : Aigun. Additional Agreement. China/Japan. Art. I: Opening River Ports to International Commerce \& Navigation. Hertslet, China, No. 67, 393.

\section{NONNA}

1905: Dec. 22 : Aigun. Additional Agreement. China/Japan. Art.

I: Permitting Commerce \& Navigation. Hertslet, China, No. $67,393$.

\section{ONON}

1912 ; Oct. 21/Nov. 3 : Urga. Convention. China/Russia. Art. XII: Freedom of Navigation for Russian Vessels established. Martens, NRG, Ser. III, VII, 17.

\section{ORKHON}

1860; Nov. 2/14: Peking. Treaty. China/Russia. Art. V: Providing for Privilege of Navigation \& Trade. Hertslet, China, No. 82,464 .

1912 ; Oct. 21/Nov. 3 : Urga. Convention. China/Russia. Art. I: Opening Navigation to Russian Vessels. Martens, NRG, Ser. III, VII, 17.

PEARL; or CHU-KIANG. See CANTON.

PAI-HO; or PEI-HO.

See also: CHINESE INLAND WATERWAYS. 1860; Oct. 24: Tientsin. Treaty. China/Great Britain. Art. IV: Opening Port of Tientsin to British Commerce \& Navigation. Hertslet, China, No. 8, 50.

1860; Oct. 25: Tientsin. Agreement. China/France. Art. VII: Recognizing the Right of French Subjects to participate in the Commerce \& Navigation of the Port of Tientsin. Hertslet, China, No. 42. 
1861; Sept. 2: Tientsin. Treaty. China/Germany. Art. VI. Hertslet, China, No. 56, 331.

1863; July 13: Tientsin. Treaty. China/Denmark. Art. XI. Hertslet, China, No. 38, 249.

1863; Oct. 6: Tientsin. Treaty. China/Netherlands. Art. II. Hertslet, China, No. 70, 407.

1864; Oct. 10: Tientsin. Treaty. China/Spain. Art. V. Hertslet, China, No. 91, 512.

1865; Nov. 2: Peking. Treaty. Belgium/China. Art. XI. Hertslet, China, No. 34, 225.

1866 ; Oct. 26 : Peking. Treaty. China/Italy. Art. XI. Hertslet, China, No. 60,354 .

1869; Sept. 2: Peking. Treaty. Austria-Hungary/China. Art. VIII. Hertslet, China, No. 33, 215.

1880; March 31: Peking. Agreement. China/Germany. Art. I: Hertslet, China, No. 57, 342.

1898; July 28: Peking. Law. Chinese Government. Hertslet, China, No. 138.

1901; July 22 : Peking. Treaty. China/Great Britain. Pai-ho Conservancy Regulations; Provisions governing Imposition of Landing \& Wharfage Dues. Hertslet, China, No. 145, 750.

1901; Sept. 7: Peking. Convention. China/Foreign Powers: Austria-Hungary, Belgium, France, Germany, Great Britain, Italy, Japan, Netherlands, Russia, Spain, \& the United States. Arts. VI, XI: Stipulations respecting the Improvement of the Navigable Channel. Hertslet, China, No. 26, 128. (Commentary: China Year Book, (1914), 687; Despagnet, Droit Int., 648.)

1907; Feb. 11: Peking. Law. British Regulations respecting Navigation \& Imposition of Landing Dues. Hertslet, China, No. 168, 1096.

PEI-KIANG. See also: CHINESE INLAND WATERWAYS. 1898; July 28: Peking. Law. Chinese Government. Universal Freedom of Navigation. Hertslet, China, No. 138.

PO-YANG-LU LAKE.

See also: CHINESE INLAND WATERWAYS. 1898; July 28: Peking. Law. Chinese Government. Universal Freedom of Navigation. Hertslet, China, No. 138.

RED. See SONGKOI. 


\section{San-fa}

SAN-FA

1905; Dec. 22 : Aigun. Agreement. China/Japan. Art. I: Permitting Commerce \& Navigation. Hertslet, China, No. 67, 393.

SEBOEKOE; or SEBOUKOU; or SIBUKU. See BORNEO.

\section{SELENGA}

1912; Oct. 21/Nov. 3: Urga. Convention. China/Russia. Art. XII: Establishing Freedom of Navigation for Russian Vessels. Martens, NRG, Ser. III, VII, 17.

SHAT-EL-ARAB.

See also: EUPHRATES; TIGRIS.

1834; Dec. 29 : Constantinople. Law (Firman). Turkish Government. Permitting British Vessels to participate in Fluvial Navigation, subject to Appropriate, Protective Regulations. Hertslet, COM. TR., XIII, 838-39.

1861; Jan. 15: Constantinople. Law (Viziral Order). Governing Navigation by British Vessels; Identical Duties to those levied on Ottoman Vessels to be imposed. Heltslet, COM. TR., XIII, 845 .

SI-KIANG. See WEST.

SIANG-KIANG.

See also: CHINESE INLAND WATERWAYS; Yang-tsze-Kiang System.

1898; July 28: Peking. Law. Chinese Government. Universal Freedom of Navigation. Hertslet, China, No. 138.

SONG-KI-KONG.

See also: CHINESE INLAND WATERWAYS. 1887; June 26: Peking. Treaty. China/France. Art. VI: Recognizing Mutual Enjoyment of Navigation. Hertslet, China, No. $48,313$.

1898; July 28: Peking. Law. Chinese Government. Universal Freedom of Navigation. Hertslet, China, No. 138.

SONGKOI; or RED

1874; March 15: Saigon. Treaty. Annam \& France. Art. XI: Opening Navigation to French Vessels. J. Dupuis, L'Ouverture du Fleuve Rouge au Commerce, (Paris, 1879), 305. 
1874; Aug. 31: Saigon. Treaty. Annam \& France. Arts. I-IV : Regulating Navigation on the Songkoi River. J. Dupuis, L'Ouverture du Fleuve Rouge . . ., 310.

1884; May 11: Tientsin. Convention. China/France. Art. III : Recognized Mutual Participation in Fluvial Transport. Hertslet, China, No. 44, 294.

1885; June 9: Tientsin. Treaty. China/France. Art. V: Fiscal Regulations; Establishment of Customs Bureaux at the Frontier. Hertslet, China, No. 46, 298.

1886; April 25: Tientsin. Treaty. China/France: Arts. X, XII: Recognizing Reciprocal Freedom of Navigation; Establishing Regulations governing Customs Examination. Clercq, RTF, Vol. 17, 164; Hertslet, China, No. 47, 306.

1887; June 26: Peking. Additional Convention. China/France. Art. II: Designating River Ports open to French Commerce. Hertslet, China, No. 48.

1895; June 20: Peking. Convention. China/France. Art. IV: Modifying Stipulations embodied in Art. IX of Treaty of Tientsin, April 25, 1886, governing Commercial Privileges \& the Imposition of Duties on Goods in Transit. Hertslet, China, No. $53,325$.

1896; Jan. 15: London. Agreement. France/Great Britain. Art. IV : Providing that any privileges or advantages secured by either in the Provinces of Yunnan or Szechuen shall be shared alike. Hertslet, China, No. 101.

\section{SUNGARI}

1858; May 16/28: Aigun. Treaty. China/Russia. Arts. I-II: Reciprocal Freedom of Navigation; Participation by Foreign Vessels explicitly Prohibited. Hertslet, China, No. 80, 454. (Commentary: H. B. MORSE, The International Relations of the Chinese Empire, pg. 477.)

1860; Nov. 2/14: Peking. Treaty. China/Russia. Arts. I, V: Demarcation of Boundaries; Freedom of Navigation \& Commerce. Hertslet, China, No. 82, 462.

1881; Feb. 12/24; St. Petersburg. Treaty. China/Russia. Art. 18: Confirming the Reciprocal Rights of Navigation as embodied in Art. I of the Treaty of Aigun, May 16/28, 1858. Hertslet, China, No. 85, 490.

1905; Dec. 22 : Aigun. Additional Agreement. China/Japan. Access secured for Commercial Purposes. Hertslet, China, No. 67, 393. 


\section{Tatsich}

TATSICH. See YUNG-KIANG.

\section{TIGRIS.}

See also: SHAT-EL-ARAB.

1846; April 2: Constantinople. Law. Turkish Government. Viziral Order concerning Navigation by British Vessels upon the River Tigris. Hertslet, COM. TR., XIII, 840.

1861; Jan. 15 : Constantinople. Law. Turkish Government. Viziral Order governing Navigation by British Vessels; Identical Duties to those levied on Ottoman Vessels to be imposed. Hertslet, COM. TR., XIII, 845.

\section{TSIEN-TANG; or CHIEN-TANG.}

See also: CHINESE INLAND WATERWAYS. 1898; July 28: Peking. Law. Chinese Government. Universal Freedom of Navigation. Hertslet, China, No. 138. (Commentary: GB. Dipl. \& Consular Reports, No. 5305, pg. 6.)

TSO-KIANG. See also: CHINESE INLAND WATERWAYS. 1887; June 26 : Peking. Treaty. China/France. Art. VI: Reciprocal Freedom of Navigation, including the Affluents Cao-Bang \& Song-ki-kong. Hertslet, China, No. 48, 313.

1898; July 28: Peking. Law. Chinese Government. Universal Freedom of Navigation. Hertslet, China, No. 138.

1905 ; April (no date): Canton. Law. Regulations governing Commerce \& Navigation on West River System. Hertslet, China, No. 159, 1035.

TUMEN.

See also: CHINESE INLAND WATERWAYS. 1898; July 28. Peking. Law. Chinese Government. Universal Freedom of Navigation. Hertslet, China, No. 138.

1905; Dec. 22 : Aigun. Additional Agreement. China/Japan. Access secured for Commercial Purposes. Hertslet, China, No. 67, 393.

1909; Sept. 4: Agreement. China \& Japan. Art. I: Demarcation of International Boundary in Thalweg. Art. V: Regulating the Establishment of Ferries. GB. BFSP, Vol. 102, 391.

TUNG-KIANG. See also: CHINESE INLAND WATERWAYS. 1898; July 28: Peking. Law. Chinese Government. Universal Freedom of Navigation. Hertslet, China, No. 138.

1902 ; Sept. 5 : Shanghai. Treaty. China/Great Britain. Art. VIII, sect. 12: Opening the Port of Hwei-chaufu (Hui-chow, or Waichow) to Commerce \& Navigation. Hertslet, China, No. 28, 180. 
TUNG-TING-LU LAKE.

See also: CHINESE INLAND WATERWAYS.

1898; July 28: Peking. Law. Chinese Government. Universal Freedom of Navigation. Hertslet, China, No. 138.

\section{USSURI}

1858; May 16/28: Aigun. Treaty. China/Russia. Arts. I-II: Reciprocal Freedom of Navigation; Participation by Foreign

Vessels explicitly Prohibited. Hertslet, China, No. 80, 454.

1860 ; Nov. 2/14: Peking. Treaty. China/Russia. Arts. I, V: Demarcation of Boundaries; Freedom of Navigation \& Commerce. Hertslet, China, No. 82, 462.

1881; Feb. 12/24: St. Petersburg. Treaty. China/Russia. Art. 18: Confirming the Reciprocal Rights of Navigation as instituted by Art. I of Treaty of Aigun, May 16/28, 1858. Hertslet, China, No. $85,490$.

WEST; or SI-KIANG.

See also: CHINESE INLAND WATERWAYS; CANTON RIVER.

1842 ; Aug. 29 : Nanking. Treaty. China/Great Britain. Art. II. Recognized Freedom of Navigation within Estuary. Hertslet, China, No. I, 7.

1844; Oct. 24: Whampoa. Treaty. China/France. Art. II: Permission extended to French Trading Vessels within the Estuary. Hertslet, China, No. 39, 258; Martens, NRG, Ser. I, VII, 431.

1847; March 20: Canton. Treaty. China/Sweden \& Norway. Art. III: Access secured by Sweden \& Norway as far as Port of Kwang-chow. Hertslet, China, No. 93, 527.

1858; June 1/13: Tientsin. Treaty. China/Russia. Art. III: Russian Merchant Vessels granted Entry. Hertslet, China, No. 81,456 .

1858; June 26: Tientsin. Treaty. China/Great Britain. Arts. I, $\mathrm{X}$ : Renewing \& Confirming Dispositions of Art. II of Treaty of Nanking, Aug. 29, 1842. Hertslet, China, No. 6, 18.

1865 ; Nov. 2: Peking. Treaty. Belgium/China. Art. XI. Hertslet, China, No. 34, 225.

1866; Oct. 26 : Peking. Treaty. China/Italy. Art. XI. Hertslet, China, No. $60,354$.

1869; Sept. 2: Peking. Treaty. Austria-Hungary/China. Art. VIII: Freedom of Access \& Navigation. Hertslet, China, No. $33,215$. 
West

1880; March 31: Peking. Additional Agreement. China/Germany. Art. I. Hertslet, China, No. 57.

1885; June 9: Tientsin. Treaty. China/France. Art. V: Regulating Commercial Navigation in the Upper Course \& upon Affluent Streams. Hertslet, China, No. 46.

1886; April 25: Tientsin. Treaty. China/France. Art. I: Recognizing Reciprocal Freedom of Commercial Navigation; Regulations governing the Establishment \& Administration of Customs Bureaux.' Clercq, RTF, Vol. 17, 164; Hertslet, China, No. 47, 306.

1887; June 26: Peking. Additional Convention. China/France. Art. II: Designating River Ports open to French Commerce. Hertslet, China, No. 48, 311.

1895 ; June 20 : Peking. Convention. China/France. Art. II: Revising Art. II of Convention of Peking, June 26, 1887, respecting Commercial Privileges. Hertslet, China, No. 53, 325.

1896; Jan. 15: London. Agreement. France/Great Britain. Art. IV: Providing that any privileges or advantages secured by either Power in the Provinces of Yunnan or Szechuen shall be shared alike. Hertslet, China, No. 101.

1897; Feb. 4: Agreement. China/Great Britain. Granting Access to the River Port of Wuchow. Hertslet, China, No. 22, 118.

1898; July 28: Peking. Law. Chinese Government. Universal Freedom of Navigation. Hertslet, China, No. 138. (NOTE: Regulations governing Navigation; Hertslet, China, No. 159, pg. 1035.)

1902 ; Sept. 5: Shanghai. Treaty. China/Great Britain. Art. VIII, sect. 12 ; Art. X: Establishing Kong-moon as Treaty Port; Permitting Access of Merchant Vessels. Hertslet, China, No. 28, 179, 181.

1904; March 23: Kong-moon. Law. Customs Regulations applicable to Merchant Vessels navigating the River. Hertslet, China, No. 201, 1182.

1905; April (no date): Canton. Law. Regulations issued by the Chinese Imperial Maritime Customs governing Commerce \& Navigation on the West River System. GB. BFSP, Vol. 98, 449; Hertslet, China, No. 159, 1035-39.

WHANGPOO; or HUANGPOO; or WOOSUNG.

See also: CHINESE INLAND WATERWAYS. 1842; Aug. 29 : Nanking. Treaty. China/Great Britain. Art. II: 
Recognized Freedom of Access \& Navigation for Commercial Vessels. Hertslet, China, No. I, 7.

1844; Oct. 24: Whampoa. Treaty. China/France. Art. II: Similar Privileges granted to French Merchant Vessels. Hertslet, China, No. 39, 258; Martens, NRG, Ser. I, VII, 431.

1847; March 20: Canton. Treaty. China/Sweden \& Norway. Art. III: Access to Port of Shanghai secured for Norwegian \& Swedish Merchant Vessels. Hertslet, China, No. 93, 527.

1858; June 1/13: Tientsin. Treaty. China/Russia. Art. III: Russian Merchant Vessels granted Entry. Hertslet, China, No. $81,456$.

1858; June 26: Tientsin. Treaty. China/Great Britain. Renewing \& Confirming Provisions of Art. II of Treaty of Nanking, Aug. 29, 1842. Hertslet, China, No. 6, 18.

1861; Sept. 2 : Tientsin. Treaty. China/Germany. Art. VI: Hertslet, China, No. 56, 331, 333.

1863; July 13: Tientsin. Treaty. China/Denmark. Art. XI. Hertslet, China, No. 38, 249.

1863; Oct. 6: Tientsin. Treaty. China/Netherlands. Art. II. Hertslet, China, No. 70, 407.

1864; Oct. 10 : Tientsin. Treaty. China/Spain. Art. V. Hertslet, China, No. 91, 512.

1865; Nov. 2 : Peking. Treaty. Belgium/China. Art. XI. Hertslet, China, No. 34, 226.

1866; Oct. 26: Peking. Treaty. China/Italy. Art. XI. Hertslet, China, No. 60, 354.

1869; Sept. 2: Peking. Treaty. Austria-Hungary/China. Art. VIII: Freedom of Access \& Navigation. Hertslet, China, No. $33,215$.

1880 ; March 31: Peking. Additional Agreement. China/Germany. Art. I. Hertslet, China, No. 57, 343.

1895; April 17: Shimonoseki. Treaty. China/Japan. Art. VI, sect.

2: Freedom of Navigation for Japanese Vessels on Whangpoo River between the Ports of Shanghai \& Soochow recognized. Hertslet, China, No. 62, 365.

1896; Oct. 19: Peking. Agreement. China/Japan. Additional Stipulations concerning the participation by Japanese Vessels in Commercial Navigation on the Whangpoo River. Hertslet, China, No. 65.

1898; July 28: Peking. Law. Chinese Government. Universal Freedom of Navigation. Hertslet, China, No. 138.

1901; Jan. 17: Shanghai. Law. Chinese Government. Regulations 


\section{Whangpoo}

governing Navigation on the River \& in the Harbor of Shanghai. Hertslet, China, No. 197.

1901; Sept. 7: Peking. Convention. China/Foreign Maritime

Powers: Austria-Hungary, Belgium, France, Germany, Great Britain, Italy, Japan, Netherlands, Russia, Spain, \& the United States. Arts. VI, XI: Provisions concerning the Improvement \& Maintenance of the Navigable Channel. GB. BFSP, Vol. 94, 709; Hertslet, China, No. 26, 128, 130. (Commentary: CHINA YEAR BOOK (1914), 687; DESPAGNET, Droit Int., 648.) 1902; March 6: London. Law. British Government. Order in Council in conformity with Section XI of the Foreign Jurisdiction Act of 1890 governing Navigation on the River Whangpoo and providing for the Improvement \& Maintenance of the Navigable Channel. GB. BFSP, Vol. 95, 620; Hertslet, China, No. $148,485$.

1907; Sept. 27: Peking. Convention. China/Foreign Maritime Powers: Austria-Hungary, Belgium, France, Germany, Great Britain, Italy, Japan, Netherlands, Russia, Spain, \& the United States of America. Rectification \& Maintenance of the Navigable Channel. GB. BFSP, Vol. 98, 1052; Hertslet, China, No. 31, 199; Martens, NRG, Ser. III, VI, 685, 688.

(NOTE :

(Regulations governing navigation in the lower course of the Woosung (Whangpoo) River in the vicinity of the Inner \& Outer Bars were promulgated at Peking, April 10, 1907. Hertslet, China, No. 171, 1102.)

1911; April 28: Peking. Law. Navigation Regulations issued by the Authority of the King of Great Britain under sanction of Article 155 of the Chinese Order in Council of 1904 governing the Transit of Vessels through the River, to \& from the Port of Shanghai. GB. BFSP, Vol. 105, 918.

WU-KIANG. See also: CHINESE INLAND WATERWAYS. 1898; July 28: Peking. Law. Chinese Government, Universal Freedom of Navigation. Hertslet, China, No. 138.

YALU. See also: CHINESE INLAND WATERWAYS. 1898; July 28: Peking. Law. Chinese Government. Universal Freedom of Navigation. Hertslet, China, No. 138.

1903; Oct. 8: Shanghai. Treaty. China/United States. Art. XII : Opening the Port of Antung to Commerce \& Navigation in con- 
formity with the Imperial Law of July 28, 1898. Hertslet, China, No. 100; Malloy, UST, 261, 267.

\section{YANG-TSZE-KIANG.}

See also: CHINESE INLAND WATERWAYS. 1842; Aug. 29: Nanking. Treaty. China/Great Britain. Art. II: Recognized Freedom of Access \& Navigation for Merchant Vessels to Port of Shashi. Hertslet, China, No. I, 7.

1844; Oct. 24: Whampoa. Treaty. China/France. Art. II: Similar Privileges granted to French Vessels engaged in Commerce. Hertslet, China, No. 39, 258; Martens, NRG, Ser. I, VII, 431.

1858; June 26: Tientsin. Treaty. China/Great Britain. Art. X: Access, likewise, granted to Merchant Vessels as far as Port of Chin-kiang: "British Merchant Vessels shall have authority to trade on the Great River (Yang-tsze-kiang)." Hertslet, China, No. 6, 18; Hertslet, COM. TR., XI, 89.

1858; June 27 : Treaty. China/France. Rendering the Port of Nanking, likewise, accessible to Merchant Vessels. Hertslet, China, No. 40, 272.

1861; Jan. 20 : Agreement. China/Great Britain. Navigation Regulations. Hertslet, COM. TR. XI, 668.

1861; Sept. 2 : Tientsin. Treaty. China/Germany. Art. VI: Hertslet, China, No. 56, 331, 333.

1863; July 13: Tientsin. Treaty. China/Denmark. Art. XI: Hertslet, China, No. 38, 249.

1863; Oct. 6: Tientsin. Treaty. China/Netherlands. Art II. Hertslet, China, No. 70, 407.

1864; Oct. 10: Tientsin. Treaty. China/Spain. Art. V. Hertslet, China, No. 91, 512.

1865; Nov 2: Peking. Treaty. Belgium/China. Art. XI. Hertslet, China, No. 34, 226.

1866 ; Oct. 26 : Peking. Treaty. China/Italy. Art. XI. Hertslet, China, No. 60, 354.

1869; Sept. 2: Peking. Treaty. Austria-Hungary/China. Art. VIII: Freedom of Access \& Navigation. Hertslet, China, No. $33,215$.

1876; Sept.13: Chefoo. Agreement. China/Great Britain. Section III, Art. I: Designating Additional Ports on the River Yangtsze where Vessels may enter. Hertslet, China, No. 12, 77 ; Hertslet, COM. TR. Vol. 17, 279.

1880; March 31: Pelking. Supplementary Convention. China/Germany; Hertslet, China, No, 57, 343, 


\section{Yang-tsze-kiang}

1890 ; March 31 : Peking. Additional Agreement. China/Great Britain. Arts. I- $\nabla$ : Regulating Navigation \& Designating the Ports accessible to British Vessels. Hertslet, China, No. 18, 94; Hertslet, COM. TR., Vol. 18, 290.

1895; April 17: Shimonoseki. Treaty. China/Japan. Art. VI: Recognized Freedom of Navigation for Japanese Merchant Vessels on the Upper Yang-tsze between the ports of Ichang \& Chungking. Hertslet, China, No. 62.

1896; July 21: Peking. Treaty. China/Japan. Art. V: Freedom of Navigation for Japanese Vessels; Designating Additional Ports open to Commerce. Hertslet, China, No. 64 .

1898; July 28: Peking. Law. Chinese Government. Universal Freedom of Navigation. Hertslet, China, No. 138. (Commentary: REINSCH, World Politics, 150-151.)

1898; August (no date) : Peking. Law. Chinese Government. Special Regulations governing participation in the Commerce \& Navigation of the River Yang-tsze. (Arts. I-X.) Hertslet, China, No. 139, 723-726.

1902; Sept. 5: Shanghai. Treaty. China/Great Britain. Art. V: Providing for the Establishment \& Maintenance of Appliances for hauling Vessels through the Rapids of the Upper Yang-tsze. Hertslet, China, No. 28, 173.

1903; Oct. 8: Shanghai. Treaty. China/Japan. Art. II: Erection of Apparatus for facilitating Navigation on the Upper Yang-tsze. Hertslet, China, No. 66.

1907; May 14: Peking. Treaty. China/Great Britain. Regulating the Imposition of Landing \& Wharfage Dues. Hertslet, China, No. 172, 1103

\section{YENISEI}

1912; Oct 21/Nov. 3 : Urga. Convention. China/Russia. Art. XII: Establishing Freedom of Navigation for Russian Vessels. Martens, NRG, Ser. III, VII, 17.

YUNG-KIANG; or TATSICH.

See also: CHINESE INLAND WATERWAYS.

1842; Aug. 29 : Nanking. Treaty. China/Great Britain. Art. II: Recognized Freedom of Access \& Navigation for Merchant Vessels. Hertslet, China, No. I, 7. 
1844; Oct. 24: Whampoa. Treaty. China/France. Art. II: Similar Privileges granted to Merchant Vessels under the French Flag. Hertslet, China, No. 39, 258; Martens, NRG, Ser. I, VII, 431.

1847; March 20: Canton. Treaty. China/Sweden \& Norway. Art. III : Access to Port of Ningpo secured for Norwegian \& Swedish Vessels. Hertslet, China, No. 93, 527.

1858; June 1/13: Tientsin. Treaty. China/Russia. Art. III: Russian Merchant Vessels granted Entry. Hertslet, China, No. $81,456$.

1858; June 26: Tientsin. Treaty. China/Great Britain. Renewing \& Confirming Provisions embodied in Article II of Treaty of Nanking, Aug. 20, 1842. Hertslet, China, No. 6, 18, 23.

1861; Sept. 2: Tientsin. Treaty. China/Germany. Art. VI: German Vessels granted Entry. Hertslet, China, No. 56, 331, 333. 1863; July 13: Tientsin. Treaty. China/Denmark. Art. XI. Hertslet, China, No. 38, 249.

1863; Oct. 6: Tientsin. Treaty. China/Netherlands. Art. II: Hertslet, China, No. 70, 407.

1864; Oct. 10: Tientsin. Treaty. China/Spain. Art. V: Hertslet, China, No. 91, 512.

1865; Nov. 2: Peking. Treaty. Belgium/China. Art. XI. Hertslet, China, No. 34, 226.

1866; Oct. 26: Peking. Treaty. China/Italy. Art. XI. Hertslet, China, No. 60, 354.

1869; Sept. 2: Peking. Treaty. Austria-Hungary/China. Art. VIII: Freedom of Access \& Navigation. Hertslet, China, No. $33,215$.

1880 ; March 31: Peking. Supplementary Convention. China/Germany. Art. I. Hertslet, China, No. 57, 343.

1898; July 28: Peking. Law. Chinese Government. Universal Freedom of Navigation. Hertslet, China, No. 138.

ZATSAN; or TZAISAN-NOR; LAKE

1864; Sept. 25/Oct. 7: Tchuguchak. Agreement. China \& Russia. Art. I: Demarcation of Boundary along Lake Shore. Hertslet, China, No. 83.

1912; Oct. 21/Nov. 3: Urga. Convention. China/Russia.. Mutual Liberty of Navigation Martens, NRG, Ser. III, VII, 17. 


\section{TENTATIVE PROVISIONS REGULATING CERTAIN EUROPEAN WATERWAYS}

\section{BUG}

1919; June 28: Versailles. Treaty. France, Great Britain, Italy, Japan, Poland, United States of America. Art. 18: Adoption of Provisions identical with Stipulations embodied in Arts. 332337 of the Treaty of Peace with Germany,- June 28, 1919,- for Regulating Navigation. American Association for International Conciliation (AAIC), No. 141, 933; New York Times Current History (N. Y. Times C. H.), Aug., 1919, pg. 280.

CHLOP LAKE

1919; June 28: Versailles. Treaty. PRINCIPAL Powers: France, Great Britain, Italy, Japan, United States of America; ALLIED \& associated Powers: Belgium, Bolivia, Brazil, China, Cuba, Czecho-Slovakia, Ecuador, Greece, Guatemala, Haiti, Hedjaz, Honduras, Liberia, Nicaragua, Panama, Peru, Poland, Portugal, Roumania, Serbo-Croat-Slovene State, Siam, Uruguay and GERMaNy. Art. 27, sec. 7: Adoption of Median Line as International Boundary between Germany \& Poland. AAIC, No. 142, 961; N. Y. Times C. H., Aug., 1919, pg. 292.

DANUBE

1919 ; June 28: Versailles. Treaty. Allied \& Associated Powers and Germany. Part XII, Section 1, Arts. 321-327: General Provisions regulating Inland Waterways. Section 2, Arts. 331-339: International Navigation Established \& Regulated. Sec. 2, Arts. 346-353: Special Stipulations relating to resumption of Power by the European Commission \& to the Institution of an International Commission. AAIC., No. 142, 1148-1155, 1158-59; N. Y. Times C. H., Aug., 1919, 354-55, 357-58.

(Commentary: Objections of the German Government to certain stipulations of the Treaty of Versailles: urging German representation on the Danubian Commission. AAIC., No. 143, pp. 84-85.)

1919; Sept. 10 : St. Germain-en-Laye. Treaty. Allied \& Associated Powers and Austria. Part XII, sect. 1, Arts. 284-289: General Provisions governing Inland Navigation. Art. 291: Special Stipulations concerning Navigation of the Danube. Art. 302: Institution of International Supervisory Commission governing Danubian Navigation. Senate Doc., No. 92, pgs. 177-79, 180-81, 185, 66th U. S. Congress, 1st Session. 
DANUBE-RHINE PROJECTED CANAL

1919; June 28: Versailles. Treaty. Allied \& Associated Powers and Germany. Part XII, Sec. 2, Chap. iii, Art. 331: Rights of International Navigation to be Recognized. Art. 353: Regulations prescribed in Arts. 332-338 of Part XII to govern Navigation on completion of the Canal. AAIC., No. 142, 1152-53, 1159; N. Y. Times C. H., Aug., 1919, 354, 358.

1919; Sept. 10: St. Germain-en-Laye. Treaty. Allied \& Associated Powers and Austria. Part XII, Sect. 1, Arts. 284-289: General Provisions governing Inland Navigation. Art. 291: Special Stipulations respecting Navigation of the Canal. Senate Doc., No. 92, pgs. 177-79, 180-81, 66th U. S. Congress, 1st Sess. ELBE

1919; June 28: Versailles. Treaty. Allied \& Associated Powers and Germany. Arts. 321-327: Regulations governing Navigation and Commerce. Arts. 331-339: Establishment and Supervision of International Navigation. Art. 340: Establishment \& Constitution of the International Commission supervising Navigation. Arts. 343-345: Special Regulations applicable to the Commission. Arts. 363-364: Special Rights accorded to the Czecho-Slovak State. Art. 282, sec. 9: Renewal of the Convention of June 22, 1861, concerning the Redemption of the Stade Toll. AAIC., No. 142, 1101, 1148-1155, 1156-57, 1165; N. Y. Times C. H., Aug., 1919, 340, 354-58, 359.

(Commentary: Declaration by German Government of vital interest in maintaining fluvial transit with Czecho-Slovakia. AAIC., No. 143, pp. 84-85.)

KÜDDOW

1919; June 28: Versailles. Treaty. Allied \& Associated Powers and Germany. Art. 27, sec. 7: Thalweg Boundary between Germany \& Poland. AAIC., No. 142, 961-62; N. Y. Times C. H., Aug., 1919, 392.

LONKENER LAKE

1919; June 28: Versailles. Treaty. Allied \& Associated Powers and Germany. Art. 100: Boundary between Germany \& Poland established on Median Line. AAIC., No. 142, 1011; N. Y. Times C. H., Aug., 1919, pg. 310.

\section{MOLDAU}

1919 ; June 28: Versailles. Treaty. Allied \& Associated Powers and Germany. Arts. 321-327: Commerce \& Navigation Regulations. Arts. 331-339; Institution of International Navigation. 
AAIC., No. 142, 1148-1155; N. Y. Times C. H., Aug., 1919, 354-56.

MORAVA

1919; Sept. 10 : St. Germain-en-Laye. Treaty. Allied \& Associated Powers and Austria. Part XII, Sect. 1, Arts. 284-89: General Provisions governing Inland Navigation. Art. 291: Special Stipulations regarding Navigation of Morava. Senate Doc., No. 92, pgs. 177-79, 180-81, 66th U. S. Congress, 1st Sess. MOSELLE

1919 ; June 28: Versailles. Treaty. Allied \& Associated Powers and Germany. Arts. 321-327: Provisions governing Commerce and Navigation. Art. 362: Option of Extending Jurisdiction of Central Rhine Commission to the Moselle below the FrancoLuxemburg Frontier. AAIC., No. 142, 1148-1151, 1165; N. Y. Times C. H., Aug., 1919, 354-55, 359.

\section{NAREST}

1919; June 28: Versailles. Treaty. France, Great Britain, Italy, Japan, Poland, United States of America. Art. 18: Application of Regulations established by Arts. 332-337 of Treaty of Peace with Germany,- June 28, 1919,-for Governing Fluvial Navigation. AAIC., No. 141, 933; N. Y. Times C. H., Aug., 1919, 280.

\section{NEIDE}

1919; June 28: Versailles. Treaty. Allied \& Associated Powers and Germany. Art. 28: Establishment of Fluvial Boundary. NETZE

AAIC., No. 142, 963; N. Y. Times C. H., Aug., 1919, 293.

1919; June 28: Versailles. Treaty. Allied \& Associated Powers and

Germany. Art. 27, sec. 7: Boundary between Germany \& Poland established in Thalweg. AAIC., No. 142, 961-62; N. Y. Times C. H., Aug., 1919, 292-93.

NIEMEN

1919; June 28: Versailles. Treaty. Allied \& Associated Powers and Germany. Art. 28: Establishment of Fluvial Boundary. Arts. 321-327: Provisions regulating Commerce \& Navigation. Arts. 331-339: International Navigation Instituted. Arts. 342-45: Special Stipulations respecting Erection \& Procedure of an International Supervisory Commission. AAIC., No. 142, 963, 11481155,1157 ; N. Y. Times C. H., Aug., 1919, 293, 354-57.

(Commentary: German Government promises co-operation with the other co-riparian states for facilitating fluvial navigation. AAIC., No. 143, pp. 84-85.) 
1919; June 28: Versailles. Treaty. Allied \& Associated Powers and Germany. Art. 28: International Boundary established in Thalweg. AAIC., No. 142, 963; N. Y. Times C. H., Aug., 1919, 293.

ODER

1919; June 28: Versailles. Treaty. Allied \& Associated Powers and Germany. Arts. 321-327: Provisions governing Commerce \& Navigation. Arts. 331-339: International Navigation Instituted. Arts. 341, 343-45: Establishment \& Regulation of an International Supervisory Commission. Arts. 363-64: Special Rights accorded to the Czecho-Slovak State. AAIC., No. 142, 1148-55, 1156-57, 1165; N. Y. Times C. H., Aug., 1919, 354$57,359$.

(Commentary: The German Government engages to rectify the navigable course, but considers establishment of the proposed Commission as superfluous. AAIC., No. 143, pp. 84-85.)

\section{PIASNITZ}

1919; June 28: Versailles. Treaty. Allied \& Associated Powers and Germany. Art. 27, sec. 7: Establishment of Fluvial Boundary between Germany \& Poland. AAIC., No. 142, 962; N. Y. Times C. H., Aug., 1919, 292-93.

POLLENZINER LAKE

1919; June 28: Versailles. Treaty. Allied \& Associated Powers and Germany. Art. 100: Boundary between Germany \& Poland established on Median Line. AAIC., No. 142, 1011; N. Y. Times RHINE

C. H., Aug., 1919, pg. 310 .

1919; June 28: Versailles. Treaty. Allied \& Associated Powers and Germany. Art. 27, sec. 3: Fluvial Boundary Established. Arts. 321-327: Provisions governing Commerce \& Navigation. Arts. 354-360: Convention of Mannheim of Oct. 17, 1868, to govern Navigation except as modified by Art. 338 of Present Treaty; Establishment \& Constitution of the Central Rhine Commission; Vessels of All Nations accorded Equality as to Navigation Privileges; Cession by Germany to France of Vessels and Port Facilities; Diversion of Waters for Power, Irrigation, and Maintenance of Canals. AAIC., No. 142, 960, 1148-1151, 1160-1164; N. Y. Times C. H., Aug., 1919, 292, 354-55, 358-59.

(Commentary: As the present Central Commission of the Rhine has proven competent to fulfill requirements, the German Government does not favor alteration. AAIC., No. 143, pp. 84-85.) 


\section{RHINE-MEUSE PROJECTED CANAL}

1919; June 28: Versailles. Treaty. Allied \& Associated Powers and Germany. Art. 358: Right of Belgium to divert Waters from Rhine for Maintenance of the Projected Rhine-Meuse Canal Recognized. Art. 361: Germany agrees to construct the Portion of the Proposed Canal within German Dominion; Administration \& Jurisdiction of the Central Rhine Commission shall extend to regulate Enjoyment of the Canal. AAIC., No. 142, 1162-64; N. Y. Times C. H., Aug., 1919, 358-59. SCHELDT

1919; June 28: Versailles. Treaty. Allied \& Associated Powers and Germany. Art. 282, sec. 10: Renewal of the Convention of July 16, 1863, concerning the Amortization of the Scheldt Toll. AAIC., No. 142, 1101; N. Y. Times C. H., Aug., 1919, 340. SKOTTAU

1919; June 28: Versailles. Treaty. Allied \& Associated Powers and Germany. Art. 28: Fluvial Boundary adopted for East Prussia. AAIC., No. 142, 963; N. Y. Times C. H., Aug., 1919, 293. THEISS

1919 ; Sept. 10 : St. Germain-en-Laye. Treaty. Allied \& Associated

Powers and Austria. Part XII, Sect. 1, Arts. 284-89: General

Provisions governing Inland Navigation. Art. 291: Special Stipulations concerning Navigation of Theiss. Senate Doc., No. 92, pgs. 177-79, 180-81, 66th U. S. Congress, 1st Sess. VISTULA

1919; June 28: Versailles. Treaty. Allied \& Associated Powers and

Germany. Art. 28: International Boundary established in Thalweg. Art. 100: Thalweg adopted as Boundary between Germany \& Poland. AAIC., No. 142, 933, 963, 1010; N. Y. Times C. H., Aug., 1919, 280, 293, 310.

(Commentary: The German Government would prefer to regulate the navigation \& administration of the Vistula by Special Convention with Poland. AAIC., No. 143, pp. 84-85.)

1919; June 28: Versailles. Treaty. France, Great Britain, Italy, Japan, Poland, United States of America. Art. 18: Navigation. AAIC., No. 141, 933; N. Y. Times C. H., Aug., 1919, $292-93$. ZARNOWITZ LAKE

1919; June 28: Versailles. Treaty. Allied \& Associated Powers and Germany. Art. 27, sec. 7: Boundary between Germany \& Poland established on Median Line. AAIC., No. 142, 961-63; N. Y. Times C. H., Aug., 1919, 292-93. 
BIBLIOGRAPHY 


\section{(W)}

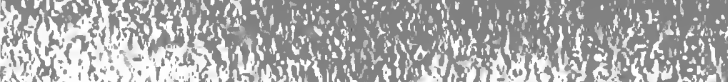

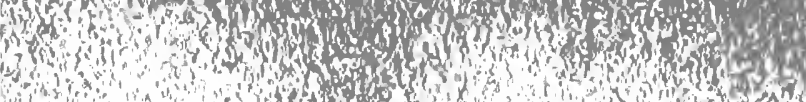

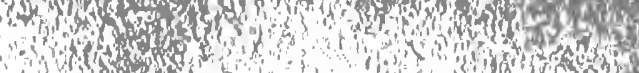

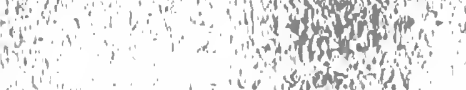

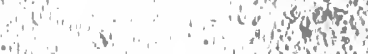

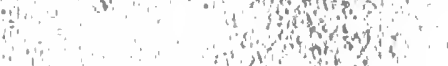

${ }_{1}^{\prime}: \cdots$ ?

$\because 14$ $\therefore$ is

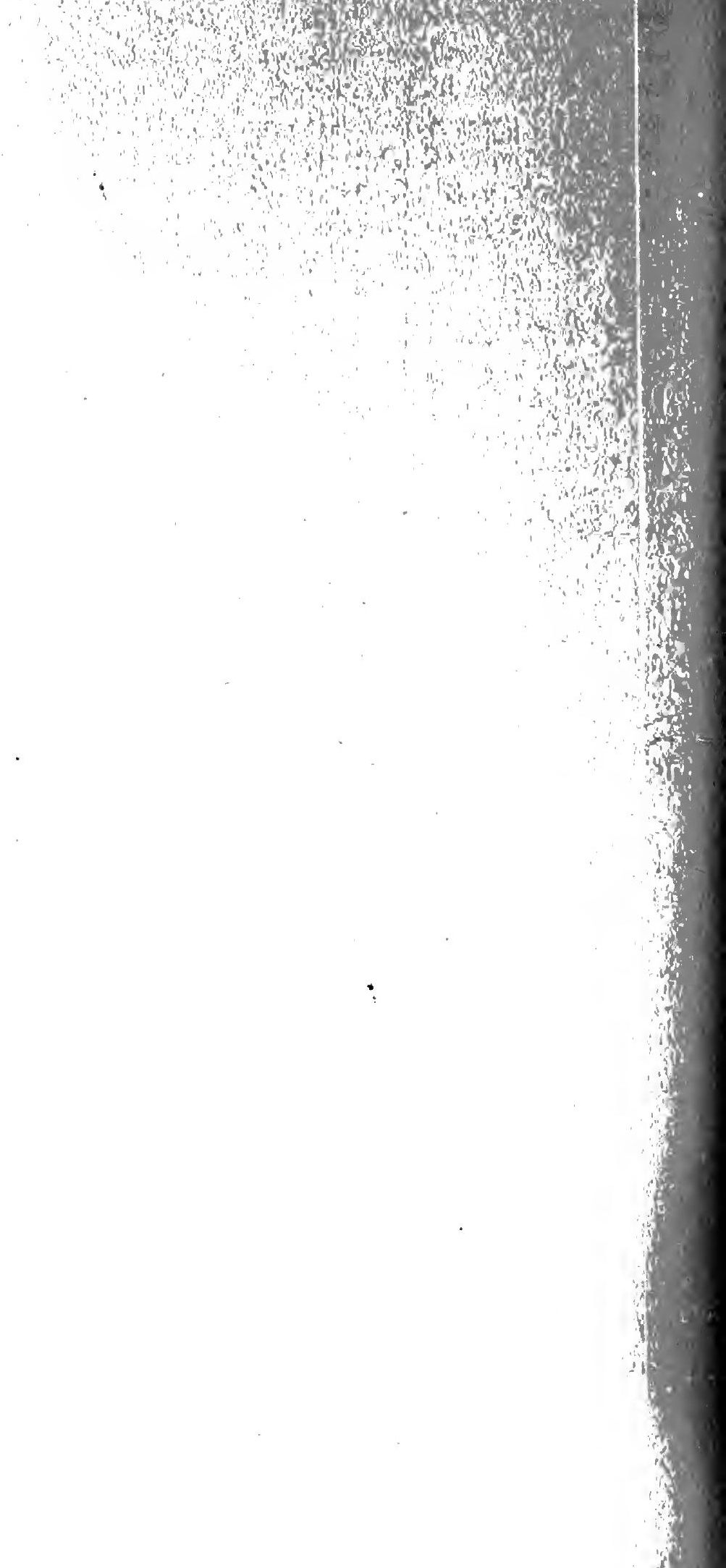




\section{BIBLIOGRAPHY}

ALVERSTONE, Viscount: Recollections of Bench and Bar. London, 1914.

American Academy of Political and Social Sciences: Vol. 31 (Jan.June, 1908), concerning American Waterways.

American Historical Review: Vol I. (1895)-Vol. XXII (1917). New York, 1895-to date.

American Journal of International Law: New York, 1907-1918.

Ashburner, Walter: The Rhodian Sea-Law. Oxford, University Press, 1909.

Azuni, Domenico, A.: Maritime Law. New York, 1806.

BEAZLEY, Charles R.: Dawn of Modern Geography. 3 v., London, 1897.

Benedict, R. D.: History of the Rhodian Law. Yale Law Journal, 1909, pg. 223.

Bering Sea Tribunal of Arbitration Proceedings: 53rd. Cong., 2nd. Sess., Senate Executive Doc., No. 177, pt. 1-16, 16 v., Washington, G. P. O., 1895.

Blair, Emma H., and Robertson, James A.: The Philippine Islands. Cleveland, 1903.

Burroughs, Sir John: Soveraignty of the British Seas; proved by records, history, and the municipal laws of this kingdom. Written 1633. Republished, London, 1739.

CAMDEN, William: Defeat of the Spanish Armada.

Camden, William: Historie of the Most Renowned and Victorious Princesse Elizabeth; late Queene of England. London, 1635.

Cauchy, Eugene: Droit Maritime International. Paris, 1862.

Clapp, Edwin J.: The Navigable Rhine. New York, 1911.

Clavell, Robert: His Majesties Propriety and Dominion of the British Seas Asserted; together with a true account of the Neatherlanders Insupportable Insolencies, and Injuries, they have committed; and the Inestimable Benefits they have gained in their Fishing on the English Seas. London, 1665.

Clowes, William L.: The Royal Navy. 7 v. London, 1898.

Coke, Sir Edward: Institutes of the Law of England. $4 \mathrm{v}$. London, 1809. 
Constans, L.: Une Redaction du Statut Maritime de Marseilles. Romanische Forschungen. Vol. 23 (1907), 645-675.

D'ANVERS, Knightley: A General Abridgement of the Common Law. 2 v. with 2 supplem. vols. London, 1705.

Daru, Count Pierre A. N. B.: Histoire de la Republique de Venise.

8 v. 3rd Edit. Paris, 1826.

Day, Clive: History of Commerce. New York, 1914.

Dumont, Jean; continued by Barbeyrac and Rousset: Corps Universel Diplomatique du Droit des Gens. (Contains treaties from A. D. 313-1730.) 13 v. Amsterdam, 1726-39.

\section{ENCYCLOP AEDIA BRITANNICA}

FISKE, John: The Discovery of America. 2 v. Boston, 1892. Fiske, John: Columbus. Boston, 1909.

Foster, John W.: Evolution of International Law. Yale Law Review, 1909, pg. 149.

France: Recueil des Traitez de Paix. 6 v. Paris, 1693.

Fulton, Thomas W.: The Sovereignty of the Sea; an historical account of the Claims of England to the Dominion of the British Seas. London, 1911.

GEOGRAPHIC JOURNAL; being the Proceedings of the Royal Geographic Society. London.

Geographic Review.

Gérard de Rayneval, Joseph M.: De la Liberté des Mers. 2 v. Paris, 1811.

Goldschmidt, Levin: Origin of Commercial Institutions. Published in "Primitive and Ancient Legal Institutions" by Albert Kocourek and John H. Wigmore. Boston, 1915.

Great Britain: Annual Register; being the continuation of the "Historical Register."

Great Britain: Foreign and State Papers.

Great Britain: Historical Register, containing an impartial relation of all transactions, Foreign and Domestic. Vol. I., 1715.

Great Britain: Parliament: Sessional Papers; Commercial, 1903, No. 7.

Grote, George: History of Greece. Boston, 12 v., 1851-1856.

Grotius, Hugo: De jure belli ac pacis. Whewell trans., Cambridge, 1853. Carnegie trans., Washington, 1914.

Grotius, Hugo: Dissertation sur la Liberté des Mers. Trans. by Guichon de Grandpont. Paris, 1845. 
HALL, William E.: A Treatise on International Law. 4th Edit. Oxford, 1895.

Hayes, Carlton J.: Political and Social History of Modern Europe. 2 v. New York, 1916.

Hakluyt, Richard: Early English and French Voyages. New York, 1906.

Hakluyt, Richard: Principal Navigations. 12 v. Glasgow, 1903.

Herodotus: History. Trans. by Rawlinson. 4 v.

Hertslet, Sir Cecil: Canals and Waterways of Belgium. In Great

Britain: Diplomatic and Consular Reports. London, 1904.

Hill, David J.: History of Diplomacy. 3 v. London, 1914.

Hirst, Margaret E.: Life of Frederich List. New York, 1909.

Holdich, Thomas H.: Political Frontiers and Boundary Making. London, 1916.

Horne, Andrew: The Mirrour of Justices; written originally in the old French, long before the Conquest; and many things added by A. Horne, translated into English by William Hughes. London, 1768.

Hough, B. Olney: Ocean Traffic and Trade. Chicago, 1914.

Huet, Pierre D.: History of Navigation and Commerce of the Ancients. Iondon, 1717.

JOHNSON, Emory R.: Inland Waterways. Annals: American Academy of Political and Social Sciences; Supplement, September, 1893.

Johnson, Emory R.: Navigation Resources of American Waterways. United States: Conservation Conference, 1908. Washington, 1909.

Johnson, Emory R.: Ocean and Inland Water Transportation. New York, 1906.

Justice, Alexander: Of the Dominion of the Sea, in general, and of the British Seas, in particular. London, 1705.

Justinian: Institutes. Abdy and Walker trans. Cambridge, 1876.

KIRCHOFF, Alfred: The Sea in the Life of Nations. Annual Report of the Smithsonian Institute. Washington, G. P. O., 1902.

LAUGHTON, John K.: From Howard to Nelson. London, 1899. Leonard, William: Reports of cases Adjudged at Westminster in the Reign of Queen Elizabeth. London, 1663.

Lindley, W. H.: Great Britain: Report of the Royal Commission on Canals and Waterways. London, 1909. 
Lindsay, William S.: History of Merchant Shipping. 4r. 1876.

List, Frederich: The National System of Political Economy. Philadelphia, 1856.

Livius, Titus: History of Rome. 4 v. London edit., 1861.

MAHAN, Alfred T.: The Influence of Sea Power on History ; 16601783. Boston, 1890.

Mahan, Alfred T.: The Problem of Asia. Boston, 1900.

Mahan, Alfred T.: Some Neglected Aspects of War. Boston, 1907. Maine, Sir Henry: Ancient Law. London, 1870.

Martens, Charles de: Causes Célèbres du Droit des Gens. 5v. Leipzig, 1858-1861.

Martens, G. F. de; continued by C. de Martens, Saalfeld, Murhard, Samwer, Hopf, Stoerk, and Triepel: Recueil des Traites. 88 vols. 1791-1910.

McCulloch, John R.: Dictionary of Commerce. London, 1882.

McCulloch, John R.: A Treatise on Economic Policy. London, 1859.

Medows, Sir P.: Observations concerning the Dominion and Sovereignty of the Seas. London, 1689.

Merchant, E. O.: Comparison of American and European Waterways. National Waterways Commission. Washington, G. P. O., 1912.

Molloy, Charles: De jure maritimo et navali ; or, a Treatise of Maritime Affairs. 2 v. 9th Edit. London, 1769.

Mommsen, Theodor: Provinces of the Roman Empire. Trans. by William P. Dickson. New York, 1887.

Montesquieu, Baron de: Spirit of Laws. Trans. by Thomas Nugent. 2 v. London, 1878.

Moore, John Bassett: American Diplomacy. New York, 1905.

Moore, John Bassett: History and Digest of International Law. 8 v. Washington, G. P. O., 1906.

Moore, John Bassett: History and Digest of International Arbitrations. 6 v. Washington, G. P. O., 1898.

Moore, John Bassett: Law and Organization. American Political Science Review, Vol. ix, No. 1.

Moore, John Bassett: The Hague Conventions. Columbia University Quarterly. New York, December, 1914, pg. 10.

NAVY Records Society Publications: Laws and Customs of the Sea; A. D. 1205-1648. London, 1915.

Nys, Ernest: Le Droit International; les Principes, les Théories, les Faits. 3 v. Brussels, 1912. 
Nys, Ernest: Un Chapitre de l'Histoire de la Mer. Academie Royale Belgique; Lettres; Bulletin, Series 3, 1900.

ORTOLAN, Theodore: Règles Internationales et Diplomatie de la Mer. 2 v. Paris, 4th. Ed., 1864.

PARDESSUS, J. M. : Collection de Lois Maritimes Anterieures au XVIIIJ Siècle. 6 v. Paris, 1828-1845.

Pascal, Blaise de: Pensées; avec les notes de Voltaire. Paris, 1873. Paston Letters, The: Edited by J. Gairdner. 4 v. Edinburgh, 1910. Payne, E. J.: Voyages of Elizabethan Seamen to America. 2 v. Oxford, 1900.

Payne, E. J.: History of European Colonies. London, 1877.

Penn, Sir William: Memorials; 1644-1670. Collected by Granville Penn. 2 v. London, 1833.

Phillimore, Sir Robert J.: Commentaries on International Law. 3rd Edit. London, 1879-1889.

Phillipson, Coleman : The International Law and Custom of Ancient Greece and Rome. 2 v. London, 1911.

Pinon, René: La Mer Noire et la Question des Détroits. Revue des Deux Mondes. Vol. 29, 800. Paris, 1905.

Plutarch: Lives. Trans. by A. Stewart. 4 v. London, 1912.

Pufendorf, Baron, Samuel von: Of the Law of Nature and Nations. Notes by M. Barbeyrac. English version by Basil Kennett and Mr. Carew. London, 1729.

RALEIGH, Sir Walter: Works. 8 v. Oxford, 1829.

Ravenstein, E. G.: Martin Behaim. London, 1908.

Rawlinson, George: Phœnicia. New York, 1889.

Reclus, Elisée: Universal Geography. Engl. Edit., 1894.

Revue des Deux Mondes.

Revue de Droit International et de Legislation Comparée. Brussels, 1869 , to date.

Revue Generale de Droit International Publique. Paris, 1894, to date.

Robinson, Sir Christopher: Consulato del Mare relating to Prize Law. London, 1800.

Rolle, Sir Henry: Un Abridgment des Plusieurs Cases del Common Ley. 2 v. London, 1668.

SAINT MARTIN, Vivien de: Geographie Universelle. 7 v. Paris, $1892-$. 
Schoell, Maxmillian S. F.: Congrès de Vienne; Recueil de Pièces Officielles. 6 v. Paris, 1816.

Schomberg, A. C.: The Maritime Laws of Rhodes. Oxford, 1786. Reprinted in J. R. McCulloch's "Select Collect of Scarce and Valuable Economic Treatises." London, 1859.

Scott, James Brown: Cases on International Law. Saint Paul, 1906.

Scott, James Brown: The Hague Peace Conferences; 1899-1907. 2

จ. Baltimore, 1909.

Seeley, Sir John R.: The Expansion of England. London, 1884. Seeley, Sir John R.: The Growth of British Policy. 2 v. Cambridge, 1895.

Selden, Sir John: Mare Clausum; the Right and Dominion of the Sea. London, 1663.

Smith, J. R.: The Organization of Ocean Commerce. Univ. of Penn. Publications, No. 17. Philadelphia, 1905.

Spears, J. R.: Master Mariners. New York, 1914.

TEDDER, Arthur W.: The Navy of the Restoration. Cambridge, 1916.

Thacher, John Boyd: Columbus. 3 v. London, 1904.

Tudor, Owen D.: Mercantile Cases. 2 v. 3rd Edit. Philadelphia, 1873

Twiss, Sir Travers: The Law of Nations. 2 v. 2nd Edit. Oxford, 1884.

Twiss, Sir Travers: Monumenta Juridica; The Black Book of the Admiralty. 4 vols. London, 1876.

UNITED STATES: Bureau of Statistics; Statistical Abstract of Foreign Commerce. Washington, G. P. O., 1915.

United States: Department of Commerce and Labor; Commissioner of Corporations; Special Report; "Transportation by Water in the United States." 3 v. Washington, G. P. O., 1910.

United States: National Waterways Commission; Final Report; 62nd Cong., 2nd Sess., Senate Doc. No. 469. Washington, G. P. O., 1912.

United States: National Waterways Commission; Document No. 7; "European Waterways." Washington, G. P. O., 1909.

United States: National Waterways Commission; Senate Doc., No. 469 ; "The Development of Seaports and Waterways," by Admiral C. S. Sperry. Washington, G. P. O., 1912.

United States: National Waterways Commission; Doc. No. 20; 
"Railway Freight Rates, Inland Waterways, and Canals in Belgium," by Ethelbert Watts. Washington, G. P. O., 1911.

United States: Navigation Laws. Washington, G. P. O., 1915.

VATTEL, Emmerich de: Le Droit des Gens. 3 v. Chitty trans., Philadelphia, 1863. Carnegie trans., Washington, 1916.

WEBER-EBENHOF, Alfred von: Waterways in Europe. International Quarterly, Vol. 9, No. 1, pg. 210. New York, 1904.

Weeden, William B.: Economic and Social History of New England; 1620-1789. 2 v. Boston, 1890.

Welwood, William: An Abridgement of all Sea-Lawes; which are to be found among any people or nation, upon the coasts of the Great Ocean and the Mediterranean Sea. London, 1613.

Westlake, John: International Law. 2 v. Cambridge, 1910-1913.

Wheaton, Henry: Elements of International Law. Lawrence edit., Boston, 1855. Dana edit., Boston, 1866. Phillipson edit., London, 1916.

Whiteway, R. S.: Rise of Portuguese Power in India; 1497-1550. Westminster, 1899.

Williamson, James A.: Maritime Enterprise; 1485-1558.

Wynne, William: Life of Sir Leoline Jenkins. 2 v. London, 1724.

ZIMMERN, Helen: The Hansa Towns, New York, 1895.

Zouche, Richard: The Jurisdiction of the Admiralty of England Asserted. London, 1663. 



\section{INDEX}

AA, navigation of. See Polish Waterways, 224.

Abuna, navigation of. See Bolivian Waterways, 297.

Aby Lagoon, navigation of, 120.

Addo, navigation of, 322 .

Adige, boundary, 180;

navigation, 180 ;

tolls prohibited, 180;

war-vessels excluded from, 180.

Adjarra. See Ajarra, 322.

Adriatic, exclusive claims of Venice to, 58, 60;

tolls levied on, navigation, 61 .

Egean, trade route, 17.

Afghanistan, isolation of, 166.

Africa, inland waterways of, 322 ;

importance of, 162 .

Aguan, navigation of, 260.

Aguarico, navigation of. See Colombian Waterways, 229-300.

Ajarra, navigation of, 322.

Aka, boundary, 323.

Akobo, boundary, 323 .

Akpakorum. See Akwayafe, 323.

Akwayafe (Akawajafe), boundary, 323;

fisheries, 323 ;

navigation, 323.

Alaska, cession of, to the United States, 122.

Albert Nyanza, international supervisory commission, 323;

diversion of waters, 323

navigation, 323.

Alexander VI, Pope, Demarcation Line of, 66;

Papal Bulls of, 64, 67;

tribute of, to Columbus, 46.

Alexander, Emperor of Russia, ukase of (1824), 121.

Alphonso X, King of Castile, 38 .

Amakuru, boundary, 292;

navigation, 292.

Amalfi, Tables of, 26, 33, 34, 36 .

Amazon, 159, 163 ;

Amur, 10;

navigation of, 293-96.

boundary, 354, 363;

navigation, 354.

Ancona, Statutes of, 29.

Anebir, boundary, 323;

fisheries, 323 ;

navigation, 323 .

Ange de Ubaldis, on Mare Liberum, 102. 
Angoustrine Canal, boundary, 180.

Anjibir. See Anebir, 323.

Annecy Lake, boundary, 180.

Anyalo (Anube), boundary, 323;

fisheries, 323 ;

navigation, 323 .

Apa, navigation of ; war-vessels prohibited on, 308.

See Paraguayan Waterways.

Apalachicola, boundary, 260.

Apure, navigation of, 296, 299.

Aquidaban, navigation of ; war-vessels prohibited on, 308.

See Paraguayan Waterways.

Arabian Sea, trade-route, 17.

Araguary, navigation of, 296.

Aravo, 180.

Arawari. See Araguary, 296.

Arbitration, of Bering Sea Claims, 125.

Arctic, dominion on, Danish, 58; Russian, 10; Swedish, 58.

Argentine Waterways, navigation of, 296, 297.

Argun, boundary, 354, 363; navigation, 354 .

Aristotle, globular theory of, 45 .

Arkansas, boundary, 261 ;

diversion of waters of, 261 ;

navigation, 261.

Armada, destruction of the, 78 .

Armed Neutrality, institution of the, 91, 92.

Aroangwa. See Loangwa, 335.

Aruwimi, supervisory commission established, 324;

navigation, 324.

Arve, boundary in, 181.

Asiatic Waterways, 354.

Asiento (1713), Spanish, 90.

Assyria, maritime resources of, 16.

Atbara, boundary, 324.

diversion of waters, 324 .

Athens, sea-power of, 18;

universal market, 19.

Atlantic, English claims on North, 58;

Portuguese sovereignty on South, 58.

Atrato, navigation of, 299.

See Colombian Waterways.

Aua. See Awa, 324.

Augustowo Canal, navigation of, 224.

See Polish Waterways.

Australian Waterways (Murray), 363.

Aveto, boundary, 181 .

Awa, boundary, 324 ;

fisheries, 324 ;

navigation, 324.

BABYLON, maritime resources of, 16;

navigation laws of, 27. 
Bachorze Canal, navigation of. See Polish Waterways, 224.

Bacon, Lord Francis, on Sea-Power, 52.

Balboa, Vasco N. de, discovery of Pacific Ocean by, 48.

Balfour, Mr. A., on necessity of Sea-Power, 110, $n$.

Baltic, attempted neutralization of, 132 ;

dominion on, Danish, 58; Russian, 10; Swedish, 58;

neutrality of, denied, 93 ;

restriction of, attempted, 91, 92, 93.

Barbary States, impositions of, 119; war with, 119.

Barima, boundary, 297 ;

navigation, 297.

Baro, boundary in, 324 .

Bayonne Decree (1808), 136.

Beirut, Mesopotamian trade of, 17.

Belgium, competition of railways and waterways in, 160 .

Belize, boundary, 261 ;

navigation, 261.

Beni, navigation of, 297.

Benue, boundary, 324 ;

navigation, $324,325,341$.

Beresina, navigation of.

Beresina Canal, navigation of. See Polish Waterways, 224.

Bering Sea, jurisdictional claims in, 123;

restriction of fisheries in, 121; renounced by treaty, 121, 122.

Bermejo. See Vermejo, 321.

Bewa (Biwa), Boundary in, 325.

Bidassoa, boundary, 181;

fisheries, 181 ;

navigation, 181, 182.

Bija. See Imba, 332.

Black River Canal, navigation, 263-64 (Canals);

tolls prohibited, 264.

Black Sea, access denied to, 43 ; navigation of, 11, 131; restrictions on,

132; Russian territory bordering, 10; Trade-Route on, 43.

Black Volta, boundary, 325;

navigation, 325 .

Blake, Robert, English fleet in command of, 86 .

Bleisse, boundary, 182;

fisheries, 182.

Blockade, effectiveness of, 133, 138.

Blue Nile, boundary in, 325 .

Bolivian Waterways, navigation of, 297, 298.

Borneo, Waterways of, navigation of, 166, 354-55;

tolls prohibited, 354.

Bosphorus, control of, 43 ; restrictions on navigation of, 132; Trade-Route through, 63; Turkish dominion over, 11.

Boug. See Polish Waterways, Bug, 224.

Boundary, Demarcation of Fluvial, on

Adige, 180;

Aka, 323;

Akobo, 323;
Akwayafe, 323 ;

Amakuru, 292 ;

Amur, 354 ;
Anebir, 323 ;

Angoustrine Cana 1 , 180 ; 
Boundary, Demarcation of Fluvial, on (Continued) :

Annecy Lake, 180;

Anyalo, 323;

Apalachicola, 260;

Argun, 354;

Arkansas, 261;

Arve, 181;

Atbara, 324;

Aveto, 181 ;

Awa, 324;

Barima, 297;

Baro, 324 ;

Belize, 261;

Benue, 324;

Bewa, 325;

Bidassoa, 181;

Black Volta, 325;

Bliesse, 182;

Blue Nile, 325 ;

Borneo Waterways, 355 ;

Bourget Lake, 185;

Bourna Sola Lake, 185 ;

Bug, 186;

Cajet, 326 ;

Cambompo, 326 ;

Cerchio, 186 ;

Chad Lake, 327 ;

Champlain Lake, 261;

Chiloango, 327;

Chilwa Lake, 328;

Chiuta Lake, 328;

Chobe, 328;

Cisa, 186 ;

Colorado, 266, 267 ;

Congo, 328;

Constance Lake, 186, 187 ;

Cross, 329 ;

Cunene, 330;

Cypress Lake, 261-62 ;

Dakka, 330 ;

Danube, 189, 191, 192 ;

Detroit, 261-62 ;

Dnieper, 199 ;

Dniester, 200;

Drewenz, 201;
Elster, 205;

Ems, 205, 206 ;

Enza, 206;

Erie Lake, 261-62, Lake of the Woods, 268 ;

Faro, 330;

Floss-Graben, 206 ;

Fly (New Guinea), 358 ;

Foron, 206, 207 ;

Fowl Lakes, 261-62;

Gaeresi, 331 ;

Garda Lake, 207 ;

Geneva Lake, 207;

Gila, 268;

Glan, 209;

Goro, 209;

Great Lakes, 269-70;

Great Scarcies, 331;

Guadiana, 209;

Hermance, 209 ;

Honde, 332 ;

Hondo, 270;

Huron Lake, 261-62, 271 ;

Imba, 332;

Inn, 210 ;

Irtish, 360 ;

Jipe Lake, 332 ;

Jora, 332 ;

Juba, 332, 333 ;

Kalombo, 333 ;

Kara-Kourt, 211;

Kassai, 333;

Kilunga, 333 ;

Komadugu, 334;

Kongama, 211 ;

Konge-Aa, 211;

Kouban, 211 ;

Kubango, 334;

Kuilu, 334;

Kulusulo, 334;

Lac Bois Blanc, 261; Nyasa Lake, 343;
La Croix Lake, 26162 ;

Laiblach, 211; 261-62, 272;

La Laire, 211;

Lauter, 212;

Lax-Elf, 212;

Leck, 212;

Liscoarta, 212;

Little Vermillion Lake, 261 ;

Loangwa, 335;

Luapula, 336 ;

Lucalla, 337 ;

Lukualli, 337 ;

Lys, 213;

Maggiore Lake, 213;

Magra, 214;

Maia, 338;

Maieteb, 338;

Makona, 338;

Makwoi, 338;

Mao Bulo, 339;

Mao Kalo, 339 ;

Mao Kam, 339;

Mao Tati, 339;

Mareb, 339;

Marquari, 339;

Mauwa, 339 ;

Meli, 340;

Memphremagog Lake, 261-62;

Mincio, 218, 219;

Mississippi, 274, 276 ;

Morno, 341;

Morro, 341 ;

Moselle, 219, 220;

Mweru, 34l ;

Nahe, 220 ;

Namecan Lake, 26162 ;

Neisse, 221;

Niagara, 261, 277;

Nicaragua Lake, 278;

Niger, 341;

Nile, 343 ;

Nuon, 343 ; 
Boundary, Demarcation of Fluvial, on (Continued) :

Ocpara, 343, 344;

Oder, 221 ;

Ontario Lake, 261-62, 278-79;

Orange, 344;

Oure, 222;

Oyapock, 304 ;

Parana, 309;

Paswig Lakes, 222;

Paswig, 222;

Pibor, 344;

Pigeon, 261-62 ;

Po, 222, 223, 224;

Podhorce, 224;

Porta, 225 ;

Prosna, 225;

Pruth, 226;

Pungwe, 345 ;

Puycerda Canal, 227 ;

Queich, 227;

Rafin Donga, 345;

Rahad, 345;

Rainy Lake, ) 261-62,

Rainy River, 280 ;

Raour, 227;

Rhine, 228, 229, 230;

Rhone, 239, 240;

Rio Grande, 281, 282;

Rovuma, 345;

Rudolph Lake, 345;

Ruo, 345, 346;

Saal, 240 ;

Sacchi, 346;

St. Croix, 261-62, 28384;

Boundary Waterways,

Austria/Italy, 182;

Austria/Poland, 182 ;

Austria/Sardinia, navigation of, 182 ;

Austria/Servia, navigation of, 182 ;

Baden/Switzerland, fisheries, 182 ;

Belgium/France/Germany, navigation of, 183;

Belgium/France/Germany/Netherlands, navigation of, 183;

Belgium/Netherlands, fisheries, 183;

navigation, 183 ;

Bolivia/Brazil, navigation of, 298;

Brazil/Colombia, navigation of, 298 ;

St. Clair $\} \begin{aligned} & 261-62 \text {, } \\ & 269-70,\end{aligned}$
St. Clair Flats Canal, Sure, 250;

St. Clair

Tagliata, 250;

Takutu, 318;

Tana, 349;

Tanganyika Lake, 349 ;

Tendo, 350;

Terneuzen Canal, 251;

Ticino, 252;

Tiel, 350;

Tornea, 252;

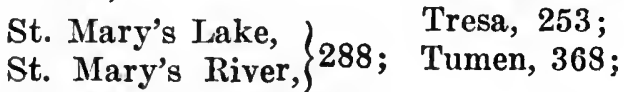

St. Mary's (Florida), 288 ;

Ulafu, 351 ;

Urbelcha, 253;

Ussuri, 369;

Valcarlos, 253;

Vanera, 253;

Victoria Nyanza, 351, 352 ;

Vistula, 254, 255;

Volta, 352;

Warthe, 255;

Weisse-Elster, 256;

Wom, 352 ;

Worms, 257, 258;

Yalpouk, 258;

Yederam, 352;

Yssel, 258;

Zambesi, 353 ;

Zatsan Lake, 375;

Zborowski, 258;

Zwin Canal, 260. 


\section{Boundary Waterways (Contimued)}

Brazil/Uruguay, navigation of, 298;

Canada/United States, international supervisory commission, 263; diversion of waters, 263 ;

fisheries, 263; navigation, 261-263;

France/Germany, navigation of, 183 ; navigation of, in Africa, 325;

France/Liberia, navigation of, 325 ;

France/Sardinia, ferry service on, 183-84;

France/Spain, 184;

France/Switzerland, fisheries, 184;

Germany/Great Britain, fisheries, 326 ; navigation, 326 ;

Hanover/Lubeck, navigation of, 184;

Italy/Switzerland, fisheries, 184, 185;

Netherlands/Prussia, fisheries, 185; navigation, 185;

Portugal/Spain, navigation of, 185; Russia/Sweden, navigation, 185.

Bourget Lake, boundary, 185.

Bourna Sola Lake, boundary, 185.

Boyana, navigation of, $185-86$.

Brazil, inclusion of, by Demarcation Line, 68 .

Breda, Treaty of (1667), recognizes Flag Tribute, 87, 88.

Bristol Channel, British claim over, 130 .

British Orders in Council (1807), 135.

Bromberg Canal, navigation of, 186; (Polish Waterways), 224.

Bruges, Purple Book (Laws) of, 39.

Brunhausen Toll, imposition of, 203, 204.

Brussels (1890), Congress of, 113.

Bug (Black Sea), boundary, 186; navigation, 186.

Bug (Vistula System), navigation of, 224.

Bulgaria, merchant flag of, 165.

Burroughs, Sir John, on Laws of Oleron, 36 ;

Busi, navigation of, 326 . on Sovereignty of the Seas, 100.

CABOT, John, Letters Patent issued to, 70;

discoveries of, 48 .

Cadiz, strategic commercial site of, 15 .

Cajet, boundary, 326.

Cambodia Lake. See Grand Lake of Cambodia, 359.

Cambompo, boundary, 326 .

Campo, navigation of, 326 .

Canals. See also: Individual Entries.

Canals, Canadian, navigation of, 263 ; tolls prohibited, 265;

United States, navigation of, 264; tolls prohibited, 265.

Canton, navigation of, 355,356 ; tolls prohibited, 357 .

Cao-Bang, navigation of, 356 ; tolls prohibited, 357 .

Cape Finisterre, recognition of English Sea-Sovereignty to, 89.

Cape of Good Hope, discovery of, 44. 
Caqueta. See Yapura, 322.

Carthage, commercial prosperity of, 15 ;

destruction of, 57 ;

dominion of, over Mediterranean, 56;

sea-trading laws of, 32 ;

war of, with Marseilles, 56.

Cascade Canal, navigation of. See Columbia, 267.

Casiquiare Canal, navigation of. See Amazon, 293; Orinoco, 303.

Caspian Sea, navigation, 356; trade route on, 17; war-vessels regulated, 356.

Cassai. See Kassai, 333.

Catahouche. See Apalachicola, 260.

Catherine II, Empress of Russia, 11.

Cauca (Madeira System), navigation of. See Colombian Waterways, 299.

Cavally, navigation of, 326 .

Cecil, Lord Robert, on British Blockade, 138.

Celilo Canal, navigation of. See Columbia, 267.

Cerchio, boundary, 186.

Ceylon, Pearl Fisheries of, 128.

Chad Lake, fisheries, 327 ; navigation, 326.

Chadda. See Benue, 324.

Chamalecon, navigation of, 265, 266.

Chambira (Chambira-Yacu), navigation of. See Ecudorean Waterways, 300 ;

Peruvian Waterways, 312.

Chambly Canal, navigation, 263 ; tolls prohibited, 265.

Champlain Canal, navigation, 264; tolls prohibited, 265. See Canals.

Champlain Lake, boundary, 261 ; commission of supervision, 262 ; diversion of waters, 261; fisheries, 266; navigation, 261, 266.

Chancellor, Richard, at Moscow (1553), 50.

Channel Islands, English retention of, 75 .

Chapare, navigation of, 298.

Chari. See Shari, 347.

Charlemagne, defeat of, by Venice, 60; commerce and navigation fostered by, 21.

Charles II, King of England, 88.

Charles V, King of France, 38.

Charles V (Charles I, King of Spain), Emperor, Spanish Sea-Power under, 69.

Chattahoochee. See Apalachicola, 260.

Chesapeake Bay, jurisdictional claims over, 130 .

Chicamocha. See Colombian Waterways: Sogamosa, 299.

Chico, navigation of. See Argentine Waterways, 296.

Chien-Tang. See Tsien-Tang, 357, 368.

Chiloango, boundary, 327.

Chilwa Lake, boundary, 328.

Chimore, navigation of, 298, 299.

China, territorial losses of, 10; waterways of, 169 .

Chinese Inland Waterways, navigation, 356, 357;

tolls prohibited, 358 .

Chioggia, Venetian naval victory off, 61, 62 . 
Chiuta Lake, boundary, 328.

Chobe, boundary, 328.

Choluteca, navigation of, 266.

Chubut, navigation of. See Argentine Waterways, 296.

Chu-kiang. See Canton, 355, 357.

Cipango (Japan), Island of, Magellan's voyage, 49.

Cisa, boundary, 186.

Coca (Napo System), navigation of. See Colombian Waterways, 299 ;

Coco, navigation of, 266, 271.

Ecuadorean Waterways, 300.

Cockburn, Chief Justice, on Sovereignty of the Seas, 108;

Coke, Sir Edward, on jurisdiction in the Four Seas, 74, $n$;

on Mare Liberum, 100.

Colombian waterways, navigation of, 299,300 .

Colonists, early, in Africa, 15.

Colorado, navigation of. See Argentine Waterways, 296.

Colorado boundary, 266, 267; commission of supervision, 267; diversion of waters, 267 ; navigation, 266-67; obstructions forbidden, 267.

Columbia, navigation, 267 ; sea-going vessels on, 159.

Columbus, voyage of, 42, 46: commercial significance of, 4 .

Commerce, international water-borne, 7 ; isolation without, 9 ; revival of, under Charlemagne, 21.

Commission, International Supervisory, on:

Albert Nyanza, 323;

Aruwami, 324;

Boundary Waterways

(Canada/United States), 263;

Champlain Lake, 263;

Colorado, 267;

Congo, 328;

Cypress Lake, 261, 263;

Danube, 191, 192, 193, 194, 195, $196,197,198$;

Detroit, 261, 263;

Edward and George Lake, 330;

Erie Lake, 263;

Fowl Lake, 261, 263;

Great Lakes, 263, 270;

Huron Lake, 261, 263;

Kalombo, 328;

Kandcko, 328;

Kassai, 328;

Kivu Lake, 328;

Kuilu, 334;

Kwa, 335;

Lac Bois Blanc, 261, 263;

La Croix Lake, 263;

Lake of the Woods, 261, 263;

Leopold II Lake, 335 ;

Little Vermillion Lake, 261, 263 ;

Llivia Canal, 212;

Loange, 328;
Lobai, 336;

Lomami, 328, 336;

Luapula, 336;

Lukualli, 337 ;

Lukuga, 337 ;

Lulanga, 337;

Makua (Ubangi System), 328;

Memphremagog Lake, 261, 263;

Mfini, 340;

Milk/St. Mary System, 274;

Mweru, 34l;

Namecan Lake, 261, 263;

Niagara, 263;

Ontario Lake, 261, 263 ;

Pama, 344;

Pigeon, 261, 263;

Pruth, 226, 227;

Rainy Lake, 261, 263;

Rainy River, 263;

Rhine, 228, 229, 231, 232, 233, 234, 235, 237;

Rhine-Rhone Canal, 238;

Rio Grande, 281 ;

Rusizi, 346;

St. Clair Flats Canal, 269, 270;

St. Clair Lake, 270;

St. Clair River, 270;

St. Croix, 261, 263;

St. Francis, 261, 263 ; 
Commission, International Supervisory, on (Contimued) :

St. John, 261, 263 ;

St. Lawrence, 261-63;

St. Mary's Lake, 269, 270;

St. Mary's River, 270;

St. Mary's (Milk System), 274;

Saisaginaga, 261-63;
Sanga, 346;

Superior Lake, 269, 270;

Tanganyika Lake, 349;

Tumba, 350;

Ubangi, 351;

Ugala, 351.

Conception Bay, claim of dominion over, 130 .

Congo System, demarcation of boundaries in, 328;

international supervisory commission on, 328 ;

navigation of, 328, 329 .

Congress of Brussels (1890), 113.

Congress of Vienna (1815), 5 .

Coni, navigation of, 300 .

Consolato del Mare, 29, 34, 35, 36, 40.

Constable, Sir John, case of 74 .

Constance Lake, access from sea to, 165 ;

boundary, 186, 187;

diversion of waters, 187 ;

fisheries, 187 ;

international traffic on, 164 .

navigation of, $186,187,188$.

Constantinople, capture of, 43 ; control of straits at, 12 .

Consulate of the Sea. See Consolato del Mare.

Continuous Voyage, doctrine of, 137.

Contraband, Law of, 133, 137.

Copenhagen, bombardment of, 93: protest of Russia, 93.

Corioco, navigation of, 300 .

Cornwall Canal, See Canals, 263-64.

navigation of,

tolls prohibited.

Corporate Ownership of Vessels, 139, 140-46.

Corporations, enemy share-holders in, 139.

Crimean War, Russian territorial expansion after, 10.

Crocodile, navigation of, 346 .

Cross, boundary, 329; fisheries, 330 ; navigation, 330 ; tolls prohibited, 330.

Crusades, the Holy, influence of, on civilization, 23: on maritime enterprise, 43.

Cuango. See Lukualli, 337.

Cunene, boundary, 330 .

Curaray (Napo System), navigation of. See Ecuadorean Waterways, 300;

Peruvian Waterways, 312.

Cypress Lake, boundary, 261; supervisory commission on, 263; diversion of waters, 262; fisheries, 263 ; navigation, 263-63.

Cyprus, Venice victorious in sea-fight off, 61,62 .

DA gama, Vasco. See Gama, Vasco da.

Dakka, boundary, 330.

Damme, Judgments of, 39 .

Danube, 12, 165 ;

boundary, 189, 191, 192;

commercial importance of, 163 ; 
Danube (Continued) :

commission of supervision, 191-198;

fisheries, 188, 189, 198;

navigation, 188-199;

trade-route, 53,152 ;

war-vessels restricted, 199.

Danube-Rhine Canal, project of Charlemagne for, 21 .

Dardanelles, control of, 43; restrictions on, 132.

Dchawe. See Shavoe, 347.

Declaration of Paris (1856), blockade regulated by, 138 .

de Gama, Vasco. See Gama, Vasco da.

De la Queich. See Queich, 227.

Delaware Bay, jurisdictional claim over, 130.

Demarcation Line, Pope Alexander VI establishes, 66;

Portuguese and Spanish rights, 65-66.

Denmark, claims of, to Marginal Sea, 129.

De Ruyter, invasion by, of Thames, 87.

Deseado, navigation of. See Argentine Waterways, 296.

Detroit, boundary, 261; commission of supervision, 263; diversion of waters, 269 ; fisheries, 262 ; navigation, 261-263; war-vessels restricted, 269-70.

Diaz, Bartholomew, voyage of discovery, 44.

Discovery, Voyages of, 3.

Diversion, Impounding and Utilization of Waters. See also: Obstructions, prohibition of, on navigable course.

Albert Nyanza, 323;

Arkansas, 261 ;

Atbara, 324;

Boundary Waterways,

(Canada/United States), 26162 ;

Champlain Lake, 261;

Colorado, 267 ;

Constance Lake, 187 ;

Cypress Lake, 262;

Detroit, 269 ;

Erie Lake, 270;

Fowl Lakes, 261;

Great Lakes, 269, 270;

Huron Lake, 270;

Lac Bois Blanc, 261-62;

La Croix Lake, 262;

Lake of the Woods, 272;

Little Vermillion Lake, 262;

Llivia Canal, 212;

Memphremagog Lake, 262;

Meuse, 218;

Milk/St. Mary System, 274;

Namecan Lake, 261-62;

Niagara, 263;

Niger, 342;

Nile, 343;
Ontario Lake, 263;

Pigeon, 261-62;

Puycerda Canal, 227;

Rainy Lake, $\{261-63$;

Rio Grande, 282;

Saal, 241;

St. Clair Flats Canal, 269-270;

St. Clair Lake,
St. Clair River, 261-63;

St. Croix, 261-63;

St. Francis, 263 ;

St. John, 263 ;

St. Lawrence, 261-62 ;

St. Mary's Lake,
St. Mary's River, 261-62;

St. Mary's/Milk System, 274;

Saisaginaga, 261-262;

Semliki, 346-47;

Sobat, 348;

Superior Lake, 261-62;

Tartares, 250;

Tort, 252;

Tsana Lake, 350 ;

Vanera, 253;

Zuid-Willems-Waart, 259. 
Djuba. See Juba, 332.

Dnieper, boundary, 199; navigation, 199: (Polish Waterways), 224.

Dniester, boundary, 200; navigation, 199, 200: (Polish Waterways), 224.

Doubs, fisheries, 200; navigation, 200.

Douro, navigation of $200,201$.

Dover $(1670)$, Treaty of, 88 .

Drake, Sir Francis, Voyage of Circumnavigation, 71.

Dredging, Regulation of, in River Tendo, 350.

Drewenz, boundary, 201; navigation, 201.

Drina, navigation of, 201.

Dubissa, navigation of. See Polish Waterways, 224.

Dues. See also: Tolls.

Dues, Maritime, levied on Pontus, 56.

Düna, navigation of, 201-202; see also: Polish Waterways.

Dutch East India Company, 72.

Dwina. See Düna, 201.

ECUADOREAN Waterways, navigation of, 300 .

Edward III, King of England, Laws of Oleron, 38.

Edward and George Lake, navigation of, 330 .

Egypt, commerce of, 16; reclusive policy, 9: abandoned, 17 ; Sea-Power of, 18; strategic commercial site of, 15.

Elbe, invasion of, by Northmen, 22 ; navigation of, 202, 203, 204; tolls prohibited, 202, 203, 204, 205.

Eleanor of Guienne, 37.

Elizabeth, Queen of England, denies Spanish Sovereignty of the Seas, 71.

Elster, navigation of, 205.

Embargo, United States establishes (1807), 135.

Ems, boundary, 205, 206; navigation, 205, 206.

England, sovereignty of on Four Seas, 82.

English-Dutch War, important engagements of, $86,87 n$; termination of, 87 .

Enza, boundary, 206.

Eratosthenes, globular theory of, 45.

Eric the Red, voyage of, 4.

Erie Barge Canal, navigation, 263; tolls prohibited, 262-63.

Escaut. See Scheldt, 243.

Espierre Canal, 206.

Euphrates, 53; navigation of, 358.

European Waterways, 180.

Euxine (Black) Sea, trade-routes on, 14, 17.

FARO, boundary, 330; fisheries, 331; navigation, 330-331.

Farran's Point Canal, navigation, 263; tolls prohibited, 264.

Fatiko, navigation of. See Niger, 341.

Ferdinand and Isabella, Columbus at Court of, 46 .

Ferry Service, Regulation of, on:

Boundary Waterways of France and Sardinia, 183-184;

Rhine, 233, 235.

Fisheries, Inland, Mutual Enjoyment of, in :

Akwayafe, 323;

Anebir, 323 ;

Anyalo, 323;
Awa, 324;

Bidassoa, 181, 182;

Bliesse, 182; 
Fisheries, Inland, Mutual Enjoyment of, in (Continued) :

Boundary Waterways of :

Baden and Switzerland, 182;

Belgium and The Netherlands, 183 ;

Canada and The United States, 261 ;

France and Switzerland, 184;

Germany and Great Britain, 326;

Italy and Switzerland, 184-185;

Netherlands and Prussia, 185;

Chad Lake, 327 ;

Champlain Lake, 263;

Constance Lake, 187 ;

Cross, 330;

Cypress Lake, 263;

Danube, 188, 189, 198 ;

Detroit, 270;

Doubs, 200;

Erie Lake, 270;

Faro, 330-331.

Fowl Lakes, 263;

Garda Lake, 207 ;

Geneva Lake, 207, 208;

Great Lakes, 269, 270;

Huron Lake, 270;

Imba, 332;

Inn, 210;

Jacobs-Elf, 210;

Kilunga, 333 ;

Komadugu, 334;

Lac Bois Blanc, 263;

La Croix Lake, 263;

Lake of the Woods, 263;

Little Vermillion Lake, 263;

Lugano Lake, 212, 213 ;

Maggiore Lake, 213, 214;

Makona, 338;

Mao Kalo, 339;

Mao Bulo, 339 ;

Mao Kam, 339;

Mao Tati, 339;

Memphremagog Lake, 273 ;

Meuse, 217;

Fisheries, Sea, 103; international participation in, 114; licenses for, 80 ;

Queen Elizabeth protests Danish claims to, 95;

restrictions on, in Mediterranean, 56;

in North Atlantic, 93;

in North Sea, 79, 94;

right to enjoyment of, 81.
Minho, 219;

Morno, 341;

Muni, 341;

Namecan Lake, 263;

Niagara, 270, 278;

Ontario Lake, 270, 279;

Paswig, 222;

Pigeon, 263;

Pruth, 227;

Rafin Donga, 345;

Rainy Lake, 263;

Rainy River, 263;

Red River, 280, 281;

Rhine, 228, 234-35, 236-38;

Rhine-Scheldt Connecting Waters, 239 ;

Rhone, 240;

Saal, 241 ;

Sabine, 282;

St. Clair Flats Canal, 270;

St. Clair Lake, 269-70, 283;

St. Clair River, 270, 283;

St. Croix, 283, 284;

St. Francis, 263;

St. John, 285;

St. Lawrence, 263, 287-88;

St. Mary's Lake, 269-70, 288;

St. Mary's River, 270, 288;

St. Mary's (Milk System), 274;

Saisaginaga, 263 ;

Sarre, 242;

Save, 243;

Scheldt, 245;

Superior Lake, 270;

Tendo, 350;

Tiel, 350;

Tornea, 252;

Trave, 253;

Tresa, 253;

Utamboni, 351 ;

Wom, 352;

Yederam, 352.

Fiske, John, on spherical form of World, 45. 
Flag, homage to, $77, .78,79,86,95,97$; recognized by Treaty of Breda, 88 :

by Treaty of Westmin. ster; 89 ;

renounced (1806), 106 .

Flag, Maritime, use of, 164.

Flag, salute to, 115.

Fleet System, Spanish, $84 n$.

Floss-Graben, boundary, 206; navigation, 206.

Fluvial Navigation. See Navigation, Freedom of Inland.

Fly River, boundary, 358; navigation, 358; tolls prohibited, 358.

Fogones, navigation, 308; war-vessels prohibited, 308. See Paraguayan Waterways.

Forced Anchorages, 152.

Foron, boundary, 206, 207.

Four Seas, definition of the 73 ; sovereignty on the, 74 .

Fowl Lakes, boundary, 262; diversion of waters, 263; fisheries, 263 ; navigation, 262-63.

France, competition of railways and waterways in, 160 .

Francis I, King of France, ignores Spanish claims, 70.

Freedom of the Seas, effect of early Sea-Laws on, 29; principles of, 13, 28, 53,102 ;

recognition of, 101: in Roman Law, 104;

restrictions on, in Bering Sea, 121:

during war, $4,110,133,149$ :

voluntary, 112,113 .

Fulton, Robert, invention by, of steamship, 156.

GAERESI, boundary, 331 ;

Gallegos, navigation of, 296. See Argentine Waterways.

Galops Canal, navigation, 263; tolls prohibited, 264.

Gama, Vasco da, all-sea route discovered by, 48; voyage of, $42,44,47$.

Gambella. See Baro, 324.

Gambia, navigation of, 331 .

Gambier, Admiral, Revised Instructions of, concerning Flag-Homage, 106.

Ganale. See Juba, 332.

Garda Lake, boundary, 207; fisheries, 207; navigation, 207.

Geneva Lake, boundary, 207; fisheries, 207, 208; navigation, 208; traffic on, 164.

Genoa, claim of, to Ligurian Sea, 62; sea-trade of, with East, 23.

Gentilis, Alberico, Advocatio Hispanica of, 72; on Mare Clausum, 71, 81.

Gera, navigation of, 208.

Ghent, Treaty of (1814), 119; slave trade in, 120.

Ghent Canal. See Terneuzen Canal, 251.

Gibraltar, cession of, to England, 90.

Gila, boundary, 268; navigation of, 268 .

Glan, boundary, 209.

Goascoran, navigation of, 268, 269.

Godfrey of Bouillon, Holy Crusade of, 22.

Gongola, navigation of, 341. See Niger.

Goro, boundary, 209.

Grand Canal, navigation, 259; tolls prohibited, 357-58.

Grand Lake of Cambodia, fisheries, 359; tolls prohibited, 359. 
Great Britain, claims of, to extensive bays, 129 : to marginal sea, in Ceylon, 128; protest of, respecting Bering Sea claims, 124.

Great Lakes, boundary, 269-70; commission of supervision, 270; diversion of waters, 270 ; fisheries, 270 ; navigation, 269, 270; traffic on, 161 ; war-vessels restricted, 269.

Great Scarcies, boundary, 331 ; navigation, 331.

Greece, maritime enterprise of, 15, 27 : supplants Phœnicia, 19; trade with Euxine, 18.

Greeks, voyages of early, 4.

Grotius, on fluvial navigation, 153, 154; on Mare Liberum, 72, 80, 102.

Guabiare. See Colombian Waterways: Guaviare, 299.

Guadiana, boundary, 209 ; navigation, 209.

Guaviare, navigation of, 299. See Colombian Waterways.

Guayape, navigation of. See Honduras: Patuca, 270-71.

Gulf of Mexico, appropriation of, by Spain, 58.

HALL, W. E., on Freedom of the Seas, 105; on present extent of the Marginal Sea, 127.

Han-kiang, navigation, 359 ; tolls prohibited, 357-58.

Hanseatic League, constitution of, 50 ; Ordinances of, 26 ; trade of, 50.

Harfleur, Castilian trade with, 38.

Henry VII, King of England, ignores Portuguese and Spanish claims, 70.

Hermance, boundary, 209.

High or Open Sea, definition of, 118.

Hoang-ho, navigation, 359 ; tolls prohibited, 357-58.

Holland, invasion of, by France, 89.

Holy Roman Empire, Princes of, impose fluvial tolls, 153.

Honde, boundary, 332.

Hondo, boundary, 270; navigation, 270.

Hondt, navigation of, 209, 210.

Honduras, navigation of waterways of, 169, 270, 271.

Huallaga, navigation of, 312. See Peruvian Waterways.

Huangpoo. See Whangpoo, 357, 370.

Hun-ho, navigation, 359-60; tolls prohibited, 357-58.

Hun-ho (Pai-ho System), navigation, 360; tolls prohibited, 357-58.

Huron Lake, boundary, 271; commission of supervision, 263; diversion of waters, 270 ; fisheries, 261-63; navigation, 269-70; war-vessels restricted, 269-70.

Hwai-ho, navigation, 359 ; tolls prohibited, 357-58.

Hwang-ho. See Hoang-ho, 357, 359.

Hyabary. See Peruvian Waterways: Yavari, 312.

Hydrum, defeat at, of Persians, 55.

ICA. See Putumayo, 317.

Imba, boundary, 332; fisheries, 332 ; navigation, 332.

Imperial Canal. See Grand Canal, 357, 359.

Impounding of Waters. See Diversion, Impounding and Utilization of Waters.

Impressment of Seamen, 119.

Indian Ocean, appropriation of, by Portugal, 58 .

Indus, navigation of, 360 ; trade-route on, 17.

Inirida, navigation of, 299. See Colombian Waterways. 
Inland Waterways. See: Boundary, Demarcation of.

Boundary Waterways.

Commission, International Supervisory.

Diversion of Waters.

Dredging, Regulation of.

Ferry Service, Regulation of.

Fisheries, Inland, Mutual Enjoyment of.

Individual Names of Canals, Lakes, Rivers.

Navigation, Inland, Freedom of.

Obstructions, Prohibition of.

Tolls, Prohibition or Regulation of.

War-Vessels, Prohibition of.

War-Vessels, Regulation of Navigation by.

Inland Waterways, navigation of, $6,150,155,169$; property rights on, 151 ;

relation of, to maritime navigation, 5 .

Inland Sea of Japan, sovereignty over, 131.

Inn, boundary, 210 ; fisheries, 210 ; navigation, 210.

Institute of International Law, resolution of (1896), on use of Merchant Flags, 139.

Interstate Commerce Act, passage of, 161.

Ireng, boundary, 301 ; navigation, 301 .

Irrawaddy, navigation of, 360 .

Irtish, boundary, 360 ; navigation, 360, 363 .

Isango. See Semliki, 346.

Islands of the Sea, waterways of: Borneo, 354; New Guinea, 358.

Isthmian Canal, project of, under Charles V, 69.

Itenes (Itenez), navigation of, 301 .

JABON. See Belize, 261.

Jacobs-Elf, fisheries, 210; navigation, 210.

Jaguary, navigation of, 301.

Jaliba, navigation of, 332 .

Japan, Inland Sea of, sovereignty over, 131.

Japura. See Yapura, 322.

Jefferson, Thomas, on piracy, 109.

Jenkins, Sir Leoline, charge of, to Cinque Ports, 74;

on Sovereignty of the Seas, 99.

Jipe Lake, boundary, 332.

John, King of England, Marine Ordinance (1200) of, 75.

John, King of Portugal, 44; remonstrance of, 67.

Jora, boundary, 332.

Juba, boundary, 332, 333 ; navigation, 332.

Julius II, Pope, sanctions Treaty of Tordesillas (1506), 68.

Jura, navigation of, 211.

Justinian, Institutes of, 28.

KADUNA, navigation of, 341. See Niger.

Kalombo, boundary, 333; commission of supervision, 328; navigation, 333.

Kambompo. See Cambompo, 326.

Kandcko, commission of supervision, 328 ; navigation, 333.

Kara-Kourt, boundary, 211.

Karun, navigation of, $169,360,361$. 
Kassai, boundary, 333 ; commission of supervision, 328 ; navigation, 333. Kent, James, on Freedom of the Seas, 5.

Kibish. See Sacchi, 346.

Kilambo. See Kalombo, 333.

Kilunga (Kilange), boundary, 333, 334; fisheries, 334 ; navigation, 334.

Kivu Lake, commission of supervision, 334; navigation, 334.

Kodyma, navigation, 224. See Polish Waterways.

Komadugu, boundary, 334 ; fisheries, 334 .

Komati. See Sabi, 346.

Kongama, boundary, 211 ; navigation, 211.

Konge-Aa, boundary, 211.

Kouban, boundary, 211.

Kuando. See Chobe, 328.

Kuango. See Lukualli, 337.

Kubango, boundary, 334.

Kuilu, boundary, 334; commission of supervision, 334 ; navigation, 334.

Kulupene. See Dakka, 330.

Kulusulo, boundary, 334.

Kunene. See Cunene, 330.

Kwa, commission of supervision, 335 ; navigation, 335.

Kwando. See Chobe, 328.

Kwango. See Lukualli, 337.

LAC BOIS BLANC, boundary, 261-63; commission of supervision, 263 ; diversion of waters, 263 ; fisheries, 263 ; navigation, 262, 263.

Lachine Canal, navigation, 263; tolls prohibited, 263. See Canals.

La Croix Lake, boundary, 261-63; commission of supervision, 263 ; diversion of waters, 263; fisheries, 263 ; navigation, 262, 263.

Lacustrine Fisheries. See Fisheries, Inland, Mutual Enjoyment of.

Lagoa de Los Patos, navigation of, 301.

Lahn, navigation of, 211.

Laiblach, boundary, 211.

Lake of the Woods, boundary, 261-63; commission of supervision, 263; diversion of waters, 263 ; fisheries, 263 ; navigation, $262,263$.

Lakes. See Individual Names.

Lakka. See Dakka, 330.

La Laire, boundary, 211.

Lande. See Lunde, 337.

Land van Staten, England claims Sea to, 89.

Lauter, boundary, 212.

Lavua. See Luapula, 336.

Law, Maritime, exceptional to Law of the Land, 27 ; growth of, 25, 28-30, 35,37 ; influence of, $24,35,38,40,42$; jurisdiction of, 26 ; necessity of, 24, 25, 27-29; obligation of, universal, 25, 26; protection afforded by, 24, 40, 42; sources of, 24-29, 32, $34-36,38,40$.

Lax-Elf, boundary, 212.

Lean, navigation of, $272,273$.

Leck, boundary, 212; navigation, 212.

Leo X, Papal Bull (1514) of, to Portugal, 68.

Leopold II Lake, commission of supervision, 335 ; navigation, 335. 
Lepanto, defeat at, of Turks, 63.

Leure, Castilian trade with, 38.

Liao-ho, navigation, 361 ; tolls prohibited, 357.

Lief the Lucky, voyage of, 4.

Ligurian Sea, appropriation of, by Genoa, 58.

Limpopo, navigation of, 335 .

Linguet, Simon, on freedom of fluvial navigation, 155.

Liscoarta, boundary, 212.

List, Friedrich, on importance of Sea-Communications, 13.

Little Vermillion Lake, boundary, 262-63; commission of supervision, 263; diversion of waters, 263 ; fisheries, 263 ; navigation, 262, 263.

Llivia Canal, commission of supervision, 212; diversion of waters, 212.

Loange, commission of supervision, 328; navigation, 328. See Congo System: Kassai.

Loangwa, boundary, 335 .

Lobai, commission of supervision, 336 ; navigation, 335, 336.

Logone (Logogne), navigation, 336.

Lomami, commission of supervision, 336 ; navigation, 336.

Long Parliament, Navigation Act of, 85.

Louis VII, Holy Crusade of, 23.

Louis XIV, alliance of, with Charles II, 88; marine ordinances of, 26.

Lualaba. See Luapula, 336.

Luapula, boundary, 336 ; commission of supervision, 336 ; navigation, 336 .

Lucalla, boundary, 337.

Luculla. See Lucalla, 337.

Lugano Lake, fisheries, 212, 213.

Lukualli, boundary, 337 ; commission of supervision, 337 ; navigation, 337.

Lukuga, commission of supervision, 337 ; navigation, 337.

Lulanga, commission of supervision, 337 ; navigation, 337.

Lunde, navigation of, 337.

Lwan-ho, navigation, 362 ; tolls prohibited, 357.

Lys, boundary, 213; navigation, 213; tolls prohibited, 213.

MADEIRA, navigation of, 301,302 .

Madre de Dios, navigation of, 312. See Peruvian Waterways.

Magdalena, navigation of, 299. See Colombian Waterways.

Magellan, voyage of, 48,49 .

Maggiore Lake, boundary, 213; fisheries, 213, 214; navigation, 214.

Magna Graecia, founding of, 4.

Magra, boundary, 214.

Maia, boundary, 338 ; navigation, 338.

Maieteb, boundary, 338.

Main, navigation, 214, 215; obstructions, prohibited, 214; tolls prohibited, 215 .

Maio Kalo. See Mao Kalo, 339.

Maio Kam. See Mao Kam, 339.

Maio M'Bulo. See Mao Bulo, 339.

Maio Tati. See Mao Tati, 399.

Makona, boundary, 338; fisheries, 338 ; navigation, 338.

Makua, commission of supervision, 328; navigation, 328. See Congo System, Ubangi. 
Makwoi, boundary, 338; navigation, 338.

Malagarazi. See Ugala, 351.

Malta, Sea-fight off, 63.

Mamore, navigation, 297, 302.

Mamoudie Canal, navigation of, 338.

Manoh, navigation of, 338, 339.

Mao Bulo, boundary, 339; fisheries, 339 ; navigation, 339.

Mao Kalo, boundary, 339 ; fisheries, 339 ; navigation, 339.

Mao Kam, boundary, 339; fisheries, 339 ; navigation, 339.

Mao Tati, boundary, 339 ; fisheries, 339 ; navigation, 339.

Mapire, navigation of, 302.

Maracaibo Lake, navigation of, 302.

Maranon, navigation of, 312. See Peruvian Waterways.

Mareb, boundary, 339.

Mare Clausum, doctrine of, 97, 100.

Mare Liberum, 100, 102.

Marginal Sea, width of, 127; excessive extension of, 128, 129.

Maritime Commerce, Roman contempt for, 19.

Maritime Discovery, causes of, 43, 44, 46; influence of, on commerce, 42, $47,49,50$; notable voyages of, $42-44,46,48,49$; restriction of, by ignorance, 45 .

Maritime Law. See Law, Maritime.

Maritime Occupation, validity of, 105.

Marne-Rhine Canal, 215.

Marquari, boundary, 339; fisheries, 339 ; navigation, 339.

Marseilles, war with Carthage, 56.

Matumba Lake. See Tumba Lake, 350.

Mauwa, boundary, 339 ; navigation, 339.

Mayo-Kebbi, navigation of, 340 .

Mazoe, navigation of, 340 .

Mediterranean Sea, 20, 54; control of, at Gibraltar, 90; decline of, as Trade-Area, 50; early trade-route, 14; highway between three continents, 14; navigation of, restricted by Barbary States, 119: by pirates, 109; trade on, restricted, 44.

Medows, Sir Philip, on Sea-Dominion, 99, $n$.

Mekong, navigation of, 362.

Mekwer. See Marquari, 339.

Moli, boundary, 340.

Meloria, Sea-Fight off, 62.

Memel. See Niemen, 221.

Memphremagog Lake, boundary, 262, 263; commission of supervision, 263; diversion of waters, 263; fisheries, 263, 273; navigation, 262, 263, 273.

Mendoza, Bernardine, protests to Queen Elizabeth, 71 .

Merchant Flag, use of, 139, 139, $n$.

Merim Lake, navigation of, 303.

Mesopotamia, trade of, 18.

Meta, navigation of, 299. See Colombian Waterways.

Meuse, diversion of waters, 218; fisheries, 217; navigation, 215, 216, 217, 218 ; obstructions prohibited, 218; tolls prohibited, 217, 218.

Mfini, commission of supervision, 340 ; navigation, 340. 
Michigan Lake, navigation of, 273.

Milan Decree (1807), 135.

Milk-St. Mary River System, commission of supervision, 274; diversion of waters, 274.

Mill, John Stuart, advocates British commercial policy, 107.

Mincio, boundary, 218, 219; obstructions forbidden, 218.

Mines, marine contact, 134.

Minho, fisheries, 219.

Min-kiang, navigation, 362,363 ; tolls prohibited, 357 .

Minorca, cession of, to England, 90.

Mississippi, boundary, 274, 276; navigable extent of, 161 ; navigation of, 274-76; tolls prohibited, 274.

Moa. See Makona, 338.

Mobile, navigation of, 277.

Modification Act, British, 107.

Moero Lake. See Mweru Lake, 341.

Mombezi. See Pungwe, 344.

Mongolian Waterways, navigation of, 363.

Mono, navigation of, 340,341 .

Montesquieu, Charles, on importance of commerce, 9.

Morno, boundary, 341; fisheries, 341 ; navigation, 341.

Morona, navigation of, 312. See Peruvian Waterways.

Morro, boundary, 341 ; navigation, 341.

Moselle, boundary, 219, 220; navigation, 219, 200.

Moslem Power, expansion of, 43.

Muni, fisheries, 341 ; navigation, 341.

Muonis, navigation of, 220.

Murray Canal, navigation, 263, 264; tolls prohibited, 264.

Murray, navigation of, 363,364 .

Muscha, navigation of, 224. See Polish Waterways.

Mutan-kiang, navigation of, 364 .

Mweru, boundary, 341 ; commission of supervision, 341 ; navigation, 341.

NAHE, navigation of, 220.

Namecan Lake, boundary, 262, 263 ; commission of supervision, 263 ; diversion of waters, 263; fisheries, 263; navigation, 262, 263.

Napo, navigation of, 299, 300. See Colombian Waterways.

Napoleon, appreciation by, of Sea-Power, 96 ; issuance by, of Bayonne Decree, 136: of Milan Decree, 135; wars of, 101.

Narew, navigation of, 224. See Polish Waterways.

Nationality, Corporate, 139.

Navigation Act (1651), abolition of, 108; enforcement of, causes war, 86 ; modification of, 88,107 ; passage of, 83 ; increases England's maritime resources, 89 ; renews EnglishDutch conflict, 87 ; policy of, 83,84 ; restrictions of, 83, 85; unwarranted limitations of, on High Seas, 84 .

Navigation, Inland, Freedom of, 150, 152, 153, 156, 157 ;

Subject to equitable tolls for maintenance of navigable channels and to appropriate fiscal, navigation, pilotage, police, and sanitary regulations.

on the:

Aa, 224;

Abuna, 297;

Aby Lagoon, 322;

Addo, 322 ; 
Navigation, Inland, Freedom of (Continued): on the:

Adige, 180;

Aguan, 260;

Aguarico, 299;

Ajarra, 322 ;

Akwayafe, 323;

Albert Nyanza, 323;

Amakuru, 292;

Amazon, 293-96 ;

Amur, 354;

Anebir, 323 ;

Anyalo, 323;

Apa, 308;

Apure, 296 ;

Aquidaban, 308;

Araguary, 296;

Argentine Waterways, 296;

Argun, 354;

Arkansas, 261;

Aruwimi, 324;

Atrato, 299;

Augustowo Canal, 224;

Awa, 324;

Bachorze Canal, 224;

Barima, 297;

Belize, 261;

Beni, 297;

Benue, 324, 325;

Beresina Canal, 224;

Beresina River, 224;

Bidassoa, 181, 182;

Black River Canal, 263;

Black Volta, 325;

Bolivian Waterways, 297, 298;

Borneo, Waterways of, 354, 355;

Boundary Waterways of: Austria/Sardinia, 182;

Austria/Servia, 182;

Belgium/France/Germany, 183;

Belgium/France/Germany/Netherlands, 183;

Belgium/Netherlands, 183;

Bolivia/Brazil, 298;

Brazil/Colombia, 298;

Brazil/Uruguay, 298;

Canada/United States, 261 ;

France/Germany, 183;

France/Germany (Africa), 325;

France/Liberia, 325;

Germany/Great Britain, 326;

Hanover/Lubeck, 184;

Boundary Waterways of (Cont'd) :

Netherlands/Prussia, 185;

Portugal/Spain, 185;

Russia/Sweden, 185;

Boyana, 185, 186;

Bromberg Canal, 186, 224;

Bug (Black Sea), 224;

Bug (Vistula System), 186, 224 ;

Bug-Pripet Canal, 224;

Busi, 326;

Campo, 326;

Canals, Canadian, 263;

United States, 264 ;

Canton, 355, 356;

Cao-bang, 356 ;

Cascade Canal, 267;

Casiquiare Canal, 293, 303.

(Amazon-Orinoco System).

Caspian Sea, 356;

Cauca, 299;

Cavally, 326;

Celilo Canal, 267;

Chad Lake, 326, 327;

Chamalecon, 265, 266;

Chambira, 300, 312;

Chambly Canal, 263-64;

Champlain Canal, 263-64;

Champlain Lake, 266 ;

Chapare, 298;

Chico, 296 ;

Chimore, 298, 299;

Chinese Inland Waterways, 356, 357,358 ;

Choluteca, 266;

Chubut, 296;

Coca, 299; 300;

Coco, 271 ;

Colombian Waterways, 299 ;

Colorado (Argentina), 296;

Colorado, 266, 267;

Columbia, 267;

Congo, 328, 329 ;

Coni, 300;

Constance Lake, 186, 187, 188;

Corioco, 300;

Cornwall Canal, 263;

Crocodile, 346 ;

Cross, 330 ;

Curaray, 300, 312;

Cypress Lake, 262, 263;

Danube, 188-199; 
Navigation, Inland, Freedom of (Continued) : on the:

\section{Deseado, 296;}

Detroit, 267 ;

Dnieper, 199, 224;

Dniester, 199, 200, 224;

Doubs, 200;

Douro, 200, 201 ;

Drewenz, 201;

Drina, 201;

Dubissa, 224;

Düna, 201, 202, 224;

Ecuadorean Waterways, 300 ;

Edward and George Lake, 330;

Elbe, 202, 203, 204;

Elster, 205;

Ems, 205, 206;

Erie Barge Canal, 264;

Erie Lake, 268;

Espierre Canal, 206;

Euphrates, 358;

Faro, 330, 331 ;

Farran's Point Canal, 263 ;

Fatiko, 341;

Floss-Graben, 206 ;

Fly River, 358;

Fogones, 308;

Fowl Lakes, 262, 263 ;

Gallegos, 296 ;

Galops Canal, 263;

Gambia, 331 ;

Garda Lake, 207 ;

Geneva Lake, 208;

Gera, 208;

Gila, 268;

Goascoran, 268, 269 ;

Gongola, 341 ;

Grand Canal, 359 ;

Great Lakes, 269, 270;

Great Scarcies, 331;

Guadiana, 209 ;

Guaviare, 299;

Guayape, 270, 271;

Han-kiang, 359 ;

Hoang-ho, 359 ;

Hondo, 270;

Hondt, 209, 210;

Honduran Waterways, 270, 271 ;

Huallaga, 312;

Hun-ho, 359;

Hun-ho (Pai-ho System), 360;

Huron Lake, 271;
Hwai-ho, 360;

Imba, 332 ;

Indus, 360 ;

Inirida, 299;

Inn, 210;

Ireng, 301 ;

Irrawaddy, 360;

Irtish, 360;

Itenes, 301;

Jacobs-Elf, 210;

Jaguary, 301;

Jaliba, 332;

Juba, 332 ;

Jura, 211;

Kaduna, 341;

Kalombo, 333 ;

Kandcko, 333 ;

Karun, 360, 361;

Kassai, 333 ;

Kilunga, 333, 334 ;

Kivu Lake, 334;

Kodyma, 224;

Kongama, 211;

Kuilu, 334;

Kwa, 335;

Lac Bois Blanc, 262, 263;

Lachine Canal, 263;

La Croix Lake, 262, 263;

Lagoa de Los Patos, 301;

Lahn, 211 ;

Lake of the Woods, 272;

Sean, 272, 273;

Leck, 212;

Leopold II Lake, 335 ;

Liao-ho, 361 ;

Limpopo, 335 ;

Little Vermillion Lake, 262, 263;

Loange (Kassai), 328;

Lobai, 335, 336 ;

Logone, 336 ;

Lomami, 336 ;

Luapula, 336 ;

Tukualli, 337 ;

Lukuga, 337 ;

Lulanga, 328, 337;

Lunde, 337 ;

Lwan-ho, 362 ;

Lys, 213;

Madeira, 301, 302 ;

Madre de Dios, 312; 
Navigation, Inland, Freedom of (Continued): on the:

Magdalena, 299;

Maggiore Lake, 213;

Maia, 338;

Main, 214, 215;

Makona, 338;

Makua, 328;

Makwoi, 338;

Mamore, 302;

Mamoudie Canal, 338;

Manoh, 338, 339;

Mao Bulo, 339;

Mao Kalo, 339;

Mao Kam, 339;

Mao Tati, 339;

Mapire, 302;

Maracaibo, 302;

Maranon, 312;

Marne-Rhine Canal, 215;

Marquari, 339;

Mauwa, 339;

Mayo-Kebbi, 340;

Mazoe, 340 ;

Mekong, 362;

Memphremagog Lake, 273;

Merim Lake, 303;

Meta, 299;

Meuse, 215, 216, 217, 218;

Mfini, 340;

Michigan Lake, 373;

Min-kiang, 362, 363;

Mississippi, 274, 275, 276 ;

Mobile, 277;

Mongolian Waterways, 363;

Mono, 340, 341;

Morno, 341;

Morona, 312;

Morro, 341;

Moselle, 219, 220;

Muni, 341 ;

Muonis, 220;

Murray Canal, 263;

Murray (Australia), 363, 364;

Muscha, 224;

Mutan-kiang, 364;

Mweru, Lake, 341 ;

Nahe, 220;

Namecan Lake, 261-63;

Napo, 299, 300, 312 ;

Narew, 224 ;

Neckar, 220, 221 ;

Negro (Argentina), 296;

Negro (Bolivia), 297;

Negro (Brazil), 303;

Negro (Honduras), 277;

Neisse, 221 ;

Netze, 221, 224;

Newjasha, 224;

Niagara, 269, 270, 278;

Nicaragua Lake, 278;

Niemen, 221, 224;

Niers Canal, 221;

Niers River, 221;

Niger, 341, 342 ;

Nile, 342, 343 ;

Njemenek, 224;

Nonna, 364;

Nuon, 343;

Nyassa Lake, 343;

Oder, 222;

Oginski Canal, 224;

Onon, 364;

Ontario Lake, 278, 279;

Orinoco, 303, 304;

Orkhon, 364;

Oswego Canal, 264;

Ottawa Canal, 263;

Oure, 222;

Pai-ho, 364, 365;

Pama, 344;

Paraguay, 305, 306, 307;

Paraguayayan Waterways, 308;

Parana, 308-312;

Parchanie Canal, 224;

Pastaca, 300, 312;

Paswig, 222;

Patuca, 279;

Paute, 300, 312;

Pei-kiang, 365;

Peruvian Waterways, 312, 313;

Pigeon, 262, 263;

Pilcomayo, 313, 314;

Piliza, 224;

Piray, 314;

Plata, 315, 316, 317;

Po. 222, 223, 224;

Polish Waterways, 224, 225;

Percupine, 279, 280;

Po-Yang-Lu Lake, 365;

Pripet, 224;

Prosna, 224; 
Navigation, Inland, Freedom of (Continued): on the:

Pruth, 224, 225, 226, 227;

Pungwe, 344;

Putumayo, 317;

Rafin Donga, 345;

Rainy Lake, 280;

Rainy River, 280;

Rapide Plat Canal, 263;

Red River, 280, 281;

Red River of the North, 280 ;

Rhine, 227-238;

Rhine-Rhone Canal, 238;

Rhine-Scheldt Connecting Waterways, 238, 239 ;

Rhine-Weser Canal, 239;

Rhone, 239;

Rideau Canal, 263;

Rio Grande, 281;

Rusizi, 346;

Saal, 241;

Sabi, 346;

Sabine, 282;

St. Andrew's Canal, 263 ;

St. Clair Flats Canal, 269, 270;

St. Clair Lake, 269, 270, 283 ;

St. Clair River, 269, 270, 283;

St. Croix, 283, 284;

St. Francis, 284 ;

St. John, 285, 286 ;

St. Lawrence, 286, 287, 288;

St. Mary's Lake, 288;

St. Mary's River, 288;

St. Ours Canal, 263;

St. Peter's Canal, 263 ;

Saisaginaga, 262, 263 ;

Salado, 296; .

Salza, 24l ;

Sambre, 241;

San, 242;

San-fa, 366;

San Francisco, 318;

Sanga, 346 ;

San Gonzola, 318;

San Juan, 289;

San Pedro, 318;

Santa Cruz, 296;

Santiago, 312;

Santiago (Honduras), 270, 271;

Sarre Canal, 242, 243;

Sault Sainte Marie Canal, 263, 264 ;

Save, 243;
Sbrucz, 224;

Schara, 224 ;

Scheldt, 243-48;

Scheschupa, 224;

Schwarze-Elster, 249 ;

Scutari Lake, 249;

Selenga, 366;

Semoy, 249 ;

Sereth, 224;

Shari, 347;

Shat-el-Arab, 366;

Shire, 347, 348;

Siang-kiang, 366 ;

Sogamoso, 299 ;

Sokoto, 348;

Song-ki-kong, 366 ;

Songkoi, 366, 367 ;

Soulanges Canal, 263 ;

Stecknitz Canal, 250;

Stikine, 290;

Sulaco (Honduras: Ulua), 270, 271 ;

Sungari, 367 ;

Superior Lake, 291;

Tagus, 250 ;

Takutu, 318;

Tanganyika Lake, 349;

Tapajoz, 318, 319;

Tembe-Counda, 341;

Tendo Lagoon, 350;

Tendo River, 350 ;

Terneuzen Canal, 251, 252;

Teterew, 224;

Ticino, 252;

Tiel, 350;

Tigre, 300, 312;

Tigris, 368 ;

Tocantins, 319 ;

Tornea, 252;

Trave, 253;

Trent Canal, 263;

Tsien-Tang, 368;

Tso-kiang, 368;

Tumba, 350;

Tumen, 368;

Tung-kiang, 368;

Tung-Ting-Lu Lake, 369;

Ubangi, 351;

Ucayli, 312;

Ugala, 351; 
Navigation, Inland, Freedom of (Continued) : on the:

Ulua, 291;

Unstrut, 253 ;

Uruguay, 319, 320, 321 ;

Ussuri, 369;

Utamboni, 351;

Valencia Lake, 321;

Venezuelan Waterways, 321;

Vermejo, 321, 322;

Vistula, 224, 253, 254, 255;

Waal, 255;

Warthe, 224, 255;

Waupes, 299;

Weisse-Elster, 255, 256 ;

Welland Canal, 263, 264;

Weser, 256, 257;

West, 369, 370;

Whangpoo, 370, 371, 372;

Wilija, 224;

Williamsburg Canal, 263;
Windau Canal, 224;

Windau River, 224;

Wjeprsh, 224;

Wom, 352;

Wu-kiang, 372 ;

Yalu, 372, 373;

Yang-tsze-kiang, 373, 374;

Yapura, 322;

Yavari, 312;

Yederam, 352;

Yenisei, 374;

Yoja, 270, 271;

Yssel, 258;

Yukon, 292;

Yung-kiang, 374, 375;

Zambesi, 352, 353;

Zatsan Lake, 375;

Zuid-Willems-Waart, 258, 259;

Zwin Canal, 259, 260.

Navigation, Maritime, restrictions on, during war, 133, 134, 149.

Navigation, Steam, 162.

Necho, King of Egypt, Circumnavigation of Africa in reign of, 55.

Neckar, navigation, 220, 221; obstructions prohibited, 221; tolls abolished, 220.

Negro (Argentina), navigation of, 296.

Negro (Bolivia), navigation of, 297.

Negro (Brazil), navigation of, 303.

Negro (Honduras), navigation of, 277.

Neisse, navigation of, 221.

Netherlands, Sea-Trade of, jeopardized, $85, n$.

Netze, navigation of, 221, 224.

Neutrality of Inland Waterways, 151.

New Guinea, Fly River, navigation of, 166, 358.

Newjasha, navigation of, 224 .

New Netherlands, cession of, to England, 87.

New Sweden, cession of, to England, 88.

Niagara, boundary, 277; commission of supervision, 269, 270; diversion of waters, 277; fisheries, 278; navigation, 261-63, 278;

War-vessels restricted, 269, 270.

Nicaragua Lake, navigation of, 278.

Nicholas V, Papal Bull (1454) of, 64.

Niemen, navigation of, 221, 224; tolls prohibited, 221.

Niers Canal, navigation of, 221 ;

Niers River, navigation of, 221.

Niger, boundary, 342; diversion of waters, 342; navigation, 341, 342.

Nigre. See Peruvian Waterways: Tigre, 312.

Nile, boundary, 343 ; diversion of waters, 343; navigation, 342,343 ; obstructions forbidden, 343 .

Njemenek, navigation of, 224.

Nonna, navigation of, 364 . 
Normans, invasions of, 22.

Norsemen, early trans-Atlantic voyages of the, 43.

North American Waterways, 260.

Nuon, boundary, 343; navigation, 343.

Nyassa Lake, boundary, 343, navigation, 343.

obstructions, Prohibition of, on the:

Colorado, 267;

Main, 214;

Meuse, 218;

Neckar, 221;

Nile, 343;

Rhine-Scheldt Connecting Waterways, 239;

Rio Grande, 281, 282;

St. Lawrence, 287 ;

Rhine, 232, 235 ;

Schcldt, 245;

Stecknitz Canal, 250;

Terneuzen Canal, 251;

Trave, 253;

Warthe, 255;

Zuid - Willems - Waart, 259.

Ochotsk, Sea of, claims to fisheries in, 122.

Ocpara, boundary, 343, 344.

Oder, boundary, 221-22; navigation, 222.

Oginski Canal, 224.

Okavango. See Kubango, 334.

Okpa. See Ocpara, 343.

Old Calabar. See Cross, 329.

Oleron, Laws (Rolls) of, 25, 31, 35, 36, 37, 39, 40.

Oliphants. See Limpopo, 335.

Onon, navigation of, 364 .

Ontario Lake, boundary, 278, 279 ; commission of supervision, 263; diversion of waters, 263; fisheries, 263, 279; navigation, 269, 270, 279; War-Vessels restricted, 278, 279.

Orange, boundary, 344 .

Orinoco, navigation of, 163, 303, 304 .

Orkhon, navigation of, 364 .

Oswego Canal, navigation, 263-64; tolls prohibited, 264.

Ottawa Canal, navigation, 263 ; tolls prohibited, 264.

Oure, boundary, 222; navigation, 222.

Outemboni. See Utamboni, 351.

Oyapock, boundary, 304 .

PACIFIC OCEAN, appropriation of, by Spain, 58 .

Pai-ho, navigation, 364, 365; tolls prohibited, 364 .

Pama, commission of supervision, 344 ; navigation, 344 .

Paraguay, navigation, 163, 165, 305, 306, 307; tolls prohibited, 306; WarVessels prohibited, 308; regulated, 306.

Paraguayan Waterways, navigation, 308; War-Vessels prohibited, 308.

Parana, boundary, 308; navigation, 163, 165, 308-312; tolls prohibited, 311; War-Vessels prohibited, 311: regulated, 311.

Parchanie Canal, navigation of, 224.

Paris, Treaty of (1814), 155.

Pastaca, navigation of, 300,312 .

Paswig Lakes, boundary, 222.

Paswig River, boundary, 222; fisheries, 222 ; navigation, 222.

Patuca, navigation of, 279.

Paul I, Emperor of Russia, ukase of ${ }_{,} 121$.

Paute, navigation of, 300, 312.

Pearl. See Canton, 355. 
Pearl Fisheries, Ceylon, 128.

Pei-ho. See Pai-ho, 364.

Pei-kiang, navigation, 365 ; tolls prohibited, 357.

Pequena. See Tigre, 300, 312.

Pericles, appeal of, for Maritime Development, 19.

Peruvian Waterways, navigation of, $312,313$.

Philip II, King of Spain, 78.

Phoenicia, influence of, in Mediterranean, 19; Maritime Enterprise of, 9, $15,16,18,54$.

Pibor, boundary, 344 .

Pigeon, boundary, 262, 263; commission of supervision, 263; diversion of waters, 263; fisheries, 263 ; navigation, 262, 263.

Pilcomayo, navigation, 313, 314; War-Vessels prohibited, 308, 314.

Piliza, navigation of, 224.

Piracy, Mediterranean, 109.

Piray, navigation of, 314.

Plata, Rio de la, navigation, 315, 316, 317 ; War-Vessels restricted, 316.

Po, boundary, 222, 223, 224; navigation, 223, 224.

Podhorce, boundary, 224.

Polish Waterways, navigation of, 224, 225.

Pomponious Mela, theory of, as to earth's form, 45.

Porcupine, navigation of, $279,280$.

Porta, boundary, 225.

Po-Yang-Lu Lake, navigation, 365; tolls prohibited, 357.

Prince Henry the Navigator, Papal Grant to, of all discoveries, 44.

Pripet, navigation of, 224.

Prosna, boundary, 225; navigation, 224.

Pruth, boundary, 225, 226; commission of supervision, 226, 227; fisheries, 227 ; navigation, $224,226,227$.

Pungwe, boundary, 345; navigation, 244.

Punic War, First, 20, 27 ; Third, 20.

Putumayo, navigation, 312; War-Vessels regulated, 317.

Puycerda Canal, boundary, 227; diversion of waters, 227.

QUEICH, boundary, 227.

RAFIN DONGA, boundary, 345 ; fisheries, 345 ; navigation, 345.

Rahad, boundary, 345 .

Rainy Lake, \}boundary, 280; commission of supervision, 263; division of

Rainy River, $\}$ waters, 263; fisheries, 280; navigation, 280.

Raleigh, Sir Walter, on Sea-Power, 52.

Raour, boundary, 227.

Rapide Plat Canal, navigation, 263 ; tolls prohibited, 264.

Red River. (Asia). See Songkoi, 366.

Red River (United States), fisheries, 281; navigation, 280.

Red River of the North, navigation of, 280.

Registry, Ship, Law of, 139, I47; American Institute of International Law on, 147, 148; British, 141-42; French, 142-44; German, 146; Japanese, 144-45; Norwegian, 14546 ; United States, 140-41.

Rex vs. Hampden, case of, 82 .

Rhine, boundary, 228-30; commission of supervision, 228, 229, 231-35, 237,238 ; economic importance of, 160 ; ferry service on, 233,235 ; 


\section{Rhine (Continued) :}

fisheries, 228, 234, 236, 237; improvement of, channel, 168; invasion of, by Northmen, 22 ; navigable, extent of, 161, 165; navigation, 227-238; obstructions forbidden, 232, 235; ocean-going vessels on, 158, 159; tolls, 153: prohibited, 228, 231, 232, 234, 236; trade route on, in Middle Ages, 152.

Rhine-Rhone Canal, commission of supervision, 238; navigation, 238.

Rhine-Scheldt Connecting Waterways, fisheries, 239; navigation, 238, 239;

Rhine-Sea Service, 158. obstructions forbidden, 239.

Rhine-Weser Canal, navigation of, 239.

Rhodes, Maritime Law of, 30, 31, 37, 39.

Rhone, boundary, 239, 240; fisheries, 240; navigation, 239.

Richard I, King of England, interest of, in Laws of Oleron, 36.

Rideau Canal, navigation, 263 ; tolls prohibited, 264.

Rio Bravo. See Rio Grande, 281.

Rio de la Plata. See Plata, 314.

Rio Grande, boundary, 281, 282 ; commission of supervision, 281 ; diversion of waters, 282 ; navigation, 281 ; obstructions forbidden, 281, 282.

Rio Grande. See Vermejo, 321.

Rio Grande de San Pedro. See San Pedro, 318.

Rio Grande del Norte. See Rio Grande, 281.

Rio Hondo. See Hondo, 270.

Rio Roxo de Nacogdoches. See Red River, 280.

Rivers. See Individual Names.

Roeskilde, Treaty of, closure of Baltic by, 92.

Rolls of Oleron. See Laws of Oleron.

Rome, Imperial Expansion of, 32; Maritime Law of, 31; strategic site of, 15.

Roman Law, 31; continuous observance of, 33 ; provisions of, as to Freedom of Seas, 104.

Roman River. See Aguan, 260.

Rovuma, boundary, 345.

Rudolph Lake, boundary, 345.

Ruera. See Pungwe, 344 .

Rule of war (1756), Trade Restrictions by, 83.

Ruo, boundary, 345,346 .

Rusizi, commission of supervision, 346 ; navigation, 346.

Russia, access of, to Mediterranean, 11; claims of, to Marginal Sea, 129; territorial acquisitions of, 10 .

Russo-Japanese War (1903), innovations during, in Naval Warfare, 136.

SAAL, boundary, 240; diversion of waters, 241 ; fisheries, 241 ; navigation, 241.

Sabi, navigation of, 346 .

Sabine, fisheries, 282 ; navigation, 282.

Sacchi, boundary, 346 .

St. Andrew's Canal, navigation, 263; tolls prohibited, 264.

St. Clair Flats Canal, boundary, 262, 263 ; commission of supervision, 270; diversion of waters, 263 ; fisheries, 263,270 ; navigation, 262, 263; War-Vessels restricted, 270. 
St. Clair Lake, boundary, 283; commission of supervision, 270; diver-

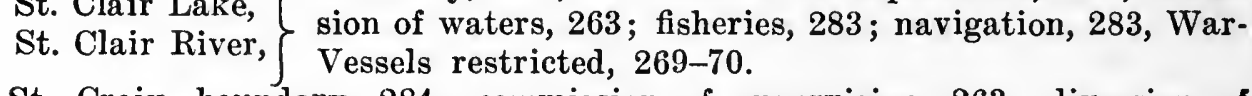

St. Croix, boundary, 284; commission of supervision, 263; diversion of waters, 263 ; fisheries, 284 ; navigation, $283,284$.

St. Francis, boundary, 284; commission of supervision, 263; diversion of waters, 263 ; fisheries, 263 ; navigation, 284.

St. John, boundary, 284, 285; commission of supervision, 263 ; diversion of waters, 263 ; fisheries, 285 ; navigation, 285,286 ; tolls prohibited, 285.

St. Lawrence, boundary, 286; commission of supervision, 263; diversion of waters, 263, 287; fisheries, 287-88; navigation, 286, 287, 288 ; obstructions forbidden, 287 ; tolls prohibited, 286.

St. Mary's Canal. See Canals: Sault Sainte Marie, 263.

St. Mary's Lake, boundary, 288; commission of supervision, 263; diverSt. Mary's River, $\}$ sion of waters, 263; fisheries, 288; navigation, 288;

St. Mary's (Florida), boundary, 288, 289.

St. Mary's (Montana), commission of supervision, 274; diversion of waters, 274.

St. Ours Canal (Lock), navigation, 263; tolls prohibited, 264.

St. Peter's Canal, navigation, 263 ; tolls prohibited, 264.

St. Petersburg, Treaty of, 126.

Saisaginaga, boundary, 262, 263; commission of supervision, 263; diversion of waters, 263 ; fisheries, 263 ; navigation, 262, 263.

Salado, navigation, 296.

Salamis, Grecian Vistory at, 18, 55 .

Salza, boundary, 241; navigation, 241.

Sama, boundary, 317.

Sambre, boundary, 242 ; navigation, 241.

San, navigation of, 242.

San-fa, navigation of, 366 .

San Francisco, navigation of, 169, 318.

Sanga, commission of supervision, 346 ; navigation, 346 .

San Gonzalo, navigation of, 318 .

San Juan, boundary, 289, 290; navigation, 289.

San Miguel. See Colombian Waterways: Aguarico, 299.

San Pedro, navigation of, 318 .

Santa Cruz, navigation of, 296.

Santiago, navigation of, 312 .

Santiago, navigation of, 270-71. See Honduras: Ulua.

Saratsika, boundary, 242.

Sarre Canal, navigation of, 242, 243.

Sarre River, boundary, 242; fisheries, 242; navigation, 242.

Sauces. See Argentine Waterways: Negro, 296.

Sault Sainte Marie Canal, navigation, 263; tolls prohibited, 264.

Save (Africa). See Sabi, 346.

Save (Europe), fisheries, 243 ; navigation, 243.

Sbrucz, navigation of, 224. See Polish Waterways.

Schara, navigation of, 224.

Scheldt, boundary, 244; fisheries, 245; navigation, 153-155, 243-248; obstructions forbidden, 245 ; tolls prohibited, $246,247$. 
Scheschupa, navigation of, 224.

Schwalb, boundary, 249.

Schwarze-Elster, boundary, 249; navigation, 249.

Scutari Lake, navigation of, 249.

Sea, The Open, appropriations of, 53, 59, 103; Freedom of, 6, 28, 55, 103; intercommunication by, $3,5,6,16$.

$\left.\begin{array}{l}\text { Sea-Codes. } \\ \text { Sea-Laws. }\end{array}\right\}$ See Law, Maritime.

Sea-Power, dominant, secured by England, 91; employment of, during peace, 109; during war, 109; French, destroyed by the Seven Years' War, 90; genesis of, 51; necessity of, 108; Neutral Rights and, 134; retention of, by Great Britain, 108; Roman, 20.

Sea-Trade, benefits of, 167 ; Dutch, jeopardized, 85, $85 n$.

Seamen, impressment of, 119.

Segovia. See Coco, 266, 271.

Selden, Sir John, definition by, of Four Seas, 73; on extent of English Maritime Dominion, 81 ; on Mare Clausum, 80, 98.

Selenga, navigation of, 366 .

Semliki, diversion of waters, 346,347 .

Semoy, boundary, 249; navigation, 249.

Sereth, navigation of, 224.

Setit, boundary, 347.

Seven Years' War, 90-91.

Shari, boundary, 347 ; navigation, 347.

Shat-el-Arab, navigation of, 366 .

Shavoe, boundary, 347 .

Ship Money, case of, 82 .

Shire, boundary, 348 ; navigation, 347,348 .

Shirwa Lake. See Chilwa Lake, 328.

Siang-kiang, navigation, 366 ; tolls prohibited, 357-58.

Sibun. See Belize, 261.

Sicily, conquest of, by Northmen, 22.

Si-kiang. See West River, 369, 370.

Slave Trade, detection of, by search, 113, 120.

Sobat, diversion of waters, 348 .

Sogamoso, navigation of, 299.

Sokoto, navigation of, 348 .

Song-ki-kong, navigation of, 366 ; tolls prohibited, 357 .

Songkoi, navigation of, 366,367 .

Songwe, boundary, 348, 349 .

Soulanges, navigation, 263 ; tolls prohibited, 264.

Sound Dues, Danish, 120; abolition of, 93, 121; Queen Elizabeth seeks modification of, 94 .

South America, Inland Waterways of, 292; vital service of, 162-63.

Sovereignty of the Seas, claims to, 58, 76, 101, 105.

Spain, Rights secured to, by Papal Bull, 65.

Spanish Succession, War of, 90 .

Spree, boundary, 249.

Squincio Lake, boundary, 249.

Stade Toll, imposition of, 203, 204.

Stecknitz Canal, navigation, 250; obstructions forbidden, 250. 
Stefanie Lake, boundary, 349.

Stikine, boundary, 290; navigation, 290-91.

Stowell, Lord, on Visit and Search during peace, 120.

Strategic Areas, maritime, 133, 136.

Styr, boundary, 250.

Submarine War-Vessels, use of, 137.

Sulaco, navigation of, 270-71. See Honduras: Ulua.

Sungari, boundary, 367 ; navigation, 367.

Superior Lake, boundary, 291; commission of supervision, 263; diversion of waters, 263 ; fisheries, 263 ; navigation, 291.

Sure, boundary, 250.

Surinam, cession of, to Netherlands, 87.

Switzerland, importance of fluvial navigation to, 166, 168.

TAGLIATA, boundary, 250.

Tagus, navigation of, 250 .

Takutu, boundary, 318; navigation, 318 .

Tana, boundary, 349 .

Tanganyika Lake, boundary, 349 ; commission of supervision, 349 ; navigation, 349, 350; tolls prohibited, 349 .

Tanoe Lagoon. See Tendo Lagoon, 350.

Tanoe River. See Tendo River, 350.

Tapajoz, navigation of, 318,319 .

Tartares, diversion of waters, 250.

Tatsich. See Yung-kiang, 357, 374.

Tembe-Counda, navigation of, 34l. Sce Niger.

Tendo Lagoon, navigation of, 350 .

Tendo River, boundary, 350; dredging for gold, 350; fisheries, 350; navigation, 350 .

Terneuzen Canal, boundary, 251; navigation, 251, 252; obstructions prohibited, 251.

Territorial Waters, extent of, 94, 107, 117, 124; seizure beyond, of vessels, 126.

Teterew, navigation of, 224 .

Texel, Sea-Fight off the, 87.

Thames, invasion of, by Dutch fleet, 87 .

Themistocles, naval policy of, 18 .

Ticino, boundary, 252; navigation, 252.

Tiel, boundary, 350 ; fisheries, 350 ; navigation, 350 .

Tigre, navigation of, 300,312 .

Tigris, navigation, 368; trade-route, 53.

Tinto. See Negro, 277.

Tocantins, navigation of, $169,319$.

Tolls, fluvial, 152.

Tolls, Prohibition or Regulation of, on the:

Adige, 180;

Black River Canal, 264;

Borneo Waterways, 354;

Cao-Bang, 357;

Chambly Canal, 263;

Champlain Canal, 264;

Canals of Canada and the United States, 263-64;

Canton, 357;

Chinese Inland Waterways, 358;

Cornwall Canal, 263;

Cross, 330; 
Tolls, Prohibition or Regulation of (Continued) : on the:

Elbe, 202-205;

Erie Barge Canal, 264;

Farran's Point Canal, 263;

Fly River (New Guinea), 358;

Galops Canal, 263;

Grand Canal, 358;

Grand Lake of Cambodia, 359 ;

Han-kiang, 358;

Hoang-ho, 358;

Hun-ho (Liao-ho System), 358;

Hun-ho (Pai-ho System), 358;

Hwai-ho, 358;

Lachine Canal, 263;

Liao-ho, 358;

Lwan-ho, 358;

Lys, 213;

Main, 215;

Meuse, 217, 218;

Min-kiang, 358;

Mississippi, 274;

Murray Canal, 263;

Neckar, 220-21;

Netze, 221 ;

Niemen, 221;

Oswego Canal, 264;

Ottawa Canal, 263;

Pai-ho, 358;

Paraguay, 306;

Parana, 311;

Pei-kiang, 358;

Po-Yang-Lu Lake, 358;

Rapide Plat Canal, 263;

Rhine, 228, 231, 232, 234, 236;

Rideau Canal, 263;

St. Andrew's Canal, 263;

St. John, 285 ;

St. Lawrence, 263;

St. Ours Canal (Lock), 263 ;

St. Peter's Canal, 263;

Sault Sainte Marie Canal, 263;

Scheldt, 246, 247;

Siang-kiang, 358;

Song-ki-kong, 358;

Soulanges Canal, 263;

Tanganyika Lake, 349 ;

Trent Canal, 263;

Tsien-tang, 358;

Tso-kiang, 358;

Tumen, 358;

Tung-kiang, 358;

Tung-Ting-Lu Lake, 358;

Vistula, 254;

Warthe, 255;

Welland Canal, 263;

Weser, 257;

West, 358;

Whangpoo, 358;

Williamsburg Canal, 263;

Wu-kiang, 358;

Yalu, 358;

Yang-tsze-kiang, 358;

Yssel, 258;

Yung-kiang, 358.

Tolls, Rhine, 153.

Tonke. See Kubango, 334.

Tordesillas, Treaty of, modifies Demarcation Line, 67; receives Papal Sanction, 68 .

Tornea, boundary, 252; fisheries, 252 ; navigation, 252.

Tort, diversion of waters, 252.

Trade-Routes, Mediterranean and Far East, 17.

Trafalgar, English victory at, 91 .

Trani, Ordinances of, 33 .

Transportation, co-relation of Railway and Waterway, 159, 160; dependence on, of society, 8 .

Trave, fisheries, 253; navigation, 253; obstructions prohibited, 253.

Trent Canal, navigation, 263; tolls prohibited, 263, 264.

Tresa, boundary, 253; fisheries, 253.

Tromp, Admiral, 86, 87.

Tsana Lake, diversion of waters, 350 .

Tsien-Tang, navigation, 368 ; tolls forbidden, 358 .

Tso-kiang, navigation, 368 ; tolls forbidden, 358. 
Tumba Lake, commission of supervision, 350; navigation, 350.

Tumen, boundary, 368 ; navigation, 368 ; tolls prohibited, 358 .

Tung-kiang, navigation, 368; tolls prohibited, 358.

Tung-Ting-Lu Lake, navigation, 369 ; tolls forbidden, 358.

Twiss, Sir Travers, on Laws of Oleron, 36.

Two Sicilies, Kingdom of the, established, 22.

Tyrrhenian Sea, 57.

Tzaisan-Nor Lake. See Zatsan Lake, 375.

UAPES. See Colombian Waterways: Waupes, 299.

Ubangi, commission of supervision, 351 ; navigation, 351.

Ucayali, navigation of, 312 .

Ugala, commission of supervision, 351 ; navigation, 351.

Ukase of Alexander, Emperor of Russia, 121.

Ukumbi. See Ugala, 351 .

Ulafu (Uldafu), boundary, 351.

Ulua, navigation of, 291.

United States, claims of, to extensive bays, 129 ; waterways of, 161 .

Unstrut, navigation of, 253.

Urbelcha, boundary, 253.

Uruguay, navigation, 319, 320, 321; War-Vessels restricted, 319.

Ussuri, boundary, 369 ; navigation, 369 ;

Utamboni, fisheries, 351 ; navigation, 351 .

Utica, strategic site of, 15.

Utrecht (1713), treaty of, 90, 153.

VALCARLOS, boundary, 253.

Valencia Lake, navigation of, 321.

Vanera, boundary, 253; diversion of waters, 253.

Vattel, Emmerich, on Freedom of the Seas, 103, 116; on international commerce, 8; on Mare Clausum, 98; on Marginal Sea, 117.

Venezuelan Waterways, navigation of, 321.

Venice, access secured by, to Constantinople, 22; maritime law of, 28; trade of, stimulated by Crusaders, 22.

Vermejo, navigation of, 321,322 .

Vessels, corporate ownership of, 138.

Victoria Nyanza, boundary, 351, 352.

Vienna, Congress of, 6, 151, 155, 161.

Visit and Search, exercise of, during peace, 113, 119.

Vistula, boundary, 254, 255; navigation, 224, 253, 254, 255; tolls prohibited, 254.

Volta, boundary, 352.

Voyages of Discovery, 3.

WAAL, navigation of, 255.

IVallis. See Belize, 261.

Wanks. See Coco, 266, 271.

War, Maritime, innovations of, 134, 137; restrictions of, on navigation, 136,149 .

Warthe (Wartha), boundary, 255; navigation, 224, 255; obstructions forbidden, 255 ; tolls prohibited, 255. 
War-Vessels, Prohibition of Navigation by, on the:

Adige, 180;

Nicaragua Lake, 278;

Apa, 308;

Paraguay, 308;

Aquidaban, 308;

Fogones, 308;

War-Vessels, Regulation of Navigation by, on the:

Caspian Sea, 356;

Putumayo, 317;

Danube, 189, 199;

Paraguayan Waterways, 308;

Pilcomayo, 314.

Detroit, 270;

Erie Lake, 269 ;

Huron Lake, 269-70;

Niagara, 269 ;

Ontario Lake, 278, 279 ;

Plata, 316;

St. Clair Flats Canal, 269-70;

St. Clair Lake, 270;

St. Clair River, 270 ;

St. Mary's Lake, 269-70;

St. Mary's River, 270;

Superior Lake, 269-70;

Uruguay, 319, 320.

Washington, Treaty of (1867), cession of Alaska by, 123; Treaty of (1892), arbitration of Bering Sea claims by, 124, 125; Treaty of (1911), for protecting fur-seals, 126.

Water-transportation, inherent economies of, 7, 8 .

Waupes, navigation of, 299.

Weisse-Elster, boundary, 256; navigation, 255, 256.

Welland Canal, navigation, 291 ; tolls prohibited, 263.

Weser, navigation, 256, 257 ; tolls prohibited, 257.

West, navigation, 369,370 ; tolls prohibited, 358 .

Westlake, John, on Freedom of the Seas, 111; on Maritime Occupation, 112; on Venetian appropriation of Adriatic, 60.

Westminster, Treaty of (1674), 89.

Westphalia, Peace of, restricts Rline traffic, 152; restricts Scheldt traffic, 153.

Whangpoo, navigation, $370,371,372$; tolls prohibited, 358 .

Whitehall Canal. See Canals: Champlain, 263-64.

Wilija, navigation of, 224.

Williamsburg Canal, navigation, 263; tolls prohibited, 264.

Wilson, Woodrow, on Freedom of the Seas, 170; on necessity of Inland Navigation, 170.

Windau Canal, navigation of, 224.

Windau River, navigation of, 224.

Wisbuy, Laws of, 25, 39, 40.

Wjeprsh, navigation of, 224.

Wom, boundary, 352 ; fisheries, 352 ; navigation, 352 .

Woosung. See Whangpoo, 370.

Woriema. See Jacobs-Elf, 210.

Worms, boundary, 257, 258.

Wu-kiang, navigation, 372 ; tolls prohibited, 358.

XERXES, defeat of, at Salamis, 18.

yacarana. See Peruvian Waterways: Yavari, 312.

Yaguaron. See Jaguary, 301.

Yalpouk, boundary, 258.

Yalu, navigation, 372-73; tolls prohibited, 358 . 
Yang-tsze-kiang, navigation, 373, 374; tolls prohibited, 358.

Yapura, navigation of, 322 .

Yavari, navigation of, 312 .

Yederam, boundary, 352; fisheries, 352 ; navigation, 352.

Yenisei, navigation of, 374 .

Yoja. See Honduras: Ulua, 270-71.

Yoro. See Coco, 266.

Yssel, boundary, 258; navigation, 258; tolls forbidden, 258.

Yukon, navigation of, 292.

Yung-kiang, navigation, 374, 375; tolls prohibited, 358.

ZAMBESI, boundary, 353; navigation, 352, 353.

Zatsan Lake, 375.

Zborowski, boundary, 258.

Zbrucz. See Podhorce, 224.

Zuid-Willems-Waart, diversion of waters, 259; navigation, 258, 259; obstructions prohibited, 259.

Zwin Canal, boundary, 260; navigation, 259, 260. 




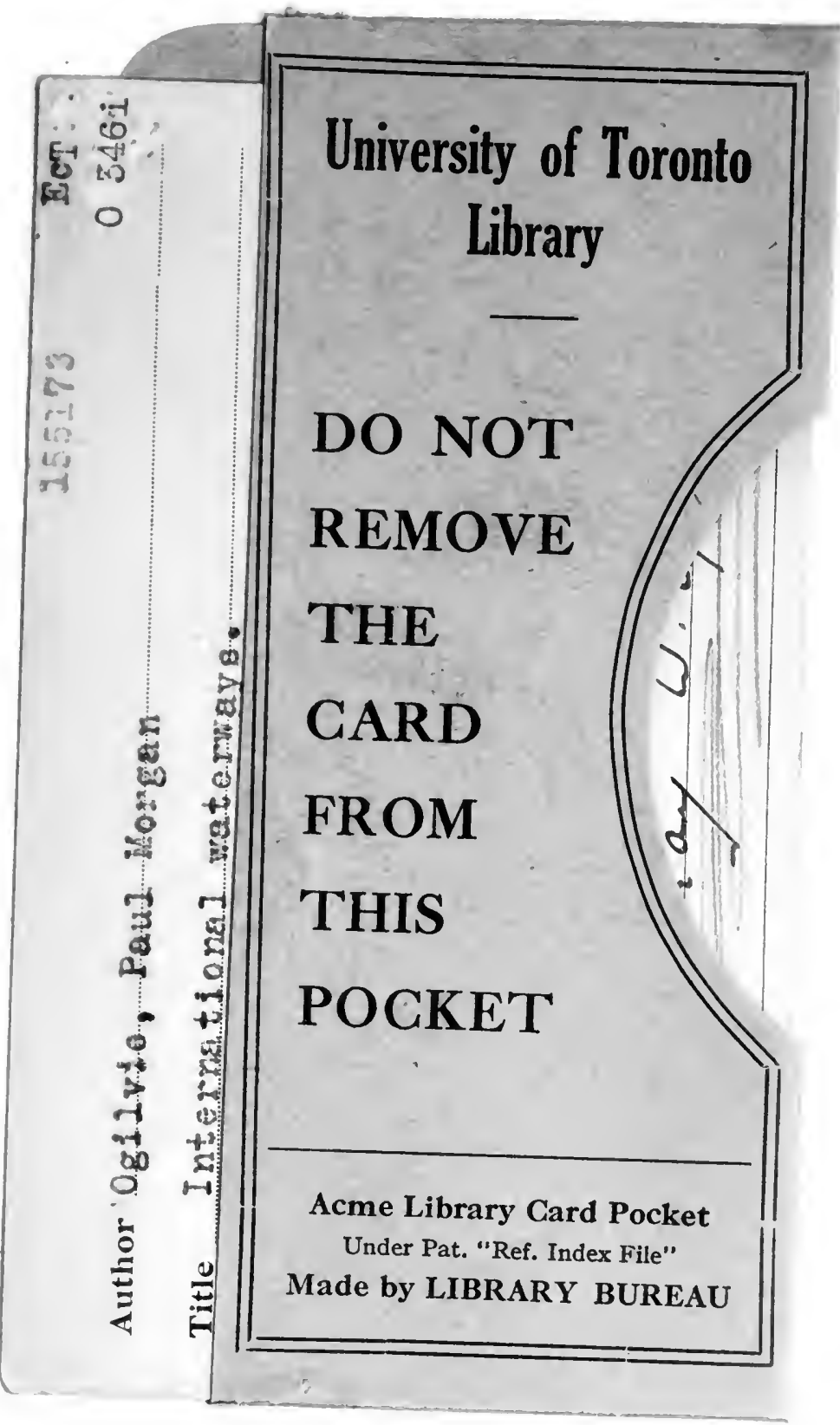


